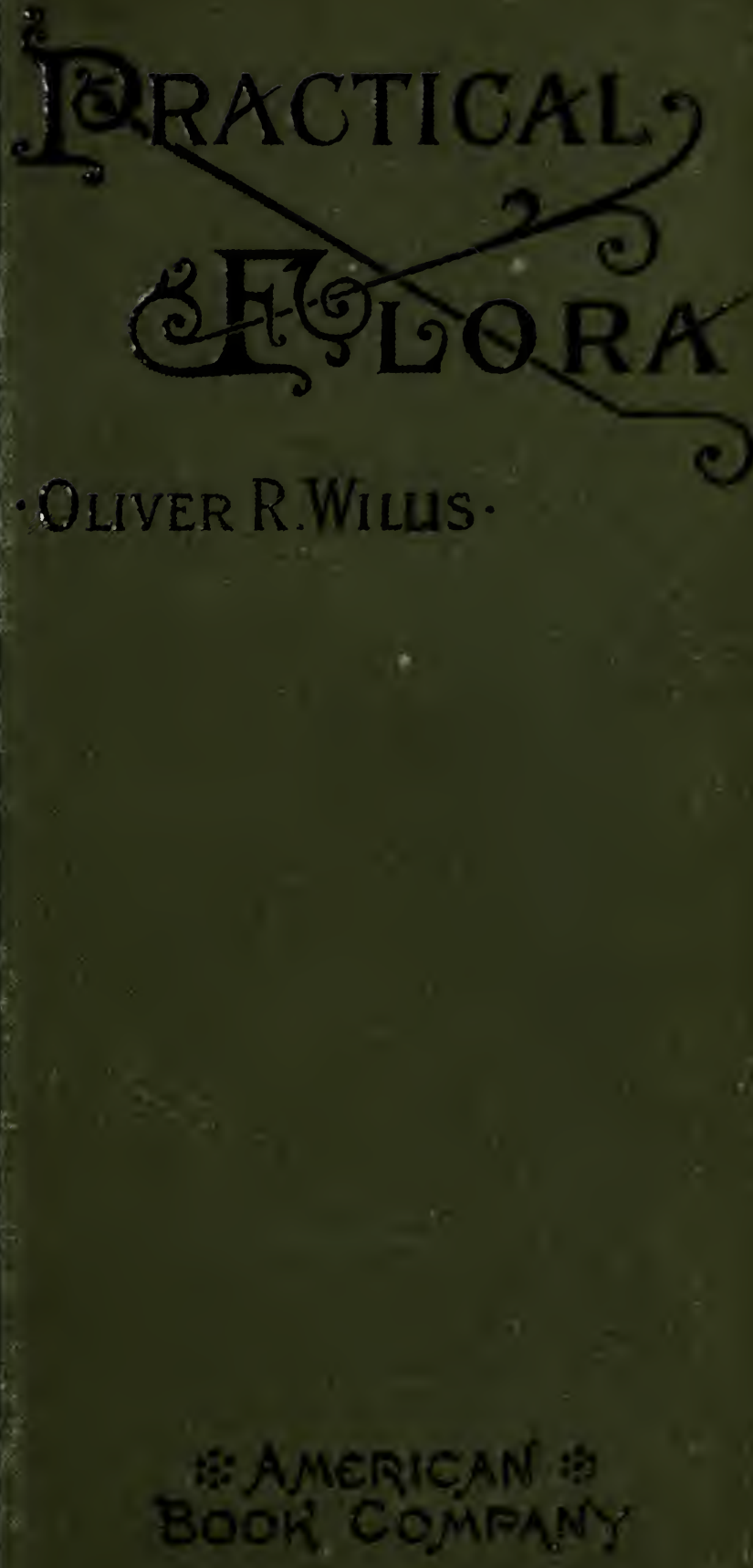




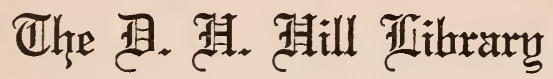

atorth Uarolina \$state Trallege

$$
\begin{aligned}
& \text { QK } 47 \\
& \text { W6 }
\end{aligned}
$$




\section{Date Due}

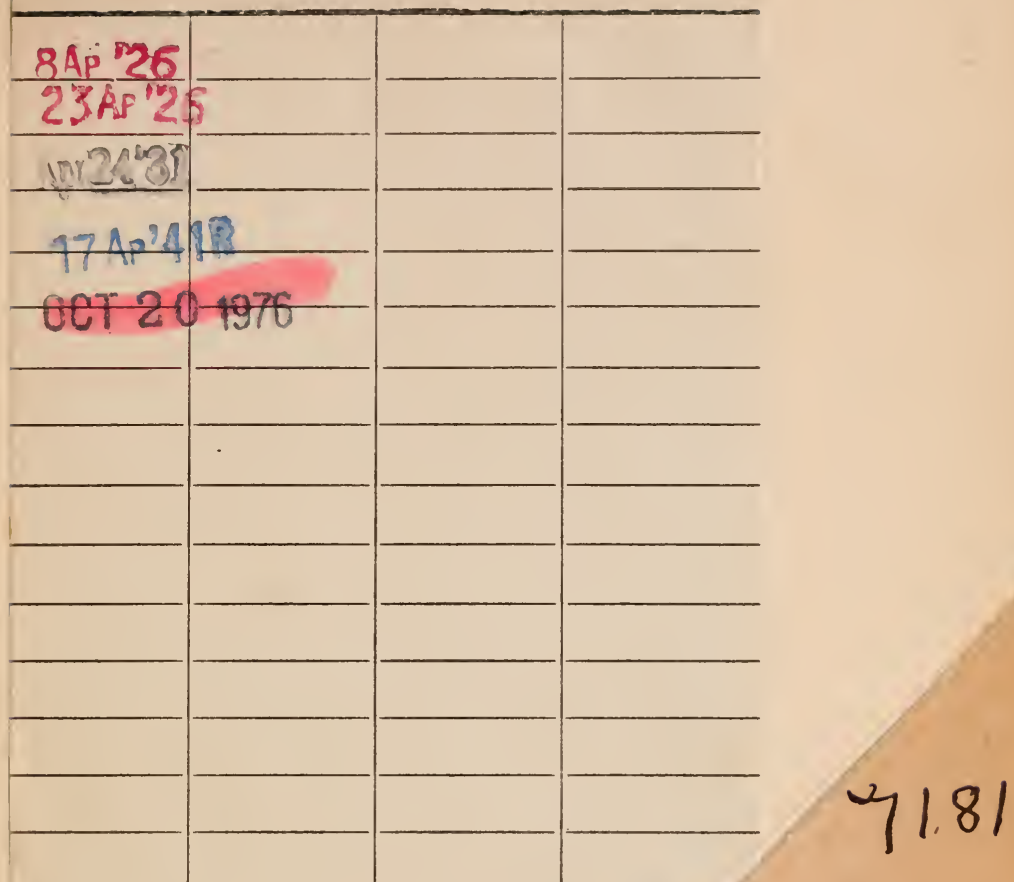







\title{
PRACTICAL FLORA
}

\section{FOR SCHOOLS AND COLLEGES}

\author{
Br \\ OLIVER R. WILLIS, A.M., PH.D. \\ INSTRUCTOR IN BOTANY, PHYSICS, AND CHEMISTRY IN THE \\ NEW YORK MILITARY ACADEMY
}

NEW YORK $\cdot \because$ CINCINNATI $\because \cdot$ CHICAGO

A MERICAN BOOK COMPANY 
Copyright, 1894,

By American Book Company.

Willis's Yract. Flora.

Drinted by

roum. Ivison

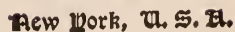




\section{P R E F A C E.}

ROTANIES without number have been published, giving $B$ scientific descriptions of plants of such character that the student is enabled by careful analysis of their structure and appearance to determine their names and physical characteristics. Such books are excellent in their way, and the information they contain is necessary for all students of the science; but all our pupils who take up this study as part of their curriculum have not the scientific mind which makes the acquirement of the science an end in itself. To engage the interest and enthusiasm of such students, it is necessary to show the practical aspects of the vegetable world, and its relations to the needs of every-day life; to reveal something of its history, which, in itself, becomes a fascinating study; and to show enough of its economic features to satisfy those who have neither the scientific mind nor the poetic temperament required for a love of the study for itself.

There has been a long-felt want for a work of such practical character, and this book has been prepared to meet the demand. It does not aim to be exhaustive, as such a treatment would make a book of many thousands of pages, which it would be impracticable to place in the hands of a pupil; but the author has made a careful selection of the most important food-producing trees, shrubs, and herbs, including ornamental plants, fruits, nuts, medicinal plants, and those which furnish oils, dyes, lumber, textile fabrics, etc. 
So far as the scientific description and classification of these plants are concerned, the plan of this book does not differ from that adopted by the best botanists. The various genera are grouped together under their respective orders, and the species and varieties under their genera in the same way as in other books. Each order has a general statement which characterizes all the plants belonging to it, and each genus and species and variety a more specific description of such other characteristics as determine its classiflcation. But in addition to this, and to supplement it, are introduced the features in which this book differs from those heretofore published. Thus, after the technical description of a plant will be found an account of its geographical range, the origin of its name, its history, including a statement of its birthplace and distribution over the globe, its uses, modes of cultivation, preparation, and propagation, and many statistics of economical and commercial interest.

The book is the outgrowth of a successful class-room experience, and the author recommends it to the notice of teachers and pupils, in the hope that they may find in it both interest and profit, and that it may tend to relieve the monotony of a strictly technical treatment of the subject, and enhance, if possible, the beauty and the usefulness of the study of Botany. 


\section{O N T E N T S.}

INTRODUCTION . . . . . . . . . . . . . . ix

Brief Statement of the Sibject axd its Subdivisions - $\mathrm{xV}$ Authors' Names and Abrreviations . . . . . . . . 3 Key to the Orders . . . . . . . . . . . . . 5

Synopsis of Orders And Genera. . . . . . . . . 12

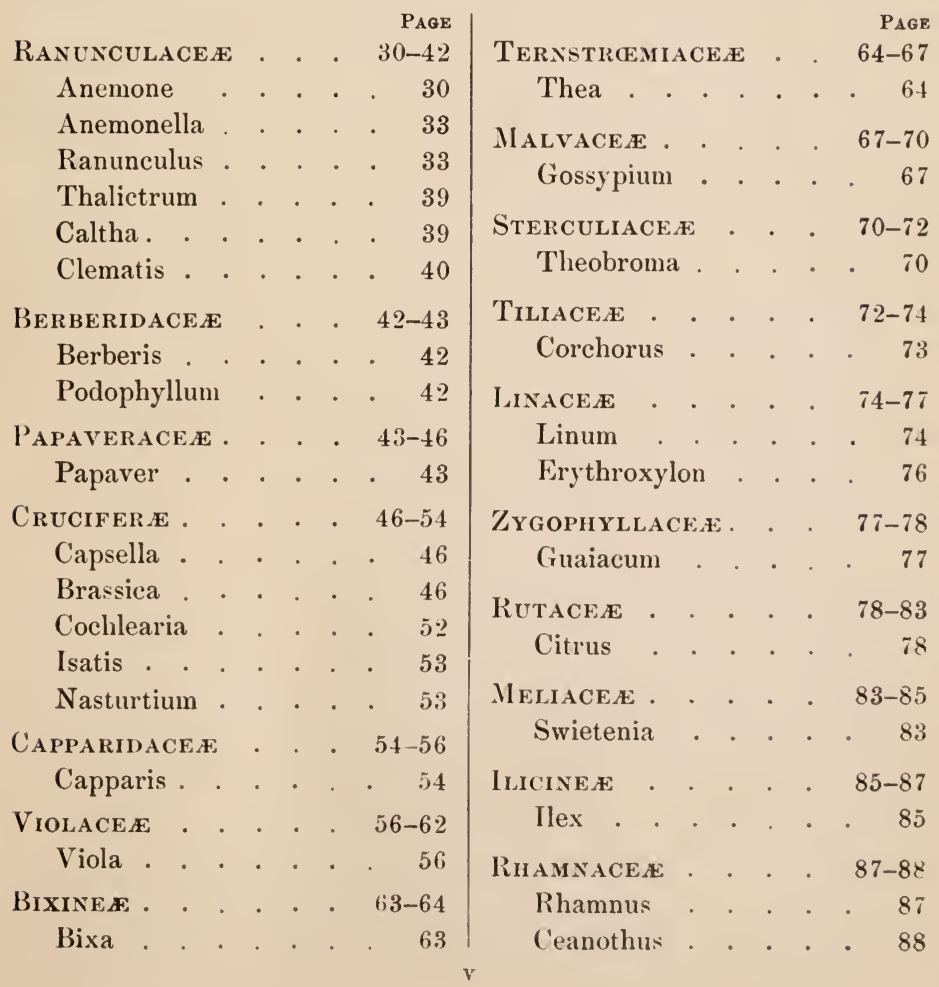


AMPElide A $^{2}$. . . 88-91

Vitis . . . . . 88

SAPINDACEA . . . 91-93

Acer . . . . . . . 91

ANACARDIACE $E$. . . 93-95

Rhus . . . . . . 93

Anacardium . . . 95

LEguminos E . . . 96-112

Indigofera . . . . . 96

Astragalus . . . . . 97

Arachis . . . . . . 99

Lens . . . . . . 100

Pisum . . . . . 101

Phaseolus . . . . 103

Glycyrrhiza . . . 105

Hæmatoxylon . . . 105

Cassia . . . . . 107

Ceratonia . . . . 108

Dalbergia . . . . . 108

Cæsalpinia . . . . . 109

Tamarindus . . . . 109

Acacia . . . . . 111

ROSACEE . . . . 113-127

Rubus . . . . . 113

Fragaria . . . . 116

Prunus . . . . . 117

Pyrus . . . . . 123

SAXIFRAGACEA . . . 128-131

Ribes . . . . . . 128

Combretace£ . . 131-132

Terminalia . . . . . 131

MyrtaceA $\quad . \quad . \quad 132-137$

Myrtus . . . . . 133

Eugenia . . . . . 134

Bertholletia . . . 137

LYTHRACEE . . . . 138-139

Punica . . . . 138

Cucurbitace $\quad . \quad$. 139-146

Cucumis . . . . . . 139

Citrullus . . . . . 142

Cucurbita . . . . 143
UMBELLIFER

Apium . . . . . 146

Pimpinella . . . . 147

Fœniculum . . . . . 148

Ferula . . . . . 149

Peucedanum . . . . 151

Coriandrum . . . . 152

Cuminum . . . . 153

Daucus . . . . . 154

Carum . . . . . 155

RubiACEA . . . . 157-164

Cinchona . . . . 157

Coffea . . . . . 160

Cephaëlis . . . . 162

Rubia . . . . . 163

COMPOSita . . . . 165-170

Inula . . . . . 165

Anthemis . . . . 166

Chrysanthemum . . . 167

Tanacetum . . . . 168

Carthamus . . . . 169

Campanulacee . . . 170-171

Lobelia . . . . 170

VACCINIACEE . . . . 171-174

Gaylussacia . . . 171

Oxycoccus . . . . 172

SAPOTACEE . . . 174-176

Dichopsis . . . . 174

EBENACEA . . . . 176-177

Diospyros . . . . . 176

Oleacee . . . . 178-180

Olea . . . . . . 178

LOGANIACEN . . . . 180-182

Strychnos . . . . 180

BORRagINACE E . . . 182-183

Symphytum . . . . 182

Convolvulacea . . 183-185

Ipomœa . . . . . . 183 
Lycopersicum . . . . 185

Nicotiana . . . . 187

Atropa . . . . . . 191

Capsicum . . . . 192

Solanum . . . . . 194

Pedalinex . . . 195-197

Sesamum . . . . 195

Verbenace . . . $197-198$

Tectona . . . . . 197

Labiata: . . . . 198-207

Lavandula . . . . 198

Mentha . . . . . 199

Origanum . . . . 201

Thymus . . . . . 203

Salvia . . . . . 204

Rosmarinus . . . . 205

Nepeta . . . . . 206

Marrubium . . . . 207

Chenopodiacea . . 208-210

Beta . . . . . . 208

Spinacia . . . . 209

Polygonacee . . 210-213

Fagopyrum . . . . 211

Rheum . . . . . 212

Piperace E . . . 213-215

Piper . . . . . 214

MYRISTICACEE • . 215-217

Myristica . . . . 215

LAURACEE . . . 217-220

Cinnamomum . . . 217

SANTALACE . . . 220-222

Santalum . . . . 220

Euphorbiacee $\quad$ • . 222-229

Euphorbia . . . . . 222

Hevea . . . . . 223

Buxus . . . . . 225

Croton . . . . . 226

Manihot . . . . 227

Ricinus . . . . 228

Morus . . . . . 230

Ulmus . . . . . 231

Humulus . . . . 233

Ficus . . . . . . 234

Cannabis . . . . 236

JUGLANDACEE . . . 238-242

Juglans . . . . . 238

Hicoria . . . . . 238

Cupulifere $\quad$. . . 242-256

Castanea . . . . 243

Quercus . . . . 245

Corylus . . . . . 254

Fagus . . . . 255

SAlicacen . . . . 256-258

Salix . . . . . 256

ORCHIDACEE . . . 258-260

Vanilla . . . . 259

Zingiberace • . . 260-268

Curcuma . . . . 260

Naranta . . . . 261

Elettaria . . . . 263

Zingiber . . . . . 264

Musa . . . . . 265

BRoMELIACEe . . . 268-270

Ananassa . . . . 269

IRIDACEE . . . . 270-271

Crocus . . . . 270

DiOSCOREACEÆ . . 271-272

Dioscorea . . . . . 271

LiLIACEA: * * . 272-278

Smilax . . . . . 273

Asparagus . . . . . 274

Phormium . . . . 276

Aloe . . . . . . 275

PALME . . . . . 278-285

Areca . . . . . 279

Phœnix . . . . . 280

Cocos . . . . . 282

Metroxylon . . . 283 


\section{CONTENTS.}

PAge Page

Graminee . . . . 285-300 Conifere . . . . 300-315

Zea . . . . . 286 Pinus . . . . 300

Triticum . . . . 288 Picea . . . . . 307

Oryza . . . . . 290 Abies . . . . . 308

Saccharum . . . . $292 \quad$ Larix . . . . . 309

Sorghum . . . . . 294 Juniperus . . . . . 310

Secale . . . . 295 Thuja . . . . 312

Hordeum . . . . 296 Tsuga . . . . . 312

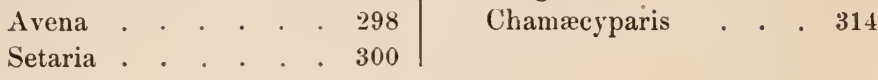

Glossary . . . . . . . . . . . . . . 317

INDEX . . . . . . . . . . . . . . . 339 


\section{IN'TRODUCTION.}

$\mathrm{D}$

URING the last century the means of acquiring knowledge in every department of science has been wonderfully increased and facilitated. In the several departments of Natural History the improvement has been striking. Naturalists no longer study any branch as a whole, but divide it into parts, each of which affords employment for a lifetime. 'Thus, in Zoology, one naturalist devotes himself to Quadrupeds, another to Birds, a third to Fishes, and a fourth to Insects.

It is less than a hundred years since Botany was allowed a place as a branch of Natural History; nevertheless it has not only become a favorite study, but is now a very important branch of science. The field has so enlarged itself that it has been found convenient, as in other sciences, to break it up into several departments.

The number of species of plants was supposed by Linnæus not to exceed ten thousand, while at the present day about one hundred and fifty thousand are known; and new species, and even new genera, are yearly increasing the names already in the vast catalogue.

The constant expansion of this broad field is a source of the highest gratification to the student of Natural History. He need entertain no fears that his insatiable curiosity will ever lack food; a long life given to the study of Botany in any one of its departments, with the most zealous and enthusiastic devotion. will leave it still mnfinished. No branch of science affords such unalloyed pleasure in its pursuit.

He who sees no beanty in the expanding Rose or the 'Tulip's variegated petals is, indeed, an olject of pity. Even al common 
observer is struck with such prominent examples of Nature's beauties, and feels what the poet felt when he wrote: -

\author{
"But who can paint \\ Like Nature? Can imagination boast, \\ Amid its gay creation, hues like hers? \\ Or can it mix them with that matchless skill, \\ And lose them in each other, as appears \\ In every bud that blows?"
}

But Botany is no longer regarded as a mere accomplishment; nor is it only to be studied for its beauty. It is a most important part of a useful education. Indeed, the value of this study is so great that it can scarcely be estimated.

Most of the early writers upon plants took into consideration only the subject of their usefulness in the art of healing. The study of structure and mode of growth was left to modern times - till after the microscope came to reveal the marvels of plant structure, and bring to light the tissues and vessels that carry on the life and activity of plant growth; till Chemistry discovered the materials that have built up, drop by drop and particle by particle, the plants of the world, from the gray Lichen of the hillside rock to the gigantic forest tree towering four hundred feet into the air.

A knowledge of the geographical locality and habits of plants enables us to select with certainty and transplant the trees and shrubs that beautify our lawns and gardens. 'To an intelligent agriculturist, an understanding of some of the departments of Botany is indispensable. He must know the habits of regetables and their mode of growth in order to prepare his ground; he must know their composition to be able to apply the requisite food; and he must know their structure and organs to determine where and how to apply it. In many departments of industry a knowledge of Botany is found invaluable and it lends assistance to the various arts and elegancies of life.

One of the most interesting departments of this subject deals with the history of the cultivation and use of plants. Their history, in a measure, runs parallel with the world's history. When communities became populous they could no longer depend upon the chase, because the demand outgrew the supply; and the use of plants for food was a natural result. The needs 
of man undoubtedly led to husbandry, and as men became more numerous, they found it necessary to provide, not only for more certain supplies of food, but for more permanent abodes; heuce the cultivation of food plants and the establishment of permanent homes must have been simultaneous.

Of the hundred and fifty thousand plants which make up the world's vast Flora, about three hundred constitute the foodbearing plants for man; of this number, by far the greater part is herbaceous. Among the rereuls, Wheut is the most important; it is one of the most ancient of human food-plants, having been cultivated four thousand year's before Christ. Reliable records point to the banks of the River Euphrates as its home. Barley has a history which makes it contemporaneous with Wheat, its early home being middle Asia. Rice had its origin in southern China, and is also believed to have been contemporaneous with Wheat. Rye and Oats, the other two great bread-plants, had their origin in southeastern Europe, and were under cultivation two thousand years before Christ.

'These five cereals furnish bread for the teeming millions of the earth, and there are no records to show that they have ever been found in a condition that would place them among those plants known as weeds.

Among plants known as table vegetables, the most prominent, beginning with those that have been longest in use, are the Turnip, the Onion, and the Cabbage, which have been used for more than four thousand years. 'The home of the Turnip and Cabbage is middle Europe, and the northern shores of the Mediterranean.

The Carrot, Beet, Parsnip, and Asparagus have been in use two thousand years. The Carrot and Beet, so far as known, are natives to western Asia and eastern Europe. The home of the Parsnip is Europe, and the Asparagus is native to the countries of the Levant.

Among the fruits that minister to man's support as food, are the Grape, found in western Asia; the Apricot, a native of China; the Apple, Pear, and Quince, natives of central Europe, which have accompanied man in all his changes of locality where the climate permitted; the Raspberry and Strawberry, choice and favorite berries, whose cultivation near the great 
cities in the Temperate Zone has become an important industry in western Asia and Europe; the Cherry, which originated near the Caspian Sea; the Plum, a native of northern Persia; and the Peach, one of the most delicious, if not the most popular, of the fruits of the Temperate Zones, a native of China.

Sugar Cane is native to Cochin China, and southwestern China; it is known to have been in use more than two thousand years.

There are a few textile plants that deserve mention, the most important of which are Flax, Hemp, and Jute. Flax was cultivated near the eastern coast of the Mediterranean four thousand years ago. Hemp is of Siberian origin, and is known to have been under cultivation over four thousand years. Jute has been known to commerce less than two thousand years.

Of the three hundred species of cultivated plants that were found in the New World, the most important food-yielding plants are: the Potato, whose home is believed to be Chile and Peru; the Sweet Potato, whose home is in the warm regions of North America; Tobacco, originally found in Ecuador and neighboring regions; Indian corn, one of the most important cereals of the present age; and the Pineapple, found in Mexico, Central America, Panama, and Colombia. These constitute about one sixth of the important food-plants of the whole world.

This introduction will give the pupil an idea of the character and magnitude of the study of the Flora of Useful Plants. As a specimen of the plan of description pursued in this book, we give here a brief outline of a few illustrations, beginning with Wheat, which stands at the head of the cereals. After classifying it under the order Gramineæ and the genus Triticum, the description proceeds as follows:-

Triticum vulgare, L. (Wheat.) Stem or culm 2 to 5 feet high, tapering from the root to the base of the head or the ear, divided by nodes into several intermodes, or lengths, from 4 to 7 inches long. At each node is a single, clasping, lance-shaped leaf, strongly veined and rough on the upper side. Flowers appear at the top of the culm in a close panicle.

The grains, or seeds, are oval in shape, a quarter of an inch in length, flat, and marked on the side next the rachis by a groove the whole length, outside convex. It is an annual, and when planted in early spring, it flowers and fruits the same season; when thus cultivated it is known as "summer wheat" or "spring wheat." The hest wheat is biennial; it is planted in early antumn, 
in time to take root and form root or radical leaves before winter sets in; it ripeus in July of the following year, aud is called "winter wheat," because it remains in the ground during the winter.

Geography. - Wheat, the most important of all the cereal family, has not been found in what is considered the wild state, and though it has assumed several forms or varieties, it has not so departed from the typical form as to lead to the conclusion that it was ever what might be regarded as a weed.

Wheat when planted north of the fiftieth parallel does not fruit; neither will it bear well south of $30^{\circ}$ in America. In Europe, it fruits as high as $51^{\circ}$ in southern Russia, and as low as $37^{\circ}$ in southern Italy. It is cultivated successfully in Turkey, Syria, northern and southern Africa, Brazil, Chile, Argentine Republic, and Australia.

Etymology. - Triticum is from the Latin tero, rub, referring to the mode of reducing the grain to flour. Vulgare, common, is from the Latin. The common name, wheat, is derived from the Sanserit seveta, white, and is due to the white flour produced from the grain.

History. - No form of wheat has ever been found in a wild state. Its home is believed to have been western Asia. It was brought to America by a negro slave belonging to Cortes, and was first planted in Mexico.

Cultivation. - Wheat will not grow upon poor soil nor thrive upon scanty fare. It demands a deep, heavy soil, well tilled, and highly fertilized. In the United States, especially in the rich soils of the Central States, fifty bushels to the acre is not an unusual yield.

Use. - Wheat is the bread grain of man in all regions of the earth where it will grow. The straw is utilized for the manufacture of hats for both men women. It furnishes the material for the fine leghorn hats and bonnets.

Marts. - The great wheat markets are Odessa on the Black Sea, Riga on the Baltic, all the north German ports, Constautinople, London, Liverpool, Chicago, San Francisco, New York, and Toronto.

The building and structural material of the world is obtained from about eighty genera, from twenty-five orders. Of these eighty genera, thirty are cone-bearing plants; hence the greatest amount of building material is furnished by the Coniferre.

We therefore choose for illustration one of its genera, the Tsuga, which yields the Hemlock.

Tsuga Canadensis, Carr. (Hemlock Spruce.) Trunk 50 to 100 feet in height, branching freely. Bark gray, smooth on young trees, but very rough and furrowed on old trees. Leaves solitary, flat, slightly toothed, blunt at the apex, in two ranks, half an inch long, and less than an eighth of an inch wide. Cones three fourths of an inch in length, and less than half an inch in diameter; scales suborbicular, half an inch long; wing less than half an inch broad. Flowers in June; seed matures in the following year in June.

Geography. - The geographical range of the liemlock is confined to a belt on both sides of the forty-fifth parallel, in the Northern Hemisphere, reaching 
down to Pennsylvania in mountainous regious, and even to North Carolina, and as far north as Oregon and Hudson Bay.

Etymology. - Tsuga is Japanese for "yew-leaved" or "evergreen." The name Canadensis comes from Canada, the home of the tree. The origin of hemlock, the common name, is not so easily determined; it is suggested that it comes from hem, the edge or border, and loc, fasten, inclose, alluding to the use of the tree in hedging. \gain, hem means "injure" or "cripple," and may allude to the poisonous properties of the cicuta, called hemlock.

History. - The hemlock is an American tree; it was taken to Europe soon after the settlement of northeastern America, and grows well in the northern parts of England.

Use. - As an ornamental tree the hemlock is a favorite in large grounds. When not crowded it rises to the height of 40 to 80 feet, a perfect pyramid, its lower branches resting on the ground. Its foliage is the most delicate of all the Coniferæ. It bears the knife well, and makes a compact and beautiful hedge. The wood is soft, easily split, and has a very coarse grain; yet it is strong, holds a nail well, requires a great force to produce a cross fracture, and is very durable. It is largely used in the frames of edifices, for joists and for sheathing, being the cheapest of all the soft-wood lumber. The lumber is obtained from the stripped trunks, which are sawed into 13-feet lengths, which during the following winter are drawn to the frozen streams and left till the spring thaw, when they are floated down to the saw-mills, where they are sawed into boards, scantling, and ceiling laths, and thence sent to market.

The bark is highly charged with tannin, and is used in immense quantities for manufacturing leather. It is obtained by felling the tree in the early summer, when the sap is in its greatest activity; girdles are cut around the trunk and large branches by means of an axe, and with a wedge-shaped bar the bark is stripped; it is then piled to dry. Its value is estimated by the cord. 


\section{BRIEF STATEMENT OF THE SUBJECT AND ITS SUBDIVISIONS.}

BOTANY may be subdivided into the following departStructural Botany has for its object the investigation of the structure, mode of growth, and functions of the cells and ressels that make up the plant. Organography is a division of this department that has special reference to the organs. Morphology is properly a division of Structural Botany and notes the changes that take place in the cells and tissues of plants.

Physiological Botany takes into consideration the vital action in the reception, preparation, and disposition of the nourishment necessary to keep up the growth of the plant and to enable it to perform the offices of flowering and fruiting.

Systematic Botany embraces the classification of plants and their arrangement under classes, with accurate descriptions in scientific terms of those characters that determine the classification of a plant. 'The Descriptive Botany in this book comes under the head of Systematic Botany. Glossology, which is a division of Systematic Botany, has for its object the application of appropriate names to the organs and parts of a regetable, by means of which a plant may be so described as to distinguish it from every other individual except one of its own species.

To the above may be added the Art or Practice of Botany, which consists in applying the principles investigated under the above heads to determining the class, order, etc., of an individual plant. It also includes the collecting, drying, labeling and arranging of botanical specimens. 
The classification and nomenclature of the Vegetable Kinglom has taxed the ingenuity and talent of the most learned and skillful hotanists. The primary object of classification is to arrange the individual plants or species that resemble each other in the greatest number of characters around a common center called a genus; those genera which possess the greatest number of constant common characters are clustered round a common center called an order; the orders in like manner are grouped into cohorts and classes; the classes in their turn have a center called a series. or' a subkingdom, - the common center of the whole being the Vegetable Kingdom. 


\section{DESCRIPTIVE BOTANY.}

PR. FL. -2 



\section{NAMES OF AU'THORS}

CI'TED IN THIS VOLUME, WITH ABBREVIATIONS.

Adanson . . . Adans.

Aiton . . . . Ait.

Allemo.

Alpinus.

Andrews.

Aublet . . . A $A$. .

Austin . . . . Aust.

Bauhin . . . Bauh.

Beauvors . . . Beauv.

Bentham . . . Benth.

Bentley.

Berg.

Blackstone . . Bl.

Boissier . . . Boiss.

Bonpland . . . B. or Bonpl.

Breyn.

Britton . . . . Britt.

Brown, R. . . . R. Br.

Carrière . . C Carr.

Chaix.

Chamisso . . Cham.

Clinton.

Coulter. . . . Coult.

Decaisne . . . Decsne.

De Candolle (A.) $\quad D C$. $f$. or $A . D C$.

De Candolle (A. P.) $D C$.

Delile.

Don.

Duchesne.

Dunal.

Du Roi.

Elliott . . . Ell.
Endlicher . . . . Endl.
Engelmann . . . Engl.
Fischer . . . . . Fisch.
Forster . . . . . Forst.
Fremont.
Gaertner . . . . Gaert.
Geyer . . . . . Gey.
Goldie.
Gray. . . . . . Gr.
Hayne.
Heretier . . . . Her.
Hoffman . . . . Hoffm.
Hooker. . . . . Hook.
Houttuyn . . . . Houtt.
Humboldt . . . . H. or Humb.
Humboldt, Bonpland,

and Kunth . . H. B. K.

Koch.

Kunth . . . . $K$.

Labilladière . . . Lab. or Labill.

Lamarck . . . Lam.

Lambert . . . Lamb.

Lawson.

Lechenault . . Lech.

Lehmann . . . Lehm.

Lind.

Lindley . . . . Lindl.

Link . . . . . $L k$.

Linnaeus . . . . L. or Linn.

Linné, C. ron (son of Linuceus) . . L.f.

Loddiges . . . Lodd. 
Loudon . . . . Loud.

Marshall . . Marsh.

Marshall aud Bieber-

stein . . . M. B.

Martius . . Mart.

Maton.

Medicus . . Medic.

Michaux . . . Michx. or Mx.

Michaux (the younger) Mx.f.

Miller . . . Mill.

Monchausen . . Monch.

Moquin . . . Moq.

Muhlenberg . . Muhl.

Necker . . . . Neck.

Nees voll Esenbeck Nees.

Nuttall . . . No or Nutt.

Olivier . . . Oliv.

Pavon . . . . Pav.

Persoon . . . Pers.

Plumier . . . Plum.

Pohl.

Poiret . . . Poir.

Presl.

Pursh . . . . Ph.

Rafinesque-Schmaltz Raf.

Reinwaldt . . . Reinw.

Retzius . . . . Retz.

Richard . . . Rich.
Risso . . . . Riss.

Robbius.

Roscoe . . . . Rosc.

Rottboell . . . Rottb.

Roxburgh . . . Rox. or Roxb.

Savi.

Schlechtendal . Schlech.

Schrader . . Schrad.

Schultes . . . Sch, or Schult.

Sims.

Spach.

Swartz . . . Sw. or Swz.

Thomas.

Thompson.

Thuillier . . . Thu. or Thuill.

Thunberg. . . Thunb.

Torrey . . . . T. or Torr.

Tournefort . . Tourn.

Wahlenberg . . Wahl.

Waldstein . . . $W$.

Wallich.

Walter . . . Walt.

Wangenheim . . Wang.

Watson, S. . . S. Wats.

Wedderburn . . Wedd.

Wight.

Willdenow . . Willd.

Willis . . . . Wil. 


\section{K E Y}

To trace a plant to its natural Order based upon those characters which are most obvious.

\section{Subkingdom I. FLOWERING PLANTS (Phaenogams).}

\section{Class I, DICOTYLEDONOL'S ANGIOSPERMS.}

Leaves netted-reined. Flowers rarely 3-parted, mostly 4-5-parted. Wood, if any, in concentric rings.

Seed in a ressel. Stigmas present. Embryos with 2 cotyledons.

\section{Cohort I.}

Calyx and corolla present; petals separate, sometimes wanting, in which case the sepals are bright colored.

APOPETALE.

\section{Cohort II.}

Calyx and corolla present; petals more or less united. SYMPETALA世.

\section{Cohort III.}

Calyx present, but no corolla, or both wanting.

APETALA.

\section{CLASE II. MONOCOTYLEDONOUS ANGIOSPERMS.}

Leares parallel-veined (rarely netted). Flowers 3-parted. Bark and wood comminglerl with pith. Root not axial. Embryo with one cotyledon.

\section{Cohort IV.}

Flowers in a spadix.

SPADICIFLORAE.

\section{Cohort V.}

Floral envelope in two 3-parted whorls; onter one green or colorel (Lilies, etc.).

\section{Cohort VI}

Floral envelope chaff-like (Grasses and Grains).

PETALOIDEÆ.

GLUMIFER

\section{Class III. GYMNOSPERMS.}

Stigma wanting. Seed naked. Bark and wool fibers in concentric rings.

\section{Cohort VII}

Cone-bearing plants (Pines, etc.). 


\title{
Subkingdom I.
}

\section{Class I. \\ COBORT I. APOPETALOUS DICOTYLEDONOUS ANGIOSPERMS.}

\author{
Herbaceous Plants.
}

Calyx and corolla present.

Stems sometimes climbing. Leaves alternate, or opposite, 2-3-ternately compound, or merely lobed. Flowers regular.

Ranunculaceæ.

Stems bifid. Leaves peltate. Sepals falling. Valves of anthers not opening upwards. Flowers regular.

Podopliyllum in Berberidaceæ.

With milky juice. Sepals falling. Ovary compound, 1-cellel, several placentæ on wall. Flowers regular.

\section{Papaveraceæ.}

Stems simple or brancher above. Leaves alternate. Flowers regular, 5-merous. Fruit a loculicidal 10-seeded capsule.

\section{Linaceæ.}

With stems. Leaves alternate, stipulate. Sepals 5. Petals 5, differing in size and shape, one terminating in a spur. Flowers irregular.

Violaceæ.

Without stems. Leaves all radical. Petals and sepals 5, one petal ending in a spur. Flowers irregular.

Violaceæ.

Leaves alternate. Flowers cruciform, regular. Sepals 4, falling. Petals 4, hypogynous. Stamens 6, 2 shorter. Fruit a 2-celled pod.

Cruciferæ.

Stems prostrate, creeping, or clambering. Flowers sympetalous, monœcious or diøcious. Limb of calyx and corolla 5-lobed. Fruit a Pepo.

Cucurbitaceæ.

Leaves alternate. Flowers in umbels. Stamens 5, styles 2. Fruit dry, dividing into halves when ripe.

Umbelliferæ.

\section{SHRUBS.}

Calyx and corolla present.

Leaves alternate. Sepals and petals 5-merous; sepals imbricate. Stamens many. Fruit a berry.

\section{Bixineæ.}

Leaves alternate. Calyx free, involucelled, 5-lohed. Corolla 5-merous. Stamens many, monadelphous, attached to the petals. Pistils several, ovaries in a ring around an axis.

Malvaceæ.

In regions of little frost. Leaves alternate, palmate. Sepals $4-8$, free or coherent. Petals 4-8. Flowers regular, cruciform.

Capparidaceæ.

With watery juice, climbing by tendrils. Stamens same in number as petals and opposite to them. Calyx lobes very small or wanting. Petals valvate. 
Leaves alternate, stipules small. Flowers perfect or without petals. Stamens alternate with sepals. Fruit a l-seerled capsule.

\section{Rhamnaceæ.}

Leaves alternate, feather-veined. Calyx persistent. Stamens on base of petals. Flowers regular.

Ternstrœmiaceæ.

Leaves alternate, simple, 3-5-lobed. Stipules adnate or 0. Stamens 5-10. Styles 2-3, distinct. Flowers regular.

\section{Saxifragaceæ.}

Leaves alternate, simple. Calyx minute. Petals ovate $4-6$, separate, or united at base. Fruit a drupaceous berry. Flowers regular.

Ilicineæ.

Leaves alternate, simple. Calyx tubular, limb 5-tootherl. Corolla 0 . Seed a drupe. Flowers regular.

Combretaceæ.

Leaves alternate, compound. Flowers small, inconspicuous, regular, 5-merous. Stigmas 3. Fruit drupaceous.

\section{Trees.}

Anacardiaceæ.

Calyx and corolla present.

Leaves alternate. Sepals 5, persistent. Petals clawed, and tongue-shaped. Stamens in a lobed tube. Flowers regular. Fruit a fleshy septicidal capsule.

Sterculiaceæ.

Leaves opposite, pinnate, stipulate. Calyx 5-parted. Sepals 5. Stamens 10. Flowers regular. Fruit a loculicidal capsule.

\section{Zygophyllaceæ.}

Leaves alternate, pinnate. Calyx obscure. Petals 5. Stamens united in a tube. Ovary many-celled. Seeds numerous. Flowers regular.

Meliaceæ.

Leaves alternate. Calyx falling. Petals 4-5. Stamens double or nultiple of the parts of corolla. Flowers regular.

Tiliaceæ.

Leaves simple. Petals sometimes 0 . Calyx $4-5$-cleft. Stamens equal in number to petals. Ovary superior. Flowers regular.

Rutaceæ.

Leaves opposite, 3-nerved. Calyx superior. Limbs 5-parted. Petals 5. Stamens many. Ovary 2- or more-celled. Flowers regular.

Myrtaceæ.

Leaves opposite. Calyx colored, 5-many-parted. Petals 5-7, on throat of calyx. Stamens many. Flowers regular. Berry globular. Seeds many.

Lythraceæ.

Leaves opposite, simple, lobed. Stamens 5-8-10. Ovary 2-celled. Flowers regular. Fruit winged.

\section{Herrs, Shrubs, and Trees.}

Sapindaceæ.

Leaves alternate, stipulate, compound. Flowers papilionaceous. Stamens united in 1-2 groups. Seed vessel a legume or bean.

Leguminosæ.

Leaves alternate, stipulate. Stamens on the calyx, clistinct. Pistils 1 to many, usually distinct, sometimes united, each with a stigma. Ovary simple, 1-celled, 1-ovuled.

Rosaceæ. 
Leaves trifoliate, radical, petioles long. Sepals 5 with 5 alternate bractlets. Petals white. Stamens and pistils many. Fruit a heart-shaped edible receptacle.

Fragaria in Rosaceæ.

Leaves compound in 2-3 pairs and a terminal one. Fruit an aggregation of little drupes on a dry receptacle. In the blackberry the receptacle is succulent and edible.

Rubus (raspberry and blackberry) in Rosaceæ.

Leaves alternate. Flowers in racemes. Fruit a smooth drupe stone or pit flattened.

Prunus (plum) in Rosaceæ.

Leaves alternate. Flowers in twos and threes or solitary. Fruit an ovoid drupe. Stone smooth.

Prunus (plum and apricot) in Rosaceæ.

Flowers in racemes. Fruit a smooth globular or heart-shaped drupe. Stone smooth, globular.

\section{Prunus (cherry) in Rosaceæ.}

Leaves appearing after the Howers. Fruit a tomentose drupe, ovoid. Stone furrowed or wrinkled.

Prunus (peach and almond) in Rosaceæ.

Leaves ovate, crenate, serrate, woolly beneath, smooth above. Flowers in corymbs. Fruit a fleshy pome. Carpels $2-5$, inclosed in a fleshy calyx.

Pyrus (apple and pear) in Rosaceæ.

Leaves oblong, or broad ovate, blunt at base and sharp at apex. Carpels 5 or more inclosed in the fleshy calyx. Fruit a fleshy, fragrant pome.

Pyrus (quince) in Rosaceæ.

\section{COHORT II. SYMPETALOUS DICOTYLEDONOUS AITGIOSPERMS.}

\section{Herbaceous Plants.}

Calyx and corolla present.

Leaves altemate. Flowers crowded in an involucrate head composed usually of a disc of yellow flowers, encircled by a ring of white, pink, or purple ones.

Compositæ.

Leaves alternate. Juice milky. Flowers perfect and regular, bell-shaped. Limb 5-lobed. Stamens 5, free.

\section{Campanulaceæ.}

Stem twining or clambering. Leaves alternate. Calyx 5-lobed. Corolla bellshaped. Limb 5-lobed. Flowers regular, axillary.

\section{Convolvulaceæ.}

Leaves alternate. Calyx and corolla 5-lobed. Stamens 5 on the corolla. Fruit usually 2-celled, many seederl.

\section{Solanaceæ.}

Leaves alternate. Calyx 5-lobed. Corolla 2-lipped, 5-lobed. Stamens 5, on corolla tube. Flowers irregular. Fruit a drupe.

\section{Pedalineæ.}

Hairy and rough. Leaves alternate. Calyx 5-parted. Corolla 5-lobed. Stamens on the tube. Ovary 4-lobed.

\section{Borraginaceæ.}

Stems square. Leaves opposite and aromatic. Flowers irregular. Corolla 2lipped. Ovary 4-lobed.

Labiatæ.

Leaves alternate. Flowers solitary. Ovary inferior, many-celled. Stamens double the number of corolla lobes. 


\section{Hzizs and Trens.}

Leaves opposite, stipulate. Calyx tubular or 0. Corolla limb 4-6-lohed. Stamens $4-6$ on corolla tube.

Rubiaceæ.

Leaves alternate. Flowers regular. Stamens inserted at the buttom of corollit tube, and twice as many as lobes.

Ebenaceæ.

Juice milky. Leaves alternate. Corolla furnisherl with scales on the inner surface. Ovary 5-many-celled.

Sapotaceæ.

Leaves opposite, pinnate. Calyx 4-cleft. Corolla 4-cleft or 0. Stamens 2. Fruit a drupe.

Oleaceæ.

Leaves opposite, entire, substipulate. Calyx and corolla 5-lohed. Stamens 5. Flowers regular.

Loganiaceæ.

Leaves opposite. Calyx toothed. Corolla $4-5$-lobed. Stamens 4 . On the corolla sometimes only 2. Flowers irregular.

Verbenaceæ.

\section{COHORT III. APETALOUS DICOTYLEDONOUS ANGIOSPERMS.}

Calyx present, but no Corolla, or hoth wanting.

HERBS.

Leaves alternate. Flowers small, inconspicuons, regular. Calyx free. Stamens equal to number of calyx lobes.

Chenopodiaceæ.

Leaves alternate, sheathing. Calyx and corolla wanting. Stamens 1-9, ustually $6-8$.

Fagopyrum in Polygonaceæ.

\section{SHRtizs.}

Leaves opposite or whorled, 5-nerverl. Calyx wanting. Ovary 1-cellerl. Flowers crowded on a long spadix. Fruit a berry.

\section{Trees.}

Piperaceæ.

Leaves alternate. Calyx oval, 3-lohed. Stamens 3-15.

Myristicaceæ.

Leaves alternate. Sepals 1-6, colored. Ovary 1-celled, 1-ovuled, another lid opening npwaris.

Lauracex.

Leaves alteruate. Sepals 5. Stamens 5. Ovary inferine. Fruit a nut.

Santalacex.

Leaves alternate, pinnate. Calyx 2-4-loherl or entire. Stamens 3 to many. Ovary 1-cellerl. Orule 1. Fruit a nut.

\section{SHrubs axu Tries.}

Juglandaceæ.

Leaves altemate anıl stipulate. Flowers in catkins, naked. Fruit 1-cellel. Porl 2-4-valverl. Seeds elotherl with a silky down.

Salicaceæ.

Leaves alternate. Stipules falling. Fertile Howers solitary. Sterile ones in cat. kins. Fruit a 1-celled, 1-seeded nut.

Cupuliferæ. 


\section{Herbs, Shrubs, axi Trees.}

Leaves alternate or opposite. Juice milky. Flowers sometimes with petals. Many staminate flowers each with a naked stamen.

Stamens inserted round a central column

Euphorlia in Euphorbiaceæ.

Hevea in Euphorbiaceæ.

Ovarian cells 1-ovuled. Staminate flowers without rudimentary ovary.

Croton in Euphorbiaceæ.

Stamens polyadelphous. No rudiment of an ovary.

Ricinus in Euphorbiaceæ.

Leaves alternate, stipulate, penninerved. Flowers with a calyciform envelope, or 0 . Ovary 1-cellert.

Urticaceæ.

Floral envelope single or 0. Styles 1-2. Fruit a cylindrical mass of little drupes. Morus in Urticaceæ.

Flowers fascicled. Perianth slightly colored, or leaf-like, 4-5-8-lobed.

Ulmus in Urticaceæ.

Perianth herbaceous. Sepals 5. Stamens 5. Flowers in strobiloid spikes.

Fruit a smooth, dry, 1-seeded pericarp.

Humulus in Urticaceæ.

Cannabis in Urticaceæ.

\section{Class II.}

\section{COHORT IV. SPADICIFLOROUS MONOCOTYLEDONOUS ANGIOSPERMS.}

Trees and shrubs with unbranched trunks. Flowers on a branching spadix bursting from a spathe.

Palmæ.

\section{COHORT V. PETALOIDEOUS MONOCOTYLEDONOUS ANGIOSPERMS.}

\section{HeRBS.}

Floral envelope in two 3-parted whorls, onter one green, frequently colorer. Rhizome tuberous and creeping. Flowers with double perianth. Outer foliaceous, inner petaloid, irregular, made up of petals and staminodes. Ovary inferior, 3-celled. Flowers irregular.

Zingiberaceæ.

Leaves at base of stem or scape, sheathing rigid, onter floral envelope calyx-like. Flowers spiked, regular.

Ananassa in Bromeliaceæ.

Leaves equitant in 2 ranks. Floral envelope petaloid. Stamens 3 . Ovary inferior, 3-celled, many seeded. Spathe 2-valved. Filaments equal.

Crocus in Iridaceæ.

Stem simple, or branched near the summit. Leaves simple, sheathing, or amplexicaul. Perianth tubular. Limb 6-lobed. Stamens on the throat.

Phormium in Liliaceæ.

Perianth tubular. Stamens on the receptacle or tube of perianth. Leaves fleslyy. Aloe in Liliaceæ.

Herbs becoming woody. Leaves alternate. Stem a woody vine. Parasitic upon large trees. Flowers irregular. Fruit a lengthened pod, many-seeded. Seeds fragrant.

\section{Vanilla in Orchidaceæ.}

Herbs becoming woody, twining or clambering vines. Leaves opposite, nettedveined. Flowers small, in racemose spikes, axillary. Periantl 6-parted. Stamens 6. Fruit 3-angled, winged. 
COHORT VI. GLUMIFEROUS MONOCOTYLEDONOUS ANGIOSPERMS.

Floral envelope chaff-like or wanting, mostly herbaceons.

Stem cylindrical, tapering, and hollow, with closed joints. Leaves alternate, sheathing, sheath split opposite the blarle. Flowers glumaceous, in spikelets. Perianth imperfect or wanting. Stamens usually 3, sometimes 6. Grasses and grains.

Gramineæ.

Spikelets in twos or threes. Stamens 3. Stigmas on long tiliform styles.

Saceharum and Sorghum in Gramineæ.

Spikelets all fertile in a panicle. Stamens 6 , sometimes 3 .

Oryza in Gramineæ.

Spikelets moncecious or polygamous, in a spicate panicle. Stamens 2-3. S'tyles elongated filamentous.

Zea in Gramineæ

Spikelets all fertile in a panicle. Stamens 3. Stigmas sessile.

Avena in Gramineæ.

Spikelets all fertile. Glumes 2, seldom 1, varying in length. Stamens 3, rarely 1. Stigmas sessile, or nearly so.

Triticum, Horleum, and Secale in Gramineæ.

Class III.

COHORT VII. CONIFEROUS GYMINOSPERMS.

('one-bearing plants, mostly trees. Juice resinous. Leaves awl- or needle-shaperl. No ealyx or corolla. Pistil on an open seale. Ovules naked.

Coniferæ. 


\section{SYNOPSIS OF ORDERS AND GENERA.}

\section{Subkingdom I. FLOWERING PLANTS (Phaenogams).}

Plants that produce proper flowers and bear seeds.

\section{Class I. DICOTYLEDONOLS ANGIOSPERMS.}

Fmbryo dicotyledonous. Leaves netted-veined. Flowers mostly 5- or 4. merous.

$$
\text { Apopetalce. }
$$

(Sometimes withont petals.)

\section{ORDER I. RANUNCULACEA.}

Herbs or small shrubs. Stamens numerous. Carpels not united. Sometimes without petals, and sepals colored like petals.

Involucre, consisting of 2-3 divided leaves an inch or more below the flower. Radical leaves, 3-i-parted. Carpels many without grooves, ending in a short heak. Receptacle hemispherical, conical, or cylindrical.

Windflower, Anemone.

Involucre compound. Sepals 5-10, white. Petals 0. Stigma, broad, flat, terminal. Leaves radical compound. Flowers umbellate.

Rue Anemone, Anemonella.

Siepals 3-5. I'etals, 5 or more, with a scale or pit at hase. Stamens numerous, seldom few. Akenes numerons, flattened, ovate, pointed, in globular or cylindrical heads. Leaves mostly radical. Flowers terminal, solitary, or corymbose.

Buttercup, Crowfoot, Ranunculus.

Flowers in compound panicles, greenish or white. Sepals $4-5-\overline{7}$, concave, falling early. No petals. Filaments larger above, longer than sepals. Numerous akenes, ribbed or swollen. I Leaves nsually ternately compound, leaflets stalked.

Meadow Rue, Thalictrum.

Growing in wet places or in the water. Sepals golden vellow, 5-9. Petals wanting. Leaves round, kidney-shaped, usually crenate, glabrous. Follicles $5-10$.

\section{Cowslip, Marsh Marigold, Caltha.}

Sepals 4, petal-like. Petals none. Akenes numerous. Styles feathery or hairy. Leaves opposite, mostly climbers.

Virgin's Bower, Clematis. 


\section{ORIER II. BERBERIDACEAE.}

Herbs and shrubs. Parts of the perianth 2-3-seriate. Stamens opposite the petals. Anthers mostly valvular. Carpel solitary, 1-celled.

Caly $x$ of 6 sepals. Corolla of 6 petals. Anthers 6. Sityle 0. Berry 1-celled.

Barberry, Berberis.

Flowers white. Petals 6-9. Stamens 12-18. Anthers opening by slits. Leaves, two in number, alternate, 5-9-loberl. Lobes tootherl.

May Apple, Mandrake, Podophyllum.

\section{Orner III. PAPAVERACEA.}

Herbs with milky or colored juice. Flowers regular. S'eprals 2. rarely :;, falling off early. L'etals t-12. Stamens many. Symcarpous ovary, 1-chambered. Placentie on the wall.

Leaves large, pinnate, and glancous. Leaflets deep ent or toothed. Flowers showy. Pods globose. Juice milky.

\section{Poppy, Papaver.}

\section{Order IV. CRUCIFER}

Herbs. Sepals and petals growing in the form of a cross. I'sually 6 stamens, 4 long anıl 2 shorter. Ovary -2-celled, with 2 united carpels.

Pods short, triaugular; septum narrow; nany-seeded. Flowers minute, white.

Shepherd's Purse, Capsella.

Pouls loug, tapering, four-sided, beaked. rieeds globose, arrauged in a row. Flowers yellow.

Turnip, Mustard, Brassica.

Pods globose or egg-shaped. Seeds obovate, Hattened, arranged in two rows in each cell. Leaves large, lower ones pinnate, upper ones entire. Flowers white.

Horse Radish, Cochlearia.

Pods oval or elliptical, flat, 1-sepderl. Valves boat-shaped. Leaves thick, large. Flowers small, yellow, and in terminal panicles.

Woad, Isatis.

Pods round or oval. Sepals spreading. Valves, convex, nerveless. Seeds in two rows in each cell.

Water Cress, Nasturtium.

\section{ORDER Y. CAPPARIDACEA.}

Herbs, shrubs, and trees. Flowers cruciate. Stamens 6 or more, never tetradynamous. Ovary leelleil; two placenta on the wall. Leaves simple, or digitate, spiny.

Sepals 4. Petals 4 , alternating with the sepals. Stamens numerons. Pistil one, longer than the stanems.

Caper, Capparis. 


\section{ORder VI. VIOLACEA.}

Herbs. Stamens 5, 2 of them with spurs. Flowers irregular. One petal dissimilar, mostly prolonged into a hollow spur. Ovary free. Fruit, a capsule. Placentæ 3, on the wall. Leaves alternate.

Sepals with or without ears. Herbs acaulescent, or with stems. Flowers white, blue, yellow, or violet. Petals 5, one of which is broader than the others and prolonged into a spur.

Violet, Viola.

\section{Order ViI. BIXINE无.}

Shrubs. Flowers usually regular, with many stamens, perfect, axillary or terminal, solitary or fascicled, racemose or panicled. Leaves alternate.

Sepals 5, fleshy, spatulate, eared, and some multiple of 5 . Style threadlike. Fruit 1-celled, in a bristled pod.

Annatto, Bixa.

\section{ORDER VIII. TERNSTREEMIACE无.}

Shrubs and small trees. Leaves alternate, simple, entire, or toothed, sometimes with pellucid dots. Flowers axillary or terminal.

Calyx 5-parted. Petals, 5 or more, united at base. Stamens numerous, distinct, or united at their base into groups.

Tea, Thea.

\section{Order IX. MALVACEAE.}

Herbs and shrubs. Leaves alternate, monadelphous. Petals 5, large, twisted in the bud. Calyx cup-like, 5-toothed. Involucre 3-leaved. Styles united. Stigmas 3-5.

Capsules 3-5-celled, many-seeded. Seeds immersed in a wool-like substance, which is the cotton of commerce.

Cotton, Gossypium.

\section{Order X. STERCULIACE}

Trees and shrubs. Like Malvacer, except that the anthers are extrorse and 2-celled. Capsules united into a 2-5-celled ovary.

Leaves large, evergreen, oblanceolate, alternate. Calyx 5-parted. P'etals 5, cordate. Strap-shaped stamens, united at base, extending npwards in ten divisions. Pistil thread-like. Fruit, in form and size like an ordinary cucumber, 5-angled, warty, with 20-40 seeds imbedded in pulp.

Cocoa, Theobroma.

\section{Order XI. TILIACE王.}

Trees and shrubs. Leaves alternate, occasionally opposite; simple or palmately lobed, coriaceous, stipulate. Fruit 2-10-celled.

Leaves alternate, serrate, stipulate. Calyx 5-parted. Petals alternating with sepals. Stamens two or three times as many as the petals. Flowers solitar or in small terminal and bracteate cymes. 


\section{ORIER XII. LINACEA.}

Herbs. Flowers perfect, regular in terminal racemes or corymbs. Ovary 5-4-celled, or spuriously 10-8-celled. ('ells 2-ovuled. Styles :3-5, free. Fruit a globular capsule. Seeds flat.

Leaves sessile, entire, simple, alternate, occasionally upposite. Calyx 5parted. Corolla, with 5 petals. Stamens 5. Styles 5, alternating.

Flax, Linum.

Sepals 5. Petals 5, with a scale on the inner side of base. Stamens 10-12. Leaves alternate. Flowers axillary. Fruit a drupe. Shrub.

Coca, Erythroxylon.

\section{Order Mill. ZYGOPHYLLACEAE.}

Trees, shrubs, and herbs. Flowers perfect, regular, or irregular, axillary, solitary, or in twos. Fruit a loculicidal capsule, pentagonal, 5-celled. Cells 1-seeded.

Leaves, opposite, pimnate, stipulate, sometimes with spines. Calyx 5-parted. Petals 5. Stameus 5-10.

Lignum-vitæ, Guaiacum.

\section{Order yiV. RUTACEAE.}

Small trees and shrubs. Flowers inferior or perigynous and fragrant. Sepals and petals imbricate, $4-5$ in number. Fruit a berry. Seed imbedded in juicy pulp.

Leaves ovate, alteruate, frequently dotted, tapering to a point on a winged petiule. Calyx 5-sepaled. Petals 5-10, white. Stamens unmerous, and some multiple of 5 . Filaments flat at base, gronped in sets.

Orange, Lemon, Citrus.

\section{Order XV. MELIACEAE.}

Trees. Flowers in axillary panicles or thyrses. Inferior. Sepals and petals imbricate. Stamens united in a tube. Fruit penr-shaped, woody, :3 or 4 inches in diameter, 5-celled, 5-valved. Seeds numerous and winged.

Leaves alternate, compound, with 4 pairs of leaflets, dark-green, shining; leaflets opposite, entire, orate-lanceolate, unequal at base. Calyx 5-cleft. Petals 5. Stamens 10, united into a tube with 10 teeth inclosing the anthers. Style short. Stigma 5-rayed.

Mahogany, Swietenia.

\section{()RDER XVI. ILICINEA.}

Trees and shrubs. Flowers perfect, small. Solitary or grouped in the axils of the leaves. 1-b-parted. Fruit a drupaceons berry, bright red, small, smooth.

Leaves alternate, oval, crenate, glossy, leathery, evergreen, darker above, reined below. Calyx with 4 or 5 teeth. Corolla 4 - or 5-eleft, wheel-shaped Stamens 4 or 5 , alteruating with segments of corolla.

Paraguay Tea, Ilex. 


\section{ORDER XVII. RHAMNACEAS.}

Trees and shrubs. Flowers small, in axillary clusters, perfect, regular, parts 4-5, frequently without petals. Fruit a 1-seeded capsule.

Leares opposite or alternate. Calyx pitcher-shaped, or 4-5-cleft. Petals notched, sometimes wanting. Yellow berries.

\section{Buckthorn, Rhamnus.}

Leares ovate, acuminate, serrate, pubescent beneath, alternate and stipulate. Calyx a semi-globular tube, with 5 segments. P'etals clawed, rolled in at the edges. Stamens with ovate 2-celled anthers. Styles 3. Stigmas diverging. Fruit 3-berried.

\section{New Jersey Tea, Ceanothus.}

\section{ORDER XVIII. AMPELIDE正.}

A woody vine. Flowers, in compound panicles, green, and opposite the leaves. Stem climbing by tendrils. Fruit globular or elliptical, a pulpy berry, with 4-5 seeds.

Leaves simple, alteruate, stipuled, palmately veined. Tendrils opposite leaves. Calyx small, 5-toothed. Petals 5. Stamens 5. Stigma sessile.

Grape, Vitis.

\section{Order yix. SAPINDACE ÆE.}

Trees and shrubs. Flowers polygamous or dicecious. Petals sometimes wanting. Ovary 2 -lobed and 2 -celled, 2 ovules in a cell, maturing one seed in a cell. Fruit with 2 diverging wings.

Leaves opposite, lobed. Lobes toothed or cut. Calyx 5-parted. Petals 5 or 4-12. Stamens 4-12. Anthers 2-lobed.

Maple, Acer.

\section{ORDER XX. ANACARDIACE 压.}

Trees and shrubs. Flowers perfect, diœcious or monœcious, regular, small, in spikes or panicles. Ovary 1-celled. Fruit a little globose or kidner-shaped drupe.

Leaves alternate, simple or compound, with 8-15 pairs of sessile leaflets and a terminal one which is petioled, all dark above, light below. Calyx with 5 small persistent sepals. Petals 5, ovate, spreading. Stamens 5-10 or none. Styles 3 , sometimes mited.

Sumach, Rhus.

Leaves elliptical, green, leathery, alternate, obcordate, or deeply emarginate. Calyx 5-toothed. Corolla 5-parted. Stamens 5. Styles 3.

Cashew Nut, Anacardium.

\section{Order XXI. LEGUMINOS AE.}

Herbs, shrubs, and trees. Flowers regular or irregular, perfect (usually axillary). Ovary superior, single. Fruit a legume. Seeu flat, kidney-shaped, or globular, with large embryo and no endosperm.

Leaves compumul, bluish green, with about 6 leaflets, and a terminal one. Calyx 5 acute segments. Petals 5 ; standard roundish, and emarginate; keel 
spurred on each side, reflexed. Stamens 10, generally united, or 1 free. style simple. Pod many-seeded.

\section{Indigo, Indigofera.}

Leaves many, spreading. Leaflets in $7-12$ pairs. Calyx tubular, swollen, with 5 short, mearly equal teeth. l'etals long-clawed; standard ovate or pandurate; wings unequal, keel shorter than wings. Stamens 10,9 united, 1 free. Ovary sessile. Ovules many, in 2 series. Style straight. Stigma small.

\section{Gum Tragacanth, Astragalus.}

Leaflets 2 pairs. Calyx of staminate flower, a slender tube. Limb 2-lipyerl, upper lip 4-toothed. Corolla resupinate. Stamens 10,9 united, 1 abortive. l'istillate flowers. Calyx and corolla none. Ovary on a peduncle, lengthening downwards, forcing the pollenized pistil under ground. Legume usually with 2 oroid seeds.

\section{Peanut, Arachis.}

Stem weak. Leaves of several pairs of oblong leaflets, with a branched tendril. Flowers in a raceme. Pods short, broad. Seeds lens-shaped.

Lentil, Lens.

Leaves in 2-3 pairs, of elliptical, entire, obtuse, mucronate leaflets, stalk terminating in long branched tendrils. Stipules large. Calyx free, leafy segments, 2 shorter. Petals 5, upper one broad, and turned back. Stamens 10, 9 united, 1 free. Pods oblung. Seeds globular.

\section{Pea, Pisum.}

Leaves trifoliate. Flowers white in racemes. Calyx with two bracts at base, bell-shaped, 2-lipped, upper lip bifid. Corolla with a beaked keel, which with the stamens and style is spirally twisted. Porls linear, curred, flat or cylindrie. Seed kidney-shaped.

Bean, Phaseolus.

Leaves imparipimuate. Anther cells confluent. Pods prickly, short, almost indehiscent.

Liquorice, Glyccyrhiza.

Leaves in 4 or 5 pairs of irregular obcordate leaflets. Flowers in terminal spikes. Calyx cup-shaped, hemispherical. Sepals 5, imbricated. Corolla papilionaceous. Stamens 10, 5 shorter. Ovary free, 2-ovuled. Pods furnished with lance-shaped, flattened beans.

\section{Logwood, Hæmatoxylon.}

Leaves alternate, in 4-6 pairs of leaflets. Sepals barely united at base. Petals 5, unequal. Stamens 5-10, some imperfect. Pods many-seeded, with cross partitions. Fluwers yellow.

\section{Senna, Cassia.}

Calyx 5 segments. Petals 0. Stamens 5. Anther pods opening lengthwise. Styles short. Stigma peltate. Leaves abruptly pinnate. Stipules minute or 0 . Fluwers in short racemes.

\section{Carob Tree, Ceratonia.}

Leaves unequally pinnate or solitary. Flowers papilionaceous, white. Calyx unequally 5-toothed; stanclard obovate or orbicular, wings oblong ' hint. Stamens 10 or 9-bifid-didymous. Ovary stipitate. Ovules 2 or more. Pods oblong linear, flat, thin.

Rosewood, Dalbergia.

Leaves bipinnate. Calyx tube short; 5 segments. Petals 5 , orbiculate. Stamens 10. Seeds trausverse.

Pr. FL. -3

Brazil Wood, Cæsalpinia. 
Leaves alternate, stipules falling; 8-16 pairs of leaflets, small, crowded oblong, blunt, mequal. Calyx funuel-shaped, segments ovate, lance-shaped, acute. Petals 3, 1 posterior, 2 lateral, yellowish-white, with red veins. Stamens 3, filaments long and free. Ovary stalked, 1-celled. Ovules many. Style long and hooked. Pods long, flat, broad, curved, three strong woody fibers extending from end to end, along the pulp with which the pod is filled. Seeds 2-8, large, flat.

\section{Tamarind, Tamarindus.}

Leaves alternate or fascicled, bipinnate, rhachis slender, tomentose, ending in a gland with one also at the base. Flowers perfect or polygamous, small, in heads or spikes. Calrx 4-5-toothed. Petals united below. Stamens free, or united below, many longer than petals. Style thread-like. Pods 2-ralved, sometimes indelisceut, flat, or cylindric. Seeds many, flat.

Gum Arabic, Acacia.

\section{Order XXII. ROSACE无.}

Trees, shrubs, and herbs. Flowers perfect, regular, terminal, solitary, cymose, or in umbels. Sepals j or less, united. Petals 5 or 0. stamens many, in series, free or cohering, inserted with the sepals on the disk. Seeds 1 or few in each carpel. Leaves alternate and stipulate.

Leaves compound, of 1-2 pairs of leaflets and a terminal one, blunt at base, sharp at apex, white or glancous below, darker above. Calyx and corolla 5-parted. Stamens many. Ovaries many. Akenes little drupes, pulps, aggregated on a succulent receptacle.

Raspberry, Rubus.

Leaves on long radical petioles, trifoliate, pubescent, dentate, lateral leaflets oblique, nearly sessile. Flowers in cymes, stalk hairy. Calyx concave, deeply cleft. Sepals 5, with 5 alternate bractlets. Petals obcordate, white, large. Stamens many. Styles numerons, akenes naked on the surface of a subglolnlar, beart-shaped, pulps, edible receptacle.

Strawberry, Fragaria.

Leaves 3-5-foliate. Stipules subulate. Leaflets ovate or ohlong-lanceolate, villous beneath, petioles and midrib aculeate. Flowers in a raceme, white. Fruit ovoid, oblong, or cylindric, changing from green to red and black when ripe.

Blackberry, Rubus.

Leaves oblong, linear or lanceolate, tapering to the base, serrate and glabrous. Flowers solitary or in twos or threes, appearing before the leares. Fruit a smooth drupe. Stone smooth, flattened.

Plum, Prunus.

Leaves conduplicate in the bud. Flowers with the leaves, in racemes or umbels. Fruit smooth, globular. Stone smooth, globular.

Cherry, Prunus.

Leaves convolute. Flowers solitary or in pairs. Fruit a drupe, soft, velvety. Stone smooth, and flattened.

Apricot, Prunus.

Leaves as above. Flowers solitary, rose-colored. Fruit a tomentose drupe. Stone flattened aud corrugated, or wrinkled. 
Leaves conduplicate, appearing after the flowers. Fruit a tomentose drupe. Stone furrowed and flattened.

\section{Almond, Prunus.}

Leaves ovate, serrate, acute, crenate, woolly underneath, glabrous above. Flowers in corymbs, roseate, appearing with the leaves. Fruit a fleshy pome. Carpels 5 or 2 , inclosed in the fleshy calyx-tube.

Apple, Pear, Pyrus.

Leaves oblong or broad, ovate, blunt at base and sharp at apex. Seeds $\mathbf{5}$ or more.

Quince, Pyrus.

\section{ORDER XXIII. SAXIFRAGACEÆ.}

Shrubs and herbs. Flowers perfect, regular. Sepals, petals, and stamens 4-5. Stamens alternating with petals. Leaves alternate or opposite. Fruit capsular or berry-shaped.

Leaves 3-5-lobed, smooth above, pubescent below, unequally toothed. Flowers in pendent racemes. Calyx tube adherent to the ovary, 5-toothed. Petals 5. Stamens 5, alternating with petals. Fruit a many-seeded berry.

\section{Currant, Ribes.}

Leaves as above, villose. Flowers solitary or in twos. Fruit a globular or ellipsoidal many-seeded berry.

Gooseberry, Ribes.

\section{ORder XXIV. COMBRETACEA.}

Shrubs and trees. Flowers perfect, or imperfect by arrest, in axillary or terminal spikes, or racemes. A bract to each flower, also two lateral opposite bractlets. Leaves alternate or opposite.

Leaves simple. Calyx tube cylindric, adhering to ovary limb, bell-shaped, 4-5-toothed. Corolla 0. Stamens 10, on the calyx. Ovary inferior. Fruit a clrupe, size of a prune.

Myrobalans, Terminalia.

\section{Order XYV. MYRTACEAs.}

Trees. Flowers perfect, superior, regular, axillary or in spikes, cymes, corymbs, or panicles. Stamens numerous. Leaves opposite or whorled, entire, exstipulate. Fruit a berry or capsule, 2- or morecelled, 1-many-seederl. The Periwinkle (Vinca) of Apocynaceæ is often incorrectly called myrtle.

Leaves opposite, with punctured spots, ovate, lanceolate, erergreen. Calyx 4-6-parted, tube attached to ovary. Petals 4-6, together with the many stamens inserted in the neck of the calyx. Filaments free. Style solitary. Seeds on a central columm.

Myrtle, Myrtus.

Leaves opposite, entire, dotted with pellucid spots. Calyx 4-5-parted. Petals 4-5, free or mited. Stamens numerous, on the throat of the calyx. Flowers in cymes, or cyme-like panicles, 2-bracted, white or purple. Fruit oliveshaped, but smaller. Seed solitary.

Cloves, Eugenia. 
Leaves opposite, evergreen, lanceolate, blunt, prominently veined. Calyx and corolla 5-parted. Stamens numerous. Style simple. Fruit a berry, with 2 or more cells.

Allspice, Eugenia.

Leaves 2-3 feet long, broad, leathery, and prominently veined beneath. Calyx 4-parted. Corolla composed of 4 fleshy petals. Stamens united at base in 5 concentric circles. Filaments short. Stigma sessile, and cruciform. Ovary inferior 4-5-celled. Flowers in terminal panicles. Fruit 3-5 inches in diameter, globular. Nuts numerous, obovoid, triangular.

Brazil Nut, Bertholletia.

\section{Order XXVI. LYTHRACE无.}

Tropical trees. Flowers perfect, symmetrical, calyx inclosing ovary, but free. Leaves mostly opposite, entire. Fruit hard. Seeds many.

Leaves opposite, or fascicled, on short stalks. Calyx large, broadly tubular, thick and leathery. Lobes 5-7, triangular, acute, smooth, valvate. Petals 5-7 on the calyx, spreading, imbricated, crumpled, crimson. Stamens many on the calyx tube beneath the petals. Style tapering. Stigma simple.

Pomegranate, Punica.

\section{Order XXVII. CUCURBITACEAE.}

Herbs. Weak, long prostrate stems, creeping over ground. Flowers monœecious or diœeious, seldom perfect, solitary or fascicled, white or yellow, bell-shaped.

Leaves large, angularly lobed. Calyx tubular, bell-shaped, with 5 long teeth. Petals 5, attached to calyx. Stamens 5, in 3 groups. Stigmas 3. Fruit cylindrical, many-seeded. Seeds whitish, flat.

\section{Cucumber, Cucumis.}

Leaves heart-shaped or reniform, 3-5 inches long. Flowers as above. Fruit globular, sometimes a prolate spheroid, but usually flattened at the poles, and ribbed. Seeds many, flat.

\section{Muskmelon, Cucumis.}

Leaves 3-6 inches long, lobed. Lobes pinnately divided, glaucous beneath. Calyx, corolla, and stamens as above. Fruit globular, or shaped like a prolate spheroid, 6 inches to 2 feet in length, and 6-15 inches in diameter. Seeds many, flat.

\section{Watermelon, Citrullus.}

Leaves 5-angled, heart-shaped. Calyx, corolla, and stamens as above. Fruit wheel-shaped, and dished about the stem, convex on the opposite side.

Squash, Cucurbita.

Leaves broad, heart-shaped, or reniform. Calyx egg-shaped. Corolla bellshaped. Petals united half way. Flowers monœcious, axillary. Fruit globular, flattened, or prolonged at the poles. Seeds many, flat.

Pumpkin, Cucurbita.

\section{ORDER XXVIII. UMBELLIFER E.}

Herbs. Flowers small, 5-parted, superior in simple or compound umbels. Calyx lobes minute. Ovary 2-celled. Fruit, 2 dry indehiscent akenes, each akene with 5 primary, and often 4 secoudary ribs. 
Leaves pinnate or serrate. Calyx teeth 0 . l'etals white, base of style flat. Carpels nearly straight; umbels opposite leaves.

Leaves decompound. Calyx teeth 0. Petals white. Carpophore 2-cleft. Bracts of involucre few, small or 0 .

Anise, Pimpinella.

Leaves triangular in outline, $3-4$ times pinnate, divisions bristly ; foot-stalks short and clasping. "Flowers bright yellow; pedicels short; umbels large, 10-30 rayed. Involucre 0 . Calyx, limb indistinct. Petals roundish, obovate, entire, truncate.

\section{Fennel, Fœniculum.}

Leares decompound near the root, numerous on the stem, alternate; lower ones bipinnate, sheathing. Sheaths larger near the middle of stem. Calyx entire, or barely toothed. Petals broad, acuminate, short, and turned in. Fruit orbicular or egg-shaped. Flowers yellow, common. Involucre falling.

Asafœtida, Ferula.

Leaves piunate, stem channelled. Flowers yellow. Fruit flattened. Base of style flat.

Parsnip, Peucedanum.

Secondary ribs most prominent. Flowers white. Fruit globose. No primary involucre, bracts of secondary involucre thread-like.

Coriander, Coriandrum.

Leaves long-stalked and clasping below, sessile above, ternately divided. Calyx teeth bristle-like, outer ones longer. Petals deeply 2-lobed. Style short, erect. Flowers white or rose-colored, few; umbels stalked, irregular, few-rayed. General involucre composed of a few long, spreading, and deflexed narrow, stiff, 3-parted, or entire bracts. Involucels 2-4; small bracts.

Fruit oblong ovate, bristly. Bracts of involucre dissected.

Cumin, Cuminum.

Carrot, Daucus.

Leares pinnate. Yetals white, notched. Base of style conical. Carpophore 2-cleft. Fruit oblong ovate.

Parsley, Carum.

\section{Sympetalce.}

\section{Order Xxix. RUBIACEAg.}

Trees, shrubs, and herbs. Flowers perfect, seldom unisexual, mostly regular. Calyx tubular, 4-5-toothed or 0. Petals uniterl, limb 4-5parted, valvate in the bud. Stamens 4-5 on tube of corolla. Ovary inferior. Style simple. Leaves opposite or whorled.

Leares opposite, elliptical, entire, smooth above, hairy beneath. Calyx cup-shaped, 5-toothed. Corolla tubular, limb 5-parted. Stamens epipetalous: Pistil divided at top. Capsule 2-celled, opening at base. Flowers panicled and pinkish. Fruit wingerl.

Peruvian Bark, Cinchona.

Leaves elliptical, lanceolate, crenate, or wary, opposite and evergreen. Calyx tubular, 5-toothed. Corolla funnel-shaped, limb diviled into 5 reflexed lanceolate divisions. Flowers white, in axillary, nearly sessile clusters. Fruit a dark-red berry, cherry-shaped. Seeds imbediled in a glntinous pulp, 2 in number, plano-convex, grooved on the longer axis of the plane. 
Leaves opposite, 6 in number, oblong, obovate, acute, entire, 4-6 inches long, 1-2 wide, rough above, downy and veined below. Stipules clasping, much divided. Calyx bell-shaped, toothed. Corolla tubular, inflated at throat, 5-parted. Stamens 5, stigma bifid. Flowers in a head, enveloped in 5 leaves. Berry 2-seeded.

\section{Ipecacuanha, Cephaëlis.}

Stems weak, 4-angled, trailing and clambering. Leaves in whorls of 6 , lanceolate, midrib and margins aculeate. Calyx tube egg-shaped, 5-toothed. Corolla rotate, 5-parted. Stamens 5, short. Styles 2, united at base. Fruit berry-like, in twos, subglobular. Flowers brownish-yellow, terminal, in twos.

\section{Madder, Rubia.}

\section{Order XXX. COMPOSIT 无.}

Herbs. Flowers collected into dense heads surrounded by an involucre. Calyx tube attached to the ovary. Limb consisting of bristles (pappus), awns, or scales, or a cup. Corolla tubular or funnel-shaped, lobed or strap-like. Stamens equal to lobes of corolla, usually 5 . Style bifid at top. Ovary 1-celled, 1-ovuled. Fruit an akene. Herb with stout stem.

Leaves alternate, clasping above, petioled near the root. Ovate, rough, downy underneath, very large, 2 feet long, serrate, midrib large. Heads large, involucre imbricated, outer scales leaf-like. Ray flowers, pistillate, yellow. Disk flowers perfect.

\section{Elecampane, Inula.}

Stems, 6 to 12 inches high, perennial. Leaves 1-2 inches long, sessile divisions linear. Flower-heads terminal, on long axillary pedicels. Rays white. Floral envelope hemispherical. Rays many and pistillate. Receptacle convex.

\section{Camomile, Anthemis.}

Stems 18 inches high. Leaves smooth, bipinnate. Segments of pinnæ acute. Ray florets 20-30 pale pink, ligulate nerved and 3-toothed. Disk florets numerous, 4-5-toothed. Receptacle flat or convex. Scales short.

Chrysanthemum, Chrysanthemum.

Stems 2 to 3 feet high, strong, angular, and branched. Leaves alternate, clasping, bipinnate. Segments oblong, cut, and serrate. Heads in corymbose crmes. Staminate flowers in the central part of the pistillate, with a tubular 3-5-toothed corolla. Seed-ressel ribbed, 3-5 ridges.

Tansy, Tanacetum.

Stems 3 to 4 feet high, smooth, much branched. Leaves ovate, lanceolate, sessile, and subclasping. Teeth armed with sharp spines. Flowers orangecolored. Heads discoid, involucre imbricated, outer bracts leaf-like. Florets tubular, perfect.

Safflower, Carthamus.

\section{ORDER XXXI. CAMPANULACEÆ.}

Herb varying from 8 inches to 2 feet high, simple or lranched, pubescent. Leaves alternate, ovate, or lanceolate, irregularly toothed. Flowers blue, red, or white. Pods inflated. 


\section{ORIER XXXII. VACCINIACE ES.}

Shrub, 1 to 8 feet high, branching. Leaves alternate. Flowers white or reddish, small, in lateral bracted racemes. Calyx adherent, 5-toothed. Fruit a black or dark-blue berry, globular, 10-celled, i0-seeded.

\section{Huckleberry, Gaylussacia.}

Herb, stem slender, 1 to 5 feet in length, prostrate, throwing up assurgent branches. Leaves one half an inch long, elliptical. Calyx 4-parted; anthers twice as long as filaments. Fruit a berry, varying from bell-shape to globular.

Cranberry, Oxycoccus.

\section{Order XXXIII. SAPOTACEAs.}

Tree, 60 to 70 feet high, 2 to 3 feet in diameter. Leaves alternate, stipules falling; petioles long, stout, thickened at base; blade obovate oblong, leathery, clothed beneath with rusty yellow short woolly pubescence. Flowers axillary, stalked.

Gutta Percha, Dichopsis.

\section{Order XXXIV. EBENACE看.}

Tree, 30 to 50 feet high, 10 to 18 inches in diameter. Leaves elliptical, bluntly acuminate, entire, dark-green, paler underneath. Flowers diøcious and polygamons, 4-6-lobed. Corolla bell-shaped, 4-6-parted, rolled together in the bud. Stamens 4-8 or numerous. Calyx an inch or more in diameter, fleshy and persistent. Fruit globular, 4-8-celled, 8-12-seeded.

Persimmon, Ebony, Diospyros.

\section{Order XXXV. OLEACEAE.}

Small tree, 20 to 30 feet in height, much brancherl. Leares lanceolate, entire, deep-green above, light, hoary, beneath, and evergreen. Flowers axillary, in short compact racemes. Small and white calyx, short, 4 -toothed, persistent. Tube of corolla short, limb 4-parted. Fruit a fleshy oily drupe.

Olive, Olea.

\section{ORder XXXVI. LOGANIACE无.}

Small tree, 20 to 30 feet high. Bark smooth, gray, much branched ; branches swollen or knotted at the nodes. Leaves 5-nerved, with 2 ribs each, side of midrib extending from base to apex; ovate pointed. Calyx somewhat bellshaped, with 4 lobes which just meet. Stamens 4 or 5 on the corolla. Filaments short, attacherl to the back of the anthers. Fruit globular, size of a merliumsized orange, rind hard, smooth, yellow, inclosing a fleshy pulp in which are imbedded a number of flat circular seeds, concave on one side and convex on the other, an inch in diameter and a quarter of an inch thick. Wood hard and bitter.

Nux Vomica, Strychnos.

\section{Order XXXVII. BORRAGINACEAE.}

Herb, 4 feet high, branching near the top. Leaves large, coarse, petioled, lower ones broad, lanceolate. Flowers in terminal racemes. Calyx 5-parted. Corolla tubular, bell-shaped. 


\section{ORDER XXXVIII. CONVOLVULACE}

Herb, stem trailing. Calyx 5-parted. Corolla bell-shaped; limb spreading. Stamens 5 within the tube. Style simple. Stigma capitate, 2-lobed. Capsule 4-celled, 4-valved, 4-seeded. Juice milky.

Sweet Potato, Ipomœa.

\section{ORDER XXXIX. SOLANACE无.}

Herb. Calyx 5-6-parted. Corolla rotate, tube short. Stamens 5-6, exserted. Anthers connate, dehiscing lengthwise. Berry many-seeded.

Tomato, Lycopersicum.

Herb. Calyx urn-shaped, 5-toothed. Corolla funnel-shaped, 5-lobed. Stamens 5. Capsules 2-celled, 2-4-valved. Flowers terminal.

Tobacco, Nicotiana.

Herb, 2 to 5 feet high, 3-forked. Leaves in pairs, unequal, entire, pointed. Petioles short, 8-12 inches long. Flowers large, axillary, pendent, brownish purple. Calyx leafy, 5-parted. Corolla bell-shaped, 5-cleft. Stamens shorter than the corolla. Fruit a berry, globular, 2-celled, black when ripe.

\section{Deadly Nightshade, Atropa.}

Herb, 18 to 30 inches high, smooth, branching. Leaves ovate, smooth, entire. Flowers solitary, axillary, white. Calyx tubular, with 5 small divisions. Corolla wheel-shaped, in 5 lapping pointed divisions. Fruit a berry, with an inflated pericarp, globose, conical, or oblong, solitary or in pairs.

Red Pepper, Cayenne Pepper, Capsicum.

Herb, erect, prostrate, or assurgent. Stem 2-4 feet long, angular, and branched towards the top. Leaves interruptedly pinnate, every alternate pair of leaflets very small. Flowers blue or white. Calyx persistent, 5-parted. Corolla rotate, bell-shaped, tube short; limb 5-cleft. Anthers connivent. Fruit a globular berry, 2-celled, many-seeded, roots swelling into tubers.

Potato, Solanum

\section{Order XL. PEDALINEÆ.}

Herb. Leaves opposite or alternate, simple exstipulate. Flowers perfect, irregular, axillary, solitary, racemed or spiked, usually with two bracts. Calyx 5-lobed, sometimes split on one side. Corolla sympetalous. Tube cylindrical. Stamens 5 on the corolla, 1 sterile, 4 fertile ones didymous. Ovary superior, 1-2-4-celled. Fruit a drupe.

Sesame, Sesamum.

\section{Order Xli. VERBENACEA.}

Tree, 80 to 150 feet high, 3 to 6 feet in diameter, branchlets 4 -sided. Leaves opposite on ternate verticils, rough above, downy beneath, entire. 1-2 feet long, 6-18 inches wide. Flowers small, sessile, white, in terminal compound dichotomous panicles. Fruit lens-shaped, 4-celled drupe. Calyx bell-shaped, short, 5-6-cleft. Tube swollen below, contracted near the mouth. Corolla tube short, limb gaping, 5-6-cleft, lobes short. Stamens 5-6, attached to corolla near the base.

Teak, Tectona.

\section{Order xlit. LABIATAE.}

Herb, 15 to 20 inches high or more, branching near the ground. Leares crowded near base of branches, whitish, downy, oblanceolate, tapering to the 
base, sessile, revolnte, upper ones narrow. Flowers in an interrupted spike. Calyx spindle-shaped, 13-15 striæ, 5-toothed, upper tooth largest. Corolla tube exserted, upper lip 2-lobed, lower one 3-lobed. Stamens slorter than corolla.

Lavender, Lavandula.

Herb, 12 to 20 inches high, from a creeping root. Leaves opposite, wrinkled, sub-sessile, lanceolate acute, cut serrate. Bracts narrow, lanceolate, bristly. Flowers in verticils, small, crowded, short-stalked. Calyx 5-toothed. Corolla 4-cleft, a little longer than calyx. Whole plant possesses a strong, agreeable odor.

Spearmint, Pennyroyal, Mentha.

Herb, 1 to 2 feet high, hairy, purple, leafy, and branched above. Leaves opposite, nearly entire, sprinklerl with resinous dots. Flowers in a terminal 3-forked panicle, in globular compact heads. Calyx egg-shaped, obsenrely 13-nerved, 5-toothed, throat hairy. Corolla 2-lipped, npper one notched, lower longer, 3-lobed. Stamens 4, ascending and spreading.

Marjoram, Origanum.

Herb, 12 inches high, slender, woody branches. Leaves sessile, linearlanceulate or ovate, revolute, hoary beneath. Flowers small, purple, in terminal globose heads. Calyx bilabiate, 10-13 stria, 5-toothed, 3 upper teeth short, lower pair linear. Corolla 2-lipped, upper lip notched, lorter one 3-lobed, midlle one sometimes larger. Stamens 4, exserted.

Sweet Thyme, Thymus.

Herb, 1 to 2 feet high, woody. Leaves elliptical, wrinkled, crenulate. Flowers in two opposite sets of 10-12 flowers. Calyx striate, 2-lipped, upper lip 3. toothed or entire, lower one bifid. Corolla 2-lipped, gaping, sometimes notched, lower one 3-lobed. The cross filament has a perfect half-anther on one end and a defective half-anther on the other.

Sage, Salvia.

Shrub, 4 feet high, much branched, hairy branchlets 4 -sided and downy. Leaves opposite, an inch long, narrow, linear, obtnse, entire, revolute, darkgreen above, smooth and shiny, woolly, veined, and silvery beneath. Flowers axillary and terminal, blue. Calyx bell-shaped, a little flattenerl, 2-lipperl, upper lip minutely 3-toothed. Corolla gaping, downy, pale-blue, variegated with purple and white, tube longer than calyx; upper lip bifid, lower one slit into 3 segments, middle segment larger. Four nutlets at bottom of calyx.

Rosemary, Rosmarinus.

Herb, 3 feet high, square, branched, hoary. Leaves cordate, crenate, toothed, and petioled, hoary. Flowers in large hoary spikes, whorled, white or purplish. Calyx cylindrical, 5-toothed, marked with 15 strix. Corolliı slender helow, swollen in the throat, upper lip emarginate, lower one spreal ing; 3-lobed, middle lobe largest, crenate, marked with crimson dots. Whole plant giving off a pleasant odor.

\section{Catnip, Nepeta.}

Herb, 12 to 18 inches in height, many stems from same root, whole plant hoary. Leaves ovate, rounded at base, crenate, toothed, wrinkled, and woolly. Flowers white, sessile, in dense globose verticils. Calyx tubular, woolly, 5-10-toothed, with a corresponding number of stria. Corolla 2-lipped. upper lip erect, sometimes divided; lower one spreading, 3-lobed; middle lobe largest and notched.

Hoarhound, Marrubium. 


\section{Apetalce.}

\section{Order XLIII. CHENOPODIACEA.}

Herb, 2 to 5 feet high, angled and branched. Leaves alternate, 6-15 inches long, 4 to 8 inches wide, upper ones smaller; dingy copper-color to dark-purple; ovate lanceolate or spatulate. Flowers greenish-white in slender spikes, arranged in leafy panicles. Calyx hollow and contracted at the mouth, 5-cleft, persistent, becoming hardened at the base. Stamens 5. Stigmas 2. Seeds rugose or wrinkled. Root conical or napiform.

Beet, Beta.

Herb, 18 to 24 inches high, slightly branched or simple. Leaves alternate, petioled, 3-5 inches long, frequently hastate and lanceolate. Flowers diœecious, bractless, axillary, clustered, staminate flowers with a 4-5-parted calyx. Calyx of the fertile flower tubular, swelled in the middle, 3-toothed. ()vary eggshaped, 1-celled, 1-ovuled, with 4 lengthened stigmas. Fruit 1-seeded, included within the hardened 2-4-horned calyx. Seeds flattened.

Spinach, Spinacia.

\section{Order Xliv. POLYGONACE无.}

Herb, 1 to 3 feet high, furrowed, stont, and hollow. Leaves cordate, triangular, or hastate. Flowers in terminal and axillary racemes, rose-colored or white. Calyx composed of 5 colored, equal sepals. Stamens 8. Styles 3. Fruit with three triangular faces.

Buckwheat, Fagopyrum.

Herb, 4 feet high, furrowed, stout, hollow. Leaves stipnlate, large, sheathing, entire, cordate, smooth, upper leaves smaller. Flowers in racemose, paniculate fascicles. Calyx colored. Sepals 6 , in double series, persistent. Stamens 9. $\Lambda$ kenes 3 -angled, edges winged. Root large, fleshy, yellow within.

Rhubarb, Rheum.

\section{Order XLV. PIPERACEAE.}

Shrub, 5 to 8 feet long, climbing, nodes swollen. Leaves opposite, ovate, cordate, uneven at base, leathery, glossy above, 5-7-nerved, 5 inches long. Flowers without perianth. Stamens $2-4$ or 5 . Ovary 1-celled. Stigmas 2-5. Fruit a small berry, globular or egg-shaped. 'Tropical and subtropical.

Pepper, Piper.

\section{ORDER XLVI. MYRISTICACEAE.}

Trees and shrubs. Juice astringent, turning red when exposed to the air. Leaves alternate, coriaceous, simple, entire, penninerved, clothed with hairs or scales. Flowers diœcious, axillary, inconspicuous, white or yellow, in racemes, panicles, or heads, with a solitary bract. Staminate flowers with 315 stamens, monadelphous, filaments united into a column. Pistillate flowers with a solitary carpel. Seed-vessel fleshy. Seed enveloped in a laciniate aromatic aril.

\section{Nutmeg, Myristica.}

\section{Order XLVII. LAURACE无.}

Tree, 30 to 80 feet high, 1 to 2 feet in diameter. Leares alternate, brightgreen above, glancous beneath, evergreen, thick. Flowers small, in cymes, 
perfect or polygamous. Receptacle funnel-shaped, periauth in 6 parts. Stamens 12, 3 of which are sterile. Fruit a berry.

Camphor Tree, Cinnamon, Cinnamomum.

\section{Order XLVIII. SANTALACE ÆE.}

Herbs, shrubs, and trees, frequently parasitic. 'The Santalum is a large tree, of Southern Asia. Leares opposite, oblong, entire, penninerred in 5 pairs. Stamens equal to sepals, and opposite to them. Ovary inferior. Fruit dry, l-seeded. Flowers terminal.

Sandal-wood, Santalum.

\section{Order Xlix. EUPHORBIACEA.}

Ilerbs, shrubs, and trees. Juice milky, acrid, sometimes watery and poisonous. Leaves alternate, rarely opposite or whorled, sometimes very small. Flowers with single, double, or no perianth.

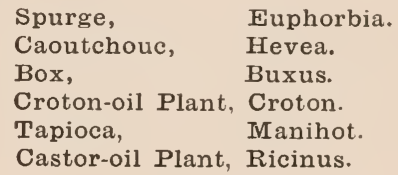

\section{ORDER L. URTICACE正.}

Trees, shrubs, and herbs. Flowers diclinous. Stamens as many as the calyx lobes, and opposite to them. Ovary 1-celled. Style simple or 2-cleft. Sap of trees milky or watery. Leaves alternate and stipulate; stipules falling.

$\begin{array}{ll}\text { Mulberry, } & \text { Morus. } \\ \text { Elm, } & \text { Ulmus. } \\ \text { Hop, } & \text { Humulus. } \\ \text { Fig, } & \text { Ficus. } \\ \text { Hemp, } & \text { Cannabis. }\end{array}$

\section{ORDER LI. JUGLANDACE ES.}

Trees. Flowers diclinous, perianth of staminate flower a scale; that of pistillate flower 2-4-toothed. Ovary 1-celled, l-ovuled. Fruit a drupe. Endocarp 2-valved. Leares pinnate, stipulate.

$$
\begin{aligned}
& \text { Butternut, Walnut, Juglans. } \\
& \text { Hickory nut, Pecan Nut, Hicoria. }
\end{aligned}
$$

\section{OrDER LII. CUPULIFER \&E.}

Trees. Staminate flowers with an unequally lobed calyx. ('alyx of pistillate flowers 6-toothed. Ovary 2-6-celled. Fruit one to three 1-seeded nuts in an involucre. Leaves alteruate, simple, stipulate.

Chestnut, Castanea.
Oak, $\quad$ Quercus.
Hazelnut, Corylus.
Beech, Fagus.




\section{Order LIII. SALICACEE⿱一𫝀.}

Shrubs and trees. Flowers in a catkin. Diœcious. Stigma 2-3-lobed. Leaves alternate, stipulate.

Willow, Osier, Salix.

\section{Class II. MONCOTYLEDONOUS ANGIOSPERMS.}

Leaves parallel-reined.

Order LIV. ORCHIDACEAE.

A woody vine. Flowers perfect, but very irregular in form. Stem climbing, 16 to 20 feet loug. Fruit 6 to 10 inches in length.

Vanilla, Vanilla.

\section{Order LV. ZINGIBERACE无.}

Herbs. Flower perfect, irregular. Perianth 6-parted. I stamen. Anther 1-celled.

$\begin{array}{ll}\text { Turmeric, } & \text { Curcuma. } \\ \text { Arrowroot, } & \text { Maranta. } \\ \text { Cardamom, } & \text { Elettaria. } \\ \text { Ginger, } & \text { Zingiber. } \\ \text { Banana, Manilla, Musa. }\end{array}$

\section{ORder LVI. BROMELIACEÆ.}

Herbs. Flowers perfect, mostly regular. Perianth 6-parted, with 6 perfect stamens.

Pineapple, Ananassa.

\section{ORDER LVII. IRIDACE㘴.}

Herbs. Flowers perfect, bell-shaped.

Saffron, Crocus.

\section{Order LVIII. DIOSCOREACEAE.}

Shrubs. Flowers diøcious, regular and axillary. Racemes inconspicuous.

Yam, Chinese Yam, Dioscorea.

\section{ORDER LIX. LILIACEAE.}

Herbs. Flowers perfect, usually terminal and solitary. Perianth 6-parted. Fruit a capsule. Leaves sheathing.

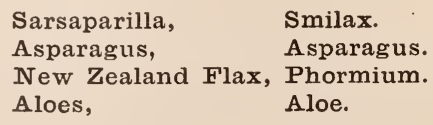




\section{Order LX. PALM 无.}

Shrubs, small and large trees. Flowers in a branched spadix. Perianth in 6 parts arranged in 2 series. Stamens usually 6. Fruit variuus in form and size.

Betel Nut, Areca.

Date Palm, Phœnix.

Cocoanut, Cocos.

Sago Palm, Metroxylon.

\section{Order LXI. GRAMINE E.}

Herbs. Flower envelope usually with 2 (rarely more) small scales. Fruit grooved on one side. Stem tapering and usually hollow. Leaves sheathing.

$\begin{array}{ll}\text { Indian Corn, } & \text { Zea. } \\ \text { Wheat, } & \text { Triticum. } \\ \text { Rice, } & \text { Oryza. } \\ \text { Sugar Cane, Saccharum. } & \text { Sacham. } \\ \text { Broom Corn, } & \text { Sorghum. } \\ \text { Rye, } & \text { Secale. } \\ \text { Barley, } & \text { Hordeum. } \\ \text { Oats, } & \text { Avena. } \\ \text { Millet, } & \text { Setaria. }\end{array}$

\section{Class III. GYMNOSPERMS.}

\section{ORDER LXII. CONIFER 必.}

Shrubs and trees, mostly trees. Flowers without perianth. Fruit nakel In the scales of a cone or in a berry-like cup. Leaves opposite, whorled, or fascicled, simple, with simple nerves.

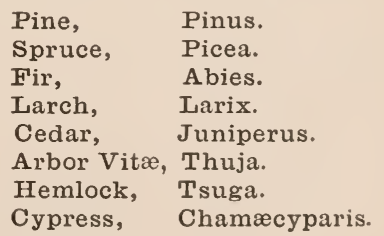




\section{DESCRIPTIVE BO'TANY.}

\section{ORDER I. RANUNCULACEÆE.}

FLowers perfect, regular or irregular, rarely diœecious, mostly terminal, solitary, racemed or panicled, white or yellow. Sepals :3many, usually 5 , free, sometimes petaloid, imbricate, seldom valvate. Petals equal to and alternate with the sepals, hypogynous, free, clawed, imbricate, equal or unequal, varied in form, frequently minute or wanting. Staukxs numerous, many-rowed, hypogynous; filaments thread-like or clarate, free; anthers terminal, ?-celled. Carpers few or many, seldom solitary ; style simple; stigma, usually on the inner surface of the top of the style; fruit pointed or feathery akenes. SEens with coriaceous testa. LEAves radical, or alternate on the stem and branches, seldom opposite, simple or compound, exstipulate; petiole broadened or clasping. Mostly herbs, or woody climbers, occasionally shrubs, with sharp, bitter, mostly poisonons juice. There are 30 genera in this Order varying greatly in form, and 540 species, growing in temperate and cold climates.

ANEMONE, L. (Windflower.) Sepals, ó or many, petal-like. Petals wanting or rudimentary. Stamens numerous, short. Fruit in roundish or subcylindrical head. Akenes mucronate. Involucre open and below the flowers, which are terminal. Herbs, peremnial, with radical leaves.

1. A. cylindrica, Gray. (Long-fruited Anemone.) Stem 1 to 2 feet high, silky, pubescent. Leaves 2-3 inches wide, 3-parted, parts wedge-shaped, deeply lobed, and toothed. Side lobes 2-parted, middle one 3-parted, lubes toothed and gashed at the apex; petioles 3 to 6 inches long; involucre longpetioled. Flowers on long, naked, 2-flowered peduncles, 3-6 in number, occasionally I- or more-involucred. Sepals 5, silky, greenish white, blunt. Fruit in cylindrical heads an inch or more long. May.

Geography. - Dry copses. Mass. to New Jersey, and west to Colorado.

2. A. decapetala, L. (A. Caroliniana, Walt.) (Carolina Anemone.) Stem 3 to 10 inches high, pubescent above; tuber round, sending up several leaves and one stem or seape. Leaves long-stalked, 3-parted, much divided into wedge-shaped linear divisions. Involucre below middle of scape, 2- or 3-leaved, each 3-parted, segments 3-cleft. Flowers showy, sepals 10-20, nearly linear, outer ones dotted with purple. Fruit in oblong cylindrical head. April, May.

Geography. - Carolina to Arkansas and Nebraska.

3. A. dichotoma, L. (A. Pennsylvanica, L.) (Pennsylvanian Anemone.) Stem 12 to 20 inches high, frequently less than 12, - dichotomous and hairy. Leaves of the root 3-i-parted, segments cuneate, 3-lobed and acuminate, or pointed, parts large and veiny; those of the main involncre 3-parted, acuminate-lobed and toothed, those of involucres, sessile. First flower appears on a naked peduncle from the base of which rise two branches, each with a 2-leaved 


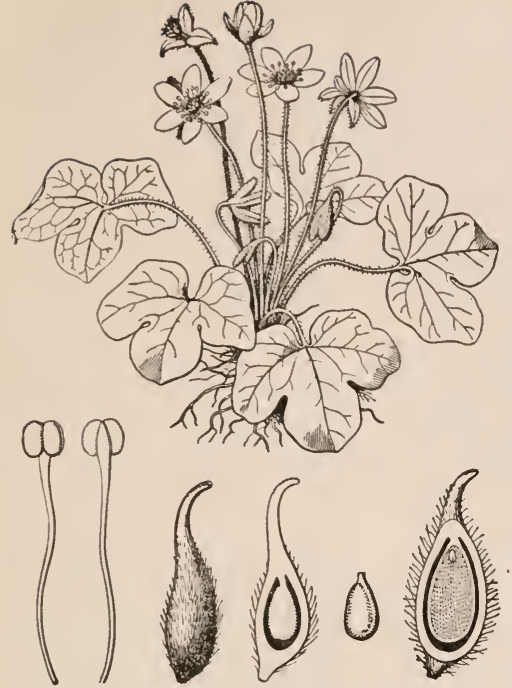

Anemone hepatica (Round-lobed Hepatica).

involucre, and one terminal flower. Flowers white, large; sepals 5 , obovate. Fruit in a globular head. June to Aug.

Geography. - ('anada to Penn. and west to Ind. and Wis. sparingly.

4. A. hepatica, I. (Hepatica triloba, (Chaix.) (Round-lubed Hepatica.) Leaves 3-lubed ; lobes ovate, obtuse, or rounded, entire, all radical, on long, hairy petioles, smooth and evergreen; purplish underneath. Flowers single, on scapes, 3 to 4 inches long, purplish blue or nearly white. Sepals 6-9. Akenes several, in a small loose head, pointed aud hairy. March to May.

$\mathrm{Th}$ is plant is one of the earliest harbingers of spring, often putting forth its blossoms in the neighborhood of some lingering snowbank.

Geography. - Canada to Georgia, and west to the Mississippi valley. In damp woods, not rare, identical with the European plant.

5. A. acutiloba, Lawson. (Hepatica acutiloba, DC.) (Sharp-lobed Hepatica.) Lobes of the leaves acute; number of lobes sometimes 5; lobes of the involucre also sharp. Sepals 7-12, pale-purple, or nearly white.

Geography. - The A. acutiluba is found in the same geographical limits as the $A$. hepatica.

6. A. multifida, DC. (Many-cleft Anemone.) Stem 6 to 12 inches high, clothed with silky hairs. Radical leaves, 3 divided segments wedgeshaped, slit into 3 narrow sharp lobes, petioles 3-4 inches long. Leaves of the involucre 2-3 on short petioles, divided as the root leaves. Flowers purple, varying to yellowish-white. Sepals 5-8, hlunt, small. Fruit in a globular head. June.

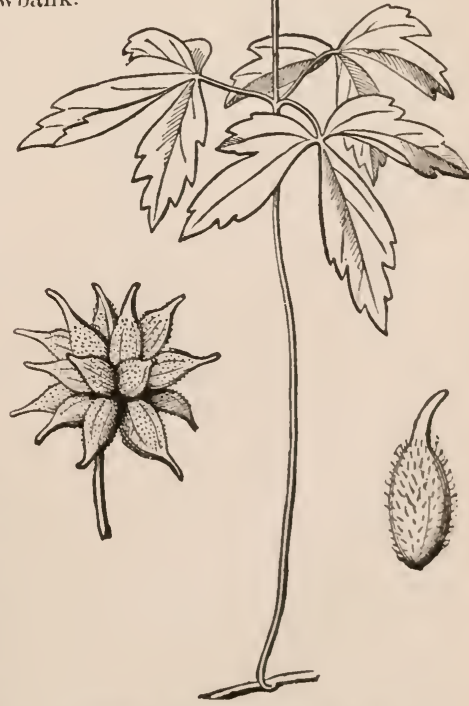

ANemone nesurosa (Windtlower). 
Geography. - Vermont, northern N. Y., and north and west to the Pacific, rare.

7. A. nemorosa, L. (Windflower. Wood Anemone.) Stem 5 to 10 inches high, smooth, from a filiform, frequently knotty, root stock. Radical leaf solitary, ternate, leaflets usually undivided, occasionally 3-parted or cleft; leaves of the involucre petioled, 3 in number, and near the summit of the stem, just above which is the solitary flower; sepals 4-7, oval or elliptical, white, pinkish or purplish outside. Fruit in a head, carpels oblong, tipped with a hooked beak. April, May.

Geograply. - Northern United States and British America, in open woods near the base of old trees.

8. A. parviflora, Mx. (Small-flowered Anemone.) Stem 3 to 10 inches high, pubescent. Leaves 3-parted, parts 3-cleft and wedge-shaped, divisions crenate; involucre 2- or 3-leaved, nearly sessile, divided as the other leaves. Flowers white, sepals 5-6, oval. Fruit in a globular head. May to June.

Geography. - Canada, near Lake Superior, west to the Colorado Mountains, and north to the Arctic Ocean.

9. A. patens, L. (Var. Nuttaliana, Gray.) (Pasque-flower.) Stem 6 to 12 inches high, clothed with silky hairs. Leaves on long petioles, silky, ternately divided segments, cut into linear and wedge-shaped sections, the middle segment stalked and 3-parted, involucre below the middle of the stem, sessile and finely dissected, concave or cup-shaped. Flower solitary, appearing before the leaves, sepals 5-6 or 7 , nearly an inch long, pale-purple and showy, silky outside.

Geography. - Dry hills. Illinois, Wisconsin, and west and north to the Rocky Momntain region.

10. A. Virginiana, L. (Virginian Anemone. Thimble weed.) Stem or scape 2 to 3 feet high, hairy, usually divided above into 2 or 3 long peduncles, with involucres of two bracts at the middle, or 1 naked, main involncre 3-leaved. Leaves on petioles 6 to 10 inches long, stalks of the bracts shorter, leaf 3-parted, parts orate-lanceolate, toothed and lobed; those of the side 2-parted, middle one 3-cleft. Sepals 5, greenish-yellow or whitish. Fruit in oblong, woolly heads. June to August.

Geography - Canada, south to Carolina. Woods and damp copses, common.

Etymology and History. - Anemone is from the Greek word a $\nu \in \mu o s$, wind; the ancients beliered the plant always appeared in places exposed to the wind. The specific names are from the Latin, and are explained by the common names, which are translations, as follows: Parviflora, small-flowered; Multifida, many-cleft; Caroliniana, Carolina Anemone, etc. Hepatica from the Greek $\dot{\eta} \pi \alpha \tau$ ткós, the liver, due to the fancied resemblance of the 3 -lobed leaves to the shape of the liver. Most of the species are natives of Europe.

Cultivation.-By cultivation the size of the flower may be increased; the colors are modified, and many of the stamens are often changed into small petals. The anemone prefers a light soil ; the root is taken up after flowering, the plant being propagated by parting the roots as well as by seed. Seeding plants do not flower till the second or third year.

Use. - Sereral species of anemone are used for ornamental purposes. They are easily raised from the seed, and a bed of the single varieties is a valuable addition to a flower-garden, as it affords in a warm situation an abundance of handsome and brilliant spring flowers, appearing almost as early as the snowdrop and the crocus. In Europe it is used as borders in planted grounds, and 
some species are such favorites with florists and amateurs as to have an important commercial value, especially in England and Germauy. 'The anemone acutiloba is used by empirics for the cure of pulmonary disorders.

ANEMONELLA, Spach. Involucre not close to the flower, composed of 2 ternate sessile leaves. Calyx regular, composed of 3 to many colored sepals. Corolla wanting. Ovaries numerous, free, forming a subglobular head. Akenes with short beak. Leaves radical.

A. thalictroides, Spach. (Thalictrum anemonoides, Mx.) (Rue Anemone.) Sitem smooth, 5 to 10 inches high. Leaves glabrous, biteruate, or triternate, common leaf-stalk 2 to 5 inches long. Leaflets roundish, 3-lobed at the end, cordate at base. Flowers subumbellate, involucre of two ternate leaves. Several white or pale-purple sepals, sometimes lobed like the leaves. Flowers in early spring.

This plant is one of the few that greet us in early spring in the Northern States, and upon which the norice in botany takes his first lessons.

Geography. - Cauada to Georgia, and west through the Mississippi valley, in open woods, near the roots of trees, and especially in windy exposures.

RANUNCULUS, L. (Buttercup. Crowfoot.) Sepals 5. Petals 5 or more, a scale or pit at the base. Stamens numerous, sel-

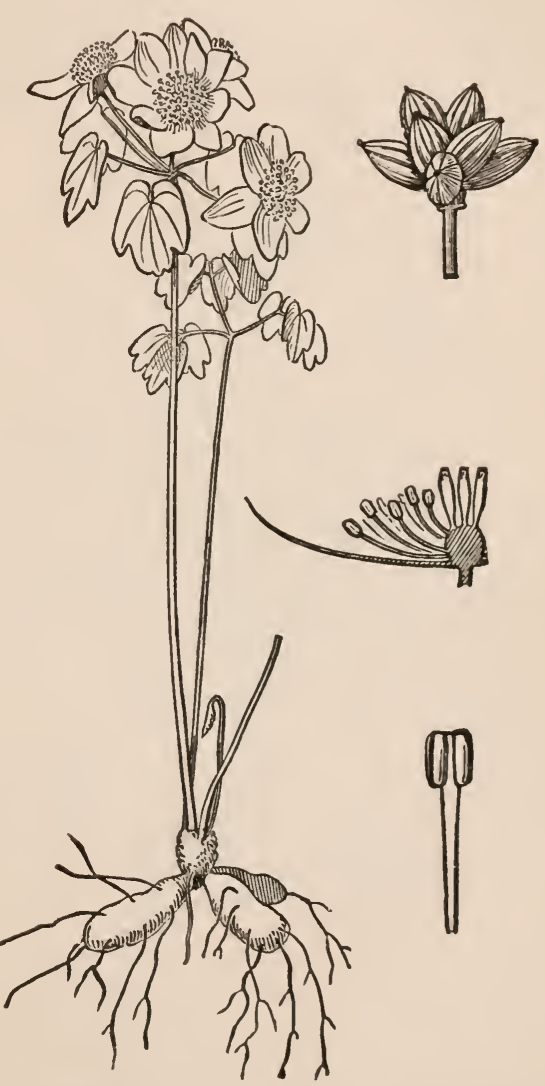

Anemonella thalictroides (Rue Anemone). dom few. Akenes many, flattened, ovate, pointed, arranged in globular or cylindrical heads. IJerbs, annual or perenuial. Leaves usually radical. Flowers terminal, solitary, or in imperfect corymbs, yellow, sometimes white.

1. R. abortivus, L. (Simall-flowered Crowfoot.) Stem branching, smooth, 6 to 30 inches high. Leaves at the base petiolate, cordate-orbicular, crenate, frequently 3-parted; stem-leaves in threes, 3-5 cleft, with linear, oblong, nearly entire segments; upper ones sessile, foliage varying greatly in form.

PR. FL. -4 
Flowers small, yellow. Sepals reflexed, longer than the petals. Carpels in a globular head tipped with a short recurved beak. May to June.

Geography. - Common throughout the northeastern States, and west to California. Damp and shaded places.

Var. micranthus, Gray. (R. micranthus, Nutt.) Has whole plant more or less clothed with soft hair's ; rout leaves seldom cordate, some of them 3-parted;

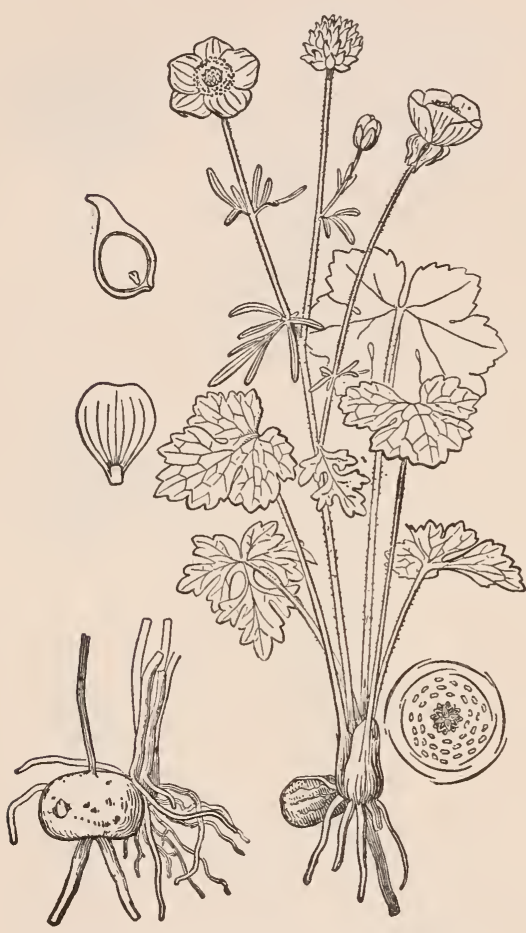

Ranunculus bulbosus (Bulbous Crowfoot). divisions of those on the upper parts of the stem more linear and entire; peduncles more slender.

Geography. - Mass., New York, Miss., and West. In dryer, more open grounds than the species.

2. R. acris, L. (Buttercup, Wayside Crowfoot. Garden Buttercup, Biting Crowfoot.) Stem erect, branched, 1 to 3 feet high, hairy, round, hollow. Leaves on long stalks at the base and on the lower parts of stem, upper ones on short sheathing petioles, divided into 3 parts or leaflets; leaflets lobed, segments acute, parts sometimes linear. Flowers large, bright-yellow, shining, becoming double by cultivation. Petals obovate, larger than the spreading sepals. Carpels roundish, smooth, compressed, terminated by a roundish recurved beak. June to August.

Geography. - This is a European plant. It was brought to northeastern N. America in seed-grain by European colonists, has spread over the Atlantic States and Canada, and is reaching towards the West. Common in fields, especially damp meadows, and roadsides.

3. R. ambigens, S. Wats. (R. alismæfolius, Gray, not Geyer.) (Water Plantain, Spearwort). Leaves entire. Stem hollow, 1 to 2 feet high, falling when young, rooting at lower joints afterwards assurgent. Leaves 3 to 6 inches long, narrow, lanceolate, entire or toothed, acute, subpetiolate, clasping, especially below, nearly sessile above. Petals 5 or 7 , golden yellow, larger than sepals. Flowers solitary. Petioles 2 to 3 inches long. Carpels flattened, large, and armed with loug, fine beak. June to Augnst.

Geography. - Northeastern North America, South Carolina, west to Oregon. In damp places, edges of still water, coves of sluggish brooks. 
4. R. aquatilis, I. (Var. trichophyllus, Gray.) (White Water-crowfoot.) Stem 1 to 2 feet long, slender, weak, round, smooth, jointed, floating. Leaves stalked, dichotomonsly divided into many diverging hairlike segments, submerged, or some tloating, rounded, 3-5-lobed. l'etals white, narrow. June to August.

Geography.-Found sparingly from Arctic Ameriea to South Carolina, west to the Rocky Mountains. In ponds and sluggish streams.

5. R. bulbosus, I. (Bullons Crowfont. Buttercup.) Stem 8 to 13 inches high, hollow, erect, sparingly clothed with appressed pubescence, or densely corered witl stiff, sprearling hairs, somewhat branched, enlarging at the base into a bulb. Leaves mostly radical, on loug stalks, teruate, middle leaflet stalked, lateral divisions sulj-sessile, lobed, with crenate or acute divisions; stem leaves ou short sheathing petioles, or nearly sessile; lubes much cut into linear divisions. Flowers brightyellow, large, showy, becoming double by cultivation. Petals rounded, werlge-shajed at base, much longer than the reflexed sepals, frequently 6-7 in number. Carpels tipped with a short beak. May to August.

Geography. - 'This is emineutly a British plaut, and was no doubt introduced into northeastern North America by British colonists in their seerlgrain, etc. Abundant in the damp mealows and

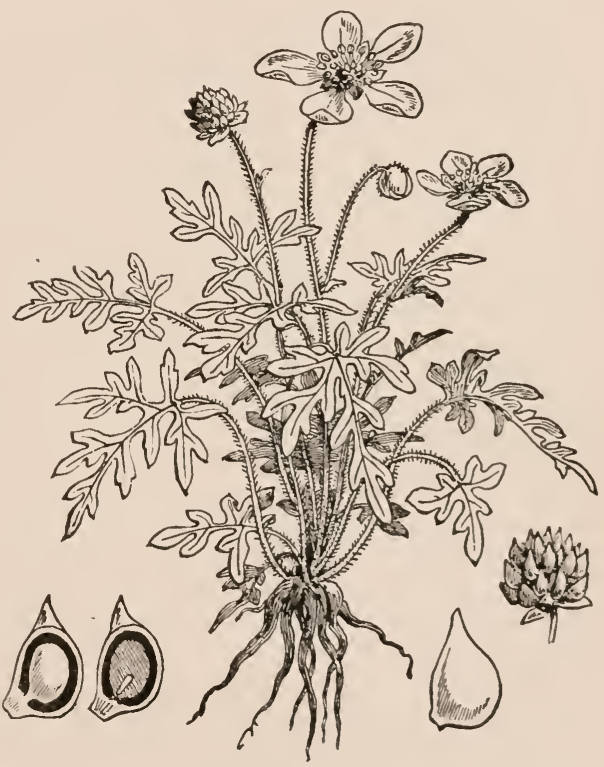

Ranunculus fascicularis (Fascicle-rooted Crowfoot). pastures of the Itlantic States, especially in New England and eastern New York and New Jersey.

6. R. Cymbalaria. Pursh. (Seaside Crowfoot.) Stem slender, 3 to 8 inches long, creeping and rooting. Leaves clustered near the root, cordate, kidneyshaped, crenate-(lentate. Flowers bright-yellow, scapes 3 to 6 inches long, $1-7$ flowered, mostly without leaves. Petals 5-8, oval. Carpels striate, beak short. June to Angust.

Geography. - Coast of New Jersey, northward to Canada, along the borders of salt marshes, especially coasts of the Bay of Fundy; near salt springs; inland along the Great Lakes; west to California.

7. R. fascicularis, Muhl. (Fascicle-rooted Crowfoot. Early Crowfoot.) Stem erect, 6 to 10 inches high, clothed with silky hairs ; root a bundle of Heshy fibers. Leaves of the mper part of the stem on short petioles, the radical and 
lower ones on stalks from 3 to 8 inches long; blade of the radical leaves pinnate, or very much divided; the terminal division stalked, lateral ones sessile. Flowers large; petals yellow, spatulate, or oblong, with a seale at base, much longer than the sepals. April, May.

Geography. - Throughout the Atlantic States in southeru exposures of rocky hillsides and open woods.

8. R. Flammula, L. (Var. intermeảius, Hook.) (Smaller Spearwort.) Stem prostrate, upright, or assurgent, frequently rooting below, usually less than a foot high. Leaves lanceolate, entire, or slightly toothed, linear lanceolate, lower ones wider on short petioles, or sessile. Petals 5, 6, or 7 , golden yellow, larger than sepals. Carpels flattish, each armed with a sharp point. Flowers from July to September.

Var. reptans, Gray. (Creeping Spearwort.) Diminutive form. Stem less than 6 inches long, prostrate, rooting at all the nodes. Leaves small, varying from linear to oblong or spatulate. Flowers from June to September.

Geography. - Northeru part of New York, and nortliward on sandy shores. Northward rare. The following form is more common.

9. R. multifidus, Pursh. (Much-divided leaved Crowfoot. Yellow Water Crowfoot.) Stem long, slender, submerged, or floating. Leaves in 3-forked, thread-like, linear, or wedge-shaped divisions, varying in uutline; floating leares lobed. Sepals reflexed, shorter than petals. Petals bright-yellow, 5-8. Carpels smooth, in a subglobular head, crowned with spine-like tips.

Geography. - Northeastern North America, in ponds, sluggish streams, and muddy places.

Var. terrestris, Gray. Does not grow in the water; has ascending stems, bearing each a small panicle of flowers at its summit. Leaves in the form of linear or oblong bracts.

Geography. - Michigan, near Ann Arbor, Minn., Alaska.

10. R. muricatus, L. (l'rickly-seeded Crowfoot) Stem erect, branched, 12 inches high, glabrous. Leaves roundish, cordate, 3-lobed ; lobes coarsely crenate-toothed; all similar and petioled; petioles 1 to 5 inches long; bracts near the flower simple. Flowers small, few, yellow; petals obovate; carpels large, aculeate, strongly margined, ending in a stout, ensiform, recurved beak. May to July.

Geography. - Seed brought from Europe in grain. Plant naturalized in southern United States, Virginia to Louisiana. Also seen by Dr. Wood in California. Loves damp places.

11. R. oblongifolius, Ell. (Oblong-leaved Crowfoot.) Stem usually erect, slender, sometimes hairy below, much branched above, about a fout high. Leaves lance-ovate, lanceolate, linear, or oblong, serrate or toothed, lower ones or all petioled. Flowers golden yellow. Petals 5, very much larger than the sepals. Stamens 20 or more. Carpels small, globular, crowned with a little spot. (R. pusillus var. Torr. \& Gray.) Flowers in June.

Geography. - Southern United States. Wet prairies. Salem, Ill.

12. R. parviflorus, L. (Small-flowered Crowfoot.) Stem 6 to 12 inches high, slender, branched. Leaves all petiolate, small, roundish, cordate, 3-lobed, segments sharply toothed. Flowers very small. Yellow petals and sepals: about the same length. Carpels globular, small, tipped with a very short beak, arranged in a globose head. May to .June.

Geography. - Naturalized from Europe. Found in gravelly places. From Virginia to Louisiana. 
13. R. Pennsylvanicus, I. f. (Bristly Crowfoot. Pennsylvanian Crowfoot.) Leaves all 3-parted. Stem stont, I to 3 feet high, erect, much branched. Leaves ternate, villous, segments sub-petiolate, acutely 3-loberl, somewhat ovate, incisely serrate; whole plant clothed with stiff, sprealing hairs. Flowers small, pale yellow. Calyx reflexed. Sepals longer than the petals. Carpels crowned with a short, straight beak, massed into an oblong head. July and August.

Geography. - Found in wet places, in Canada, eastern Lnited States, and west to Colorado.

14. R. pusillus, P'oir. (Puny ('rowfoot.) Stem slender, erect, sometimes prostrate, 6 to 12 inches high, branched. Leaves petioled, lower ones ovate, orbicular or cordate, entire or sparingly toothed, upper ones linear-lanceolate, obscurely touthed, nearly sessile. Flowers small, pale-yellow, on long pednncles, 1-flowered. l'etals 1-5, sometimes 3, barely longer than the sepals. Stamens 5-10. Carpels crowned with small blunt point. June to August.

Geography. - Southern New York, and along the eastern and southern parts of the Southern and Gulf States to Louisiana, in wet places.

15. R. recurvatus, Poir (Hooked Crowfoot. Wool Crowfoot.) Stem erect, 8 to 18 inches ligh, whole plant clothed with roughish hairs, sometimes forkedly branched. Leaves ternate, or deeply 3-parted, leaflets or segments broad, wedge-shaperl, and acnte; lateral ones 2-lobed; lower petioles long, sheathing at base; upper ones much shorter. Flowers small, pale-yellow, on short peduncles; petals shorter than the reflexed sepals. Carpels in a globular head, margined, and crowned with the sharp-hooked style. Whole plant pale-green. May to July.

Geography. - Labrator to Florida, thronghout uortheastern North America. Sharly woods aud (lamp places.

16. R. repens, I. (Creeping Crowfoot.) Stem 6 to 15 inches long, runners sometimes longer, hairy when in dry ground, glabrous when in wet places; sparingly branched. Root fascicled and large. Leaves ternate, on long stalks; leaflets werlge-shaped, 3-lobed, incisely toothed, midlle one petioled, lateral ones on short petioles or nearly sessile; hairy on the veins and eilges when in dry ground, veins conspicuous underneath. Flowers large, bright yellow; petals obovate, larger than the pilose sprearling sepals. Carpels with a straight point, strongly nargined. May to Angust.

Foliage and general appearance of the plant very variable. When found in a damp mearlow and sprearling up a dry hillside, it seems to run into No. 13, in form of leaf and stem.

Geography. - Atlantic States, and west to the l'acific. It lores damp gromul, but is frequently found on the lower erlges of hillsides.

17. R. rhomboideus, Gollie. (Rhomboill-leaved Crowfoot.) Stem 3 to 6 inches high, much branched, hairy. Leaves at the root, on long stalks, rhomboid-ovate, crenate-rlentate; stem leaves helow similar, 3-5-loberl, ti]per ones nearly sessile, lobes linear. Flowers deep-yellow. l'etals larger than the sepals. Carpels glolmlar, heak small, head spherical. A pril to May.

Geography. - Michigan, Ill., Wis., sonthwest to Colorado, and north to British America.

18. R. sceleratus, I. (Wickerl Crowfoot. Celery-leaved Crowfont. Cursed Crowfoot.) Stem thick, hollow, 10 to 15 inches high, glal,rous, and branched. Leaves at the base 3-lubed, long-petioled; lobes divided, those on the lower 
stem 3-parted, on shorter petioles; upper ones nearly sessile, lobes oblong, linear, entire, or toothed. Flowers small, numerous, pale-yellow. Carpels small, numerous, in cylindrical heads. Juice very acrid. May to August.

Geography. - Canada to Georgia, and west to Colorado. Sparingly in damp places, edges of ditches, and near living water, brooksides, etc.

19. R. septentrionalis, Poir. (R. palmatus, Ell.) (Hand-shaped-leaf Crowfoot.) Stem 12 to 18 inches high, pubescent, slightly branched, branches slender. Leaves on long stalks, pentangular in outline, pubescent, 3-5-palmately eleft; segments all sessile, and cut-toothed or lobed, upper leaves composed of 3 linear segments. Flowers few, small, sellow. Carpels few, margined, and straight-beaked. April and May.

Geography. - Southern U. S., in pine woods, from Carolina to Florida.

Etymology. - Ranunculus, the generic name, is derived from the Latin rana, a frog, due to the circumstance

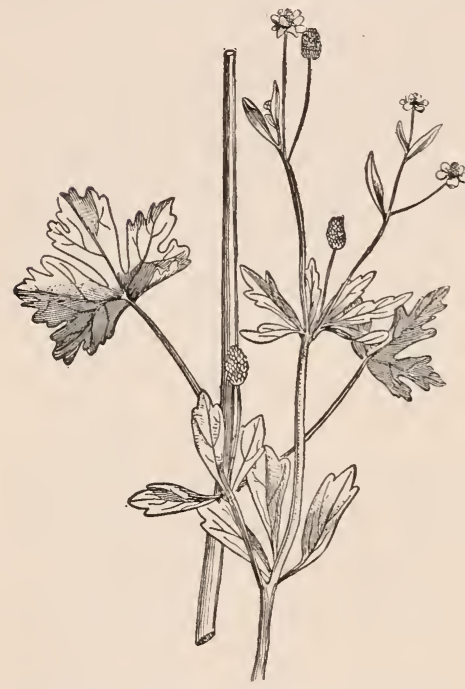

Ranunculus sceleratus (Wicked Crowfoot). that many of the species grow in wet places, the home of the frog. The specific names are derived from the following Latin words: Abortivus, not bringing forth properly, due to its small flowers. Acris, from acer, sharp, or biting, due to the sharp, acrid taste of the juice. Aquatilis, living in or near the water. Bulbosus, having small heads or bulbs, named from the bulb-shaped root. Cymbalaria, boat-like cup, said to have been applied on account of the fancied resemblance of the calyx to a boat. Fascicularis, from fasciculus, a little bundle, applied becanse the fibrous roots of this species appear in groups. Flammula, flame, due to the bright, flame-like color of the petals of this species. Multifidus, many-cleft as to the leaf. Muricatus, abounding in sharp points. Oblongifolius, from oblongus, oblong, and folium, a leaf; hence oblong-leaved. Parriflorus, from parcus, small, and fos, a flower; hence small-flowered. Pusillus, small, referring to the size of the plant. Recurvatus, bent back, the carpels have a hooked heak. Repens, creeping. Rhomboidens, like a rhombus, dne to the shape of the leaves. Sceleratus, wicked, or hiting, due to the burning, acrid taste of the juice of this species. Septentrionalis, northern, i.e., growing in the north.

Use. - Some of the species are very showy, and early attracted the attention of gardeners and cultivators of flowers, and are still farorites. The medicinal properties of the Ranunculus are little known. The acrid juice of the R. sceleratus and some other species blisters the skin very rapidly.

The leares of the R. ficaria are used for salad in France. The root of this species was formerly used as a remedy in the cure of piles. The roots of the R. bulbosus are edible when cooked. R. aconitifolius, L., Tan-1/ais of France, is a farorite in cultivation for its white flowers. 
THALICTRUM, L. (Meadow Rue.) No involıcre. Calyx usually colored. Sepals $4-5$ or 7 , concave, falling early. No corolla. Filaments generally enlarged above and longer than the calyx, numerous. Flowers in panicles, dicecious, or polyganous. Ovaries many. Akenes usually sessile, occasionally stipulate, ribbed or swollen, pointed with the short style. Leaves usually ternately compound. Leaflets stalked. Perennial herbs.

1. T. clavatum, IC. Stem 2 to 3 feet high, smooth. Leaves biternate, on petioles an inch long; leaflets roundish, obtusely 3-5-lobed, glaucous beneath. Flowers in loose panicles. Fruit swollen, obovate, striate, acute, and as long as the stipe. June.

Geography. - Southern Virginia and North Carolina.

2. T. dioicum, L. (Meadow Rue.) Stem smooth, pale-green, or bluish, 1 to 2 feet high, slender. Leaves teruately decompound, on short general petioles. Leaflets roundish, obtusely 3-5-7 lobed, paler beneath. Flowers purplish or pale-green, filaments threadlike, longer than the calyx; anthers linear, rellowish, mucronate. Sepals 5, obtuse. Inflorescence a panicle. Fruit strongly ribbed and pointed. May.

Geography. - British America to Georgia and Alabama. In hilly, rocky woods.

3. T. polygamum, Muhl. (T. Cornuti, Gray). ('Tall Meadow Rue.) Stem 3 to 5 feet high, branching, smooth, or slightly pubescent. Leaves variable in form, dark-green above and paler beneath, smooth or pubescent; stem leares without general petioles, decompound ; leaflets roundish-oborate or oblong, 3-lobed at the apex, lobes sharp, peduncles longer than the leaves. Flowers perfect, white, in large panicles, very compound diccious or polygamous; filaments somewhat club-shaped. Carpels strongly ribbed, sharp at both ends, longer than the style. June and July.

Geography. - Atlantic States, and west to Colorado.

4. T. purpurascens, I. (Purplish Meadow Rue.) Stem 2 to 4 feet high, purplish, smooth, or finely pubescent. Leaves roundish, or longer than wide, wider towards the end, mostly 3 -lobed, veins prominent, paler underneath, margins rolled over. Flowers in compound panicles, purplish or with a greenish tinge; anthers nearly linear; filaments broader at the ends ; anthers drooping. May to July.

Geography. - New York, Southern New England, south to Georgia, and west to the Mississippi Valley.

Var. ceriferum, C. F. Austin. Differs from T. purpurascens in having the lower surface of the leaves and the fruit beset witl waxy particles, and when bruised exhales a peculiar, stroug odor.

Etymology. - Thalictrum is from the Greek word $\theta \alpha \dot{\lambda} \lambda \omega$, spring forth green, in allusion to the bright green foliage of the roung shoots. The specific names are: Dioicum, thus named becanse the flowers are sometimes diacions or dioicons. Purpurascens, purplish thalictrum. Ceriferum, wax-bearing. Cornuti, for a French physician, Cornutus. Claratum, club-shaped, due to the form of the filaments of this species.

CALThA, I. (Cowslip. Marsh Marigold.) Sepals 5 to 9, bright yellow, petal-like. Petals wanting. Pistils j to 10, styles very short. 
Pods flattened, spreading, many-seeded. Whole plant glabrous. Leaves undivided, but toothed and large. Perennial herb.

1. C. leptosepala, DC. Differs from the above in the leaf, which is oblongovate, lower ones serrate. Flowers usually solitary, rarely two. White or bluish.

Geography. - From New Mexico to Alaska. (Coulter.)

2. C. palustris, L. Stem hollow, from 8 to 12 inches high, cylindrical, grooved, and sometimes prostrate, forkedly branched. Root large and branched. Leaves dark-green, veiny, and smouth; lower

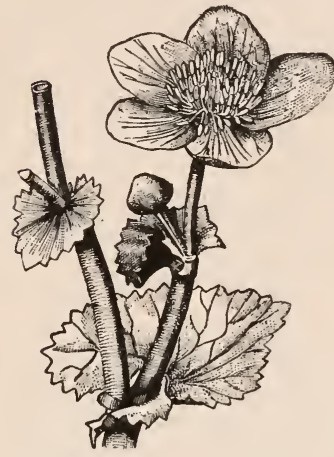

Caltha palustris (Cowslip). ones 2 to 4 inches wide, on long stems; npper ones sessile, round-reniform. Flowers bright yellow, axillary, 3-5.

Geography. - Found in wet meadows and swamps, from Canada to Carolina, and west to Oregou.

Number of species about a dozen, of which six are found in North America.

Etymology and History. - Caltha, the generic name, is from the Greek word кádatos, a goblet, due to the form of the calyx, which resembles a golden cup. Palustris is from the Latin word paluster, marshy, on account of the fondness of the plant for such localities. Leptosepala is from the Greek $\lambda \in \pi \tau$ ós, weak, and the Latin sepio, to inclose or surround, alluding to the size and thinness of the sepals.

Use. - The leaves of both these species are used for greens, and when very young for salad.

Clematis, L. (Virgin's Bower.) Calyx 4, sometimes 5-8-sepaled usually colored, and pubescent. Petals wanting, or rudimentary. Filaments many. Anthers linear. Akenes numerous, in heads tipped with the long, persistent, feathery styles. Clinging to and climbing over shrubbery, by means of the leaf-stalks. Perennial. Leaves mostly opposite and compound.

1. C. crispa, L. (cylindrica, Sims.) Stem climbing, sinooth. Tueaves varying in form; leaflets 5 or 9 , broad, ovate, or lanceolate, slightly cordate at base, entire, occasionally 3-5-lobed, prominently veined, thin. Flowers terminal, large, nodding, campanulate, bluish-purple. Calyx cylindrical, bell-shaped. Sepals dilated above and spreading, edges thin and wavy. Tails of the fruit silky, pubescent.

Geography. - Near Norfolk, Virginia, and south to Georgia.

2. C. ochroleuca, Ait. Stem 8 to 10 feet long, usually smaller, and silky. Leaves simple, ovate, silky, hairy underneath, sessile, entire, occasionally 3lobed, 2 to 4 inches long; veins prominent, upper surface smooth. Flowers terminal, nodding, bell-shaped. Sepals silky outside, creamy white within. Plumes of the fruit long and straw-colored. May.

Geography. - Copses and river banks. New York to Georgia. Rare. 
3. C. Pitcheri, Torr. and Gray. Leaves pimate, $3-9$; leaflets rough, veins prominent, slightly cordate, orate, entire, or 3-kobed, leathery, upper. ones frequently simple. Flowers nodding. Calyx bell-shaped. Sepuls ovatelanceolate, dull purple; points narrow, and recurved, nearly an inch in length. Fruit tipped with thread-like plumes, naked or slightly pulescent. June.

Geography. - Mississippi Valley in Arkansas, lowa, and Hinois.

4. C. verticillaris, DC. (Whorled-leaved Virgin's Bower.) Sitem 10 to 20 feet long, climbing on small trees by means of its coiling petioles, woody. nearly smooth. Leaves in whorls or clusters of 4 , ternate; leaflets acute, ovate, slightly notched or lobed. Flowers appearing in 2's, at the nodes, with the leaves; sepals lanceolate, acute, an inch long, bluish-purple. Filaments about 24 , onter ones spatulate, or petaloid, tipped with rudimentary anthers. May to June.

Geography. - Atlantic States from Maine to North Carolina, and west to California, in upland woods. Not common.

5. C. viorna, L. (Leather Flower. Way - allomer.) Stem climbing, 10 to 15 feet long, round or striate, pubescent, purple, woody. Leaves opposite, pinnately decompound, with 9-12 leaflets, parts entire or 3-lobed, ovate and acute. Flowers bellshaped, axillary, purple, nodding on long peduncles, with a pair of simple entire leaves near the middle; sepals very thick and leathery, acumilate, and connivent and re-

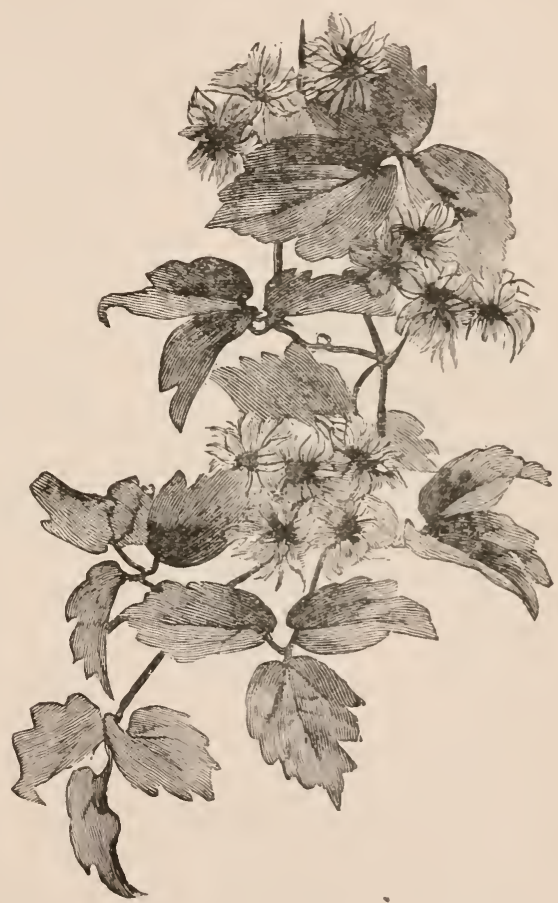

Clematis Virginiana (Common Virgin's Bower). flexed at the apex. l'lumes of the fruit from 1 to 2 inches long. June, July.

Geography. - Pennsylvania to Georgia, west to ()hio. Rich, open woods.

6. C. Virginiana, I. (Common Virgin's Bower.) Stem climbing, or clambering over shrublery, 8 to 30 feet long, slender, woody, and chamelled. Leaves opposite, ternate; leaflets ovate, acute, coarsely toothed; teeth mucronate; more or less 3-lobed. Flowers white, axillary, abundant, diucions; sepals 4, oblong, ovate, blunt. Fruit tipped with loug plumose tails, very shuwy in antumn. July, Angust.

Geography. - Canala to Georgia, and west to the Missisisippi Valley. Liver banks and damp places. Common. Also cultivated. 
Etymology. - Clematis, the generic name, is from the Greek word $\kappa \lambda \hat{\eta} \mu \alpha$, a tendril, on account of the climbing habit of this genus. Verticillaris, Latin, is due to the mode in which the leaves are borne, in whorls. Tiorna, Latin, via, the way, and orno, adorn - beautifier of the way. Pitcheri, for Dr. Pitcher, who first found it in these limits. Cylindrica, round, is due to the cylindrical shape of the calyx. Virginiana, Virginian Clematis.

Use. - Nearly all the species of this genus are ornamental, and are cultivated for their beauty.

\section{ORdER II. BERBERIDACE A.}

Shrubs or perennial herbs.

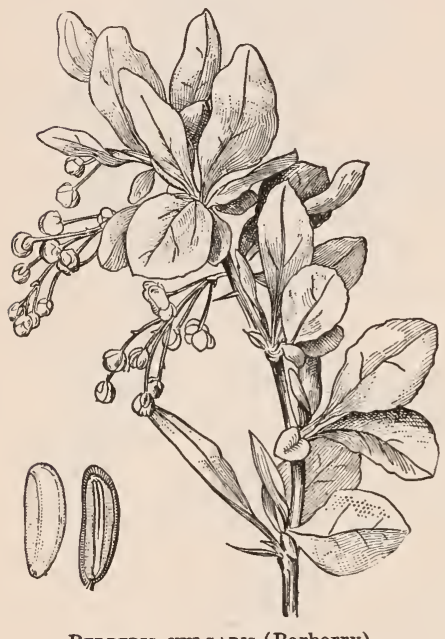

BERBERIS VULGARIS (Barberry).

Leaves alternate and exstipulate. Flowers regular, mostly 3-merous and hypogynous; sepals and petals imbricated in the bud. Stamens equal in number to the petals, and opposite to them. Anthers mostly opening by valves, hinged at the top. (In the Podophyllum, by slits.) One pistil ; style short, or wanting. Fruit a berry or capsule. Seeds numerous.

No. of genera, 19. Species, 100 .

BERBERIS, L. (Barberry.) Leaves 1-9 foliate. Sepals roundish, 6 in number, enveloped by 2-6 bractlets. Petals 6 , each with a short claw, above which, on the inside, are two glandular spots. Stamens 6, irritable; stigma circular and flattened. Fruit a sour berry, 1-several seeded. Seeds erect, with a crustaceous covering. Shrubs. Wood yellow. Flowers in nodding racemes, sometimes drooping. Fruit a sour berry.

B. vulgaris, L. (Barberry.) Leaves few on the new shoots of the season, usnally merely branched spines from whose axils the leaves of the next season arise in rosettes, of obovate oblong, bristled, toothed, drooping, many-flowered racemes; petals entire; berries oblong, scarlet. Thickets and near dwellings. Eastern New England. May to June. From Europe.

Geography. - Native of Europe, naturalized in New England. B. canadensis, native in the Alleghenies, a curious and interesting plant.

Etymology. - Name from the Arabic, Berbèrys.

Use. - A favorite ornamental shrub. The fruit is preserved, and the inner bark is held to be medicinal.

PoDophyllum, L. (May Apple. Mandrake.) Early floral envelope composed of three foliaceous bracts: 6 petaloid sepals, petals 6 to 9 . Stamens double the number of petals. Anthers linear; stigma large, 
peltate, nearly sessile. Fruit a berry, egg-shaped, 2 inches in length, fleshy, 1-celled, many-seeded. Root-stocks creeping. Roots thick and fibrous. Perennial herb.

P. peltatum, L. (May Apple. Mandrake.) Stem 1 to 2 feet high, 2-leaved, I-flowered; flower in the crutch, or fork of the stem, nodding, large, the two parts of the stem bearing each a 1 -sided leaf, palmately lobed. Flower white. May.

Geography. - The Podophyllum is found sparingly in eastern North Amerina, from the St. Lawrence to Florida, west on the Kansis, and north near Lake Huron. There is another species found in the Hinalaya Mountains.

Etymology and History. - Podophyllum is derived from the Greek moús, a foot, and фú $\lambda \lambda o v$, a leaf, on account of the resemblance of the leaf to the fort of a web-footed bird. Peltatum, the specific name, comes from the Latin pelta, a shield, because the foot-stalk is attached to the blade, not at the edge.

How this plant obtained the name V/ay apple is not apparent, for the fruit does not ripen in May. And what gave rise to the popular name mandrake is equally obscure. It is possible that it arose from the similarity of the fruit of the Mandragora officinalis of Syria, which is no doubt the mandrake spoken of in the Old Testament.

Podophyllum was described, figured, and its emetic properties noted by Mark Catesby, in 1731. See Hist. of Carolina.

Use. - The root of the mandrake, or Podophyllum, yields to the chemist a substance known as Podophyllin. This substance is an active purgative, and is said to promote especially the secretions of the liver and kidners, and is largely used in bilious attacks. It is also used as an emetic and a vermifuge, and as an alterative in rheumatic affections. It has heen for years the principal purgative administered by the Thompsonian practitioners, and is their substitute for calomel.

\section{ORDER III. PAPAVERACEEE.}

Annual or perennial herbs. Juice milky, sometimes colored. Leares alternate, simple or pinnate, lobed or toothed, exstipulate. Flowers regular, terminal, and often solitary. Sepals falling soon, usually two. Petals four, sometimes six, rarely more; sprearling and imbricated in the bud. Stamens numerous, and some multiple of four. Orary solitary; style short; stigmas 2 or more, star-shaped, upon the flat top of the ovary. Fruit pod-shaped, with two divisions, or capsular with several partitions. Principal genera, ahout 24.

PAPAVER, Tourn. (Poppy.) Calyx composed of 2 thin sepals, falling soon after the expansion of the flower. Corolla t-petaled, crmmpled at top. Stamens numerous, attached below the orary, 1-celled, manyovuled. Style short, expanding into a broad, persistent stigma. Seed-ressel varying in shape from an oblate to a prolate spheroill. surmounted by the broad, persistent stigma. Seeds kidney-shaped, pitted, very oily. Leaves alternate, lobed, or cut; flowers terminal. on long peduncles; buds drooping.

There are ahout a dozen well-marked species, and as they are grown from seed they sport freely, producing many varieties. The l'. somniferum, and 
one of its varieties, called the black poppy (on account of its black seeds), are the plants that produce the opium of commerce. The P. somniferum is called the white poppy, on account of its white seeds. Nos. 1, 2, and 4 are found in and near cultivated grounds in the United States.

1. P. Rhœas, L. (Corn Poppy of Great Britain.) Stem hairy, 2 feet high, many-flowered. Leaves glaucous, pinnatifil, incised. Flowers large, showy,

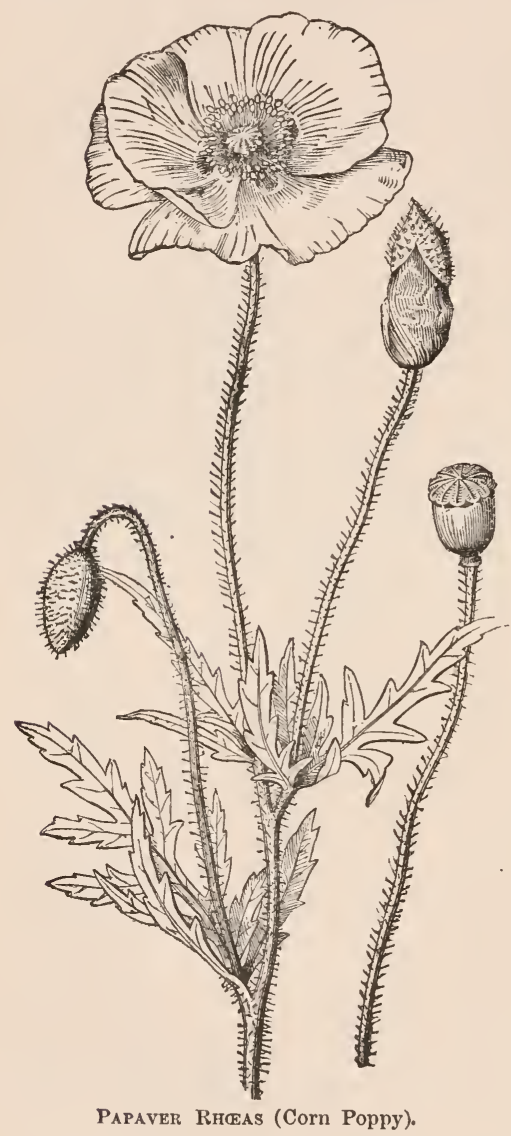
scarlet, sometimes variegated and double, seed-vessel globose or oval.

2. P. dubium, L. (Longleaved Poppy.) Stem slender, 2 feet high, clothed with spreading hairs. Leaves pinnate; leaflets deep-toothed and cut. Flowers light-red, sometimes scarlet, smaller than the $\mathrm{P}$. somniferum. Flower-stalk slender and hairy; sepals hairy; seed-vessels club-shaped.

3. P. somniferum, Linn. (Opium Poppy. Garden Poppy.) Stem $1 \frac{1}{2}$ to 3 feet high, erect, cylindrical, glaucous - green, smooth below, with scattered soft hairs near the summit, branching. Leaves alternate, clasping, deeply toothed or cut, whole plant smooth and glaucous. Flowers large, terminal, bluish-purple or white; petals 4 , edged at base with a purple border. Stamens many, attached to the receptacle; filaments bristle-like ; anthers oblong, blunt, flattened, and erect. Fruit globose, 1 inch to $1 \frac{1}{2}$ inches in diameter, crowned with the broad, persistent, radiating stigma; the margin of stigma deflexerl. Seed-vessel l-celled, with wedge-like processes extending half-way to the center, to which the seeds are attached. Seerls kidney-shaped, whitish, numerous. It is said that Linnæus counted 32,000 in one cell, or seed-vessel. The seed-ressel, when wounded, discharges a thick, creamy juice.

4. P. orientale, L. Stem 3 feet high, rough, terminated with one rich scarletcolored flower. Leaves pinnate, rongh; leaflets serrate. Seed-ressel subglobose and smooth.

Geography. - Gardens and cultivated grounds, for ornament. (Adv. from Levant.) The geographical home of the poppy is the southern edge of the 
north temperate zone; but it has spread towards both the north and sunth. It fruits as far north as the forty-tifth parallel, lut produces most largely south of the thirty-fifth degree. The great opium districts are the valley of the Ganges, Asiatic 'Turkey, Persia, and Egypt. The best is produced in Asia Minor. In late years the cultivation has so extended in China as to cause great alarm to the goverument.

Etymology. - Paparer is said to be derived from the Celtic word papa, a name applied to a soft food fed to infants, and contracted into paly in English. 'The seeds of the poppy were boiled in pap, to induce slecp in the infant, hence the association. Somniferum is from the Latiu words somnus, slerelp, and fero, bear; hence sleep-bearing, alluding to the sleep-producing property of opium. Poppy, the common name, is a corruption of papa.

History. - The mediciual properties of the poppy were known to the Romans, in the days of Hippocrates, abont 400 years B. C. Vergil also speaks of the poppy. History informs us that opium was first prepared at Thebes, and called Thebaicum. The juice of the whole plant was used by the ancients, and called Meconium, which means the juice of the poppy.

Mode of Cultivation. - In Turkey the poppy is sown on well-prepared land in rows, and thinned out so as to stand from 12 to 18 inches apart, and kept free from weeds. When the capsules are nearly full-growu, incisions are made in them in the evening, with a guarded knife, which cuts through the cuticle only. The milky liquid appears on the surface the following morning, and is removed with a spoon-like instrument, and placed in an earthen vessel, from which it is poured into a shallow, open brass dish, which is tilted on the side to allow the watery part of the liquid to drain off. It is then exposed to evaporation, and daily turned until it is sufficiently hardenerl to be kneaded into balls, which are placed upon slats in large rooms, to dry. Here they are tended and turned by boys till they are dry enough to pack, when they are sent to smyrua, where they are inspected and graded, packed into tin-lined cases, and sent to market.

The value of the Turkish opium depends upon the amount of morphia it contains. Opium brought to the Lnited States is assayed before it is exposed for sale, and if found to contain less than nine per cent of morphia, is rejected. The cultivation of the poppy for opium has been attempted in the I'nited States in Vermont, Virginia, Tennessee, and California, also in France and England, and opium far richer in morphia than the Asiatic opium has been produced, but on account of the high price of labor its cultivation proved unprofitable.

Chemistry. - Opium, the product of the poppy, is a very complex substance, containing a large number of bases in combination with sulphuric and meconic acids. Morphine, whose formula is $\mathrm{C}_{17} \mathrm{H}_{19} \mathrm{NO}_{3}$, and Narcotine, whose formula is $\mathrm{C}_{22} \mathrm{H}_{23} \mathrm{NO}_{7}$, are the most abmudant and important.

The best known of the others are:-

Codeine, whose formula is $\mathrm{C}_{18} \mathrm{H}_{21} \mathrm{NO}_{3}$

Thebaine, " " " $\mathrm{C}_{19} \mathrm{H}_{21} \mathrm{~N}\left(\mathrm{O}_{3}\right.$

Papaverine, " " " $\quad \mathrm{C}_{21} \mathrm{H}_{21} \mathrm{~N}_{4}$

Narceine, " " " $\mathrm{C}_{23} \mathrm{H}_{29} \mathrm{NO}_{4}$

So far as known, the merlicinal properties of opium reside in these six substances, and principally in the first two, Morphine and Narcotiue.

Use. - As a mexlicine opium is alministered to relieve pain, to pronote sleep, to allay irritation of the nervous system, and to relax the nuscles 
in spasmodic affections. It diminishes secretions, and for this purpose is largely used. So important has it become that it has passed into a proverb that a physician without opium is like a soldier without weapons. The most important preparations of opium are laudanum, which is an alcoholic tincture, paregoric, which is a compound of opium, benzoic acid, honey, oil of anise, and dilute alcohol. Soothing syrups, given to keep children quiet, contain much opium, and sometimes cause sickness, and occasionally insanity.

The seed yields an oil only inferior to the best olive oil, and is used both as a substitute and an adulterant. Opium is used as a luxury for an intoxicant, either taken in small doses internally or smoked, when it.is mixed with the hashish, or gum of the hemp, and with grateful spices. If indulged in to excess, it enfeebles the mind and enervates the body, and is said to shorten the life of the offspring of the debauchee. It enables people to bear fatigue without food, and travellers in Turkey, Syria, and India carry it with them for that purpose. Even horses are sustained, in the East, under its influence. It is eaten, not smoked, in Persia and India; smoking it is a recent Chinese invention. In Amoy, China, fifteen out of every twenty adults smoke it.

Statistics. - Great quantities of opium are carried into China and vicinity. That from India alone is over $14,000,000$ pounds annually. Large quantities go overland from Persia and Turkey, but this is only abont one fifth of the amount consumed there, as they produce four fifths of what they use, making an anuual cousumption of $71,001,840$ pounds, at a cost of $\$ 280,000,000$.

\section{Order IV. CRUCIFER A..}

Sepals 4. Petals 4, hypogynous, arranged opposite to each other in pairs, forming a cross. Stamens 6, 4 long and 2 shorter. Flowers perfect, usually in a terminal raceme, white or yellow. Ovary sessile, usually 2-celled. Stigmas 2. Fruit a pod, one to many seeded, seeds commonly yielding oil. Mostly herbs, sometimes woody. Juice watery, frequently acid, anti-scorbutic, and never poisonous. Stem cylindrical, or angular. Leaves simple, alternate, occasionally opposite, entire, lobed, or dissected; upjer ones sometimes eared, lower ones often runcinate, for the most part without stipules. Genera, 172.

CAPSELLA, Medic. Seed-vessel, triangular-obcordate; valves, boatshaped without wings. Seeds many, with incumbent cotyledons. Pod flattened contrary to partition. Flowers white. A common weed.

C. Bursa-pastoris. (Shepherd's Purse.) Root-leaves rosulate, cut-lobed; stem-leaves linear lanceolate, clasping, sagittate; racemelong. Radical leaves clustering, subpinnatifid. Waste ground about dwellings. Common weed. A pril to September.

Geography. - Naturalized from Europe, where it is a troublesome weed in gardens and near dwellings.

Etymology. - C'apsella is the diminutive of Latin capsa, a box.

BRAssicA, L. (Turnip, Mustard.) Pod long, terete, somewhat 4-sided, terminating in a stout 1-seeded beak; valves 1-3-veined; 
seeds in a single row, glohular. Flowers yellow. Lower leaves lyrate or pinnatifid.

1. B. oleracea, I. (Cabbage.) Stem slencler, much branched, appearing the second year, smooth, from two to three feet high. Leaf smooth, glaucous, twenty inches long and three to fifteen wide, the first year growing compactly, forming a more or less solid head, which is the edible part; the stem leaves are lyrate below, entire and lanceolite above. Flowers yellow, and in great profusion, terminal on the branches. Seed-ressels cylindrical, and curved. A biennial herb.

Iarieties. - This plant sports with great freedom, ret there are a number of well-marked varieties that propagate with considerable coustancy.

In the vicinity of the great Atlantic cities and in Europe there are about a dozen distinct varieties that have become favorites with market gardeners and amateurs, arranged under the following heads : -

The Common or White Cabbage, known as Sugar Loaf, Flat Dutch, Drumhead, Saroy, or Wrinkled, etc., etc.

The Red, or I'urple Cabbage, used for pickling, etc.

Cauliflower, and several

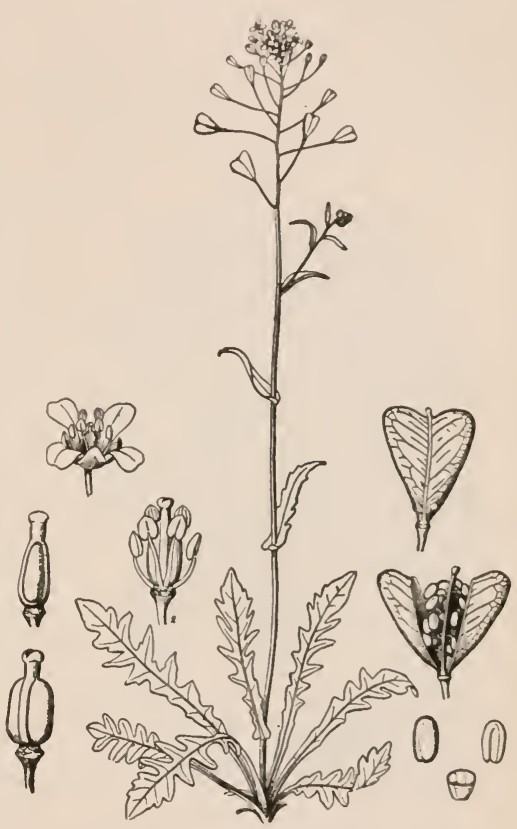

Capsella Bursa-pastoris (Shepherd's Purse), others, which have assumed new forms nnder cultivation. It seems almost a woncler that these varieties are so constaut as they are.

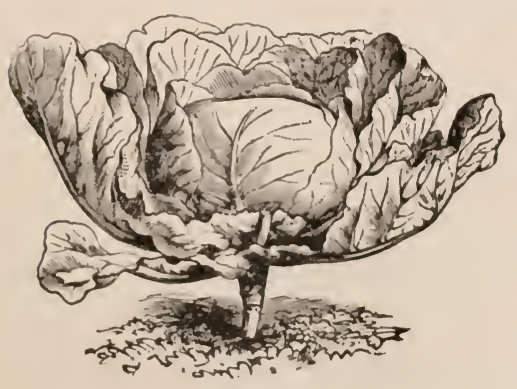

Brassica oleracea (Drumhead Cabbage).

In Europe the number of varieties is very great. As all plants raised from the seed sport more or less freely, it is no wonder that the cabbage assumes so many forms.

There is a perennial variety grown in the Chamnel Islands, called the cou cabbage, or tree cabbage, or Bore Cole, which reaches the height of ten feet. The leaves are stripped off and fed to cattle, and the stalks are used for bean-poles, canes, etc.

Geography. - The cabbage ar- 
rives at perfection in cool, damp climates, but is successfully cultivated in the edge of the torrid zone during the wet, cooler season, and is found under cultivation in a broad zone all around the world, north of the twenty-fifth parallel, and has been carried to Australia and the islands of the Pacific

Etymology. - Brassica is the Latinized Celtic name for cabbage, the signification of which is not apparent.

Oleracea, the specific name of the cabbage, comes from the Latin olus, a potherb.

History. - The home of this plant is middle and western Europe. It is not known when it was first used as food, but there is reason to believe it was so used very early in the history of European peoples; and it has be-

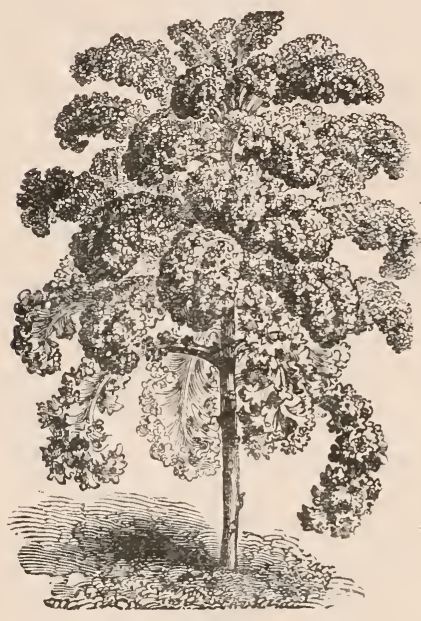

Bore cole (Tree Cabbage). come so great a favorite that its spread throughout the world is limited only by civilization. Wherever colonization has occurred, climate permitting, the cabbage has followed.

The ancients knew it. Theophrastus, who lived three hundred years before the Christian era, wrote of it, and Pliny also mentions it and speaks of its cultivation.

Use. - The most common use of this plant is in the character of a pot-herb, and it is universally esteemed. It is also prepared as a salad, under the name of Cold Chou, which has been corrupted into Cold Slaw. The Scotch call it Cauld Kail. In Germany and all northern European nations large quantities of cabbage are made into Sauer-kraut. It is chopped fine and packed tightly into casks, with alternate layers of salt, and being kept under heavy pressure it soon arrives at a state of fermentation.

When it begins to ferment it is fit for use, and is removed to a cool place. It is eaten with oil or other dressings, and is a very important article of food in all northern Europe.

Saner-kraut soup, with rye-bread and occasionally a little pork, is the daily fuod of the Russian peasant. Cabbage is also an important food for cattle, and especially for milch cows.

2. B. alba, Gray. (White Mustard.) Stem 2 to 5 feet high, stouter than No. 1, much branched. Leaves petioled, lyrate, or subpinnate; terminal segment large, 3-lobed. Flowers yellow, in racemes; petals larger than in No. 1, and seeds fewer. June to Angust. Fruits in Angust.

3. B. nigra, Koch. (Black Mustard.) Stem from 3 to 6 feet high, diffusely branched, smooth or hairy. Leaves petioled, and variously lobed and toothed; green above and lighter beneath. Flowers in slender racemes, greenish-yellow. Seeds dark-brown, sharp to the taste. Annual. June, July. Fruits in August.

4. B. juncea, Hooker and Thompson. A coarser species, the seeds of which are rich in oil, yielding about 20 per cent of their weight. 
Geography. - The B. juncea is largely grown in India, whence the seeds are exported to England.

Etymology. - The specific name, niyra, is Latin for black, lue to the black seed. Alba, Latin for white, refers to the white seed. Muslard, the popular name, grew ont of the circumstance that mustarl was prepared for the table by mixing it with new wine, called must.

History. - When or where mustard was first cultivated is not known. It is spoken of in the Scriptures, but it is now believed that the plant referred to was Salvadora l'ersica, allied to the olive, whose fruit has the taste and pungency of the mustard-seed.

The common mustarl, Sinapis, is mentioned by 'Theophrastus, showing that it was known to the ancient Greeks and Romans, three hundred years before the beginning of the Christian era; hence it has been under cultivation and in use more than two thonsand years. It has been cultivated throughout the ages of the Christian era, and was known as a medicine as well as a condiment for food. 1)uring the latter part of the Christian era, especially, it has been used more largely in western Europe and the British islands as a dressing for food than for medical purposes. A pleasant oil is obtained from the seed, used for a dressing for food and for making fine soaps.

Preparation. - When the seeds are ground and mixed with warm water, fermentation takes place, and furnishes a very pungent essential oil.

Table mustard is prepared by mixing and grinding together the seeds of B. nigra and B. alba, and is frequently ground into a paste in its own oil. The species from which the sweet oil of mustard is obtained is the B. juncea (Hook.), largely raised in India and Russia, for the oil. The seeds yield by pressure about 20 per cent of their weight of oil.

The pungency of prepared mustard is due to the presence of an essential oil which does not exist in the seed, but is generated by the powdered seed when mixed with warm water, and arises from a fermentation due to the presence of two substances, known as myrosin and sinapin. This oil is the most pungent sulstance known, eausing strangulation when breathed. It is not present in the white seed, but a mixture of the white and black produces it in greater abundance than the black alone, and it is found that the mixture of both kinds of seels makes the best mustard for table use.

Use. - The oil is used in dressings, for salads, etc., and for soap-making. The seeds swallowed whole act as a tonic and stimulant; in larger doses, as a laxative. The flour, mixed with warm water, acts as a quick emetic. The seed is ground into flour, in which form it is mixed with vinegar or oil, or both, into a paste for table use, as a condiment for meats. 'The seerls of $\mathrm{B}$. alba are used whole for flavoring fancy pickles. It is also employed in an entire state, to preserve cider in a sweet condition. The flour is used for a poultice, as a counter-irritant in inflammations, and as a remedy for stomach disorders and nervous affections.

In Eingland mustard is much sown as a crop for forage and for green manuring. When sowed at the rate of alont $1211 \mathrm{~s}$. to the acre it gives an abundant crop of succulent forage, which is cut before the seels begin to mature, and ferl to cattle, sheep, and swine.

5. B. campestris, L. (Ficld 'Turnip.) stem slender, appearing the second year, 18 to 30 inches high, much branched, smooth. Lower leaves lyrate, 3 to 7 inches long; lobes toothed, somewhat hairy and glancous underneath, clasping and terminating in an abrupt acumination. Calyx closed. Corolla yellow,

I'K. FL. -5 
half-inch in diameter, spreading. Seed-vessel 1 to 2 inches long. Root somewhat in the shape of an inverted cone, or spindle-shaperd, fleshy, 3 to 10 inches

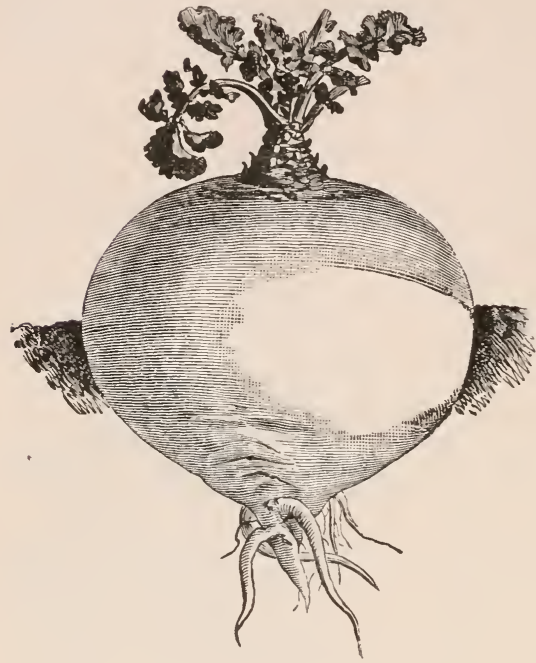

BRAssica CAMpestris (Field Turnip). in diameter, and 6 to 12 inches long, terminating in a slender, tapering radicle, besprinkled with fibrous rootlets. Biennial herb.

Under B. campestris there are several forms. The most important is the sub-species :

Napa-brassica, L. var. rutabaga. (Rutabaga. Swedish Turnip. Russia Turnip.) Root subglobose, flesh yellowish.

6. B. rapa, L. var. depressa. (Flat Turnip. Red Top Turnip. Strap-leaved Turnip.) Stem and leaves as above in No. 5, except that the leaves are frequently narrow, long, and linear; the root flattened at the poles, or flat above and convex beneath; radicle long and slender. A favorite variety for summer use.

The turnip sports freely, forming many varieties. The Swedish turnip varies in color and size, but very little in quality. It is yellow or white. A recent sport is called the White Stone.

There are other varieties and forms of considerable constancy, but those already described are the most important.

Geography. - The turnip is found under cultivation in Greece, Egypt, and Syria, but especially in middle and northern Europe, and is said to be indigenous to Sweden, Russia, and Siberia. It was introduced by European colonists into North America, and is largely grown all over the middle and northern United States and southern Canada. It has also been introduced by the British into India and Australia.

Etymology. - Campestris, the specific name, is from the Latin campester, inhabiting an open place, or field. The specific name, Rapa, is from the Latin rapa, a turnip. Turnip or Turnep is from the old French

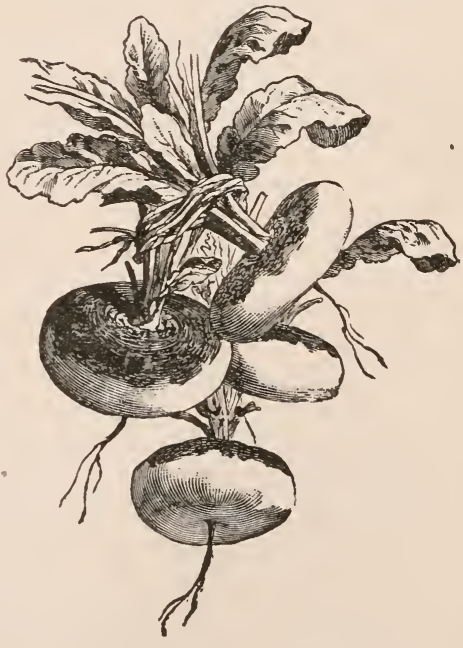

Brassica rapa (F'lat 'Turnip). 
tour, turned, or round, and the Anglo-Saxon nepe, white, siguifying round and white. Sucdish and liussia are names due to the countries where these varieties have originatel or where they are largely grown. Flat top is named from its form.

History. - IVhen the turnip was first cultivated, or where it was first used for food, history does not reveal. The liomans were acrquainted with it. Pliny relates that single specimens sometimes weighed forty pounds. This seems remarkable, since the turnip does not at the present day grow well in warm, dry climates, neither cloes it arrive at perfection in very cold regions. 'The British Isles and the low countries of western Europe are best suited to it. It also grows well in the middle parts of the north temperate zone in North America, to which it was taken by English colonists. Theophrastus and Dioscorides both speak of the turnip. It was taken to Britain by the Romans, most likely under Igricola.

But little attention seems to have been given to it till the early part of the 17th century, when it was an important erop in England. It requires rich, deep soil, and a damp, cool climate, but grows well in damp, warm countries. 1)e Canclolle thinks the bulk of evidence shows that it is a native of western Europe, or possibly of Siberia.

Use. - The turnip is one of the most valuable of all the root vegetables; it is prepared for the table in many ways, and is largely employed for feeding stock. Cattle, sheep, and horses are foud of it, and it is especially valuable for milch cows.

It has been sliced, dried, ground into powder, and used to adulterate flour for making bread.

Dary analyzed the turnip, and found it to contain 3 per cent of nutritive matter.

7. B. napus, L. (Rape.) This species differs from B. campestris in the form of its root, which is long and slender, and nsually carrot-shaped; seed-ressels spreading, foliage more abundant; otherwise as B. campestris.

Geography. - The geographical range of the rape is the same as that of the turnip and cabbage. Its home is no doubt in the regions of middle and northern Europe and Siberia. It is found wild in Sweden also, but may have escaped from cultivation.

Etymology. - Napus is the ancient Latin name for turnip, and signifies a shape which tapers both ways from the middle.

History. - How long the rape has been in nse as an economic plant is not known. I)ioscorides and Pliny both speak of it under different names, and Je Candolle thinks that it and the turnip have been cultivated for more than 4000 years.

C se. - In northern Europe and especially in Russia it is raised in large crops for its seed, of which an oil is made for lubricating purposes, and also for illuminating. When carefully refined it is employed for enlinary and table uses At the world's exposition in I'hiladelphia in 1876, a very fine rape oil was on exhibition in the Rinssian agricultural department. The refuse is pressed into cakes called raje cake, and fed to cattle and ponltry. The rape seed is frequently mixed with turuip, cabbage, and other cruciferous seeds. 'To obtain the oil, the sceds are ground or beaten into paste, put iuto hempen hags, and placed between growed planks standing in an upright position, so arranged as to be nearer togrether at the bottom than at the top. 'The planks are then forced together by wedgers, which forces the oil ont. This oil constitutes a very important article of food among the Russian peasantry. 
COCHLEARIA, 'Tournefort. (Horse Radish.) Calyx equal at the base. Sepals short and slightly spreading. Petals entire, larger than the sepals, with short claws. Style short, occasionally long. Pod globular or egg-shaped; valves convex, nerve dorsal. Seeds usually few, obovate, flattened, arranged in two rows in each cell. Leaves large, oblong, lower ones pinnate, those on the upper part of the stem entire. Root perennial.

1. C. armoracia, L. (Horse Radish.) Stem 2 to 4 feet in height, striate, much branched; branches ascending. Leaves large and thick, radical ones 12 to 18 inches long; on the lower part of the stem either pinnate, crenate, (1) toother, on long stalks 6 to 12 inches in length; upper leaves on short

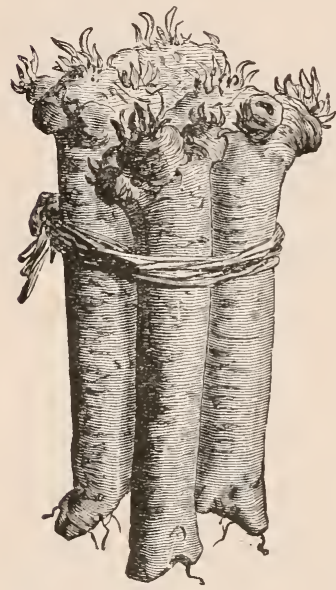

Cochlearia ARMORACIA (Horse Radish). petioles, sometimes sessile, entire, elliptical, or strap-shaped. Flower's in corymbs, white. Seed-vessel egg-shaped, seldom ripening seed. Root large, fleshy, and edible, and of very rapid growth. Flowers in June.

2. C. officinalis, L. (Seurvy Grass). The leaf has the shape of a spoon, hence the generic name. Sometimes cultivated in the United States. There are other species, but they are not cultivated.

Geography. - The geographical range of the Cochlearia is the middle and southern edges of the north temperate zone, extending from Great Britain to western Asia, and northeast America.

Etymology. - Cochlearia, the generic name, is from the Latin cochlear, a spoon, due to the shape of the leaf of the C. officinalis. Armoracia, the specific name, is derived from Armorica, a province in France where the Horse Radish was thought to be native; but it has been ascertained that Armorica is not the home of this plant, hence the name did not arise in that way, and the derivation is obscure. Horse Radish, the common name, signifies a strong Radish, due to the very pungent taste of the root. Officinalis means "of the shops," or " useful."

History. - It is not certain that this plant was known to the ancients. Pliny, in the first century, applied the name to another plant. It was taken to Great Britain before Cæsar's invasion, and has become naturalized, and is growing freely and propagating itself, without cultivation, throughout temperate Europe. It was brought to northeastern America by colonists, where it is cultivated, and is also naturalized. It is an important plant to the market gardener.

Use. - The medical properties of the Horse Radish are stimulant, diaphoretic, diuretic, and anti-scorbutic, and when applied externally, rubefacient. It is administered in paralysis, rheumatism, dropsy, and in other complaints to excite the secretions.

As a food, the root is esteemed for flaroring and preparing sauces for meats and fish. It is prepared by grating the root and preserving it with vinegar. It is adulterated with grated turnip, which renders it more mild and palatable. 
ISATIS, L. (Woad.) Pod or silicle oval or elliptical, flat, one-seeded : valves boat-shaped, subdehiscent; cotyledons accumbent. Biennial.

1. I. tinctoria, L. (Woad.) Sitem 4 foret high, half an inch in rliameter, much branched. Leaves thick, light-green, oval, subclasping, ears rounded, radieal leaves petiolerl, and 10 to 12 inches long and 6 wide, abundant, giving the plant a coarse appearance. Flowers small, rellow, and in terminal panicles. Appearing in .July.

Grography. - Woad is indigenous throughout the continent of liurope, and Great Brituin. It is cultivated in England, sweden, Germany, switzerland, and in the Azores and Canary Islands.

Etymology and History. - Isatis is lerived from the Greek word i $\sigma \alpha \dot{\zeta} \omega$, make smooth or even, because it was supposed to remove roughness of the skin. It has heen called glastum, from the Celtic word ylas, blue. The ancient Britons, at the time of the invasion by Julius Casar, adorned their bodies by painting the formis of animals and other oljects on them with woad, hence the Romans gave them the name of l'icts, or pictured men.

Woad imparts a permanent blue color,

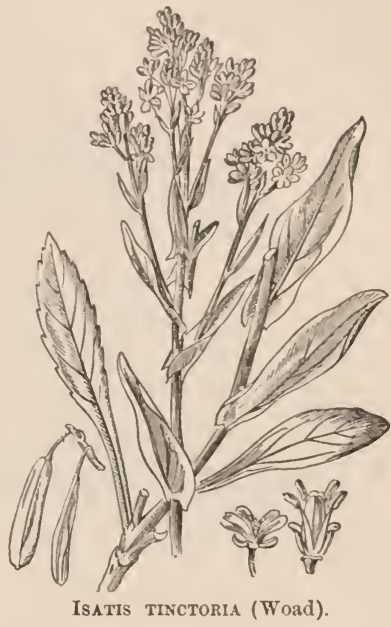
the shade depending upon the quantity, and manner of using it. It is capable of giving a very dark blue, approaching a blue-black.

I'se. - Notwithstanding the inroarls that indigo has made upon the use of woad, on accont of the permanency of the eolor imparted by woad it still holds an important place among coloring sulistances. Dyers are in the habit of mixing it with indigo; the dyes are said to coalesce, and strengthen each other. Its use is rapidly dying out in England.

NASTURTIUM, R. Br. Sepals 4. regular, and equal at hase. letals regular, white, seed-vessel or silique tapering. cylindrical. short, and curved upwards. Seeds small, irregularly arranged in a double row. Leaves alternate. Herbs which delight in wet places. or in the edges of the waters of slowly flowing streams.

1. N. officinale, R. Br. (Water Cress.) Stem perennial, 6 to 18 inches long branched, prostrate, and assurgent. Leaves pinmately dividerl ; leaflets very inconstant, ranging in number from 3 to 5 pairs, and a terminal one, rom ded usually entire, and glahrous, ocasionally sinuately tootherl Flowers in oune. Fruits in July.

Geography. - The geographical distribution of this plant is very wide, as is the case with all ecomomic plants which follow colonization. It grows all over Europe in Palestine, Hindustan, Japan, the islaurls of the Atlantic and the Pacific, wherever linropean colonies have heen established.

Etymolon!y. - Nasturtium is lerived from the Latin nasus, the nose, and tortus, a twisting, said to he due tu the effect which its pungency has upon the nose 
when taken in large mouthfuls. Officinalis, Latin, signifies that the plant belongs to commerce, or the shops. Water Cress, the common name, comes from the Latin cresco, grow, and "water" alludes to its habit of growing in the water.

History. - The home of the Nasturtium is Europe and northern Asia. Where or when it was first introduced into the catalogue of table regetables is not known. It was noticed by Dioscorides and Pliny, and therefore

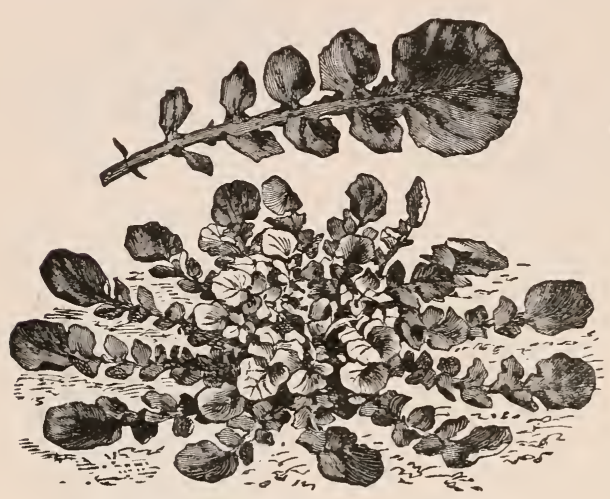

Nasturtium officinale (Water Cress). must have been in use in Italy before the Christian era. It has been seen near the mouth of the Colmmbia River, in North America. It was brought to eastern North America probably by colonists from Holland, where it is grown to a considerable extent.

Use. - It is eaten as a salar, and used to garnish dishes of meats and of fish. It is served always without cooking, eaten with salt, or a vinegar dressing, and is a popular salad-plant with oysters and game.

Note. - The nasturtium of the garden is Tropæolnm, which belongs to the geranium family, and is an immigrant from Peru. It has showy yellow flowers, and is cultivated both for ornament and its fruit, which is curiously curved and ribbed. The frnit is plucked before it is mature, and pickled. It has a pungency similar to the Nasturtium, hence its common name.

\section{ORDER V. CAPPARIDACE As.}

Sepals 4-8, free or sometimes cohering. Petals hypogynous or perigynous, $4-8$, sometimes wanting. Stamens 6 or many, hypogynous or perigynous. Ovaries generally stipulate, 1-celled, or spuriously 2-8 celled, with parietal placentæ, ovules curved. Flowers usually perfect. Herbs, shrubs, or small trees. Leaves simple, or digitate and spiny. The Capparis is a small shrub. Number of genera. 23.

CAPPARIS, L. Calyx divided into 4 spreading, orate sepals. Petals 4, alternate with the sepals, wedge-strap shape, longer than the sepals, spreading or recurved. Stamens numerous, inserted on a subconical receptacle, free, anthers attached lengthwise along their backs to the filaments, and the cells turned out. Pistil one, longer than the stamens. Shrub.

1. C. spinosa, L. (Caper.) Stem from 2 to 3 feet long, straggling or prostrate, very much hranched, bark white. Leaves ovate or orbicular, thick, 
glaucous, and deciduous, 22 crooked spines appearing at the hase of the leafstalk. Flowers on long stalks, white, numerous and axillary, large and showy, but without fragrance. P'etals much louger than the sepals, wedge strapshape, spreading or recurved. stamens sometimes 60 in number, about as long as the petals. Fruit a leathery, obovoil, sneculent (ansule, berry-like; seeds numerous, kidney-shaped. Shrub. Flowers from June to August.

2. C. soldada is fomm in central $\Lambda$ frica, bearing a fruit resembling the currant, and is eaten fresh from the bush, and also dried.

3. C. ferruginea las a rusty, narrow leaf. It is found in the Wrest Indies. The berries have a pungent, mustard-like taste, and on that account the plant is called the mustard shrub.

Geography. - The Capparis grows and fruits in sonthern Europe, and all the countries of the Mediterranean. The market is supplied frum the plantations and wild copses of Sicily and Malta, and other islands of the Mediterrauean, and from the south of France. It loves the rocks, and its habit is well pictured in the following quotation :

"This beautiful plant is rooted in many a crevice of the palace of the Casars at Rome; it spreads its green, glossy leaves and starry white flowers, with their long, purple anthers, over the ruins of that once stirring place, the Colasseum, and clothes the arches of the temple of peace with festoons which adorn without hiding their

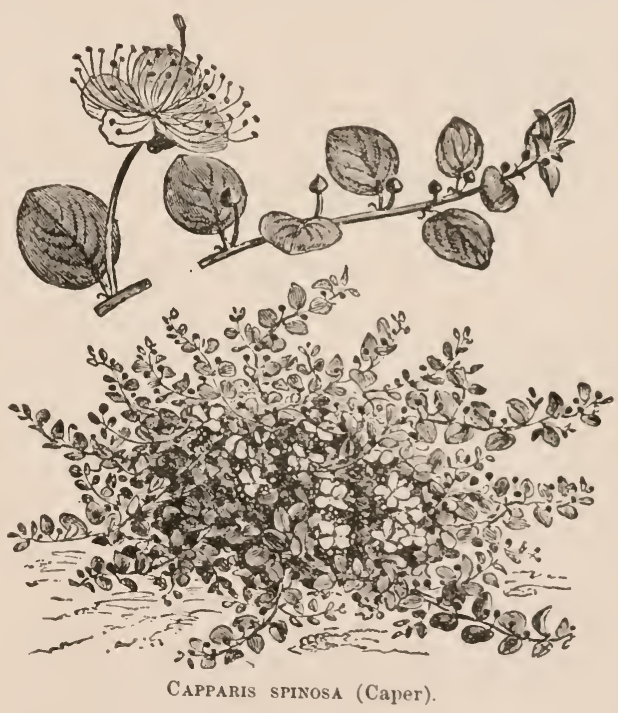
heanty ; the ancient tombs of the Campagna are frequently hung with it ; the rocks of Naples are favorable to it; and it has fixed itself not only on the mouldering cliffs of Malta, but in the narrow crevices of the fortification."

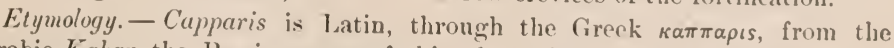
Arabie Kabar, the Persian name of this plant, the meaning of which is not known. Spinosa is Latin, meaning prickly, and is dne to the thorns that appear at the hase of the leaf-stalks. Caper, the popular name, is a corruption of capparis, the generic name.

History. - The caper was well known to the (ireeks and Romans, and was mentioned hy the early writers on natural history, especially Theophrastus, Dioscorides, and Pliny. The eapparis is amnug the plants known to the ancient Ilebrews as thorns. The flower-huds were preserved in salt or vinegar, and offered to guests just before dimner as an excitant to the appetite. It is clained 
by some authors that this is the plant called in the Scriptures Hyssop, and the one used to sprinkle the doorposts and lintels with blood, in Egypt; also the plant mentioned in connection with the wisdom of solomon, when it is stated that he knew all the plants, from the "cedar of Lebanon unto the Hyssop that springeth ont of the wall;" but this has been disputed, and claims have been made for a genus of the mint family.

The flower-buds are collected by women and children (whose hands and wrists are torn by the sharp thorus by which every leaf-stalk is guarded), placed in salt or vinegar, and in Italy the fruit in an uuripe state is also gathered and prepared just as the undeveloped flower-buds are. It was carried to the south of France by Greek colonists, and has been grown largely since that time near Marseilles. It grows best in rocky places or among ruins. Gerard says it refuses to be domesticated.

Use.-The medicinal qualities of the caper are stimulant, anti-scorbutic, aperient, diuretic, and stomachic.

In Italy, the unripe fruit, which is very pungent, is eaten not only as a pickle but as a salad, and is also cooked with meat. The undeveloped flower-buds are sent abroad, and are used in this country to flavor sauces and dressings for boiled meats.

The fruit of the C. soldada resembles currants, and is eaten in the same manner. The fruit of the $\mathrm{C}$. ferruginea has the taste of mustard, and is largely used as a condiment for meats.

\section{Order VI. VIOLACE无.}

Flowers perfect, irregular, axillary, mostly solitary, 2 bracts, usually at the base or near the middle of pedicel. Sepals 5, mostly free, persistent. Petals 5, hypogynous, alternate with the sepals, unequal, lower one dissimilar and prolonged into a hollow spur, below the insertion. Stamens 5, inserted on the bottom of the calyx; filaments short, dilated, usually free. Orary free, sessile; style simple. Fruit a capsule, many-seeded, with parietal placentæ. Seeds ovoid, or globose; testa membranous. Leaves alternate, stipulate. Herb.

No. of genera, about 21 .

VIoLA, L. (Violet.) Sepals 5, unequal, and eared at base. Petals 5, unequal, the broad one spurred at base, 2 lateral ones equal. Stamens 5, approaching ; filaments free ; anthers connate ; capsule 1-celled, 3-ralved; seeds attached at the middle of the valves. Pedicels angular, solitary, 1-flowered, curved at the summit. Flowers nodding in an inverted position. Perennial herbs.

1. V. blanda, Willd. (Delicate Violet.) Leaves cordate or kıdney-shaped, crenate, toothed or entire, early ones orbicular, flat and thiu, head of sinus rounded. Flowers white, odorous, and small; sepals ovate; petals ovate, obtuse, frequently striped with purple, slightly bearded. Stigna depressed, margined. April and May.

Geography. - Found in wet places from Canadia to Penusylvania.

2 V. Canadensis, L. (Canada Violet.) Stem 9 to 18 inches high, smooth, slender. Leaves prominently heart-shaped, and acuminate or pointed, irregularly serrate, lower ones on long petioles; stipules large, orate-lanceolate, 
entire. Flowers large, blue without, nearly white within ; upper petals marked with blue lines, side ones bearded; spur short; stigna short, and without beak; sepals lanceolate. May to August.

Geography. - British America to C'aroliua, west to Colorado, Montana, and Wyoming. Rich woods, not rare.

3. V. canina, L. (V. Muhlenbergii, 'I'orr.) (I)og V'iolet.) V'ar. Sylvestris, legel. Stem leafy, 2 to 8 inches high, many from the same root, sending off creeping branches. Leaves at the root kidney-shaped or orbicular heart-shaped, upper ones acuminate; all crenate, thin, reins prominent, stipules large, lanceolate, fringetoothed. Flowers jale-purplish, showy ; petals obovate, obtuse, lateral ones bearded; spur tapering, half as long as petals; stigma rostrate. May to June.

Geography. - Eastern North America, from Labrador to Florida, and west to Colorado. In damp meadows, edges of swamps, and fringes of damp woods.

4. V. hastata, Mx. (Halberd-leaved Violet.) Stem slender, erect, simple, nearly smooth, leafy above, 6 to 10 inches high. Leaves on long petioles, cordate, lanceolate, or hastate, acuminate, dentate; lobes obtuse, stipules minute, orate. Flowers yellow, peduncles shorter than the leaves ; lower petal broader, 3 -sub-lobed, lateral ones slightly bearled. May.

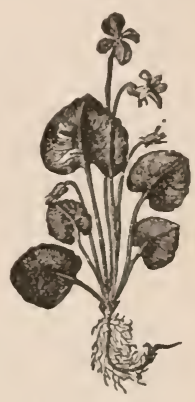

Viola BLANDA (Delicate Violet).

Geography. - 'Tenn. to Florida, mountains of P'enn. and northern Ohio. In pine woods, not common.

5. V. lanceolata, I. (Iance-leaved Violet.) Quite smootl, lanceolate, tapering into a long petiole, obscurely toothed, or entire. Leaves generally a little longer than the scapes, 4-6 inches high. Flowers white, inorlorous, striped with purple lines; spur short. Sepals lanceolate; petals beardless. A pril to June.

Gongraphy. - From Cauada, throughout eastern U. S., in damp places.

6. V. odorata, L. (Sweet Violet. Fnglish Violet.) Leaves heart-shaped, cre nate, sparingly hairy, stipules lance-shaped and toothed. Flower-stalks taller

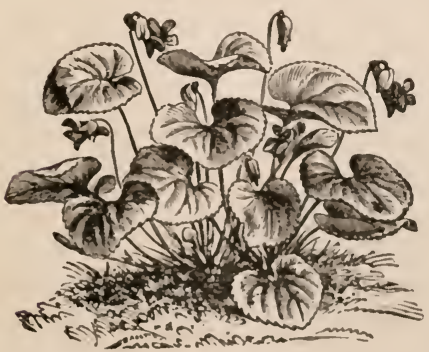

Viola odorata (Sweet Violet) than the leaves. Flowers purjule and fragrant. Sepals obtuse; lateral petals with a hairy line.

'There are several varieties, hasel ıpon the color and size of the Howers. -

a. l'urple Siwert Violet.

b. White sweet Violet.

c. Blue siweet Violet.

By coltivation all these frequently hecume doulle; they are great favorites with forrist:

Geomruplen. -..- Imligenous throughunt Europe; foumd also in some parts of ('hina, Japan, and India: it has es. caped frum cultivation, and is frequent in the fields near the great cities of the United States. 
7. V. palmata, L. (Hand-shaped Violet.) Leaves varying from broad cordate to reniform, repand toothed, sparingly cucullate at base. Whole plant slightly pubescent. Early leaves purple underneath. Growing in dry grounds and open woods. 6 to 10 inches high.

Form No. 2. Early leaves broad cordate, or reniform, somewhat fleshy, on short petioles, under side frequently purple, serrate toothed, usually 2 or 3 in number, rarely many; later leaves usually $2-4$ in number, on long petioles, 3-lobed, the middle lobe sometimes lanceolate, occasionally with parallel sides, and terminating in a blnnt angle, with lateral lobes hatchetshaped, with the margins sometimes serrate toothed, sometimes deeply cut into 2 or 3 divisions. The whole leaf is frequently divided into narrow parts, approaching V. pedata. Again, the whole margin will be made up of divisions, varying in number from 6 to 12 , and from an eighth to half an inch in width, the middle ones generally the broadest, and the incisions extending half-way into the blade. The early leaves are usually smooth, the later ones covered with pubescence. Flowers apetalous aud frequently subterranean. high.

Geography. - Dry grounds and open woods. May to August. 6 to 12 inches

'The author watched this plant closely throughout five successive seasons in the same localities, and it seems to depart from the distinctive characters of $V$. cucullata as its distance from damp ground increases. He placed specimens with divided leaves in the lawn of the Freehold (N.J.) Institute, in damp, rich soil, and in the course of four years they were free from pubescence, the leaves entire, and in every way identical with $\mathrm{V}$. cucullata growing within ten feet of it. He also saw specimens which had been transplanted into a dry, gravelly, rather sterile border, in Flushing, on Long Island, and they retained their pubescence and divided leaves.

8. V. cucullata, Ait. (Common Blue Violet.) Plant 6 to 12 inches high, flower-stalks frequently as long or longer than the petioles. Leaves glabrous, cordate, rolled in at the base, serrate-crenate, or remotely toothed, those appearing first frequently kidney-shaped, and purple underneath near the base. Flowers blue, large, late ones apetalous and subterranean. Sepals linear, lanceolate; upper one smooth, the others bearded; lateral ones obovate; spur short and rounded. April to July.

Geography. - The distribution of this species is very broad. It is found in the temperate zone quite across the continent of North America.

Var. striata, Willis. (Streaked or Spotted Violet.) Four to eight inches high. Leaves cordate, frequently reniform, early ones entire or crenate, purple underneath near the base, and glabrous, later ones becoming more and more clothed with hairs, and taking on a lobed form as the season advances, or as the plant creeps up dry hillsides from damp and lower grounds. Flowers few or many, pure white, marked with purple lines ; sometimes sprinkled with purple dots, or splashed with large, irregular, or ragged purple spots, but the lines are always present. Petals very irregular as to size, even in the same plant; sometimes very small, and sometimes irregularly cut, toothed, or even fringed; later flowers cleistogamous.

Geography. - Found sparingly near Freehold, N. J., and more frequently in the vales and on the acclivities among the Gneissic hills about White Plains, N. Y.; also in the northeastern parts of New Jersey. 
Var. reniformis, Willis, is quite distinct and constant. Leaves very broad, cordate, or promineutly reniform ; frequently 4 to 5 inches wide, and an inch from base to apex; sometimes with a deep, hroad sinus at the apex, seldom flowering; flowers subterranean, leaf-stalks 12 to 15 inches loug, growing in rich, damp, shady places.

Var. cordata, Walt. Leaves prostrate, round, corlate, sinnoth or clotlied with soft hairs, small. Dry lills and open woodlands. (V. villosa and V'. cordata, Walt. and V. sorosis, Willd.)
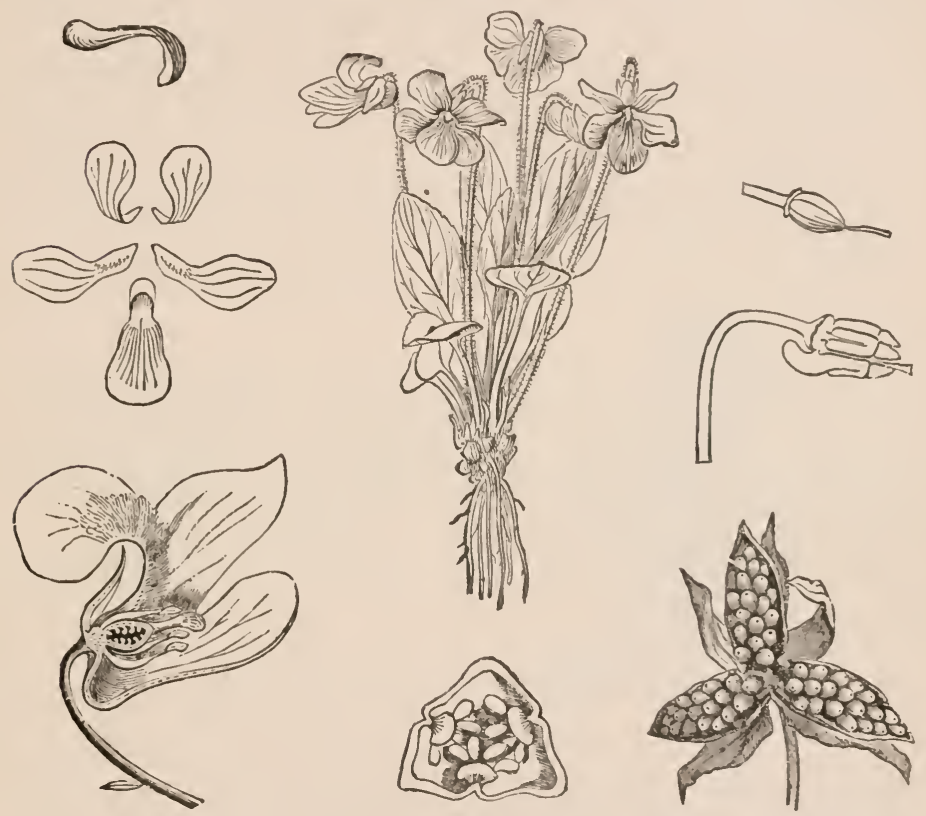

Viola sagittata (Arrow-leaved Violet).

9. V. palustris, I. (Meadow Violet, or Marsh Violet.) Leaves cordate, or kidney-shaped, obseurely crenate; stipules hroadly owate, and acuminate. Rhizomes creeping and scaly. Sepals ovate, obtuse. P'etals small, pale hlue; spur short and blunt; peduncles longer than the leaves. I'lant 2 to 3 inches high. June.

Geography. - Tops of White Mountains in NeW IIanplshire, also mountains of Colorado aid Vtah; identical with the European species.

10. V. pedata, I. (Birl-foot Violet.) Leaves perlate, smootll, 5-9-piarted, lobes linear, lanceolate, ohtuse or acute, 1-2-toutherl or 3-lobed at the apex, tapering downwards, stipules lacerated. Flowers lange, paln-blue: petals rounded at the extremities, heardless: spur short; stimma large, obliquely. truncate; heak obscure. Scapes 2 to 5 inches high, several from the same root. May to June. 
Var. bicolor, Pursh. Varies from the above description, in having the two upper petals deep riolet, presenting a relvety appearance; the others lightblue, with yellow at their bases, resembling the V. tricolor, or pansy.

Geography. - Canada to Florida, and west to Ill. In southern exposures of sandy woodsides.

11. V. primulæfolia, L. (Primrose-leaved Violet.) Smooth, rarying from cordate, broad ovate, to lanceolate, tapering into a winged petiole, slightly repand or crenate; when growing in dry places sparingly pubescent; sepals lanceolate ; stigma beaked. Flowers white, sometimes striped with purple streaks, slightly odorous ; petals slightly bearded, especially the lateral ones. April to July. Wet meadows; growing with V. lanceolata and V. blanda, and seems to be a connecting link between them. Specimens sometimes seem to possess the characteristics of both. Dr. Beck suggests that it may be identical with V. lanceolata, but the anthor's observations do not lead him to that conclusion. It seems more like a variety of $\mathrm{V}$. blanda; its flowers are odorous like $\mathrm{V}$. blanda, and its foliage more nearly approaches that of $\mathrm{V}$. blanda than of V. lanceolata, 4 to 6 inches high.

Geography. - Found in the Atlantic States, and west to Tennessee; in damp grounds.

12. V. pubescens, Ait. (Dowuy Yellow Violet.) Stem 6 to 12 inches high, somewhat angular, erect, softly pubescent. Leares broadly heart-shaped, dentate, acuminate; stipules large, orate, sparingly toothed. Flowers middlesized, yellow, lateral ; petals slightly bearded, lower ones striped with dark purple; spur rery short. Peduncles shorter than the leaves, axillary, solitary, furnished with 2 awl-shaped bracts. May.

Var. scabriuscula, Torr. and Gray. Smaller, less pubescent, brighter green, stem frequently prostrate, 3 to 9 inches high, and branching near the root.

Geography. - Canada, eastern United States to Georgia, and west to Missouri. Frequent in dry, stony, open woods throughout these limits.

13. V. rostrata, Pursh. (Long-spurred Violet.) Stem diffuse, erect, 4 to 8 inches high, smooth. Leaves smooth, thin, roundish, heart-shaped below, cordate-lanceolate or sub-triangular and acute above ; lower ones crenate-toothed, upper ones sub-serrate. Stipules large, lanceolate, serrate ciliate. Flowers large, pale-blue; petals obovate, beardless; spur slender and very long. June.

Geography. - Eastern North America, Canada to Virginia, and south and west in the Alleghanies. Found sparingly on shaded hillsides throughout these limits.

14. V. rotundifolia, Mx. (Round-leaved Violet.) Early leaves orbicular or kidney-shaped, later ones longer than broad, heart-shaped, sparingly toothed, slightly crenate, 1 to 2 inches wide, 2 to 4 inches long; stalks pubescent, about as long as the hlade. Flowers pale-rellow, middle-sized; side petals bearded, marked with dark lines, sometimes notched at the summit. Stalks 1 to 3 inches long, generally smooth, occasionally pubescent, sometimes bracted in the middle; spur short.

Geography. - Found sparingly in damp ground from New England to Tennessee.

15. V. sagittata, Ait. (Arrow-leared Violet.) Leaf entirely smooth, when growing in damp soil ; slightly pubescent when growing in dry soil. Sub- 
linear, lanceolate; sometimes triangular, oblong heart-shaped, arrow-shaped, or halberd-shaped; sparingly toothed or cut-toothed at the base; 4 to 10 inches high. Flower deep blue; petals obovate, bearded, and enarginate; spur short and thick; sepals lanceolate, acute. A pril to .July.

Var. ovata. Leaves oblong-ovate, crenate, frequently repand toothed wear the base ; pubescent; stipules ciliate; flowers large and dark. (irowing in dry, open woods; sandy soil. 2 to 4 inches high. April, May. '(V.ovata, Nutt.)

Geography. - Found thronghout eastern North $\Lambda$ merica from Cauada to Florida, and west to the Mississippi valley, Dry or moist open grounds.

16. V. Selkirkii, Pursh, Goldie. (Great-spurred Violet.) Leaves numerous orbicular, heart-shaped, slightly hairy on the upper side, crenately toothed; sinus deep, sometimes hroad, at other times nearly closed. Root-stuck filrous rooted. Flowers small, pale blue; spur very large; petals beardless, upper one marked with blue lines. Plant about 2 inches high. May.

Geography. - Found in Canada, Mass., and N. Y. C'hautanqua Co. (Judge Clinton), Lake superior (Robbins), rare.
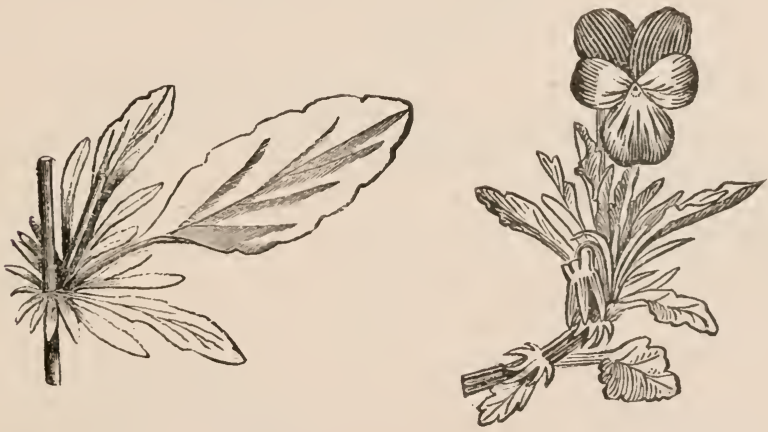

Viold TRicolor (Pansy).

17. V. striata, Ait. (Pale Violet. Striped Violet.) Stem asisurgent, angular, or half-romud, smooth, 6 to 12 inches high. Leaves alternate, heart-shaped, frequently acuminate, crenate, serrate; petioles 1 to 2 inches long; stipules large, oblong-lanceolate, strongly fringe-toothed. Flowers large, yellowishwhite; side petals densely bearded; lower one striped with dark purple; spur thickish, shorter than the petals; stigma recurved. May.

Geography. - Eastern North America, from Canada, sonth and west. I.uW grounds. Found sparingly throughout these limits.

18. V. tricolor, I. (Pansy. Heartsease.) Stem angular, much branched, 6 to 20 inches high, leafy Leaves oblong-ovate, lower leaves cordate, remotely toothed, or sulb-crenate; stipules pimatifid or lyrate, eud lobes as long as the leaves. Flowers variable in size; two upper jetals purple; sille ones white: the lower one striate at base; all yellow at hase. Spur short and thick. April to sieptember.

Escaped from gardens, sparingly naturalized in fields near old dwellings.

Var. arvensis, DC. (V. tenella, Muhl.), (V. tricolor, L.). Flowers a little smaller; petals unly as long as sepals. The whole plant usually smaller. 
Geography. - Sparingly naturalized in New York, and south to Georgia. Around dwellings, in dry, sandy soil. Brought to North America by English colonists.

Note. - This violet was bronght to the notice of florists in England about 90 years ago, by Mary Bennet, daughter of the Earl of Tankerville, who, aided by her father's gardener, produced several seedling varieties, the flowers of which were greatly enlarged and beantified. From this beginning the plant has been changed into the pansy of the present day.

Etymology. - Viola is from the Greek 'Iov, from the following myth: Jupiter loved ${ }^{\prime} I \omega$, the danghter of Inachus, first king of Argos, and on account of the jealousy of Juno he transformed ${ }^{2} I \omega$ into a beautiful white heifer, and im mediately the earth brought forth the violet for her food; hence its name, the cow plant. It is also derived, by some, from the Latin vitula, a heifer, by eliding the $t$ and changing the $u$ into $o$, making viola, the cow plant, or heifer plant.

History. - It is not to be wondered at that this beautiful little flower should have attracted the attention of the ancients. 'The early writers on plants mention the violet on account of its beanty and delicacy, and it has been lauded by both poets and painters. In the language of flowers, the violet represents faithfulness.

It was the farorite flower of the Empress Josephine. On the day before their marriage Napoleon Bonaparte sent her a bouquet of violets, after which it became the court flower.

It was the rallying sign of the Emperor's partisans, on his return from Elba. It is related that two days before he set out on his exile journey, he, while walking alone in the garden of Fontainebleau, asked a little child to give him a bunch of violets he had gathered. These he showed to some of his officers, remarking that he consiclered the flower an emblem of modesty which he proposed to imitate. The next morning, a private of his oll guard saw him collecting violets, and said to him, "sire, they will be more plentiful here next year." To which Napoleon replied, " Do you think I shall be here next year?" The soldier said, "Your Majesty will permit the storm to pass." Napoleon asked, "Do your comrades think so?" "Nearly all, Sire," was the answer. Napoleon said, "Let them think, but not say so." The soldier repeated the conversation to his fellows, and it was then agreed to speak of him always as Father Violet. After this, men throughout France began to talk of the violets of the coming spring, and of a certain Corporal Violet, who would perhaps come in the spring. Ladies who longed for his coming wore violets in their bonnets. In fact, treason lurkerl everywhere beneath a bunch of violets, and tiny pictures of the Emperor were concealed among the leaves and flowers in every buttonhole bouquet, and bunches of the flower were painted so as to reveal his profile.

Use. - The medicinal qualities of this plant are said to be curative in lung complaints, rheumatism, and catarrh. Most of the violets contain an emetic principle, ealled violine, especially in their roots. The flowers are laxative and the sirup of violets is used as a laxative for infants. The sirup is also used occasionally as a test for acids and alkalies. The roots of some species produce false ipecacuanha. The flower is used by dyers to produce the color known as the Azure of Athens, and the delicate odor of the sweet violet is a most popular perfume. The florist finds it among the flowers that are largely sought after for ornamental purposes. 


\section{ORDER VII. BIXINEAE.}

Sepals distinct, or united at base, imbricate in the bud, 2-6 in number. Corolla polypetalous or absent; petals as many as the sepals. Stamens liypogynous. Flower's usually perfect, regular, axillary or terminal, either solitary or fascicled, sometimes racemose or panicled. Leaves alternate, simple toothed, occasionally palmately lohed. 'Trees and shrubs.

Genera, 29.

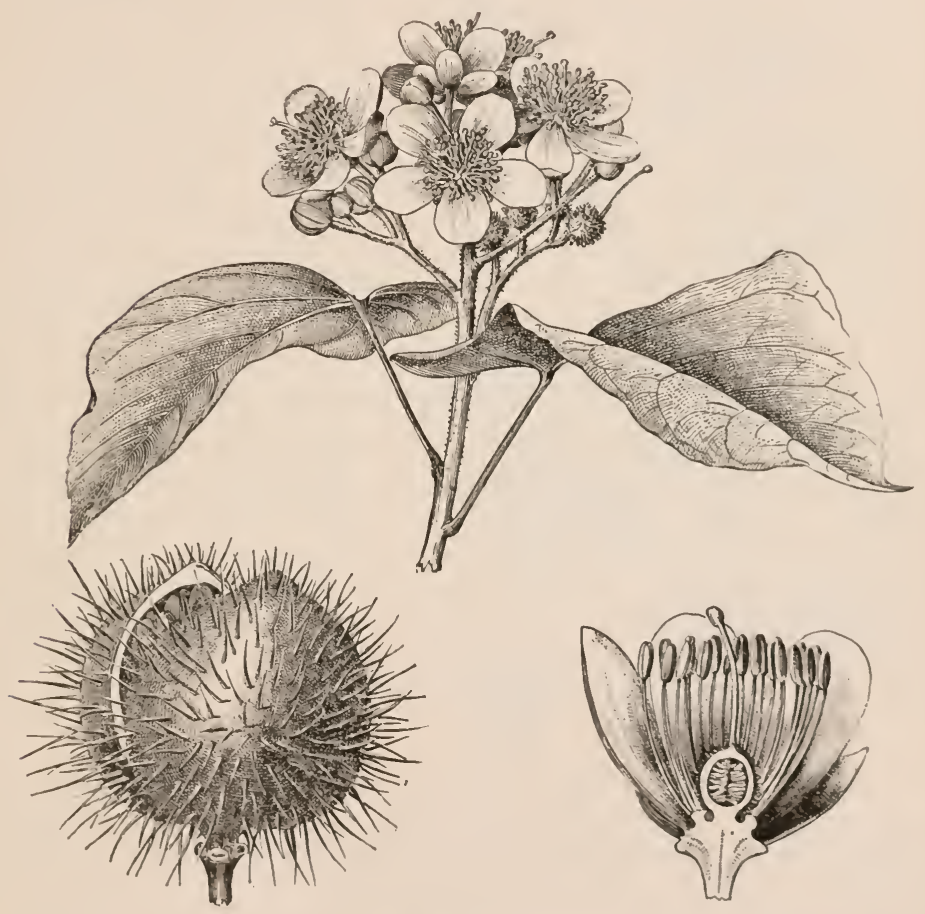

Bixa orellana (Annatto).

BIXA, I. (Annatto.) Calyx fleshy. Sepals 5, spatulate, eared near the base. Stamens numerous, some multiple of 5. Style filiform. Fruit 1-celled, in an oblong, bristled pod, somewhat like a chestnut, but longer.

1. B. orellana, L. (Anuatto.) Stem 8 to 12 feet high, branching. Leaves deep-green abuve, pale beneath, 4 inches long, broad cordate at the base, and tapering and pointed at the apex. Inflorescence a loose panicle. Flowers jink. 
Geography. - The Bixa grows in tropical America, and has been iutroduced by Europeans into suuthern Europe, Burmah, the Philippine Islands, and Hindustan. It grows freely in all regions of no frost.

Etymology. - Bixa is the South American name for this tree, and the common name Annatto is quite as obscure as to its signification.

History. - It was noticed that the natives of tropical America painted or stained their skin with a bright yellow dye. On inquiry it was learned that the material was obtained from the pulp in which the seeds of the Bixa were imbedded.

The pulp is washed or soaked off the seeds, the water is then removed by eraporation, and the residuum is made into cakes, in which form it is introduced into the market wrapped in leaves. The soft wood is used by the natives of tropical America to obtain fire by friction.

$U$ se. - The fiber of the stem furnishes excellent material for cordage.

The coloring matter is said to be of a fire color, and when mixed with cheese or butter it imparts a rich, creamy yellow; it is largely used in Holland and England as well as in America for that purpose. It is also used to color varnish, and it is mixed with chocolate to enliven the color and to improve the flavor. The roots are used in soups. The seeds are cordial, and a drink made from them is said to be remedial in allaying fevers.

Marts. - The anmul import of annatto into England is about 300,000 pounds, valued at about $\$ 65,000$.

\section{ORDER VIII. TERNSTREEMIACE丑.}

Sepals 5, occasionally 4-6 or 7, free or slightly connate at the base, imbricated in the bud. Petals 5, free, hypogynous, imbricated or twisted. Stamens sometimes equal in number to the petals, but usually indefinite. Flowers perfect, regular, axillary, solitary, or fascicled, sometimes in terminal racemes or panicles. Ovary 3-5celled. Ovules pendulous or ascending. Fruit indehiscent or capsular. Leaves alternate, occasionally opposite, frequently fascicled, at summit of the branchlets. Trees or shrubs.

Number of genera, 32 .

THEA, L. (Tea.) Calyx 5-parted, sepals short and scale-like. Corolla much longer than the calyx, white. Stamens many. Style 3-parted. Several flowers appear in the axils of the leaves. Capsule 3-celled. Shrubs.

1. T. viridis, I. Stem in a natural state grows to the height of 15 to 20 feet, but is dwarfed under cultivation, by stripping the leaves, and seldom reaches a height above 5 feet, diffusely branched. Leares lanceolate, entire at the base, serrate, with blunt teeth towards the apex, alternate. Flowers white. When grown in the Middle States, it flowers in winter under glass.

2. T. Bohea, L. corresponds with T. viridis except that the flower has many petals, and is most likely a variety of it, as the only striking difference is in the numerous petals.

Varieties. - The tea plant is grown from seed, and sports freely; hence there are many varieties, differing from each other chiefly in the form of the leaf. 
Geography. - 'The native country of the tea plant is generally supposed to be China, but it grows well in a belt induded lietween the parallels of $25^{\circ}$ and $35^{\circ}$ throughont $\Lambda$ sia, and is more prolific on hillsides than in the bottom lands. It is cultivated further north by the Chiuese, but its quality and pro. duetiveness are best in the above-named belt.

Tea is cultivated in Kangra, Gurhwal, and in Assam, Cachar, Sylhet, Chittagong, Darjeeling, and ('hota-Nagpore.

In Hindustan the cultivation has greatly increased, and is still increasing. The yield per acre ranges from 100 to 200 jounds. 'The conditions of successful tea culture are, first, a low, undulating, hilly country, where the valleys have good drainage; second, a climate warm, moist, and of uniform temperature. Assam presents a most favorable region, the temperature seldom rising above $95^{\circ}$ in the daytime nor falling below $60^{\circ}$ at night, while the rainfall is remarkably uniform throughont the year, being about 12 inches monthly. Wherever these conditions are approached, tea may be successfully cultirated, Japan, Australia, Jamaica, Brazil, and parts of North America all possess localities favorable to tea culture, and if labor sufficiently skilled and cheap were obtainable, these countries wonld be independent of tea importations. In 1836 the attention of the Indian Government was called to $A$ ssam by 1)r. Royle, the botanist, as a suitable locality for the cultivation of the plant, which has been found there in a wild state.

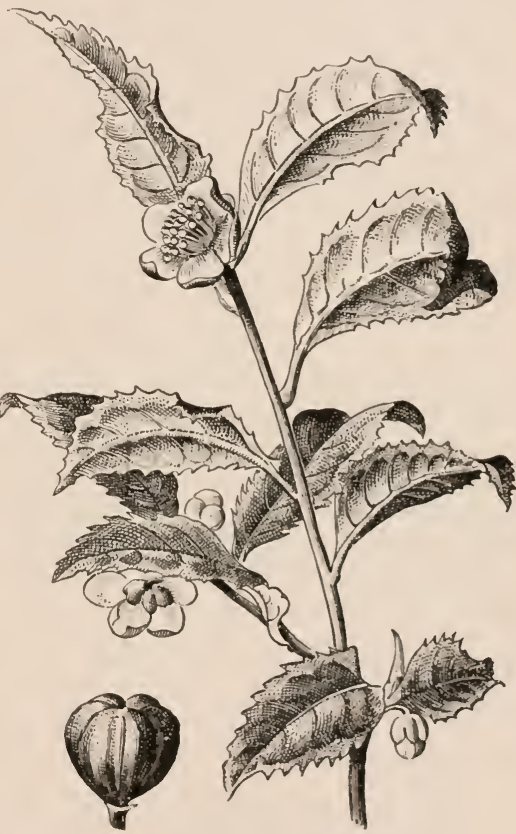

TнЕA VIRIDIS (Tea).

Etymology. - The name Thea is derived from the (hinese word, which is pronounced Teha, the meaning of which is obscure.

Mistory. - It is not known when this plant was first nsed to furnish a beverage, but it is well established that it has heen an article of traffic for more than fifteen hundred years. It was cultivated and used in the Chinese Empire in the fonrth century, and in Japan in the ninth century. Farly in the seventeenth century dried green-tea leaves were presented to a Rnssian embassy in China, and forced on them against their protestations. When hrought to Moscow the tea met with very great favor. It did not make its appearance in Europe nutil about the millile of the seventeenth century.

It was bronght to Enrope by the Jutch East India Company, and introdueed into England from Holland by Lord Arlington. In 1664 the East India Company presented the Queen of Eigland with two pounds of tea. It cost at

PL. FL. -6 
first about $\$ 25$ per pound. For a long time, because of its great price, its use was confined to the wealthy, and even in the early part of the present century it was sold in France only by druggists.

Chemistry. - The characteristic substance found in tea is theine, whose formula is $\mathrm{C}_{8} \mathrm{H}_{10} \mathrm{~N}_{4} \mathrm{O}_{2}$.

Preparation. - The varieties of tea are due to different methods of preparaation. The first gathering of the season is the best, and the last, which consists of large leaves, of an inferior flaror, is the worst. Black tea is exposed to the atmosphere for a considerable time; in this exposure an oxidation takes place, which produces chemical changes greatly modifying the tannin, theine, volatile vil, etc., but the green teas are not exposed to the action of the air in the same way, and the same chemical changes do not occur. They are roasted without fermenting, and are afterwards rolled and dried. Hence the different effect of the green teas upon the nervous system. Pekoe is green tea scented by flowers of the fragrant olive and other plants.

Use. - The leaves are steeped in boiling water, and the decoction is used as a beverage. This beverage has an exhilarating effect upon the system, due to a chemical substance found in it known as theine (see Chemistry), which is an alkaloid. It also yields a large percentage of tannic acid, with essential oil. When first introduced into Europe it was looked upon with disfavor and suspicion, and the origin of a number of diseases was traced to its use; but it has overcome all obstacles, and is now the daily beverage of more than $600,000,000$ people, who consume over $2,306,500,000$ pounds annually, and this quantity is constantly increasing.

Statistics. - The quantity of tea used in the world is amazingly large. In Great Britain alone (mostly in England) about $163,000,000$ pounds are consumed annually. In one year $52,424,545$ pounds were brought into the eastern ports of the U.S., besides what came from China and Japan to California.

The following table shows the comparative consumption among the great tea-drinking peoples : -

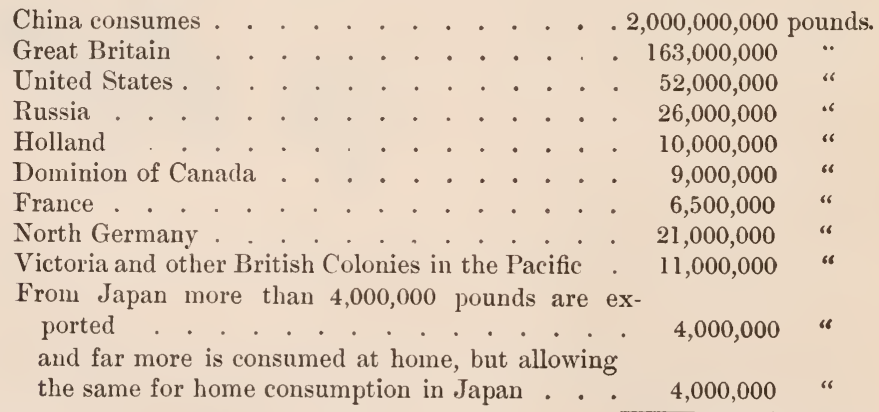

The world's annual consumption amounts to . . . $\overline{2,306,500,000}$ pounds.

Propagation. - The propagation is by seeds. The seeds must be planted as soon as they are ripe, in a moist soil, and as soon as the plants are three inches high, they must be pricked out as the gardener puts out his cabbage or lettuce; when they are six to eight inches high they may be reset in a nursery, six to twelve inches apart, and kept free from weeds. After six to ten months in the nursery they may be planted in the orchard or plantation. 
The picking is done by women and children, who twitch off the young leaves and terminal buds with the thumb and finger. They are then carried to the house or sherl, where they are spread ont on mats, then roasterl in pans, rolled in the hands, and dried orer a charcoal fire, when they are ready for packing.

This is a brief description of one process. Several methods are in use to accomplish the same end.

Marts. - Canton is the great tea-exporting market for China. Most of the best teas taken into Russia are carried orerland. Teas are also shipped from other Chinese ports besides Canton. Imports into Great Britain ar. chiefly lancled at Liverpool; into the U.S., at New York, Buston, and Siu Franciseo. The marketable character of each variety of tea depencls upon its purity, time of harvesting, and the perfection of preparation or curing. When these three things are perfect, tea discharges a certain aroma and possesses a peculiar taste. The taste and aroma are so delicate that tea merchants do not trust their own judgment, but employ professional tasters, who command high salaries. These tasters suffer in health on account of breathing and absorbing a volatile oil given off by the tea while in an infused state.

\section{Order IX. MALVACE正.}

Herbs or shrubs. Flowers regular; sepals 5, united at the base. valvate in the bud; petals 5, hypogrnous, convolute in the bud; stamens numerous, monadelphous, and hypogynous; anthers kidneyshaped, 1-celled; pistils sereral, distinct or united; stigmas various. Leaves alternate and stipulate. Fruit, several-celled capsules, or made up of 1-seeded carpels; embryo of the seed curved.

GOSSYPIUM, I. (Cotton Plant). Calyx cup-like, 5-toothed, encircled by a :3-leaved involucre, the cordate leaflets united at the base, incisely toothed; petals 5, large; styles united; stigmas 3-5; capsules 3-5-celled, n1nany-seeded; seeds brown, immersed in soft, wool-like, white, fibrous hairs, which is the cotton of commerce. Herlss and shrubs.

1. G. herbaceum, L. (Herb Cotton.) Stem 5 feet high, clothed with stiff hairs above. I.eaves large, cordate, 3-5-lobed below, 3-lobed above, somewhat in form of the graje leaf, with mueronate lobes; leaf-stalk as long as the blarle. Flower-stalk longer than the petioles, flowers axillary, yellow, with a reddish center, showy, 3 inches in diameter. Herb.

2. G. Barbadense, I. (Sea-Islaud Cotton). Ieaf has 3 glands on the under sicle of the millrib. Seed black, cotton very white, fibers long.

3. G. arboreum, L. (Tree Cotton). Stem arborescent, 15 to 20 feet high, branching. Leaves 5-lobed, not so broal as those of $\mathrm{f}$ herbaceum. General shape lanceolate; petioles hirsute. Flowers red and showy.

The species of Gossypium are numerons, those described above, with their varieties, are the most important that are under cultivation. As the cottonplant is propagated from seed it is liable to sport, and a great number of forms or varieties have arisen, differing from the parent in strength, length, or colur of the fiber. The cotton tiber of commerce consists of the long silky 
hairs with which the seeds are clothed; these hairs are tubular, unjointed, Hattened, and slightly twisted. When ripe, the seed is gathered, and the hairs and the seed are separated by a machine called a gin; the cotton is then packed in bales for the inarket.

Geography. - The geographical distribution of the cotton-plant is mostly confined to tropical and subtropical comntries, though it has sume varieties that have gradually become acclimated to regions of light frost. It is cultivater in a broad belt all around the globe.

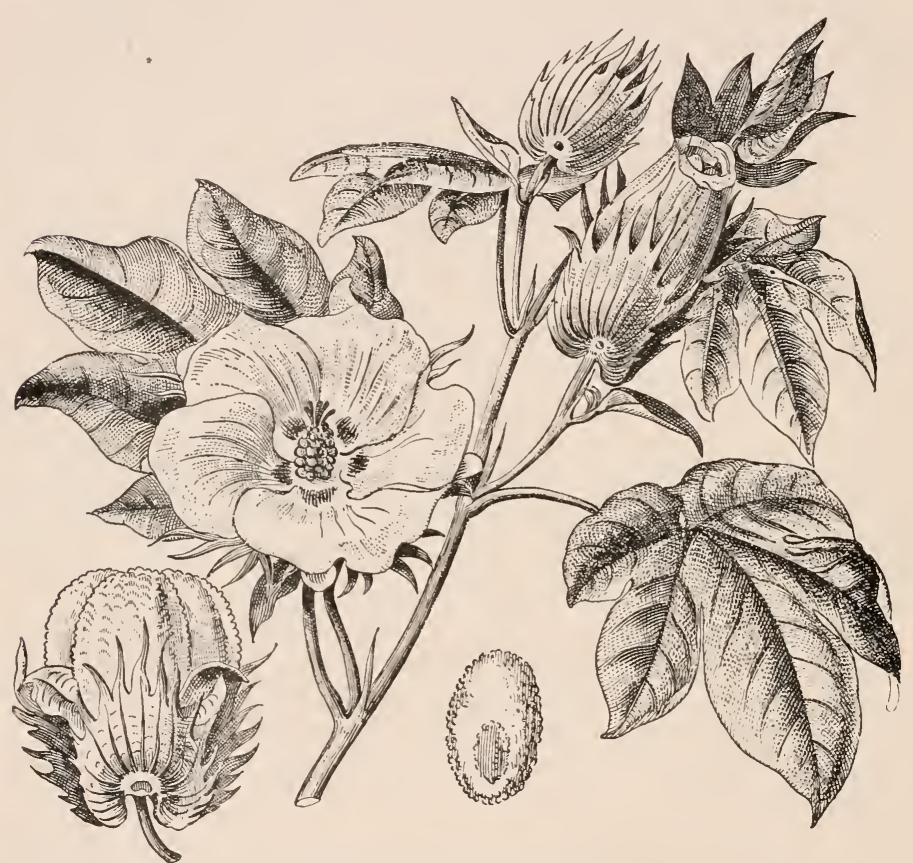

Gossypium ARBoreum (Tree Cotton).

The cotton-plant will fruit well in the same latitude with the sugar-cane. The East Indies, China, the Asiatic islands, Greece, and the islands of the Eastern Mediterranean, the countries of the Levant, Asia Minor, Northern and Western Africa, Anstralia, and the isles of the Pacific, the West Indies, Sonthern United States, Venezuela, British Guiana, and Brazil, are the centers of cultivation.

Etymolog!y. - Gossypinm is from Goz, an Arabian word, signifying silky. The specific name, herbacenm, signifies herb-like, and Barbadense is for Barbadoes. Arboreum means tree-like. The word cotton is from a Syriac word meaning fine, delicate.

History. - It is not known when or where the cotton-plant first began to minister to man's comfort; it is a reasonable inference that it was among the first, if not the very first, of the fibrous plants to attract attention. 
The flowers and the bursting pols are showy and very heautiful, and must always have been objects of aimiration. Cotton was unknown to the ancient Figrptians, as no cotton cluthes or wrappings have been lound in the mummy pits. The seeds of tree-cotton were found by Losellini in an Egyptian tomb. IIerodotus speaks of a plant in India which produced a tiner and hetter quality of wool than that of sheep, of which the natives male their clothing. Five centuries after Herodotus, l'liny deserihes the cotton-plant, and states that it was under cultivation in Egypt, and that the fiber was need to make the fabries worn by the priests. Arahian travellers who visited China during the ninth century state that the Chinese lid not at that time use cotton liahrics, such as were used in Southern Eurne, Northem Africa, and the countries of the Levant, but instead used silk. It is believed that Alexander the (ireat, about $325 \mathrm{~B} . \mathrm{c}$., carried the cotton-seed to the Levant from India, where he found it growing in the country between the forks of the Indus. Another account gives the $\lambda$ rabs credit for its introduction into Egrgt, whence it spread into 1.ia Minor and the islands of the Eistern Mediterranean.

'lhe raw material did not become an article of commerce until many years after the oceupation of India by the British; but manufactured cotton gouds were imported into (ireat Britain as early as 1666 from Bombay and other ports of Hindustan. 'The 1)utch, English, and P'ortuguese merchaints all dealt largely in cotton fabrics made in Southern Asia. The first impurtation of raw cotton into England from the East Indies occurred in 1798. The protit on cotton when it first entered into commerce was five hmudred per cent. Napoleon I. during his reign cut off all trade with neighboring nations, and one of the results was an attempt to bring cotton under cultivation in Italy, Southern France, and the islaud of Corsica.

It has been claimed that a cotton-plant has been found in Mexico entirely different from the Asiatic varieties, growing without cultivation, and that the Mexicans and the I'ernvians wore cotton clothing when concutered by the spaniards, soon after the discovery of the new world. The plant grown now in America was introduced in early colonial times, but did not reach any commercial importance till the beginning of the present (eutury, when ahout two thousand pounds were shipped to England; from that time the quautity rapilly increased until the outbreak of the Civil War.

In the vear $1860,2,160,000,000$ poumls were exported. The quality of the Americai production is so far superior to all others that it hrings in the open market a much higher price than the cotton of India. Next to the United States, India takes the greatest quantity to Great Britain.

Before the power loom and spimers were hrought into use, (hina and India made the cotton fabrics and juints of the world; but now England exchanges the woven fahries with those comntries for the raw material.

I se. - The wool or fiber of the cotton-plant is now wrought into every sort of fahric that enters into the clothing of civilizenl peoples of tropical and subtropieal countries, and that constitutes the under garments of people of higher latimiles, aml it forms a large part of the attire of females thronghont the rivilized worlh. (iun-cotton, a highly explosive substance, is prohlued by soaking eotton in nitric and sulphuric acids. Gun-cotton treated with snlphuric ether gives colloulion.

() the seds an oil is male which rivals the hest olive oil for culinary purposes. The seeds, gromml and pressed into masses, are sold molder the name of oil-cake, and used to feed poultry and cattle, for which purpose they are highly valued. 
Cotton, treated with antiseptics, forms a rery important article of modern surgery. From the roots a fluid extract is made, much used in the Southern United States by irregular practitioners.

Statistics. - The amount of cotton consumed in the world is not easily ascertained. There are about 3,000,000,000 pounds exported annually from Southern Asia, and 2,000,000,000 pounds from the United States, and about the same amount is consumed in those countries; so that an estimate of $12,000,000,000$ pounds for the whole world would not be too high. This quantity, at ten cents per pound, amounts to the exormous sum of $\$ 1,200,000,000$ for the value of the raw material.

\section{ORdER X. STERCULIACE E.}

Trees or shrubs, agreeing with Malvaceæ, except that the anthers are extrorse and 2-celled; petals sometimes wanting; capsules united into a 2-5-celled ovary.

THeobroma, L. (Cocoa.) Calyx spreading, sepals 5. Petals 5. cordate at the base, extending into a strap. Stamens united at the

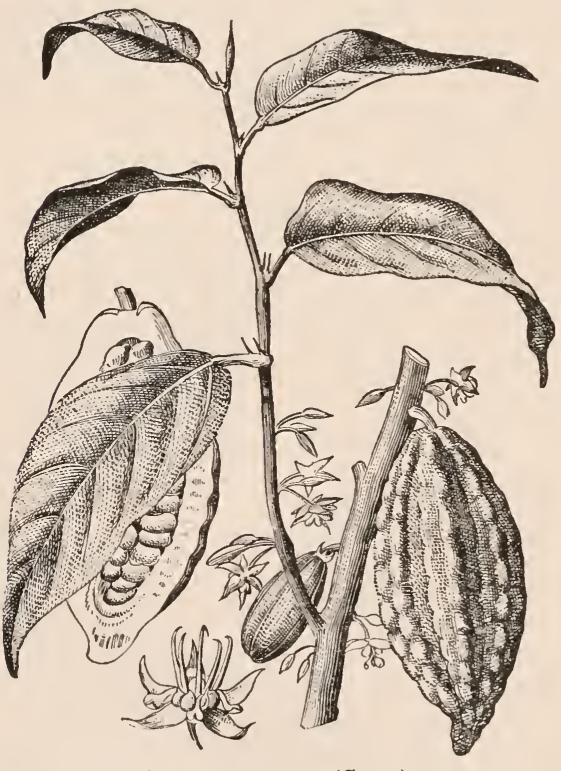

Тнвовroma rocon (Cocoa). base, extending upwards into 10 divisions, each alternate one terminated by 2 anthers each, the other divisions sterile. Pistil filiform, divided into a 5-parted stigma. Fruit a 5-angled, elongated, warty capsule. in the form of a cucumber, 5-7 inches long, and 3 inches in diameter, containing from 25-40 seeds. Seeds about three eighths of an inch long and two eighths wide, imberlded in pulp.

1. T. cocoa, Wallich. Stem upright, muchhranched; branches commence about 4 or 5 feet from the ground, and form a srmmetrical head. Bark light-brown, smooth; the whole from 10 to 15 feet in height, presenting a beautiful appearance. Leaves oblong, lanceolate, 4 inches in length and 2 in width, entire, dark-green, and evergreen. Flowers, leaves, and fruit after the third year of the plant's life are always present. Fruit harvested twice a year, June and December. 
Besides the above-described species, there are some 10 others, all of which ar the same description, with the exception of some slight variation in the size and shape of the fruit or leaf, the most important of which are:-

2. T. angustifolia, DC. Narrow-leaved.

3. T. ovatifolia, DC. A Mexican species called finconosco, with ovate leaves.

4. T. bicolor, Humboldt. A species found in Colombia, S. A., with rariegated leaves.

5. T. Guianensis, Aublet. A species indigenous to Gniana, S. A

6. T. microcarpa, Mart. A West Iulia species, witl small seeds.

†. T. sylvestris, Martius, A species found in the selvas of Brazil.

As the plant is produced from seed, varieties are constantly occurring.

Geography. - The Theobroma is a native of America, and is indigenous to tropical and subtropical regions, or at least to regions of no frost. It is found in Brazil and all parts of South America north of Brazil, the West India islands, and Mexico. It has been introdnced into the Philippine islands and other parts of the Indian Archipelago, but the great supply is produced in the new world.

The Spaniards introdnced its culture into sonthern Europe ahout the year 1560. Some years ago the British introduced the cultivation of the cocoa into India with success.

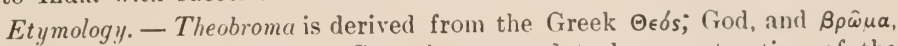
food, hence food of the gods. Cocoa is supposed to be a contraction of the Portuguese word macoco, monkey, applied to the tree on account of the resemhlance of the end of the fruit to the face of a monkey.

History. - Cocoa was first brought to the notice of Europeans at the time of the invasion and conquest of Mexico by the Spaniards in 1520. The Mexicans prepare it with spices, as chocolate is now prepared. That prepared for the emperor was flavored with vanilla. When Cortes, the conqueror of Mexico, sent the valuable products of the New World to Charles V., cocoa was sent as one of the choicest. The Spaniards took it to Europe and introduced it into commerce. The medical men found that it possessed curative properties, and a monograph was written by Hoffman in which he entitled it Potus Chocolait. He states that ('ardinal Richelieu was cured of a general wasting of the body by its use.

Though used in spain and Portugal early in the sixtecuth century, it was not known in England until more than a hundred years afterwards. The earliest mention of its use was in a periodical known as Needham's Mercurius l'oliticus, 1659. The mode of preparing it was introdnced into England by 1)r. Sloane.

A. De Candolle states that, when the Sianiards explored and conquered Mexico, the fruit of the Theobroma was so highly prized that the seeds were used for money. In 16it the Spaniarcls carriel the plant to the Philippine Islands, where its cultivation became wonderfully successful.

Chemistry. - Various results have heen obtained by chemists in the analysis of the bean of the Theobroma, arising no doubt from different conditions or varieties of the bean. In one thonsant parts it yields- 
Fat (Cocoa-Butter) . . 510

Albuminoids . . . . . 210

Starch or Sugar . . . . 220

Mineral substances . . . 40

Theobromine . . . . 20

$\frac{20}{1000}$

ForMULA OF THEOBROMINE. -

$\mathrm{C}_{7}, \mathrm{H}_{8}, \mathrm{~N}_{4}, \mathrm{O}_{2}$. This is the substance that affects the nervous system somewhat as theine and caffeine do.

Comparative analysis with milk (approximate) :-

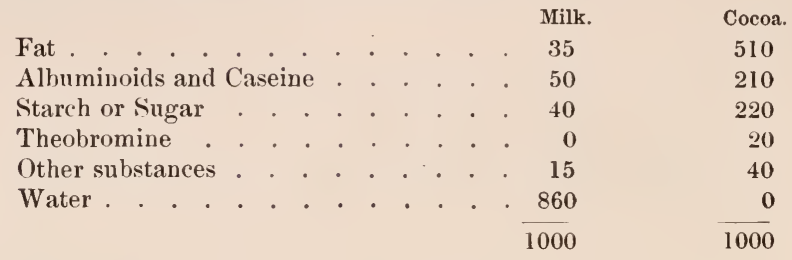

This shows that the cocoa bean contains materials to sustain life. Amoug the mineral substances of Theobroma is Phosphate of Lime.

Use. - The dried and split cotyledons of Theobroma seeds are cocoa nibs, and when ground and made into a paste, they form chocolate. The seeds, when roasted and ground, are cocoa; this when mixed with starch and finely ground, is soluble cocoa.

Like tea and coffee, cocoa is one of the most important and useful articles of domestic economy, and in the formation of warm table beverages stands first among the peoples of Sonthern Europe, South America, and Southern North America, and forms an article of consideration in commerce in the marts of all the civilized world. The natives of the countries where it grows break the capsule or seed-ressel and suck out the pulp, which has a glntinous, sweetish taste. It is also preserved, and rinegar, spirits, liquors, and jellies are made of it; but the most important part is the seeds, which are roasted, ground, and made into a beverage, as coffee is prepared, and are used in the same way.

Statistics. - The production of cocoa in the New World amounts to about $60,000,000$ pounds, worth $\$ 7,000,000$. In the absence of statistics, the quantities produced in Europe and Asia cannot be arrived at.

Marts. - The markets of South America are La Guayra, Puerto Cabello, Maracaibo, Campano; of North America, Vera Cruz; of the IVest Indies, Martinique and Guadaloupe.

\section{ORDER XI. TILIACEA.}

Calyx valvate, and falling early ; sepals 5; petals 4-5, or as many as sepals, rarely gamopetalous, hypogynous, twisted, imbricated, or valvate in the bud. Stamens some nultiple of the number of the petals, free or in bundles; anthers 2-celled. Flowers perfect, with rare exceptions, regular, axillary, or terminal, solitary, or in fewflowered cymes or panicles. Leaves alternate, occasionally nearly opposite, simple, entire, or palmately lobed; sometimes crenulate or dentate, frequently coriaceous; veins prominently reticulate beneath : 
stipules 2. Fruit 2-10-celled, varying from 1 cell by suppression to 10 by false septa.

Trees and shrubs, seldom herbs. No. of genera, 40.

CORCHORUS, L. (Yellow Jute.) Calyx 5-prarted, sepals valvate, petals alternating with the sepals; stamens two or three times as many as the petals, nearly all fertile, or a few of the interior ones without anthers, filaments free, anthers '2-valved, opening by longitudinal slits. Style simple; apex broadened, hollow, truncate, and toothed, or crenulate. Ovary 2-5-valved, cells frequently incomplete, the placenta falling short of the center, many-oruled. Capsule short, subglobular, or elongated, varying to orate-oblong or subcylindrical, velvety, or clothed with soft bristle-like processes or hairs. Seeds numerous. Leaves simple or compound, alternate, serrate, stipulate. Flowers solitary, or in small terminal and bracteate cymes.

1. C. capsularis, W. (Jute.) Stem 5 to 10 feet in height, hranched. Leaves alternate, acuminate, serrate, palmately compound ; leaflets 6 , lanceolate, tapering to the base. Flowers terminal and at the ends of the branches, in loose compound racemes, small, yellowish. Capsule globose, wrinkled, 5-celled seeds, few in a cell.

2. C. olitorius, W. (Jute.) Stem 5 to 6 feet in height, erect. Leares alternate, ovate, acuminate, serrate, the lower teeth terminating in threatl-like processes. Flowers small, yellow, on a perluncle; sepals 5; petals 5 . Capsules subcylinlrical, resembling the seedvessel of a cruciferous plant, 10-ribbed, 5. celled, 5-ralved. Seeds numerons.

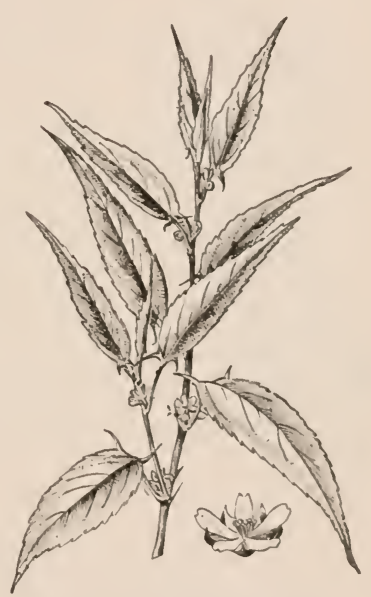

Corchorus olitorius (Jute).

3. C. siliquosa, I., whose fruit resembles a silique, is found in Florida; but the first two species described above furnish the fiber known as jute.

Geography. - Southern belt of the north temperate zone and the tropics.

There are about forty species, all of which are natives of tropical and subtropical countries.

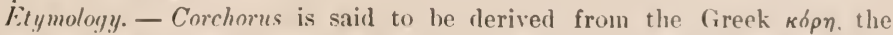

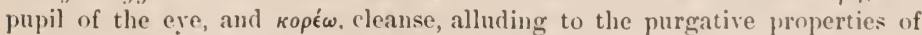
some of the species. (How it applies to the eye is not apparent.) ('apsularns alludes to the peculiar form of the seed-ressel of this species, and nlitorus means a garden-plant. Jute is from sanskrit djat, the Indian name for the plant, the meaning of which is obscure.

History. - The home of the C. capsularis is Java and Cevlon, and undonbtedly other Asiatic islands. C. olitorins is a native of western India, aul has spread by cultivation to Asia Minor, Africa, etc. It is certain that the Greeks used this plant as a pot-herb, and by many other nations around the shores of the Mediterranean this use of it was common. 
Cultivation - A hot, moist climate, an abundant rainfall, and a rich, allurial soil appear to be the conditions most favorable for the successful cultivation of the jute plants. The land must be well tilled and abundantly manured. The time for sowing the seed in India extends from about the middle of March to the end of May; the seed is sown broadcast in the prepared ground, the young plants are thinned out to 6 inches apart, and the ground is carefully wreeded. The stalks are ready for cutting down between the middle of August and the middle of October.

Cse. - The fiber of the jute is long, hard, coarse, and glossy, but much inferior to hemp and flax in point of strength. It is cultirated in Southern and Western Asia and in the Grecian Archipelago, and in Central and Northern Africa. In the Levant the C. olitorius is grown for a pot-herb, and eaten for a regetable with meats. The fiber is obtained by steeping the plant and rotting it, in the manner rlescribed for preparing hemp; the fiber is hard and woody. When used to manufacture wearing-apparel, it is worked through a machine and treated with fish oil, which in a measure remedies the evil.

It is used in the manufacture of coarse cloth, gunny bags, sails, and cordage for vessels. It is employed in the adulteration of hemp, and of late years has been applied to the adulteration of silk.

The pulverized bark is an active purgative, and is employed by the Hindus for that purpose. The Hindus also manufacture paper of jute. Theatrical wigs, switches, water-falls, fronts, backs, and bangs are also made of the fiber of this plant.

Statistics. - Jute ranks in commercial and economic importance, as a textile, next to flax, cotton, and hemp. Great Britain imports large quantities annually, the greatest supply, over 500,000,000 pounds, coming from India. Dundee, in Scotland, is the center of jute manufacture.

\section{OrdER XII. LINACE王.}

Calyx of 5, rarely 4, parts, imbricate in the bud. Petals as numerous as parts of calyx, hypogynous, twisted. Stamens equal in number to petals. and alternate with them. Ovary 5-4 celled : cells 2-oruled; or ovary spuriously 10-8-celled. Styles 3-5, free. Flowers perfect. regular, in terminal racemes or corrmbs. Fruit a globular capsule. Seed compressed. Stem herbaceous, sub-זoody.

Herbs. Number of genera, about 14.

LINUM, L. (Flax.) Calyx 5-parted, persistent. Petals. stamens. and styles in 5's, alternating with each other. Seed-ressel 5-celled, each cell partly or entirely separated into 2 cells by a false partition, thus forming 10 imperfect cells; true cells mostly 2-seeded; seeds flattened. Leaves sessile, entire, simple, alternate, occasionally opposite, exstipulate. Herhs. Annual.

1. L. usitatissimum, L. (Common flax.) Stem about 3 feet high, slender, tapering, smooth. Leaves alternate, linear-lanceolate, acute, an inch to an inch and a half long. Flowers in a corrmbose panicle; sepals ovate, acute; margins membranaceous. Petals subcrenate, large, blue, with a purple tinge, caducous. Seeds compressed, ovate, smooth, and shining, mucilaginous. Annual. 
2. L. angustifolium, I. (Narrow-leaved Flax.) Herb, hears the ahove description, with narrower leaves. l'erenuial.

These two species and their varieties furnish the flax of commerce.

3. L. Virginianum, L. (Wild Flax), is a heatiful plant, incligenous to eastern North Ameriea; bears the above description except that the sepals are mueronate and the seerl-ressel depressed. IIills and edges of woods. ("ommon.

There are nearly a hundred species of the Limm, the inner barks of all of which in a greater or less degree possess the strong, fibrous character of the I. usitatissimum and the $\mathrm{L}$. angustifolium.

Geography. - No plant known to domestic economy has a wider geograph. ieal range than the flax. It is found growing luxuriantly in the subtropical bottom lands of Ilindustan, in sonthern Egypt, and thronghont Europe to the shores of the Baltic, in southern and middle Russia, and northeastern $\Lambda$ merica.

Etymology. - Linum is from the Greek word Xívov, thread. The specific name usitatissimum signifies most used, or useful, and angustifolium has reference to the narrow leaves of this species. Virginianum signifies Virginian flax, or flax found in Virginia, a name once applied to a much larger extent of territory thau that occupied by the present State. Flax is the Anglo-saxon name for the plant, and signifies to plait, or weave, referring to the use made of the fibrous bark of the plant.

History. - The home of the varieties of flax under cultivation is believerl to be the countries of the I,evant and the Mediterranean. Flax was used by the people of western $\mathrm{A}$ sia at a period prior to the founding of Babylon. It was well known to the ancient Egyptians. The mummies were wrapped in linen cloth, usually of very fine texture. In the Swiss lake. dwellings evidence is found that the L. angustifolium had been cultivated. The stems of the plant used were cut, indicating a perennial species. Similar dis-

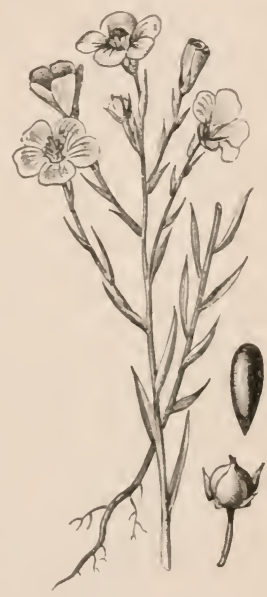

LINUM USITATISSIMUM (Common Flax). coveries have been made in the peat-hogs of Lombardy. The species grown in ancient Egypt was L. usitatissimum. In the Seriptures fune linen is frequently mentioned. In the temple of Minerva at Lindus there was kept a linen corslet of fine workmanship, which had heen worn by Amasis, an Egyptian king who reigned 600 years before Christ, each thread of which was composed of 360 filaments. The garment was decorated with cotton and gold. At the beginning of the Christian era linen fabries were in use net only in Palestine and Egypt, hut also in Europe.

Pliny, in speaking of the flax of spain, says that it was smperior to that produced in other countries, showing thereby that it was under cultivation throughout the sonth of Europe at that time. It was introduced into England soon after the Norman rule hegan, but never hecame a profitable crop there

Cultivation and Preparation. - Flax requires a damp, molerately fertile soil. It is sown broadeast, about three bushels to the acre, and rolled or har. rowerl; aud just hefore the seed is ripe, it is pulled, male up into bundles, and sunk under water, to dissolve the gumuy substance botween the bark and the stalk. After it is removel from the water it is spread unt to dry ; it is then 
passed between grooved rollers to break the woody parts of the stem, and beaten with a large, broadsword-like wooden knife to separate the fiber from the broken woody parts. The whole of this preparation at the present day is better performed by machinery.

Use. - The use of flax is well known. It furnishes material for the coarse sails of our shipping, for the cordage with which they are rigged, and for the celebrated Irish linens, and the delicate laces which adorn the ladies' toilet. The ancient Romans did not, as the Italians do now, make great use of linen as wearing-apparel, but they used it for cordage and for the sails of their vessels.

In early colonial times it was raised in the British colonies of North America, and every family prepared, spun, and wove the linen necessary for the beds, table, and underwear for the family. A coarse fabric was made called tow-cloth, which was used for pantaloons and farmers' and teamsters' frocks.

Of the seed is made linseed oil, used in mixing paints. It rapidly oxidizes, and causes a hard, glossr surface. It is an ingredient in printers' ink and in the manufacture of oil cloths. The seeds when boiled are used for drinks for throat and bronchial troubles. A liniment made of lime-water and linseed oil is applied to burns, with great success.

Marts. - Flax for linen fabrics is produced more largely in Belgium than in any other Enropean comutry. The finest flax in the world is raised in Flanders, where the material for the celebrated Brussels lace is produced. The Hax used for Brussels lace is sold for $\$ 500-\$ 900$ per ton, vielding a greater return per acre than the price of the land upon which it grows would amount to. Flax is also the chief staple of the north of Ireland, Belfast being the metropolis of the linen trade. The great markets for linen fabrics are the large towns of these countries.

Seed for linseed oil is furnished to the world by Russia, Holland, America, and the East Indies.

ERYTHROXYLON, I. Sepals 5. Petals 5, imbricate, each furnished with a double or plaited scale on the inner side of the base. Stamens 10, rarely 12. Leaves alternate. Flowers axillary. Fruit drupaceous. Shrub.

E. coca, Lam. (Coca.) Stem 6 to 8 feet high, ramified into a symmetrical head. Leaf dark-green above, paler beneath; thin, entire, ovate; tapering at each end; strongly veined, two lateral lines extending from the base to the apex parallel with the midrib. Flowers small, white, solitary, on short pedicels. Stamens united at the base. Ovary 3-celled, 2 cells empty, fertile cell l-seeded.

Geography. - Tropical and subtropical. Found in the northwestern parts of South America, in Bolivia, Peru, Fcuador, and Colombia; also in northern parts of Brazil.

Etymoloqy. - Erythroxylon, the generic name, is derived from the Greek

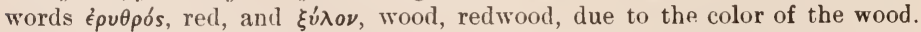
Coca is the Indian name. In the northwestern parts of Brazil it is called Spadic. The signification of neither of these names is known.

History - The practice of chewing the leaves of the coca existed in Peru at the time of the Spanish conquest. How long previously it had been used we have no means of knowing: 
Use. - The dried leaves are placed in the side of the mouth with a littl. ashes or slaked lime, and chewed until exluausted, the operation being repeated several times during the day. It acts as an excitant to the salivary glands. The saliva, having extracted the properties of the leaves, is swallowed, and produces a pleasurable stimulating effect upon the system, nentralizing the pangs of hunger and thirst, and wonderfully increasing the power of endurance of physical exertion, enabling travellers and burden-hearers to endure wonderful fatigue.

It is believed by some that the chewers of coca are speerlily injured in both mind and body by effects similar to those produced by alcohol and opium habits.

I). H. H. Rusby, who has recently returned from a visit to liolivia and other parts of tropical South America, where he lias spent some time in the examination of the butanical characters and medicinal properties of the trees and plants of those regions, is eminently qualified to speak of their wonderful qualities. From his article on the coca we gather that the most important medical properties residing in the plant are found in the leaf, and are stinulant, carminative, anzesthetic, and supporting.

Dr. Rusby has har unusual opportmnities for watching and studying the effects of the use of the coca, and his observations do not leal him to the conclusion that the constant use of the leaf by the uatives either impairs their health or enfeebles their intellect.

\section{ORDER XIII. ZYGOPHYLLACEA.}

Calyx of 4-5 parts, imbricate in the bud. Petals lyyogynous, imbricate or contorted. Stamens double the number of petals, hypogymous; filaments with a scale insicle. Uvary several-celled. Flowers perfect, regular or irregular, axillary, 1-2 from an axil. Leaves opposite, pimnate; petioles stipulate, sometimes with spines. Branches frequently divaricate and jointed. Fruit a loculicidal capsule. Herbs, shrubs, and trees.

Number of genera, 17 .

GUAIACUM, L. (Lignmm-vita). Calyx 5-parted. Petals 5. Stamens 5े or 10. Fruit a pentagonal capsule, with 5 cells : a single seed in each cell. Tropical and subtropical trees.

G. officinale, I. (Lignum-vita. Fuaiacmm Wood.) Stem erooked, 40 feet high and 18 inches in diameter, branching irregularly. Bark gray, with green spots. lioot very large, lescending very deep into the earth. Leaves compound, with 3 pairs of ovate, blunt leaflets.

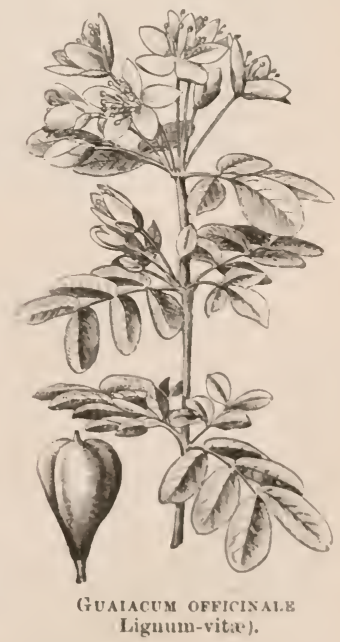

Flowers axillary clusters, blue, hamlsome, like hepatica. sap wood yellow; heart wood greenish-brown; cluse grain, sinks in water; a gum resin 
exudes from wounds in the bark, which is the Gum Guaiac of the Materia Merica. The resin yields to the chemist $\mathrm{HO}, \mathrm{C}_{12} \mathrm{H}_{7}()_{5}$, Guaiacic Acid.

Geography. - This tree is exclusively American; it has a narrow geographical distribution, indigenous in the West India Islands, but thus far has not been found upon the mainland. Another species, (i. sanctum, has been detected in Florida.

Etymology. - The name Guaiacum is from the native name, Guaiac, which undoubtedly refers to some property of the plant. Officinale signifies, of the shops, referring to its sale and use. Lignum-vitce, the wood of life, is named from its medicinal properties, as it is said to preserve life.

History. - The Guaiac is a resinous substance which flows from wounds in the bark, and hardens on exposure to the air and sum heat. It is friable, and of a greenish-red color. The bark and wood also are charged with this resin, and are therefore medicinal. 'The leaves, fruit, and flowers are all purgative. As it is an American tree its use is recent, but soon after the discovery of America, in 1508, it was obtained from the natives of Haiti by Gonsalvo Ferrand and taken to Europe.

Use. - The wood is very hard, takes a fine polish, and is so heavy and closegrained as to sink in water. It is a favorite wood in the hands of the turner ; it is manufactured into rulers, pulleys, ships' blocks, bearings in steam machinery, mortars, pestles, bowls, and vases.

The resin is stimulant and very diffusive in the system, and affects the skin, kidneys, and the intestinal canal very actively. In large doses it is cathartic. It is administered in the form of pills and tinctures

\section{OrDer XIV. RUTACEA.}

Flowers inferior or perigynous. Sepals and petals imbricate, 4-5. Stamens double the number of petals, or equal (in the citrus, numerous and indefinite), inserted on the receptacle or a surrounding disk. Leaves alternate, sprinkled with pellucid dots, containing a bitter, aromatic oil. Fruit in the orange family a berry. Shrubs and small trees.

Gènera, 8:). Species, 450 .

CITRUs, L. Calyx 5-sepaled. Petals 5-10, white, fleshy, fragrant. Stamens numerous and some multiple of 5. Filaments flat at the base and united in sets. Anthers versatile. Style 1. Ovary manycelled, ripening into a pulpy berry. Shrubs and small trees.

1. C. aurantium, L. (Sweet Orange.) Stem about 6 to 8 feet to the point where the head begins to form, much branched; branchlets armed with spines, forming a symmetrical tree from 15 to 25 feet in height. Leaves ovate, tapering to a point ; petiole wiuged ; blade leathery, dark-green above, lighter beneath, evergreen, articulated to the petiole. Flower white, with a very delicate, fragrant odor. Fruit a berry, globular, or flattened at the poles, bright yellow, two to four inches in diameter, composed of a juicy, edible pulp, divided into 10-13 cells, each cell with $1-3$ seeds, the whole inclosed in a bright golden, tough rind. In a state of cultivation the spines on the branchlets are usually wauting. 
Var. sanguinea. (Blood Orange.) This form has become constaut, and differs from the typical plant in the color of the pulp in the fruit, which varies from a light blood-red to a deep dark-red, the branches being usually, but not always, without spines. The anthor has cousulted inteligent fruit-growers and dealers, who all say that the characteristics are perpetuated by budding, and that as the trees grow older the fruit show's a tendency to return to the normal type.

Botanists and naturalists have thus far treated it as an accident, unexplainable, or alusus nuture, thus leaving the nurseryman and fruit-grower to solve the mystery by experiment and observation.

This form is more frequently taken on when the pomegrauate stock is used, but occurs occasionally with regular stocks, and does not always appear wheu the pomegranate stock is used.

Varieties. - $A$ s the orange is propagated from seed, it departs in furm from the pareut, and forms varieties. In a very complete natural histury of the orange family, published by Risso, an eminent scholar of Nice, one hundred and sixty-nine sorts are described, with characters sufficiently distinct to make varieties; these are grouped under eight species. Under the first, C. aurantium, the author arranges forty-three varieties, differing as to qualities, form, or size of the fruit.

An orange-tree in full bearing presents an object of surpassing beauty to the landscape. Conceive a tree with a well-formed, symmetrical head, the branches clothed with a dark-green foliage, besprinkled with delicate white flowers, and dotted all over with bright golden-colored fruit, and you have an object whose heauty is simply enchanting.

Geography. - The geographical distribution of the orauge is very wide. It is to be found in all the regions of no frost, where agriculture and horticulture are practiced. The $A$ rabs carried it from India into westeru $A$ sia, northeru Ifrica, and southern Europe. The China orange was carriel through Persia, Syria, and along the northerin coasts of the Mediterranean to southeru Europe 'The bitter, or Seville orange, went by way of Arabia, along the southern shore: of the Mediterranean, to northern $A$ frica and over into spain. Though the orange-tree has a very broad geographical range, it is a tropical and subtropi cal plant. It dues not ripen its fruit well except where the temperature has a meau abure $60^{\circ}$ Farenheit. China, suutheru Japau, ludia, westeru Asia, 
suuthern Spain, Sicily, northern Africa, Australia, Brazil, West India Islands, Florida and southern California, and the Azores Islands are the chief growing regions.

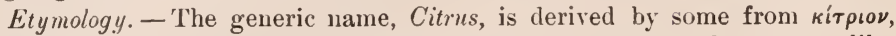
supposed to be a corruption of $\kappa \in \delta \rho \rho s$, a cedar-tree, because the orange, like the cedar, is evergreen. 'This is a very improbable etymology.

It is held by others that the name is due to the city of Citron in Judea. The specific name, aurantium, arises naturally from its golden color, the Golden Citrus. The common name, orange, is a corruption of the Latin word aureum, golden. The ancient Romaus were not acquainted with the orange.

History. - The date of its introduction into Europe is not known with certainty, but it is believed that it came to Spain with the Moors. It was taken iuto Portugal early in the sixteenth century. Sir Walter Raleigh, who lived in the latter part of the same century, has the credit of introducing the orange into England, in the southern part of which, with careful protection, it flowers, but does not mature fruit. One account of the introduction of the orange into Europe makes it due to the Crusades, which occurred during the twelfth and thirteenth centuries.

The home of the orange has been a subject of considerable research. One account makes it a native of India, and states that it was carried from southern Inclia to Syria and the countries of the Levant by Alexander the Great on his return from the invasion of that country, and that it was thence taken into Europe during the period of the Crusades.

It requires no great stretch of the imagination to picture the foot-sore, famished pilgrim reposing in the shade of the orange-tree, while he cools his parched tongue with its golden fruit, whose enchanting beauty is as startling to his astonished vision as the fragrant fluids of its juicy pulp are delightful to his palate.

Gallesio maintains that the orange was not among the fruits mentioned by Nearchus as seen by Alexander in his invasion of India, and hence infers that it could not at that time have been known in the countries through which he passed. It has been stated as probable that the Arabs carried it from India (where they found it east of the Ganges) to southwestern Asia and northeastern Africa, whence it has emigrated with civilized man into all countries where the climate favors its growth.

A. De Candolle believes its origin to have been in China, and thinks the bitter orange of central Asia may be the ancestral stock, and the sweet orange the offspring, having been obtained from seed in China and Cochin-China.

The orange-tree attains a great age. It has been known to reach the age of 600 to 700 years. In Cordora, the ancient Moorish capital, the broad avenues are skirted by old orange trees 30 feet high, whose heads are frequently 30 to 40 feet in diameter. The larger trees bear from 12,000 to 16,000 orainges in a single crop, and the fruit of the current year is frequently mingled with the flowers for the following crop.

Use and Products. - The orange is a favorite dessert, but is not preserved to any great extent. It is recommended by medical men as a stomachic, taken before breakfast. 'The bitter orange is very largely used for marmalade (from its rind), to Havor sances for puddings, etc.

The woorl of the orauge-tree is close-grained and takes a fine polish, and is used by turners and wood engravers. The stems of young trees when about an inch in diameter are highly prized for walking sticks. 
The peel of the sweet orange yields by pressure an essential oil of great value for perfumers' use and for flavoring confectionery. It is known in Europe as Essence de P'ortugal, and in the United States as Uil of Sweet Orange. All that reaches this country is the product of the island of Sicily. It is shipped from Messina in copper canisters of twenty and forty pounds each.

Essential oils, etc., from C.vulgaris, liss. (Bitter Orange). The fruit of this tree is the bitter, or Seville orange. From the peel is extracted the Essence of Bigaradia, called, in America, Oil of Bitter Orange. It is used for Havoring liqueurs and bitters. From the flowers, the Oil of Neroli Bigaradia is obtained. 'The best is made at Grasse, in the southeast corner of France. It is the chief ingredient of Eau de Cologne. 'This distilled Oil of Orangeflowers was known to P'orta in the sixteenth century. It obtained its present name from the P'rincess of Neroli, who used it for perfuming gloves towards the end of the seventeenth century.

Orange-flower Water is consumed very largely in Europe in cookery, and sugar saturated with it is eaten by the French and Italians. It is obtained by distilling the flowers with water.

Oil of l'etit-Grain, as its name signifies, was originally made by distilling the immature oranges when about the size of large peas, but the oil now known by that name is obtained from the leaves by distillation. It is used as a cheap substitute for Neroli.

The sweet orange yields from the flowers and leaves Oils of Neroli and PetitGrain, but they are scant in quantity and poor in quality. They are known commercially as Neroli l'ortugal and Petit-Grain Portugal.

The fruit of a variety of the C. aurantium, known as Curaçoa orange, yields an essential oil of a peculiar flaror; the fruit of C. myrtifolius, the mandarin orange, another.

Statistics. - North America is largely supplied with oranges from Jamaica, the Bahamas, and from the Mediterranean; but the extensive and rapidly increasing cultivation of the tree in Florida and southern California is beginning to supersede the foreign importation.

The climate of Florida is remarkably adapted for orange culture, and orangeries are becoming yearly more numerous and more extensive. In the other Gulf States this industry is pursued to some extent, and in California the orange groves are very productive.

Oil of orange-peel and oil of orange-flower are imported into the United States in great quantities.

Large numbers of oranges are exported to Great Britain from the Azores, from P'ortugal, and from Spain, Sicily, and other Mediterranean countries.

France consumes great quantities of oranges, a large percentage of them being exported from $\mathrm{Algeria.}$

The loss by decay on European oranges is 37 in each 100 ; on those from American ports 33 in each 100 (the voyage being shorter).

2. C. decumana. (Shadllock.) 'Tree from 15 to 20 feet in height, forming spreading head, branches armed with prickles. Leaves downy unlerneath, ovate, somewhat acnte, occasionally blunt; wings of the petioles as broad as the leaves and heart-shaped at the hase. Flower white: stamens 1030 ; petals 5 ; sepals 5. Fruit a berry of a dull greenish-yellow, form an oblate spheroid, from 4 to 8 inches in dianeter. It is said that in Japan it grows to the size of a child's head, weighing 14 pounds. 'The pulp of those brought to the American market is bitter, though in the varieties grown in 
China and Japan it is sweet. As it is propagated from seed the varieties are numerous.

Geography. - The zone of the Shaddock is the same as that of the orange and lemon. It is cultivated in China, Japan, and the islands of the Pacific, and has been carried by Europeans to the West Indies and southern Europe.

Etymology. - The application of the name decumana, which signifies "by teus," is not apparent. The common name, Shaddock, was given because it was taken from China to the West Indies by Captain Shaddock.

History. - According to the best authorities the home of the Shaddock is the islands south of Asia. It is cultivated in China, where it is called sweet ball, on account of the sweet taste of the pulp. The varieties brcught to our market are bitter. The trees are raised from seed, and the Chinese engraft or propagate upon them buds and cuttings of the sweet rarieties.

The tree is a beautiful evergreen, with dark, shining leaves always adorned with fruit, and part of the time with both flowers and fruit, - the fruit in various stages of advancement making the most charming object imaginable for the lawn, in all regions of no frost.

The fruit forms an important article of commerce.

3. C. Limonum, Risso. (Lemon.) Stem 12 to 15 feet high, branched into a symmetrical head, branches armed. Leaf ovoid or elliptical, dark green on both sides, leathery, entire, petioles winged. Flower white and fragrant. Fruit a golden yellow, from 2 to + inches in diameter, and lengthened at the poles, making a prolate spheroidal berry, ending in a short, teat-like process; pulp is dirided into cells or compartments from 10 to 20 in number, each containing one or more seeds. In the cultivated varieties the seeds are frequently few in number, many cells being vacant.

Varieties. - Like the orange it sports freely, and there are 38 distinct varieties, all of which possess some prominent quality which commends them to the grower, - the differences being in size, shape, thickness of skin, or intensity of acidity.

Geography. - The zone of the lemon is the same as that of the orange. Most of the lemons that enter into commerce are grown in the south of Europe. The island of Sicily produces excellent lemons, and sends nearly all it produces to the U.S. Large quantities are now grown in Florida.

Etymology. - The specific name of the lemon is from Lymoun, the Arabic name for lemon. The common name, lemon, is a corruption of the specific name, Limonum.

History. - The home of the lemon is India and western Asia. It is said to have been known to the ancient Jews. Theoplirastus and Dioscorides both speak of it, but it was not known to any extent in Europe before the Crusades, at which time it is said to have been carried into western Europe from Syria, where it had been bronght by the Arabs from beyond the Ganges. Writers of the twelfth century inform us that it was common in Italy and Egypt. It has also been stated that it was under cultivation in Italy in the third century.

4. C. Limetta, Risso. (Lime.) Small tree, 8 to 10 feet in height, trunk crooked or zigzag, forming a dense, spreading head 6 to 8 feet in diameter, branches armed with sharp, strong spines, or prickles; some of the petioles winged. Leaves orate-orbicular, serrate-toothed or entire, dark green above, lighter underneath. Flowers white; petals 5 . Stamens sometimes 30 in number. Fruit a ylobular berry, protruding at top, an inch and a half in 
diameter, clull yellow; skin thin; pulp sharply acid, divided like sther species of the genus into a number of cells, containing 1 or more seeds each.

Varieties. - Less attention has been given to the cultivation of the line than to that of the orange, hence the varieties are less numeruus than of any other species of this genus.

Geography. - The geographical zone of the lime is subtropical and tropical. It arrives at the greatest height of fruit-bearing in a temperature not below $70^{\circ}$ Fahrenheit. It grows well in southern India, and in the West India Islands, in southern Europe, and in northern Africa.

Etymology. - The specific name of the lime, Limetta, is said to be derived from the city of Lima, near which it was largely cultivated, and the common, or English name, lime, is an abbreviation of the botanic name. This history' of the uame is not to be depended upon.

History. - The lome of the lime is the same as that of the other species of this genus, India east of the Indus, whence it was carried into westeru Asia, sunthern Europe, and northern Africa by the Arabs; but as it is not edible, its culture for fruit was not prosecuted. Much attention has been paid to its cultivation of late in the British West Indies. It grows and fruits well in moderately fertile soil, needs but little care, and lives to a great age.

Use. - The lime is used for its juice, which is the material for the manufacture of citric acil. It is also useful for setting or fixing dyes. The juice is more acid than the juice of the lemon, though by some it is considered more palatable. It is an important article of commerce between Portugal and England, countries of central Europe, and the United States. In the West Indies it is cultivated for hedging as well as for its fruit.

Statistics. - Lime juice is manufactured in large quantities in the British West Indies. Nearly 13,000 gallons are annually exported from the island of Domingo alone. The ports of southern Spain export large quantities of the fruit as well as of the juice. It is consumed in France, Germany, England, and the Lnited States.

5. C. Medica, Risso. (Citron.) Fruit oblong, 6 inches long; riud thick.

\section{Order XV. MELIACE正.}

The characters of this order are like those of Rutacer. Leaves alternate and pinnate. Stamens united, forming a tube, the introrse anthers sessile on its top. Leaves rarely dotted. Mostly trees.

Number of genera, 37.

SWIETENIA, I. Calyx 5-cleft. Petals 7. Stamens 10, united into a tube with 10 teeth, inclosing the anthers. Style short. Stigma 5rayed. Leares alternate, even-pinnate. Leaflets opposite, entire, oratelanceolate, unequal at the base. Flower's greenish-yellow, in axillary panicles. Fruit woody, pear-shaped, 2 to 4 inches in diameter, 5-celled, 5-valved; seeds numerous and winged, imbricated in two rows. Large tree.

S. mahogani, L. (Malıogany Tree.) Stem 80 to 100 feet high, and 5 to 8 feet in diameter. Irregularly bramched. Leaves compound, with four pairs of 
leaflets, green, shining, and about two and a half inches long. Flowers small, in a thyrse, yellowish-white.

This is the only species of the genus.

Geography. - The mahogany is tropical or subtropical. It is indigenous to the West Indies, the Bahamas, Central America, and to southern Florida. It has been planted and is successfully growing in southern British India.

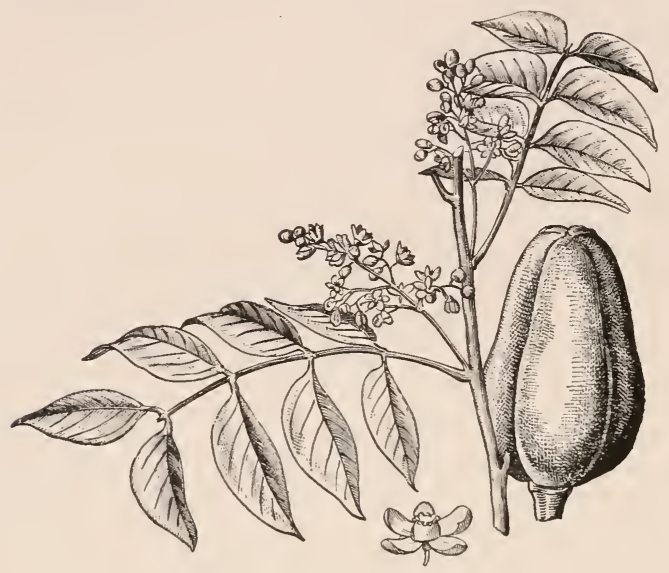

Swietenia mahogani (Mahogany).

Etymology. - Suietenia was the name given by Jaquin, in honor of Gerard L. B. Van Swieten. Mahogani is the name by which the tree is kuown to the aborigines of South and Central America, but the signification of this is unknown.

History. - This beantiful wood was introduced to notice in the latter part of the sixteenth century. A few planks were sent to Dr. Gibbon of London
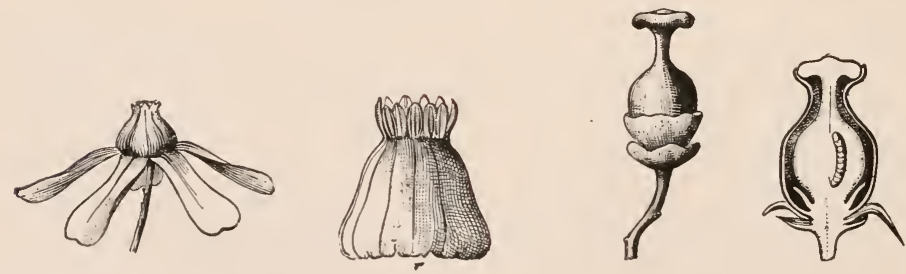

Mahogany.

by his brother, a sea-captain, sailing to the West Indies. At the time he received them he was erecting a dwelling, and gave the planks to his joiner to finish some part of the house; but the workmen refused to use them on account of the hardness of the wood. The cabinet-maker was then ordered to 
construct a candle-box of a part of one of the planks, which, when finished, so far exceederl in fineness all Gibbon's other furniture that it became an object of notice and wonder, and was placed upon exhibition. Soon after this it becanc a favorite material for the construction of furniture, and very speedily found its way into the lwellings of the wealthy classes.

Mahogany is to this day the favorite wood for cabinet ware. 'The tree was first noticed as a native of the territory of the United States hy I)r. Muhlenberg. It is found on the Florida Keys, reaching the height of 50 to 90 feet. That which furnishes the fine curls and apparent interlacing of the fibers, nsed for veneers, grow's on rocky hillsides, and is from that part of the tree where the branches join the trunk. It is said to attain a great age. Sir WVilliam Hooker counted 200 rings in a block, but the rings may not each have denoted a year.

Use. Mahogany is one of the best woods known to the cabinet-maker. The tinest is sawn into thin slices and used for veneers. It is worked into chairs, tables, cabinets, rlesks, bureaus, bedsteads, and other furniture, and is much more common in Europe than with us. Its value depends upon its hardness, and its ability to take a high polish. It is not liable to shrink and warp. It was formerly used in naval architecture, and ranked by the English as second to the celebrated English oak for that purpose. On the Bay shore in Central America the wood of the mahogany, which is coarser grained and softer, is used for inferior purposes, such as common tables, wainscoting, flooring, the making of cigar-boxes, ete, and is called Bay Wood.

There is a bitter principle residing in the bark which is efticacious in remittent fevers, and the lark is used by the uatives in the same way and for the same purposes as the cinchona hark.

statistics. - Great quantities are imported annually by England and by the Uniterl States. $\Lambda$ single $\log$ has been known to sell for $\$ 5,000$; this when sliced up into material for veneers was male to cover an immense surface.

\section{OrDER XVI. ILICINEAE.}

Sepals 4-6, imbricated in the bud, small. Corolla 4-6 cleft, hypogynous, imbricated in the bud. Stamens inserted in the throat of the corolla, alternate with the segments; anthers adnate. Flowers perfect, small, solitary, or grouper in the axils of the leares. Fruit a irupe. Ieaves alternate or opposite, simple, leathery, glabrous, shining, and without stipules. Trees and shrubs.

Nimber of genera, 3.

ILEX, I. (IIolly.) Calyx with $t$ or 5 teeth. Corolla 4-j-cleft, wheel-shaped. Stamens $i-5$, alternating with the segments of the corolla. Ovary sessile, with 4 stigmas. Berry with 4 or 5 one-seeded nuts. Small tree.

I. Paraguayensis, Lamb. (Paragnay 'Tea, or' Yerla Maté.) Stem from 5 to 15 fect in height and 3 to 6 inches in diameter. Much branched. Ieaves alternate, oval, crenate, glossy, leathery, 4 inches long, evergreen, dark green above, paler underneath. Fruit a berry, bright red, small and smooth. 
There are many species to this genus, and as it is propagated from the seed it has many varieties The I, Paraguayensis is very constant, and is the only species whose leaves furnish tea.

Geography. - This plant is indigenous to Paraguay, and forms entire forests, extending over large tracts throughout the central, eastern, and northern parts of the republic. It is also found under cultivation, but no observations have been made to justify a statement as to the comparative value of the cultivated plants. The Jesuits, previous to their expulsion from Paraguay in 1867, gave great attention to its cultivation, and instructed the natives in its preparation. It grows also in Paranagua, but that found in Paraguay yields four times the strength. The Government monopolizes the sale, buying cheap and selling at a high price, thus securing a large revenue.

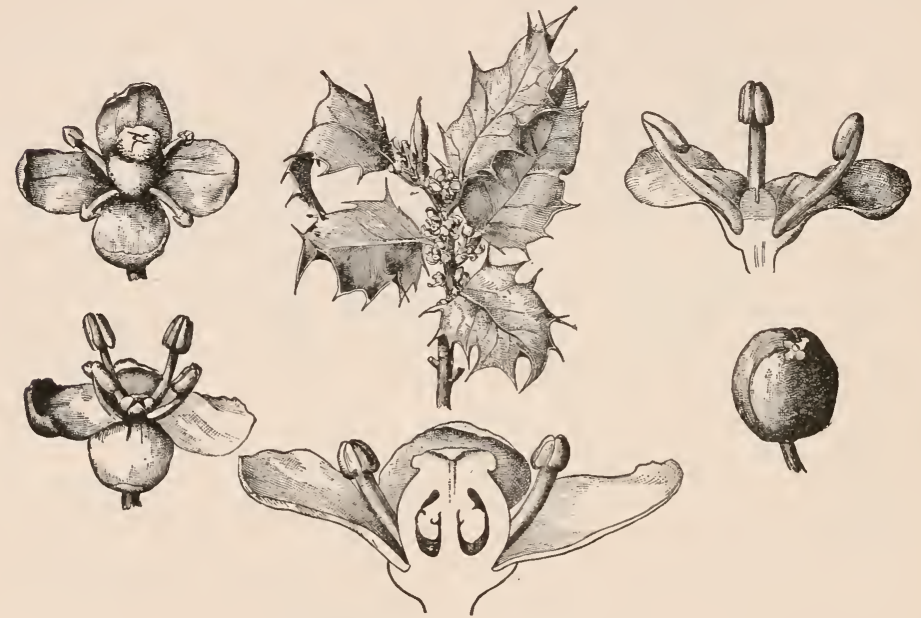

Ilex Paraguayensis (Paraguay Tea).

Statistics. - Europeans do not usually relish its peculiarly bitter taste. The inhabitants of South America, on the other hand, prize it highly, and have come to consider it, not as an article of luxury, but as one of necessity. In harresting, the work is so carelessly and slovenly done that the plant in a wild state is rapidly undergoing destruction. Its increasing demand will bring about a more careful method of harvesting. In Parana about $10,000,000$ pounds are annually produced. Abont 6,000 persons are employed in Brazil in the preparation of Maté ; and about 3,000,000 pounds are shipped anuually at Itaguy, a town on the Uruguay.

Etymology. - Ilex received its generic name from the resemblance of its leaf to that of the Quercus Ilex. 'The specific name is from the country where it is found indigenous (Paraguay). Holly, the common name of the genus, is a corruption of the word holy. Holly bush, or Holly tree, - that is, holy. tree, because the erergreen leaves of the Ilex opaca are used for decoration at the holy time of Christmas.

Chemistry. - The leaf of the I. Paraguayensis yields to chemical analysis about the same percentage of Theine as the leares of the Thea viridis. 
Preparation and $U$ se. - The small branches aro cut or broken from the tree; they are thrown upon a wire gamze over a fire and thus dried; the leaves and twigs are then bruised or ground in a rude mill, which reduces the whole to powder. It is then packed in green bullock-hides, making packages of about 200 pounds each, and thus sent to market.

Marts. - It is carried to Itaguy, on the Uruguay, and to the ports of Porto Algre, Lruguay, and l'araguay. From the last three ports about 13,000,000 pounds are annually exported.

\section{ORDER IVII. RHAMNACEA.}

Flowers perfect, or defective, regular, perigynous. Sepals, petals, and stamens 4-5. frequently apetalous; stamens alternate with the valvate sepals, and opposite to the petals. Fruit a 1-seeded capsule. Trees and shrubs.

Number of genera, 37 .

RHAMNUS, L. (Buckthorn.) Calyx pitcher-shaped, from 4-5̌-cleft. Petals notched, sometimes wanting. No. of styles, 2-4, partially united. Drupe with $2-4$ cartilaginous nuts. Leaves opposite or alternate. Flowers in clusters, axillary. Shrubs and small trees.

R. infectorius, L. (Yellow Berries.) Stem made up of ramifications commencing to branch at the root, subprocumbent; the assurgent, spiny branches rising to the height of 2 feet. Leaves orate-lanceolate, serrulate, smoothish, and deciduous. Flowers diœcious; petals in both sexes greenish-yellow. Fruit 3-seeded, black when ripe, but harrested when green, to be used for a dye by calico printers.

Geography. - This plant grows as far north as England, though it properly belongs to a more southern climate. Its native haunts are southern Persia and southern countries of the Levant. The fruit is known in commerce also as Persian berries.

R. chlorophorus and R. utilis are natives of China. Their fruit vields a fine green dye for silk, which is imported into Europe

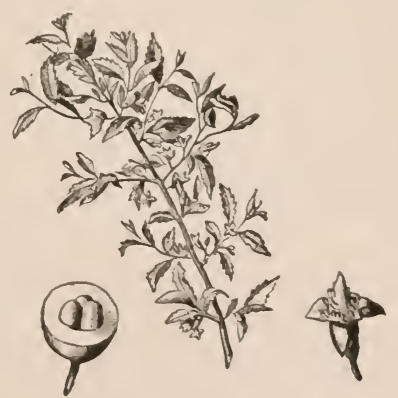

Rhaminus infectorius (Fellow Berries). under the name of Chinese Green Indigo.

Etymology. - Rhamnus is derived from the Celtic word ram, a bunch or tuft of branches. The specific name comes from the Latin word inficio, color, tinge, or paint. Buckthorn, the common name of the genus, is not easily explained. Indeed it is difficult to comprehend why the name is applied to the plant. Some suppose it is due to its crooked stems, which resemble the horns of the buck. It is also known under the name of Yellow Berrics, on account of the color produced by the fruit.

History. - The home of the Rhamnus infectorius. the Staining buckthorn, is Persia, syria, and southern Europe. It is cultivated in Turkey and the 
Levant, and in the south of France. The largest and best berries come from Persia.

Use. - The berries furnish a yellow dye, which is employed in the dyeing of morocco in Turkey, and in calico printing. It also produces, by the aid of chemicals, the Sap green and the Dutch pink.

Marts. - The Persian berries come from Aleppo and Smyrna. Some are also shipped from France and Turkey. These ports ship to England annually $1,200,000$ pounds, but more are used in the countries where they are produced.

CEanothus, L. (New Jersey Tea. Red Root.) Calyx a semi-globular tube, with 5 segments. Petals clawed, rolled in at the edges, bending down. Stamens with ovate, 2-celled anthers. Styles 3, diverging. Stigmas papillate. Fruit tricoccous. Small shrub, 1 to 3 feet high.

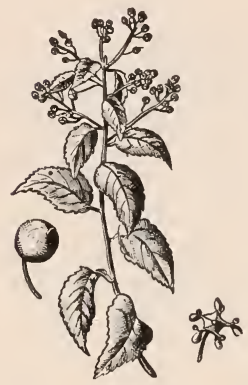

Ceanothus Americanus

(New Jersey Tea).

C. Americanus, L. (New Jersey Tea.) Stem 1 to 3 feet high, 1 inch in diameter. Leaf orate-acuminate, serrate, pubescent beneath, alternate, stipulate. Flowers in a thyrse, axillary.

Geography. - Geographical limits, eastern North America.

Etymology. - Ceanothus, is derived from $\kappa \in a ́ v \omega \theta 0 s$, a name given by Theophrastus to indicate a plant with

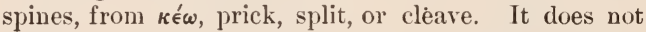
apply well to the American plant, which is without thorns. The specific name explains itself. The common name, Red Root, is given on account of the color of the roots, and New.Jersey tea is a name given because it is said that the leaves were used in New Jersey, during the time of the Revolution, for tea.

Use. - The young leaves are collected and dried in the shade, when they are said to furnish a bererage superior in flavor, and resembling the China teas. It has become an article of local commerce in some parts of Pennsylvania.*

\section{ORdER XVIII. AMPELIDE无.}

Woody, climbing by tendrils. Calyx small; petals 5; stamens 5 ; stigmas sessile and capitate; filaments distinct, or slightly cohering at the base. Ovarium 2-celled; fruit a pulpy berry; seeds 4-5, hony; leaves simple, alternate, stipuled, palmately veined; tendrils opposite the leaves. Trees or shrubs, usually climbing by tendrils. Small number of genera. (The term vine is used widely in America for every climbing or trailing plant.)

VITIS, I. (Grape Vine.) Petals deciduous, spreading, or attached at the top. Calyx very short, entire, or obscurely 5-toothed.

* The young leaves of the Rubus strigosus (common red raspberry) when dried are used for tea, and are said to be far superior to the common grades of the imported article. 
Althongh the genus Vitis comprises more than 200 species, mostly natives of tropical and subtropical regions, less than half a dozen species have any economic value.

1. V. labrusca, L. (Fox (Grape.) Stem trailing or climling into trees, reaching sometimes the enormous height of 100 feet, branching freely. When in the borders of woods, it sends out lateral branches, covering the shrubbery and small trees for long distances. The main vine sometimes attains a diameter of 6 inches or more; bark rough, sloughing off in strips. Leaves very large, 3-lobed ; when young, white and downy beneath. Flowers in compound panicles, green, and opposite the leaves. Fruit globular, three quarters of an inch in diameter.

Species. - There are 6 other species growing in North America, but most of the varieties now under cultivation in the U'nited States, amounting to several hunclred, are seedlings of the V. labrusca or its offspring.

2. V. vinifera, L. (Enropean Wine Grape.) Habit of stem as V. labrusca. Leaves cordate, 5-lobed,

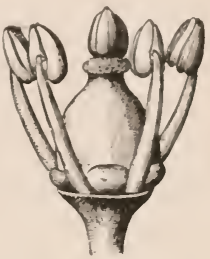

Vitis LABRUSCA

(Fox Grape). deeply sinuate, serrate, downy underneath. Flowers greenish-yellow, odorons. Frnit green, red, or black. This is the wine grape of Europe, from which hundreds of forms have been obtained. All the varieties of the grapes raised under glass in America are seedlings of this vine or of its progeny There are also hardy rarieties from it grown in the United States. Zante Currants, the name of which is supposed to be a corruption of Corinth, from the city of that name whence they were formerly shipped, are a small variety of the $\mathrm{V}$. vinifera. They form a considerable article of commerce.

Geography. - The zone of the grape extends from about 21 degrees of north latitude to 48 . In the old world this belt trends east from the British

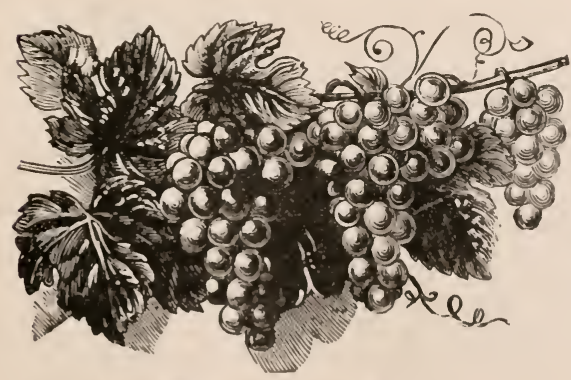

Vitis visifkna (Furopean Wine Grape).

Isles and P'ortugal to P'ersia, but the fruit ripens to greatest perfection along the middle and southern parts of the belt. In the new world the zone dine: not extend above the $43 \mathrm{~d}$ degree north latitude, reaching south to 33 degrees, trending east and west from the shores of the Atlantic to the Pacific coast. The centers of growth are the midlle $\mathbf{A t}$ lantic states and ('alifornia.

In late years the grape has been largely cultivated in .Instralia.

Etymology. - The generic name, Vits, is derived from the Cultic word Givid, signifying "the best of trees." This origin is disputed, and it is said to be derived from an Aryan root, WI, signifying to hind, or twine. The specific name, labrusca, is a Latin worl, signifying "wild," and the name vinifera is 
from two Latin words, vinum, wine, and fero, bear, whence wine-bearing plant. The common name, grape, is from the old French rappe, a bunch or cluster.

History. - The grape was known to man at a very early period of his existence. Mention of this fruit comes down to us among the first records of history. Pictures left by the ancient Egyptians, and remains by the lakedwellers of Italy and Switzerland, from the bronze age, reveal to us that the grape was known to those peoples. It was cultivated in Egypt as early as 4000 B. C.; not in China until 122 B. C. The Egyptians and the Greeks both have a mythological history of the introduction of the grape.

The ancient Scriptures frequently speak of the grape. The weight of history points to western Asia as the home of the species known as the Vitis vinifera, but there seems little doubt that it is also native to Europe. It is supposed to have been introduced into England by the Romans, yet it was not known there during the time of Agricola, who was governor in the reign of Claudius Cæsar, about 78 years after the beginning of the Christian era. But among the earliest conveyances of estates under the Saxon rule vineyards are named. And in the reign of William the Norman vineyards are among the valuables enumerated in the Dooms-Day Book. 'It is also recorded that in the twelfth century there was a vineyard attached to every monastery in the south of England.

The grape is indigenous to America, and much attention has of late rears been given to its cultivation. In the United States it has become a very large and important industry, and considerable wine is made in Ohio, Indiana. New York, and in California.

The best wines and brandies are made in southern Europe. Sonthern Germany, Spain, Portugal, Italy, and Madeira are wine-making countries; but France is the great wine-producing nation. More than $500,000,000$ gallons are produced annually in France alone. In Spain and l'ortngal much attention is paid to the production of raisins, which are the sweet grapes of these countries dried. Along the sonthern shores of Spain and Greece the grape forms sugar in abundance, but does not easily enter into vinous fermentation, hence the fruit is dried; and the raisin crop is one of great economic and commercial importance.

Cultivation. - The vine requires a high summer temperature and a prolonged period in which to ripen its fruit. When these conditions exist it can be profitably cultivated, even though the winter temperature be very low. In the Alps it is profitably cultivated to an altitude of 1870 feet, and in the north of Piedmont as high as 3180 feet.

Use. - The grape is among the most delicious and highly prizerl fruits of the temperate zone. It is a great favorite as a dessert, and for a table ornament has no equal; it is also preserved, and is a farorite jelly material. The raisin, or grape in a dried state, is also a farorite dessert. In central and southern France and Italy the chief use made of the grape is for the manufacture of wine. The common wines are cheap, but the finer sorts cost several dollars a bottle.

Argols is the commercial name for the crucle deposit from wine, which forms on the bottom and sides of wine casks, from which Cream of Tartar, or Bitartrate of Potassa, and Tartaric Acid are obtainerl.

Diseases of the Vine. - The organic diseases which affect the vine may be divided into two categories, - those caused by parasitic fungi, and those caused by insects. In 1849 the vine in France, southern Germany, Italy, and Spain was attacked by a mildew fungus, Oidum Tuckeri, which in many 
localities destroyed the crop. After some years this blight disappeared, and a new pest made its appearance, in the character of a tiny insect, the Phylloxera vastatrix, which lives and propagates upon the roots of the vine, and in a very short time destroys the plant. There are certain symptoms of the disease cansed by this insect by means of which an infected spot may be readily recognized. 'The vines become stunted and bear few leaves, and those are small. When the disease reaches an advanced stage, the leaves are discolored yellow or reddish, with the erlges turned back or withered. The grapes are arrested in growth, and their skin is wrinkled.

I'lants grown in Califoruia possess the power to resist this enemy hetter than those grown in Europe, and are frequently ned for stocks upon which to graft the European plants.

Marts. - The great markets for export are Marseilles, Bordeaux, and Havre, in France; Genoa and Naples in Italy, - but mostly Malaga and Lisbon. The import markets are Iiverpool and Loudon, in Eugland; the north German ports, in northern Europe; New York and Buston, in the Lnited States; and Quebec, in Canada.

\section{Order XIX. SAPINDACE无.}

Flowers unsymmetrical. Stamens sometimes trice as many as calyx-lobes or sepals, usually fewer, or equal, alternating with the petals in the Maple family (sub-order Acerinece). Flowers usually polygamous or dinecious, sometimes without petals. Orary 2-lobed and 2-celled, 2 orules in a cell, maturing one seed in each cell. Fruit winged, cotyledons crumpled in the embryo. Leaves opposite, exstipulate, lobed. Trees and shrubs.

Genera, 73.

ACER, I. (Maple.) Calyx 5-parted. Petals 5, sometimes 4-12. Stamens 4-12. Anthers 2-lobed, seeds 2. sometimes 3. in a 2-minged vessel or samara united at the hase, wings direrging. Leares simple, opposite, lobed. Trees. Flowers axillary, in corymbs.

A. saccharinum. Marsh. (Sugar Maple. Rock Maple. Bird's-eye Maple.) Stem 50 to 80 feet higl, 1 to 2 feet in diameter; branches erect; heal sym. metrical. Leaves cordate, smooth, glancons beneath, green ahove, 5-lobed; lohes aenminate, coarsely toothed or subloberl. Flowers small, yellowish, on long, slender peduncles. Samaras brown when ripe. Flowers in May. Fruit ripe in september. Tree.)

Var. nigrum (Mx. f.), Britt. (Black Maple.) A. nigrum, Mx. f. (Sugar

This species or variety is like the $\Lambda$. saceharinum, with darker leaves, sometimes nearly peltate; bark rough. The sap is as rich in sugar as the sap of A. saccharinum.

The leaves of both these species are ahout 5 inches wide, and from 5 to 7 inches long when the tree is young, shorter as the tree grows older, palmately. or unevenly divided into 5 lobes; edges coarsely tontherl.

Geography. - The geographical range of the sugar tree is not great. It does not flourish sonth of $38^{\circ} \mathrm{N}$. latitucle except in high mountains. It abomsls in the northern parts of the I'nited states and in sonthern British America. 
Etymology. - Acer is a Latin word, signifying sharp, and is supposed to have been applied to the maple tree because it was, on account of its hardness, used for spears. Saccharinum, the specific name, is from the Latin word succharum, sugar, due to the sugar-bearing sap. Nigrum, name of the variety, is a Latin word signifying black, due to the dark foliage.

History. - When or where the sap of the maple was first used for the manufacture of sugar is not known; but we have no record that sugar was made from this tree till after the colonization of northeastern America. It is therefore probable that its manufacture was begun by the early settlers of the French and British colonies of this continent. At the present time about $10,000,000$ pounds are exported from Canada; allowing 5,000,000 pounds for home consumption would make the amount produced about $15,000,000$ pounds. In the United States the production is about $30,000,000$ pounds, which makes an aggregate production of $45,000,000$ pounds. The sap flows from the tree throngh wounds made in the trunk near the ground, into which are inserted

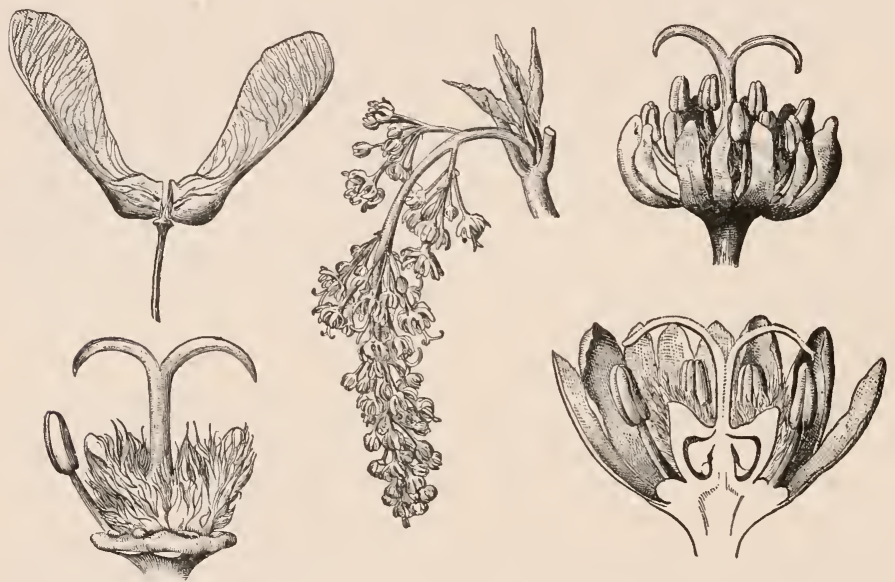

ACER SACCHARINUM (Sugar Maple).

tubes; it is caught in pails or tubs and placed in large pans, in which it is evaporated by heat to a syrup. A tree will rield from 2 to 4 pounds yearly, and will continue to do so for 40 years without suffering injury. The trees are tapped early in spring, when the sap is ascending. The boiled sap is used as molasses under the name of maple molasses or syrup. By further evaporation, straining, and refining by boiling with it lime, milk, and eggs, a white sugar is produced of a very delicate flavor.

Use. - Maple Sugar is used for the same purposes as the cane sugar, and when purified by the ordinary modes of refining, it has much the same character; but when user without refining, it has a smoky taste, which is grateful to most palates.

The sap of the Sugar Maple has been for more than a century used for the manufacture of sugar.

The wood of the Sugar or Rock Maple is also of very great valne. Wheelwrights use it for axles of carriages. It constitntes a large part of the material 
used for school furniture, herlsteads, table-legs, aul chairs. It also furnishes to the cabinet-maker the heautiful curled, or birl's-eye maple, aud is excelleut for fuel.

\section{OKDER XX. ANACARDIACE}

Flowers perfect, diøecions, or moncecions, regular; small, spiked, or f'anicled. Sepals $30-5$, united at the base. Petals :3-5, sometimes absent, imbricated. Stanens alternate with the petals, and same number, perigynous. Ovary 1-celled, free. Stigmas 3. Fruit a herry or drupe, 1-seeded. 'Trees and shrubs. Number of genera, abont ti.

RHUS, L. (Sumach.) Sepals comected below, small and persistent, 5 in number; petals free, ovate, spreading from the margin of a rounded disk ; stamens 5-10 or wanting, inserted on the disk; styles 3, sometimes united; stigmas subcapitate. Fruit, a small dry nut, hard and globose, 1-celled. Shrubs with alternate, compound, or simple leaves.

1. R. glabra, L. (Common Sumach, Smooth Sumach.) Sitem 3 to 12 feet high, much-branched, forming a flattish top; hranch and leaf-stalks smooth. Leaves of 8-15 pairs of sessile leaflets, and a terminal one which is petioled; upper sile dark green, under side lighter. Flowers yellowish-green, frequently abortive, in densely crowded panicles. Fruit a little drupe, covered with a crimson down which is charged with malic acid, sour but agreeable to the taste. Flowers appear in Jnne and July, fruit in antumn. 'The color of the leaves in antumn is a rich crimson.

2. R. typhina, L. (Ntag-horn Sumach.) Stem reaches the height of 20 feet: lathets serrate; otherwise as in R. glabra

3. R. copallina, I. (Mountain Sumach.) Stem from 5 to 12 feet in height, much-branched; leaflets $4-10$ pairs, with a terminal one unequal at the hase; the common petiole margined with a wing between each pair of leaflets; otherwise like li. glabra.

4. R. venenata, DC. (Poison Sumach.) Trunk 10 to 15 feet high, tree-like, 3 to 5 inches in diameter, branching so as to make a spreading tolp. Leaves of 3 to 6 pairs of leaflets, with a terminal one, deep green, shining above Flowers in panicles, small and green. Fruit a drupe, the size of a pea; juice puisonous, producing an eruption of the skin, accompanied by swelling.

5 R. Toxicodendron, I. (Poison Iry, l'oison Oak.) Stem trailing or climbing, vine-like, 10 to 50 feet long, fastening itself to the trunk of trees by rootlets. Leaves green, shining, in threes, terminal leatlet pointed. Flowers racemed in axillary panicles, greenish. Fruit a dull-white berry : juice poisonous, and forms an indelible ink. When growing without support, it assumes the form of a little tree.

6. R. Cotinus, I. (Venetian Sumacls. Smoke Tree.) Sten 6 to s feet high, irregularly and stragglingly hranched. Leaves alternate, simple, ohovate, entire, conspicunously veined, veins nearly at right angles to the midrib, stiff and translucent, on long petioles. Flowers very small, purplish, in louse panicles, perlicles of abortive flowers lengthen and become hairy after blooming; groups of these feathery perlicles give the plaut at a distance the appearance of a Heecy cloud, Fruit white. 
7. R. coriaria, IT. (Hide-tanning Rhus.) Stem 6 to 10 feet in height, dividing near the root into an irregular ramification; bark hairy, and of a brown color. Leaves compound alternate, in 7 or 8 pairs of leaflets, and a terminal one yellowish-green and hairy on the under side. Flowers in terminal, loose panicles, greenish-white.

Geography. - All the above-described species are indigenous in North America, except R. coriaria. The American species are common throughout the northeastern parts of North America, from Canada to the Gulf States. The Cotinus is found in Arkansas, and is identical with the European species, which is indigenous from the Levant to Western Europe. The Coriaria is indigenous in Syria, but has been introduced into Sicily, Italy, and Turkey, also into Spain and Portugal, where it is carefully and extensively cultivated.
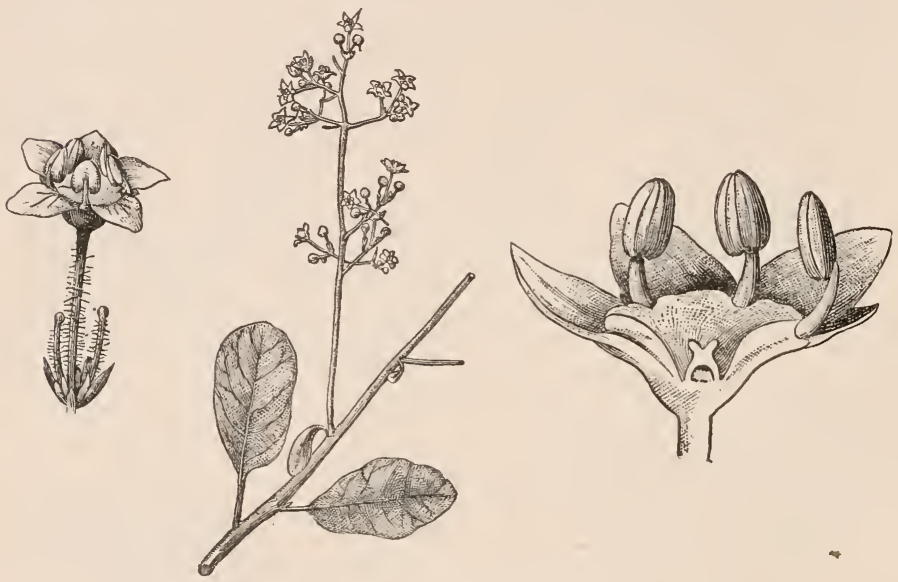

Rhus Cotinus (Venetian Sumach).

The bark of all the American species is highly charged with tannin. The Coriaria is especially rich in this material, and is so highly prized as to have found a market in America.

Etymology. - Rhus is from the Greek word povs, an old name, the signification of which is not known. It is also supposed to have been derived from the Celtic word rhudd, signifying "red," due to the color of the fruit. Sumach is supposed to come from the Arabic summage, a shrub. Glabra signifies "smooth," due to the smoothness of the leaves. Typhina, giant, on account of the size. Copallina, connected, from the winged petiole by which the leaflets are united. Venenata, from venenum, poison. Toxicodendron, from the Greek $\tau o \xi\llcorner\kappa o ́ \nu$, poison, and $\delta \epsilon \epsilon \delta \rho \nu \nu$, a tree, hence poison-tree. Cotinus, ancient name, signification ubscure. Coriaria, from corium, a hide, referring to the use of the bark and leaves of this species in tanning hides.

Use. - The bark and leaves of most of the species of Rhus are charged with tannin of a superior quality. The R. glabra in America and R. coriaria in Europe are especially rich in this material, which is used in making the fine moroccos. 
The fruit of the R. glabra is used by the Thompsonian practitioners ats a remedy for cauker, sore mouth and throat. 'The wood and fruit of the other sjecies are used for dyes and inks. 'The juice of R. 'T'oxicodenIron produces an indelible ink. li. venenata is very poisonous, cansing an inflamed eruption of the skin. R. Toxicodendron produces similar effects of a milder character.

Marts. - $\Delta$ bout ten million pounds are carried from the continent to Great Britain anuually. It sells for four dollars a hundred.

ANACARDIUM, $\mathbf{W}$. (Cashew Nut.) Calyx 5-toothed; corolla 5-parted; stamens 5, styles 3. Fruit a kidney-shaped or heartshaped nut, on the end of a pear-shaped, fleshy peduncle, which is edible.

A. occidentale, W. Trunk branching a few feet from the ground, ramifying into a beautiful second-class tree. Leaves elliptical, green, leathery, alternate, obcordate, or deeply emarginate. Flowers in a loose corymbose panicle, red and fragrant. Fruit of the size aud somewhat of the shape of a rabbit's kidney.

Geography. - The Anacardium is a native of the cropical regions of both Asia and America; flourishes in Jamaica, and is cultivated for its fruit, and also used in planted grounds for ornament in that island.

Etymology. - Anacardium, the generic name, is
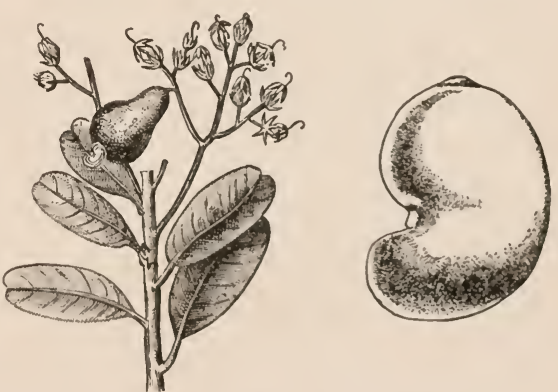

Anacardium occidentale (Cashew Nut). from the Greek $\alpha \nu \alpha$, like, and $\kappa \alpha \rho \delta i \alpha$, heart, heart-shaped, due to the form of the fruit. Occidentale is the Latin word for west, or belonging to the western continent.

Use. - The fleshy stem or the apple is eaten as it is plucked from the tree; it has a slight acid taste, and an agreeable flaror. 'The juice produces a delicate wine; the wine distilled produces a liquor far superior to rum, used for disease of the kidueys, and for a beverage, in mixing punches, etc. 'The dried and broken kernels are used for flavoring Madeira wine.

'The cotyledons are inclosed by a double covering, or by two separate shells; between these shells a thick oily substance forms, which is inflammable. It is also very caustic and blisters the skin. For this reason it has been applied by practitioners for eating away corns, ulcers, ringworms, and even caucers.

The kernels, when fresh, are eaten raw; they are also used for making puddings, and they form an ingredient in custarls, etc. When older, the nut is roasted and eaten as chestmuts are; it is also roasted and ground with cocoa in the manufacture of chocolate. By tapping, a milky juice is also obtained, which makes an indelible black ink. A gum, which possesses the character of gum arabic, is also obtained by wounds made in the bark. 


\section{Order XXI. LEGUMINOSAE.}

Flowers irregular or regular, perfect. Sepals 5, more or less united, unequal, the odd one anterior. Petals 5, odd one posterior. Stamens distinct, or 9 united, and one (the posterior one) free. Ovary superior, single and simple. Style and stigma simple. Fruit a legume. Leaves stipulate, usually compound. Herbs, shrubs, or trees. Number of genera, about 400 .

INDIGOFERA, L. (Indigo.) Calyx with 5 acute segments; vexillum roundish and emarginate; keel with a spur on each side, at length reflexed; legume 2-valved, and 1- to many-seeded. Shrubs.

I. tinctoria, L. (Indigo Plaut.) Stem 2 to 3 feet high, and from a quarter to half an inch in diameter, subligneous, brauching. Leaves compound, consisting of about 6 pairs of longish bluish-green leaflets, and a terminal soft one, darker above; flowers in axillary racemes, papilionaceous and pale-red. July and $\mathrm{Au}$ gust.

Species. - There are about 150 species of this genus, most of which yield indigo, but the species that are found to be most productive are -

1. I. tinctoria, L. (Coloring Indigofera.)

2. I. argentea, N. (Silver-leaved Indigofera.)

3. I. Caroliniana, L. (Carolina Indigofera.)

Besides the 150 species of A. De Candolle, there are as many or more varieties, most of which yield this dye.

The following plants also contain indigo:

Nerium tinctorium, Rottb. (A pocynacex.)

Tephrosia tinctoria, L. (Leguminosæ.)

Tephrosia apollinea, L.

Tephrosia toxicaria.

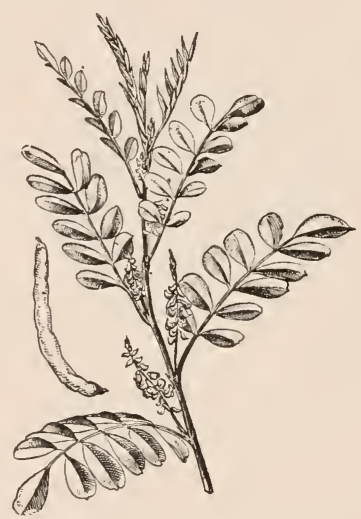

INDIGOFERA TINCTORIA (Indigo).

Polygala tinctoria, Persoon. (Polygalaceæ.)

Polygonum Chinense, L. (Polygonaceæ.) China.

Polygonum tinctorium, L. China and Japan.

Polygonum barbatum, L.

Polygonum perfoliatum, L.

Polygonum aviculare, $\mathrm{L}$.

Wrightia tinctoria, R. Brown. (Apocynaceæ.) India.

Amorpha fruticosa, L. (Leguminosæ.)

Baptisia tinctoria, R. Br. (Leguminosæ.)

Marsdenia tinctoria. (Asclepiadaceæ.) India.

Randia aculeata. (Cinchonaceæ.) West Indies.

Geography. - The indigo-bearing plants flourish in a hot climate. The Indigofera tinctoria is a native of India, and is cultivated between $20^{\circ}$ and $30^{\circ}$ of north latitude. It is grown in Java, the East Indies, Northern Africa, the West Indies, and Central America. That from India and Central America is the most valuable. 
Etymology. - Indigofera is derived from the Indian word indigo, and the Latin word fero, bear or carry, signifying indigo-bearing. The specific name comes from the Latin word tinctorius, coloring.

Mistory. - We do not know when indigo was first used as a dye. For some time after it was introduced into Lurope it was believed to be a mineral substance. Marco Polo, the earliest traveller into India and China, gave an account of the plant that produces the indigo, and the methods of preparing it. After the diseovery of America the plant was found in the warm parts of the new world, and it was also learned that the ancient Mexicans were acyuainted with it as a dye. In 1747 the Indigofera Caroliniana was discovered in Carolina, and large quantities of indigo were mannfactured there and sent to England, but the cultivation in the Inited States is not now prosecuted to any great extent. Soon after the discorery of the indigo-plant in America, the French began to produce it at Goree, an island on the west coast of $\mathrm{A}$ frica.

Cultivation. - The seed is sown in drills eighteen inches apart. The ground should be damp. The seed soon germinates, and in two months begins to flower, at which time it is fit to harvest. Great care is exercised to cut it at the exact time, to prevent damage from the rains. As soon as harvested it is carefully placed in a vat; the vat is then filled with water, and a heavy frame is laid upon the plants to keep them under water. After fermentation, the liquor is drawn off into another tank. It is then violently agitated by dropping heavy blocks into it, or heavy buckets whose bottoms and sides are perforated with many holes; this separates the fecula, or grain, as it is called, from the liçuid. It is then drawn into a third rat, where by evaporation it is freed from the liquid, and the indigo is left; and before it is quite dry it is cut into small cakes, in which form it is sent to market.

The supply of indigo is sulject to many contingencies, which is the cause of great fluctuation in the price; lence it is frequently the basis of commercial speculation.

Use. - The food value of the plants of this order is very great, due to the large anount of nitrogen stored in the seeds. Peas yield 23 per cent. Many species furnish important dyeing substances. Indigo is a most important substance in the hands of the dyer. It has a strong affinity for fibrous texture, whether animal or vegetable, and imparts, without a mordant, a permanent and beautiful blue. It yields to the chemist a substance known as Indigotin $\left(\mathrm{C}_{16} \mathrm{H}_{5} \mathrm{NO}_{2}\right)$, which is the coloring matter.

Marts. - Indigo is slippel from most of the ports of British India and the Easteru Archipelago. In America, the ports are Vera Cruz in Mexico, Belize in Yucatan, Truxillo in Honduras, and San Juan in Costa Rica, Kingston in Jamaica, and the ports of New Granadil. 'The United States is supplied by Mexico, Central America, and South America direct.

astragalus, Tourn. (Milk Vetch.) Calyx tubular, inflated, 5toothed; tecth short, nearly equal. Petals long-clawed; standard orate, or fiddle-shaped; wings unequally oblong; limb sometimes eared above the base; leel a little shorter than the wings. Stamens 10, 9 commate into a sheath, cleft ahove, 1 free. Ovary sessile; ovules mmerons, in two series. Style slender, straight or curved. Stigma small and terminal. Legmine sessile or stipulate, with its sutures turned in so that it is sometimes 2-celled. small shrubs or herbs, variable in form.

PK. FL. -8 
A. gummifer, Labill. (Gum Tragacanth.) Shrub, 2 feet high. Stems short, naked; branches numerous and straggling; bark reddish-gray, slightly rough, marked with scars of fallen leaves; young twigs woolly. Leaves numerous, spreading in all directions, two and a half inches long, pinnate; rachis hard, stiff, smooth, yellow, acutely pointed, furnished at the base with broad, membranous, acute, glabrous, rusty, clasping stipules, cut at the edges; leaflets opposite or alteruate, nearly sessile, very small, obovate, acute, entire, glabrous, both sides grayish-green, veined, articulated with the rachis, soon falling off. Flowers small, sessile, solitary or two to three together in the axils of the lower leaves, each with a membranous, acute bract as long as the calyx. Calyx cut to the base into 5 equal, very narrow, acute segments, clothed with silky, white hairs, persistent. P'etals papilionaceous, a little longer than the calyx, pale yellow, and persistent; wings a little shorter than the standard, with a long linear claw; keel-petals nearly as

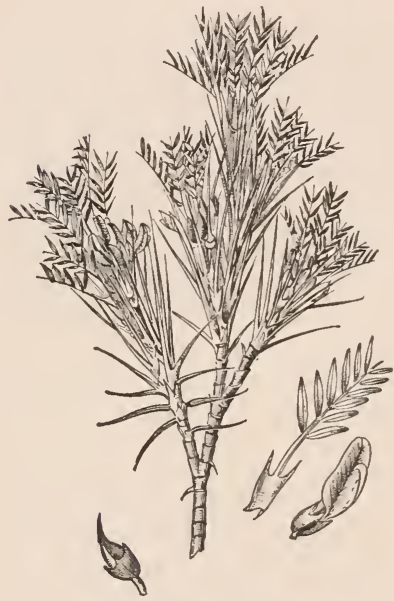

Astragalus gumifer (Gum Tragacanth). long as the wings. Stamens 10, upper one free, 9 united into a sheath, which is attached to the petals at the base. Ovary villous; style long and filiform; stigma minute. Pod small and kidney-shaped, smooth, and pale brown.

This is a very large genus. Most of the woody and spiny species produce the tragacanth gums, but this species is prominent among those that produce it, and the first that was accurately described. The species A. tragacantha, from which the gum takes its name, does not yield the drug.

Geography. - The Astragalus gummifer and other gum-bearing species are subtropical plants, and do not produce the gum unless they grow in a warm climate. The gum which supplies the market is produced in Persia and the region sonth of the Black Sea, Greece and the islauds of the eastern Mediterranean, also in Syria.

Etymology. - Astragalus, the generic name of this plant, is from the Greek à $\sigma \tau \rho \dot{\gamma} \gamma \alpha \lambda o s$, vertebra, an allusion to the crowded and apparently jointed appearance of the beans or seeds in the pods of some of the species of this large genus. Gummifer is from the Latin gummis, gum, and fero, bear, hence gumhearing. Tragacanth, the name of the gum, is from the Greek $\tau \rho a$ ros, a goat, áк $\alpha \nu \alpha$, beard, hence a goat's thorn, this name being an allusion to the slender spines with which the branchlets of the $\mathrm{A}$. tragacantha are armed, and which bear a slight resemblance to a goat's beard, which is somewhat like a thorn in shape.

History. - When or by whom this drug was first used is not known. The ancients were acquainted with it. Theophrastus, who wrote more than three hundred years before the commencement of the Christian era, mentions it.

Preparation. - The mode of collecting the gum is to remove the earth from the crown of the root, and then make wounds in the bark, from which exudes a whitish gummy sap that hardens in flakes, when it is removed. This 
is the fiue flake gum of commeree. 'There are also small lumps constantly appearing on the stem and branches, which are picked off. 'These kinds are mixed, but are afterwards separated into several varieties, according to quality, for the markets of Europe and America. The gum consists of two sulstances, Arabin, which resembles gum Arabic, which is readily soluble in water, and Tragucunthin, which water causes to swell but will not dissolve. Gum tragacanth forms a mucilaginous jelly, with fifty times its weight of water.

I se. - In medicine, gum tragaeanth is used as a demulcent, and a medium to aid in suspending liquidl medicines. It is also used for a paste or cement; for suspending inks and dres; for preparing fabrics for dyeing, and for stiffening crapes. Shoemakers use it for a paste to fasten the linings in shoes. It is nsed by confectioners and pharmacists to furnish adhesireness to materials of which lozenges are made.

ARACHIS, I. (Peanut.) Calyx of the staminate flower with a slender tube; limb 2-lipped, upper lip 4-toothed. Corolla resupinate. Stameus 9 , united in a tube. Pistillate flowers without calyx, corolla, or stamens. Ovary on a slender peduncle, which lengthens downwards, and forces the fertilized pistil into the ground, where the legume matures. Legume oblong, obtuse at each end, somewhat cylindrical, 1, 2, or 3-seeded ; seeds oroid. Flowers axillary, lower ones fertile, upper ones sterile.

A. hypogæa, Willd. (Peanut. Ground Nint. Ground l'ea. Monkey Nut.) Stem 9 to 18 inches long, prostrate, branching, and hairy.

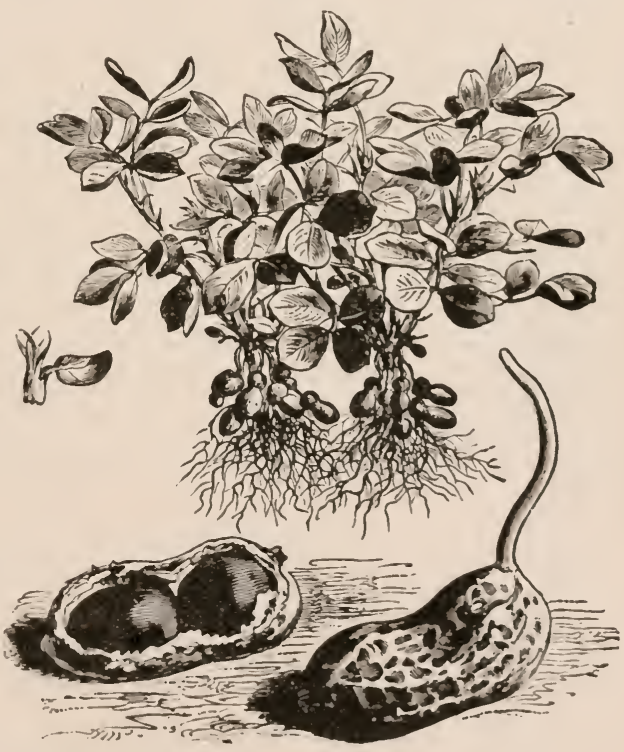

ARAchis hypog.モa (Peanut). Leaves composed of 2 pairs of leaflets, which are an inch to an inch and a half long, obovate, entire, mueronate at the apex, bordered by a hairy nerve, sub-sessile; common petiole 1 to 2 inches long, chameled above, and hairy. Flowers axillary, orange-yellow, appearing in July. Fruit ripens in latter part of september. While the process of ripening is going on the pod sinks under ground.

Of this plant there are seven species, only one of which seems to be uncler cultivation. Of this one there are several varieties, differing from each uther 
in size and delicacy of flavor, one very conspicuous for its large fruit, which is about two inches long and nearly an inch in diameter. The ordinary nut of commerce is about an inch to an inch and a quarter in length and half an inch or less in diameter. A third variety is barely more than half an inch in length, and correspondingly small in diameter, but of very delicate flavor.

Geography. - The peanut is a subtropical plant. It grows and fruits in the southern United States, but will not fruit in regions of severe frost. It is an important crop in southern and central Virginia, and the Carolinas and Temnessee.

Etymology. - Arachis, the generic name, is derived by some from the Greek words $\alpha$, without, and $\rho a ́ \chi \iota s$, the backbone, which signifies, in this application, "without a stem," which is incorrect; hence this derivation is obscure. Others derive it from ăpaxos, a name applied to a kind of vetch by Theophrastus.

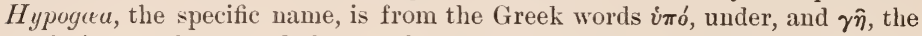
earth, i.e., underground, due to the mode of ripening the fruit. Peanut is named from the fact that the plant appears like the pea while growing. Ground $N u$ and Ground Pea are thus named because they ripen under ground. Monkey $N$ ut receives its name from the fact that monkeys are fond of it.

History. - De Candolle believes the peanut to be an Americau plant. It is found in the tombs of the ancient Peruvians. It was introduced into Africa from Brazil by the Spaniards, to feed the slaves on the passage orer the ocean, and it spread by commerce into northern Africa, southern Europe, India, China, Japan, and North America.

Use. - The peanut is a very popular nut among children and young people in general. It is used sometimes as a dessert. It yields an excellent sweet oil, which is substituted for olive oil in the arts and for culinary purposes. In China the oil is used for illuminating, and also for lubricating. Its roots are sometimes used as a substitute for liquorice.

In Virginia it is ground into flour and used for making pastry and biscuits, and is said to be superior to wheat, on account of its rich, delicate flavor.

Statistics and Commercial Importance. - The annual yield of the peanut in Virginia is about 2,100,000 bushels; in Tennessee, 250,000 bushels; in North Carolina, 135,000 bushels. Besides these, large quantities are imported from South America and Africa.

LENS, Moench. (Lentil.) Calyx 5-parted, parts narrow, lanceolate. Corolla small, nearly concealed by the long segments of the calyx, varying in color from white to lilac, or pale blue. Style erect. Stigma smooth. Pods short and blunt, thin, smooth, and 2-seeded; seeds in form of a circular double-convex lens. Anmual.

1. L. esculenta, Møench. Stem weak, about 10 to 18 inches high, branching. Leaves pinnate, composed of 6 to 8 pairs of elliptical leaflets, the main leafstock terminating in a branched tendril; lower leaves without tendrils. Fruit a short pod, with 1 to 2 seeds, abont two eighths of an inch in diameter, yellowishbrown. Flowers June to July. Fruits August.

There are several varieties of the lentil, three of which are usually under cultivation. The Lens esculenta is the most common, and the most esteemed.

Var. lutea, the yellow lentil, is said to be a favorite with the French.

Var. Provence is a large, coarse sort, grown for stock.

Geography. - The zone of the Lens is the middle and sonthern parts of the north temperate zone, Syria, Egypt, southern and central Europe, and 
Hindustan. It escapes from cultivation and hecomes a troublesome weed, and it has been suggested that it was the plant mentioned in the parable of the Tares.

Etymology. - Lens, the generic name, is the old Latin name of the plant, the signification of which is very obscure. Esculenta is Latin for "eatable," heuce eatable lens or lentil. Lentil, the common name, is from the Latin lenticula, a little lens.

Mistory. - When or where this food plant was first cultivated it is very difticult to determine. It is believed by the best anthorities to have been nrown in western $\Lambda$ sia, and along the shores of the Mediterranean, as far west as Italy, in prehistoric times, and thence introduced into Egypt, alter which it spread over Europe, and erept eastward into India. It is spoken of by the ancient writers on Botany, and was no doubt the material employed by Jacob to prepare his pottage with which he purchaserl his brother's birthright. It is at the present day an important foor in Palestine. It is occasionally cultivated in the eastern United States, but is not very profitable. It is to be found on sale in the Italian and German groceries of our large cities.

Use. - It is prepared as beans are, boiled with or without meat; it is also haked with pork or mutton, and is mate into soups, and used to thicken gratvies. It is largely used by the Arabs in a parched state, while on their marches. It was in early times the only fond of large armies while on the march, lut is areatly inferior in quality and clelicac'y to either the pea or the bean. Its meal is solel as a fool for invalids muler the name "lieralenta."

PISUM, l. (l'ea.) ('alyx with leafy segments, is in

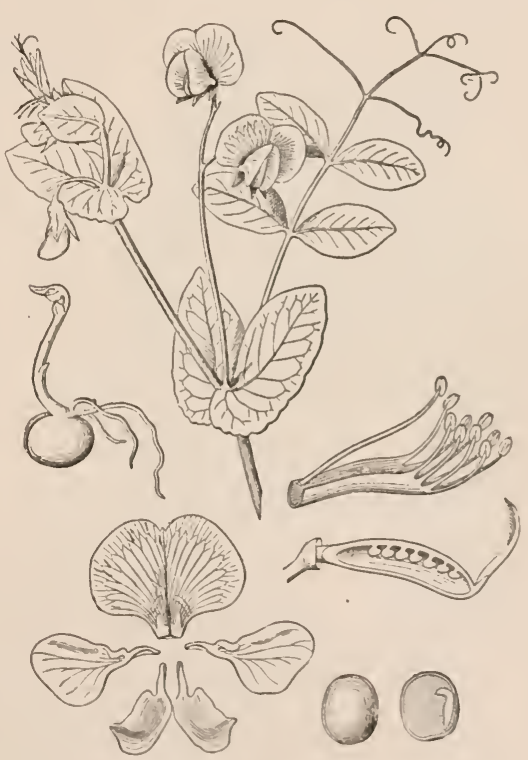

Pisom satuver (Garlen Pea). number, 2 upper ones shorter. Petals .i, upper one lowal and turued back. Stamens 9 and 1. Style flattened and ridged. velvety on the upper elge. Porl oblong; seeds globular, from is to 10 in a porl. Annual herb.

1. P. sativum. (Farilen I'ea.) Stem I to 4 feet high, terete. smooth, and weak, climbing by tendrils. Leaves composed of 2 to 3 pairs of elliptical, obtuse, entire, mucronate leaflet, an inch to two inches long; the common leaf stalk strong, terete, terminating in a long hranchesl tenclril. Stipules large, orate, somewhat sigittate, cronate, dentate at the base. Flower-stalks 
axillary, 1 to 6 inches long, terminated by 1 to 2 flowers each. Style turned back; flowers white. Pod an inch and a half to three inches long, somewhat cylindrical or flattened. Flowers in June. Fruits July to August.

As the pea is grown from the seed, it sports. Gardeners, making use of this tendency, have produced a great number of varieties, differing in length of stem, size, shape, and especially in delicacy of flaror in the fruit.

The varieties are usually arranged under the heads Short-stalked and Longstalked, and named from some real or imaginary quality, or after the propagator, or discoverer.

2. P. arvense, L. (Field Pea.) Differ's from the P'. satirum in being less delicate to the taste. Has only one flower on a flower-stalk. Flower's red. Seeds crowded in the pod, presenting the form of short, quadrangular prisms. Whule plant coarser, and nore hardy, enduring heary frosts; one variety planted in France endures the hardest frosts of winter, and fruits the following summer. Raised largely in Europe for feed for cattle and horses.

Geography. - The liabitat of the pea is from the middle of the temperate zones to the edges of the tropics. It fruits well throughout central and soutlern Europe, Egypt, Syria, Japan, India, China, and Cochin China; but nowhere is it more productive and more largely cultivated than in southern Japan, where it coustitutes a very important article of food and of interual commerce.

Etymolog!y. - Pisum, the generic name, is derived from the Latin word piso, beat, pound, or bruise, due either to the means employed to separate the seeds from the pods, or to grind them into flour. Arrense, the specific name, is from the Latin, signifying "field," and sativum from the Latin, sow, or plant. Pea, the common name, is a corruption of the word piso, grind, or bruise.

History. - The home of the Pisum arvense is not positively known. It is found without cultivation in Italy. The P. sativum is not known at present to be wild anywhere, hence the place where it originated is difficult to discover. It has been claimed to be a variety of $\mathrm{P}$. arrense, but its botanical characteristics are so distinct and constant as to throw that hypothesis into great doubt.

There are reasons to believe that it was carried into Europe by the Aryans, at a remote period of history; and it is supposed to have been indigenous in western Asia, along the foothills of the Cancasus, towards Syria, and southeastward to Persia. It was brought to North America by European colonists, and is grown in the kitclen and market garden, and in many regions in the field.

Cultivation. - The pea flourishes in a light, rich soil, and yields an abundant harvest to generous cultivation. The garden mode of cultivation is usually in drills six to eight inches apart (callerl double rows), with a space of three feet, and another double row. In the field it is either sown in drills and worked with a horse-hoe or a plough, or sown broadcast like the oat. Among the peasantry of Scotland, England, and the Isle of Man the P. arvense is an important field crop, furnishing food for themselves and their domestic animals.

Use. - The pea is plucked before the seed is ripe, when it is in the milky state; it is then shelled, and boiled in a small quantity of water, to preserve the delicate flavor, and served plain or with gravies; it is also cooked with a small quantity of salt meat. When ripe, it is used for soup, or ground into 
flour to thicken gravies and soups; it is also ground and fed to cattle and horses. It constitutes a very important article of food, and is found in every kitchen and market garden.

PHASEOLUS, L. (Bean.) Calyx with 2 brats at the base, bellshaped, somewhat --lipped, "1per lip "-parted, lower one 3-parted. Keel of the corolla beaked, and, together with the stamens and style, spirally twisted. Legume, or pod, linear enred, Hattened, or somewhat cylindrical; many-seeded; seeds kidney-shaped. Ammal herb.

1. P. vulgaris, Kavi. (Pole Bean, Kidney Bean, Haricot, String Bean.) Stem 4 to 10 feet long, slender, voluble, aud twining always against the sun, or towards the west or southwest. leaves trifoliate, or a pair of leaflets and a terminal one, common petiole 1 to 6 inches loug. Flowers white, in racemes, on stout peduucles, 1 to 4 inches long. Pod 3 to 6 inches loug; seeds more or less kidneyshaped, whitish, dullyellow, or mottled.

Var. nanus, L. (Bush Bean) is a clwarf, with a short, erect, brauching stem 8 to 15 inches high. Leaflets sharp-pointed, and bracts larger than in the above; otherwise like $\mathrm{P}$. vulgaris.

2. P. lunatus, I. (Lima Bean.) Stem as in P. rulgaris, except longer and disposed to branch more; leatlets larger, oblique or triangular, 2 to 4 inches

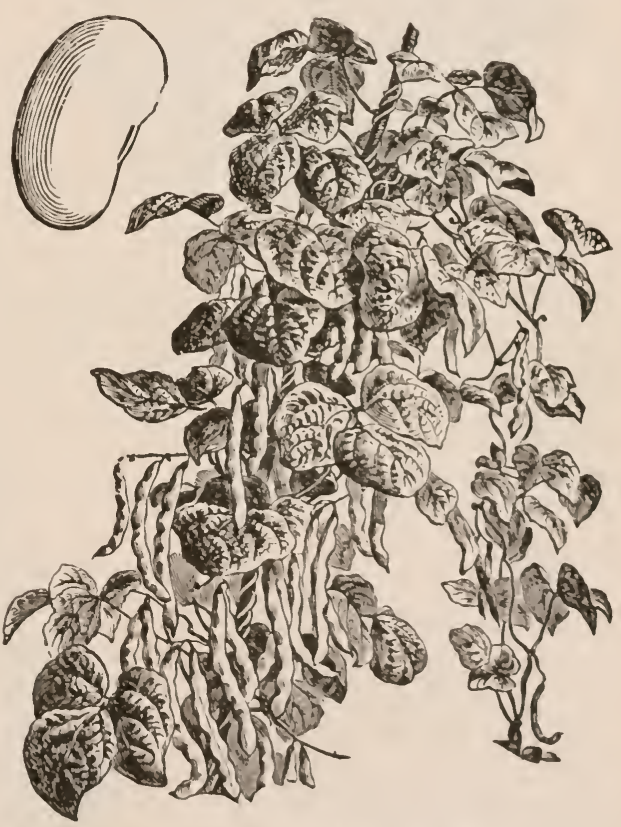

Phaseulus vulgaris (String Bean). long, common petiole

2 to 6 inches long, racemes louse, pedicels short. Flowers greenish-white, smaller bracts shorter than the "alyx. I'ods 2 to 3 inches long, an inch wide, curved or mom-shaped. Seeds 1-4, large, Hat, gremish, or white. Flowers in July; fruits in August to September, remanumg till frost appears.

Species. - The above are the species which have given rise to all the forms now under cultivation. In the south of North . Imrrica. Mrexico, and the West India islands, a small hlack bean, called turtle-somp bean, is largely cultivated, especially by the spanish Americams. 
(The beans of a different species, Ticia faba, L., otherwise called Faba sativa, are not flattened, and are smaller than the above. They are often given to horses.)

Geography. - The zone of the bean is rery wide, including the tropics and

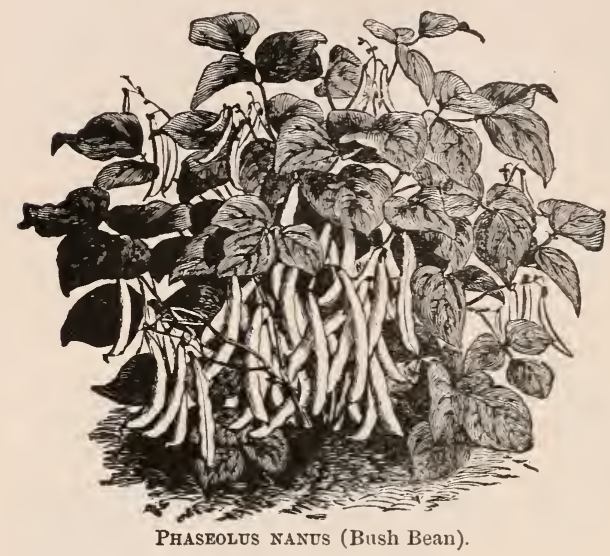

the temperate zones to the 45 th parallels, and even beyond in some localities.

Etymology. - Phaseolus, the generic name is from the Latin phaselus, a little ship, due to the shape of the flower. Tulyaris, from the Latin, means common or usual. Nanus, from the Latiu, signifies small or dwarf. Lunatus, Latin, indicates that the pod is in the shape of a new moon. Bean, the common name, comes to us from the old middle English, and is supposed to signify good,

i. e., good food, or good for food. Bush Bean is named from the fact that the plant appears in the shape of a little bush. Pole Bean is named from the circumstance of planting poles in the hills with the seed for the stems to climb upon. Kidney Bean takes its name from the kidneyshaped seeds. Lima is supposed to be named from the fact that this species was found near the city of that name.

History. - The bean was supposed to be a native of India and Western Asia, and to have thence worked its way into southern Europe by commerce and travel; but recent inquiries have disturbed this belief. De Candolle, who is the best authority on the subject, thinks that the Phaseolus vulgaris, and $\mathrm{P}$. lunatus are indigenous to South and Central America, and that the bean was carried thence to southern Europe by the Spaniards, and to western Africa by Spanish slave-traders. To reconcile these statements

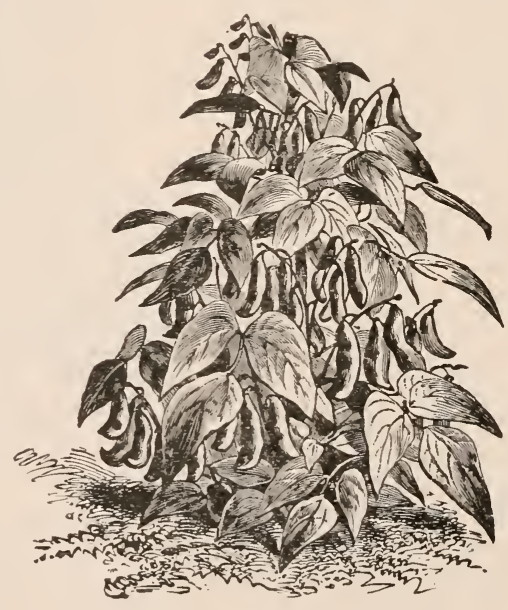

Phaseolus lunatus (Lima Bean). with the accounts of ancient writers, we must conclude that the beans of the ancients were varieties of other species, or different genera, of the Pulse family. 
Cultivation. - The bean grows so easily in almost every variety of anil that nearly every locality produces sufficient for home consumption. Hence, though it has become one of the most important table regetables, it has little more than a local sale.

It is planted in hills two and a half to three feet apart, or in drills three feet apart.

Use. - The bean, in its numerons forms, constitutes a very important article of food. The ripened seeds are boiled, and served plain or mate into somps. A flour is also produced from the ground seeds, and employed to thicken gravies and soups. In New England, baked beans form a favorite dish. The green pods of the l'. rulgaris, when the seeds are about half-ripened, are cut into half-inch pieces, and boiled, either with or without salt meat, and served as a regetable. Beans are largely used at sea and in the army, for rations for the sailors and soldiers, and they are helieved to afford more nutritive material than any other substance of the same bulk.

GLYCYRRHIZA, L. (Liquorice.) The description of Astragalus applies to Glycyrrhiza, except that in the latter the anther-cells are united, and the legume is continuous interually.

G. glabra. 3 to 4 feet high. Leaves pinnate, 4 to 5 pairs, and a terminal one; leaflets ovate. Flowers axillary, in racemes, whitisl-violet.

Geography. - The liquorice is native to Italy and southern Europe ; it also grows in the south of England, and is cultivated in S pain and Portugal.

Etymology and History. - Glycyrrhiza, the generic name, is from the Greek

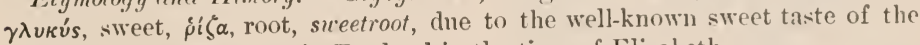
liquorice. It was grown in England in the time of Elizaheth.

l'se.-Its medicinal qualities are demulcent and emollient. It is arlministered in catarrh and other irritations of the mucous membrane, and for $]^{\circ}$ sore throat. It is largely used to sweeten tohacco. Brewers also nse it to give body and to impart a sweet taste to porter and to sicotch ale. It is also mixed with purgatives, under the name of liquorice-powders, to disguise the taste of other drugs, as senua, ete.

hamatoxylon, I. (Logrrood.) Calyx cup-shaped, hemispherical. Sepals 5, nearly equal, imbricated ; corolla papilionaceous. Stamens 10, 5 shorter. Orary inserted in the hollow receptacle, free, short, stipitate, usually 2-oruled. Pods furnished with lance-shaped, flattened. leaf-like beans or seeds, $1-2$ in a pod. Small tree.

H. Campechianum, I. (Iogwood.) Stem 20 to 30 feet in height, aml 1:2 to 18 inches in diameter : cronked, much-branched, branchlets armed wit h sharp spines; sometimes appears as a shrub forming dense thorny thickets. Bark dark and rongh. Leaves pinuate, with 4 or 5 pairs of irregular olseordate leaflets. Flowers yellow, in terminal spikes. Pods long, double-valved; seeds ohlong, kidney-shaped, flattened.

The only species of the genus.

Geography. - The lugwood-tree is native in all parts of the damp foreste of Central America, heing most ahundant on the peninsula of Yueatan, and along the low-womled shores of finatemala and Honduras; but it grow: well along the low banks of streams and damp groumds of the Isthmus of 
Panama and the West Indies. It has been planted by the British in Burmah, where it grows to perfection.

Etymology. - Hamatoxylon is from the Greek words aîna, blood, and $\xi \dot{v} \lambda o \nu$, wood, signifying blood-wood, on account of its red color. Campechianum is the name of the region where it was first obtained. Logwood, the common name, is due to the form in which it is brought to market, i.e., in short logs, four feet long and six inches in diameter. For the same reason it is called blockwood. On the continent of Europe it is called Campeachy wood.

History. - It grows and thrives best in damp ground. Though a quick grower, the wood is of a fine, hard texture. It was known as a dye-wood as early as the middle of the sixteenth century.

The dyers of that day prepared beautiful colors from this wood, but its chemistry not being understood, they were unable to fix them; hence its use

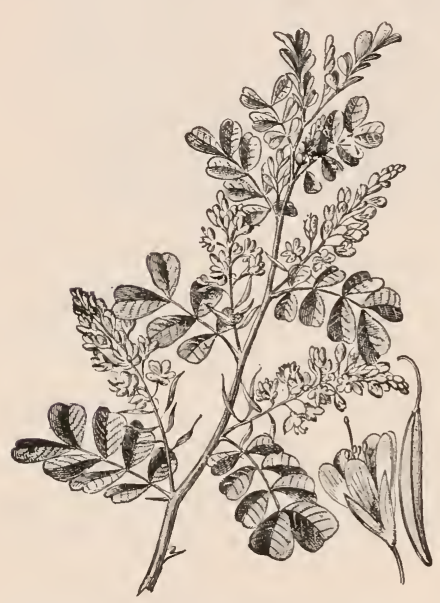

Hematoxylon Campechianum (Logwood). was forbidden by a law, which was rigorously enforced. After about a hundred years the act was repealed or made roid by the passage of another, in 1661 , which read as follows: "The ingenious industry of the times hath taught the drers of England the art of fixing colors made of logwood, so that by experience they are found as lasting and serviceable as the color made by any other sort of dye-wood." And logwood from that time became a popular dye. In 1675 the demand for the wood dereloped a great industry in cutting, preparing, shipping, and freighting the wood. The Spaniards interfered with the English, who had established a colony of choppers on the shores of the Bay of Campeachy. The English thereupon made plantations in Jamaica, but the wood produced did not yield the dye of the wood grown in its native swamps.

When the tree is 10 years old it is about 20 feet high and 10 inches in diameter; it is then felled, the sap-wood chipped off, cut into pieces 3 to 4 feet in length, and shipped to Great Britain or the United States. The best wood is from Honduras, the next best from St. Domingo, and the third class from Jamaica.

Chemistry. $-\mathrm{A}$ blood-red crystalline substance is dispersed through the wood, and this when extracted gives the violet dye. It yields to the chemist a substance indicated by the following formula: $\mathrm{C}_{32} \mathrm{H}_{14} \mathrm{O}_{12}+2 \mathrm{HO}$. This when isolated appears in yellow crystals, and has the taste of liquorice, and was named Hæmatoxylon by Cherreuil, a professor of chemistry in Paris, who obtained it. It is not itself a dye; but when united with certain alkaline bases, and exposed to the action of the air, it produces beautiful red, purple, and blue colors.

Use. - It was first used in 1646. Its medicinal properties seem to be a mild astringent and tonic, and it is administered in the form of extract or decoction for infantile cholera, chronic diarrhoa, and chronic dysentery. 
Its most important use is as an ingredient in the production of dyes.

As a hedging-plant it is highly esteemed; on accomt of its rapid growth, its crooked labit of growth, and its stroug spines, it is one of the best-known plants for fencing purposes.

It makes excellent fuel, and is rery hard and heary

Statistics. - Abont 64,000 tous are anmually taken into (ireat Britain, and nearly as much inte the Luited States.

Marts. - The principal ports to which logwood is taken are: London, in Great Britain; Versailles, in France; and New York, in the Lnited States.

CASSIA, L. (Senna.) sepals 5, barely united at hase. l'etals 5, unequal, spreading. Stanens is to 10, unequal aprat, frequently imperfect. Inthers opening by two chinks at the alpex. P'od manyseeded, often with eross partitions. Leaves pimate. Flowers yellow.

1. C. acutifolia, Delile. Stem wooly, 3 feet high. Leaves alternate, pinnate, stipulate; leaflets in from + to 6 pairs, sessile, oval-lanceolate, acute, oblique at hase, nerved, three fourths of an inch long. Flowers yellow, in axillary spikes. Fruit a pod or legume, an inch long, half an inch broad, flat, elliptical, obtuse, membranous, and smooth, divided into 6 or $i$ cells, each coutainiug I seed.

2. C. obovata, I)(. Like the above, except that it is 18 inches in height. Leaf with 5 to 7 pairs of leatlets, obovate and mucromate. Legume Hat, kidney-shaped, and cluthed with a short inconspicnous down.

3. C. angustifolia, Wahl. Stem erect, smooth. Leaflets in 4 to 8 pairs, sesisile, lanceulate, obscurely mucronate, smouth, downy beneath, with a wavy line along the muler sille of margin, one to one and a quarter inches long. Legume oblong, abrupt at base, round at ajpex, an inch and a half loug and half au inch bruad. Anuual.

4. C. Marilandica, L. Sitem 3 to 5 feet high.

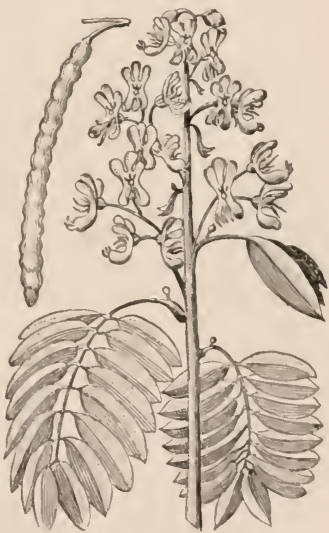

Cassia Marilandica (Senua).

Leaflets in 8 to 10 pairs, an inch and a half long and half an inch wide, oblong, blunt, and mucronate; the main petiole has a club-shaped gland at its base. Flowers in short axillary racemes on the upper part of stem, yellow, fading to white. Anthers black, 10 in number, and unecyual. L'ods langing, 3 inches long, flat, linear, laairy at first, stipules falling off.

5. C. fistula, L. Latge tree, branchiug regularly, and forming a symmetrical head ; wood hard and heary. Leares of 5 to 6 pairs of opposite leatlets; leaflets 3 to 5 inches long, ovate, pointed, unclulate, smootl, on short petioles. Pod a foot long, an inch thick, cylindrical, woxly, dark-brown, hanging. When the plant is disturbed by the wind the pods strike together and produce a sound which may be heard at a considerable distauce. Native in Upper ligrpt.

Species. - There are many species of the Cassia, hut those already described are the ones from which the commercial products are obtained that enter into the American trate. 
Geography. - The geographical range of most of the species of Cassia which enter into the materia medica is tropical and subtropical, extending quite around the globe.

Etymology. - The common name Senna is derived from the Arabic name Sana. The generic name is said to have been traced back to the Hebrew word Ketzioth, signifying "to cut;" but the application of this signification is not apparent. The specific names are Latin, with one exception, Marilandica, which signifies "Maryland," this being the State from which specimens of the plant were first sent to Europe. Acutifolia, Latin, acute- or sharp-leaved Oborata, obovate-leaved. Angustifolia, narrow-leaved. Fistula, a tube-shaped fruit.

History. - Senna was introduced into medical practice in the tenth century by the Arabic physician, Serapion.

The most valuable is the Alexandrian senna. It is a mixture of the leaves and pods of C. acutifolia and C.obovata and the leaves of Cynanchum oleæfolium; the mixture is prepared at Boulac, in Egypt, where it is put up in bales and sent to Alexandria.

The East India senna is obtained from C. angustifolia, in southeastern Arabia, where it grows withont cultivation. The leaves and pods are gathererl and sent to Bomhar, whence it reaches Europe.

Tinnevelly senna is obtained from C. angustifolia, which was introduced into India from Arabia, and is now largely cultirated in the vicinity of Tinnevelly. The imported article consists of unbroken leaflets, of a fine darkgreen color.

The American senna is from the C. Marilandica, and is found throughout the Middle and Sonthern Lnited States. It is collected in a wild state, dried in the shade, and the leatlets and pods are sent to market.

$U$ se. - The active merlicinal principle of senna has thus far defied the skill of the chemist. By experience the drug is found to be a safe and efficient, hut not a violent purgative. It is usually administered in combination with salts of magnesia. It is used for alterative purposes in the form of confections; the pulverized leaves, the pulp of the fruit of C. fistula, with fruits and spices, are made into a mass, and are prepared in the form of lozenges.

\section{CERATONIA, I. (Caroh Tree.)}

C. Siliqua. Found in the countries of the Levant, hearing large pods, which are fed to cattle, and believed to be the plant referred to in the New Testament in the parahle of the Prodigal Son. Pods have been found in Egyptian monuments, with a piece of wood, which microscopic examination proved to be from this tree.

DALBERGIA, L. (Blackrood.) Calyx unequally j-toothed; vexillum oborate or orbiculate; wings oblong; keel blunt. Stamens 10 or 9 , bifid-didymous. Orary stipitate; orules 2 or more. Pod oblong linear, compressed, thin, wingless. Leaves unequally pinnate or 1-leaved. Trees and rines.

1. D. nigra, Allemo. (Fine Rosewood.) Trunk 50 to 70 feet high, branched into a symmetrical head. Leaves unequally pinnate, or solitary. Flowers papilionaceous, white. Pods flat, 1-2-seeded. Wood brown, and beautifully mottled with yellow spots and veins. 
2. D. latifolia, Rox. (Indian Rosewood.) Trunk so feet iu height, beautifully brauched. Leaves pinnate, with few leaflets. I'ods Hat, tew-seeded. Wood hard, heavy, elose-grained, takes a fine polish, color brown to l, lack, streaked with rich yellowish veins.

Note. - The name liosewood is applied to several different trees. There is some confusion with regard to the genera that produce all the woods known by that name. The Dalbergia uigral, and 1). latifolia are known to be trees from which rosewood is protuced, and 1). nigra is the tree whose wood discharges an odor of roses.

Geography. - Dalbergia nigra is found native in Brazil, both tropical and subtropical. 'The 1). latifolia is indigenous to sonthern Asia. Though tropical, it extends north to the elge of the north temperate zome, and is extra tropical in regions of no frost.

Etymoloyy. - Dalbergia was the name given to this genus to compliment Nicholas I)alberg, a Swedish botanist of distinction. Nigra, Latin, signifying black, due to the color of the wood. Latifolia, Latin, broadleaved, from latus, broad, and folium, a leaf. Rosewood, the popular name is due to the odor given off by the

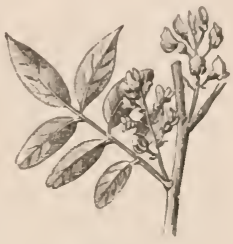

DALBERGIA NIGKA (Rosewood). wood when muder the saw and plane of the workman. The names, Kinguood, Blackwood, are also applied to all the woods known as livsewoods. The Dalbergia is known among the inhabitants of Brazil under the name Jucaranda, the signification of which is unknown.

Use. - It is brought to market in logs or plauks. The logs are usually split in half, in order to make sure that they are sound.

The wood is highly prized for musical wind-instruments, polishiug-sticks for shoemaker's, piano-cases, chairs, sofats, bedsteads, bureans, and for veneering all sorts of cabinet work.

\section{CAESALPINIA. (Brazil Wood.)}

C. crista, L., and C. Braziliensis furnish fine dyes and red ink. The woor takes a fine polish, and is used for violin-bows, etc.

The name Braziliensis dues not seem to come from Brazil, for it was known before the discovery of America. It has been suggested that the discovery of the tree in Brazil may lave given its name to the country.

TAMARINDUS, I. ('Tamarind.) Calyx fumel-shaped, narrow, divided into 4 ovate, lancolate, acute segments, inhlicated in the lud. P'etals 3, 1 posterior and the other 2 lateral, oblong, white or yellowishwhite, with red reins. Stamens 3, filaments long and free. Anthers opening lengthwise. Ovary stalked, 1-celled; ovules numerous. Style long and hooked. Fruit pendulous, pod-shaped, compressed. 3 to 6 inches long, 1 inch wide, curved, nearly smooth, chocolatebrown; seeds imbedded in a firm pulp; 3 strong woody cords extending along the edge of the pulp from base to apex. Seeds 2 to 8 iil a poil.

T. Indica, I. Trunk from 60 to 80 feet in height, and 2 to 4 feet in diameter; bark rongh, twigs smouth or pubescent. Branches long, horizontal, forming a very large head. Leaves alternate; stipules falling; leatlets in 
8 to 16 pairs, opposite, one half to three quarters of an inch long, sessile and overlapping, oblong, blunt, nnequal at the base, thick-veined underneath. This is the only species of the genus; but as it is propagated from the seed, it sports and prodnces varieties differing in the size and quality of the fruit. The pods of the Indian and African varieties have more beans in them than those of America.

Hymencea verrucosa, of Madigascar, and H. combaril of the West Indies, are allied to the Tamarindus. H. combaril is the locust-tree of the IVest Indies.

Trachylobium Hornemannianum, of eastern Africa, is also an ally of Tamarindus.

Geography. - The geographical zone of the tamarind is tropical and subtropical. It is indigenous to Africa, but it has spread by cultivation to Arabia, to sonthern India, Ceylon, Java, the Philippines, northern Australia, the tropical isles of the Pacific, the West India islands, and to tropical South America.

Etymology. - Tamarindus is from the Arabic Tamar, a date, and Indus, India, hence Indian date. Indica denotes the conntry in which it grows, yet it is not known to be a native of India. Tamarind, the common name, is the generic name Anglicized.

History. - There is reason to believe that the ancient Greeks and Romans were not acquainted with the tamarind, but it seems to have been known to
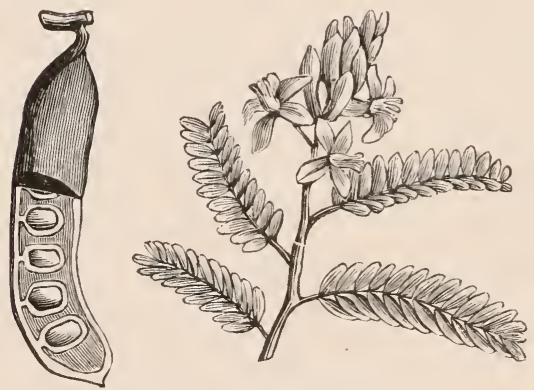

TAMarindus (Tamarind). the ancient Egyptians. It is mentioned in the Koran, and was well known to Arabic physicians in the middle ages.

Preparation. - In the IVest Indies the fruit is picked when ripe, packed in small kegs, and hot syrup is poured over it; then the ressels are closed, and it is fit for the market.

In Asia the fruit is packed in salt, and a syrup made from the fruit is poured over it.

In Africa the pulp is separated from the pod and seed and pressed into cakes, then dried in the sun.

Us . - The medicinal properties of the tamarind are laxative, cooling, and anti-febrile. It contains abont one tenth of its weight of citric acid, also small quantities of acetic, malic, and tartaric acids, hence its value in producing acid drinks, for which it is largely used in the countries where it grows.

It is an important article of food among the natives of the hot countries of Asia and Africa. The seeds are roasted, and reduced to flour, of which cakes are made; they are also boiled. The Hindus make use of the leaves, flowers, bark, and seeds in the preparation of healing remedies.

In the Atlantic cities of the United States it is used as a preserve. In the famine of 1878-9 the leares were used as food in the Deccan.

The timber produced by these trees is hard and durable, and they all produce a resinous gum known as copal, which when heated with linseed oil or spirits of turpentine, dissolves and forms the best rarnish. The gum 
flows from wemuls made in the trunk and hranches. It also flows from the roots, and is found by digging alsut the fout of the tree. Mnch of this resin that comes to market is fossil, as it is frequently foumd where there are no trees.

Marts. - The ports of export are Aden, in sumbern Arabia, Alexandria, and ports of the East and West Indies.

ACACIA, Necker. Flowers regular, perfect or polygamous. C'alyx t-5-toothed. Petals nnited below. Stamens free or united below, numerous, longer than the corolla. Anthers small. Style threacllike. Pod sometimes two-valved, and at other times not opening when ripe: Hattened or cylinglrical, containing many flattened seeds. Leaves bi-pinnate; leaflets small; stipules frequently spinous. Flowers small, in glohular heads or cylindrical spikes, axillary, and yellow. Shrubs or small trees, usually armed with prickles or thorns.

A. Senegal, Willd. (Gum Arabic.) Stem 20 feet high, erect. Branches irregular, crooked, and twisted, the young branchlets thickened at the nodes, which are armed with three hooked thorns. Bark smooth, grayish, or white. Leaves alteruate, or appearing in bunches, or fascicles, bi-pinnate; rachis slender, tomentose, terminated with a gland, having one also at the base; pinnæ opposite, 3 to 5 pairs; leaflets opposite, 10 to 20 pairs, sessile and linear-oblong, rigirl, gravish-green, one sixth of an inch long. Flowers axillary, sessile, small, in slender, cylindrieal, erect spikes. Calyx bellshaped, downy, cut into 5 acute segments, reaching half-way down. Corolla campanulate, twice as long as the calyx, divisions extending half-way down. Stamens umerous; filaments slender, erect, 3 times the length of corolla, yellowish, united at the base into a short tube, which is inserted on the base of corolla. Anthers small and roumlislı. Ovary on a short stalk, small, oblong. Style filiform, shorter than stamens; stigma terminal.

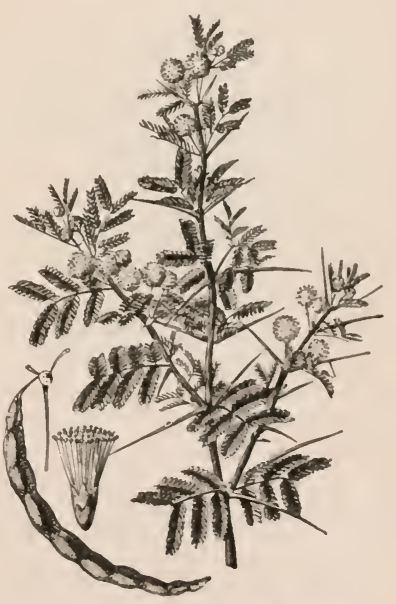

Acacta Senegal (Gum Arabic). Pexl short-stalked, 3 to 4 inches long, and three fourths of an inch wille, constricted between the seeds, smooth, pale, membranous, with a strong marginal rib. No. of seeds $2-6$; funiculus long; beans roundish, much flattened, hrown.

There are over 400 species of this genus, but the pure fum Irabic is from the $A$. Senegal, found in Kordofan.

Geography. - The geographical distribution of the acacia is very extensive. It occupies a hroas belt both sides of the equator, all around the glube. Though it is for the most part a tropical and subtropical plant, it reaches far into the temperate \%ones. Many species grow in Australia, and some in America. Most of the species, however, are found in tropical $\lambda$ friea and Asia, and in the tropical l'acific Islands. 
Etymology and History. - Acacia is from the Greek àkakia, a name given to a thorny plant by Dioscorides, derived from àкń, a sharp point. Senegal, the specific name, is from the district in Africa where the tree abounds. Gium Arabic, the popular name, is due to the circumstance that formerly the gum was carried from Aden in Egyptian ships through the Rerl Sea to Egypt, and thence reshipped to Europe.

At present none of the gums of commerce known as Gum Arabic are ubtained from Arabia.

The pure gum used in medicine is from Kordofan, is carried down the Nile to Egypt, and is a white opaque substance which when pulverized resembles wheat Hour in color. The several gums sold for gum arabic are from other species, and are usually brought to market mixed.

The gum exudes from wounds or incisions in the bark, and appears in tears from the size of a pea to that of a small hen's-egg. The different sorts are known in commerce by names which indicate the countries whence they are brought, as Mogador gum, North Africa gum, Jedda gum from Jedda in Arabia, Cape gum from the Cape of Good Hope. East India gum is carried from the east coast of Africa to Bombay, from which point it is shipped to Europe.

'There is also a gum sold for gum arabic which is an Australian product, and is obtained from the Acacia pycnantha, Benth. The beautiful A. dealbata of Australia, frequently seen in our green-houses, yields a good gum.

The Acacia Seral is the Shittim wood of Scripture, and the Acacia Suma is one of the sacred trees used by the Brahmins to obtain fire by friction, for their altars.

The fine white gums of commerce are known as Turkey gums. The darker, translucent, reddish gums are known commercially as Senegal gum.

Use. - The gum begins to flow in the flowering season early in December, and the harvest extends to the last of January, during which time the harvesters subsist almost entirely upon the gum.

1. Catechu of India yields by decoction a valuable tonic (Catechu), and in the hands of the dyer it forms the colors black, brou'n, green, drab, and fawn. 'The decoction is highly charged with tannin.

As a medicine, gum arabic is used largely as an emollient and demulcent; it is prescribed in stomach difficulties, dysentery, and other bowel disorders; and is used in throat tronbles, and for cough mixtures.

In confectionery, it is mixed with sugar and formed into lozenges and gumirops.

It is largely used for a cement, or sticking substance. 'The Egyptians employed it to suspend their water-colors in painting.

The commoner qualities are used for giving luster to crape, silk, etc., to stiffen the fibers in cloth-finishing, and in calico-printing. For labels, etc., it is usual to mix sugar or glycerine with it to prevent it from cracking.

The tree has great heanty, and is highly prized in planted grounds where it is able to endure the temperature. The wood is hard, and takes a fine polish. The bark of many of the species is highly charged with tannin, and though used in the manufacture of leather, is not a favorite for that purpose, becanse it imparts a stiff, brittle character to hides during the process of tanning. 'These barks, however, are largely imported into England. 'They are known in commerce as Wattle Barks.

A species of an allied genus Prosopis (P. juliflora, l.)C.), a native of T'exas, yields an inferior gum locally substituted for gum arabic. 


\section{ORDER IXII. ROSACEAE.}

Flowers perfect, regular, teminal, usually in a corymb, cyme, or nmbel. Sepals 5, occasionally fewer, united at the base. l'etals 5, occasionally wanting. Stanens numerous, in several series, distinct or cohering together, inserted with the petals on the disk which lines the calyx-tube. Leaves alternate, stipulate. Fruit a pome, drupe, or akene. Sieeds one or few in each carpel. Herbs, shrubs, or trees.

Number of genera, 71 ; of species, 1000 .

RUBUS, I. Calyx spreading, 5-parted; petals 5 in number, falling. Stamens many, on the border of the disk; ovaries numerous, with 2 ovules, 1 ahortire. Alienes pulpy, drupe-like, aggregated upon a succulent receptacle. Shrub.

1. R. strigosus, Mx. (Wild Red Raspberry.) Stem 3 feet high, half an inch in diameter, sparingly or diffusely branched, armed with weak prickles. Leaves pimately 3-5-leaved; leaflets oblong-ovate, obtuse at the base, pointed at the apex, serrate, gasher, teeth mequal, sessile and hoary beneath, wrinkled. Flowers white; corolla cup-shaped, and smaller than the ealyx. Fruit hemispherical, when removed from the receptacle; it is hollow, aud forms a little cup. The aroma and taste are very grateful. Common in Northern L'nited States. Flowers in June. Fruits in July and August. Root perennial. stem biennial.

2. R. occidentalis, I. (Black Raspberry. Thimble Berry. Black Cap.) Stem 3 to 5 feet high, gliucous, recurverl, bending to the ground, armed with strong recurvel

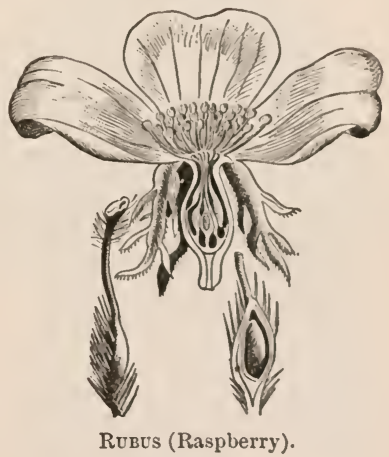
prickles. Leaf 3 -foliate; leaflets acuminate, sulsessile, doubly serrate, tomentose, or white lowny beneath. Flowers axillary and terminal; corolla smaller than the calyx. Fruit like the last, except that it is black. Flowers in May and Jume; fruit ripens in July. Common where the last is fouml. Dr. Gray says it flourishes best in gromid that has been burned over.

3. R. Idæus, I. (Garlen Raspberry.) Stem 5 to 8 feet high, armed with strong bristles or recurved prickles. Leaf pimnate, with 3 to 5 leaflets; the leaflets broad-ovate, acmminate, mnequally ('nt and toothed, hoary underneath; lateral ones sessile, terminal one petioled. Flowers in cormmbs or panicles; petals shorter than the divisions of the "alyx, white, terminal. Frnit red, like No. 1. 1)r. Gray thinks it identical with the Imerican species lR. strigosus. Wood says Dr. Rublins fouml it in a will state in Vermont, also in Connecticnt.

R. Idlens is the plant from which all the varieties of the rel raspberry have sprung, either by hybrilizing or from seedlings.

The black eap varieties lave arisen by similar means from the $R$. occidentalis.

There are about 150 varieties under cultivation in North America.

P'R. FL. -9 
Feography. - The geographical distribution of the Rubus is very broad. It grows well in the temperate zone, between $30^{\circ}$ and $50^{\circ}$ latitude in North America, and the belt extends from the Atlantic to the Pacific oceans. In Europe it is found as far north as the 60th parallel, and extends to the northern parts of Africa, and from Asia Minor west to the British islands, and eastward into India. It is said to be found in Japan, but it is supposed to have been carried there by Europeans.

Etymology. - Rubus, the generic name of the raspberry, is derived from the Celtic word rub, signifying red, Latin ruber. The specific name strigosus

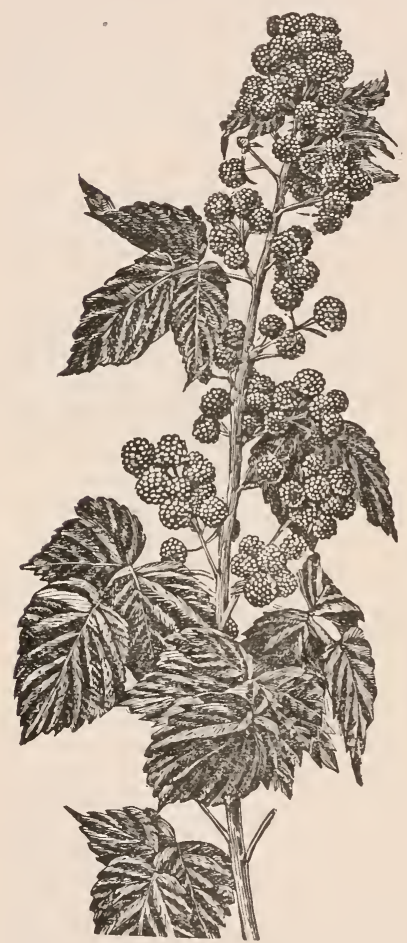
is a Latin word, which means scraggy, or meager, relating to the small size of the plant. The specific name occidentalis means western. The name Idous, is from Momnt Ida, where it is believed this species had its origin. Raspberry comes from the Italian word raspo, rough, on account of the roughness of the stem and leaves; it is also called raspis in Scotland for the same reason.

The Idcus is the cultivated plant in Europe, and was brought to North America by European colonists.

History. - There is no record to show when the rasplerry was first brought under cultivation or when it was carried into Europe, but its value as a food-plant must have drawn attention to it at a very early period of man's civilization. The seed of the raspberry is said to have been found in the hands of mummies, which points to great antiquity in its use.

Use. - The raspberry is a favorite dessert fruit. It has a delightful perfume, and a subacid taste agreeable to most palates.

It ripens just at the end of the strawberry period, and thus prolongs the early fruit season. It is used for jams, raspberry vinegar or wine, for syrup to flavor soda water and other drinks. It is largely canned and dried. A wine made from it Rubus strigosus (Wild Red Raspberry). is distilled into Raspberry Brandy.

Marts. - The ease with which it is cultivated enables gardeners in the vicinity of our large cities to supply the market. It is so perishable that it cannot be shipped to long distances, hence the markets must be local.

4. R. villosus, Ait. (High Blackberry.) Stem from 3 to 8 feet high, curved, from half an inch to an inch in diameter; young branches, and villous peduncles, grooved, and armed with strong curved prickles. Root creeping. Leaves 3 -foliate, or pedately 5 -foliate; stipules subulate; leaflets orate or oblonglanceolate, umequally serrate, villous beneath, petioles and midrib aculeate. Flowers in a racene, abundant, white; sepals linear at their extremities; 
petals longer than the sepals, obovate, spreading. Fruit ovoid-oblong or cylindrical, from half an inch to an inch in length, and half an inch in dianeter, ehanging from green to red, and black when ripe. Flowers in Nay; fruits in July.

Var. frondosus, (iray. Leaflets incisely toothed, smooth. Flowers more corymbosed, with leafy bracts, and roundish petals.

Var. humifusus, Gray. Stem trailing, and smaller pedmucles; few-flowered.

5. R. fruticosus. (Iligh l3lackberry.) A plant common in the British Isles. But little attention is paid to it, and it has not been bronght unler cultivation.

Varieties. - There are some 20 varieties now under cultivation, differing from eacl other as to the quality of the fruit and the hardiness of the plant.

The varieties of the blackberry grown in our garlens, and from which our markets are snpplied, are seedlings from the R. villosus, or high blacklyerry, found in onr fields and fencerows all over the Northern and Middle States. 'The Kittatinny was found in the Kittatinny Mountains in Warren County, New Jersey, growing without cultivation. The New Rochelle blackberry was foumd by Mr. Lewis Secor by the roadsille in the town of New Rochelle, Westchester Comnty, New York, and was callerl Secor's Mammoth. Mr. Lawton, of New Rochelle, took great interest in it, and propagated it in his mrsery at New Rochelle. The names Lawton and New Rochelle blackberry are both dne to this circumstance.

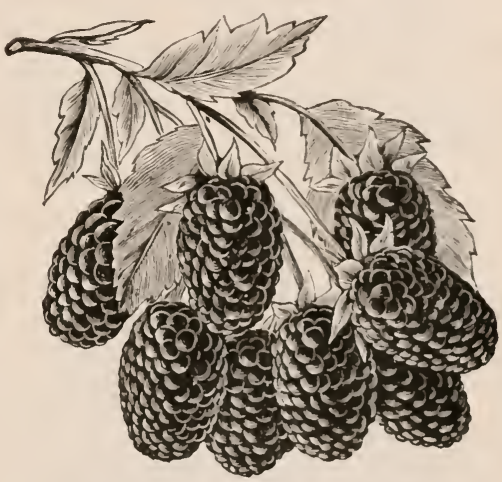

Rubus villoses (High Blackberry).

Geography - The Rubus vil-

losus or high blackherry is an American plant, and grows freely all over the Northern and Middle States, in fence-rows, pastures, and elges of wools and old fields.

Etymology. - The specific name villosus comes from the Latin worl villus, wool, and signifies woolly, a name applied to this plant becaltse it is clothed with weak, long hairs. The common name blackberry arises from the color of the fruit when ripe.

Mistory. - There is but little to be said of the history of the blackberry. The villosus, the parent of all the cultivated varieties, is an $\Delta$ merican plant, and has bren used as a food-plant since the settlement of the country, but has only recently become an article of commerce. Of late years it has engaged the attention of fruit growers to a great extent, and many fine varieties have been prodnced by hybridizing and from seedlings.

Ise. - It is a favorite dessert fruit, eaten with sugar or milk without cooking; it is preserved in sugar and brandy, and is canned; it is also prepared as a jam. A syrup male from it is used as a remedy in chronic stomach and bowel difficulties, because of the astringent properties it contains.

Marts. - On account of the perishable character of this frnit the markets must be local. 
FRAGARIA, (Strawberry.) Tourn. Calyx concave, deeply cleft; sepals or divisions 5 in number, with 5 alternate bractlets; petals obcordate, white and large; stamens numerous; styles numerous; akenes naked, on the surface of a subglobular, heart-shaped, or irregular pulpy eatable receptacle. Perennial stemless herb.

1. F. Virginiana, Iuchesne. (American Strawberry.) Without stem. Leaves and flower-stalks pubescent; leaves on long radical petioles, composed of 3 dentate leaflets, lateral ones oblique, nearly sessile; flower-stalks less hairy

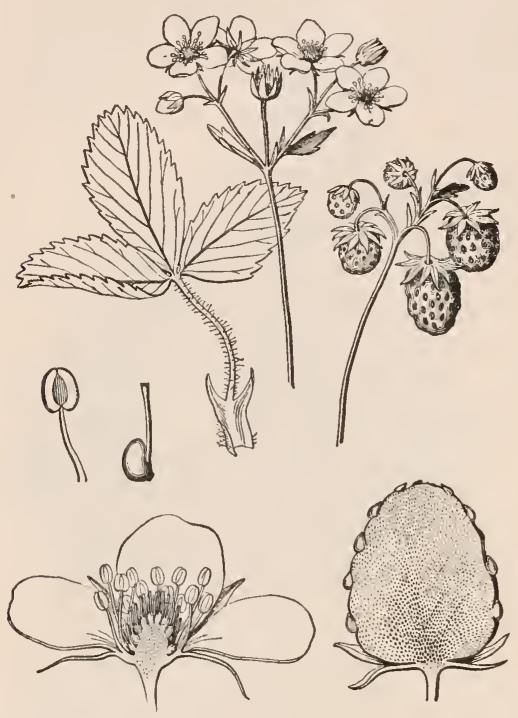

Fragaria vesca (English Strawberry). than the petioles. Flowers in a cyme; calyx erect. Flowers in April; fruits in May, June, and July.

2. F. vesca, L. (English Strawberry.) Calyx spreading or reflexed. Akenes superficial, not imbedded in pits in the receptacle. Otherwise as in $\mathrm{F}$. Virginiana.

By propagating from seeds and by hybridizing, many varieties have been prodnced. American nurserymen catalogne abont 400.

Geography. - The geographical range of the strawberry is very wide; in fact, it extends arouind the globe. Captain Cook speaks of the fine strawberries he found in great profusion in Kamchatka and Alaska, where they are still found to grow in abundance.

Etymology. - Fragaria, the
eneric name was given to this plant by Tournefort, on account of its fragrance; it is derived from the Latin fragrans, a pleasant odor. 'The specific name Virginiana is from the place where it was found native; and vesca, small, on account of the size of the fruit. The name strawberry is said to have arisen from the circumstance that in England straw was spread around the plants upon the ground for the fruit to rest upon to keep it from the sand and mud.

History. - There is very little history to this fruit. No mention is made of it until the days of Henry VI. of England, the last of the reigning sovereigns of the house of Lancaster, 1453, when a poem appeared which shows that strawberries were known in London at that time.

It is also related that when Gloster was planning the murder of Hastings, he requested the Bishop of Ely to send him strawberries, and Shakespeare makes him say :-

" My lord of Ely, when I was last in Holborn, I saw good strawberries in your garden there." 
The strawherry requires a generous soil of light loam to bring it to perfection; and during the ripening season it needs dry, sunny days and warm nights to perfect its aroma and taste. When practicalble, the fruit should be taken from the garden immediately to the table.

Use. - The strawberry is a delicious fruit for dessert or for preserving. The mode of serving is well expressed in the line:-

\section{"A dish of ripe strawberries smothered in cream."}

It is not only noted for its delicate fragrance and delightful flavor, but has a high reputation for its healthfulness. It is related that the father of botany, Limieus, was cured of a fit of gout by eating strawberries, which, if true, would establish its sanitary or eurative propertics.

Marts. - Markets for the strawberry nust he local, on account of the perishable character of the fruit.

PRUNUS, L. (Plum, etc.) Ovary superior. Carpel 1. Style terminal. Ovules 2, pendulous. Drupe 1-seeded. 'Trees or shrubs.

1. P. domestica, L. (1)amson Plum.) Stem from 4 to 6 feet to the point where the head begins to form, and from 4 to 6 inches in diameter; much-branched, forming an open head about 15 feet in diancter; whole tree 10 to 20 feet in height. Leaves ovate-lanceolate, acute or obtuse, varying very much in shape, 1 to 3 inches long, and three fourths of an inch wide; petioles ahont 1 inch long. Flowers white, usmally solitary, appearing with the leares. Fruit very dark, varying to nearly white, clothed with a glaneons bloom. Stone smooth, more or less flattenerl. Flowers in April and May. Fruit ripens in Angust.

The number of varieties is very great; about 300 are catalogned by the nurservmen and fruit-growers, differing in shape, size, color, or taste of the fruit.

Geography. - The plum is widely distributerl; it is foumd in all parts of the temperate zone south of $60^{\circ}$, thronghout Europe and w'stern $\mathrm{A}$ sia. It flourishes best in the northern and throughout the uidille regions, and is so well spread thronghumt western

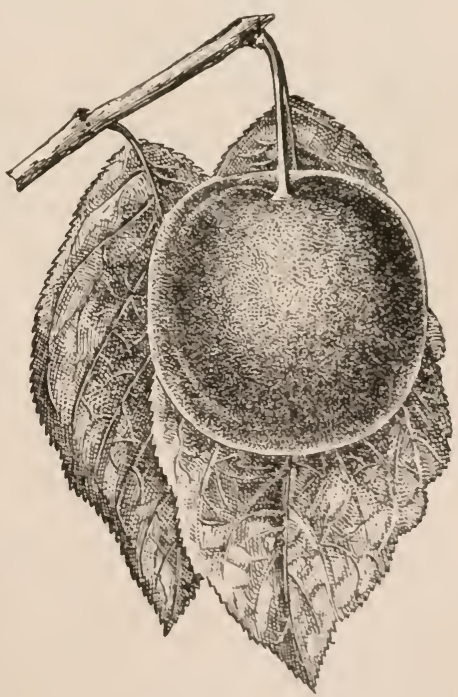

Prunus domestica (1)amson Plum). Asia as to make it diflicult to fix upon its native home. It was lorought to northeastern America by European (colonists.

Etymolog!y. - The generie name prunus is from the Latin, monus, a plum. 'The specific name, domestirn, given hy Limnas, explains itself, - the houseplum, or cultivaterl plum. The word plum is of obscure signification; no meaning is known for it. 
History. - The plum is a native of northern Persia. It has been thought by some botanists to be either indigenous in Europe or well naturalized. This, however, is disputed by De Candolle, and he gives good reasons for his opinion; yet it has been found in the ruins of the Swiss lake-dwellings.

Preparation. - The prunes, so well known in our markets, are dried plums. They are sold under the name of Turkish, French, and German prunes. Those prepared in Turkey are mostly dried in the sun; but the German and French prunes are kiln-dried, and the German fruit, especially, frequently has a smoky taste.

'The French prunes are prepared by first exposing them to the sun in thin layers on frames made of wicker-work. They are then placed in slightly heated ovens, removed, turned, and put back. A slight heat is kept up, and after twenty-four hours they are again withdrawn and turned; the oven is then heated to $120^{\circ}$ Fahrenheit, the fruit is again put in and left a day, after which it is packed in boxes holding about fifty pounds each. The finest fruit is gathered, dried as described above, and carefully packed, each one put in singly in small boxes weighing from five to ten pounds each, and sent to market for dessert purposes. Some sorts are used as remedies to regulate the howels. Large quantities of prunes of an excellent quality are now grown and prepared for market in sonthern California. In Bosnia, Servia, Spain, Portugal, and southern France, the industry of preparing prunes is also largely carried on.

Use. - The plum, though not so delicate as the peach and apricot, is nevertheless a delicious and farorite dessert fruit, and highly esteemed for culinary purposes. For pies, tarts, preserves, and canning it ranks high, and there is no fruit dried that enters so largely into commerce. The French and Turkish prunes are well known to every housekeeper in our cities and towns.

Because of its harlihood, the plum is one of the most valuable fruit-trees for the farmer. It is not particular as to soil, and the crop is not likely to be destroyed by spring frosts.

2. P. avium, IV. (Ox Heart. English Cherry.) Trunk 6 to 8 feet to the point where the head begins to form, and from 10 to 18 inches in diameter; bark smooth or cracked. Branches erect, forming a compact head; entire tree from 20 to 40 feet in height. Leaves oblong-ovate, acuminate, hairy beneath, and double-toothed, about 3 inches long. Flowers in umbels, appearing with the foliage. Fruit globular, ovoid, or heart-shaped. Flowers appear in May ; fruit ripens in June and July. Drupe smooth, no bloom. Stone smooth, globular.

3. P. cerasus, L. (Morello, or common Red or Sour Cherry.) 'Trunk 6 to 12 inches in diameter; head low and globular. Leaves serrate, acute. Fruit globular, red, acill, esteemed for preserving.

The cherry sports freely, and we have many varieties; American nurserymen catalogue about 500 .

The French divide their varieties into three sections: Griottes, tenderfleshed; bigar'reaux, hard-fleshed; guignes, small-fruited cherry.

The Romans had eight varieties during the first century.

Geography. - The cherry grows well throughout the temperate zone wherever the apple flourishes, and even further north than the apple. It has spread over northern Africa, and the Dutch and Portuguese have taken it to southeastern Africa. It was brought to America by European colonists, where. great attention has been given to its cultivation. 'The climate of England suits the cherry, and Belgium and the British Isles produce the best cherries 
in the worll. Cherry-trees in hlossom are greatly prized by the Japanese as ornaments to their gardens.

Etymology. - The specific name, avium, is deriverl from the Latin word avis, a bird, and arose from the circumstance that hirds aro fond of this fruit. Cherry, the common name, is a corruption of the old Greek name cerasus, a name applied to this fruit because it was found growing at ('erasus, a town in Pontus.

History. - This delicions fruit is said to have been bronght from Armenia to Italy ly Lucullus, a victorions general, about seventy years before the commencement of the Christian era, whence it spread westward, and was no donbt car. rierl to England in the days of Agricola. Its popularity may be inferred from the circumstance that it sprearl over southern and middle Europe in a very short time; for abont the beginning of the second century of the Christian era it was to be found in the grounds and gardens of the wealthy thronghout northern Italy, spain, France, southern Germany, and England, - this too at a period in the world's history before agriculture or fruitgrowing had attained any scientific importance.

In the southern parts of Europe and in northern Africa the cherry was called

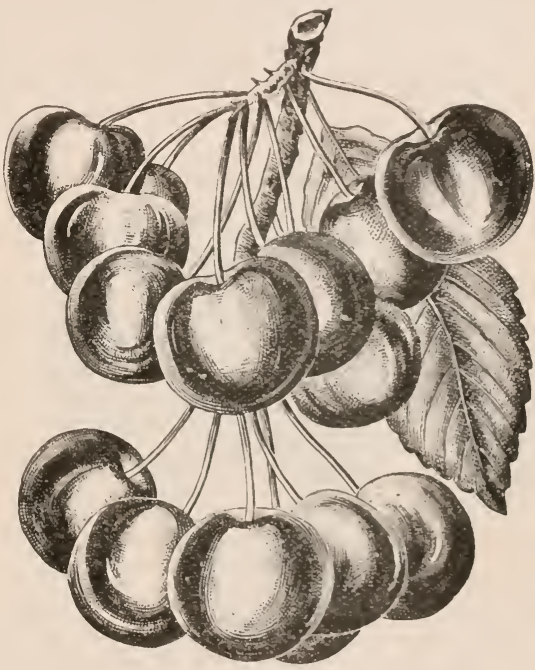

Prunus cerasus (Common Sour Cherry). the "berry of the king."

For many years this fruit has been a farorite in Germany. Iondon, in his aceunt of trees, says that in Germany and Switzerland the local governments encourage the inhabitants to plant trees, and in some neighborhoods the highway passes through avenues of cherry-trees, to the fruit of which the traveller is at liberty to help himself, provided that he takes no more than he can eat on the spot. In Moravia the highway from Brum to ()lmutz, a distance of sixty miles, passes through an avenue of cherry-trees.

The ancient home of the cherry is believed by De Candolle to be the (ountry south and east of the Black Sea, extending from the Caspian to the Propontis. He believes also that the cherry was known to the liomans before the days of Lucullus, and that he only introduced an improved variety, which gave rise to the supposition that he had brought to liome a new fruit.

Use. - The cherry varies in form from globular to heart-shaped, and in size from half an inch in diameter to three quirters, and from three quarters of an inch to an inch and a quarter in length. It is the most dolicious fruit of its season. It is highly prized as a dessert. It excels as a fruit for pies, puddings, and tarts, is a favorite preserve in sugar or hrandy, and is largely canned and dried. 
4. P. Armeniaca, Willd. (Apricot.) Calyx 5-cleft, regular, falling; petals spreading; stamens 15 to 30 . Fruit a drupe, Heshy, usually glancous, covered with bloom; the pit or nucleus ovate, compressed, smooth; kernel shape of the shell. Small tree. Stem 4 to 5 feet to the point of ramification, and 3 to 5 inches in diameter. Branches numerous, spreading, forming an open head; whole tree 10 to 20 feet high, and about 15 in diameter throngl the head. Leaves ovate, acuminate, subcordate at the base, denticulate conduplicate in the bud. Flowers sessile and solitary, white, appearing before the foliage; petioles with one or more glands each. Fruit yellow. It flowers in April and fruits in July and August.

There are many varieties of this tree. Nurserymen in the United States catalogue 120, based upon some form or quality of the fruit.

Geography. - The geographical zone of the apricot is tropical and subtrop-

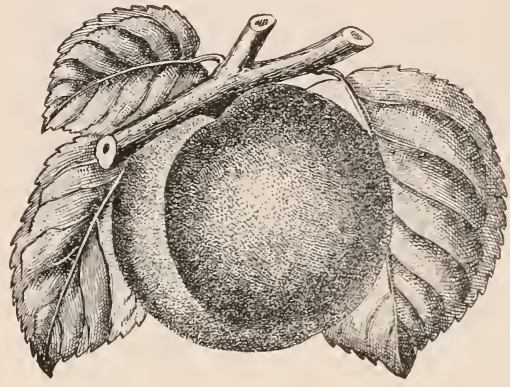

Prunus Armeniaca (Breda Apricot). ical, reaching as far north in Europe as the 40th parallel, and in America to the 38th.

It has become very widely spread in Asia, Armenia, Persia, China, and Japan. Its great abundance and high quality in Armenia led the early botanists to suppose it indigenous there, but it is quite as common both in China and Japan, and in the latter country the tree grows to a larger size than elsewhere. It grows well in the Southern United States, and especially in California, where it is canned

in large quantities for the eastern market.

Etymology. - The specific name indicates that the Greeks and Romans received it from Armenia, and therefore called it Armeniaca. Apricot seems to be derived from the Latin words precox, early, and arbor, tree, early tree, on account of the early ripening of the fruit.

History. - The apricot was carried into Europe alout the beginning of the first century of the Christian era. It is supposed to be a native of China as well as of western Asia. It attains to great perfection in Persia; and on account of its delicate flavor the Persians call those grown in the vicinity of Iran, "the seed of the sun." The French naturalist, M. Regnier, thinks the apricot is a native of Africa, and has spread by cultiration into Asia and Europe. De Candolle, in his "Origin of Cultivated Plants," gives substantial reasons for believing that the apricot is a native of China, introduced thence into western Asia, and finally into Enrope, and by European colonists brought to northeast America, where considerable attention has been given to its cultivation.

Use. - The apricot is a beautiful smooth fruit, smaller than the peach, but closely resembling it in form, and only a little less delicious in flavor. It is used as a dessert, and is highly prized for preserving, either in sugar or brandy. For puddings, pies, and dumplings, it is next to the peach in favor.

Marts. - San Francisco is the great shipping mart in America for the canned fruit. 
5. P. Persica, L. (Peach.) Calyx tubular, bell-shaperl, 5 parterl. Petals 5. Fruit either smootl or tomentose. 'The stone or pit ruguse or wrinklexl, ovate, flat, or compressed, acute, separating lengthwise when struck with a hammer, inclosing a kernel much the shape of the hormy shell, charged with I'russic acid. Small tree. Sitem about four feet to the point of ramification, and + to 8 inches in diameter, forming a symmetrical head, from 1.2 to 20 feet high and 10 to 15 feet in dianeter. Leaves lanceolate, serrate, shining above. Flowers solitary, rose-colored, appearing in May. Fruit ripens Angust, September, and ()etuber.

The peach, as it is propagated from the seed, sports, and many varieties occur. Charles Downing catalogues over 400. About 80 of these arc sufficiently constant to be relied upon. Of this number a few are clings, sit) callerl hecause the pulpy envelope adheres or clings to the stone; when the flesh comes off freely, or separates from the stone, the peach is callerl freestone.

Var. lævis (Nectarine) is an important variety, having a number of snbvarieties. It is a tree like the peach in form and size, flowers and leaves. The fruit is glabrous or lowny.

Darwin considered the peach a variety of almond, and the nectarine a form of peach. and held that the same tree has borne in sncessive years peaches and almonds, and that peach trees have produced nectarines; also that - the seeds of the peach have produced nectarine trees.

On the other hand Decaisne and A.P. De Candolle consider the peach and the almonl distinct species, each possessing peculiar botanical characteristics.

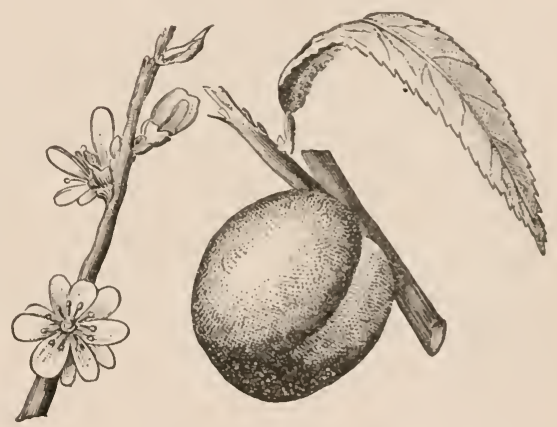

Prunus Persica (Peach).

Igain, the home of the

almond is western $\mathrm{Asia}$; that of the peach China, where it was grown centuries hefore the Chinese hecame acquainted with the almond.

The peach is not at the present day found in a wild state, thongh it escapes: from cultivation, and propagates itself freely, especially in the sunthern parts of the north temperate zone.

Gongraphy. - The gengraphical zone of the peach is the sonthern half of the north temperate zone in $\Lambda$ sia, Europe, and Imerica.

In America, south of $40^{\circ}$ north latitude and north of $32^{\circ}$, the peach is an important crop. In the United States, sonthern New Iersey, I'ennsylvania, and the states of Delaware and Maryland are largely engageil in its eultiration.

Etymology. - Persica, the specific name of the peach tree, is due to the circumstance that the Greeks and Romans received it from l'ersia. The common nane, peach, is supposed to be a cormption of the low Latin name pesku.

History. - It was thought for somr time that l'ersia was the home of the peach, but De Candolle, in his "Gengraphical Distribution of Plants," and again in his recent "Origin of Cultivated Plants," shows conclusively that 
China is the place of the peach's nativity, whence it has travelled westward to Persia, and finally to Europe.

It was introduced into Italy from Persia by the Romans, in the reign of Claudius Cæsar. It was introduced into Great Britain during the sixteenth century, and thence brought in 1680 by the settlers of Virginia to America, where it grows to great perfection. It does not ripen well in England without the protection of glass, or at least of walls. It is a considerable crop in France, especially in the south. In China and the Lnited States it reaches the greatest perfection.

The peaches of Pekin are said to be the finest in the world. But Delaware and Maryland raise peaches whose lusciousuess it is difficult to equal and impossible to excel.

It is related that in Persia the delicious flavor of the peach was supposed to be accompanied by poisonons qualities. Pliny, in his work on plants, says it was supposed that the king of Persia sent the peach into Egypt to poison the people with whom he was then at war.

It is also noteworthy that the peach-tree holds the same place in the ancient writings of the Chinese that the tree of knowledge does in the sacred Scriptures, and that the golden Hesperides apples of the heathens hold among the western nations. There are traditions of a peach-tree whose fruit possessed the power of producing immortality upon those who partook of it, but which bore fruit only once in a thousand years. There is also preserved in the early books of the Chinese, an account of a peach-tree which existed in the infancy of the nation, growing on a mountain whose approaches were guarded by a hundred demons. The fruit of this guarded tree, when taken, prodnced instant death.

Use. - The peach ranks with the pear as a dessert fruit, and if it were . not for its perishable character it would grade far above the pear.

'The season of the peach is very short, lasting from August through September and October, to Norember. For pies, puddings, dumplings, and preserves it has no equal.

'The fermented juice of the peach is distilled, and produces a highly prizert brandy.

The commercial value of the peach crop, including the large quantities that are dried and canned, is of great importance.

Marts. - New York is the point to which most of the fresh crop is brought. Baltimore in Maryland, and Dover in Delaware, are the centers of canned and dried peaches. Canning for winter use and export has become a very important industry.

6. P. communis, L. (Amygdalus communis.) (Almond.) Stem 10 to 12 feet high, branching into a symmetrical head, entire tree reaching the height of 25 feet. Leaves oblong-linear or lanceolate, tapering towards the base, serrate and glabrous. Flowers developing before the leaves, white or pinkish, appearing in March and April. Drupe tomentose or stone furrowed, compressed.

Var. amara, De Candolle (Bitter Almond), is the variety producing the bitter almonds of the market. Flowers larger, pink, tinged with rose; nut hard. A sub-variety has brittle shells.

7. P. nana, L. (Dwarf Almond.) Differs from the P. communis in being a shrub 2 to 3 feet in height. Flowers solitary with a colored calyx.

Varieties. - As the almond is produced from seed it sports freely, and varieties are numerous. There are about a dozen varieties under cultivation, differing in the size and quality of the fruit and the fruit envelopes. 
Geography. - The geographical limit of this fruit is hetween $30^{\circ}$ and $42^{\circ}$ north latitude. 'The tree grows woll in the latter parallel, but does not fruit freely north of $45^{\circ}$. It fruits wall in Virginia, and as far north ats central New Jersey.

Etymology. - The old name, 1 mygdulus, is from the Greek á $\mu$ v́ $\sigma \omega$, lacerate, due to the gashes and fisinres in the shell or husk. "The sjecific name, communis, Latin, signifies "common," and nuna means " dwarf." The variety name amara is also from the Latin, and signifies "bitter."

History. - The home of the almond is Persia and western $A$ sia. It is also indigenous throughout the countries of the Levant, and was no doubt carried thence to northern $\Lambda$ frica, southern Europe, and eastern $\Lambda$ sia, and by European colonists was brought to the United Sitates.

Use. - The sweet almond is a favorite nut, and is much esteemed as a dessert. It is largely used in confectionery and sances. The bitter almond is used in cookery, for flavoring, and in perfumery. 'The nut constitutes an important article of commerce. 'Turbid water from the river Nile is cleared by rubbing bitter almonds on the inside of the ressels which hold it.

Oils. - Fixed or sweet oil of almonds of commerce is obtained ly pressure from both sweet and bitter almonds. When bitter almonds are used, the residuum or cake is subjected to fermentation, and the rolatile oil or essential oil of bitter almonds is obtained therefrom by distillation. This oil contains l'russic or hydrocyanic acid, in its concentrated form a virulent poison. l'rop. erly diluted, essential oil of almouds is a pleasant and wholesome substance for flavoring custards, puddings, etc.

PYRUS, L. (Pear, Apple.) Calyx superior to ovary, pitcher-shaped, 5-cleft. Petals 5, roundish. Stamens many. Sityles .5, frequently united at the base. Fruit a fleshy pome, with 5-2 carpels, consoliclated with the fleshy calyx-tube. Trees, with mostly simple leaves and free stipules.

1. P. malus, L. (Apple.) Stem 5 to 10 feet to the point where ramification hegins to form a diffusely branched head from 10 to 20 feet in diameter, and 20 to 30 feet high. Branches slender. Leaves ovate, selrate, acute, crenate, woolly on the under surface, glabrous and shining above. Flowers in sessile corymbs, roseate, appearing with the leaves. Fruit spherical. Carpels 2-seeded. May. Fruiting from July to Oetoler.

The number of varieties of the apple is rery great, and as it is propagated from the seed, it sports freely, and new varieties are constantly arising. Of late years the number has been greatly increased. In 1870 the number grown in the United States was over 1500 , every one of which claims some desirable quality, and amateurs are yearly adding to the vast catalogue; yet so frequently do some of these varieties deteriorate or die out that only abont sa are regarded as constant.

Geography. - The apple-twe flomrishes in the parts of the north temperate zone between the parallels of $35^{\circ}$ and $50^{\circ}$. It does not fruit well south of that limit unless in elevited localities. England. Frane, (iermany, the Nether lands, Prussia, ancient Poland, the Fuited States, and southern Australia are the most important apple-growing countries. 'The varieties which have originated in America are numerous, and smme of then, fur size and delieacy of flavor excel any yet produced in Europye. 
Etymology. - The word pyrus comes from the Celtic word peren, signifying pear. Malus, the specific name, is the old Latin name for apple.

The common name, apple, is said to come from two Sanscrit words meaning water-fruit. Others derive it from abala, or $a b$, a ball, and ala, little, a little ball-shaped fruit. 'The Latin word pomum favors the signification of a watery fruit, inasmuch as it comes from po, drink.

History. - This fruit was known and extensively used by the Swiss lakedwellers. 'They preserved it by cutting it lengthwise and drying it in the sun.

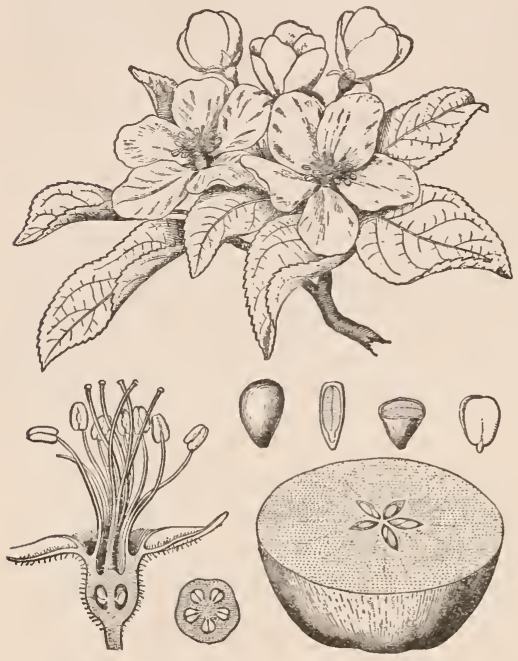

Pyrus Malus (Apple).

The home of the apple is supposed to be Persia and the northern regions of Asia Minor. It is found without cultivation in northern India and middle China, and throughout middle Europe.

It is held by some that all our varieties are from the crab apple. While apples are spoken of in the Old Testament, it is not certain that the fruit referred to is our apple. It was taken to Rome 450 years before the Christian era, but was confined to the gardens and planted grounds of the wealthy for many years. Pliny, in his book on plants, written in the first century, speaks of the apple as a profitable crop on account of its scarcity in the vicinity of Rome.

It seems that engrafting was practiced at that time; for the same writer speaks of apples that will honor the fruit-grafter forever.

When this method of improving fruit was first used is not known. The Romans harl 22 varieties, but no doubt some of these were natural.

At the time of Vergil, apples must have been common, and were no doubt an important article of food for the peasants; for the poet in the First Eclogue makes Tityrus say to Melibous :-

"Stay with me to-night, for I have ripe apples, soft chestnuts, and plenty of cheese."

The apple was brought to northeast America by European colonists, and was the most important fruit grown in British North America. The attention paid to the apple in the early days of the colonies is due, no doubt, to the superior intelligence of many of the first settlers. Its distribution in western Penusvlvania and Ohio was greatly aided by the efforts of an eccentric man who appeared in the settlements of western Pennsylvania early in the present century and busierl himself about cider-mills in collecting apple-seeds from the pomace. Having placed the seeds in sacks, he loaded them upon a horse and proceeded to the unoccupied lands in Pennsylvania and Ohio, and wherever he found a clearing, he planted his seeds; then felling trees 
around the plantation to protect the young growth, he went on to new fields, and as years passed on he returned to exact payment from those who had settled on the lands. He was a benevolent, inoffensive man, distributing religious books anong the people with whom he put np at night. IJis name was Jonathan Chajman. He was born in Boston in 1775. Very little was known about him. (In aceount of his strange employment he received the name of Johmny Apple-seed.

In the door-yard of l)elos llotelikiss, at Cheshire, ('onn., stands an appletree which is supposed to lie the oldest, largest, and most fruitful in Xiew England. It is the last survivor of the orchard which was set ont ly the first settlers of that neighborhood, and popular lelief fixes its age at 180 years. 'The tree is sixty feet high, and the tips of its outermost branches are we hundred and four feet apart. Mr. Hotehkiss affirms that he hats picked 12.; bushels of sound apples from it in a single rear.

Use. - The apple must be regaried as foremost anong the fruits of the temperate zone. No other fruit is so agreeable to all palates, and so generally used. There are 80 many ways in which it serves man, and they are so grener ally known, that it seems superfluous to attempt to name them. A moderately. sized apple, of any variety, either sweet or sub-acicl, is a very popular frut for dessert. For pies, puddings, dumplings, and sances it should be sour ur tart. The farmers of Pennsylvania make "apple butter" by boiling sliced apples (1) a pulp in new eider. In the same manner apples are cooked in sweet wine in France, and the preparation is called raisine. Apple juice, wheu fermented, is rider, and forms a common table drink among farmers, as wine does in the wine-making districts of France, Germany, Italy, and spain. Verjuice is the fermented juice of the crab apple. Cider when exposed to the air soon becomes sour or hard, from the formation in it of lactic acid.

Apples are preserved by drying them in the sun. In late years large quantities have been dried by steam heat. Apples form an important food, and large quantities are exported to tropical and subtropical comntries.

The wood of the apple-tree is close-grained, hard, and it takes a polish. It is valuable for turners and cabinet-makers, and is largely used in the minufacture of shoemakers' lasts.

2. P. communis, L. (Pear.) Stem from 20 to 40 feet in lieight, and from 8 inches to 20 in diameter, branching; the branching is upright, forming a pyramidal head. Leaves ovate, lanceolate, acute, sometimes acuminate, somewhat crenate, serrate, glabrous. Flowers in corymbs, white and fragrant, appearing in May. Fruit pyriform, ripening from July to Octoher. Carpels 2-seeded.

The number of varieties of this tree is very great. 'There is no single fruit upon which more eare and expeuse has been lavished than upon the pear. 'The nurserymen in the U'nited states catalogue about 3,000 varieties, each one of which is represented to possess excellencies to recommend it to ('ultivators; but the pear faneiers of France and Belgium publish lists of far greater uumbers. It is related of a single nurseryman in Belginm that he had growing at one time 80,000 seedlings for the purpose of dereloping new varietirs.

The varieties have reference to the character of the fruit alone.

Geography. - The geographical zone of the pear is from $35^{\circ}$ to $55^{\circ}$ north latitude. It is native to China, Syria, l'ersia, contral and northern Europe, and Great Britain. It was brought by colonists to northeast America. It thrives wherever the apple flomishes, hut arrives at its maximum excellence in size and flavor in Belgium and northeru France. 
Etymology. - The specific name of this tree signifies ordinary or common, from the Latin word communis.

The varieties are named usually to indicate some quality of the fruit, or in honor of some person, or they take the name of the places whence they originate.

History. - The pear is a native of Europe. It is spoken of by Homer, who says it was one of the trees in the garden of Laertes, the father of Ulysses.

Pliny also mentions several varieties growing about Rome. There is good authority for believing that the Romans cultivated about thirty-six varieties; and it is believed that they took their choice varieties to England after the middle of the first century, during the administration of Agricola. It could not have been largely cultivated, and was no doubt confined to the gardens of the wealthy for a long time; for, when spoken of, reference is made to its delicacy. A record is preserved that in the days of Henry VIII. twopence was awarded an old woman for presenting pears to the king. I)uring the sixteenth century much attention was paid to its cultivation. Near the end of the sixteenth century Gerard published his herbal, in which he says that the number and sorts of pears and apples would require a book to hold their description.

The best pears liare originated in France and Belgium, so that nurserymen have come to regard Belgium as the Eden of this fruit.

There are some remarkable pear-trees whose size and age may be mentioned in this connection. Several on the continent of Europe are known to be 400 years old, but the most wonderful pear-tree is one in Hertfordshire, England, from which were made in one year fifteen hogsheads of perry. In 1805 it covered more than half an acre of land; its branches had bent to the ground, taken root, and thrown up shoots. By favoring this habit, a grove of trees all connected has been produced. A very remarkable pear-tree is now growing in Indiana, abont ten miles north of Vincennes. It was planted by Mrs. Ockle. tree about the year 1805 . The circumference of this tree a foot above the ground is twelve feet, or about four feet in diameter. In 1834 it bore 184 bushels of pears, and in 1840 the yield was 140 bushels. The fruit is of large size, of good flaror, and ripens in early autumn. It bore its first crop in 1820 , and has borne a crop every year since.

The old Sturvesant pear-tree, which was planted by Peter Stuyresant, one of the Iutch governors of the New Netherlands, on his farm in the city of New York about the year 1645 , was blown down in 1867 , making it about two hundred and twenty years old. It stood on the edge of the sidewalk in Third Avenue on the corner of Thirteenth Street.

When the pear was first used for fruit or bronght under cultivation is not known; it has been stated that there is evidence that it was in use in the days of the lake-dwellers of Switzerland, and it is represented in the pictures of Pompeii.

Use.-The apple is without doubt the most important fruit of the tem. perate zone, on account of the great variety of forms in which it may be pre. pared as an article of food, and the ease with which it may be preserved; but for delicacy of flavor, the pear takes the precedence. It is more highly valued as a dessert than any other fruit, and is found upon the tables of the wealthy throughout its season. The favorite mode of use is without cooking or any other preparation.

It moreover constitutes one of the most relicate preserves, either as a candied or braullied fruit. It cooks well as a preserve or a baked food; but on account of its lack of a pungent acid it is not suitable for pies, puddings, or sauces. 
The juice of the pear when fermented is called perry, and is used as a table beverage, as wine is used.

3. P. Cydonia, L. (Quince.) Sten branching very near the ground, from 3 to 6 inches in diameter; branches very crooked and irregular, spariugly arıned with spines. Leaves oblong, ovate, obtuse at the hase, and acute at the apex ; entire, suooth above, woolly beneath. Flowers solitary, large, on short perlicels, at the ends of the branchlets; calyx lobes expanding into small tomeutose leaves. Fruit globular or pear-shaped, golden-yellow when ripe; clothed with a soft down in an mnipe state. Seeds numerous. Flowers appear in May. Fruit ripens in ()ctober.

Like other fruits grown from the seed, the quince sports, and we have varieties. The nurserymen in the United States catalogue about 20 varieties, each of which has some quality to recommend it to growers.

Geogruphy. - The geographical zone of the quince is between $35^{\circ}$ and $60^{\circ}$ north latitude, extending from northern Yersia both east and west. It was brought to northeast America by European colonists. It reaches great perfection in Portugal.

Etymology. - The name Cydonia is derived from $C y d o n$, in the island of Crete. 'The common name is supposed to be a corruption of one of the various names by which it is known, most likely from the Mildle English name

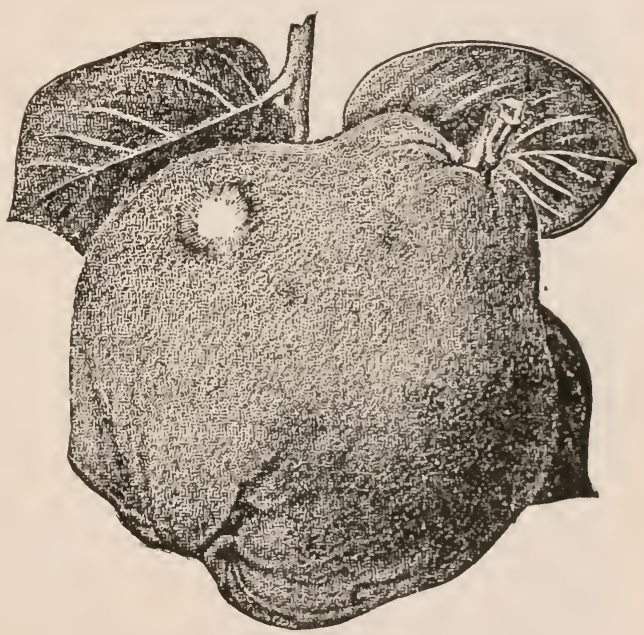

Pyrus Cydonia (Quince). coine.

History. - The quince was known to the ancient Greeks and Romans, and was highly esteemed by them. It is a native of northern P'ersia, and was found in the island of Crete. It has spread westward, through middle and northern Einrope.

Use. - The quince is a well-known fruit of the apple family. It is not edilue in a raw state, but is valued as a flavorer of other fruits, especially of apples. It is highly esteemed for preserving, and for marmalades and jellies. It is also preserved by drying. In England it is used for wine-making. 'The seedlings are largely employed by nurserymen for grafting pears upon. The seeds yield large amomts of mucilage used in preparations for hair-dressing, and as a lotion for sore eres.

4. P. Japonica (Pyrus Japonica, or Japan Quince) is a native of Japan. The fruit is not edible; but the flowers are very showy, and the tree is a farorite slirub for oruanental purposes and for hedging. 


\section{ORDER XXIII. SAXIFRAGACE}

Flowers perfect, regular, occasionally irregular, variously arranged. Sepals $4-5$, more or less cohering, adherent to ovary. Petals 4-5, inserted on the rim of the calyx. Stamens equal to the number of petals alternating with them, or 2 to 10 times as many. Ovary usually more or less inferior. Fruit mostly a 2-celled capsule or berry; seeds

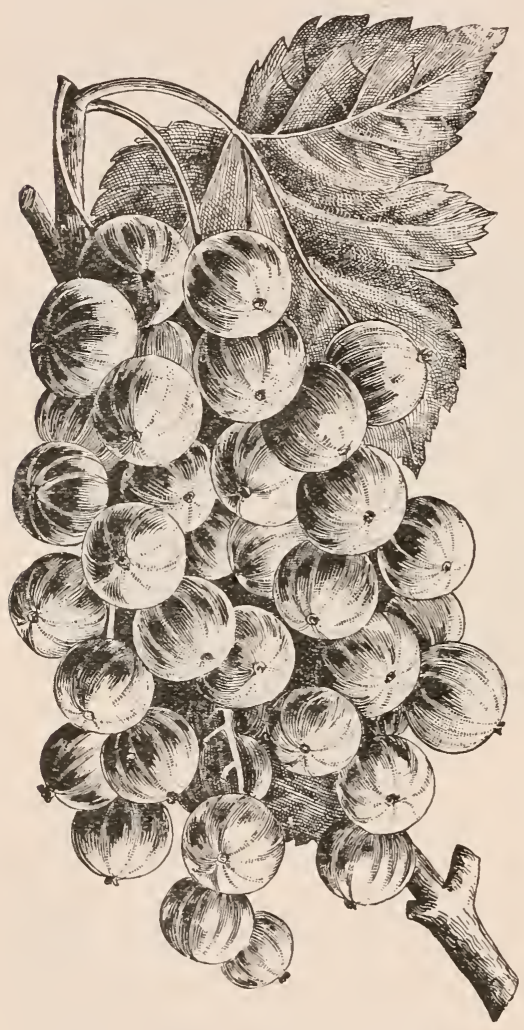

Ribes RUbrex (Common Red Currant). small. Leaves alternate or opposite, sometimes whorled. Herbs or shrubs. Number of genera, 73 ; of species, 540.

RIBES, L. (Currant. Gooseberry.) Calyx tube adherent to the ovary, 5 -parted. Petals 5. Stamens $\tilde{5}$, alternating with the petals. Ovary 1 celled, with 2 opposite parietal placentæ. Styles 2 in number. Fruit a succulent berry crowned by a persistent calyx. A shrub.

1. R. rubrum, L. (Common Red Currant.) Stems numerous, slender, sparingly branched, 2 to 4 feet high. Leaves obtusely 3-5-lobed, smooth above, pubescent beneath, 2 to 3 inches long, about as wile as long; unequally toothed, incised; petioles as long as the leaves. Flowers in pendent racemes, not axillary ; bracts ovate; petals small, greenishyellow. Berries globular, from two to three tenths of an inch in diameter, red when ripe. Flowers in April ; fruit ripens in June and July.

The currant sports freely, and many varieties are under cultivation. About 70 varieties are catalogued by American nurserymen, differing from the species in size and quality of the fruit.

Among the favorite varieties are: Cherry, Versailles, Red Dutch, Red Grape, White 1)utch. One or all of these may be found in every well-furnished garden.

2. R. floridum, Heretier. (Black Currant.) Like R. rubrum as to habit of the stem. Leaf blunt or subcordate at base, sharply 3-5-lobed, sprinkled with resinous dots, and doubly serrate. Flowers abundant and showy, white. Fruit ovoid, and black when ripe. Sometimes cultivated for the flowers. 
3. R. nigrum, I. (Black ('urrant.) Stem as in K. rubrum, but higher. Leaves dotted with resinous spots, 3-5-lobed. Flowers whitish-green. Stamens sometimes more than 5 ; for every additional stamen over 5, there is one less petal. Stigma bifid. Fruit globose, black. Flowers in May; fruits in June and July. lntroduced from lurope.

Geography. - The zone of the currant is from Lapland to sonthern Europe, extending quite across the continent of the ()ld World and the northern parts of the United States and southern and middle Canada. It delights in cool, lamp grounds.

Etymolog!y. - The word ribes is supposed to be the Arabian namp for the plant. De Candolle, however, believes it to come from the 1)anish word ribs, by which the plant is known. 'The specific names rubrum and nigrum, red and black, from the Latin, are due to the color of the fruit of these species. The wild black currant of North America, R. Horidum, was thus named on account of the showy flowers of that species. 'The common name, currant, is supposed to be a corruption of the word Corinth, a name applied to the small seedless grapes of southern (ireece, which are dried and taken to Corinth for export under the name of currants. (Nice Grape.)

History. - When or where the currant of our gardens was first cultivated is not known, but its usefulness and popularity point to its early cultivation, so that we may date its origin at a very early period in the history of agriculture, as we are justitied in the inference that as soon as man began to reside in fixed habitations he commenced to gather such shrubs and trees around his dwellings as he found producing edible fruit.

The 1)utch have been very successful in producing from seedlings varieties that are now under cultivation both in Europe and America. The currant is found in a wild state in north and middle Europe from eastern Siberia to Great Britain, and in North America quite across the continent, and north to the Mackenzie River. In northeastern Russia and Siheria the currant is employed for wine-making.

Use. - The currant is used sparingly for a dessert fruit, but largely for jellies, and to some extent for wine-making. It is preserved in sugar, and canned. It is used in a green state for tarts. The dried currant of commerce is a small grape.

No other small fruit is more generally cultivated. It is not only grown in the gardens of the rich, but is also to be found in the planted grounds of the most humble cottager.

Marts. - The markets, on account of the perishable character of the fruit, are local, except for the dried and preserved fruit.

4 R. Grossularia, L. (Gooseberry.) Stem 2 to 3 feet high, numerous, slenler, 2 or 3 prickles under each bud. Leaves 3-5-lobed, villons. Flowers greenish ; pedicels 1-2-flowered; calyx bell- or pear-shaped; segments reflexed, shorter than the tube; petals rounded at the apex, bearded in the throat; style beset with long down. Fruit usually dark-red when ripe, globular or ellipsoid, and in the cultivated rarieties from an inch to an inch and a half in diameter. Flowers in early summer, fruits in $\Lambda$ ugust. Indigenous in Europe. Its varieties are the cultivated gooseberry:

There are about 100 varieties under cultivation in the I'nited States. One of the most popular, though by no means the largest, is "Smith's improved." The American varieties are inferior to those of the British Isles.

5. R. cynosbate, L. (Wild Fonseberry of Canadla) This species grows withont cultivation in the northern Lnited states and Canada. The stem is sparPR. FL. -10 
ingly beset with sharp prickles, in pairs, just below the leaf. Leaves cordate, lobed, cut-toothed, and pubescent; fruit armed with prickles. Flowers in May; fruits in August. 'This has not been improved by cultivation, though for many year's it has been an occupant of our gardens in the Northern States and Canada.

6. R. oxyacanthoides, L. (K. hirtellum, Mx.) (American Gooseberry.) Stem as in the last; rarely prickly; spines, when present, short and solitary. Leaves rounded, cordate, 3-5-lobed, cleft half-way to the middle; toothed, pubescent underneath. Flowers drooping, green, on short 1-2-flowered

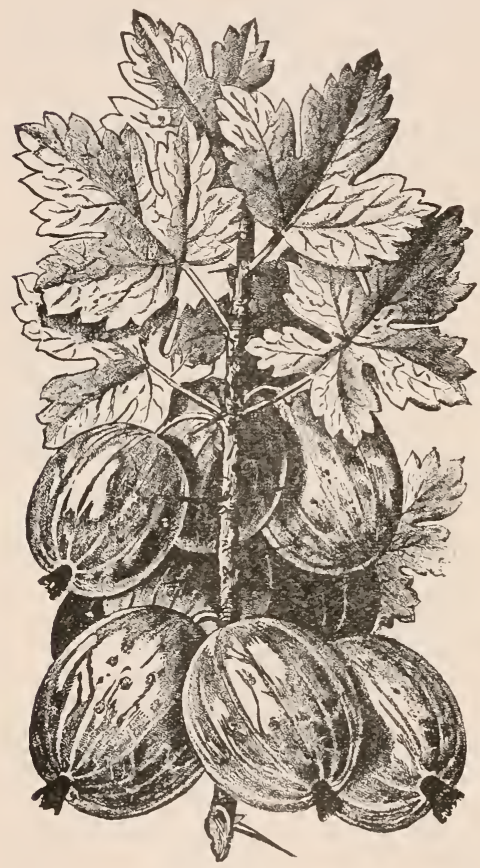

Ribes Grossularia (Gooseberry). pedicels; calyx tube smooth, bellshaped; segments much longer than the petals; stamens protruding; style hairy, 2-cleft. Berry purple and smooth, small. This species is cultivated in gardens, but does not improve by cultivation. Flowers in May; ripens in August. Northern United States and Canada, and west and north.

7. R. rotundifolium, $\mathrm{Mx}$. Stems 3 to 4 feet high, numerous, slender; bark whitish, frequently without spines, subaxillary one solitary. Leaves roundish, smooth, crenatedentate, slashed, with 3-5 lobes, truncate at base, shining above; petioles ciliate, 2 inches long. Flowers yellowish-white; calyx cylindrical, smooth, segments linear, reflexed; petals spatulate; stamens protruding; style smooth. Fruit smooth, purple, very pleasant to the taste. Flowers in May; fruit ripens in August. Northern United States and Canada to North Carolina. Edges of open woods.

The last three are frequently found in gardens, but they have not been improved either in quality or size.

Geography. - The varieties of the gooseberry under cultivation are the offspring of plants found in a natural or wild state in England, France, and Germany.

It also has its representatives in the Alps, the Himalaya mountains, and throughout the northern United States and Canada.

It is indigenous in northeastern Rnssia and siberia, and along the Valdai hills, and the cold bogs of the lowlands of central Russia.

Etymology. - The specific names are all Latin words. Grossularia signifies "thick," referring to the size of the fruit. Hirtellum has reference to the roughness of the plant. Rotundifolium means "round-leaved." Cynosbate signifies "briery," referring to the spines on the stem. Gooseberry, the common name 
is sald to have arisen from the fact that a satuce male of gooseberries was eaten with roast gonse. Inother derivation is from groise, a herry (old French), corrupted into gooseberry.

History. - The gooseberry, like the currant, hats un history which points to its first introduction into the garden. 'The fruit arrives at its greatest perfection as to (quality in the scottish highlands; but as to size, the operatives in the factories of Lancashire, in Eugland, raise in their little garlens the largest gooseberries known. Specimens have been exhibited measuring 2 inches in diameter. The large varieties do not arrive at perfection in the United States. The clinate of England, and the damp, cool atmosphere, seem exactly suited to their full development, while the hot suns of the northern linited States seem to induce a monld that prevents perfection in the fruit while the plaut flourishes. 'The great berries grown in England do not possess the high flavor of the smaller berry grown in scotland.

Use. - The gooseberry is well known, and almost as common as the curraut in our garlens.

It is used in a green state for pies, puddings, and tarts. When quite ripe, the fruit is used as a table dessert. It is also canned, preserved in sugar, and, when nearly ripe, bottled in water. It is set in a ressel of cold water, bruught to a boiling heat, then corked and kept in a cool cellar, with the neck of the buttle down. In this way it will keep for an indefinite period. It is also a favorite fruit for making jam.

Marts. - The markets, like those of the currant, are local.

\section{Order XXIV. COMBRETACEAE.}

Flowers perfect, or occasionally imperfect by arrest, in axillary or terminal spikes, racemes, or heads; a bract to each flower, also ? lateral opposite bractlets. Calyx superior, 4-5-lobed, valvate in the bud. Corolla sometimes absent; when present, the petals equal in number the parts of the calyx. Stamens are inserted alternately with the petals on the calyx, and are either equal in number to the parts of the corolla, or double. Ovary inferior, with 2-5 pendulous orules, 1-celled. Fruit a drupe, or berry; seed solitary, frequently winged; testa thin, membranons. I.eares alternate or opposite, simple, penninerved, entire or toothed, leathery. 'Trees or shrubs, sumetimes climbing. Number of genera, 7 .

TERMINALIA, I. Flowers polygamous. Calyx tube cylindrical, adherent to the ovary, contracted above; limb bell-shiped, 1-5toothed, decidnous; corolla wanting. Stamens 10, inserted on the calyx; filaments awl-shaped ; anthers 2-valved, egg-shaped or globular, opening lengthwise. Ovary inferior, 1-valred; ovules 2-33. Style awl-shaped; stigma sharp. Large trees.

1. T. chebula, Retz. (Myrobalaus.) Trunk 40 to 70 feet in height, regularly branched, in verticils, forming a symmetrical head. Leaves vvate, ou short petioles, alternate, entire or slightly toothed, collected at the ends of the branchlets, spotted. Flowers in spikes or racemes. Fruit a drupe, about the size of a prume. 
Species. - There are about 80 species of Terminalia; those besides the T. chebula whose products enter into commerce are-

2. T. bellerica, Roxb.

3. T. citrina, Roxb.

4. T. catappa, L.

5. T. angustifolia, Wight.

Geography. - The homes of all the species which yield the myrobalans of commerce are in tropical India, along the southern fringes of the Ghaut mountains, and in Burmah.

Etymology. - Terminalia, the generic name, is from the circumstance that the leaves are usually at the ends of the branches, and is derived from the

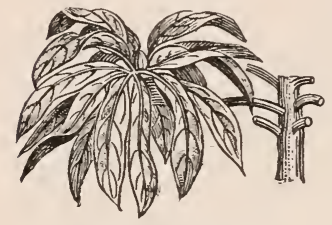

Terminalia chebula (Myrobalans). Latin terminalis, belonging to the end. The specific, chelula, is Arabic, but the signification is not known.

Myrobalans is the old Latin name for the fruit, through the Greek $\mu \dot{v} \rho \nu$, sweet juice, and Báravos, a drupe-like fruit.

History. - The products of terminalia were unknown to the early botanists. Their medical qualities were revealed in the writings of Arabian naturalists, but especially by those of Prince Mesues, a learned physician who lived about the middle of the twelfth century. The fruits were first introduced into Europe by the way of Arabia and the Red Sea. They are brought to market in a preserved state, and the bark and pits are shipped, either entire or in a pulverized state, for tanning and dyeing.

Use. - The medicinal properties are purgative, tonic, and astringent. In India and China it is highly prized, and supposed to possess curative properties for every ill. The wood is hard takes a fine polish, and is used for cabinet work.

The fruit, bark, and leaves are all charged with tannin. They also yield a dye which, with alım, prodnces a beautiful yellow, and with iron, a fine black. The leaves and bark of the T. catappa furnish a pigment from which the celebrated India ink is made.

T. angustifolia is charged with a fragrant juice of a creamy consistency. This, when dried, is used in the temples for incense, and for tanning and dyeing.

The tree itself is sacred, and has a mythological origin and history.

\section{Order XXV. MYRTACEAE. (Suborder MYrteæ.)}

Flowers perfect, regular, axillary, solitary, or in spikes, cymes, corymbs, or panicles. Calyx superior, limb 4-6-parted, persistent, or falling, valvate in the bud, occasionally entire, falling away with the expansion of the flower. Petals inserted in the throat of calyx. Stamens inserted on the calyx throat, mostly numerous, frequently double or treble the parts of corolla, or indefinite; filaments thread. like, free or in bundles. Ovary with 2 or more cells; seeds numerous. Leaves opposite, rarely whorled, entire, exstipulate. Berry or capsule 
2- or more- celled, 1- to many-seeded. Small trees and shrubs; seldom herbs. No. of genera, 76 .

MYRTUS, Tourn. (Myrtle.) Calyx 4-6-parted, tube attached to the ovary. I'etals $4-6$, inserted together with the many stamens in the throat of the ealyx; sometimes absent. Filanents long, free, or combined in groups. Anthers opening lengthwise, dehiscence inwards. Style solitary; seeds attached to a central column.

I. M. communis, L. (Common Myrtle.) Stem 6 to 8 feet highl, hranched. Leaves opposite, with punctured spots, orate, lanceolate, variable in breadth,
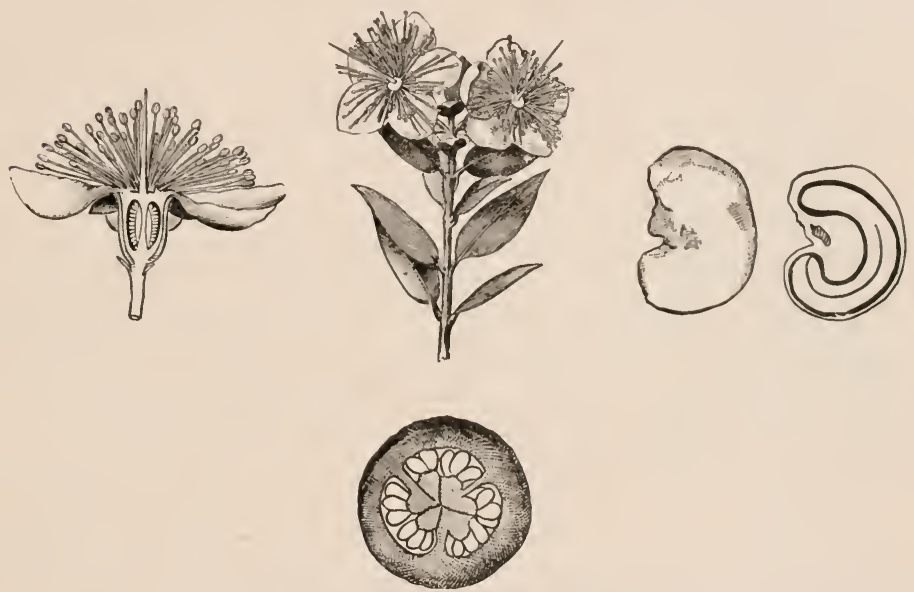

Myrtus comunis (Common Myrtle).

evergreen. Flowers axillary, solitary, white. Fruit a berry, 2-3-celled. Evergreen shrub.

Varieties. - There are many species, and of the communis there are 5 varieties known to the Horists.

Var. Romana, broad-leaverl. Leaves leathery.

Var. Tarentina. Leaves like those of the box.

Var. Bœotica. Leaves like those of the orange.

Var. Belgica. Broad-leaved, Dutch.

Var. mucronata. Leaves like those of the rosemary.

There are other varieties of this species, but these 5 are the most important.

Gengraphy. - The geographical home of the myrtle is tropical and subtropical, hut it grows well in regions of light frost, gralually becoming acclimated. Ly some it is supposed to be native in southeastern Italy, and it is growing now in all the countries around the Merliterranean sea.

Etymology. - Myrtus, the Latin name, is through the Greek púpros, a myrtle-tree, derived from the Greek $\mu$ úpov, perfume, due to the pleasant odor discharged from the bruised leaves. Communis is the Latin for common, or 
usual. Myrtle, the popular name, is Dutch, and is a corruption of myrtus, the generic name. In America the periwinkle, which belongs to a different order of plants, is popularly called myrtle.

History. - The home of the myrtle is western Asia, Asia Mlinor, and other countries of the Levant. It has been known from the earliest historic periods, and is said to have been growing upon the site of the city of Rome when it was founded; it was common in Egypt before the beginning of the present century.

Pickering makes its home near the Persian Gulf, whence it has been carried to Egypt and other comntries of the Mediterranean. It is spoken of by the earliest historians. Aneclotes are rife illustrating its use and value, but we have not room for them.

Use. - The medicinal properties of the myrtle are mostly stimulant and astringent.

It was formerly a favorite flavorer of wine and food ; the flavoring substance resides in the young twigs, the leaves, and the berries. 'The leaves are said to make a very tolerable tea. It was held in great esteem by the ancient Greeks; and a place was set apart in all their markets for its sale. It was nsed by both the Greeks and Romans for wreaths to decorate victors in the Olympian and other games. The Jews held it in great veneration as an emblem of peace, and among them it constituted a part of the bride's decoration. It is frequently mentioned in the Scriptures. The Mahometans hold that it is one of the pure things that Adam carried with him ont of Paradise. It was an emblem of authority as well as of hollor, and worn by the magistrates of Athens when in the exercise of their duties.

The fruit and leaves are both used for tamning goat-skins.

The plant is a beautiful object, a favorite in planted grounds, and on that account has an important commercial value.

EUGENIA, I. Calyx 4-lobed, rarely 5. Petals 4 or 5, free or united. Stamens numerous, inserted in the throat of the calyx, and on the receptacle, in several rows; filaments free, threadlike; anthers 2 celled. Ovary 2-3- or more- celled, ova numerous. Style simple; stigma terminal. Berry crowned with the persistent limb of the calyx. Leaves opposite, entire, dotted with pellucid spots, without stipules. Flowers axillary or terminal, in solitary cymes, or panicles, 2-bracted, white, or purple. Fruit black, red, or purple. Trees.

1. E. caryophyllata, Thunb. (Cloves.) Trunk 20 to 40 feet high, hranching regularly into a hemispherical or conical head of great beanty. Bark yellowishgray. Leaves opposite, numerons, evergreen, oval, acute at each end, entire, smooth, thick, dotted with pellucid spots, dark-green and shining above, paler beneath, midrib and lateral veins prominent, petioles short, blade 3 to 5 inches long. Flowers axillary or terminal, in loose, small cymes; bracts small and falling off; calyx half an inch long, fleshy, round below, upper part divided into 4 triangnlar, spreading teeth. Petals 4 , tightly imbricated in the bud, forming a smooth, spherical head, fringed by the teeth of the calyx, falling off early. Stamens many, inserted on a raised disk; filaments as long as the petals, spreading; anthers small, roundish, opening lengthwise. Ovary inclosed in the calyx, small, 2-celled; ovules many; style simple, shorter than the stamens, slender, tapering. Fruit in shape like an olive, but not so 
large; seed solitary; all the ovules but one become abortive ; onter covering membranous.

Geography. - The zone of the clove tree is narrow. Its home is the Molucca Islands. It has been planted in Brazil, the West Indies, and extended to distant islands of the Indian aud l'acific ()ceans; but out of the latitude of the Moluceis, its spicy character is very inferior.

Etymology. - Eugenia, the generic name, is for l'rince Eugene of Savoy, a

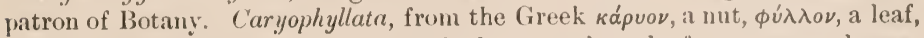
due to the appearance of the flower-bud, a nut in a leat, or anong leaves. Clove, from the Spanish clavo, a nail, on account of the fancied resemblance to a nail.

History. - The clove has been in use among the western nations of the (H) World for more than two thousand years, and was taken to Europe overland ly the Persians and Arabs; but its native country was not revealed until after 1511, when the Portuguese came into possession of the Molneca Islands. $\Lambda$ s it is not known in a wild state, the exact locality of its nativity is not elearly determined.

The enterprise and bolduess that the discovery of America gave to navigators and merchants led them to the Indian Ucean, and discovery of the islands of the coast of Asia thus opened the great storehouse of the spices of India to the commerce of the world, and the homes of the clove, cinnamon, allspice, and pepper became known to the wondering nations.

In the 17th century the Dutch came into the possession of the Spice Islands and established a monopoly of the spice trade. They raised prices to exorbitant figures, and confined the cultivation of the clove to the Island of Am-

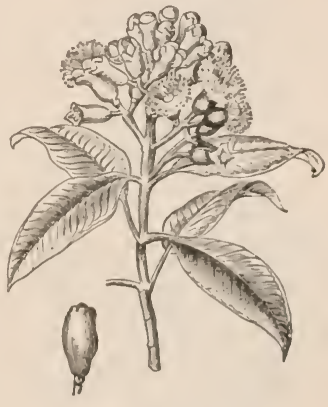

Eugenia caryophyllata (Clove). hoyna. During the French war in 1810 the English for a short time held possession of these islands. They transplanted the trees to other islands, and broke the monopoly.

Mode of Hariesting. - Just before the flower-hnds develop they are picked or shaken off and dried over a fire or in the sun, then packed in bags made of the leaf of the cocoa-nut, and thus sent to market. A tree rields about five pounds for a crop, and bears two crops in a year.

Use. - The tree is used for ornamental purposes in subtropical countries. The wond of the clove-tree is hard, takes a fine polish, and is used hy the cahinet-maker in fine and ornamental articles of furniture. The clove, in medicine, is a stimulant, aromatic, and irritant, and largely employed to corer up the taste of disagreeable Irugs. The orlor resiles in the essential oil, of which the clove vields a very large percentage. Its principal use is as a spice for flavoring cake, sauces, and confectionery. The oil and tincture are both used in the manufacture of cordials and bitter's.

2. E. pimenta, DC. (Allspice.) Trunk 25 to 30 feet high, unch branched; branches long and horizontal, forming a hemispherical heal, in form and sizo like an apple-tree. Bark light-gray. Leaves ellipticnl, lanceolate, opposite, evergreen, obtusely pointed, conspicuonsly reined, deep-green, shining above. Flowers small, inconspicuous, in terminal, 3 -forked panicles. Fruit a globular 
berry, crowned with the persistent calyx, smooth, black or purple, and shining when ripe.

Geography. - The geographical zone of the allspice is tropical and subtropical, and its distribution is very limited. Jamaica supplies the markets of the world.

Etymology. - Pimenta, the specific name, is said to be derived from the Portuguese pimenta, which signifies "a color," from the Latin pigmentum. This name is probably derived from the fact that a decoction of the fruit, bark, or leaves, treated with sulphate of iron, produces an inky black, and the bark and leaves are highly charged with tamnin. Allspice, the popular name, is said to be due to the circumstance that the taste of this spice was thought to resemble that of clores, nutmeg, and cinnamon combined, hence was said to possess the properties of all the spices.

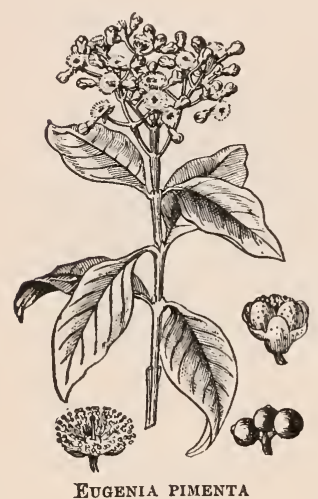

(Allspice).

History. - When this spice first became known to civilized man is not recorded, but it was no doubt taken to Europe soon after the discovery of the West Indies.

Its home is the island of Jamaica, and it is abmulant in the mountains on the northern side of the island. It also grows in Yucatan, but the fruit is not exported from any locality but Jamaica. Attempts have been made to introduce it to cultivation in Cuba and in Brazil, but all efforts have failed to improve the quality of the fruit or the size of the tree.

The leaves and bark, as well as the fruit, are aromatic.

Cultiration. - The tree grows best without cultivation, or, at least, is not improved thereby. As the groves are exhausted, new ones are obtained by removing all trees from a suitable spot in the forest near an old or exhausted grove, and very soon a thicket of pimenta trees appears from seeds which have been sown, carried by the wind or birds to the clearing. The young trees are allowed to reach the age of two or three years, when they are thinned out by removing the weaker, after which the grove (or $u a l k$, as it is called) needs no attention till harvest, which commences as soon as the berries are full grown but not mature. The trees are full grown in about seven years from the time the grove is begun.

The mode of harvesting is to break off the ends of the branches which are laden with fruit, and drop them to the ground (the tree is greatly benefited by removing the fruit before it matures), where women and children pick off the berries and place them in bags, in which they are carried to a place to cure either by the rays of the sun or by artificial heat, when they are packed in bags for market.

The harvest occurs in July and August.

Use. - The tree is sparingly used for ornamental purposes. The leaves are used for tanning leather. The fruit forms one of our most popular spices, used for flavoring sauces, cakes, bread, and for spicing wines, pickles, and cordials.

Its medicinal properties, as to the fruit and the oil, are identical with those of cloves. 
BERTholletia, Humb. and Bonpl. Calyx 1-parted. Corolla made II) of 4 fleshy petals. Stamens united at the base in 5 concentric circles; filaments thread-like, short. Stigna cruciform, sessile. Ovary inferior, 1-5-celled. Inflorescence in terminal janicles. Fruit large, globular, woody. Nuts numerous, obovoid, triangular. Leaves alternate. Iarge tree.

B. excelsa, Humb. and Bonpl. (Brazil Nut.) (Cannon-ball Tree.) 'Trunk 3 to 4 feet in diameter, rising to the height of 150 feet, branching into a symmetrical head. Leaves 2 to 3 feet in length, broad, glabrous, prominently veined underneath, leathery. Fruit subglobular. Shell or husk woody, 6 inches in diameter, 4-elled, each cell containing 3 or 4 nuts an inch and a half long, three quarters of an inch in diameter, the testa hard, horny, and rough, kernel creamy white, oily, and possessing a delicate flavor. 'There is only oue species of this magnificent tree.

Geography. - The geographical distribution of the Bertholletia is limited to the tropical regions of South $A$ merica, extending to the Isthmus of Panama. large tracts along the $A$ mazon and the lower reaches of its tributaries are covered by this gigantic tree.

Etymology. - Bertholletia, the generic name, was given to this plant by I)e Candolle in honor of Berthollet, a celebrated chemist. Excelsa is from the Latin excelsus, grand, or lofty, due to the gigantic size and character of the tree. Brazil Nut is named from Brazil, its home; Cannon-ball Tree, from the shape of the fruit.

History. - At the time of harvest the natives ascend the rivers and enter the vast groves to gather the crop. For the same reason the vegetable-eating animals assemble to secure their share of the lelicious fruit. When the great seed-vessels, weighing several pounds, fall from the height of 60 to 100 feet and burst open as they strike the ground, scattering the seed in the midst of the assembled men and their monkey consins, the imagination must

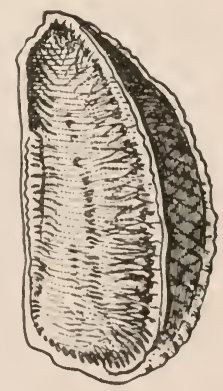

Bertholletia ExCELSA (Brazil Nut). be drawn upon to picture the scene. Men, women, and children, monkeys of all the Brazilian varieties, rodents, and other nut-eating brutes all rush to secure the prize, and mingle in the scramble. The Indians club and pelt the monkeys, while they in turn seize the unbroken balls, flee to the branches of the trees, and hurl them at the heads of the Indians, thus presenting a feast, frolic, and fight combined.

The seed-ressels are forced open either by dashing them upon the ground or striking them with mallets male for the purpose. The nuts are collected into hags and baskets, earried down the rivers, and shipped to Europe and the Inited States from the seaports near the mouth of the Amazon, principally from Para.

Use. - The nut affords an important food to a large number of the inhahitants of Brazil. It is an esteemed dessert, and though very inligestible, is highly prized by children. The oil obtained from it is an excellent table and salad oil ; it is also much used in the compounding of hair-dressings and for illuminating and lubricating purposes.

Statistics. - From Para alone it is estimated that upwards of two and a half million fruits, yielıling abunt fifty million nuts, are exported annually, in addition to the large quantities which leave uther Brazilian harbors. 


\section{ORDER XXVI. LYTHRACEA.}

Flowers perfect, symmetrical, perigynous. Calyx inclosing, but not adhering to the ovary. Petals sometimes wanting; when present, free. Stamens equal to petals in number, or twice as many or more, inserted on the calyx-tube; anthers versatile. Ovary 2 to 6 , rarely 1 celled; style 1 . Seeds numerous, usually on axile placentæ. No albumen. Fruit a pod, more or less inclosed by the calyx. Trees or shrubs, branches frequently 4-angled. Leaves mostly opposite, entire, exstipulate.

No. of genera, 30 ; of species, 250 .

PUNICA, L. Calyx large, broadly tubular, an inch and a half long, thick and leathery, attached to the ovary below; lobes 5-7, thick, triangular, acute, smooth, shining, scarlet, valvate. Petals 5-7, inserted on the calyx, alternating with its lobes, spreading, imbricated, crumpled, roundish, with a short, broad claw, crimson. Stamens numerous, free, inserted on the calyx-tube beneath the petals, crowded, erect. Anthers turned inwards, yellow, opening lengthwise. Ovary thick and leathery, with two tiers of cells, upper tier 5-8 in numher; ovules many. Style tapering; stigma simple, head-shaped. Fruit hard, sub-globular, abruptly contracted at the top into a short neck, crowned by the thick calyx, size of an orange, reddish-yellow. Seeds numerous, angular, covered with a pinkish, juicy coating.

P. granatum, L. (Pomegranate.) Arborescent, 14 to 15 feet high. Bark brownish-gray, furrowed. Branches straight, strong, sub-angular, armed

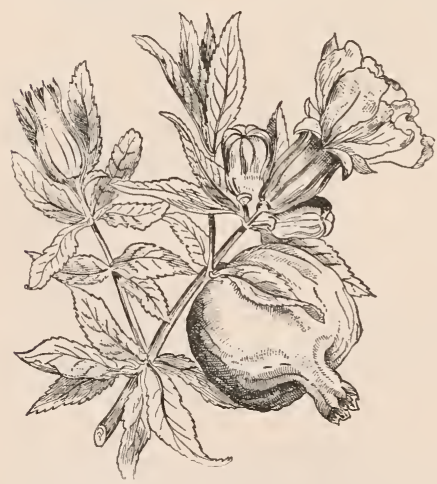

Punica granatom (Pomegranate). near the ends with spines; young shoots and buds red. Leaves opposite or fascicled, short-stalked, and without stipules. Flowers large, solitary, or two to three together in the axils of the leaves, near the ends of the branchlets. A beautiful object for planted grounds.

Varieties. - This is the only species, but as it is grown from seed it sports, consequently varieties have been produced. The two most prominent are :

Var. alba, white-flowered.

Var. plena, double-flowered.

Geography. - The zone of the pomegranate is within the region of no frost, and along its outer fringes, in the north temperate zone, all around the globe.

Etymology. - Punica, the generic name, is from the Latin punicus, red, due to the color of the fruit. Punicus also means Carthaginian, signifying " deceitful " (the Carthaginians had the reputation of being unfaithful), applied to the fruit, which is beautiful in appearance, but not delightful to the taste. The name may have been applied to the plant because it was largely planted near 
Carthage, hence called Pomum I'unicum, or ('arthage Ipple. Granatum is the Iatin for grained or serded, due to the ahmulance of seed in the fruit. Pomegranate, the common name, is made up of pomum, apple, and granatum, seeded.

History. - The home of this beautiful little tree is l'orsia and the adjacent conntries, whence it has spread throughont Syria, $\Lambda$ sia Minor, the Levant, southern lurope, Africa, China, and Jajan. It has also been bronght by European colonists to southeru North America.

It was known to the ancients and is spoken of frequently in the Bible. The Hebrews on their journeyings through the desert of Arabia, (onmplained to Moses, saying, "It is no place of seed or of figs or of vines or of pomegranates." And Moses himself describes the promised land as a conntry of " wheat, barley and vines, tig-trees and pomegranates." Solomon speaks of an "orchard of pomegranates with pleasaut fruits."

By these quotations we are led to the inference that the pomegranate was an important food-plant at that time.

Use. - The plant is cultivated largely in the regions of no frost as an ornamental tree, and in colder climates in conservatories, throughont Europe and the United States.

The fruit is used for a dessert, heing prepared by cutting it into halves, removing the seeds, filling their places with sugar, and sprinkling the whole with rose-water.

The bark is highly charged with tannin, and produces a beantiful yellow dye, with which the yellow Levant moroceo is colored. The bark of the root is used as a vermifuge, and was formerly considered a specific for tape worm.

Statistics. - Ontside of the conntries of $A$ sia and Africal, where the pomegranate is grown, it is of very small commercial importance.

\section{Order XXVII. CUCURBITACEAE.}

Flowers monnecious, or diocious, seldom perfect, solitary, sometimes fascicled, or racemed, usually white or yellow. Calyx bell-shaped, 5-toothed or lohed, inhricate in the bud. Corolla with petals united. wheel-or hell-shaped, 5-lohed. Stamens 5, mostly:3, one of the anthers 1-celled, the others 2-celled. Ovary inferior, 1- or many-celled. Fruit a many-seeded berry. Ieaves alternate, petiolsd, msually cordate. Stem succulent, climbing or clambering over undershrubs, etc. Mostly herbs.

Genera, 68.

CUCUMIS, L. Calyx tubular, hell-shaped, 5-parted or toothed, teeth awl-shaped, about as long as the tube. P'etals 5, slightly attached to the calyx. Stamens in three groups. Stigmas 3, nearly sessile, stout, and 2-lobed. Fruit globular, sometimes flattened at the poles, and again lengthened into a prolate splieroil or short cylinder. Feods numerous, white or yellowish, ohlanceolate, acnte at the hase, and flattened.

1. C. sativus, L. (Cueumber.) Stem trailing, rongh, hairy, 5 to 12 feet long, branched; tendrils simple. Leaves cordate, is to 6 inches long, angularly 
lobed, terminal lobe largest. Fruit cylindrical, 5 to 10 inches long, and from 2 to 4 inches in diameter. When young, the surface is besprinkled with tubercles, armed with rigid, sharp bristles, which fall off at a later state. Green, turning yellow when ripe. Seeds very numerous, yellowish-white, three eighths of an inch long and less than two eighths wide, oblanceolate, flattened; about twelve hundred weigh an ounce, and they retain their vitality about ten years, if kept from the air.

Varieties. - The cucumber sports freely, and many varieties are under cultivation. There are about thirty choice kinds recommended by seedsmen. 'The Cluster, Early French, White Spine, and Early Russian are among the most desirable for the market garden.

Amateurs favor other varieties, but the above four are the most popular.

Geography. - The zone of the cucumber is very broad. It grows well in rich soil wherever there are three or four months without frost, but requires

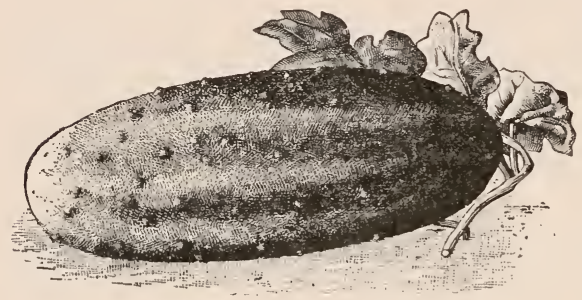

Cucumis sativus (Cuenmber). warm nights and hot days to be prolific.

Etymology. - Cucumis is Latin, and signifies a vessel, alluding to the rind of the fruit, which when the puly, is removed forms a cup which may be used for drinking. It is said to be derived from the Celtic word cucc, a hollow vessel, or from the Latin cucuma, a cooking-ressel. Sativus,

the specific name, is Latin, and signifies sown, or cultivated. Cucumber, the common name, is a corruption of the word cucumis, the generic name.

History. - The home of the cncumber is the northwest of India and the region north of Afghanistan, and it was no doubt taken into the Levant and southern Asia at a very early period in history. It was under cultivation in Hindustan three thousand years before the Christian era, and was known to the ancient Greeks.

It is by no means certain that the plant referred to under the name cucumber in Scripture was the Cucumis sativus. Nothing has appeared on the Egyptian monuments to prove that the Israelites became acquainted with it during the period of their bondage, but it is possible that it reached them in Syria from the East.

It worked its way into southern Europe and Africa by commerce and travel, was brought to America in the dars of Columbus, and has become one of our most important garden crops about our great cities.

Use. - It is largely used raw when in an unripe state, as a salad, with a salt and vinegar dressing, and as a pickle, in America, Europe, and especially in sonthern Russia among the peasantry, by whom it is stored in casks under heavy weight, and allowed to heat and reach the vinous fermentation, when it is eaten with coarse bread, serving the purpose of butter or oil. In the Southern States, in North America, it is sliced, fried in oil or butter, and served up as egg plant is.

2. C. melo, L. (Muskmelon. Cantalonpe.) Stem rough, hairy, 5 to 10 feet long, trailing. Leaves heart-shaped, or somewhat kidney-shaped, with rounded 
lobes, rough, hairy, 3 inches long. Flowers axillary, on short stalks, yellow. Fruit globose, from 3 to 12 inches in diameter, generally ridged and furrowed, sometimes much flattened at the poles, while in somm varieties it is much elongated, forming a short cylinder, or oval. Seeds yellowish-white, oblanceolate, flattened; ahout a thousand to an onnee; when kept in a uniform temperature they retain their germinating properties abont ten years. Flowers in June. Fruits in August.

There are many species, and as it sports freely, very many varieties are under cultivation. The leading varieties in America are :-

The Beechuod, an early variety, flesh sugary.

The Black-Rock, large-fruited, very sweet.

The Citron, rich, juicy, and sugary.

The Large-ribbed, very large, oval in form, flesh sweet.

The Nutmeg, delicious in Havor, and popular.

Geography. - The muskmelon grows to perfection in rich, sandy soil, in all the comntries of the Levant, on the shores of the Mediterranean, in India, China, Japan, and in fact in all tropieal and subtropical countries through. out the world. It is a very important crop on the southern plains of New Jersey and throughout the Middle and sonthrru States.

Etymology. - Melo, the specific name, is from the frreek $\mu \hat{\eta} \lambda o \nu$, an apple, hence an apple-shaped fruit. Latin melo, a melon. Velon, the popmlar name,

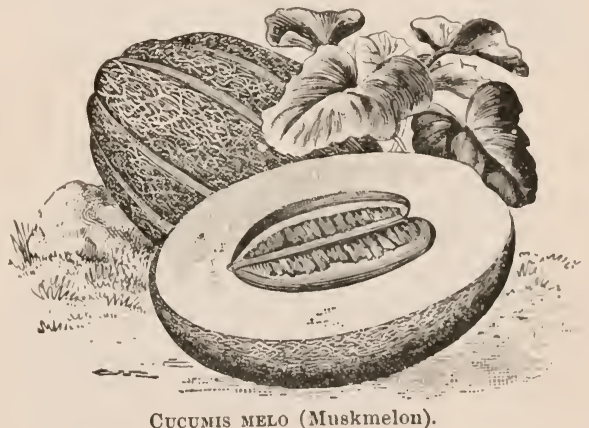

Cucumis melo (IIuskmelon). is a corruption of the same word, or rather an Anglicizing of the Greek word. Muskmelon is due to the peculiar aroma shed by some of the rarieties, which has fancifully been.com pared to the odor of musk. Cantaloupe arose from the circumstance that une of the varieties was cultivated or originated at a country-seat of the l'upe, called Cantalouppi.

History. - The muskmelon or Cucumis melo, is indigenous to British India and Baluchistan. It has also been found wild in western Africa, in Guinea, and along the banks of the Niger.

It was enltivated by the ancient Egrptians, but how early there is n') meatus of knowing. It was also known to the Greeks and Romans at an early periud in history, bronght either from the last by commerce or travel or introduced from $\triangle$ fricia.

$U$ se. - The muskmelon is the richest and most juicy fruit of all the pepu family. In the Itlantic States it is the favorite first course at breakfast, and is highly esteemed as a dessert. The rinds are preserved in ginger syrup as a sweetimeat, and also hrandied.

The following anecilote is told of Frederick the (ireat, who was extravagantly fond of a small bigntian melon, which he cansed to he enltivated in his grounds. He one day called his phrsician to treat him for an attack of indi. gestion. The doctor, aware of the king's fondness for the melon, inferred that 
his indisposition was due to its excessive use. He therefore advised the king to abstain from its use; to which the monarch replied: "I will only eat five for my breakfast." At the same time calling his gardener, he ordered him to send the doctor a dozen for his breakfast.

CITRULLUs, Schrad. (Melon.) Divisions of the calyx 5, narrow, lanceolate. Petals 5, united at the base and attached to the bottom of the calyx. Stamens, in three groups, connected. Style 3-parted. Stigmas convex, heart or kidney-shaped. Fruit globular or in the form of a prolate spheroid, from 6 inches to 2 feet in length, and from 6 to 15 inches in diameter. Rind leathery, greenish-brown, mottled or striped, with alternate green and yellow lines from an inch to an inch and a half wide, filled with a fleshy, juicy placenta, or core, of an orange-red color, sweet and edible. An herbaceous vine.

C. vulgaris, Schrad. (Watermelon.) Stem 8 to 15 feet long, angular, branched, rough, hairy, slender, trailing. Leaves 3 to 6 inches in length,

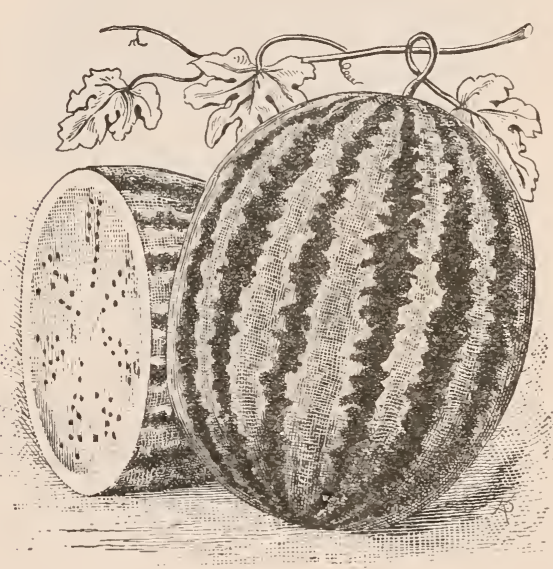

Citrullus vulgaris (Watermelon).

lobed, and the lobes pinnately divided, glaucous beneatl, petioles 2 to 3 inches long. Flowers axillary, on lairy pedicels, about an incli and a half in length, corolla yellow. Flowers in Jume to July. Fruits August to October.

I'arieties. - There are numerous varieties. Among the most popular are-

'The Black Spanish, somewhat globular, deeply ribbed lengthwise, skin dark or blackish-green. Quality excellent, and grows well in New Jersey, and as far north as southern New York, especially on Long Island.

The Bradford, or Carolina watermelon, a favorite in the Southern States ; one and a half to two feet long, striped or mottled; pulp tender and delicious.

The Mountain Sweet, a hardy and greatly esteemed variety; grows well in New Jersey, Delaware, southern Penusylvania, and Long Island. Pulp dark-red, and delicions.

Odell's Large, of enormous size, round, gray ; seeds large, grayish-black. A single melon of this variety has been known to weigh sixty pounds.

Citron Watermelon, 6 to 10 inches in diameter, color pale-green, marbled with darker shades; not edible raw, but highly prized for preserving.

Geography. - It arrives at perfection only in tropical and subtropical countries, but succeeds well in all southern Europe and southern and middle North America, up to the 41 st degree of latitude in North Autrica. 
Etymolony. - Citrullus is derived from the color of the pulp, which is some times of an orange red, hence orange color, or citrus color. liulgaris, conmon, is from the Latin. "Intermelon refers to the watery pul]. Melon is an adoption of the fireek word $\mu \hat{\eta} \lambda u \nu$, an apple, becanse of the supposed apple-shape uf the fruit.

History. - It is not known where or when the wattermelon was first brought under cultivation. Its home is in $\Lambda$ frica, in the torrid zone. Livingstone states that large districts are covered with it in a wild state, and it has not been seen growing without cultivation ont of $A$ frica. It was cultivated by the aucient ligyptians. It was grown in 1 sia at an early date, and was known in all the Mediterranean countries in the beginning of the ('hristian era. It was brought to the New World by European settlers, and is common in all the warm countries of both North and South America, where Europeans have settled.

Use. - The watermelon is a very popular dessert fruit, and the rinds are preserved in sugar and also brandied. In Egypt it is not only prized by the wealthy as a desiert, but it constitutes a very important article of food for the poorer classes, who eat it with their bread, and in fact largely subsist upon it during its season, which is long.

C U C U R B I T A, L. (Pumpkin. Gourd. squash.) Calyx eggshaped, corolla bell-

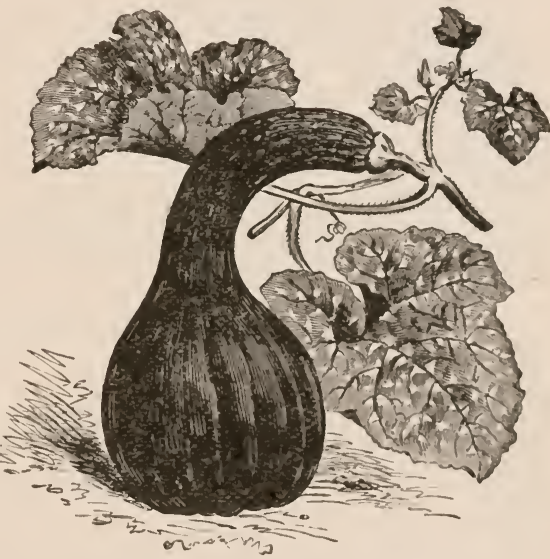

Cucurbita maxima (Gourd Squash). shaped, petals united half-way up, yellow. Flowers monœecious, axillary, on angular stalks. Stamens with anthers cohering. Fruit-stalk deeply grooved. Fruit globose, flattened or prolonged at the poles; seeds yellowish white, obovate, with slightly convex sides. Leaves heart or kidney shaped, stem trailing with branching 2-3-cleft tendrils. Annuals.

1. C. melopepo, I. (Flat Squaslı.) Sitem 5 to 20 feet in length, branching. tendrils hranched, or partially dereloped into leaves. Leaves heart-shaped, 5-angled, 6 to 8 inches long on a foot-stalk as long as the blade. Flowers yellow, large. Frnit wheel-shaped, flattened and dished about the stem, and convex on the opposite side; circumference lobed or estalloped. Flowers and fruits July to Oct. Fruit cooked in a green state, with or without salt meats.

2. C. verrucosa, I. (Warty Squash. Long-necked Siquash.) Stem 10 to 15 feet long, teudrils branched. Leaves from 6 to 12 inches long, and nearly as wide; leaf-stalk same length as the blarle. Flowers large and yellow. Fruit obovoid, or club-shaped, neck frequently erooked or curved, ronghened with warty tubercles; when ripe the shell becomes hard or bony. Like the above, 
the fruit is prepared for the table in an unripe state. Flowers and fruits from July to Oct.

3. C. maxima, DC. (Winter Squash. Gourd Squash.) Stem 8 to 20 feet long, trailing. Leaves large, with rounded lobes. Corolla yellow, segments curved, or rolled outwards ; Hower-stalks smooth. Fruit ovoid or pear-shaped, neck sometimes crooked or curved. Variable in size, frequently reaching the length of 3 feet, and specimens have been known to weigh 70 pounds. 'The neck is usually solid, the end farthest from the stem enlarged, and contains the seeds. This squash has the characteristics of a pumpkin, and is used much in the same way that the cheese pumpkin is.

Var. corona (Crowned Siquash). Fruit expanded near the stem into a broad, circular, turban-like process, mnch larger in diameter than the extended part. This expanded part is solid, and the cell containing the seed is in the contracted end.

I arieties. - These are the principal marrow squashes. 'There are many forms, but the above are the favorites with gardeners and amateurs.

The Custard Squash, a large variety, is grown for stock.

Puritan Squash, grown largely in New England, is very constant, very hardy and productive, and raised both for the table and for stock ; skin white, marked with green mottled stripes.

The Valparaiso Squashes, of which we frequently have specimens brought from California, some of them weighing more than a hundred pounds, have not been fully described.

4. c. ovifera, Gray. (Orange Gourd Squash.) The fruit of this species is small and egg-shaped, and by cultivation it is supposed to have given rise to the following forms:-

Autumnal I/Arrow. Stem 10 to 15 feet in length, and stout. Fruit ovoid or spindle-shaped, furrowed and ridged, the blossom end tipped with a short nipple; skin very creamy, yellow ; flesh sweet and delicate. Ripens early in August. Keeps well.

Hubbard Squash is in shape and quality very much like the Autumnal Marrow, color a bluish-green, flesh orange-color and delicate; smoother than the last, 8 to 10 inches long, and 6 to 8 in diameter.

Sweet Potato Squash resembles the above two in shape and character, a foot long, 7 or 8 inches in diameter, skin ashy green, smooth and polished; flesh salmon-yellow; thick-fleshed and fine-grained.

Var. Medullosa.

Vegetable Marrou. Its stem 12 to 15 feet in length, leaves deeply 5-lobed; fruit 8 to 10 inches long, elliptical in shape, ribbed and furrowed lengthwise; flesh white and delicate. Keeps well through the winter.

Etymolog.y. - Melopepo is from the two Greek words $\mu \hat{\eta} \lambda o \nu$, an apple, and $\pi \epsilon \dot{\pi} \omega \nu$, a melon, an apple melon. The fruit in a natural state is of the size and shape of an apple. Maxima is Latin for great, and is due to the size of this species. Corona is Latin for croun, given on account of the turban or crown-like process at the stem end of this variety. Verrucosa is from the Latin rerrucosus, warty, on account of the warts that abonnd on the skin of the fruit of this variety. Orifera, from the Latin orum, an egg, is due to the oval shape of the fruit of this species.

History. - Dr. Gray believes that the C. ovifera is the ancestor of all the American squashes. It is claimed, however, by some authorities that Europe or western Asia is the home of the C. maxima. But Pickering claims that 
the C. maxima is an American plant, and says it has heen carried thence by colonists to the Pacific islands, to southern $A$ sia, and to Europe and Africa. If this be so, it leaves us in the dark as to what the (' maxima kuown to the ancients was.

5. C. pepo, L. (l'umpkin.) Stem prostrate, 5 to 20 feet long, rough, hairy, sparingly branched, with branched tendrils. Leaves large, 9 to 13 inches long. and 5 to 10 wide, heart- or kidney-shaped, 5-lobed. Flowers yellow and axillary. Fruit cheese-shaped or club-shaped, or sub-globular, on deeply grooved perluncles, flesh yellow, sweet, sulid, but not hard; cavity of the fruit filled with a stringy pulp and seeds.

Flowers in July; fruit ripens in October.

Varieties. - There are many varieties of the Pumpkin under cultivation, the must popular of which are the following:-

Cheese Pumpkin, which is flattened at the poles, and from 10 to 20 inches in diameter, and 4 to 10 inches from pule to pole, deeply ribbed, dished about the stem, skin reddishorange color, leathery ; flesh yellow, sweet, and delicate. The cheese pump-

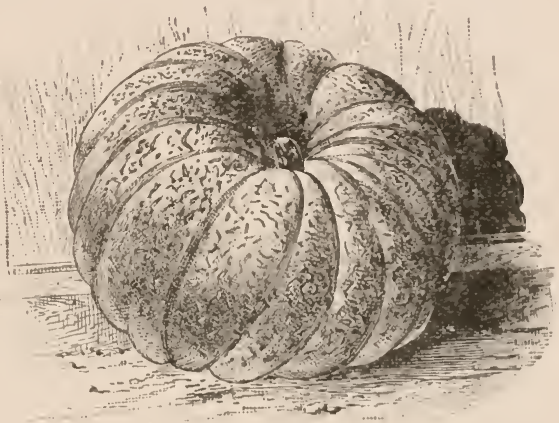

Cocurbita pepo (Pumpkin).

kin holds the highest place among the varieties of this plant, on account of its hardy character, its size, productiveness, and the delicacy of its flesh. It has been claimed that it is a variety of the C. maxima, brought to America by European colonists; but history favors the belief that it is an Imerican plant. It was extensively cultivated throughout the Middle States at the time of the Revolutionary War, and was carried to New England by the soldiers returning home from service in New Jersey, southern Penusylvania, and adjacent states further south, where it is still found growing, with great constancy as to form, size, and qualities, thougl the cultivation lias been in many cases careless and slovenly.

Canadu Pumplin is in the form of a flattened globe, deeply ribhed, 10 to 15 inches in diameter, and 8 to 10 inches at the poles. Skin yellow and hard; flesh yellow. Much cultivated for cattle, and also for tahle use. It grow: better in a higher latitude than the cheese pumpkin.

Common Field Pumpkin, or Leather Buck. Globose, ends flattened, rather longer than broal, 10 to 14 inches long, and 8 to 12 in diameter. Gruwn for stock, and sparingly for the table. Ribbed, rellow; skin hard, Hesk yellow. Leaves deeply lobed.

Sugar Pumpkin. Grows in the form of a flattened sphere, about 9 inche: in diameter, and 6 at the poles. The smallest of the varieties under cultivation; a prolific bearer, and of excellent quality. Grooved skin, bright orange-yellow; Hesh yellow, sweet, delicate, and fint-grained. Stem long. ridged, and grooved.

There are other varieties, but the above are the favorites, and nost important to gardeners and agriculturists.

Pr. Fr. -11 
Geography. - The Gourd family, of which the pumpkin and squash are members, delights in a warm climate, but fruits well as far north and south of the equator as the middle of the temperate zones.

Etymology. - Cucurbita is the Latin for gourd, a hollow vessel or a cup, and must allude to the circumstance that these plants are hollow, or become so when allowed to ripen on the vine. Some derive this from the Latin curvitas, crookedness, alludiug to the form of some of the club-shaped gourds, whose necks are curved. Pepo is from the Greek $\pi \epsilon ́ \pi \nu$, a melon. Pumpkin is a corruption of the Freuch word pompon, a melon. 'The popular names all explain themselves.

History. - The home of the pumpkin is believed to be America. It has been found growing wild in Mexico, and was under cultivation by the aborigines in Florida, Mexico, and the IVest Indies, when these regions were first visited by Europeans. Dr. Gray believed that all the species except C. maxima are American. The species and varieties of this genus have been so confused that this is not certain.

Use. - The cheese pumpkin and the sugar pumpkin are esteemed for making the celebrated New England pumpkin pies. 'They also, like the other varieties, are growu for feeding cattle. They are valuable for milch cows because they not ouly promote the flow of milk but improve its quality. In Europe the pumpkin pie is prepared by making a circular orifice in the top, the center of which is the stem. Through this hole the seeds and pulp are removed, and the cavity filled with sliced apples, spices and sugar. The whole is theu baked, and served.

\section{Order XXVIII. UMBELLIFER EE.}

Flowers small, 5-merous, superior, in simple or compound umbels. Calyx lobes minute, tube adnate to ovary. Ovary 2-celled, each with a pendulous ovule. Fruit, 2 dry indehiscent akenes, separating from a carpophore; each akene with 5 primary and often 4 secondary ribs. Number of genera, 152 .

APIUM, Hoffm. (Celery.) Calyx without teeth, base of style flat. Petals white, entire, with a small apex bent in. Fruit, egg- or globeshaped. Carpels nearly straight, with 5 thread-like ribs; channels with single oil-tubes, except the outer ones, which sometimes have more. Leaves pinnately or ternately divided; divisions wedge-shaped; umbels opposite the leaves. Biennial herb.

A. graveolens, I. Stem 2 to 3 feet high, branching, channelled. Leaves from the root, on long, stont stalks, green; stem leaves on short stalks. Flowers terminal and axillary, those in the axils on very short foot-stalks; rays unequal; petals greenish-white. Fruit subglobular. Flowers in July. Fruit in September.

The celery sports freely, and many varieties have arisen, for the names of which the student is referred to the seedsmen's catalogues. There are about 20 choice varieties under cultivation by the market gardeners and amateurs.

Geography. - Its geographical distribution is very wide. It is indigenous to Great Britain, all the coast of western Europe, the shores of the Mediterrauean, and it is found in the Peloponnesus, on the foothills of the Caucasus, 
and in l'alestine. It is also native to South America, and along the western coast as far north as southern California. W'atson, in his "Flora of California," speaks of it as very rare, but says it is found in the salt marshes down the coast.

Etymology. - Apium is traced to the Celtic word apon, water, due to the habitat of the plant, which is in wet places. Graveolens, the specific name, is from the Latin gravis, heavy, and oleo, smell, whence "heary smell," or "strong smell," on account of the peculiar odor of the plant. Celery, the common name, is a corruption of the Greek word $\sigma \epsilon^{\prime} \lambda \iota \nu o \nu$, parsley.

Mistory. - We do not know where or when the celery was first used as a table regetable. It was known to the ancient Greeks and Romans, and is mentioned by 'Theophrastus, 1)ioscorides, and l'liny. It was also used by the ancient Egyjtians.

Cultication. - The seed is sown like a cabbage-seed; and when the plants are from three to six inches high, they are pricked out in beds. In August they are set in well fertilized trenches, about 8 to 12 inches apart in the row, and allowed to grow till October, at which time a number of long-stalked leaves are developed; these are then held together to prevent the earth from getting anong them, and banked, and thus left to bleach till frost appears, when they are ready for the table.

$U$ se. - Celery is the most delicate and highly esteemed of all salads in use. When properly blauched, the leaf-stalks are a delicate creamy white, and the flavor is greatly almired. It is either served in this form and eaten with salt or with prepared dressing; occasionally it is cooked and eaten with a vinegar dressing. The Turnip-rooted variety is cooked and eaten with salad dressings. It is used also for flavoring soups and gravies. Its medicinal properties are said to be diuretic and tonic, producing biliary secretion, and it is recommended for rheumatism. The Egyptians used it to prevent and to cure sea-sickness.

PIMPINELLA, L. (Anise.) Calyx limb indistinct, teeth wanting; petals white, obcordate, unequal, notched, flowers usuary perfect, but sometimes the stamens and pistils are on different flowers. Styles long and slender. Bracts of involucre few, small or wanting. Leaves decompound. Fruit egg-shaped, ribbed, with convex intervals. Perennial hert.

P. anisum, L. Stem 2 feet high; hranches slender; lower leaves roundishheart-shaped, cut into three lobes by deep incisions; leaves on the middle and upper parts of the stem pinnate, parts wedge-shaped; umbels large and loose; stalks of the umbellets unequal in length; flowers yellowish-white, appearing in July.

'There are many species, but the anisum is the one under cultivation for the production of the oil of anise.

Geography. - The anise seeds of commerce are produced in Egrpt, Syria, in the island of Malta, and in Spain, and in late years the plant has been largely eultivated in Southern Germany. It has worked its way east of Syria to Hindustan, and to Japan. The best seel is brought from Egypt. The plant is supposed to be indigenons to Egypt, Asia Minor, and the Greek Islauds.

Etymology. - Pimpinella is a corruption of bipimate, due to the divisions of its leaf. Anisum is from the Greek word ávónosos, unequal, the ancient 
name referring to the inequality in the length of stalks of umbellets, or perhaps to the unequal petals. Anise, the popular name, is a corruption of anisum.

History. - The anise was known to the ancients, and is mentioned by Dioscorides, and described by I'liny, who says the best is brought from Crete and from Egypt. It is one of the plants Charlemagne ordered his gardener to cultivate in the royal gardens. It is oue of the products carried into England early in the fourteenth century, and upon which an impost duty was levied. It was brought to North America about the middle of the seventeenth century by Luropean colonists, and is sometimes planted in gardens in the Middle

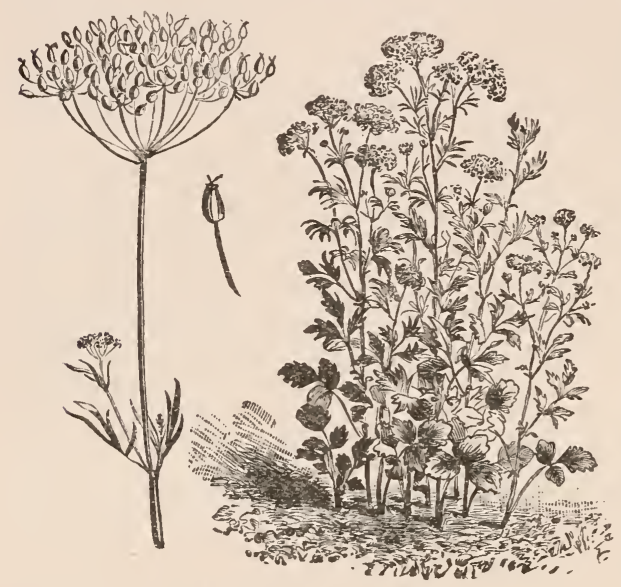

Pimpinella anisum (Anise). States, but seldom fruits. The anise named in the New Testament is held by some to be another plant.

Use. - The essential oil of anise is obtained by distillation from the seed. It is nsed in medicine as a stimulant and carminative, as a stomachic and antispasmodic, and to cover the disagreeable taste of other medicines in compounding remedies such as paregoric, congh mixtures, and cordials.

Rats and mice are very fond of it, and it is nsed by vermin-destroyers to perfume their bait. The sprigs are sometimes used to garnish dishes at the table, and as a condiment for meats. In Germany and Middle Europe it is used to flaror bread, cakes, and cheese.

Note. - The fruit of the Illicium anisatum (Star Anise), a small evergreen tree of the order Magnoliacer, when distilled yields an oil identical in odor, chemical analysis, and medicinal properties with the oil of pimpinella, for which it is sometimes substituted.

FENICULUM, Hoffm. Calyx limb indistinct. Petals roundishobovate, entire, truncate, involute. Cremocarps oblong or ellipsoid, ovoid, not flattened. Columella 2-parted, the branches attached to mericarps; mericarps with 5 prominent obtusely keeled ridges, side ones a little broader and marginial, a single oil-vessel in each space. Flowers, small, deep yellow, not radiant. Cmbels large and compound, without involucres. Leaves decompound, with thread-like segments. A biennial herb.

I. F. vulgare, Gaert. (Fennel.) Stem erect, terete, thick, striate, smooth, bright green, large pith, through the center of which extends a small tube. 
Rootstock thickened. Leaves on short, Hattened footstalks embracing the stem, triangular in outline, three or four times pinnate, segments or divisions thread-like and bristly. Flowers small, on short peclicels, bright yellow, in large, regular, 10-30-rayed umbels, without involucres: petals entire, involute. Cremocarps olive-colorerl, oblong-oval, hately flattened, one fifth of an inch in length, prominently ridged; whole plant drep green. Fruit aromatic, stimulant, stomachic. Root and leares aromatic, medicinal, nutritive, and stimulating.

Biemnial herb, July.

2. F. dulce is a species found in Italy and used for food.

Geography. - The geographical range of Fœniculum is the midile and southern parts of the uurth temperate zone.

Etymology. - Faniculum is from the Latiu fenum, hay, due to the odor of fenmel, which is that of new-mown hay. The specitic name, vulgare, means "common," and dulce, "sweet."

History. - Indigenous in the countries of the Levant, carried by Europeans to Hindustan, and bronglit to the Atlantic States by colonists. Cultivated in france, Germany, Great Britain, and all southeru Europe.

Use. - The merlicinal qualities of fennel are carminative, and it is frequently arlministered to disguise the disigreeahle taste of other medicines. It is used in Germany to

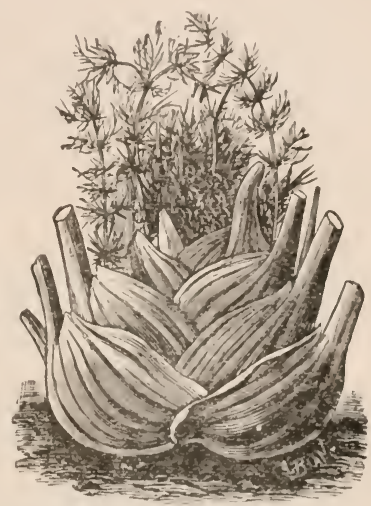

Foxiculum volgare (Fennel). flavor bread and eakes. The leaves and the root of $\mathrm{F}$. llulee are used in southern Europe as a table regetable, both as a saliul and cooked. It is a favorite regetable with fish. In former class it had the reputation of curing all sorts of poisons, restoring sight, and imparting strength to the body The Roman gladiators mingled the seeds with their food, and wore the leaves as erowns of victory

An esisential oil is obtained from the seed by distillation, ('allesl Fennel oil.

FERULA, L. Calyx entire, or obscurely tootherl: petals broadacuminate, frequently short and tumed in. Disk small. stylopodium flattenerl. Fruit orbicular or orate, margined: seeds with 3 lines along the back, interrals and commissure grooved or channelled. Common involucre falling off. involucels many-leaved. Rialical leaves decompound. Flowers yellow. in globose umbellets.

F. narthex, Boiss. (Asiffeticla.) Stem 6 to 8 feet in height, cylindrical. smooth, solicl, and furporerl. Leaves, at the root, 2 fect long, bipinnate, stem leaves mmerms, alteruate. lower ones hipinnate, on sheathing petioles. sheaths increasing $i n$ size towards the middle of the stem and decreasing from the milllle upwaril.

Flowers polyganoms, staminate flowers much smaller than the others, crowdel into dense glohular umbellets: involuere wanting. Calyx slightly striate. l'etals oblong-oval acute aml entire, pale vellow, unequal in the staminate flowers. Filaments as long as the petals; styles long and falling 
off. Fruit half an inch long, oval, smooth, yellowish. The root which yields the gum is in the form of a carrot, and 3 to 4 inches in diameter. The plant dies after flowering, but sometimes does not flower until the third or fourth year.

Geography. - The geographical distribution of the plants whose roots furnish asafœetida is not large; it is confined to middle and western Asia. It has been taken to England and to Africa, but it is not known to be successful in the production of the gum outside of Asia. It has been found in the Himalaya mountains at an elevation of 7,000 feet.

Etymology. - Ferula, the generic name, is from the Latin ferio, strike, alluding to the use made of the stem as a rod for scourging, employed by schoolmasters. Narthex is from the Greek word, $\nu a ́ \rho \theta \eta \xi$, a box or magazine to contain medicine, alluding to the medicine stored up in the plant. Accord-

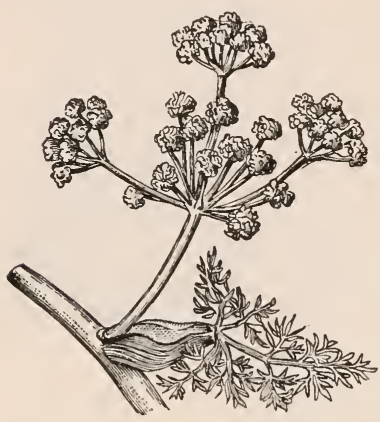

Ferula narthex (Asafœetida). ing to the fabulous history of the doings of the gods, Prometheus used a stalk of this plant, which had been hollowed ont, to conceal the sacred fire which he brought down from heaven, hence a magazine for fire; it is also said to have been employed to make boxes or magazines for other purposes. Asafoctida, the common name, is from the Arabic $a z a$, gum, and the Latin word foetidus, fetid, or bad-smelling.

History. - The home of the Ferula is Persia, Afganistan, the Punjaub, and northern Hindustan. When its products were first used as a medicine, or as a condiment for food, is not known. The Greeks and Romans made use of it; Dioscorides and Pliny both speak of it. The plant is described in the books of the Buddhists as one of the ornaments of the Himalayan forests.

Preparation. - The gum is the dried milky juice which issues from the wounded root of F. narthex and other species of the genus. There seems to be good anthority for the belief that most of the asafotida is from the F. narthex.

To obtain it, the leaves and stalk are twisted off. The earth is removed from the upper part of the root, which is covered to protect it from the sun, and left for forty days, when it is exposed and the crown of the root sliced off. Two days later, the juice which is deposited upon this wound is removed, and a thin slice taken off, making a new wound. This operation goes on from the middle of May to the end of July, when the root is exhausted; a root yields from half an ounce to two pounds. The sap of the first scrapings is thin, and to make it more easy to handle it is mixed with earth; therefore the gum reaches market containing much earthy impurity. The gum, when hardened, has a brownish appearance, and in cold weather is brittle.

It is taken to Bombay from the ports of the Persian Gulf. whence it reaches the markets of the world

Use. - Asafotida contains a resin, a gum, and an essential oil. The odor resides in the oil, and is like that of onions, or garlics, accompanied by a separate fetid odor which is very offensive when the drug is warmed. 
Its medicinal qualities are stomachic and antispasmodic; it is administered in hysteria, hypochondria, and nervous disorders. 'The tissues of the human system absorb it readily, and it affects the kidneys with great activity.

The essential oil is distilled in (iermany, and is nsed in medicine on the continent of Europe.

Asafotida is used in India as a condiment for food; it was also employed by the Romans for the same purpose.

The peculiar and inimitable Havor of the celebrated Worcestershire sauce is supposed to be due to the presence of asafoetida.

PEUCEDANUM, L. Calyx 5-toothed, or obsolete; petals broadlanceolate, point long and turued in. Fruit flat, oval, with a broad margin. C'arpels obscurely 5-ribbed, secoudary ribs wanting; valleys furnished with single oil-vessels. Flowers yellow, involucre many or few-leaved or absent; involucels the same. Root conical, large, and fleshy. Biennial.

P. pastinaca, L. (Pastinaca sativa, L.) (Parsnip.) Sitem groured, tapering, hollow, 2 to 4 feet high, branching. Root-leares of the first year, orbicular, cordate, and crenate." Stem or upper leaves of the second vear, compound; leaflets 2 to 3 inches long, cut, toothed, ovate, and obtuse, in 3 to 4 pairs, with a terminal one which is 3-lobed. Flowers in June. Fruits in August to October.

Note. - There are several varieties; a great favorite is the Guernsey, which is an improved form of the common, or l'. pastinaca. It is said that in the island of Guerisey, where deep cultivation is practiced, the root reaches the length of four feet. The Student has come into favor, and is said to excel all others in its sweet, mild, and pleasant flavor.

Geography. - The parsnip is found all over Europe south of 60 degrees of latitude, southern Freece, western Asia, Hindustan, and Siam. It sows its seeds easily, and escapes from gardens and cultivated grounds, and therefore is fouml growing outsicle of cultivation wherever it has been ('ropped.

Etymology. - Peucedanum is derived from the Greek $\pi \epsilon \dot{v} \kappa \eta$, a pine tree, and $\delta a \nu \delta s$, burut, a burnt pine tree, dne to the peculiar odlor of the parsuip. Pastinaca is by some authors derived from the Latin word pastimm, a dihble, an instrument for digging into the ground, in reference to the deep

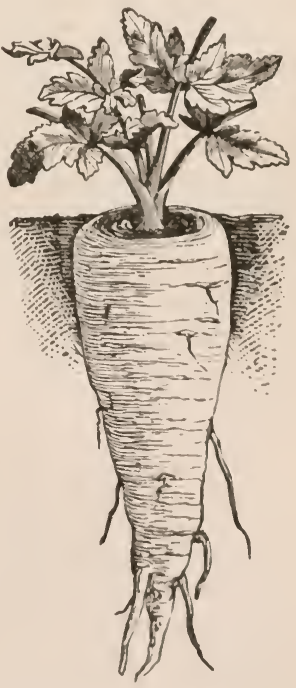

Prucedastm pastinaca (Parsuip). piercing of the ground hy the root of this plant. By others it is derived from the Latin word pustus, fool, fodder, pasture, on accomnt of the edible character of the ront, and its use for feeding stock. Satiza is Latin for "sown" or "planted." The common name, parsnip, is supposed to be a corruption of the latin word pastinare, to dig up, hence something dug up.

History. - The home of the parsnip is Europe. It was cultivated in Britain 
in early times, and eaten with salt fish during Lent; we have no means of knowing when or where it was first used for food, but it is known that it has been in use a long time. It is now cultivated largely throughout Europe for the table and for feed for cattle and horses. It is also found growing in a state of nature. It was brought to eastern North America by British colonists, and carried to other countries by emigrants from other parts of Europe.

Use. - It is an important table regetable, eaten with meats, as potatoes are. It is prepared by simply boiling, or, after being boiled, it is sliced and fried in lard or butter, or mashed, made into balls, and fried; it is also stewed with pork, bacon, or other meats. It is extensively raised for stock. Horses, cattle, and sheep are said to fatten on it with great facility, and it is especially valuable for milch cows.

CORIANDRUM, Hoffm. Calyx-teeth conspicuous, 5 in number. Petals obcordate, turned in at the point, outer oues radiate and 2-parted. Fruit globose, smooth. Carpels cohering; 5 primary ribs depressed, the 4 secondary ones more prominent; seeds concave on their faces. Involucre 1-leaved or wanting. Involucels 3-leaved. unilateral. Annual.

C sativum, L. (Coriander.) Stem 1 to 2 feet high, slender, striate, and branched at top. Leaves bipinnate, with deeply cut, wedge-shaped segments below, segments of the npper leaves linear. Ovary inferior and globular, with 2 short diverging styles; stigmas flat or obtuse. Stamens 5, filaments slender, anthers roundish and yellow. Petals 5, white or purplish, obcordate, and turued in at the top, outer ones 2-parted. Calyx 5-toothed; teeth sharp and unequal. Umbels terminal, rather small, rays 5 to 8 , bracts about 3 in number. Flowers in July.

There are only two species of coriaudrum. The C. sativum, however, furnishes all the seeds of commerce.

Geography. - The coriander grows well in subtropical regions, and flourishes high up in the north temperate zone It is found east of the Black Sea, in the cultivated fields of Tartary, in Hindustan, and Burmah, and is in eultivation in middle, southern, and western Europe. It was brought by European colonists to North America.

Etymology. - Coriandrum is from the Greek кópıs, a bug, due to the disagreeable odor of the bruised leaves. Sativum is Latin for "sown " or "planted." Coriander, the popular name, is a corruption of the botanic name.

History.-The home of this plant is said to be southwestern Tartary, but it is now spread over western Enrope, is found in all the countries of the Mediterranean, and has made its way to the gardens of North America, whence it frequently escapes to the fields and roadsides in the northern and middle United States. Theophrastus, who wrote about three centuries before the Christian era, mentions it, and Pliny speaks of it as growing both in Italy and Africa in the middle of the first century.

Use. - The seeds and the oil of the coriander are used for flavoring desert sauces, confectionery, cordials, and English gin. In Germany and the coun. tries of northern Europe they are employed as a condiment in both bread and cake. The ground seeds are used in the mixture known as curry powder, and in other culinary mixtures. The flavor depends upon an essential oil which is obtained from the seeds by distillation.

Its medicinal properties are stimulant, carminative, sedative, and pectoral, 
and it is frequently administered to modify the griping effects of active purgatives. It was formerly prescribed for gout, St. Authony's fire, and that class of difficulties. The Mahometan practitioners prepare from the seed an eyewash which they believe preserves the sight in small-pox.

cominom, L. Calyx-teeth bristle-like, persistent, the outer ones longer. Petals nearly equal, deeply 2-lobed, white or rose colored; style short, erect. Umbels stalked, somewhat irregular, with few rays; general involucre composed of a few long, spreading and deflexed, narrow, stiff, 3-parted or entire bracts; the umbellets with 2 to 4 small bracts. Flowers few in number. Fruit aromatic, bitter.

C. cyminum, L. C. sativum. (Cumin.) Stem 10 to 15 inches high, brauched, cyliudrical, solid, striate, smooth; brauches spreading. Leaves nearly sessile above, louger stalked below; stalks flattened and clasping, blade teruately divided into long, entire, acute segments, smooth and pale green. The oil-ressels small. Cultivated aunual. The only species of the genus.

Geography. - The geographical zone of this plant is northern Africa, middle and southern Enrope, and extends eastward through Syria, Hindnstan, Bombay, and Burmah.

Etymology. - Cuminum, the generic name, is from the Arabic Gamoun, the ancient name of the plant, of obscure signification. Cyminum, the specific name, is a variation of the same word. C'umin is an abridgment of the generic name.

History. - The exact home of

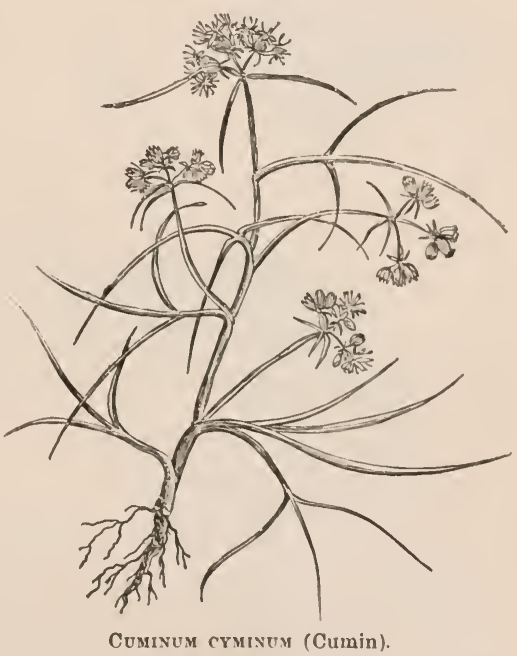
this plant is not known; it is found under cultivation in southern and western Asia, throughout the countries of the Lerant, and in northern $A$ frica. It is sparingly cultivated through midllle Europe, and fruits as far north as south. ern Sweden. It is no doubt the plant spoken of in Scripture in the 231 chapter of Matthew, as a minor crop on which tithe was paid. It was cultirated in Asia Minor in the carly part of the first century, and is mentioned by Ioscorides. The bruised seeds emit a heavy, disagreeable orlor.

Use. - The seeds are used in Germany as a couliment and for flaroring. and the Dutch use them to flavor gin. Their medical properties are carminative, stomachic, and astringent, and they furnish a favorite medicine among the Hindus for dyspepsia and chronic diarrhoa. They are used in external applications for dispersing swellings and allaying pain and irritation. It the present day their use is nearly confined to veterinary practice.

The medicinal qualities are due to an essential oil obtained from the seeds by distillation, known as the vil of cumin. 
DAUCUS, Tourn. (Carrot.) Calyx 5-toothed; petals notched at the end, with point turned in, the two outer larger and deeply cleft. Leaves 3-pinnate. Fruit oblong; carpels with 5 primary bristly ribs and 4 secondary, the latter more prominent, winged, and divided each into a row of prickles having a single oil-gland beneath. Flower envelope pinnate. Bracts of the involucels entire or 3-cleft. Fruit oblong-ovate, bristly. Biennial herb.

D. carota, L. Var. sativa. (Garden Carrot.) Stem rough, 2 to 3 feet high, clothed with rough hairs, terete, branched from below the middle

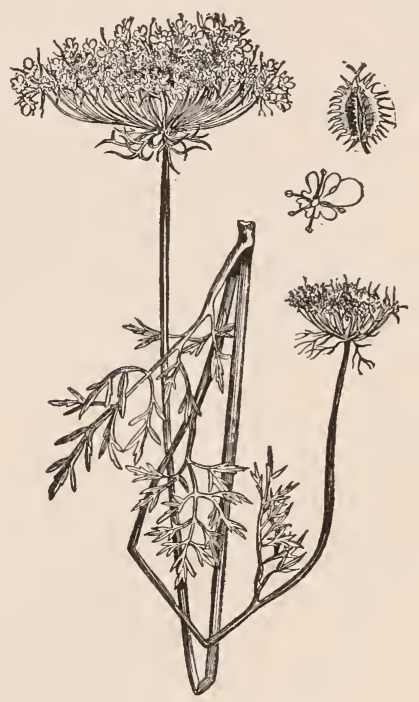

Dadcus (Wild Carrot).

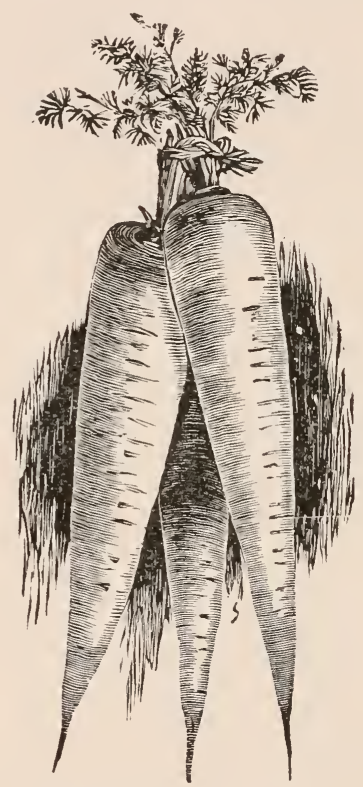

Daucus carota (Carrot).

upwards. Leaves 3-pinnate, deep-green; segments linear, pointed. Flowers white or yellowish-white. Root fleshy, fusiform or conical, either white-orange or reddish-yellow.

There are many varieties known to the market gardeners, differing from each other only in the size, shape, and color of the root, which is a valuable culinary vegetable.

Geography. - The carrot is found under cultivation in the British isles, all over the continent of Europe south of 60 degrees, especially in France and Germany, in northern Africa, southwestern Asia, China, Japan, and many of the Pacific islands; in fact, it has found its way into all parts of the world where European settlers have established themselves. It was brought to North America by English colonists, where it has run wild and become a pest. 


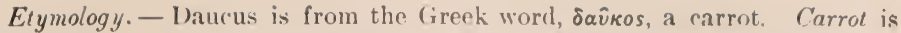
said to come from the Celtic word kar, red. Sativa, the sprecific name, is Latin, meaning "sown" or "cultivated."

History. - When or where the carrot was first introducer into culinary use is not known. It wats known to the Greeks and Romans at least three hundred years before the beginning of the ('hristian era.

Use. - The carrot is an important culinary vegetable, used to flavor soups, sauces, etc., and is eaten with meats; boiled and reduced to a pulp it is used for pies and custards. It is a very important feed for horses and cattle, and especially for milch cows.

CARUM, I. Flowers hermaphrodite or polygamous. Sepals wanting, or very small. Petals white, 5, unequal, dilated, emarginate, sub-two-lobed or entire, point short, sometimes long and turned in. Fruit oval or oblong-ovoid, compresied, and without wings ; carpels 5-ribbed, lateral ribs marginal; umbels perfect. Leaves pinnate. Biennial.

1. C. petroselinum, Willd. (Parsley.) Stem angular or striate, 2 to 4 feet high, hranched. Leaves smooth and glabrous, decompound, parts incised segments of the lower ones wedge-shaped, terminal ones trifid. Flowers in terminal and axillary umbels Involucre, a single linear leatlet, occasionally made up of two or more bracts. Petals roundish, incurved, greenish. Fruit ovate. Carpels 5-ribbed. July.

In eommon witl all plants that are propagated from seed, parsley sports freely, hence cultivation develops varieties. Dwarf Curled, Mitchell's Matchless, Myatt's Triple Curled,

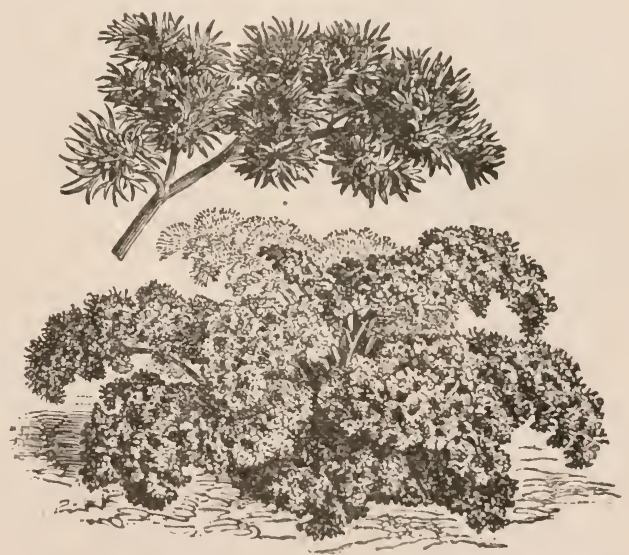

Carum petroselinem (Parsley). Hamburg Large-lionted and Naples or Celery l'arsley, are the most prominent

Geography. - larsley is found in the middle and sonthern edge of the north temperate zone, and grows well in molerately fertile soil.

Etymology. - Carmm, the generie name of the palsley, is from Caria, in Asia Minor, where it was first hrought to the notice of man. Petroselimum, the specific name, is from the Greek $\pi \dot{\epsilon} \tau \rho \alpha$ a rock, anl $\sigma \epsilon \dot{\lambda} \iota \nu o \nu$. parsley, hence rock parsley, due to the place where it grows, - among the rocks. Parsley. the common name, is a corruption of Petroselinnm

History. - Parsley is found wild in the Mediterranean countries of Europe and in Asia Minor. It has been seen in Japan unter cultivation, and is common 
in the gardens throughout middle Europe and the British Isles; it was brought to northeastern America by English colonists, and has spread over the whole country, but is rarely seen outside of cultivation. It was used by the Greeks and inhabitants of the Levant to decorate the bridesmaids at the marriage feast, to make wreaths, and to adorn graves. A superstition is also attached to it which no doubt arose from its connection with the dead.

Use. - Parsley is used as a flavoring lierb in somps, sauces, and in meat and fish stews. 'To garnish meats, fish, and salads, there is perhaps no flavoring herb more widely used.

'The medicinal properties of parsley, as well as its flavoring quality, are due to an active principle known to chemists as apiol. This substance is said to have the same effect upon the human systom as quinine, and was formerly used in intermittent fevers. Infusions of the roots are administered as a cure for fevers and affections of the liver.

2. C. Carui, L. (Caraway.) Stem smooth, channeled, branching, 3 feet in height. Leaves smooth, deep-green, bipinnate, cut; segments narrow, linear, pointed. Flowers numerous, in terminal umbels; involucre composed of narrow leaflets, sometimes wanting; petals 5, nearly equal, white or pinkish; filaments slender, rather longer than the petals; anthers small, roundish; orary inferior, bearing short capillary styles with simple stigmas. Seeds two, bent, one quarter of an inch long, brown; striæ 5 , the interspaces furrowed; seed ripens at the end of the second season. Root fusiform and edible.

Geography. - The geographical range of the caraway is between $42^{\circ}$ and $60^{\circ}$ of the north temperate zone, and it is said by $A$. de Candolle to be indigenous in a belt from Lapland to Siberia. It grows in Great Britain and all parts of the continent south of $60^{\circ}$. It is also found in northern Africa, Hindustan, and Burmah.

Etymology. - Carui is derived from carum, whose etymology is given under parsley.

History. - Mention was made of the caraway in an account of Morocco in the twelfth century. In the fourteenth century a custom of eating caraway seeds with apples had been established in England. To this custom Shakespeare refers in Henry IV., Part II., Act Y., Sc. 3, where Shallow addresses Silence: "Nay, you shall see mine orchard, where, in an arbor, we will eat a last year's pippin of my own graffing, with a dish of caraways, and so forth." The custom of eating baked apples with caraway seeds is still kept up at one of the colleges of the University of Cambridge, England, aud at the ceremonial feasts of some of the London livery companies.

Pliny makes Caria the home of the caraway; if so, it must have spread rapidly, for it is growing in most parts of Europe without cultivation. It is common in the gardens of northeast America, and is frequently found outside of cultivation.

Use. - The root of the caraway plant is eaten as a table vegetable in the north of Europe. The seeds are employed to flaror bread, cake, confectionery, pastry, and cheese; and in Russia, Sweden, Germany, and in parts of the United States, to flavor alcoholic cordials.

An essenticl oil (oil of caraway) is procured from the seed by distillation, large quantities of which are made in Leipzig. As a medicine, it is aromatic and stimulant, and mnch used to disguise the unpleasant taste of other drugs. Manufacturers of faucy soap use it in large quantities. 


\section{ORDER XXIX. RUBIACEE.}

Flower's perfect, rarely unisexual, sometimes defective, but usually regular. Calyx superior, tubular, 2-6-toothed, or wanting. Corolla superior; petals united; limb 4-6-toothed or lobed; segments valvate in the bud. Stamens, 4-6 insertert on the tube of the corolla. Ovary inferior. Style simple, bifid or multifid; stigmas at top or sides; ovules, 1 or more in a cell. Fruit a capsule, berry, or drupe. Seeds in various positions. Leaves opposite and stipulate or whorled, simple. entire. Trees, shrubs, and herbs.

Number of genera, 337.

CINCHONA, L. Calyx cup-shaped, 5-toothed; corolla tuhular, limb 5-parted; stamens 5-epipetalous; anther's "-celled; pistil divided at top ; capsule 2-celled, many-seeded, opening at the base. Fruit winged. 'Trees.

1. C. officinalis, L. (Perurian Bark; Jesuit's Bark.) 'Trunk 40 to 50 feet high, and 12 to 18 inches in diameter; branches stout. Leares opposite, elliptical, entire, and nerved, smooth on the upper side, hairy beneath; petioles short. Flowers panicled; ealyx campanulate, margin 5-toothed; corolla tubular, spreading at the throat, and divided into 5 segments; edges serrate; stamens 5 ; corolla downy on outside.

2. C. calisaya, Wedd, (Calisaya or Yellow Cinchona Bark.) Trunk 50 to 100 feet in height, and 5 feet in circumference. Leaves oblong and obtuse, varying in size and shape, 3 to 6 inches long. Flowers in pyramidal panicles, pink. Fruit in orate capsules, 2-celled; seeds winged.

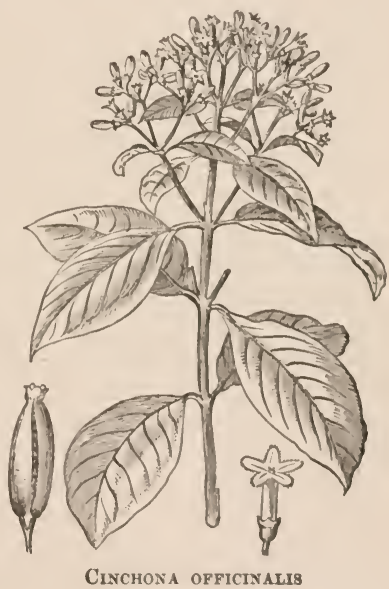

(Peruvian Bark).

3. C. micrantha, Wedd. Trunk 30 to 40

feet in height, and from 10 to 15 inches in diameter. Leaves from 4 to 12 inches long, and 2 to 6 inches wide, oblong, smootl, and shining above, pitted beneath at the axils of the veins. Flowers small, in loose, leatiess panicles.

4. C. succirubra, Pavon. (Red Cinchona Bark.) Trunk from 60 to 80 feet high. Leaves broad, oval, 12 inclies long, glabrous above, pubescent beneath. Flowers, in large terminal panicles, rose-colored; seed-vessels an inch in length. Sap and wood red. Western slope of the Andes, near the equator, three to five thousand feet ahore the sea.

Species. - There are thirty-six well marked species of cinchona, and unmerous varieties, all natives of the Andes. Those described here furnish the barks of the shops of the Inited States and Great Britain; but the trees that furnish the materials for the production of quiuine are the C. P'itarensis, C. cordifolia, C. lancifolia, and other species which grow in the Luited States 
of Colombia. The barks of these species are admitted into market only when they yield two per cent, or over, of alkaloids.

Geography. - The geographical home of the cinchona is in the tropical Andes, extending from $10^{\circ}$ north to $20^{\circ}$ south latitude, a region about two thousand miles long, mostly on the eastern slopes, in Bolivia, Peru, Ecuador, New Granada, and Venezuela, from 5,000 to 11,000 feet above the level of the sea; the best barks are produced where the temperature ranges from $54^{\circ}$ to $68^{\circ}$ Fahrenheit. The minimum height for the best barks is not below 5,000 feet. It grows well in similar heights and temperatures in India, where it has been introduced and is under successful cultivation. It is also cultivated in Ceylon and in Jamaica.

Etymology. - The generic name cinchona was given to this plant by Linuæus, to honor the Countess of Chinchon, who while residing in Lima was cured of a fever by the use of the bark. The specific names are derived as follows: Officinalis signifies "useful," or "of the shops," and is derived from the Latin word officina, a shop. Micrantha is from the Greek word

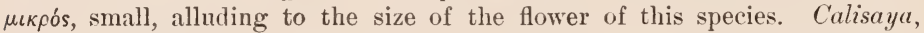
which produces the "yellow bark" of commerce, has a history which is somewhat obscure. Markham gives the following derivations: 1st, from calla, a remedy, and salla, rocky, meaning a medicine growing among the rocks. 2d, from ceali, strong, and sayay, become, meaning a medicine that will strengthen the patient. 3d. In Caravaya is a family of caciques, by the name of Calisaya, one of whom distinguished himself in the revolt of 17801781 , and it is suggested that this species was named to honor him. Succi. rubra is from succus, juice, and rubra, red; hence, red-barked cinchona.

History. - It is stated upon good authority that the aborigines were not acquainted with its medicinal properties before the country was visited by Europeans. Humboldt states that it is not upon the list of native remedies.

There is a story as follows: A savage was taken ill with a fever in the forest, near a pool of water, into which a number of cinchona trees had fallen, whereby the water had been made bitter. He was offered some of this water, as no other could be procured, and drinking, was speedily cured. Thus the curative qualities of the bark were revealed.

In 1638 Ana de Osoria, wife of the fourth count of Chinchon, viceroy of Peru, lay dangerously ill with a tertian fever at Lima. When accounts of her sickness reached Don Francisco Lopez de Canizares Corregidor of Loxa, he sent the bark to her physician, Don Juan de Vega, who administered it to his patient, and thereby effected a speedy cure.

The countess was so grateful for her recovery that she determined, on hel return to Europe, two years later, to take with her a quantity of the powdered bark, to be administered to the sufferers from chills and fever upon her hus. band's estate. From this circumstance it was called Countess Powder, and for a long time retained that name. De Vega, on returning to Spain, earried with him large quantities, which he sold in Seville at 100 reals a pound. Linnæus to honor the countess, named the tree cinchona, which was intended to be "Chinchon," and the error in spelling has never been corrected.

Another account relates that it was made known to the civilized worla through a monk, who, lying at the point of death with a fever, received a, decoction of the bark from the hands of a native medicine man, and was cured. It is not improbable that both these accounts are correct, and that the circumstances occurred as stated. The tree is a native of the tropical Andes, on a chain of mountains in Peru. 
The history of the cinchona would be defective without some account of its introduction into India. In 1839, I)r Royle, the English East India botanist, drew the attention of the home government to the importance of providing a febrifuge for medical practice among the natives, and adrocated the introduction of the cinchona into India.

In 1859 the British government sent an expedition to South America to procure seeds and plants of all the species possessing commercial value. The party encountered great difficulty and endured great hardships, but secured seeds and living plants, which were taken to England and sent to India, where suitable localities in the mountains were selected, and a successful plantation was commenced. Previous to this, the Dutch East India Company had sent an agent to South America who had procured seerls, but when the trees came to maturity, they proved to be worthless. 'Ihose taken to India and C'eylon were very productive, and they far exceed in value the trees in a native state.

In 1878 a Germau company established a plautation in Bolivia, where there are now about $10,000,000$ trees under cultivation. Though only a little more than a quarter of a century has elajsed since the first plantations were com. menced, the barks which supply the markets of the world are nearly all from cultivated trees.

Chemistry. - The cinchona barks yield to the chemist a number of alkaloids, the principal of which are the following :-

Quinia, $\mathrm{C}_{20}, \mathrm{H}_{24}, \mathrm{~N}_{2}, \mathrm{O}_{22}$.

Cinchona, $\mathrm{C}_{20}, \mathrm{H}_{24}, \mathrm{~N}_{2}, \mathrm{O}$.

The lowest per cent of alkaloids in the barks of commerce is 2, and the highest $13 \frac{1}{2}$. This high per cent is obtained from the C. officinalis, var. lanceolata, under cultivation; 9 per cent of the $13 \frac{1}{2}$ is Quinia.

Quinia and Cinchonia were discovered in 1820 by the chemists Pelletier and Caventon, who secured the prize of 10,000 francs offered by the French Academy of Science.

Preparation. - The mode of collecting the bark is to cut down the tree, and then strip the bark, after which it is dried in the sun and sewn up in green ox-hides, and exported in large bundles or packages.

This wasteful mode of collecting the bark is not practiced upon the trees planted in India, but alternate strips are removed; the wounds are then bound up, and when properly healed the other spaces are stripped, by which means the tree is indefinitely preservel. Trees under cultivation yield barks far richer in alkaloids, and the successive new layers of bark are more and more highly charged with the valuable products.

Use. - The substances yielded by the cinchona barks are powerfully tonic, antiseptic, and antiperiodic, and the bark itself as a whole is highly astringent. Quinine, the sulphate of quinia, contains the properties of the bark in the most concentrated form.

No substance in the materia medica is of such importance in the healing art where malarial and intermittent fevers prevail. Though it is a specific as a febrifuge, it is administered in all complaints that attack the system at intervals, as neuralgia, rheumatism, etc.

It has been found that a solution of quinine in 20,000 parts of water will destroy bacteria. It is believed that malarial fevers are due to the direct introduction into the blood of living organisms. Quinine is supposed either to destroy these organisms or to render the coudition of the blood unfarorable to their developmeut. 
COFFEA, I. (Coffee.) Calyx, tubular, 5-toothed; corolla funnelshaped, separated at the crown into 5 reflexed lanceolate divisions; stamens 5 in number; anthers oblong; style, with 2 stigmas; ovary 2-celled. Shrubs.

1. C. Arabica, Alpinus. Stem 10 to 15 feet in height, and 2 to 4 inches in diameter, diffusely branched; branches slender and drooping; bark greenishbrown. Leaves elliptical-lanceolate, entire, crenate or wavy, 3 to 5 inches long, on short foot-stalks, opposite and evergreen. Flowers white, in axillary small, nearly sessile, clusters. Fruit, a dark-red berry, in form of a cherry, with a glutinous, tasteless pulp inclosing 2 plano-convex seeds about three eighths of an inch in length, two eighths wide, a groove extending along the longer axis of the plane side.

2. C. occidentalis is no doubt a variety of C. Arabica, from which have arisen most of the varieties which are known in South America.

Like all plants grown from the seed, coffee sports freely, hence we have many species, among which the following are well marked and constant.

Growing in Brazil :-
3. C. Australis.
7. C. jasminoides.
11. C. meridionalis.
4. C. nodosa.
8. C. parvifolia.
12. C. stipulacea.
5. C. biflora.
9. C. magnolifolia.
13. C. minor.
6. C. paguiodes.
10. C. sessilis.
14. C. truncata.

Growing in the East Indies are four species:-
15. C. semiezserta.
17. C. tetrandra.
16. C. Travancorensis.
18. C. Wightiana.

Three species are cultivated in Mexico:-
19. C. Mexicana.
20. C. obovata.
21. C. rosea.

In New Granada there is one species:-

22. C. spicata.

The following species grow in Peru:-

23. C. nitida.

26. C. umbellata.

29. C. ciliata.

24. C. racemosa.

27. C. verticillata.

30. C. acuminata.

25. C. subsessilis.

28. C. longifolia.

In Java there are two prevailing species under cultivation :-

31. C. densiflora.

32. C. Indica.

In the Molucca isles one single species prevails :-

33. C. pedunculata.

In the Sandwich Islands two species are cultivated :-

34. C. Chamissonis.

35. C. kaduana.

In Arabia and Abyssinia the C. Arabica prevails, and is very constant. On the western coast of Africa two species are cultivated: C. laurina, and C. Liberica ; while on the eastern coast the C. Mozambicana and the C. Zanguebarica are grown.

Geography. - Coffee will grow and ripen its fruit in all regions of no frost and is grown in all tropical and subtropical countries. The market is largely 
supplierl from South Imerica and the East India islands. The principal coffeegrowing regions are Brazil, Gnatemala, Cuba, British West Inclies, St. Domingo, Java, Padang, Simmatra, Maccassar, Ceylon, Lritish India, and Manilla.

Etymology. - Coffee is said to have derived its name from the Turkish queh, a decoction of berries. The common name is a corruption of the botanic name. 'The specific name of the principal species comes from Arabia, where it was first used.

Mistory. - Persia, the home of delicions fruits, seems to have given birth to coffee. Thence sometime in the fifteenth century it was carried by Magalleddin Mnfti of Aden into Arabia Felix, where it was first used, not as a heverage, but for medicinal purposes.

Coffee was not known in commerce till about the middle of the sixteenth century, when it became an article of trade in the markets of Constantinople.

The government of Syria forbade its use, ostensibly because of its intoxicating qualities. After its introduction into Constantinople, the Mohammedan priests complained that the mosques were neglected, while the coffee-honses were thronged. The government interfered and forbade its sale, and a strict police espionage was instituted; but as it was found impossible to suppress its sale, the state levied an excise tax on it, and thus reaped a large income from it.

Coffee is consumed in Turkey in large quantities. There was a time when it was regarded as so necessary to the people that

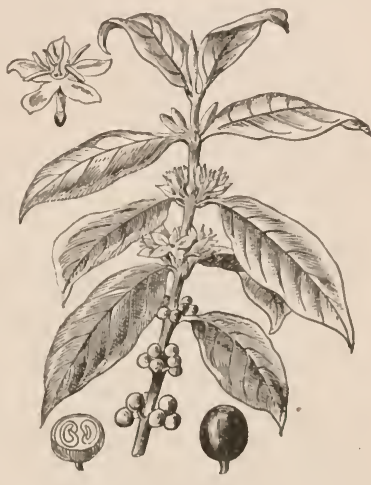

Coffea (Coffee).

it became one of the legal causes for divorce when a man refused to furnish his wife with coffee.

Though the coffee tree in cultivation is supposed to have been brought to Arabia from Persia, yet there is good reason to believe that it is indigenous in Arabia Felix, and in Africa, on the opposite shores of the Red Sea. Ranwolfins took it into Europe in 1573; hut its introduction is traced also to the Dutch, who procured berries at Mocha, which were planted at Batavia. In 1690, a plant was sent to Amsterdam, which was planted and bore fruit (under glass). The seeds of this fruit were then planted, and many young trees were produced therefrom. 'These trees were sent to the gardens in the I)uteh possessions in the East Indies, and some of the plants were presented to Louis XIV. by the Dutch anthorities; these were placed under the charge of Jussieu, by whom young plants were sent to the French West Indies, whenee the coffeetree has spread, not mly thronghont the islands, but to the continent of south America.

All the coffee grown in the new world is saicl to have sprung from a single plant which a French naval oflicer carried to Martinique in 1720, depriving himself of water when parching with thirst in order to nourish his coffee-plant. From this tree, it is said, all the American tropical colonies obtained their seed, which has multiplient to such an extent that Brazil, Mexico, and the Wrest Indies proluce as much coffee as Java and ('eylon.

It is not known when coffee came into nse in western Europe as a beverage. The Venetiaus, who traled with the Fist, no loubt first nsed it. P1. FL. -12 
It was not known in Italy in 1615. In 1645, some men returning home from Constantinople to Marseilles took with them a supply of coffee, with suitable vessels for preparing it for the table; it was thus introduced into France. About twenty years later a house was opened at Marseilles for the sale of coffee.

In 1671 the first coffee-house was established at Paris. Other places were soon opened for its sale, but upon a very humble scale, and fashionable people did not resort to them. Some Frenchmen, shrewdly guessing the reason for a want of genteel patronage, fitted up a coffee-house in a liberal and elegant style, to which well-bred people were attracted. About the same time a successful coffee-house was opened at London.

Nieber, in his account of coffee, maintains that it was grown upon the hills of Yemen in Arabia, introduced from Abyssinia by the Arabs, long before it was used by Europeans.

Chemistry. - Coffee yields to chemical analysis the same substances that are found in tea, though in different quantities; hence the effects upon the nerves and the circulation are similar to those produced by tea.

In 100 parts of tea in a dry state there is one part of thein; in the same quantity of coffee there is only one half as much. Of nitrogenous substances, there are in tea 25 parts, in coffee, 13 ; but of essential oil, tea has about $\frac{3}{4}$ of 1 per cent, while coffee has only $\frac{3}{10} \overline{0}$ of 1 per cent.

Tea has 12 parts of tannic acid, coffee has $5 \frac{1}{2}$. Potash, phosphoric acid, and oxide of iron are found in both in nearly equal quantities, amounting to about five per cent.

Preparation. - Coffee is prepared by first browning it over a gentle heat, called burning or roasting; it is then crushed or ground ; hot water is applied to it and kept at the boiling-point for a short time; some substance is then mixed with it to precipitate the grounds or powdered coffee held in suspension; after which, the liquor is poured into cups, and milk and sugar are added to suit the taste.

Use. - In most families it is used for breakfast, and for dinner. It is so well known that further description is not necessary.

Statistics. - No other warm dietetic beverage is so largely used as coffee. It is the daily drink of more than $100,000,000$ people We have no means of knowing the actual consumption in Turkey and Africa, but the tables of import show the consumption in other countrues. In the several coffeedrinking countries the consumption is as follows:-

In the United States of North America, 400,000,000 of pounds are annually consumed, which is equal to 8 pounds for every man, woman, and child. The amount used in Holland is equal to 21 pounds for each person. In Belgium and Denmark the consumption is equal to 13 pounds for a person; in Norway, 10 pounds; in Switzerland, 7 ; and in Sweden, 6 . These are the great coffeedrinking peoples of Europe and America. In the kingdom of Great Britain, a greater amount of tea is used than in any other nation, amounting to about 4 pounds for each individual; the amount of coffee consumed is only one pound to each person.

CEPHAËLIS, Swartz. Calyx bell-shaped, toothed; corolla tubular, inflated at throat, 5-parted; stamens 5; stigmas 2-parted. Flowers crowded into a head, inclosed in a 5-leaved envelope. Berry 2-seeded. Shrub. 
C. Ipecacuanha, Richaril. (Ipecac.) Ntem pubescent at top, 18 to 24 inches high; root 4 to 6 inches long, about the size of a goose-yuill. Leaves, about 6 in number, opposite, petioled, oblong-obovate, acute, entire, 4 to 6 inches long, 1 to 2 widle, rough above, downy and veined beneath; stipules clasping. membranous at base, split above into numerous bristle-like divisions, falling. Flowers, 8 to 10 , small, white, each with a green bract, forming a little head on an axillary foot-stalk, and inelosed by a l-leaved involucre, cut into + or 6 segments. Fruit, an orate, purple berry, becoming black; seeds small, planuconvex, 2 in number.

Geography. - The cephaëlis is a tropical and subtropical plant, and flourishes in rich, damp woods.

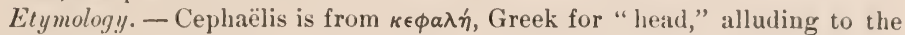
form of inflorescence. Ipecacuauha is from the Brazilian ipecauguen, roadside, sick-making plant,

History. - This drug is said to have been introlluced into the $m a$ teria medica by John Helvetius, a Dutch physician practicing in Paris. He first nsed it as a seeret remedy in dysentery, and was induced by Louis XIV. to reveal his secret, for which the sum of 25,000 francs was awarded him. 'The home of the Cephaelis is the damp, rich wools of the valley of the Amazon. It is found in Bolivia and Colombia, has been introduced into the Wrest Indies and Hindustan, and is under successful cultivation in India.

The American ipecacuanha is the root of the Euphorbia Ipecacuanha; it has a local reputation as an emetic, and is occasionally nserl

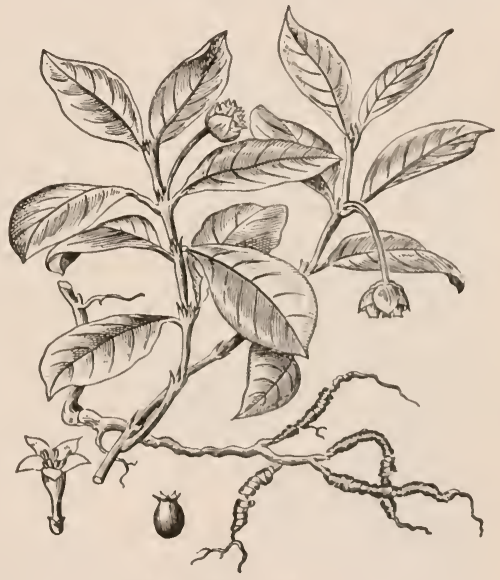

Cefhä̈lis Ipecacuanha (Ipecac). as a substitute for the South $A$ merican dirng.

Chemistry. - The active principle of ipeeac is emetine, of which it contains less than 1 per cent. Pelletier discovered, or rather isolated, it in $1 \leqslant 17$, and found it to he an alkaloid.

Use. - The medical properties are astringent, diaphoretic, expectorant, and emetic. The active principle is largely in the bark of the root, thongh the woudy part of the root also possesses it.

It forms, in combination with opium, the well-known Dover's powders. It is an important medicine in dysentery, and is an ingredient in most cough merlicines.

RUBIA, Tourn. (Madder.) Calyx-tube eggr-shaped, j-toothed : corolla rotate, 5-parted; stanens 5. short, 2 styles, united at the base. Fruit in twos, berry-like, smooth and subglobular. Perennial, herbaceous, does not flower until the third year.

1. R. tinctorum, I. Stem weak, 4-angled, angles armed with prickles turned backwarls, or downwards, trailing or climbing. Leaves in whorls of 
6, lanceolate, margins and midribs aculeate; flower-stalk axillary or terminal, trifid. Flowers, brownish-yellow. Root consists of many long prickly shoots half an inch in diameter, and 3 to 4 feet long, descending deep into the ground, all united near the surface in a sort of head.

2. R. Chiliensis is used as a dye in South America.

3. R. cordifolia, a native of Persia, is largely used in Hindustan, both as a dye and as an article of medicine. Other species are used for dyes in the countries where they grow.

Geography. - Its geographical range is the middle and southern parts of the north temperate zone. It is indigenous to western Asia and the Mediterranean countries of eastern Europe. It is cultivated successfully in Hindnstan, China, Japan, and Northern Afriea, Turkey, Greece, Spain, France, Germany, and Hollaud, and in the middle and central United States of North America.

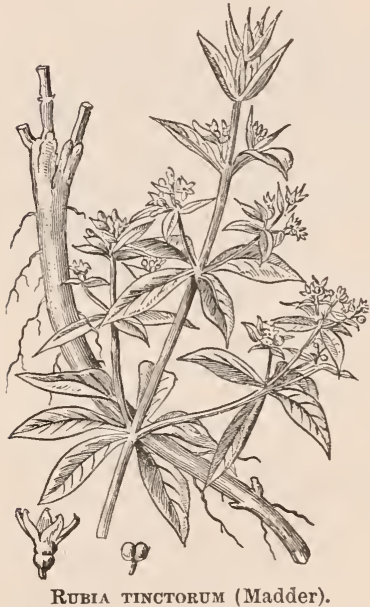

RUBiA TINCTORUM (Madder).

It has been cultivated for market in Ohio and Delaware. It is shipped to England from the ports of India and from the eastern Mediterranean, and thence to America.

Etymology. - Rubia is derived from the Latin word ruber, red, from the color of its root. Tinctorum is from the Latin word tinctor, a colorer. Chiliensis is derived from Chile, the home of this species. Cordifolia, from the Latin, refers to the heartshaped leaves. Madder is derived from the Sanscrit madhura, sweet, or tender, alluding to the character of the root.

History. - The madder was known to the ancients, and it is believed that some of the cloths in which the mummies were rolled were colored with madder. It was one of the most important dyes known to the Greeks and Romans.

Preparation. - The long, slender roots are dug when the plant is three years old, and when dry are about the thickness of a goosequill, and of a deep red color. The method of preparation is to grind the root and wash it with water, which takes out the inert matter, among which is sugar. Straining through woollen cloth leaves the bruised root upou the cloth; the root is then dried and reground. The liquor is preserved in vats and allowed to ferment, after which it is distilled, and yields a quart of alcohol for every 100 pounds of root.

Use. - Madder is used for a dye, especially in the printing of muslins. The fine Turkey red is produced by madder. By the use of chemicals, every shade of red, purple, lilac, and rose-color can be obtained from the madder-root. The color is suspended both by alcohol and by water. As a medicine, it excites the secretory organs, and especially the kidneys. IVhen fed to cattle, it enters into the milk and other fluids of the body, and even colors the bones.

The Alizarine of the shops is artificial, and is a derivative of anthracine, a coal-oil product. Since its introduction, the cultivation of madder has almost ceased; over a million acres of madder land have gone out of cultivation in France alone. 


\section{Order XXX. COMPOSIT EE.}

Flowers in close heads, polygamous, monocions. The central flowers in a liead are called the disk; the narginal flowers, if of different shape from the disk, form the ray. Flower heads each on a common receptacle, inclosed by an involucre of scale-like bracts; the whole head resembling a flower, and the involucre like its calyx; each of the proper flowers (termed florets) having the calyx adhering to the ovary, its limb represented by a hairy pappus or scales, or wanting. Calyx tube adhering to the ovary, its limb usually made "1 of hairy bristles or scales, occasionally wanting. Corolla either tubular or strap-shaped, generally j-tootled or lobed; stamens 5, inserted on the corolla; anthers united in a tube around the 2-cleft style. Fruit an akene, one-seeded. Leaves alternate or opposite, frequently divided or cut, without stipules. 'The florets, or little flowers, are aggregated upon a receptacle, the tubular florets forming a circular disk, while the strap-shaped ones form a circular ring outside the disk ; in some cases all are strap-shaped. 'The under side of the receptacle is clothed witis or included in a foliaceous aggregation of bract-like scales, which take the place of a common calyx, and are called the involucre. Nearly all herbs. A very large order, containing 766 genera, about one tenth of all flowering plants.

INULA, L. Heads many-flowered, with an imbricated involucre. Ray flowers numerous, pistillate; disk flowers perfect. Receptacle naked; pappus simple, scabrous; anthers with two bristles at the base.

I. Helenium, L. (Elecampane.) Stem 5 feet high, stout, coarse, furrowed, downy, and branching above. Leaves clasping above and petioled at the root, orate, rough, downy underneath, very large, 2 feet long and 1 foot wide; serrate, crowded with a network of veins, midrib large. Flower-heads large, solitary, and terminal; rays linear, yellow ends, 2-3-tootherl. Flower's in August.

Geography. - It grows freely thronghont the middle of the temperate zone, both in Europe and North America as well as $A$ sia, in rich, damp soil.

Etymology. - Ileleninm, the specific nime, comes from the Greek name of the plaut, é $\lambda \in \operatorname{\nu } \iota \nu \nu$, griven in honor of

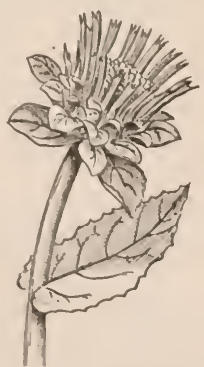

INULA HELENTUM (Elecampane).

Helen of Troy. Imula, the generic name, is the Latiniond form of the same.

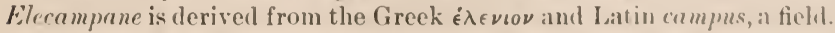

History. - The Elecampane was eaten by the ancients in the conntries of the Levant, and was used by the Egyptiaus for medicine. Ilosenrides deseribes it. 'Thunbern saw it in Japan, near Jedlo, both under cultivation and without. He hearl un . Japanese name, hence inferred that it was introduced there by Europeans It is indigenous to middle Asia, and was carried west throughont middle Enrupe by travellers, and was brought tu northeast I merica by kuropean colouists. 
Use. - It is used in the materia medica as a tonic in weak digestion and nervous complaints, throat diseases, and as an expectorant.

ANTHEMIS, L. (Camomile.) Flower-envelope, in form of a hemisphere; scales equal; rays numerous, pistillate; akenes terete, angular, or striate, crowned with a border. Receptacle convex. A perennial herb.

1. A. nobilis, L. (Roman Camomile.) Stems numerous, 6 to 12 inches long, spreading, and decumbent. Leaves 1 to 2 inches long, sessile, and

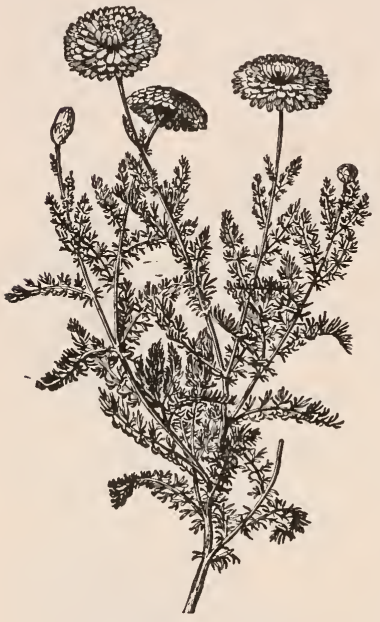

ANTHEMIS NOBILIS

(Roman camomile). velvety; divisions of the leaves linear. Flower-heads terminal, on long, axillary pedicels; rays white; disk yellow; scales of receptacle broad and obtuse; whole plant has a pleasant aromatic odor and bitter taste, especially the flowers.

Var. flore pleno has double flowers.

2. A. arvensis, L. (Common camomile. Field camomile.) Differs from A nobilis very little, except that the flowers are smaller, and the bitter taste is less agreeable. It is a troublesome weed in corn and potato fields and on roadsides.

Geography. - The anthemis grows well throughout the middle and southern portions of the north temperate zone, in Europe, America, and Africa. The home of the camomile is western Europe. It is cultivated in Italy, France, Spain, and Germany, but the best is produced in England, and was brought to northeast America by European colonists. By cultivation, the yellow-disk florets change into ray florets, and become white; they are then called "double." But their medicinal character is thereby damaged.

Etymology and History. - Anthemis is from the Greek ä $\theta 0$, a flower, due to the profusion of flowers it produces. Nobilis, the specific name, Latin for "noble" or "grand," is due to the large size and showy character of the Hower of this species. Arvensis is from the Latin arvum, a plowerl field, where the plant loves to grow. Camomile is from the Greek $\chi a \mu a i$, on the earth, and $\mu \hat{\eta} \lambda o \nu$, an apple, due to the apple-like smell of the flower. There is a popular belief that the worse the usage it receives the better it grows. Shakespeare, in his Henry IV., says: "For though the camomile the more it is trodden on the faster it grows, yet youth the more it is wasted the sooner it wears."

Use. - The medicinal properties of camomile are stimulant and tonic, and it is a favorite domestic remedy for stomach disorders and loss of appetite. The effects, besides being stimulant and tonic, are also carminative and anodyne. A strong infusion, administered warm, is emetic. The flowers are used in domestic practice for fomentations and poultices. 'The extract of the flowers, as well as the essential oil, is used in the manufacture of bitters. 'The flowers 
are chewerd and the saliva swallowed for stomach disorders; and it is recorded that the ancient Egyptians made an ointment by bruising the flowers with oil, which they used for skin diseases. The constituents of the flowers are a fixed oil, contained in the seeds; an essential oil, upon which the odor depends; and a substance obtained by extraction, to which the bitteruess is dne. The essential oil is obtained by distillation.

CHRYSANTHEMUM, Tourn. Heads many-Howered, with numerous pistillate rays; disk flowers fertile. Involucre, a flattened hemisphere; scales short, appressed, thin, and imbricated. Receptacle Hat or convex, naked. Rays usually elongated; corollas of the disk flowers flattened or ¿-winged, below 1 -to j-toothed. Akenes short, ribbed or angled, truncate at the tip, often destitute of pappus. Herbaceous perennials, or anumals.

There are many species belonging to this genus. 'The celebrated Persian insect-powder is the pulverized flowers of C. roseum, C. carneum, and C. Wilmoti. The Dalmatian insectpowder is the product of C. cinerariffolium, Tres., var. rotundifolium. In the south of Europe the C. corymbosum also furnishes an insect powder.

C. carneum, M. B. (Chrysanthemum.) Stem 18 inches high. Leaf smooth, bipinuate; segments of prismal acute. Flower-heads one and a half inches broad; involucre imbricated ; margin brown and scarions ; receptacle convex, naked. Ray-flowers 20 to 30 , ligulate, nerved, and 3-toothed; disk-flowers numerous, tubular, 5-toothed. Akenes dark brown, angular, wingless, crowned with a short membranaceous pappus. Ray florets pale pink. Anthers projecting. Perennial.

Geography. - The C. carneum, C. roseum, and C. Wilmoti are found native in the mountainous regions of northern Persia, and the country east of the Black and Caspian

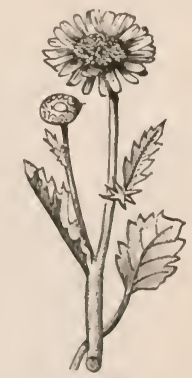

ChrysanthemuM CARXEUM

(Chrysanthemum).

Seas. The C. cinerariifolium is indigenous to Dalmatia, Montenegro, and Herzegovina, and has been introduced into southwestern Europe and California. The C. corymbosum is native in southern Europe.

Etymology. - Chrysanthemum is from the Greck $\chi \rho v \sigma o ́ s$, gold, and $\alpha_{\nu} \theta_{0 s}$, a flower, due to the yellow color of some of the species. ('ainenm, the specific name, is Latin for "Heshy," possibly derived from the thick Heshy leaf of this species. Roseum refers to the color of the flower. The name cinerarifolium. from the Latin word cinis, ashes, and folium, leaf, ash-leaved, is duc to an ashy down, with which the leaves are clothed. Wilmoti is for Wilmot. Rotundifolium, from rotundus, round, and folium, a leaf, round-leaved.

History. - The use of these flowers as an insecticide was known to the ancients in the countries of $\Lambda$ sia, but their introduction as articles of commerce in western Enrope and America is quite recent.

It is advertised nuder the name of l'ersian l'uwler, but very extravagant claims are made for the Dalmatian Powder.

Use. - The insect-powder is scattered abont the flower, or blown into cracks and crevices where the insects hide. It is especially nseful in the destruction of croton bugs, roaches, fleas, the house-fly, muspuitos, spiders, auts, etc., and 
all forms of insect life that infest dwellings. Lice upon poultry or cattle are exterminated by it. Scorpions and centipedes also succumb before its potent presence.

The best powder is produced from the flower when the pollen is just mature; in fact it has been supposed that it is the pollen alone that is effective, but it is elaimed that it is the odor that effects the destruction of the insect, and there seems to be reason for this belief; if that be true, it eannot be the pollen that canses the death of the insect, for the oclor does not reside in the pollen alone. Again, it has been asserted that the pollen possesses an independent odor from the plant, which is lestructive to insect life.

The powder is produced by grinding the flower's, which have been harvested just as the pollen is ripe. The powders of commerce are said to be adulterated with the pulverized flowers of anthemis.

It is destructive to the caterpillar family, as well as the coleoptera tribe, and this has been used as an argument against the odor theory. Professor Riley, in 1878, showed that it destroys the cotton-worm. The reason for its destructive character to insect life, while harmless to higher forms of existence, is not understood. Men, quadrupeds, and birds breathe it with impunity.

TANACETUM, L. Heads many-flowered and corymbosely cymose, staminate flowers occupying the central part of the head. Pistillate flowers, with a tubular :3-5-toothed

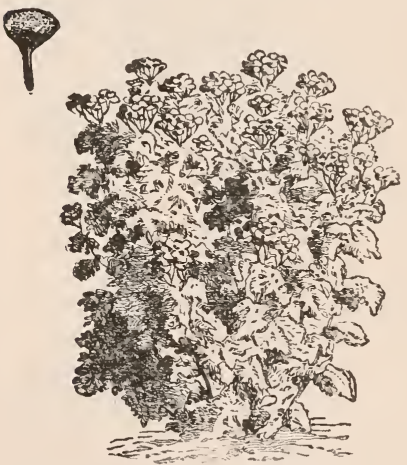

Tanacetum vulgare (Tansy). corolla, sometimes imperfect, or partly ligulate, arranged around the outer edge of the head; the little seed-vessels, ribbed or angled, with 3-5 ridges, flat on top.

T. vulgare, L. ('Tansy.) Stem erect, strong, angular, leafy, and branched above; smooth and purplish, 2 to 3 feet high. Leaves numerous, alternate, clasping, bipinnate ; segments oblong, eut, and serrate; the lower leaves bipinnate; the little leaflets trifid, spreading at the base along the petiole, deep green, roughish, though not hairy, deep green, paler beneath. Flowers yellow, in a terminal flat corymb; involucre hemispherical; scales imbricated, numerous, linear, lance-

olate, acute. Ray flowers few and inconspicnous, limb toothed. Disk flowers many, perfect, tubular, 5-cleft. Stamens 5; anthers united; all included within the corolla tube. Ovary oblong; style setaceous; stigma forked. Fruit small, obovate, angular, crowned with a 5-sided membranous pappus containing a single seed. August.

Geography. - The geographical range of the tansy is not very wide. Indigenous to the Crimea and adjacent parts of western Asia, it has spread through middle and western Europe and northern Africa, where it is found in gardens and by the roadsides near dwellings. It was brought to North America by European settlers early in the colonization of New England, whence it has sprearl throughout the Atlantic States, escaping from gardens, and has become naturalized. 
Etymology. - Tanacetum is said to he altered from athanasia, which is derived from the two Greek words, $\alpha$, withont, and $\theta$ ávaros, death, in allusion to the durable character of the fowers. I ulgare, the specific name, is f rom the Iatin arljective vulgaris, and signifies " common." Tansy is a corruption of Tanacetum.

History. - The Egyptians had a legend that their deity Isis discovered the properties of tansy. The plant was known to the ancients, but when and where it was introduced into medical practice is not known,

$U$ se. - The medical properties of tansy are stimulant, carminative, sudorific, and anthelmintic. It is used principally at the present day in domestic practice. The pulverized leaves, mixed with sirup, are said to be a specific for ascaris. A tincture is used for stomach bitters, and in some rural districts the hrnised leaves and flowers are used to flavor gin, taken for stomach troubles. It is also administered for agne, in the form of tea.

The medical properties depend upon an essential oil, called oil of tansy, obtained by distilling the whole plant

CARThamUS, L. (Sathower, Saffron.) velope imbricated, outer bracts leaf-like perfect; filaments smooth; without pappus; receptacle with bristly bracts or paleæ. Akene 4-angled. Annual.

C. tinctorius, l. (Nattlower.) Stem smooth, 3 to 4 feet high, much-branched near the top. Leaves ovate, lanceolate, sessile, and subamplexicault, teeth armed with sharp spines. Flowers orange-colored; heads large, terminal; florets long and slender.

Geography. - The Carthamus is indigenous to all eastern $A$ sia and the Levant, and has been introduced into Egypt and western Europe. It thrives well in France and sonthern Germany, and was brought by Enropean colonists into the eastern United States of North America, where it is cultivated for ormament.

Etymology and History. - Carthamus is derived from the Arabic worl quortom, paint.

The specific name, tinctorins, is from the latin word tinctura, a dyeing. Sufflower is supposed to be a contraction of saffron-flower, but its origin is not clear. The flowers were bronght into western Asia and southeastern linrope, overland, as early as $115 \mathrm{lb}$. "

Preparation. - To obtain the dyeing principle - carthanine - the young florets are pickerl and washed to free them from a solnble yellow coloring matter which they contain. They are then dried in kilns and powdered, and placed in an alkaline solntion in which pieces of elean white cotton are immersed. The alkaline solution having been nentralized with weak acetic acid, the cotton is removed and washed in another alkaline solution. The second solntion is again nentralized with acid, and carthamine in a pure condition is precipitated. Dried carthamine has a rich metallic green color. 
Use. - The coloring matter of the safflower is used in cosmetics for delicate red tints. Its principal value is as a dye. The Chinese, by the use of mordants, alkalies, and acids, produce from this plant the delicate rose, scarlet, purple, and violet colors that make their silks so valuable. The spaniards employ the flowers to color their soups. The l'oles mix them with their bread and cakes. The seed is a valuable food for parrots and other caged birds; domestic fowls eat it greedily, and fatten rapidly when fed upon it. The yellow coloring-matter is an extract, but the red is known to the chemist under the name of carthamine.

As a medicine the safflower is purgative when taken in large doses. The seeds yield an oil which is prescribed as a remedy for rheumatism and paralysis.

\section{Order XXxi. CAMPanUlace无. (Bell Flower.)}

Flowers superior, 5-merous, symmetrical; perianth and stamens adhering to the ovary; anthers distinct or united; ovary usually 2-3-celled; seeds numerous. Herbs or shrubs, with milky juice. Leaves usually alternate, exstipulate.

No. of genera, 53 .

LOBELIA, L. Calyx 5-parted; tube short, egg-shaped; corolla irregular, 2-lipped, upper lip 2-lobed, lower lip 3-cleft; stigma 2-lobed;

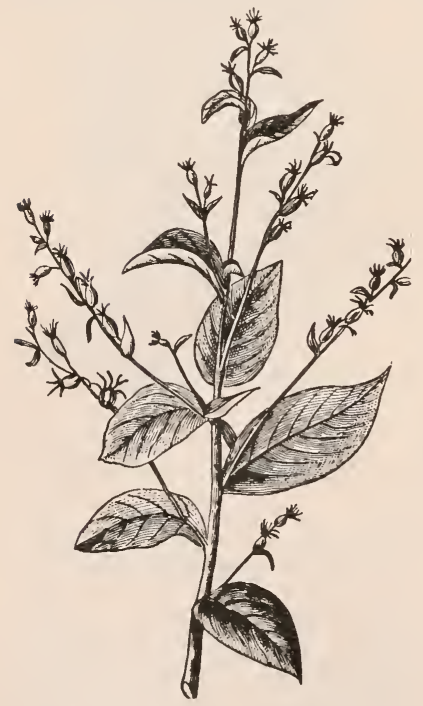

Lobelia inflata (Fmetic Weed). seed-vessels 2-celled, many-seeded, opening above. Leaves alternate. Biennial.

1. I. inflata, L. (Indian Tobacco. Emetic Weed.) Stem 10 to 20 inches in height, much-branched, clothed with hairs. Leaves ovate or lanceolate, irregularly toothed, sessile, lower ones blunt at the apex. Inflorescence a paniculated leafy raceme. Flowers pale-blue, on short pedicels, lobes of the calyx as long as the corolla ; pods inflated. Flowers in July.

2. I. cardinalis, L. (Cardinal Flower.) Stem simple, erect, 1 to 2 feet high, pubescent. Leaves lanceolate, pointed at each end, 3 inches long, pubescent and toothed. Flowers scarlet, in a terminal lengthened raceme, 1-sided, pedicels shorter than the bracts; stamens exsert, color deep flaming red, very showy. Damp grounds throughout the northeastern States. Easily cultivated.

3. L. syphilitica, I. (Blue Cardinal Flower. Great Lobelia.) Like the last, except in the color of the flower, which is bright blue, rarely white. Wet grounds by the roadsides, common in the northeastern states. Bears cultivation. 
This genus is very large, containing about 400 species, about 20 of which are indigenous to the Uuited States. Buth the L. cardinalis and L.syphilitica possess the narcotic poisonous properties of L. inflati, but in a miller degree.

Geography. - The geographical distribution of this genus is very wide, and it has representatives in all parts of the world; lut the L. intlata is confined to North America, rauging from North ('arolina to ('anada, and west to Kentucky.

Etymology. - The name Lobelia was given to this plant in honor of Mathias de Lobel, a native of Lisle, botanist and physician to James I. 'The specifie name inflata is Latin, and due to the circumstance that the pods are inflated. Emetic weed derives its name from the powerful emetic qualities which the plant possesses. Indian tobacco owes its name to the fact that this plant is used by the North Americau Indians, aud that its effects are similar to those of tobacco. It is expectorant and diaphoretic in small doses, but in full medicinal doses, nauseating and emetic. Cordinalis aud cardinal are names due to the large, showy, intensely red flowers of this species. Syphilitica derives its name from the fact that this plant is used as a remedy in syphilitic diseases, while the common name, blue cardinal, is due to the fact that this species, though otherwise similar to the L. cardinalis, has bright blue flowers.

History. - The only history the Lohelia inflatal can boast of is due to the controversy carried on some years ago by the physicians of the old school and the 'Thomsonian empirics, the latter claiming marvelous curative properties for it, and proclaiming it a useful and harmless medicine, while the regular physicians denounced it as a dangerous poison, to he avoided or used with great caution.

Chemistry. - The exact chemical character is not known. It yields to analysis an alkaloid liquid lobeliane, and an acid called lobelic acid; these substances reside in all parts of the plant.

Use.- Lobelia inflata has gainerl renown as an empiric remerly. It enters into almost every preparation of the Thomsonian physicians; they place great reliance upon its virtues as a tonic, emetic, and bilious excitant. The root of the I. syphilitiea is extensively used by the North American Indians.

\section{Order XXXII VACCINIACE正.}

Flowers 1-5-merous, regular. Calyx adnate to the nvary: petals united : 8-10 stamens; anthers opening at the apex : nvary several. celled. Fruit, a berry or drupe. Shrubs, with alternate exstipulate leaves.

No. of genera, 26.

GAYLUSSACIA, II. B. K. (IIuckleherry.) Corolla a short, egg-shaped tube, with a j-cleft edge; limb reflexed: stamens 10) anthers withont awns; cells tapering upwards, forming a sub-tubular process opening at top; style longer than stamens; stigma flat. Fruit glohular, flattened at top with 1-i cells: seeds many. Flower solitary. pedicellate, racemose, drooping, piukish. Fruit hlack m luluish

1. G. dumosa, 'Torr. and Fray. (I)warf Whortleloerry, or Huckleherry.) Clothed with fine hairs, and glaulular. Leaves ol, nng-ovate, mucronate, both sides green, shining when old; racemes long ; hracts oval, and as long as the pedicels, persistent; corolla campanulate. Finit hlack, tasteless. Var. Hirtella is distinguisherl by having the young branchlets, racemes, and leaves 
clothed with hairs. This variety is found along the coast of New Jersey, and south.

2. G. frondosa, Torr. and Gray. (Blueberry. Tangleberry. High Blueberry.) Smooth branches, slender and spreading. Leaves ovate, blunt, twice as long as wide, pale beneath. Racemes slender, loose; bracts sublinear; corolla globular, bell-shaped. Branches slender, with grayish bark. Flowers small, nearly globular, reddish-white. Fruit large, clothed with a glaucous bloom.

3. G. resinosa, Torr. and Gray. (Black Huckleberry.) Branched, rigid, somewhat hairy when young. Leaves petioled, oblong, egg-shaped, entire, sprinkled with resinous dots, 2 inches long, sometimes acute, shining beneath; jacemes short, 1-sided, bracteate; corolla conically egg-shaped or cylindrical, narrowed at the mouth. Flower's reddish; corymbose in dense clusters, small

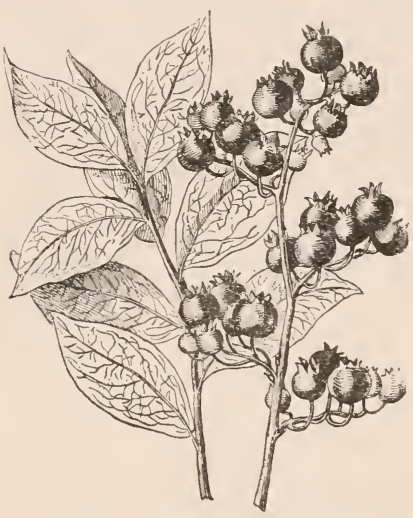

Gaylussacia resinosa (Huckleberry). and drooping, greenish- or yellowish-purple, longer than the stamens; style exserted. Fruit black, globular, sweet, and edible. Ripe in July and August.

Geography. - G. dumosa is found common along the coast of North America, from Newfoundland to Florida. The G. frondosa is common in New England, Pennsylvania, and Kentucky, and south to Louisiana and Florida. G. resinosa is found in damp woods, from Newfoundland to Georgia.

Etymology. - The name Gaylussacia was given to the genus in honor of $\mathbf{M}$. Gay Lussac, the eminent French chemist. Dumosa, the Latin for " bush," is applied to this plant to denote its character in that respect. Frondosa is Latin for "leafy," and was given to the species on account of the length of the leaf. The specific name resinosa was applied on account of the presence of resinous dots, or globules, on the leaves. Whortleberry is derived from the Anglo-Saxon wyrtil, a small shrub. Huckleberry is a corruption of lurtleberry, derived from whorlleberry. The derivation of tangleberry is ubscure. Blueberry is named from the color of the berries.

History and Use.-G. resinosa is the huckleberry of the markets. It was the favorite berry used by the natives of North America in their celebrated attitash, consisting of huckleberries of sereral sorts dried and beaten to powder Another favorite dish, called sautaash, consisted of the attitash mixed with corn meal, and was always prepared for their festivals.

oxycoccus, Pers. (Cranberry.) Calyx adhering to the ovary, t-cleft. Corolla 4-parted; segments narrow and turned back; stamens 8, convergent; anthers tubular, 2-parted, opening by oblique pores. Fruit a globular, 4-celled, many-seeded berry. Shrubs, with slender, creeping, assurgent stems and branches.

1. 0. macrocarpus, Pers. (Vaccinium macrocarpum, Ait.) (Large-fruited Cran berry.) Stem from 1 to 5 feet long, prostrate, throwing up assurgent flower- 
ing and fruit-hearing branches. Leaves elliptical, margins rolled over, upper side dark green, glaucous underneath; flower large; anthers more than twice the length of the filament. Fruit varying from campanulate to orbicular, dark when ripe. The crauberry sports freely at to the fruit; the leaf is very coustant, except as to size.

There are three well-marked and quite constant varieties known among cultivators, as follows: Bell-shaped, or l'ear-shaped; Bugle-shaperl ; Cherryshaped. This last form is sometimes flattened at the poles, and is then called Cheese-shaped. Cultivators who have made careful observatious think they have detected from 20 to 40 rarieties. 'The following five forms are very constant : -

1. Fruit pear-shaped, from six tenths of an inch to an inch in length, and four to seven tenths in diameter; dark when ripe.

2. Varying in shape from fusiform to cylindrical, sometimes smaller in the middle than at the ends, and every way larger thau No. 1; dark when ripe. This is what the growers call bugle-shaped.

3. Nearly globular, from a quarter to three quarters of an inch in diameter; very dark when ripe.

4. About the size and shape of No. 3, but creamy white when ripe.

5. Very much smaller than Nos. 3 and 4. Globular, three to four tenths of an inch in dianeter; very prolific, and very dark when ripe.

2. 0. palustris, Pers. (Vaccinium oxycoccus.) (Small Cranberry.) Differs from O. macrocarpus in bearing very much smaller leaves and fruit. The fruit also yields a sharper acil, indicated by its name, sour-berried. It is collected where it grows spontaueously, but is not cultivated.

Geography. - The geographical range of the cranberry is very wide; it reaches from $38^{\circ}$ to $60^{\circ}$ north latitude, and covers a belt trending east and west from Siberia to the British Isles, and in North America from the Atlantic coast to the

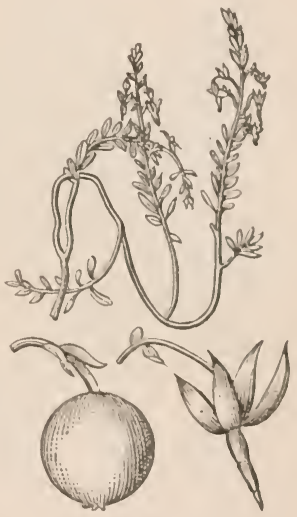

OXYCOCCUS MACROCARPUS (Cranberry). Mississippi.

Etymolngy. - Orycoccus, the generic name, is from the Greek ókús, sonr, and ко́ккоs, a berry, - sour herry. The specific name, macrocarpus, is from the

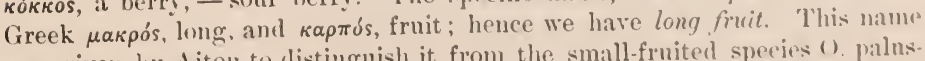
was given by Aiton to distinguish it from the small-fruited speeies (1. palnstris. The genns was formerly known by the name of vaccinium, the meaning of which is obscure. The common name cranbery, which is a corruption of crane berry, is saill to have been given hecanse the assurgent hranches bent over in a curve resembling the neck of the crane.

History. - The history of this plant furnishes little of interest. It has for some years been under cultivation, but its importance as a food-plant or an article of commerce is of recent date. It is largely cultivated in the middle Atlantic States, Massachnsetts, lihode Island, Vew York, New .Jersey, Delaware, and Maryland. More attention has been grim to it in New Jersey than elsewhere.

Cultication. - The mode of enltivation in ()eran. Mommonth, and Burling- 
ton counties, in New Jersey, in the Beaver Dam Company's plantations, and those of the Hon. Ephraim P. Empson at Collier's Mills, which are amoug the most extensive, and are fair specimens of the others, is as follows: 'The location is selected along a small stream, whose valley is of some width and the adjacent banks of which are high enough to allow flooding by constructing a low dam. 'The ground is then cleared of the trees and shrubbery, roots and all. These are piled in heaps, and as soon as dry they are burned, and the ashes are spread. The whole is then covered with sand, into which the plants are set in rows, so that the following year they may be kept free from weeds with the hoe. When the plants begin to fruit they are flooded for several months, beginning in November, and in May the water is let off. In September picking commences, which is paid for by the crate, or bushel, the price varying from forty to sixty cents a crate. The owners of the bogs, as the plantations are called, erect cabins on or near the grounds to accommodate the pickers, who come from far and near; old men and women, girls and boys, flock to the cranberry harvest. The quantity picked in a day varies from one crate to five; the women and young girls are the most dexterous, and frequently earn as much as two and a half dollars a day when the fruit is abundant.

Use. - The cranberry has a sharp, acid, and astringent taste, in a raw state. Cooking destroys the astringency, but does not nentralize the acid. It is a favorite sauce with poultry and game, and is largely used for jellies and preserves. The ripe fruit can be kept for a long time in vessels of water tightly sealed. It may be kept for any length of time immersed in molasses, and kept in a nniform and cool temperature. Large quantities are shipped to France, where the berries are used in the manufacture of colors.

Marts. - The great market for cranberries is New York City. The prices have ranged during the last ten years from two to five dollars a crate or bushel.

\section{Order XXXIII. SAPOTACEÆ.}

Flowers perfect, regular, axillary; calyx 4-S-parted; corolla with united petals, hypogynous, $t-S$-lobed, imbricated in the bud; stamens on the corolla, fertile ones equalling number of, and opposite to, the corolla-lobes; ovary several-celled; style cylindrical ; stigma acute or capitellate; ovules solitary, in the cells. Fruit a berry, with one to many cells. Seeds with a bony testa, embryo large. Leaves alternate, entire, and coriaceous; stipules wanting or falling early. Trees or shrubs, with milky juice and stellate leaves.

No. of genera, 26 ; species, 325. Tropical or subtropical.

DICHOPsis, Thu. Calyx 6-parted in two series, outer row valvate; corolla 6-lobed, usually acute; stamens 12, attached to the base of the corolla, every alternate one shorter; anthers lanceolate; ovarium villous, 6-celled; style awl-shaped. Large trees. Leaves leathery, clothed underneath with rusty-yellow, short, woolly, pubescence. Flowers axillary, stalked.

D. gutta, Bentley and T. (Gutta Percha.) Trunk 60 to 70 feet high, 2 to 3 feet in diameter; bark rough; twigs tomentose. Leaves alternate; stipules deciduous ; petioles long, stout, thickened at the base; blade obovate, oblong, short, acuminate, tapering at the base, entire; margin revolute, glabrous 
above, densely tomentose underneath, and leathery, with parallel veins nearly at right angles with the prominent midrib. Flowers small, on short, recurved, silky pedicels, clustered in the axils of the leaves. ('alyx bell-shaped; segments 6, in 2 imbricated rows, persistent. ('orolla-tube scarcely longer than the calyx, with 6 segments; stamens 12 , inserted on the throat of the corolla; filaments in one row, equal, slender, extending bevond the segments of the corolla ; anthers ovate acute, 2-celled, opening lengthwise outwardly ; orary glubuse, slightly pubescent, 6-cellerl, with an ovnle in each cell; style simple, slender, longer than the stamens; stigna terminal, blunt. Fruit one and a half inches long, ovoid, pointel, and rusty-pubescent. Seed not described.

Geography. - The tree that furnishes the gutta percha of commerce is tropical, found native in the East Indies, Ceylon, and the Malay Islands.

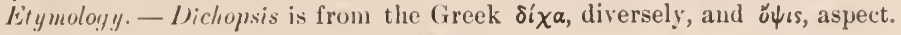
Gutla, the specific name, is from the Malay, and signities "sticky juice;" and percha is Malay for "tree;" hence "sticky-juiced tree."

Mistory. - Gutta perclia was first introducel to the notice of Europeans by royagers who had visited the coasts of Malacea and the Malay Islands. The sailors obtained it from the natives, in the form of bowls, cujs, etc., as drinking-ressels, knife-handles, aud other useful articles. 1)r. Montgomerie carriell gutta percha to England in 1843, and showed the method of forming it into domestic utensils and surgieal instruments; it has now attained a point of wonderful importance in domestic economy.

Some notice of the tree was taken to Europe in 1656, nearly two hundred years prior, but the world seemed not yet ready for it.

Preparation. - It was at first obtained by

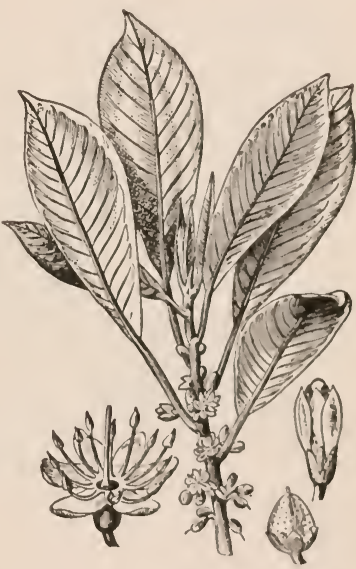

Dichopsis gutta (Gutta Percha). felling the tree, stripping off the bark, and removing the cambinm layer, which is charged with sap containing the substance. Now a less wasteful method is practiced, which consists in tapping by horing into the sap-wood and inserting a tube. The sap thus caught soon coagulates, and can he knearled into eakes for market, at which time it has the appearance of leather and the odor of cheese. Though not elastic, it is made plastic by heat, when it takes any form to snit the workman's fancy.

$C$ se. - The timber of this magnificent tree is not valuable for building purposes, as it is soft and weak. 'The gum it produces, however, has become of great economic importance. It is of intermediate consistence between wood and leather, softens by heat, and is immersed in hot water for that purpose; while in a soft state it takes delieate impressions, which remain sharp when (ool

It is formed into knife-landles, whips, surgical instruments, splints, combs, soles of shoes, and covers for bouks; but the most important nse to which it has been applierl is to insulate telegraphic cables. Being impervious to water and a bad conductor of electricity, it is the best of all naterials for that purpose. 
Note. - Achras sapota, Wight, a tree of this order, bears a pear-like fruit, which, when a little over-ripe, is sweet and edible. Native of Panama.

Bassia latifolia, Roxb., another tree of this order, is one of the Butter Trees. The flowers are used for food; a wine is also made from them. By distilling, a spirit comes over, and by expression, an oil is obtained from the seeds. Native of Bengal.

The Bassia Parkii is the butter tree of Africa, which supplies material for candles and soap.

The Mimusops elata, the Cow Tree of Para, in northeastern parts of Brazil, - is another of this order, the sap of which resembles rich cream. The fruit, of about the size of an ordinary apple, is edible.

\section{Order TXYIV. EBENACEAE.}

Flowers seldom perfect, usually diœcious, in crowded cymes or scattered along the ends of the branchlets; calyx 3-6-parted ; corolla on the receptacle; petals united, urn-shaped, leathery, smooth within and pubescent outside; limb 3-6-parted, imbricated in the bud; stamens inserted on the bottom of the corolla, twice as many as the number of lobes in the corolla, occasionally equal or 4 times as many; filaments free or in pairs; ovary sessile, 3 to many-celled. Fruit a berry, globular or oroid, succulent, fer-seeded. Seeds inverted; testa membranous. Leaves alternate, leathery, entire, and without stipules. Trees and shrubs, with hard wood.

No. of genera, 6 .

DIOSPYRos, L. Flowers diœcious and polygamous ; calyx 4-6-lobed; corolla bell-shaped, 4-6-parted, rolled together in the bud; stamens 4-8, or numerous ; filaments short. Fruit globular, an inch to an inch and a half in diameter, surrounded at the base by a fleshy, persistent calyx, 4-8-celled, with 8 to 12 seeds. Tree.

1. D. Virginiana, L. (Persimmon.) Trunk 30 to 50 feet in height, 10 to 18 inches in diameter, forming a symmetrical head. Leaves elliptical, bluntly acuminate, entire, dark green, paler underneath, smooth, and 3 to 5 inches long: petioles and veins somewhat hairy, glancons underneath ; calyx 4-parted; stamens 8. Flowers greenish yellow. Fruit globular, an inch to an inch and a half in diameter. Sap-wood yellowish white, light and soft; heart-wood dark, heavier, and harder.

2. D. ebenum, Retz. (Ebony.) Trunk 50 to 80 feet high, 2 to 3 feet in diameter, branching into a beantiful head. Leaves elliptical, pointed, and mucronate. Fruit large, 1 to 2 inches in diameter, edible. Wood black, very close-grained, sinks in water, and takes a fine polish.

There are many species of the Diospyros, all yielding a hard, dark wood. The wood of the $\mathrm{D}$. ebenum, however, is the wood known as ebony, or iron-wood.

3. D. melanoxylon, Roxb., produces the black ebony found native in southern Asia. Wood very hard, heavy, sinks in water, and takes a fine polish.

Geography. - The Diospyros Virginiana is a native of North America, thronghout the eastern part of the north temperate zone up to $40^{\circ}$ of north 
latitude. 1). ebenum is a native of ('eylon, and is not indigenous outside of the tropics; it is found, however, at an elevation of 5,000 feet, which suggests that it wonld grow in the edge of the temperate zones, in regious of no frost. The 1). ebenum is also found native in Mauritius.

Etymology. - Jiuspyros in derived from the Greek words $\Delta$ ios, Jove, and $\pi$ upós, fruit, - the fruit of Jore, or the fruit of the gods, or heavenly fruit. Ebenum, from the Hebrew eben, a stone, is in allusion to its harduess. Firginiana is derived from Iringin, the country where it was first found by botanists.

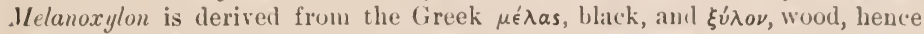
black woul. Ebony (the common name of 1). ebenum) is a corruption of the scientific name Ebenum. Persimmon is the name given to this species by the American Indians; its meaning is unknown.

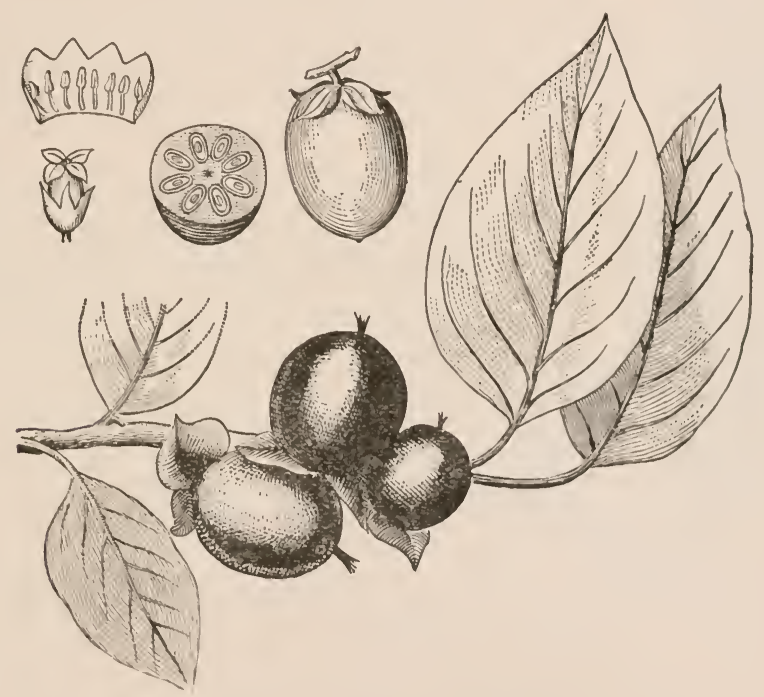

Diospyros Virginiana (Persimmon).

Preparation. - The best ehouy is produced by the D. ehenum, and is taken from Ceylon to Eugland in logs from 18 to 24 inches in diameter, and 12 feet long ; large quantities of excellent ebony are also sent from Mauritius (D). reti culata) in poles or logs from 10 to 20 feet long and 12 to 15 inches in diameter. It is seasoned muler water. When felled it is immersel in water, where it remains for six to eighteen months, when removel from the water the encls are hooped with iron rings, to prevent cheeking and splitting An ebony is also obtained in the Island of st Helena from the Dombera melanoxylon, of the orler Pyttneriacear.

Use. - Ehony is highly prized hy turners as a material for their purpose; largely userl for wind instruments, as Hutes, fifes, piccolos, etc.; it is used for veneering. inlaying, and for piano keys, unts for violins; also the finger-boards and tail pieces, with the serews for tuning, are male of ehouy.

PH. FL. -13 


\section{Order XXXY. OLEACEA.}

Flowers perfect, occasionally dicecious and without petals, in a raceme or trichotomous panicle; calyx, with sepals united, 4-lobed or toothed, sometimes wanting; corolla hypogynous; petals 4 , united at the base in pairs, or all united; stamens 2, inserted on the corolla, and alternating with its lobes; ovary free, 2-celled. Fruit a drupe, a 2-celled berry or a samara. Leaves opposite, petioled, simple, or oddpinnate. Trees and shrubs.

No. of genera, 18 ; species, 280 .

OLEA, Tourn. (Olive.) Calyx short, 4-toothed, persistent ; corolla tube short; limb 4-parted, and spreading; stamens 2, inserted in the base of the tube, longer than the corolla tube; ovary with 4 suspended ovules, 2 or 3 of which prove abortive. Fruit a fleshy drupe, and oily. An evergreen shrub or tree, with opposite leaves.

0. Europæa, L. (Olive.) Trunk 20 to 30 feet high, much-branched and spreading, forming a symmetrical head; branches angular. Leaves lanceolate, entire, deep green above, light hoary beneath, and evergreen. Flowers axillary, in short, compact racemes, small and white Fruit greenish, or whitish-violet, sometimes nearly black, size of a pigeon's egg, oval, sometimes globular or obovate, and rery abundant.

There are several species, but the O. Europæa is the one usually cultivated. Of this species there are five important varieties:-

Var. longifolia. Leaves linear, lanceolate, flat and silky beneath.

Var. latifolia. Leaves broad, oblong, flat and hoary beneath.

Var. ferruginea. Leaves narrow, acute at each end, rusty beneath.

Var. obliqua. Leaves oblong, bent obliquely, pale beneath.

Var. buxifolia. Leaves oblong-ovate, and branches divaricate.

Var. sylvestris, found outside of cultivation, is characterized by smaller fruit. It is common in the Mediterranean countries, the Canary and Madeira Isles. There are other varieties, but those mentioned are the most approved.

Geography. - The geographical range of the olive-tree is not very broad; it grows best just on the edge of the region of no frost, and on the seacoast. Its area of growth is especially the countries around the Mediterranean sea. Asia Minor, Greece, Syria, Spain, Italy, northern Africa, and the islands of the Mediterranean are the great olive-growing regions. The ports of export are Trani, Barletta, Bari, Mola di Bari, Molfetta, Otranto, Taranto, and especially Gallipoli.

Etymology. - Olea, the generic name, is from the Greek énaía, through the Celtic or Gothic word olew, oil, due to the oil-sacs deposited near and just under the skin of the fruit. Europaca, the specific name, is due to the circumstance that this species is the one under cultivation throughout Europe. Olive, the common name, is plainly a corruption of the generic name, or a contraction of the French Olivier.

History. - The home of the olive has been traced to Syria, whence it easily spread through the countries of the Levant and southern Europe. Though it has no Sanscrit name, it is referred to as one of the plants upon Mount A rarat at the time of the Deluge. The wood is found in the stone coffins of Egyp 
tians. But we have no means of determining the exact date of its introduction into Europe. It propagates itself freely, and is growing without cultivation in all the countries around the Mediterranean. The olive tree is of slow growth, but where its natural development is allowed for ages, the trunk often attains a cousiderable diameter. De Caudolle records one 23 feet in girth whose age was supposed to be seven centuries. Some Italian olives are credited with an antiquity reaching back to the days of republican Rome; but the age of such ancient trees is always doubtful during growth, and their ilentity with old descriptions is still more difficult to establish.

Cultivation. - Its mode of culture, or rather the method of making a plantation, is singular and interesting. The province of Susa, in Morocco, produces great abundance of olive oil, which has the reputation of being of such excellent quality as to rival the celebrated Florence oils. In Jackson's account of the empire of Morocco there is a description of an extensive olive plantation. The order and arrangement of the trees struck him as being very curious, and on inquiring the cause of the arrangement he was told by an official high in authority that during the Saddia dynasty, a king, on the march with his army to the Soudan, encamped on the spot, and that the pegs to which his horses were picketed were cut from an adjacent olive grove, and each one became a tree. This explanation he regarded as fabulous, but goes on to relate that he had occasion to plant some fruit-trees in a garden. The person employed to make the plantation procured some olive-branches, cut them up into pieces a foot long, sharpened one end with a knife, and proceeded to drive them into the ground with a stone. Supposing the fellow was imposing upon him, he ordered him away; but on being assured that it was the usual method, he allowed him to proceed, and each peg grew into a thrifty olive-tree.

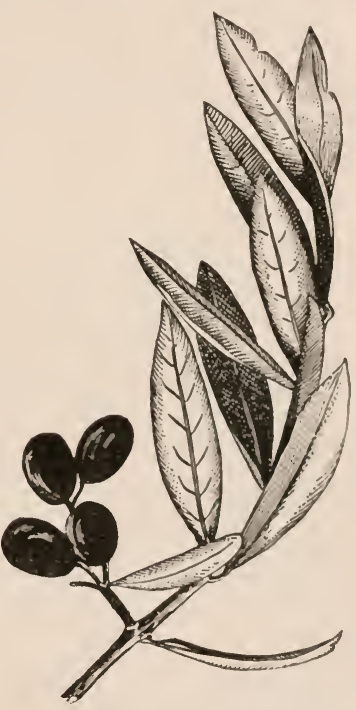

Olea Europea (Olive).

Engrafting the better varieties upon wild stocks greatly inereases the production of fruit.

Preparation of olive oil. - The fruit is crnsherl in a mill, the pulp then placed in woollen bags and subjected to pressure and the application of hot water. The oil is skimmed off the water and placed in tubs, barrels, bottles, crock: (a sort of earthen jar or pot), and other vessels. In the remote districts, where it is made in small quantities, it is taken to market in lottles made of goatskins. On that part of the Italian peninsula skirting the month of the Adriatic, the eutire conntry is an olive orchard. In the oil season, hundreds of mules and donkeys crowd the highways going into fallipoli, the seaport, laten with oil, where nay he seen at the same time fifteen to twenty ships taking in their cargoes of oil and olives. When the oil is first brought in from the mills it is emptied into a large vat, or cistern, at which time it is dark and turbid. After remaining for some months in this mass, it settles. becomes clarified, aud takes on a beautiful amber color, when it is drawn off 
into barrels and other vessels for shipping to the United States, England, France, Genoa, and elsewhere. 'The best oil comes from Florence, and was formerly shipped exclusively in glass flasks, called Florentine Hasks.

Use. - The olive is eaten when in an under-ripe state. The taste is bitter and slightly astringent, hence a taste for it must be acquired. The fruit is put up in either glass or wood, and preserved in salt. To prepare it for the table it is soaked in water, and afterwards placed in vinegar or oil. The principal use of the olive is for the manufacture of oil. The oil obtained from the olive is esteemed for its soft, delicate flavor, and is largely used for culinary purposes and for table use, for salad dressings, etc. It is also an excellent lubricator, and valuable for illuminating purposes. It solidifies at $10^{\circ}$ to $15^{\circ}$ Fahreuheit. Its specific gravity is .9176 ; it is frequently adulterated with cotton-seed oil, the specific gravity of which is .9300 .

The wood of the olive-tree is hard, of a fine, close grain, and takes an excelleut polish; it is used largely by turners for the manufacture of small articles. The root is esteemed on account of its guarls and curls.

\section{Order XXXVI. LOGANIACEA.}

Flowers perfect, regular, in axillary or terminal cymes ; calyx, with united sepals, valvate in the bud, or 4 to 5 free imbricated sepals; corolla hypogynous, with sepals united, wheel-shaped, or bell-shaped; limb 5-10-cleft, sometimes 4-lobed; stamens on the corolla equal to and alteruate with its lobes; filaments thread-like or awl-shaped; ovary superior, 2-t-celled; style thread-like; stigma shield-shaped; ovules numerous. Fruit a capsule or berry. Trees and shrubs. Leaves simple, opposite or whorled.

No. of genera, 30 ; species, 350 ; mostly tropical.

STRYCHNOS, L. Calvx somewhat bell-shaped, or wheel-shaped, with 4 lobes, whose edges just meet; stamens 4 or 5 , on the corolla; filaments short, attached to the backs of the short anthers; ovary 2-celled; style thread-like. Fruit a berry, globular, covering hard, and without valves. Leaves opposite. Flowers in cymes, axillary or terminal, small and white.

1. S. nux vomica, L. (Nux Vomica.) Stem from 20 to 35 feet high ; bark smooth, gray; much-branched, the branchlets swollen or knotted at the nodes. Leaves 5-nerved, with 2 ribs each side of the midrib, reaching from the hase to the apex, ovate, pointed ; calyx tubular, 5 -toothed ; corolla tubular, greenishwhite, lengthened; limb 5-parted, parts lanceolate ; stamens 5 ; anthers erect; pistil longer than the stamens ; stigma glohose. Fruit as large as a middlingsized orange, with a hard, bitter, smooth, yellow peel, inclosing fleshy pulp, in which are embedded a number of flat, circular seerls, concave on one side and convex on the other, an inch in diameter, and a quarter of an inch thick, covered with a gray, velvety down, hard and horny, containing a gummy, resinous matter, soluble in alcohol. Wood hard, bitter, and very durable.

Chemistry. - The seeds yield to the chemist two sulstances, - strychnine and brucine.

Strychniue, $\mathrm{C}_{21} \mathrm{H}_{22} \mathrm{~N}_{2} \mathrm{O}_{2}$.

Brucine, $\mathrm{C}_{22} \mathrm{H}_{21} \mathrm{~N}_{2} \mathrm{O}_{4}$. 
Brucine differs little in composition from strychnine, but is not so active in its poisonous qualities. These two substances in crmbination form one of the most active poisons known. Strychnine is intensely hitter ; one grain gives to 110 gallons of water a pereeptible bitter taste. It requires 2,000 parts of boiling water to dissolve it; but alcohol suspends it more readily, and it is very soluble in chloroform.

2. S. Ignatii, Berg. 'The seeds of this species are said to be far richer in the yield of strychnine than the nux vomica. The tree is native in the Philippine Islands. The seeds are known in commerce as the beans of Tt. Ignatius. They were brought to the notice of Ray, the English hotanist, in 1699, by a Jesuit, who obtained them through missionaries.

3. S. colubrina (Snakewood), L., yields strychnine from the wood of the root.

4. S. tieuté, Lech, yields it from the bark of the root.

5. S. potatorum, L. (Clearing Nut.) Like the nux romica, hut a larger tree; fruit similar in form, but does not possess the same poisonous qualities. Found in the mountaius of East Indies. The pulp is eaten by the natives, and the seeds are used to purify water. One of the seeds is rubbed smartly upon the sides of a water ressel, which is then filled with water, that in a very short time becomes clear and pure; the effect of the seed is to precipitate not only suspended regetable matter, but impurities of every sort. This effect is attributed to some albuminoid property of the seed.

When the fruit is ripe it is attacked by birds and climbing animals: they eat the rind, and throw down the pulp and seeds. The seeds are collected, washed, and sold to country merchants for a quarter of a cent a pound.

6. S. toxifera, Bth., found in the silvas of the Amazon and Oronoco, furnishes the celebrated poison, curari, with which the natives preprare their arrows for battle.

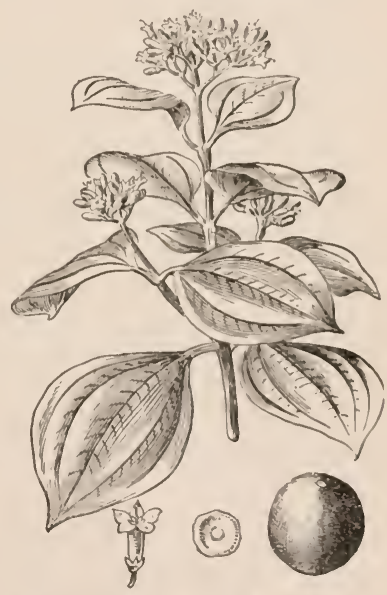

Strychnos nux vomica (Nux Vomica). The poison resides in a resin found in the bark of the tree, and is separated by maceration in "ater. The sulstance is harmless when taken into the stomach, but fatal when introluced into the blond. The preparation for the poisoned arrows is a mixture of the product of several different species, but the mode of preparation is a secret.

Geography. - These trees are tropical and subtropical, natives of India and the islauds south of $\Lambda$ sia.

Etymology. - The name strychnos is from the Greek word, orpúxuos, which signifies to "strew" or "throw down," in fancied allusion to the stupefying effects it produces upon the animal system. Vur romirr signifies foul $\mathrm{nut},-$ from the Latin nux, a nut, and eumicu, a plangue or Joathsume disease, alluding to its poisonous qualities Ignatii is named afters st Iguatius. Colubrina. Latin. is a general name fur innocuous serpents. hence alsosnake-urod Chettik 
is the Javanese name for the S. tieuté, which is a native of Java, and tieuté is probably derived from chettik. Potatorum, Latin, drinking, and clearing nut, are names due to the fact that it is used in the East Indies for clearing muddy

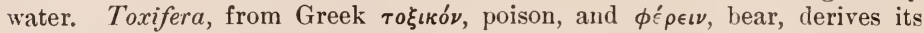
name from the fact that the Indians use it to poison their arrows.

History. - This poison was discovered by the chemists Pelletier and Caventon in the seeds of Strychnos Ignatii and S. nux romica.

Use. - The medical properties are stimulant, tonic, and narcotic, - and it is used as a remedy in rheumatic paralysis and lead poisoning. In large doses it attacks the brain and spinal cord, producing dizziness, contraction of the heart, and muscular spasms. Thirty grains of the powdered nut have proved fatal, and three grains of the extract. Half a grain taken by mistake caused the death of Dr. Warner. It is said that swine and goats are not injured by it. It enters into the medical preparations of homœopathic practitioners for stomach disorders, and is by them regarded as a specific in dyspepsia. It is largely used in the United States to destroy vermin, and especially animals and birds injurious to agriculture.

It has been charged that large quantities of strychnine are used in the preparation of whiskey; this is a mistake, as its intensely bitter properties would render the liquor unpalatable and unsalable. The wood is hard, durable, and takes a good polish; some of the species yield a snake-wood.

The spinal cord is the seat of strychnine poisoning, and the effects are intermittent tetanic convulsions. In some cases the respiratory muscles become rigid, and death ensues from suffocation. Large doses of opium are said to nentralize the effects of strychnine.

\section{Order XXXVII. BORRAGINACEAE.}

Flowers perfect, usually regular, axillary or terminal. solitary, or mostly in 1-sided scorpioid cymes; calyx persistent; sepals united, 4-5-parted; corolla regular, with scales under the middle of lobes, hypogynous, with united petals, deciduous, bell-shaped or wheel-shaped: throat naked, or clothed with hairs or scales; limb 5-lobed, imbricate in the bud; stamens 5 , on the throat of corolla, alternate with its divisions. Fruit, 4 distinct, nut-like akenes, sometimes united in pairs. Mostly rough, hairy. Herbs.

No. of genera, 68 ; species, 1,200 ; cosmopolitan.

SYMPHYTUM, Tourn. Calyx 5-parted; corolla tubular, bell-shaped; mouth closed by 5 awl-shaped scales, forming a cone. Fruit smooth and ovoid. A perennial herb.

S. officinale, L. (Comfrey.) Stem stout, winged, 4 feet high, branching towards the top, hairy. Leaves large, coarse, petioled, lower ones broad, lanceolate, upper ones lanceolate. Flowers in racemes, and terminal; sepals lanceolate; border of corolla divided into 5 recurved teeth; yellow, white, pink, or red.

Var. Bohemicum, Sch. has bright red flowers.

Geography. - The geographical range of this plant is not great, but it grows well about the midile of the temperate zone, and is found throughout middle Europe and the older parts of the United States of America. 
Etymology. - Symphytum is from the freek $\sigma \dot{v} \nu$, together, and $\phi u \tau o v$, a plant, in allusion to the gummy character of the mucilage contained in the root of this plant. Comfrey, from the Latin ronfirmare, strengthen, owes its name to its healing properties.

History. - This plant is indigenous to the Peloponnesus and Greek islands, whence it has worked its way westward to the British Isles; it was introduced by European colonists into northeast America, where it has become naturalized about old dwellings and around ruins, having escaped from gardens. It loves damp, rich soil.

Use. - The root abounds in a gummy, glue-like mucilage; a decoction of it is used to bind up wounds. It is also used for throat and lung troubles, on account of the soothing properties of its mucilage. It is grateful in irritable stomach complaints.

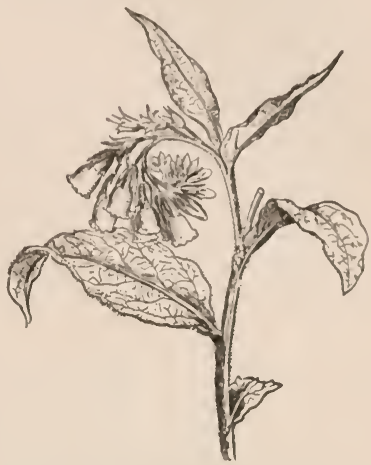

Symphytum officinale (Comfrey). It likewise serves as a remedy for bleeding at the lungs; and the bruised heated root is sometimes applied to wounds, in the form of a poultice.

\section{Order XXXVIII. CONVOLVULACEAE.}

Flowers perfect, regular; peduncles axillary or terminal, simple or dichotomous, usually bibracteate ; calyx 5-sepaled, usually free and persistent: corolla hypogynous; petals united and funnel-shaped, twisted in the bud; stamens 5 , inserted at the bottom of the corolla-tube, alternating with its lobes; filaments swollen below, thread-like above; style simple, or nearly so; seeds few, 2 in each of the $2-3$ cells of the ovary. Fruit capsular; carpels comnate. Herbaceous, woody, or subwoody plants, climbing or trailing.

No. of genera, 32 ; species, 800 ; cosmopolitan: mostly in warm sands.

IPOMGEA, L. Calyx 5-parted; sepals green; corolla salver or fumelshaperl, spreading; number of stamens 5 in the throat; style simple. terminated by a head-shaped stigma, which is sometimes 2-lobed; seed-ressel 2- or 3-ralved, 2- or spuriously 4-or 3-celled; seeds 1-6.

1. I. batatas, Lam. (Sweet I'otato.) Ovary spuriously 4-celled; stem from 2 to 10 feet long, creeping and ronting at every node, from an eighth to a quarter of an inch in diameter. Leaves very variable, usually triangular or 3-lobed; general outline heart shaped, the sinus at the hase broad, 5-veined, smooth; blade 2 to 5 inches long, on long petioles. Flowers on long peduncles. 2 to 5 in a cluster, jurple; root gives rise to long, spindle-shaped tubers. In herbaceous perennial.

Geography. - The sweet potato is largely unltivated in southern Enited States, and comes to perfection as far north as the Carolinas. North of . Worth Carolina it was not formerly supposed to be perfect: hut for the last quarter 
of a century it has been successfully cultivated as a market-crop in eastern Virginia, Maryland, Delaware, and southern New Jersey; in fact the sweets, as they are called in New York market, from sonth Jersey are as popular as the Carolinas. It is grown in southern spain and Italy. The British Isles are too damp for it.

Etymoloyy. - Ipomoa, the generic name, is derived by Loudon from the Greek $\chi \psi$, a worm, and $\delta \mu o \hat{\imath}$, like, - like a worm. Batatas comes from the spanish batuta, the native name of the sweet potato. Potuto is a corruption of batatas, and sweet refers to the taste of this species.

History. - Its home is held by some aluthorities to be America; by others, Asia; and there seem to be good reasons for believing it to be indigenous both to Asia and America. It was introduced into southern Europe by the Spaniards soon after the discovery of America. It now forms an important

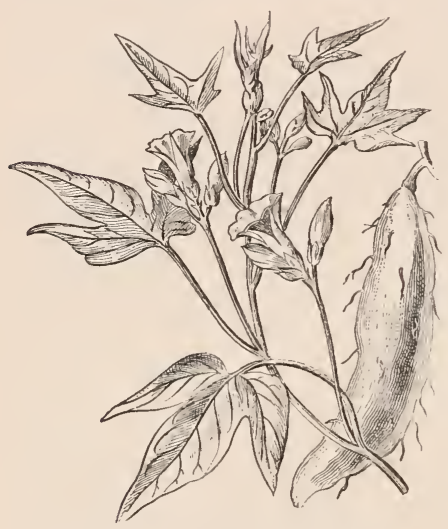

I pomea Batatas (Sweet Potato). article of food throughout tropical and subtropical countries, and needs a high temperature to develop the peculiar delicate sweet taste.

It is not known when this tuber was introduced into the kitchen.

Cultivation. - The mode of cultivating the sweet potato is to place the tubers in a hot-bed, where they sprout. The sprouts, when six to ten inches long, are taken off and transplanted, in the same mauner as cabbage-plants are treated. They grow to greatest perfection as to quality in loose sand. A shovelful of well-rotted baruyard man. ure is dropped, and over it with a hoe is formed a conical hill, in the top of which the plant is transplanted; in about two months the tubers hegin to form about the base of the plant, which by that time has become a prostrate vine, six to ten feet in length, rooting at every node. A part of the labor of cultivating is the destruction of these rootlets, by frequently lifting the vine from the ground, which violence breaks them.

Use. - The sweet potato in tropical and sulstropical countries is an article of food of vast importance. The rudest modes of cooking are roasting and boiling, but it is also largely used for pies, custards, and other delicacies ; it is also minced while raw, roasted with Maracaibo coffee, then ground and sold for coffee. It is in common use in the southern and middle States as a vegetable at breakfast and dimer.

2. I. purga, Hayne. (Bind-weed Jalap.) Stems twining, 12 feet long, many from the same globular, tuberous, fleshy root; branched. Leaves alternate, on stout foot-stalks, which are 4 to 5 inches long; base cordate, lobes pointed, narrowed at the apex, entire, smooth both sides, paler beneath, with conspicuous veins. Flowers in cymes, axillar, few-flowered ; peduncles long and twisted ; pedicels bracted ; calyx, short, smooth, 5-parted ; corolla large, tubular, with flattened, spreading limb, contracterl just where the limb begins to flatten, dull pink; stamens inserted in the tube near the base; filaments flattened, three longer than the other two, all extending beyond the mouth of 
corolla-tube; anthers small; ovary tapering into the slender style, which is a little longer than the stamens, 2-cellerl, 2 ovules in each cell. The ront is somewhat the size and shape of a medinn-sized swerlish turnip, tuberous in character, giving off stems from all points near the crown; Hesliy and soft when growing, very hard when dry. Perennial.

Geography. - Its home is in the high lands of Mexicu, near the 2oth parallel, a rainy district; it grows at an elevation of four to six thousind feet above the sea level. It is now cultivated in British India, in corresponding latitules and altitudes to its Ameriean home. The species and its locality were in doubt till 1829, when 1)r (Coxe of Philadelphia ubtained living plants from Mexico, and settled the question.

Etymology. - Purga, the specific uame, is the Spanish name for the plant, and indicates its medicinal property. Jalap, the popular name, is derived from the name of the city Xalapa in Mexico, near which the plant was first found.

History. - It was carried to Europe by the spaniards for its melicinal properties early in the serenteenth century.

Preparation. - The medicinal properties reside in a resin found in the rout. The root when in perfect condition, yields about 20 per cent of the resin

The roots are washed, and the larger ones cut into slices and suspented in nets over fires till dry, when they are very hard; they are then really for the market.

Use. - The medicinal properties of jalap are especially cathartic; when arlministered in small doses it is alterative, and, in still smaller doses, tonic. In orlinary doses it is a safe lut violent cathartie; ginger mixel with it modifies its activity. It was formerly administered with ealomel. Its tincture constitutes a part of the black dranght, and it is regarded as a very valuable cathartic in brain trombles. Though violent, it does not irritate and inflame the intestinal canal, and is lence a safe medicine.

\section{ORDER XXYIX. SOLANACEÆ.}

Flowers perfect, generally regular, axillary or terminal, solitary, fascicled, or subcorymbose; calyx, with sepals uniterl, usually 5-lobed or toothed, occasionally + to 6 , persistent; corolla hypogynous ; petals uniter, rotate or campanulate; segments 5 , rarely 4 to 6 , folded or twisted in the bud; stamens on the corolla-tube equal and alternate with its segments, sometimes united at top; ovary --5-celled; ovules many. Fruit varied in form, frequently a many-seeded, pulpy herry, sometimes a dry capsule. Herbaceous or woody plants, with watery juice.

No. of genera, tit; species, 1,200; fomd in warmer parts of the old world, and in temperate parts of America.

LYCOPERSICUM. 'Tourn. Calyx 5- or 10-parted. persistent: corolla wheel-shaped, tule short: limb plicated. with .) to 10 lobes ; stamens, 5 or 6 in the throat of the corolla, protruling; filaments short ; anthers oblong-conical, cohering by an elongated membrane at top, opening lengthwise on the inner side. Fruit a hery, varying from a prolate spheroid to subglobular, usually an ohlate spheroid or flattened glohe. pulpy, and many-seceled. Ammual. 
L. esculentum, Mill. (Tomato. Wolf Peach.) Stem 2 to 5 feet high, branching, or straggling over shrubbery, prostrate when not supported. Leaves pinnately divided, alternate pairs of leaflets very small. Flowers in raceme-like clusters, common flower-stalk about 2 inches long, forked; sepals 5 to 10, linear-lanceolate, spreading; anthers united, pointed, with the points turned back. Fruit 1 to 5 inches in diameter, usually red, sometimes yellowish. Flowers June to August. Fruit ripens August to September.

The bruised leaves of the tomato emit a peculiar, disagreeable odor. Like other plants that grow from seed, it sports freely, producing varieties that differ mostly in size, shape, anid quality of the fruit. Some of the larger fruit is very irregular, with deep grooves and alternate ridges; the favorites with market-gardeners and amateurs are the medium-sized, smooth-fruited varieties.

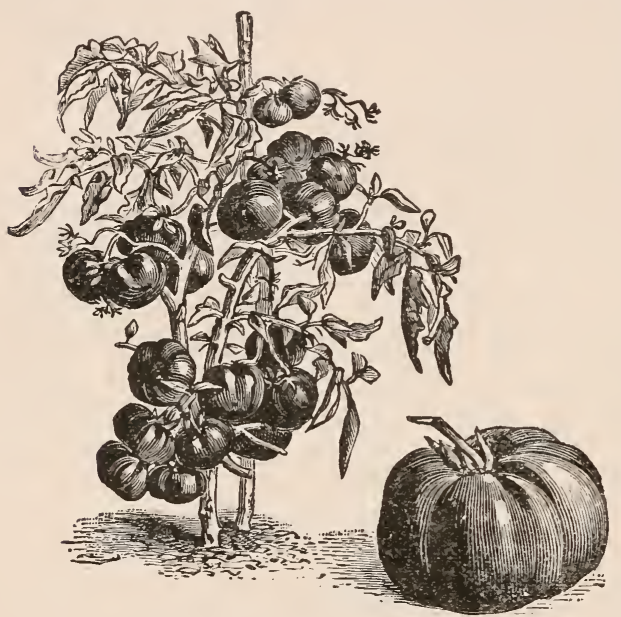

LyCOPERSicum ESCULENTUM (Tomato).

Some are very small, from an inch to an inch and a half in diameter, and globular, called plum and cherry tomatoes ; others small, pearshaped. The last two varieties are esteemed for preserves and pickles.

Geography. - It grows and fruits well in all southern Europe, especially in Italy and southern France and Spain, in Greece and northern Africa. It has been taken by Europeans to the islands of southern Asia and contiguous parts of the continent; is fruited in England, but under glass; and is an important crop in eastern United States, especially in the southeastern part of Virginia and the Carolinas, and is sent north as an early vegetable.

Etymology. - Lycopersicum is derived from the Greek words $\lambda$ úкоs, a wolf. and $\pi \epsilon \rho \sigma \iota \sigma^{\prime}$, a peach. The application is not apparent. Esculentum, the specific name, is of Latin origin, signifying "eatable." Tomato, the common name, is the native South or Central American name, carried to Europe by the Spaniards; its meaning is unknown.

History. - It is native to South and Central America, and is supposed to have been cultivated in Mexico at an ancient date. DeCandolle thinks it was first found by Europeans under cultivation in Peru. It was taken to Europe by the Spaniards, and introduced into the United States by Europeans; it came suddenly into pretty general use in the eastern United States after 1840, and is now one of the most popular and important table regetables of the country. It is in very general use also in southern Europe.

Use. - The tomato is used raw as a salad, cooked as a sauce with meats, nsed to flavor gravies and soups, and is found very generally on the tables of both rich and poor throughout the United States and Europe. 
Nicotiana, Tourn. ('Tohaceo.) Calyx tubular, hairy, divided into 5 parts, divisions narrow and puinted, half as long as the corolla-tube; corolla fumnel-shaped, tube hairy : limh divided into 5 sharp segments, turned back, reddish; filaments 5, curved inwards, terminating in a lengthened, slender style, crowned with a round cleft stigma. Seedvessel divided into 2 cells; seeds small, round, and numerous. Flowers in July and August in Americi:.

1. N. tabacum, L. Stem round, terete, hairy, 4 to 6 feet high, stont and leafy (in cultivation). Root large and fibrous; bracts linear and pointed. Leaves 10 to 25 inches loug, and 8 to 10 inches broad, entire, oblong, strongly veined, pointed and sessile. Flowers terminal, in loose panicles, rose-color. July.

2. N. rustica, L. Stem 3 to 5 feet high, round, terete, and stout. Leaves petioled, ovate, and shorter than in No. 1 ; segments of the corolla rounderl. The whole plant is smaller and more harly than No. 1, and is cultivated further north.

There are several other species, among which are :-

3. N. macrophylla, Lehm. (Greatleaved.) Leaves very large, clasping, ovate, and eared at the base; corolla inflated at the mouth.

4. N. Persica, Lindl. Lower leaves oblong, upper ones lanceolate and sessile; corolla salver-shaped; tubnle elongated. Cultivated in Persia, and furuishes the celebrated Shiraz tobacco.

5. N. repanda, W. (Wavy 'Tobacco.) Leaves clasping, cordate, spatulate, repand; tuhe of corolla long and slender. Cultivated in Cuba.

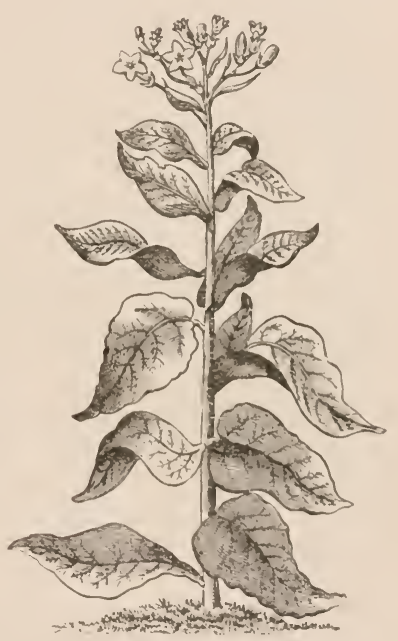

Nicotrana tabacev (Tobacco).

6. N. quadrivalvis, Pursh. (Funrvalved Tobacco.) Stem hramched. Ifeaves petioled, oblong; corolla-tuhe twice as long as the calyx, segments obtuse; capsule t-valved, round. Found under cultivation among the Indians in the Missonri valley.

7. N. nana, Lindl. (Dwarf Tobacco.) Leaves laucenlate; whole plant smaller than any other species. Found under cultivation among the savages of the valley of the Columbia river.

Geography - Tobacco arrives at the greatest perfection on virgin soil, or what the agriculturist calls "new land." It grows well in all parts south of the middle of the temperate zomes and in the tropies. The hest qualities are raised in Virginia, Kentucky, and the Carolinas, Venwyela, Cuba, and Brazil. It has heen of late years an important crop in some parts of the Midlle Atlantic States, especially Connecticut and l'enusclvania.

In Great Britain the growing of tobacen is prohithitesl hy law, as a large portion of the national revenue consists of duty un its impurtation It is an 
important crop in Holland, Flanders, France, Alsace, Hungary, and European Turkey.

Tobacco of a good marketable quality is raised in the Levant. Large quantities of an excellent quality are prociuced in the Indian Archipelago, in China, and Japan. The Dutch introduced its cultivation into south Ifrica, and the English have recently commenced its culture in Australia. The quality of that raised north of the middle of the temperate zones, as in Europe, is not so good.

Etymology. - Nicotiana, the generic name, was given to this plant in honor of John Nicot, a French statesman, who was instrumental in bringing it under cultivation in France. Tabacum is derived by some from tabaco, the name used by the American aborigines to indicate the instrument or pipe they used to smoke the dried leaves of the plant. (Others derive it from Tobago, in the West Indies, others from Tabasco, in Mexico. The common name tobacco is derived from the same source. The other specific names explain themselves; as, rustica, of the field or the country; macrophylla, large-leaved, or long-leaved; Persica, grown in Persia; repanda, wavy, or sinuate-leaved; quadrivalvis, seed-vessel with four valves; nana, small, or dwarf.

History. - Soon after the permanent settlement of North America, learned societies and some of the sovereigns of Europe became interested in the natural history of the New Wrorld. They sent over men devoted to the study of nature to collect specimens of the animals and other objects of interest to be found in Virginia, the name applied at that time to the large tract of land claimed by the English. Among the naturalists sent out were enthusiastic botanists, who made large collections of plants and seeds, and conveyed them to the Old World.

In their explorations they found a plant, the dried leaves of which the aborigines smoked in an instrument called by them tabaco. The imperfect knowledge of the dialect of the sarages possessed by the Europeans at that time led to the error that the substance they smoked was called tabaco, instead of the pipe through which they smoked it. Another history of the origin of the name is that a Spanish monk found the plant growing in Tobago, a province of St. Domingo.

It was introduced into Portugal in 1558 , by $\mathrm{Dr}$ Feruandes, and thence into Spain in 1559, where it was gruwn as a medicinal plant. John Nicot, a French statesman, who was at that time minister to the court of Portugal, sent seed to Queen Catherine de Médicis, who caused it to be cultivated in France; and on account of the interest she took in its culture, it received the name of Queen's Herb. (On account of the instrumentality of John Nicot in its introduction into France, Tournefort, a French botanist, named it Nicotiana.

Ralph Lane, the first governor of Virginia, and Sir Francis Drake brought to England in 1586 the implements and material for tobacco smoking, which they handed over to Nir Walter Raleigh. Lane is credited with having been the first English smoker; and through the influence and example of the illustrious Raleigh, the habit of smoking soon became rooted among the English. The custom was carried into Holland by young Englishmen who went there to prosecute their studies.

In less than fifty years after the tobacco-plant was first cultivated in Portn. gal the custom of smoking it spread over Turkey, Persia, India, Java, Chiıa, and Japan. This rapid spread is no doubt due in part to the ease with which the plant is cultivated throughout the temperate zones where rich soil is found. 
It is claimed by the Chinese that they cultivated and used tobacco before the discovery of America; yet recent investigations have developed the fact that the plant cultivated there is a variety of the species most commouly cultivated in America, and has no characteristic difference, except such as different soils and modes of cultivation would induce. . But the strongest argument is that the eastern languages have no name for it, but thonghout the countries of Asia it is known by its American name, tobacco, which was uo doubt obtained from the l'ortuguese who introduced it into China and Japan.

After careful examination we are forced to the conclusion that tobacco was brought to the notice of civilized man in the West Indies soon after their dis covery, and that the practice of smoking it originated among the savages of the New World.

In the countries where the use of tobaceo prevails, 27 of every 40 adult males are wedded to the custom. An account of the efforts to suppress the use of tobaceo that have been made by medical men and by the highest authority constitutes an important chapter in its history.

'The pope at one time lent his aid to its suppression. James I. of England, and the authorities of Russia and of Turkey, passed stringent laws forbidding its use, and executed them with savage barbarity. For using tubacco, meu were whipped, their noses were slit, and sometimes cut off. In Turkey they were bastinadoed and belieaded. The pope thundered his bulls of excommunication at them.

James I. of England, in the beginning of the seventecutl century, published his counterblast against tobacco, in which he undertook to show how unworthy it is for a civilized nation to adopt customs from such barharians as the Ameri(an savages.

Notwithstanding this royal diatribe and many others that have followed all along down through the history of tobacco, its use has extended to every nook and corner of the world where civilized man has erected his habitation. frood men have written against it on the ground of its immoral effects. I'olitical reonomists have attacked it on account of its entire uselessness. Physicians have fought it because of its mischievons effects on the health of the body; yet it has crept on and is still advancing.

Cultivation. - The plant is propagated from seed, and sports, forming varieties, many of which are under cultivation; but less attention lias lieen paicl to obtaining new varieties than the importance of the plant warrants.

Chemistry. - Nicotiana yields to the chemist eighteen different substances, the most important and characteristic of which are nicotine and nicntianin. Nieotine is composed of $\mathrm{C}_{20} \mathrm{H}_{14} \mathrm{~N}_{2}$. It is an oily liguid without color, and one of the most active poisons known; a single drop placed upon the tongue of a serpent causes death as instantaneously as an electric shock. It is an alkali which has the most intense attinity for acids; it is soluble in alcohol. and will mix with water. The disagreeable, sickening effect proluced by the fumes of tobacco burned in an old pipe is due to the presence of nicotine.

Nicotianin contains the same substances, hut in different proportions, and furnishes the odor of tobacco. The nicotic property appears in the leaf after fermentation.

These two substances are accompanied hy sixteen others, the principal of which are resin, potassa, chlorine, lime, silicu, lignin, and glutin; and the whole plant is richer in nitrogen than any other vegrablile sulsstance that has heen subjected to chemical tests. No one of the substances detected in tobacco 
possesses any nutritive qualities, and no animal is known to eat it. Man alone has found a nse for it.

Use. - The dried leaves are used to chew or to smoke. 'They undergo various processes as preparation for chewing and smoking. The leaves are stripped from the stems, dried, and then rolled into cigars, or cut by machinery into shreds and put in the pipe; in that state tobacco is also chewed. It is also soaked in a liquor macle of molasses and liquorice-water, after which it is pressed, and is then called "plug-tobacco."

The stems and other refuse parts are ground into snuff, flavored with sub. stances to suit the fancy of buyers The custom of snuffing is less common than formerly.

Effects upon the system. - Wheu administered as a medicine it causes a sensation of heat in the throat, and a feeling of warmth in the stomach. The effect upon the system generally is to increase the activity and capacity of the absorbents, and dropsical affections sometimes disappear under its treatment. It produces nausea, causing romiting and purging when administered in large doses, and gives rise to an indescribable sinking sensation at the pit of the stomach peculiar to itself. It sometimes acts as an anodyne, and occasionally promotes sleep.

Large doses bring on trembling of the limbs, faintness, dimness of sight, and cold sweats, succeeded by convulsions, paralysis, and torpor, terminating in death. The use of tobacco as a luxury is followed by effects which are very startling. It has been demonstrated that it has an injurious effect upon the mind, tending to enfeeble it and rob it of moral energy, impairing the memory, and producing a low grade of intellect.

Tobacco-oil is one of the most deadly poisons. It acts on the brain and nerve cord, first exciting, then lesiening their activity; it induces convulsions and paralysis, and at length arrests respiration; it also injuriously affects the heart and contracts the intestines. Tobacco-poisoning in some degree is very common, and is probably experienced by every smoker when first acquiring the habit. In larger doses nicotine will kill like prussic acid; in small doses it causes tetanus, - one to two drops being enough to kill a dog or a rabbit in five minutes Horses have been known to die from eating oats that had been kept in a granary along with tobacco. Tobacco-juice is distilled in smoking, and is very poisonous; some that was put in a student's beer caused his death; even contact of tobacco with the skin may poison the system. Thus a squadron of hussars who sinnggled tobacco-leaf next the skin, were all made sick.

Statistics. - On the islands of Great Britain and Ireland there are about 300,000 shops in which tobacco is exposed for sale; the amount of sales exceeds 250,000,000 dollars per annum. In France a larger amount is sold in proportion to the iuhabitants.

In Denmark the annual consumption is equal to 7 pounds to the person, including women and children. In the United States the proportion exceeds that of any other comntry of which we have statistics.

In New York City, Brooklyn, and Jersey City, it is estimated that about 800,000 people smoke; which is not far from one in every three, counting men, women, and children.

The entire consumption of the world is 5,580,000,000 pounds; and it is also estimated that about $300,000,000$ of the whole human family smoke, and that the money spent for tobacco in the world would buy breacl for the entire population of the United States. 
Most of the govermments of Lurope have either mouopolized the sale or imposed a high excise or import duty upon it. In fact the influence it exerts upon the reveuue of nations forms an important feature in its history. It is a special object of legislation in several governments of Europe; in some it is a royal monopoly, in whers it is admitted from abroad under high import duties.

When we consider that this plant prodnces no nutritive substance, has no beauty of fluwers nor delicacy of foliage, has no pleasant odors, has a lisagreeable taste when a very little is eaten, producing vomiting and giddiness, and when taken in larger quantities causing death, we are surprised that it should play the part it does in the world, - that it should have become an importaut agricultural product; that it should be produced in such quantities as to require a large fraction of the tonnage of the world to freight it; that its commercial importance should compare favorably with any other single article; that it should be made the pet of empires and the object of special legislation; that thousands should be busied in its production and manufacture; that vast amounts of capital should be employed in its purchase and sale; and finally, that about one half of the male population of the globe should be aldicted to its use, from which no good results can possibly flow.

ATROPA, L. (Deadly Nightshade.) Calyx leafy, 5-parted; corolla bell-shaped, limb 5-cleft; stamens distant, shorter than the corolla: anthers opening by slits; style longer. Berry globular, 2celled upon the calyx, the size of a large cherry, black when ripe; the whole plant downy. Perennial herb. Leaves entire; pedicels solitary, recurved.

1. A. Belladonna, L. (Deadly Nightshade.) Stem trichotomous, brauching, purple, 2 to 5 feet high. Leaves in pairs, unequal, oval, entire, pointed. from 8 to 12 inches loug; petioles very short, radical Flowers large, axillary, and pendent, brownish purple. Flowers in June.

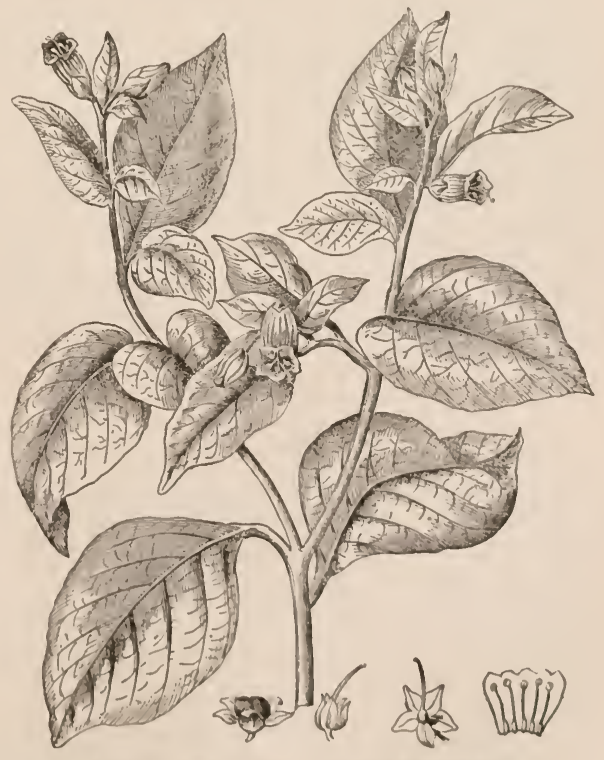

Atropa Belladonsa (Deadly Nightshade).

2. A. Mandragora, $\mathrm{I}$.

(Mandragora officinarum, 1.) is a plant found in southeru Eurupe, pussessing similar properties to belladouna. 
Geography. - The geographical distribution of the belladonna is not wide: it is found in the middle parts of the north temperate zone, in Europe, western Asia, and easteru North America.

Etymology. - Atropa was named for Atropos, one of the three Fates, daugh. ter of Night, whose office it was to sever the thread of human life, - representing thereby the deadly character of this poisonous plant. Belladonna, the specific name, is from two Spanish words, bella and donna, and signifies "fine lady;" it is supposed to have been so styled because the fine ladies of Italy used it as a beautifier. The reason for the name nightshade is not apparent.

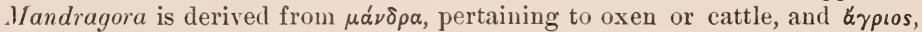
cruel, and relates to the poisonous effect this plant has upon cattle when it is accidentally eaten with their food.

History. - This plant was known to medical practice in the time of 'Theophrastus, and is supposed to be the plant whose fruit was eaten by Anthony's famished army (while retreating before the Parthians), by which so many were poisoned. It is also supposed to have played a part in the destruction of Sweyn's army when he invaded Scotland. A truce was agreed upon, and during the cessation of arms the Scots were to furnish food. They mixed the juice of the atropa berries with the bread and drink, which produced an intoxicating effect upon the Danes; and while in the deep sleep which succeeded, the Scots fell upon and slew them.

It is indigenous to Europe and western Asia, and was brought to North America by colonists, and in a few places, according to Dr. Gray, has escaped from cultivation.

Chemistry. - Atropa belladonna yields to the chemist two substances, atropine and belladonine.

These are the active principles of the plant, and are found in all its parts, leaves, fruit, and bark.

Use. - Belladonna is administered in extract tincture, and in the form of plasters and ointment ${ }^{\circ} \quad \Lambda 1$ parts of the plant yield an active narcotic poison. It relieves inflammation, soothes irritation, and allays nervous excitement. It is used by oculists to cause insensibility or temporary paralysis of the retina. It is much used in homœopathic practice, especially in scarlet fever, and considered by this school a specific. Wrhen taken in large quantities it causes intoxication, accompanied by fits of laughter, ending in convulsions and death

CAPSICUM, L. - Calyx, short, broad, bell-shaped, dentate, with 5 bristle-like teeth; corolla wheel-shaped, deeply 5-cleft, divisions or lobes valvate; stamens slender, rising from the base of the corolla; anthers short, opening lengthwise; disk inconspicuous: style threadlike; stigma club-shaped; ovary usually 3-celled; ovules numerous. Fruit a berry, with a thick or thin inflated pericarp, leathery or succulent, erect or nodding, globose, conical, linear, or oblong. Seeds flat, rough or smooth. Annual herb. Pedicels solitary or in pairs.

1. C. annuum, I. (Red Pepper.) Stem smooth, crooked branching, 2 to 3 feet high. Leaves egg-shaped, smooth, entire, on loug foot-stalks. Flowers axillary, solitary, white; calyx tubular, with 5 small divisions; corolla wheelshaped, in 5 divisions, plaited, and pointed; filaments short and tapering; anthers oblong; ovary egg-shaped; style slender, longer than the filaments; 
stigna blunt. Fruit drooping, conical, 1 to 2 inches long, pod with a thin shell, reddish-yellow when ripe, 2-celled, many-seeded; seeds yellowish-white, Hat, kidney-shinperl.

2. C. fastigiatum, I. (Cayeune l'epler. Bird Pepper.) like the last, except that the Hower's are in clusters of 2 to 3 , and that the fruit is very small and in the shape of a cock's spur, and the pungency very much sharper.

3. C. frutescens. (Cayenne Pepper.) Much cultivated; is like the last, except that the pods are larger, and nore pungent.

These three bear the most pungent fruit, and furnish the red pepper of commerce.

4. C. grossum, W. (Bell Pepper. Bull Pepper.) This is unlike any of the above, inasmuch as the fruit is not only very large, but the walls of the pod are thick and succulent, and rery mild as to pungeney.

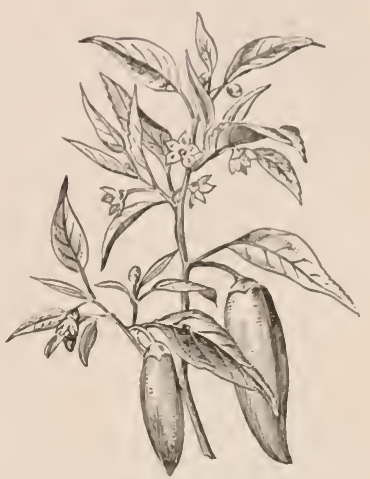

Capsicum annuus (Red Pepper). lod from 2 to 6 inches long, and from 1 to 4 inches in diameter. Fruit used for piekling.

Geography. - The home of the eapsicum is America. It is believed that it was first brought to the notice of Europeans as a condiment for food by the physician of the fleet on the second royage of Columbus to the New Wiorld. It is now cultivated in almost every civilized country in the world where the climate admits of its cultivation. The sonthern $A$ siatics have names of their own for it; this goes to show that it is also indigenous there, but it has never been found in the Old World ontside of eultivation; on the other hand, it has been found wilel in South America. Capsienm is a tropical and subtropical plant, though it fruits in sonthern Europe, and in the United States as far north as the $43 \mathrm{~d}$ parallel. It is grown in all tropical countries as a condiment

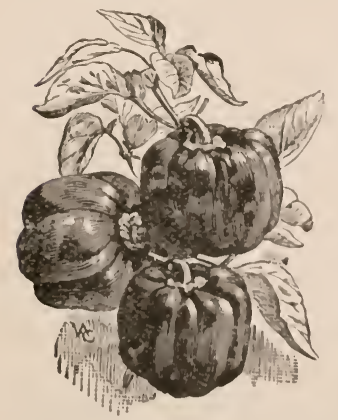

Capsicum grossum (Bell Pepper). or food. The West India islands, miclle $\Lambda$ friea, and southern $\Lambda$ sia are all grateful regions of this fiery fruit. The outer skin of the fruit, as well as the seed, yields a red oil.

Etymology. - Capsicum is supposed to be

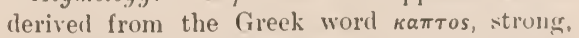
alluling to the pungent taste of the fruit pocls. It has also been derivel from $\kappa a ́ \psi a$, a coffer, bux, or chest, referring to the pod which holds the seerls Annum is Latin, and means "yearly;" frutescens, having the appearance of a shrub; fastigiatum, tapering, or pyramidal, grossum, from the Latin (frossus, thick, referring to the thick poul of this species. Pepper comes from the Greek $\pi i \pi \in \rho$, and Coypmne refers to the country whence the lest is brought.

U'se, $-A$ s a medicine, (apsicum is highly stimulant; a tea of red pepper is a specific in nansea. largely used in compounding the medicines of the Thompsonian practitioners. 'The ground fruit,

Pli. FL. -14 
or "pepper," is largely used as a condiment for food, especially in hot countries, and is much used in linimeuts. When mixed with the food of poultry it is said to preserve health and promote the laying of eggs.

SOLANUM, L. Calyx persistent, 5-parted ; corolla rotate, subcampanulate; tube very short; limb plaited in the bud, 5-cleft, lobed or angular; anthers erect, connivent, but not united, opening at the top by 2 pores. Fruit a globular berry, 2-celled, many-seeded; seeds small. Flowering in August. Unarmed or prickly herb.

1. S. tuberosum, L. (Potato. Irish Potato. White Potato. Common Potato.) Stem herbaceous, erect, prostrate, or assurgent, 2 to 4 feet long, angular and branched towards the top, smooth or clothed with soft hairs at and near to the

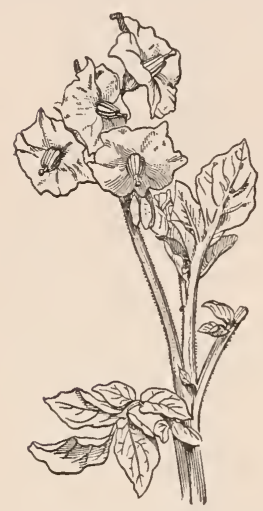

Solanum TUBERosum (Potato). extremities. Leaves interruptedly pinnate; leaflets roundish, petioled, dark green, every alternate pair of leaflets very small; peduncles few-flowered; flowers blue or white. Rootlets give rise to tubers, globular or lengthened. Fruit a green berry, about the size of an ordinary marble; seeds numerous. Flowers in July and August. Roots giving rise to globular or reniform tubers. Tubers ripen July to October.

When propagated from the seed, the tubers of the first year are about the size of peas; the tubers produced by these are much larger, and the product of the third year is fit for the table. When propagated from the seed, the plant sports freely, and new varieties are thus produced. When the tubers are used to propagate from, the rariety is constant.

There are other allied species, but they have not stood the test of cultivation, on account especially of the small size of their tubers, as follows:-

2. S. Commersonii, Dunal. Chile.

3. S. immite, Dunal. Peru.

4. S. verrucosum, Schlechtendal. Mexico.

These all differ in botanical features as well as in size and quality of their tubers, so much so as to entitle them to a specific character.

No plant in the whole range of table vegetables has had so large a share of attention from gardeners and amateurs as the potato, and every year new varieties are offered for sale by the seedsmen.

Geography. - The geographical zone of the potato is between the 35 th and 50 th parallels, and it even produces well up to $60^{\circ}$. It will grow and fruit well in any latitude where the cereals flourish.

It yields best in cool, damp climates; and the edible qualities are best where the plant is grown in rich sandy loam.

Etymology. - Solanum is of very doubtful derivation. The most plausible history of the word is that it is from the Latin word solor, solace, or comfort, due to the narcotic effect of some of the plants of this very large genus. Tuberosum is due to the tuberous character of its products. Potato is a cor. ruption of batata, already explained. The French, from the same source, have made it patate. 
History. - Humboldt helieves the plant kuown to the Spaniards under the name maglia is the original of the potato. The potato is indigenons to Chile, and has been taken thence to neighboring parts of South America. Darwin, in his voyage to the sonth seas in 1840 , touched at Chile, where he found the potato wild anong the islands on the coast, growing in great luxuriance, with every appearauce of being native to the soil, but saw nothing to lead him to believe that the natives cultivated it. In Peru, travellers report that the natives pay much attention to its growth. It is believed that the spaniards carried it from l'eru to Europe. This is the view taken by De Candolle. Another theory is that it was taken to Florida by the spaniards, whence it found its way into the English settlements of Virginia, and thence to England. It has also been suggested that Raleigh, in warring against the Spaniarls as a privateer, might have captured vessels with potatoes on board, and in that way have introduced the plant into Ireland. It is related that he had it planter on his estate in the south of Ireland, and that his gardener one lay hrought him a potato ball, or berry; tasting it, he was so disgusted with it that he ordered the gardener to root it out and destroy it. In attempting to do this, the gardener discovered the tubers attached to its roots; they were cooked, the value of this wonderful plant was revealed, and the cultivation of the potato dates from that incident This occurrence is said to have taken place near the end of the sixteenth century. It was, however, known in other parts of Europe before taken to Ireland by Raleigh. It was for a long time confinel to Ireland as a food-plant, but has now found its way throughout Europe.

Chemistry. - The potato yields to the chemist in 100 parts by weight: water, 68 ; starch, 17; wood, $09 ;$ mucilage, $06 ;=100$.

Comparel with wheat, it is as $2-7 ; i$. e., a pound of wheat is worth $3 \frac{1}{2}$ pounds of potatoes; or one bushel of wheat is worth $3 \frac{1}{2}$ bushels of potatoes.

Use. - During the 300 years which have elapsed since its discovery, the potato has steadily advanced in value, until it has reached a point of importance in the economy of human life unequalled by any other food-plant outside of the cereals. As a root-regetable for the table, nothing equals it. In all the countries of Europe, the United States of North America, and in Canada, it constitutes a large part of the food of the working classes, and is always upon the tables of the rich. The natives of Peru cook it by roasting it in the ashes. The most common mole of cooking is boiling; it is also fried, baked, and stewed with meat or milk. It is said that the Poles excel in cooking the potato, and that they practice thirty different methods of preparing it for the table.

\section{OrDER YI. PEDALINEAE.}

Flowers perfect, irregular, axillary, solitary, racemed or in spikes, mostly 2-bracteolate: calyx 5-parted; corolla-tube cylindrical, throat swollen, 5-lobed: limb bilabiate. imbricate or subvalvate; stamens 5) on corolla-tube, 1 sterile, 4 fertile, 2 long and 2 short : ovary superior, 1-celled, rarely 2-4-celled. Fruit a capsule or drupe. 4-seeded. l.eaves opposite or alternate, simple. Herbs.

No. of genera, about 10; species, 40 ; found in warm climates.

SESAMUM. I. (Oil Seed.) Calyx small, 5-partel; corolla bellshaped, long and curved, oblique at base, 5-lobed, lateral lobes open, 
anterior shorter; stamens 4, attached to the base of the corolla, included; anthers arrow-shaped, attached at their backs, cells nearly parallel; ovary 2-celled, each cell divided into 2 dry false partitions; ovules many in each cell, arranged in a line; capsule oblong or ovate; seeds numerous, small, triangular in outline, differing in color; embryo straight, radical, short, testa crustaceous. Leaves opposite below, and alternate above, petioled, entire, incised or dentate, 3-parted or dissected. Flowers pale, violet, solitary, axillary, nearly sessile. Whole plant scabrous, erect, or prostrate.

1. S. Indicum, DC. (Sesame.) Stalk 2 to 3 feet in height, scabrous. Leaves ovate, oblong, or lanceolate, and alternate above, the lower ones 3-lobed or

3-parted and opposite, conspicuously
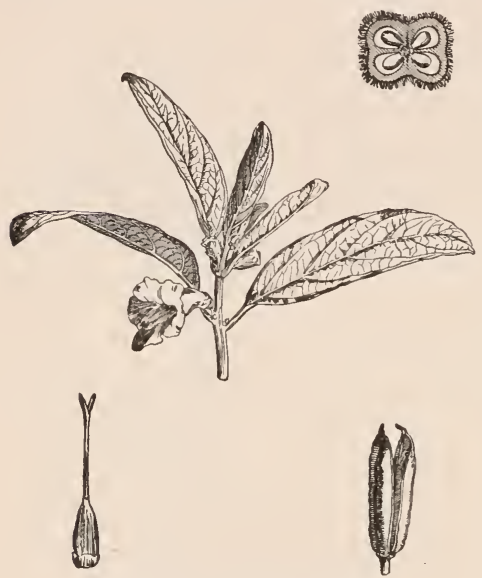

Sesamum Indicum (Sesame). feather-veined with yellow glands at the base of the peduncles. Flowers resembling the flowers of the foxglove in shape, color dingy white to rose; capsule velvety and pubescent, mucronate, 2-celled, developing in 4 cells; seeds numerous, ovoid, flat, varying in color, white, brown, or black, rather smaller than flaxseed. This species varies greatly in the form of its leaves aud color of its seeds.

2. S. orientale, L. Larger leaves than in S. Indicum; flowers white, otherwise as in No. 1.

Leaves of both species abound in a gummy substance which they yield to water, forming a pleasant demulgent beverage.

Geography. - The home of the plant is believed to be the Sunda Isles, whence it was introduced into India, and thence to western Asia, southern Europe, and northern Africa, and from there to the New World. To obtain the oil, the ripe seeds are first washed to remove all mucilage, and the oil is obtained by expression ; the seeds yield 45 per cent of oil, as to weight. Its geographical zone is a tropical and sub. tropical belt extending both sides of the equator to the parallel of $35^{\circ}$ all around the globe. It grows sparingly in higher latitudes.

Etymology. - Sesamum is derived from $\sigma \eta \sigma \alpha \mu \eta$, the Greek name of this plant; the specific name, Indicum, denotes the country where it is cultivated. The seeds are known in commerce as Til, Gingeli, and Tingili, Sesame, and Benne seeds. Orientale is from the Latin orientalis, and signifies " eastern."

History. - The S. orientale was known in the Levant and southern Europe and Egypt at least four centuries prior to the opening of the Christian era, being mentioned by Xenophon. It was taken to the West Indies by Europeans, and S. Indicum has found its way to Florida and other Southern States, and has crept along as far north as the vicinity of Philadelphia. It was detected by Judge Addison Brown in the ballast heaps at Commmnipaw, N. J. It is knowu as the thuuderbolt tlower. It is also the potent legendary opener 
of doors and caves. In the celebrated story of $\mathrm{Ali}$ Baba, the conjuror pronounces the words, "Open Sesame," and the door flies open.

Use. - The plant is used in Europe and India for a pot-herb, but it is most valuable for the oil it produces.

The oil resists putrefaction longer than any other fixed oil, and is considered the most delicate of all the sweet vils, except olive oil. It is used in India for food and for anointing the body, and for the fragrant oils used in religions ceremonies. It is used in all civilized countries for the same purposes for which olive oil is used. It is applied to illuminating purposes, to the manufacture of cosmetics and hair dressings, and especially to the manufacture of fine toilet soaps.

It congeals at a much lower temperature than other oils, and is hence well adapted to cold climates. It has of late years been largely employed in the manufacture of spurious butter, or oleomargarine. The natives of India make an article of diet of the seeds, and also of the refuse eakes after the oil is pressed ont of the seeds, and they place the seeds in the graves with their learl relatives.

\section{Order MLI. VERBENACEAE.}

Flowers perfect, irregular, or nearly regular, in a head. spike. raceme, or cyme, rarely solitary, usually bracteate; calyx with united sepals, persistent, tubular, limb toothed; corolla hypogynous; petals united and tubular, limb 4-5-lobed, frequently unequal, and lip-shaped, imbricate in the bud; stamens, 2 long and 2 shorter, rarely $\tilde{5}$, attached to the corolla; orary free; style terminal, forked at top. Fruit, a fleshy drupe, with 2-4 nutlets. Leares opposite or whorled, rarely alternate, exstipulate, simple, or rarely compound. IIerbaceous and woody. Plants and trees.

No. of genera, 59 ; species, 700 ; warm climates.

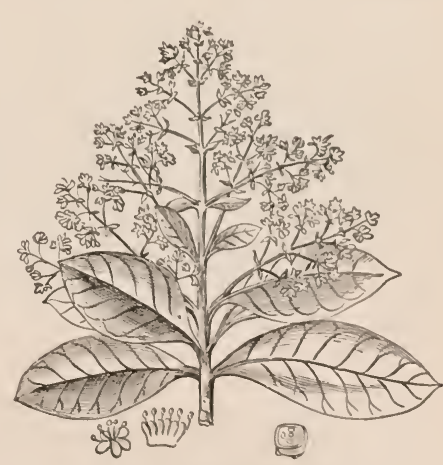

Tectona grandis (Teak).

TECTONA, I.f. Calyx bell-shaped, short, 5-6-cleft, sharp, tube swollen below, and contracted near the month; corolla-tube short, limb gaping, 5-6-cleft, lobes short, nearly equal, imbricated; stamens 5 to 6 , attached to the corolla near its base, longer than corollatube; anthers ovate or oblong ; ovarium fleshy, 4-celled, cells 1-ovuled ; style elongated, 2-cleft, orules attached to thr sisle: drupe inclosed in the calyx; exocarp thin, endocarp fleshy. Siseds erect, oblong.

T. grandis, I.f. (Teak.) 'Trunk erect, 80 to 150 feet in height, and from 3 to 6 feet in diameter. Bark smonth, gray; branchlets 4-sided. Leaves opposite, or in verticils of 3 , rough on the upper surface, downy beneath. entire, from 1 to 2 feet in length, and 6 to 18 inches wille. Flowers small, 
sessile, white, in terminal, compound, dichotomons panicles, bracts small. Fruit lens-shaped, in 4-celled drupes.

There are three species of this magnificent tree.

Geography. - The geographical home of the Tectona is tropical. One species is found in the East Indies, another in Burmah, and the third in the Philippines.

Etymology. - The generic name, Tectona, was altered from 'l'ekka, the native name, whose signification is unknown. Grandis, the specific name, is the Latin for large, or noble, and is due to its magnificent size.

Use. - The teak is used in India in all structures where strength and durability are desired. It has been called the oak of the East. England has constructed some of her best ships of teak, some of which were built in India, and others in England, the timber having been taken home.

The leaf yields a red dye, and is also charged with an oil, the extraction of which forms an important industry. The oil is used for polishing and varnishing purposes.

\section{Order Xli. LABIAT必.}

Flowers irregular, rarely regular, solitary or in pairs, or clustered in cymes in the axils of leaves or bracts, scattered along the extremities of the stems, or in densely crowded spikes; calyx persistent; sepals 5, connate, mostly lipped; corolla with united petals, hypogynous, tube occasionally twisted, limb $4-5$-lobed. imbricated in the bud, usually 2-lipped, upper lip entire or notched, lower 3-lobed, sometimes 1-lipped and deeply cleft, sometimes bell-shaped or funnelshaped, with four equal lobes and rearly equal stamens; stamens on corolla-tube usually $t$, didynamous; ovary free; style simple, rising from the base of the ovarian lobes, H-lobed; stigma usually forked. Fruit 4 akene-like lobes or nutlets, free or in pairs. Stems square; leaves opposite or whorled, exstipulate; subwooly and herbaceous plants, covered with glands containing an odoriferous volatile oil.

No. of genera, 136 ; species, 2,600; cosmopolitan.

LAVANDULA, L. Calyx spindle-shaped, 13-15 striate, 5-toothed, upper tooth longest; corolla-tube exserted, upper lip 2-lobed, lower one 3-lobed; stamens shorter than the corolla-tube; anthers 1-celled by confluence. Flowers small, spicate. Perennial herb.

1. L. spica, L. (Lavender.) Stem woody at the base, 15 to 20 inches high in a natural state, but reaching 5 feet under cultivation, branching near the ground. Leaves crowded about the base of the branches, whitish downy, oblanceolate, tapering to the base, sessile, edges revolute, leaves on the branches and upper part of the stem linear-lanceolate, nppermost ones shorter than the calyx bracts, and awl-shaped. Flowers in an interrupted spike, lilaccolored. July.

Var. alba, IV. Has white flowers, otherwise as above.

Var. latifolia, IV. Has broader leaves.

2. L. vera, DC., and L. stœchas, L. Were formerly in use, but are not used at the present day.

There are some twenty species in all; the above are the important ones. 
Gengraph!. - The Lavandula is a native of Greece and the Grecian islands, whence it spread west, and was carried hy Europeans to Hindustan; it was brought in the same way to the Atlantic States of North America, where it has become a common garden plant, cultivated for its delicate fragrance. It grows thronghout the middle of the north temperate zone, has spread over the countries of the Levant, has been seen in gardens in Hindustan, and is com. mon in the gardens of the eastern United States of North America. It is occasionally found growing wild near deserted dwellings.

Etymology. - Lavandula is from the Latin word lavare, wash, due to the circumstance that the spikes were used to perfume freshly-washed linen. The liomans perfumed their baths with it. The name spica, Latiu, a spike, is due to the mode of inflorescence.

Preparation. - The Howers are distilled, the product being a delicate essential oil, and a coarser oil is obtained from the leaves aud ends of the branches. The oil is largely manufactured in the department of the "Alpes Maritimes," in the southeast of France. The best, however, is prodnced in England, and brings in open market fifteen times more than the best French oil.

Use. - Lavender is stimulant and tonic.

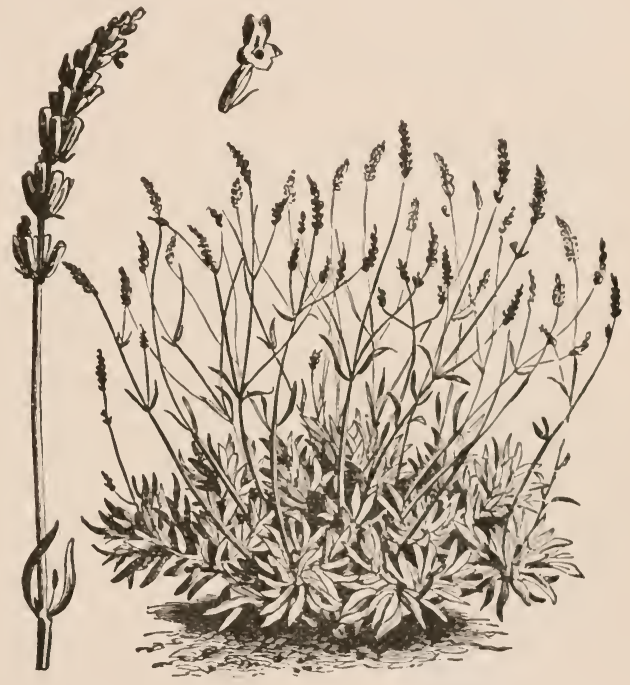

LAVANDUla SPICA (Lavender). The pulverized dried leaves are used for a suuff to cause sneezing.

The leaves are laid among linen to perfume it.

The oil of lavender is a favorite perfume for manufacturing fragrant waters, and for componnding an aromatic spirit to remedy nausea, also to disguise the disagreeable taste of other drugs. 'The coarser oil produced from the leaves and stems is called spike oil, and is used by artists to mix their colors, and especially for painting on pottery.

MENTHA, L. Calyx 5-toothed; corolla t-cleft, just a little longer than the calyx, nearly equal, one division broader and emarginate; stamens 1, straight, separate. Flowers in verticils, small, crowded, short-stalked, or subsessile.

1. M. viridis, I. (Spearmint.) Stem 4 -angled, from a creeping root, 12 to 20 inches high. Leaves wrinkled, subsessile or short-petioled, lanceolate acute, and cut serrate; bracts narruw, lanceolate or bristly; teeth of the 
(alyx hairy, spikes slender, interrupted. Whole plant possesses a strong agreeable odor. Damp places.

2. M. piperita, L. (Peppermint.) Stem quadrangular and grooved, sometimes hairy, from 1 to 2 feet high, slender, weak, purplish, and branching. Leaves on short petioles, ovate, pointed, and serrate, dark green above, smooth. and shining, paler underneath, with purplish veins. Flowers in terminal spikes, lower parts interrupted, the lower whorl remote; bracts lanceolate and ciliate; calyx furrowed, with 5 dark purple ciliated striæ; corolla purple; filaments short, anthers included; stigma forked.

Var. subhirsuta, Benth. Has scattered hairs on the petioles and veins of the leaves.

There are many species to this genus, but those we have described are the most important, and the only ones that possess any economic or commercial value.

Geography. - The geographical distribution of the mint is a belt between $35^{\circ}$ and $50^{\circ}$ of north latitude, extending from the eastern side of the Missis-

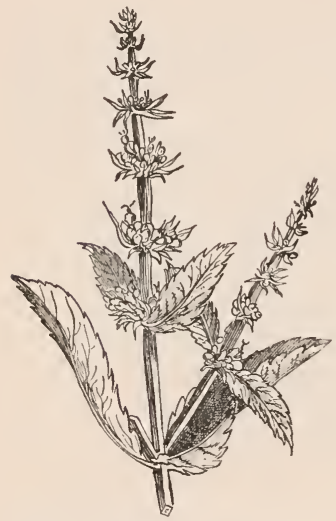

Mentha Piperita (Peppermint). sippi valley to Japan. Loudon claims England as the home of the spearmint, as well as the peppermint. The $\boldsymbol{M}$. Piperita is found wild in Hinclustan, Japan, Persia, northwestern India, and in Egypt. In the days of Linnæus it was a well-known plant in gardens throughout central Europe.

Both these species were brought to the British colonies in North America by European emigrants, and have become naturalized throughout the northern and middle Atlantic States.

Etymology. - Mentha, the generic name, is sail to have been given to this plant in honor of Mintha, the daughter of Cocytus, who according to the myth was turned into mint by Proserpine in a fit of jealousy. Viridis is the Latin word for green, due to the color of the plant. Piperita, from the Greek $\pi l \pi \epsilon \rho \iota$, pepper, was given to this species on account of the biting pungency of the taste of the leaves. Spearmint is due to the spear-shaped spikes in which the flowers appear. Peppermint is merely a translation of Piperita. Mint is supposed to be a corruption of the word mentha, or mintha.

History. - Mentha viridis, or spearmint, was under cultivation in the convent gardens in the ninth century. The exact locality which may be claimed as its home is not known, but it is a European plant.

It is claimed that the mentha piperita is a native of England, was discovered in Hertfordshire by a physician in 1696, and was described by Ray.

Cultivation. - It is cultivated for the production of oil of peppermint, which is obtained by distilling the green plant.

The cultivation for this purpose is carried on in England, on the European continent, and in the States of New York and Ohio in North America. 'The ground, which should be damp, is prepared in furrows, and roots are laid in them, after which they are lightly covered with earth and allowed to grow till 
the ground is covered. When in flower it is ant, and after lying for a part of a day, is placed into the stills. After the oil is extrateted, the mint is cured and fed to cattle.

U'se. - spearmint is used to flavor sancess for meats, and to prepare a very popular beverage known as mint julep; also in the mannfacture of essences and cordials; its medical qualities are carminative and anthelmintic.

l'eppermint is largely used in the manulacture of the essential oil of peppermint, on which the medicinal character of the plant depends. Its molicinal qualities are anti-spasmodic, and it is used in domestic practice for pains in the stomach and lower intestines. In China and Hindustan it is largely used to relieve the flatulency incident to a vegetable diet. The taste is aromatic, warm, pmugent, somewhat like camphor, and highly stimulant. 'The greater part of the oil, however, is used by the manufacturers of confectionery and cordials.

3. M. pulegium, L. (Pennyroyal.) Sitem 6 to 10 inches long, bluntly t-ingled, much branched, usually trailing, slightly hairy. Leaves on short petioles, small, bluntly serrate, hairy mulermeath. Flower-stalks covered with short, thick hairs; flowers numerons, in sessile whorls; calyx greenish-purple, furrowed and hairy, with 5 unequal, eiliated, pointed teeth; corolla twice the length of the ealyx, purple, t-cleft, white at the base, clothed with long, soft hairs; stamens erect, longer than the corolla. Annual. Flowering from June to September.

Geography. - Found growing throughont Europe, Asia Minor, Persia, and northern Africa; was loronght to northeastern America and introluced into cultivation; but the character and properties are so nearly allied to those of the American plant (Hedeoma pmlegioides, Pers.) that it has disappeared, and the American plant is used in its place.

Etymology and History. - Puieginm is from the two Latin words, pulex, a flea, and rego, have power over, due to its reputation for destroying this lively insect. Pennyroyal is a curious corruption of the specific name. In England it is called pudding grass, because of its nse for flavoring blood puddings ; also flea mint, for the reason alrealy stated.

The peunyroyal was known in the first century, and is mentioned by both Diosenriles and I'lins.

I se - The medicinal properties of pennyroyal are carminative, antispasmolic, tonic, and stimulant. It is a well-known remedy in throat diseases. It is used as a gargle and as a liniment; also as an insecticide. or insectifuge, as the odur is said to hanish various insects. The medieal qualities reside in an essential oil obtained by distilling the entire plant.

l'eunyroyal is administered by quacks for a blood-purifier, under the name of Orgains.

ORIGANUM, I. Calyx ovate, hell-shaped, ohscurely 13-nerred. 5-toothed, throat hairy; corolla 2-lipped, upper lip erect and notehed. lower longer, and composed of 3 spreading lobes; stamens 4 , ascending and spreading, mostly longer than the tube of corolla. Perennials; leaves nearly entire: flowers in crowded short or cylindrical heads; bracts usually colored: flowers purplish.

Species, 25 in number; mostly European. 
1. 0. vulgare, L. (Common Marjoram.) Stem purple, leafy, branched near the top, 1 to 2 feet high, and hairy. Leaves stalked, entire, or slightly serrate, sprinkled with resinous dots, paler underneath, ovate, lanceolate, an inch in length, petioles shorter than the blades, bracts purplish. Flowers in a terminal 3-forked panicle, in globular, compact heads; calyx hairy inside, with short, nearly equal, teeth ; corolla twice as long as the calyx, with 4 broad, nearly equal, lobes, the upper one broadest and erect; stamens longer than corolla-tube. Flowers purplish-white. Whole plant highly aromatic to the taste. July to August.

2. 0. marjorana, L. (Marjoram. Sweet Marjoram.) Stems numerous, woody, 12-18 inches high, much-branched. Leaves oval, obtuse, entire, on short

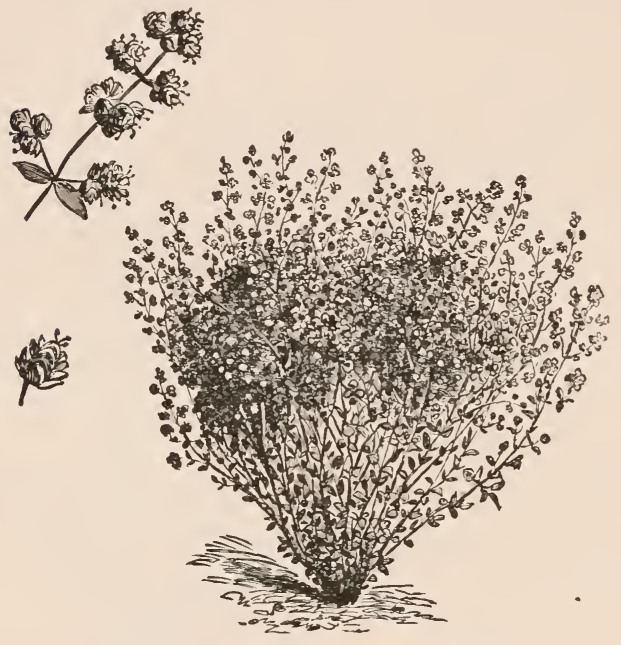

Origanum vulgare (Common Marjoram). petioles, blade hoarypubescent, pale-green. Flowers small, white or pinkish, in crowded, roundish, compact, terminal spikes, bracts numerous and large; calyx tubular, 5toothel, teeth sharp; corolla funnel-shaped, 2-lipped, upper one erect and rounded, lower one cut into 3 pointed segments. Leares and flowers possess a pleasant aromatic odor. July to August.

These two species are the only ones whuse medicinal or commercial value is of any importance.

Geography. - The geographical range of these two species is wide; they grow well all through the Levant and Mediterranean countries, and all over Europe as far north as the 50th parallel.

Etymolog!y. - Origanum, the generic name, is from the Greek words úpos, "an elevation" or "hill," and yávos, "beauty," hence the beauty of the hills. Vulgare is Latin for "common." Marjorana is supposed to be from the low Latin name, majorica. Marjoram, the common name, is a corruption of the Latin majorica.

History. - The Origanum was well known to the Greek and Romans, and was a favorite decorative plant at their marriage feasts, when it was woven into wreaths to crown the young married couple. It is mentioned by Pliny and Vergil. It was brought to North America by European colonists, and is a native of Europe and adjacent parts of Asia.

Use. - As a medicine it is stimulant, carminative, tonic, and sudorific, and it is prescribed for dyspepsia and other disorders of the stomach.

The Thompsonian practitioners use the dried leaves for snuff in cephalic 
difficulties. The leaves are nsed for tea as table beverage, and are preforred by some to teas from China.

The oil is very sharp, and used in liniments for sprains and rheumatism. On account of its beatuty it is a favorite plant in the flower-garden.

THYMUS, L. Calyx bilabiate, with 10 to $1: 3$ strice, j-toothed, 3 upper teeth short, triangular, lower pair linear, subulate, ascending; corolla -lipped, upper lip notched, lower lip 3-lobed, lobes equal or middle lobe larger; stamens 4, mostly exserted; filaments straight, divergent. Leaves small, entire, strongly veined. P'eremial her', or woody.

1. T. vulgaris, L. (Sweet 'l'hyme.) Stem a foot high, slender, wooly, branched. Leaves sessile, linear-lanceolate or ovate, quarter of an inch long, edges revolute, hoary, especially beneath, and ilutted with oil-glands. Flowers small, purple, in terminal globose heads, occasionally a few lower whorls. In a state of nature, clotherl with a gray pubescence; under cultivation, greener, more luxuriant, and barely tomentose ; fragrant, pungent, and aromatic. Perennial herb. July.

2. T. serpyllum, I. Stem slender, much-branched, procumbent, hard, approaching woodiness at the base, forming low, lense tufts, 6 to 12 inches in cliameter, and covered with flowers. Leaves very small, ovate or oblong, fringed at the base by a few long hairs on each sile; Horal leaves smaller. Flowers nsually 6 in a whorl, without any other bracts than the floral

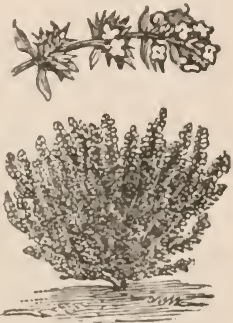

Thymes volgaris (Thyme). leaves, forming short, terminal, loose, leafy spikes; calyx hairy, and the whole plant sometimes clothed with hoary hairs.

Geography. - Thyme is indigenous to Spain and other parts of sonthern Europe, the coasts of the Mediterranean, the mountains of Creece and the islands of the Archipelago, the British Isles, and north to southern Siberia.

Etymology. - Thymus is from the Greek $\theta u \mu o$ s, signifying "conrage" or "strength." Vulgaris, Latin vulgus, signifies " common." Serpyllum, Latin, means "creeping," and is due to the prostrate character of this species. Thyme, the common name, is a contraction of the generic name.

History. - Thyme was known to the ancient liomans, who nsed it in rarions ways to season fool. It was in modern times described by Tournefort, anil was bronght to North America by European colonists. It was a favorite aromatic herb of the Greeks, and ahounded on Mt. Hymettus, near Athens. famed for its thyme and honey. (1)irl, Vergil, and Pliny, all speak of the thyme in connection with bees; and honey made from the thyme possessed the flavor of the plant, and was on that account highly esteemed.

Use. - Thyme is usel in many culiuary preparations for flavoring sances. gravies, cheese, and meats, sansage, ete. The plint vichls to distillation an essential oil, which is a powerful local stimulant. In combination with camphor and alcohol, it is used as a liniment for chronic rhemmatism. It is an important ingredient in liniments, and is largely usen for low grades of scentel soaps. The plant is also employed for borilurs in planterl grounds. The variegated varieties. 'T. platifolia, and I'. aurifolia, are used for that purpose. 
SALVIA, L. (Sage.) Calyx striate, 2-lipped, upper lip 3-toothed or entire, lower bifid, throat naked; corolla 2-lipped, gaping, the upper lip straight or curved, sometimes notched, the lower spreading and 3-lobed, middle larger; perfect stamens 2, the filaments have at their summits a cross thread, the transverse connective, one end of which bears a perfect half-anther. The other end has on it a defective halfanther. This transverse thread is an essential character of this large genus.

1. S. officinalis, L. (Common or Garden Sage.) Stem woody, 1 to 2 feet high. Leaves elliptical-lanceolate, wrinkled, margins crenulated; calyx mucronate; whorls 6-10-flowered, in two opposite sets, of purplish-blue flowers. Whole plant strongly aromatic.

Var. variegata has leares spotted with white. This genus has about 400 species, though $\mathrm{S}$. officinalis is the only one of culinary importance.

2. The S. pomifera, I. (Apple-bearing Sage), is found upon some of the islands of the Grecian Archipelago. Lpon its branches appear fleshy tumors from half to three quarters of an inch in diameter, supposed to be caused by the bite of an insect.

Geography. - The home of the sage is the countries of the Mediterranean. It was known to the most ancient writers on medicine and botany on account of its medical rirtues and pleasant odor. From ancient time it has been cultivated thronghout midlle and sonthern Europe and the British Isles, and like similar plants was brought to northeast America by European colonists. It is also growing in British India, where it has been carried by the English.

The genus is very large, and some of the species are found in erery quarter of the glohe. The home of the S. officinalis and S. pomifera is the Levant and other Mediterranean countries. The $S$. officinalis grows well in all countries between $35^{\circ}$ and $60^{\circ}$ of the north temperate zone. It has been introduced into North America, but not naturalized; it is not growing except under cultivation.

Etymology. - Salvia, the generic name, is from the Latin salvus, "well," or "in good health," in allusion to its curative qualities. Officinalis, the specific name, means "of the shops." Pomifera, "apple-bearing," is due to the fleshy tumors on its branches. The common name, sage, is said to be due to properties of the plant, which tend to strengthen the mind, and thereby make men wise.

Use. - The sage is used to flavor sansage, for stuffings for roast poultry and other meats, and the pulverized dried leaves are used to flavor cheese. An infusion of the leaves is an astringent tonic gargle. The cold tea is administered for nervous headache; when sweetened with honey, the sage is a remedy for canker in the month and throat. Gerard says: "It is good for the head and brain. It quickens the memory and the senses. The juice of the leaves mixed with honey is good for those who spit blood. No man needs to donbt of the wholesomeness of sage." It was also nsed in his day as a hair-dye. It is used as a cooling drink in ferers, and is an important plant in the list of domestic remedies.

There are many species used for ornamental purposes. A variety of $S$. officinalis, var. rariegata, is a favorite, and there are many with very showy flowers. 
Rosmarinus, I. (liosemary, Dew of the Sea.) ('alyx bell-shaped, slightly compressed, 2-lipped, upper lip concave, minutely 3-toothed, lower bitid, naked within; corolla gaping, downy, pale-blue, variegated with purple and white, tube longer than the ealyx, upper lip erect and shortly bifid, the lower spreading and slit into three segments, the middle segment larger, concave, and declined; perfect stanems ?, longer than the upper lip, arched, bearing a flexed tooth above the base, supporting the blue oblong anther; style as long as the stamens, thread-like, 2 -cleft, the posterior lobe small; nutlets, I at the hottom of the calyx. Slurub. Leaves narrow and entire. Floral leares smaller. Unly 1 species.

R. officinalis, L. (Rosemary.) Stem erect, 4 feet high, much-l,ranched; branches hairy; branchlets 4-sided and dowuy. Leaves opposite, nearly sessile. an inch long, narrow, linear, obtuse, entire, revolute, dark-green, smooth and shining above, woolly, veined, and silvery beneath. Flowers axillary and terminal, blue. Both Howers and leaves have a strong odor, resembling camphor. A beautiful evergreen shrul,.

Var. variegata, W., has variegated leaves. This, with other varieties, are under cultivation; but the R. ofticimalis is highly valuable for other purposes.

Geography. - The rosemary is no loubt native in all sontheru

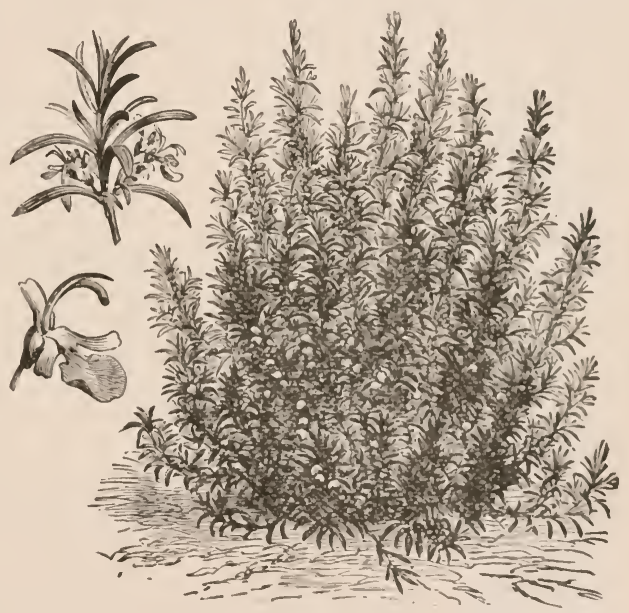

Rosmarinus officinalis (Rosemary). Europe. It is found withont cultivation on the Greek islands in the l'eloponnesus, and is under cultivation from western Europe to Japan, in the southern parts of the north temperate zone. It is a farorite in the garlens of Egypt, and is cultivated in Ilindustan for medicinal purposes. As no native name is found for it in $\Lambda$ sia, it is inferable that it has been introdnced into those countries by Europeans.

Etymolog!y. - Rosmarimus is componnded of the Latin words ros, "dew," and marimus, "of the sea," - dew of the sea, or sea-dew. Officinalis, Latin, means " of the shops." Variegata, Latin, means "variegated." Rosemary is without doubt a corruption of rosmarinns.

History. - When it was introdnced inte nso is not known, but it was known to the ancients, Dioseorides, Pliny, Galen, and the Arabic physicians. It was known to the Saxoms before the Norman conquest, and uo donbt cultivated by them in Euglaud. Charlemagne mrered it plauted in his 
garden; Vergil recummends it for the use of bees; and Lindley says the delicate flavor of Narboune honey is due to access of the bees to the rosemary. It was brought to North America by colonists in the latter part of the seventeenth century.

Use. - It is difficult to find a plant to which greater and more numerous qualities have been attributed, or one that is more widely known or in greater repute than this humble shrub. The Greeks bound it on the head for garlands. The leaves and flowers decorated the bride to indicate fidelity. Anne of Cleves wore it at her wedding with Henry. It was laid upon the coffin, thrown into the open grave, or carried in the hand at funerals to indicate that the mourners would remember the dead. A sprig was worn to proclaim that the wearer harl repented. Queen Bess adorned the walls of Hampton Court with rosemary. It was always found in the woman's department of the gardens of the high-born, and there was an English proverb, that "rosemary grows where the mistress is master." We have not space to relate half of what has been said of this little shrub. It is highly aromatic in all its parts. The flowers are distilled to procure the oil of rosemary, which is an ingredient in the perfumery of Hungary water and eau de cologne; it is used also to flavor spirits and liqueurs. It is used in making the well-known soap liniment, and the compound spirits of lavender. It is an ingredient in the manufacture of nearly all perfumery and of toilet soaps. The pulverized leaves are used for snuff.

NEPETA, L. Calyx cylindrical, marked with 15 striæ or nerves, 5-toothed, generally oblique, barely 2-lipped; corolla slender below, swollen in the throat, upper lip emarginate, lower

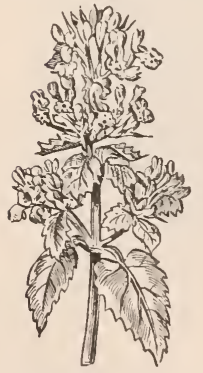

NEPETA CATARIA (Catnip). one spreading, 3-lobed, middle lobe largest, crenate, marked with crimson dots, margin turned over; stamens 4 , ascending under the upper lip, near together. Peremial or annual herb. Leares sometimes lobed or incised.

A large genus; some of the species are cultivated for ornamental purposes.

N. cataria, L. (Catnip or catmint.) Stem square, 3 feet high, branched; whole plant hoary. Leaves cordate, coarsely crenate-toothed and petioled. Flowers crowded, in large, hoary spikes, whorled, white or purplish. July to September.

Geography. - The home of the Nepeta Cataria is Europe and western Asia. It is found throughout the countries of the Lerant. It was brought to North America by Furopean settlers, from whose gardens it has escaped, and is found growing freely about dwellings and by the roadsides without cultivation.

Etymology. - Nepeta, the generic name of this plant, is said to have been given to it because it was first brought to the notice of naturalists at Nepet, a town in Tuscany. It is also claimed to be due to the fact that it cures the bite of the nepa, a scorpion. Cataria, the specific name, arises from the fact that cats delight in it, take it for medicine, and roll upon it when opportunity offers. Catnep or catnip, the popular name, was given for the reason that cats bite it or nip it. 
$U^{\top}$ se. - Catnip is an important article in the materia medica of the matron. 'Tea male of the dried leaves, stems, and Hower-buds is administered to infants to relieve pains in the bowels and to promote sleep. Herbal practitioners claim for it the qualities of a febrifuge, carminative, tonic, and soporific, and a slight narcotic.

MARRUBIUM, L. Calyx tubular, woolly, 5-10-toothed, with a corresponding number of strix, teeth erect or spreading, setaceous, alternately shorter, erect or hooked; corolla 2-lipped, upper lip erect, Hattish, sometimes divided, lower lip spreading, nearly flat or concave, 3-lobed, middle lobe largest and notched, tube the length of the calyx; stamens shorter than corolla, 4 in number; filaments parallel under the upper side of corolla; anthers 2-celled; verticils many-flowered, globose, with slender bracts. Leaves woolly and wrinkled, rounded at the base, serrate; floral leaves similar to the others in form. Flower's white or purple. Peremuial herbs.

No. of species, 30 .

M. vulgare, L. (Hoarhound.) Stem 12 to 18 inches in height, hoary, branching at the base, or numerous stems from the same root. Leaves ovate, rounded at the base, crenate-toothed, wrinkled, hoary, lighter underneath, on short stalks. Flowers white, sessile, in dense, globose rerticils; nutlets dark-brown, obovate, and truncate. July.

Geography. - It is native in the countries of the Levant, the Peloponnesus, and other regions around the Mediterranean Sea. It is at

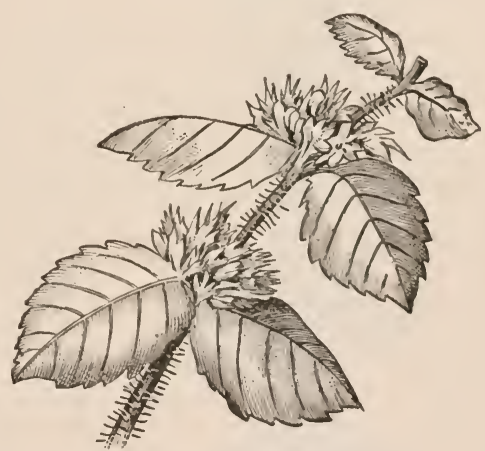

MARRUBIUM VULGARE (Hoarhound). the present day found growing in gardens all over Europe in the temperate zone. It was brought to the Atlantic States in America by European colonists, and escaping from gardens is found growing without eultivation abont dwellings. It is found throughont the temperate zone in Europe, Asia, and America, keeping pace with civilization.

Etymology. - Marmbinm is lerived from Marruvium, an ancient city of Italy, on the shore of Iake Fucine. Vulgare. the specific name, signifies "common." Hoarhound, the common name, is clue to the hoary appearance of the plant ; hound is from houn, "bitter," or " disagreeable."

History. - This plant was known in the days of Theophrastus. l'liny, who lived 300 vears later, also speaks of it. In those days the plant had a high reputation for curing pulmonary liseases.

$U$ se. - As a remedy, the ancients attached great value to hoarhound, and more particularly for pulmonary diseases. At the present day it is a popular domestic remedy for coughs, colds, and affections of the lungs, administered in teas, syrups, and candies. The hoarhound has an aromatic smell, but a very bitter tlavor. 


\section{Order XliII. CHENOPODIACE无.}

Flowers perfect, small, sometimes polygamous, sessile or pediceled, solitary or agglomerated, axillary or terminal, bracteate or naked; calyx 5-3-sepals, greenish and coherent at base, imbricate in the bud; corolla wanting; stamens hypogynous, or as many as sepals, or fewer at the bottom of calyx, opposite the sepals; filaments thread-like, mostly free, sometimes united just at the base in a cup; ovary eggshaped, usually free, 1-celled; style 2-3-lobed or 2-33 styles. Fruit, a utricle; seed mostly free, lens-shaped or kidney-shaped. Leaves alternate, simple, sessile or petioled, entire, toothed or sinuate, frequently fleshy, without stipules. Herbaceous or suffrutescent, sometimes shrubby.

No. of genera, 80 ; species, 520 ; cosmopolitan ; mostly in temperate climates.

BETA, Tournefort. Calyx hollow and contracted at the mouth, 5-cleft, persistent, becoming hardened at the base; stamens 5; ovary depressed, partly inferior; stigmas 2 , the small bladdery fruit, with a thickish, hardened, depressed pericarp, enclosed in the calyx: seed horizontal. Leaves alternate; flowers in spikes. Herbs.

B. vulgaris, Moq. (Beet.) Stem 2 to 5 feet high, angled, branched in form of panicle, appearing the second year. Leaves of the first year 6 to 15 inches

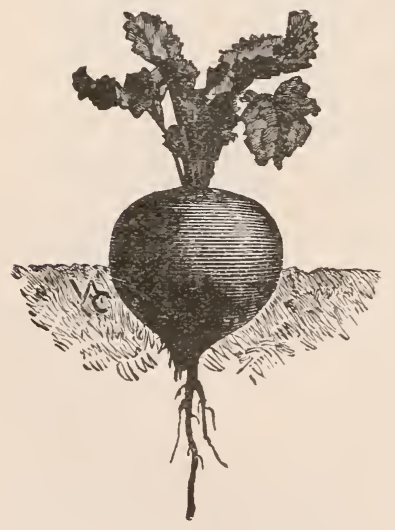

Beta volgaris rapa (Turnip Beet).

long, 4 to 8 inches wide, spatulate, edges wavy; radical leaves of the second year like those of the first; stem-leaves smaller, of dingy copper-color to dark-purple, ovate, lanceolate; root biennial, 3 to 10 inches in diameter, and 5 to 15 inches long, fusiform, tapering downwards to a slender fibrous point. Color, from dark-yellow to dark-red. Flowers greenish-white, in sessile, head-like cymes, forming slender spikes, arranged in leafy panicles; appearing in Jnly. Seed rugose or wrinkled.

The beet is propagated from the seed, and sports freely, producing many varieties, the general forms of which are two, - the long beet, and the turnip beet.

Var. cicla, the long, cylindrical-rooted beet.

Var. rapa, flat or turnip-rooted beet.

Var. mangel-würzel, large-rooted beet.

Encler these forms there are many varieties, as may be seen by consulting the catalognes of the seedsmen, and the varieties under cultivation are rery constant.

Geography. - The beet grows well in rich soil throughout the middle parts of the temperate zone, especially in Europe, north Africa, and the temperate parts of British India. It was bronght to North America by British and l)utch colouists, and is largely grown here. 
Etymology. - Beta, the generic name, is said to be from the Celtic word bett, "rell," due to the color of the root. It is also claimed to be from bete, Anglo-saxon, but derived from the Latin befa, used by l'liny. The specific name, vulyaris, is Latin, and signifies "common." Beet, the common name, is a mere corruption of the scientific name.

History. - The beet is a native of Europe and Western Asia, along the shores of the Mediterranean, and adjacent countries. 'T'he /seta maritima is believed to be the original plant, the seed of which is supposed to have given rise to the B. vulgaris of the gardeus, out of which have grown by sports the numerous varieties that now exist. It was known to the Greeks and Romans at least 500 years lefore the Christian era. It is supposed to have been taken to Great Britain by the Romans in the time of Agricola, A. 1. 79, and the spread into Gaul and Germany was no doubt due to the conquest of those countries by the Romans.

$U$ se. - The beet is an important table vegetable and pickle, and in Germany, France, and the British Isles is used as a salad. In central Europe, Germany and France especially, it is extensirely used for sugar-making, and very largely for a feed for stock.

The sugar-bearing property of the beet although discovered in Germany, was first turned to practical use in France in the reigu of Napoleon I., who, to render France independent of foreign nations for sugar, encouraged the manufacture of beet-sugar at home. From France it spread into arljacent European countries, and especially into Belgium, Germany, Austria and Russia; and at

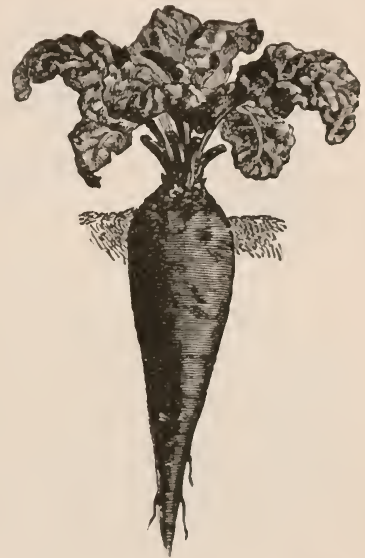

Beta vulgaris cicla (Long Betu). present beet-growing and sugar making from the beet are ranked anong the great industries of central and western Europe.

Statistics. - The annual product in Europe is about 600,000,000 bushels. An aere will prodnce 4,000 pounds of sugar. In acre of cane yields $\tau, 200$ pounds.

The crude beet-sugar contains a greater number of foreign substances than cane-sugar, and the refining process is more difticult and expensive. Its sweetening power is identical.

SPINACIA, Tourn. (Spinach. Spinage.) Flowers diœcious: bractlets; staminate flowers with a 4-5-parted calyx, segments equal, stamens on the receptacle, opposite the segments of the calyx ; calyx of the fertile flowers tulular, swelled in the middle, :3-toothed; ovary egg-shaped, 1-celled, 1-ovuled, with 4 lengthened stigmas. Fruit 1-seeded, included within the hardened 2-1-horned calyx; sereds flattened. Leaves alternate and petioled. Flowers greenish and axillary. Anumal herl.

S. oleracea, Mill. (Spinach.) Stem 18 to 24 inches high, slightly bran hed. more frequently simple. Leaves 3 to 5 inches long, tapering towards the base, frequently hastate and lanceolate; leaf-stalk varies from i to 4 inches in

PR. FL. -15 
length. Flowers axillary, densely clustered or in raceme-like panicles, greenish. Fruit or ripened calyx generally armed with 2 or more strong, blunt spines; in some varieties the fruit is smooth or without spines. Flowers in June.

This plant, which is grown from the seed, sports, and many varieties have arisen. The most important ones are the round, smooth-leared, and the prickly-leared; the last is more hardy, and best for autumn planting.

A variety known as the Flanders Spinach has double-hastate and wrinkled leaves. The Large Prickly has very large leaves, rounded or spatulate.

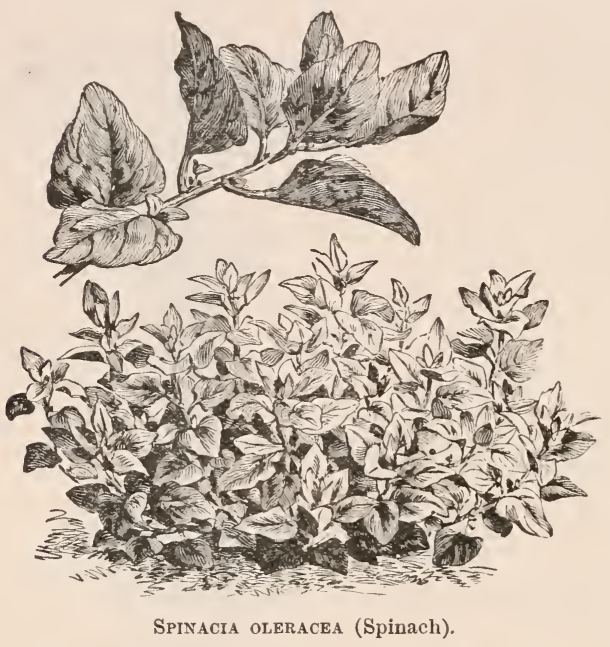
'The Lettuce-leaved has rounded, deep green, smooth leaves on short stalks. These are the favorite varieties; there are others intermediate.

Geography. - The spinach grows well throughout the middle of the north temperate zone, and is found in the kitchen and market gardens of the Old World, from Hindustan to the western shores and islands of Europe; and in the eastern United States of North America. It also has been carried to the islands of the South Pacific by European colonists.

Etymology. - Spinacia is derived from the Latin spina, "a thorn," on account of the armed condition of the seed-vessel. Oleracea is from the Latin oleraceus, "a pot herb." Spinach, or spinage, the common name, is a corruption of spinacia.

History. - The home of this plant is Persia, whence it has found its way by commerce, colonization, and travellers to all parts of the civilized world.

Just how or when it was taken to Europe is not known. It was brought to the United States from Europe, where it receives much attention by gardeners. It is fit for use early in the spring, to which circumstance its popularity and market value are largely due.

Use. - The leaves of spinach are boiled with salt meats, or alone, and served plain or with a vinegar-sauce, or eaten with salt only as a condiment. It is one of the most delicate of all the plants used for greens, and on this account justly ranks high as a table vegetable.

\section{ORdER XLIV. POLYGONACEAs.}

Flowers perfect or polygamous, without involucre ; perianth of 3-6 segments, inner ones or all often petaloid; stamens 1 to 9 or 6 to 8 . sometimes 12 to 17 ; ovary free, occasionally adhering below, 1-celled, 
1-ovuled, ovule basilar and erect. Fruit 3-angled, sometimes winged. Leaves alternate and entire, largely collected at the base of the stern, rarely opposite, mostly with clasping petioles and sheathing stipules. Herbaceous or frutescent, and sometimes climbing.

No. of genera, about 30 ; species, 600 .

FAGOPYRUM, T'ourn. Calyx composed of 5 colored equal sepals or parts; stamens 8 , alternating with 8 honey-glands. Number of styles 3, capitate. Fruit 3-angled, in lax or dense cymes.

1. F. esculentum, Tourn. (Buckwheat.) Stem smooth, 1 to 3 feet high, branched, in an irregular panicle, furrowed, stout and hollow. Leaves varying, cordate, triangular, or hastate. Flowers in terminal and axillary cymuse panicles, rose white. Fruit 3-angled, nut or grain inclosed in a dark-colored, coriaceous shell; kernel white.

Flowers in August ; fruit ripens in September and October.

2. F. Tartaricum is a hardy species grown in Tartary and in northeru Europe, endures light frost, differs from $F$. esculentum in the leaves, which are broader than long, with acute lobes. Fruit triaugular, lance-shaped, with the angles sinuate-dentate ; ealyx very small.

3. F. emarginatum differs from the last in its fruit, whose angles are margined by a broad wing.

Geography. - The zone of the buckwhent is not very wide; it is found in Russia, far north, and grows well in Canada and the northern United States. It will grow south of $35^{\circ}$ of latitude, but does not thrive in hot climates. Though it does not endure the frost, it will not fill unless it has a temperature as low as $35^{\circ}$ Fahrenheit.

Etymology. - Fagopyrum is derived from

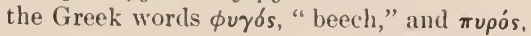
"wheat," - beech wheat or grain. Escu-

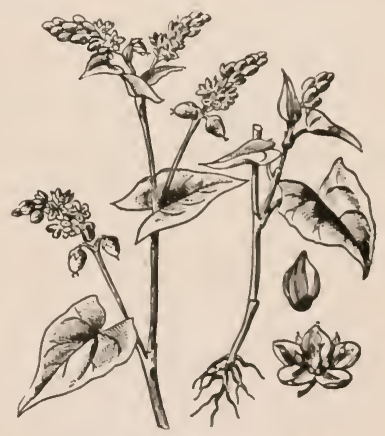

Fagopyrum escolentum (Buckwheat). lentum, the specific name, is Latin, and signifies that the grain is eatable. The common name, buckutheat, is derived from the Angle-saxon word boc, "beech," and the word "wheat" signifying "beech-wheat." Linna called this plant Polygonum fagopyrum, "many-angled beech-wheat." Tournefort, the great French botanist, named it Fagopyrum esculentum, "eatal,le beechwheat." Tartaricum, Latin, is derived from Tartary, the home of this species. Emarginatum, Latin, is due to the fact that the angles of the fruit are margined by broad wings.

History. - It is a native of central $\Lambda$ sia and Tartary, and is found growing without cultivation in the valley of the Volga, and along the shores of the Caspian Sea. It was earried to Spain by the Moors, and has thence spread throughout northern and central Europe, where it has become naturalized. In France it is called lilé Saracin, or Sarasin Wheat.

Another account of its introduction into Enrope is that it was brought by the Crusalers from Asia Minor, in whose northern fields it was found under cultivation, which would account for its Freuch name. 
Still another account is that it was brought into Russia from Tartary early in 1700, and thence spread through Europe.

It was introduced into northeast America by European colonists.

Cultivation. - In latitude $40^{\circ}$ to $45^{\circ}$ it is sown about the 1st of July, and ripens in September. It is planted when practicable upon new ground, and leaves the land in a good condition for next year's planting of other crops. 'The yield ranges in the northern and northwestern states from 20 to 50 bushels to the acre, but 30 bushels is a satisfactory vield. In the south Atlautic States the yield is less, ranging from 10 to 25 bushels.

Use. - Although this grain has not the importance of the cereals, yet it constitutes the bread of a large number of the people of central Asia and northern Europe. It is very popular as a material for griddle-cakes. In northern Europe it is used in making a dark bread, and there too the grain is hulled and used in the same manner as rice. It is an excellent feed for cattle and poultry.

RHEUM, L. Calyx colored, sepals 6, in double series, persistent; stamens 9, opposite the outer sepals; styles 3 , very short and spreading; stigmas 3 ; fruit with 3 winged angles. Leaves large, mostly radical, on long stalks. Flowers in racemose or paniculate fascicles. Perennial herb.

1. R. rhaponticum, Linn. (Rhubarb.) Stem stout, hollow, 4 feet high, furrowed; stipules large and sheathing. Leaves entire, corlate, ovate, obtuse,

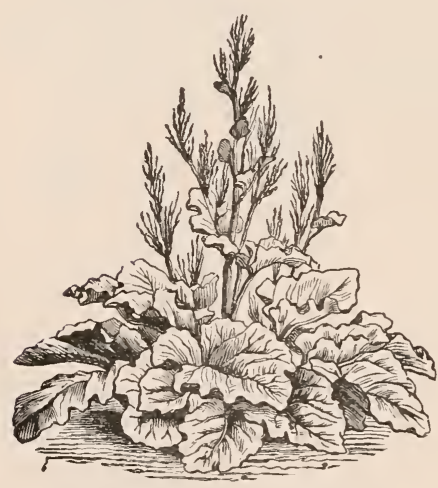

RheUM RHAPONTICUM (Rhubarb). and smooth, 12 to 24 inches long and 10 to 15 wide, cauline leaves smaller; sepals greenish, with white margins. Root large, fleshy, tuberous, and yellow within.

2. R. palmatum, Linn. Leaves 5-lobed, palmate, rough; lobes sinuate-toothed, acute.

3. R. undulatum, Linn. Leaves oval-cordate, with undulated margins.

4. R. compactum, Linn. Leaves with a general heart-shaped contour, but interrupted with a number of deep sinuses.

The last three are the species which furnish the rhubarb-root of commerce, the R. palmatum supplying the larger part.

Several varieties have been obtained by sporting and hybridizing, which furnish very large leaf-stalks. There are some 10 varieties, that for one or another reason recommend themselves to the cultivator. The Victoria is admired for its gigantic size. The most delicate and desirable for the private garden is the R. compactum.

Geography. - Rhubarb will grow well as far north as the 50th parallel. The market is supplied by the products of regions lying between $35^{\circ}$ and $45^{\circ}$. Unusuccessful attempts have been made in Eugland to raise it for the druggist. 
Darwin states that the root grown in kngland does not possess the merlical properties of that raised in Tartary. It is found also growing in tropieal India.

Etymology. - The name Rheum is from $K$ ha, the ancient name of the Volga river, the plant having been first brought to the notice of man by specimens procured along the banks of the Volga. Rhaponticum, the speeifie name of the plant under garden cultivation, and from which the several varieties have been derived, is made up of the words Rhu, the name of the Volga, and Pontus, a district of country where the plant was found. De Candolle gave it this name, which signifies "rhubarb from l'ontus." It was formerly supposed to be the species which produces the root of commerce, and it has also been claimed that the li. palmatum is the true or parent species, from which all others have arisen, and that the R. compactum is the original species. IBut the properties of the different species and varieties are so similar that they may be substituted for each other. Rhubarb is a contraction of rheum barbarum, the rheum of the barbarians.

History. - The fine medicinal rhubarb known as liussian or Turkey Rhuharb entircly disappeared from commerce in 1863 . It derived its name of Turkey from its being formerly brought into Europe through the Levantine ports, and in more recent times was named Russian from its being imported through the Russo-Chinese frontier town of Kiachta, at which place the Russian government maintained an establishment for its rigid inspection for nearly two hundred years, up to 1863 , when all inspection was abolisherl. Neither the botanical souree of this rhubarb nor the place of its origin were ever known. The present rhubarb of commeree, known as China or Last Indian Rhubarb, is collected in the Chinese provinces of Shensi Kaushu and Szechuen, thence sent to Iankow, whence it reaches Europe and America by way of Shanghai. It is defined in the Pharmacopoia of the Inited States as "the root of Rheum officinale and of other mudetermined species of rhemu."

Use. - The root of the rheum furnishes one of the most reliahle substances in the materia medica. It is eathartic, astringent, and tonic ; and is largely nsed in alterative medicines and in preparations to correct and excite the digestive apparatus, as well as in medicines for reducing inflammatory conditions of the bowels. It contains much oxalic acid.

The leaf-stalk is used in culinary preparations,--tarts, pies, puddings, dumplings, and sance. It is also preserved in sugar. It is now found in every well-kept kitchen-garden, and is an important article in the marketgarrien.

\section{Orneli XLY. PIPERACE正.}

Flowers perfect or dinecious, withont envelopes, in long. preduncled spikes, each flower protected by a peltate or decurrent bract; stamens 2 or 3 , sometimes 6 to many, filaments short; ovary sesile, globular, of 3-4-distinct carpels, with several orules, or 1-celled, 1-oruled. Berry dry or fleshy; seed globose, testa thin, cartilaginous. Leaves frequently succulent, opposite or whorled, occasionally alternate. entire; nerves obscure, reticulate; petiole short, shrathing at hase. Herbs or shrubs.

No. of genera, s; species, 1,000. C'hiefly tropical; Isia and America. 
PIPER, Linn. Flowers without perianth; stamens 2 to 4 , occasionally 5, rarely more; filaments short; ovary 1 -celled; stigmas 2 to 5 . Fruit, a small berry, globular or egg-shaped; climbing shrubs, with alternate, entire leaves, which are strongly veined or nerved.

l. P. betel, Linn. (Betel Pepper.) Stem climbing, 5 to 8 feet high, or long, knotted at the nodes. Leares opposite, 5 inches long, ovate, acuminate, uneven or obliquely cordate at base, 5-7-veined, leathery, glossy above.

There are over 600 species of the Piper, but this and the following are the most important.

Geography. - The Piper betel is a tropical and subtropical plant, and is distributed throughout the regions of southern Asia.

Etymology and History. - Piper and pepper are derived from the Greek $\pi i \pi \epsilon \rho \iota$ and $\pi \dot{\epsilon} \pi \epsilon \rho l$, pepper. Betel, the specific name, is the Malabar name of the

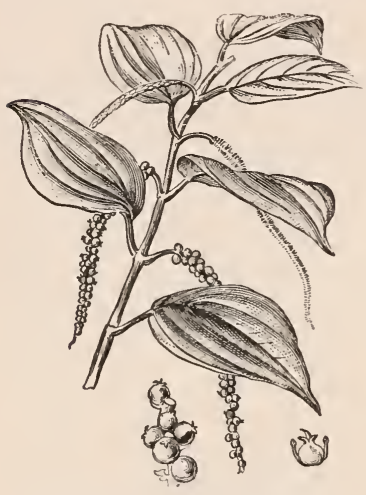

Piper nigrdm (Black Pepper). plant. It is native to Java, and is cultivated wherever the betel-nut grows.

Use. - The leaves are sparingly sprinkled with shell-lime, and then wrapped around slices of betel-nut, and in that state they are used as a masticatory. They are also used for the same purpose without the betel-nut.

Medical practitioners among the Hindus recommend their use in the morning fasting, also after meals and on retiring. The properties of the betel-pepper are aromatic, carminative, stimulant, and astringent, and it is said to be a specific for headache.

In connection with the betel-nut, it is used by about one tenth of the whole human race, yet is not an important article of foreign commerce.

2. P. nigrum, L. (Black Pepper.) Stem climbing, 20 to 30 feet long, with jointed or swelled processes at the nodes, branching in forks. Leaves hroadly ovate, lanceolate, 5- 7 -veined, petioled, and 3 to 6 inches long, darkgreen. Flowers in slender spikes, opposite the leaves, 3 to 6 inches long, greenish. Fruit, a globular, 1-celled berry, as large as a middling-sized pea, sessile, in loose clusters, to the number of 20 to 30 on a drooping stalk; the berries are first green, then red, and when ripe, rellow. A perennial shrub. This species produces both the black and the white pepper of commerce.

Var. longum produces a fruit similar to the $P$. nigrum, but inferior in strength and flavor, and is used to adulterate the $P$. nigrum.

Geography. - The home of the pepper-plant is southern Asia and the adjacent isles. Pepper has been an important article of commerce from the earliest times of communication between the East Indies and Europe, and was cultivated in southern India, Java, Sumatra, and Malabar, but especially at Bantam, in Java, whence the earliest shipments were marle.

Etymolog.y. - The specific name, nigrum, from the Latin, signifying "black," is due to the color of the berry when fit for market.

History. - It was known to the early botanists, Theophrastus, Dioscorides, and Pliny. It was in early times carried by caravans through lower Arabia 
and then across the Red Sea into Africa, and so to the shores of the Mediterranean, where a heavy duty was laid on it. The Mrabian physicians of the middle ages used it as a medicine. The duties to which pepper was subject were so great in the middle ages that only the rich were able to procure it. In 1623 the impost-tax in Great Britain was five shillings per pound, and even as late as 1823 it was two-and-sixpence per pounl, equal to 63 cents.

Cultivation. - The plant grows easily from slips, and is usually slipperl heneath trees which it is to climb. It fruits the first year after slipping, but reaches its maximum crop in the fifth year. A plant in full bearing yields 10 pounds, and will last 20 years.

Chemistry. - The chemist ubtains from the pepper-corn or herry an essential oil and a resin, on which its pungency depents. The oil known as the oil of black pepper gives the peculiar flavor. There is also present a tisteless alkaline substance known as piperine, $\mathrm{C}_{17} \mathrm{II}_{19} \mathrm{NO}_{31}$, which forms four-sided prismatic crystals.

Preparation. - It is prepared for use by picking when in a semi-ripe state, and drying; in drying it turus black, hence its name. The white pepper is taken from the plant when nearly ripe, macerated in water, and the outer skin being removed, is bleached. The pungeney of pepper is largely due to an oil which resides in the enticle, bence white pepper is not so strong as the black.

Use. - Black pepper is used in civilized nations in almost all the preparations into which meat or fish enter, and in small quantities is supposed to promote digestion.

It was formerly used in medical practice as a stimulant and carminative in disorlers of the stomach.

\section{ORDER XLVI. MYRISTICACE无.}

Flowers diœcious, inconspicuous, with simple perianth; male flowers with $3-15$ monadelphous stamens; anthers often on the margin of a broad disk; female flowers with 1 -celled ovary, having 1 erect orule; capsule fleshy; seer erect, nut-like, enveloped in in aromatic, laciniated aril; testa hard. Leaves alternate, exstipulate, coriaceous, simple, entire, pubescent or scaly. Small aromatic trees or shrubs.

Only 1 genus, with 80 species; tropical.

MYRIsTICA, L. Flowers diøcious, perianth leathery, tubular, somewhat bell-shaped, 2-1-parted. Staminate flowers, with 3 to 15 filaments, united into a column which terminates in a toothed disk: anthers attached to the filaments along the backs, and their deliscence turned ontwards, opening longitudinally. Pistillate flowers with a single style; stigma entire or lohed: orule solitary, fruit appearing at the base or botton of the pistillate Hower : capsule fleshy, about the size of an apricot, and shaped like a short pear: the outer covering is half an inch thick. When ripe it opens by a smooth suture which extends from the stem all aromel to the opposite sicles separating the shell into two equal parts. When partly open it exposes the mut enveloped in a network, which is the nace of commerce: inside the mace is the mut, inclosing a hard, black shell, inside of which is the kernel or nutmeg. 
1. M. fragrans, Houtt. (Nutmeg and Mace.) Trunk 20 to 35 feet high, much-branched, branches erect, forming a tree which resembles the pear-tree; bark smooth, ash-colored, when wounded bleeding a glutinous red juice. Leares alteruate, on short petioles, elliptical, pointed, wary, entire, obliquely nerved, bright-green above, grayish beneath, aromatic. Flowers and fruit present at the same time; Howers inodorous, small, axillary, 1 to 3 on a stem; calyx smooth, fleshy, 3-parted; segments spreading; corolla wanting; ovary oval; style short, with 2 stigmas. Fruit as described under the genus.

'There are many species, about 80 in all; the 11 . fiagrans is the most important, though several produce aromatic seeds.

2. M. spuria, Houtt., yields a mace, which is first yellow, turning red. From wounds in the bark it bleeds a red sap, sold as a sulstitute for dragon's blood.

3. M. fatua, Houtt., yields an inferior nutmeg, called loug or wild nutmeg. It is used in India, but does not enter into commerce.

Geography. - The nutmeg requires a tropical climate, or at least a region of no frost. It has, by the appointed means for geographical distribution of plants, - the winds, waves, birds, and by human agency, - been carried from the Moluceas to the mainland of both hemispheres and their adjacent isles, and occupies at present a geographical belt all around the globe, extending just outside the tropics in both hemispheres.

Etymology. - Myristica, the generic name, is from the Greek $\mu \dot{v} \rho \rho \alpha$, myrrh, due to the aromatic fruit and leaves. Fragrans, the specific name, is Latin, also due to the odor-bearing fruit, leaves, and the oils obtained therefrom Nutmeg, the popular name, is from the low Latin word muscata, a nutmeg, or a musk-like nut, referring to the perfume, which was supposed to resemble the odor of musk. Mace is from the Greek $\mu \alpha \dot{\kappa} \in \rho$, a spice.

History. - The nutmeg was introduced into European commerce by the Arabs through the Red Sea, early in the sixth century. An account of the tree and place of its growth was first given by an Arab traveller in the beginning of the tenth century.

The home of the nutmeg is the Molucea islands, but especially the Banda group of the Spice Islands. When the Dutch first eame into possession of these islands, they attempted to confine the tree to a very few of them, in order the better to monopolize the trade as they did of the clove. When the English obtained possession of them, in the latter part of the eighteenth century, they made an effort to extend the area of growth, and introrluced young trees into Sumatra, near Bencoolen, the Isle of Bourbon, Mauritius, and Madagascar, and also into the IVest Indies. The tree comes into bearing after ten years, but does not yield its largest crops till after 100 years, producing three full crops in a year.

Preparation. - When the nutmeg is harvested, the mace is removed and pickled in salt, afterwards dried in the sun and packed in boxes, and sent to market. The nut is dried either in the sun or by artificial heat, when it shrinks so that the shell may be broken without damage to the kernel. The kernel is then soaked in sea-water and lime, after which it is placed in heaps and left to heat sufficiently to destroy its vitality, when it is fit for market The kernels that come to the United States take 100 to the pound; those sent to England, about 60, or about 4 to the ounce.

$U$ se. - The medicinal properties of the nutmeg are tonic, digestive, stimulant, and intoxicating. In excessive doses it produces stupor, delirium, and 
death. It is used in the kitchen to flavor dessert sances, and as a spice and an aromatic addition to corlials, and was at one time a favorite perfume.

'The Hindu physicians pulverize it, and use it for a poultice for nervous headache, applying it above the eyes.

The odor or tlavor, as well as the medicinal properties, depend upon the essential oil, of which the nuts yield about six per cent. The mace also yields an oil in somewhat larger quantities, which is very similar to that of the nut.

The mace also contains a fixerl oil, which is obtained by crushing and pressure ; used in pomades, soaps, and aromatic plasters.

Propagution. - It is raised from seed, and in its third rear is ingrafted with branches from pistillate trees; and in the orchards a few staminate trees are planted to fertilize the others.

\section{URHER XLVII. LAURACEA.}

Flowers perfect or declinous, regular, small, white or yellow, fragrant; periantlı simple; calyx with mited sepals, 6-lober, herbaceous or petaloid, fleshy, usually inferior, rotate or urn-shaped; stamens, at the base or throat of calyx about 9 in number, 3 inner ones extrorse; filaments free or rarely monadelphous; anthers opening by uplifted valves; ovary free, 1-celled; style simple, stout, short; stigma obtuse, discoid, 2-3-lobed. Fruit, a herry, globose or ellipsoid. Leaves alternate, near each other, sometimes nearly opposite or whorled, exstipulate. Aromatic trees or shrubs.

No. of principal genera, about 34 ; species, 900 ; mostly tropical.

CINNAMOMUM. B. Flower's perfect or polygamous, receptacle funnelform; perianth in 6 parts, with 12 stamens, 9 fertile and 3 sterile. Fruit, a berry, attached to the base of the receptacle; pericarp thin. Flowers in panicles, axillary or terminal, simple or in 3- to manyflowered cymes. Tree.

1. C. camphora, Nees. (Camphor Tree.) Stem 30 to 80 feet high, 1 to 2 feet in diameter; branches spreading horizontally, forming a symmetrical head; bark green, and on the young branches shining. Leafbuds conical, glabrons, protected by stiff scales; leaves numerous, alternate, 3 to 6 inches long, on slender petioles, slender at each end, acuminate, entire, smooth, hright green, shining above and glaucous underneath, thick, stiff, and evergreen. Flowers small, on slender, spreading pedicels, forming small, spreading eymes, 2 to 3 in a long-stalkerl, axillary panicle, shorter than the leaves; periautlı campaumlate, smooth outside. very hairy within, greenish-white; vary free, l-celled, l-ovuled; style slender, as long as the stamens; stigma small; seedl egg-shaped, as large as a medimu-sized

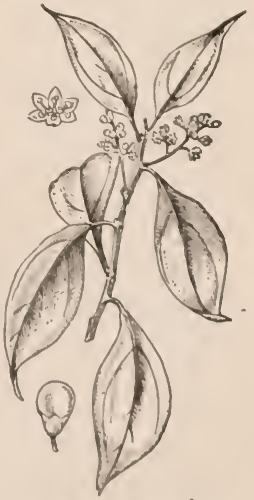

CINNAMOMUM CAMPHORA (Camphor-tree). pea, purplish, surrounded at the base by the enlarged tube of the persistent perianth; seed solitary. Flowers in July. This tree sometimes attains a very large diameter; it is reported that one in Japan has reached a circum- 
ference of 50 feet. There are about 50 species of this genus, but they do not all yield camphor.

Geography. - The camphor-tree is found native in the edge and fringes of the tropic of Cancer. It is found in China, Japan, Borneo, and the island of Formosa. It also grows in regions of light frost, having been planted in southern Europe and in California.

Etymology. - Cinnamomum is derived from the Arabic word kinamon, cinnamon. Camphora is of Eastern origin ; the signification is obscure, but it is supposed to mean "white," in allusion to the color of the gum.

History. - Camphor is a concrete volatile oil, obtained by distilling the wood with water. It yields to the chemist $\mathrm{C}_{10} \mathrm{H}_{16} \mathrm{O}$, melts at $347^{\circ}$ Fahrenheit, and boils at $400^{\circ}$; it is soluble in alcohol, and slightly so in water. It is purified by sublimation.

Camphor was not known to the ancients, and it is believed that it was carried into Europe by the Arabs in the sixth century, and by them introduced into the materia medica. The camphor of commerce is exported from the island of Formosa and Japan.

Preparation. - The mode of procuring camphor is to cut down the tree and reduce the trunk to fragments, and place the chips in a large still, the head of which is filled with rice-straw, the bottom of the still being filled with water. In the vaporization the camphor passes to the head of the still and crystallizes on the straw ; it is picked from the straw, placed in packages, and sent to market. It is afterwards purified by sublimation in glass flasks, when the impurities are left at the bottom. In America the process is somewhat different. The gum is condensed in flat iron pans about sixteen inches square and one inch deep.

Use. - Camphor oil, obtained by draining the crystals in large vats before removing them from the straw and sticks that are taken from the heads of the stills, is used for medicine by the natives of Formosa.

The medicinal properties of the gum are stimulant, diaphoretic, anodyne, and narcotic. It is used to quiet restlessness, as a carminative, and a remedy in typhoid ailments.

It is dissolved in alcohol and in oil, and used as a liniment, and is an important medicine in domestic practice. It is poisonons and very inflammable. It is an insecticide, and used to preserve woollen and fur goods from the ravages of moths; also in herbariums, to prevent the destruction of dried plants by insects.

Note. - The Blumea balsamifera, an herbaceous plant of the order Compositæ, found in China, yields to distillation a camphor which is heavier than water, and more volatile than the ordinary camphor of commerce; it is used by the Chinese in medicine and to perfume the celebrated India ink.

The Borneo camphor is obtained from Dryobalanops Camphora, Colebr. This tree is a most magnificent object. The trunk rises to the height of 130 feet withont a branch, the base is fortified with gigantic buttresses, and the top crowned with a cluster of branches clothed with large, shining leaves. Flowers showy, abundant, and fragrant. The camphor is obtained by felling the tree, cutting it into lengths, and then splitting it up, when the gum is exposed in layers in the wood, from which it is detached by means of a sharpened stick. The camphor is so pure as to need no process of refining, and is the precious camphor of the East, used in religious ceremonies and funeral rites. 
2. C. zeylanicum, Breyn. (Cinnamon.) Second-class tree; trunk 20 to 30 feet high, forming a low, broad he:td; bark brown. Leaves opposite, oval, 4 to 5 inches long, rounded at the liase, dark-green above, paler beneath, prominently 3-verved. Flowers in large terminal patuicles; flowers distant and bractless ; petals inconspicuous; periauth divided into 6 ollong, rather blunt, equal lobes, imbricated in 2 rows, 9 stamens and 3 staminoids; anthers short; filaments hairy; ovary superior, 1-celled, with 1 ovule; style shorter than the stamens; stigma 2-lubed. Fruit oroid, fleshy, half an inch long, smooth; seeds not filling the seed-ressel.

As this tree is propagated from seed, it sports freely, and many varieties are produced, but all constant as to quality of bark.

Geography. - The Cinnamomum zeylanicum is a tropical and subtropical tree, requiring a mean temperature, not below $70^{\circ}$. It grows throughout the East Indian Archipelago. It was formerly largely cultivated in Ceylon, but the cultivation of tea and coffee are rapidly supplanting it. It has been taken to the West Indies, South America, and the isles of the Pacific.

Etymology and History. - Zeylanicum is the Latinized form of Ceylon. When cinnamon was first introduced into use as a spice or a medicine is not known; it is spoken of in the Bible as one of the substances of the anointing oil used in the installation of the priesthood; it was known in Fugland in the eleventh century, and has always been a farorite spice. When the Dutch came into possession of Ceylon, they limited the supply to sustain the price, and the English dic the same. ln the beginning of the last century the oil of cinnamon sold in London for its weight in gold.

Cultivation. - The Dutch hegan the cultivation in Cerlon. 'The plants are cut baek to ahout six huds; from these the shoots are allowed to grow to the height of ten feet, at

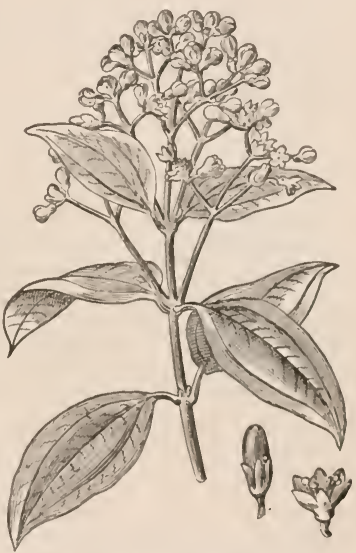

CixiamomUM zEYLANICUM (Cinnamon). which time they will have reached a diameter of abont an inch or more: these are cut at the time the sap begins to flow, and divided into lengths a foot long, which are split in halves, and the bark removed. The picces are laid one inside the other and tied together in small bundles, which are left a few days to dry; the strips are then laid upon a rounded stick, and the cuticle seraped off. The pieces are then allowed to dry and eurl up; when dry, the sinaller are inserted into the larger, and in that way male into a sort of solid to prevent breaking. These are tied together into bundles weighing alout thirty pounds each, covered with gmuny (loth, and sent to market.

Use. - The chips and pealed sticks, with the hark mpon the twigs, are distilled, and yield the oil of cintamon; the leaf also vielils an vil. The root yields a peculiar ramphor.

Cimamon is used as a spice in confectionery, eakes, and pustry, cordials and prepared liquenrs, and perfumery. In medicine it is stimulant, aromatic, carminative, and a remedy for nausea.

3. C. cassia. 131. Stem 20 to 30 feet in height, symmetrically brancheo Leaves like those of (c. zeylanicum, hut more olituse, when young, flame 
colored. This tree, when clothed with its flame-colored leaves, interspersed with pure white flowers, is an object of enchanting beauty.

Besides the $C$. cassia, there are three other well-marked species, as follows :-

4. C. obtusifolium, Nees, with very blunt leaves.

5. C. pauciflorum, Nees, few-flowered.

6. C. iners, Reinw., feeble-wooded.

These all produce bark resembling the Cinnamomum zeylanicum, but less pungent and delicate. The bark of the cassia is sold in the American market for cinnamon; very little true cinnamon reaches the United States. It is easily distinguished by the druggist and dealer. The taste and flavor are higher, and the bark is not thicker than good writing-paper. The barks of the shops of America are cassia, and not the true cinnamon, and the oils are likewise mostly cassia oils.

Geography. - The cinnamon-producing cassia trees are tropical and subtropical. Found in southern India, Java, Sumatra and Ceylon, eastern Africa, and Australia.

Etymology. - Cassia is the Latinized Hebrew word, ketzioth: and gatsa, to cut, is also given as the root of this word, alluding to the mode of obtaining or harvesting the bark, $i$. e., a bark which is cut.

Cultivation. - The modes of growing the tree and harresting the bark are precisely like those for the true cinnamon. Cassia buds of commerce are the unripe fruit of the C. cassia and other species.

Use. - The properties of cassia products are about the same as those of true cinnamon, only less intense. The cassia buds are used in confections, and to flavor bitters and cordials. The bark is user in all cases the same as cinna. mon; most consumers do not know what the true bark is.

\section{Order XLVIII. SANTALACE无.}

Flowers perfect or polygamous, white, green, yellow, or red, lateral. or terminal; perianth single, tubular, variously 5-3-lobed, valvate in the bud; stamens equal and opposite to the perianth lobes, inserted on their middle; filaments short; ovary inferior, 1-celled, mostly 3-ovuled. Leaves opposite or alternate, entire, narrow, usually sessile. Trees, shrubs, or herbs.

No. of genera, 28 ; species, 220 ; tropical and temperate regions.

SANTALUM, I. (Sandal-wood Tree.) Perianth bell-shaped, 45-parted ; lobes spreading; petals 4, spreading; stamens 4; filaments thread-like; anthers ovoid; style conical or cylindrical; stigmas 2 to 4 ; drupe globose, truncate, or crowned. Leaves alternate. Trees.

1. S. album, L. Trunk 20 to 30 feet high, branches numerous, opposite, drooping; bark smooth, grayish-brown; twigs glabrous. Leaves without stipules; petioles slender, half an inch long; blade 1 to 3 inches long, oval or lanceolate, tapering at the base, sharp or blunt at the extremity, entire, smooth both sides, glaucous underneath. Flowers small, numerous, shortstalked, in small pyramidal, erect, terminal, and axillary 3-forked, panicleshaped cymes, withont odor; bracts small; perianth bell-shaped, smooth. 
short; segments 4, triangular, sharp, spreading, fleshy, straw colored, changing to purple; stamens 4 , oppusite the segments of the perianth; filaments short, inserted on the mouth of the perianth, alternating with the erect lobes; anthers short, 2-celled; style thread-like; stigma small, 3-4-lobed, ou a level with the anthers. Fruit the size of a pea, bearing a sort of crown, which is the remains of the perianth, nearly black, nut hard and bony, with 3 ridges extending half way down from the top.

There are.eight species, three of which, besides the S. album, yield an oil and perfume, lut of an inferior quality to that of the S. album.

2. S. myrtifolium, East Indies.

3. S. yasi, Fiji Islands.

4. S. Freycinetianum, Sandwich Islands.

Geography. - The geographical range is tropical and subtropical, in Asia, Malaysia, and the islands of the l'acific Ocean. Farther India and China produce most of the wood that reaches England and America.

Etymology. - Santalum, the generic name, is the Latiuized form of the l'ersian name, said to come from the Sanskrit chandana, siudal, the tree. 'The word chand signifies "shine," hence the shining tree. Album, the specific name, is the Latin for white. sandal-wood, the popular name, signifies "shining wood," due to the light color of the sap-wood.

Ilistory. - This tree is a native of the East Indies, and is highly prized on account of its fragrance. The use of sandal-wood dates as far back at least as the fifth century в. c., for the wood is mentioned under its Sanskrit name "chandana" in the Nirukta, the earliest extant Vedic commentary. It is still extensively used in India and China, wherever Buddhism prevails, being employed in funeral rites and religions ceremonies;

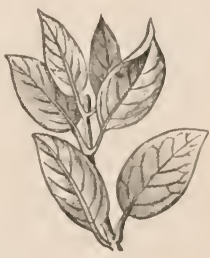

SANTALUM ALBITM (Sandal-wood Tree). comparatively poor people often spend as much as fifty rupees on sandal-wood for a single cremation. Until the mildle of the eighteenth century India was the only source of sandal-wood. When it beeame known to the western or European nations we have no means of knowing; most likely the wood was introduced into commerce very early, increasing as the means of conveyance improved. The discovery of sandal-wod in the islands of the Pacific led to a considerable trade of a somewhat piratical nature, resulting in difliculties with the natives, often ending in bloodshed, the celehrated missionary John Williams, amongst others, having fallen al victim to an indiscriminate retaliation by the natives on white men visiting the islands. The loss of life in this trade was at one time eren greater than in that of whaling, with which it ranked as one of the most adventurums of eallings $A$ bout the year 1810 as much as four hundred thousand dollars is said to have been received annually for sandal-wood hy liamehamoha, King of Hawaii. 'The trees consequently have hecome almost extinct in all the wellknown islauds, except New ('aledonia, where the wood is now cultivated.

l'repuration. - The tree is propagated hy seeds, which must be placed where they are intended to grow, since the seedlings will not bear transplantation, probably on acconnt of deriving their nourishment parasiti. cally by means of tuberous swellings attached to the roots of other plants The trees are cut down when between eighteen and twenty-five years oh, when they have attained their maturity, the trunks heing about one foot 
in diameter. The felling takes place at the end of the year, and the trunk is allowed to remain on the ground for several months, during which time the white ants eat away the valueless sap wood but leave the fragrant heartwood untonched. The heart-wood is then sawn into lengths two to four feet long. 'These are afterwards more carefully trimmed at the forest depots, and left to dry slowly in a close warehouse for some weeks, by which the odor is improved, and the tendency of the wood to split obviated. An annual auction of the wood takes place, at which merchants from all parts of India congregate. 'The largest pieces are chiefly exported to China, the small pieces to Arabia; and those of medium size are retained for use in India.

Use. - The fragrance resides in the heart-wood and the root. The heartwood also is valuable in the arts, the sap-wood being too soft for the construction of furniture. Sandal-wood is hard, close-grained, takes a fine polish, and is employed for making musical instruments, toilet-boxes, fans, and fancy articles; drawers and boxes for preserving furs, silks, and woollens from the depredations of insects are also constructed from it, and it is largely used by engravers, for whose purposes it excels the famous box-wood. It is also used by the Chinese and other Asiatic pagans as a perfume to burn before their idols.

Oil of sandal-wood is obtained from the chips, sawdust, and raspings of the wood, by slow distillation. The oil is employed for adulterating the attar of roses, and for compounding medicines. It is an ingredient in the favorite handkerchief extracts, colognes, and fancy soaps of the shops. The seed of the sandal-wood yields a fatty oil by decoction, used for illuminating purposes.

\section{Order Xlix. EUPHORBIACEAE. (Spurge Fanily.)}

Plants of various habits, generally with milky juice. Leaves mostly alternate, stipulate, and often undivided; inflorescence usually compound, sometimes with a calyx-like involucre inclosing several reduced declinous flowers; perianth single, of united sepals, or none, or double (when double it consists mostly of small, distinct petals); stamens 1-1,000; ovary superior, usually 3-celled (rarely 2-many-celled) ; cells 1-2-ovuled; ovules pendulous from the inner angle, anatropous. Fruit capsular, separating from the axis into cocci (sometimes a drupe); embryo in axis; fleshy or oily endosperm ; radicle superior.

No. of genera, 195 ; species, 3,000. Habitat, tropical and temperate zones.

EUPHORBIA, L. (Spurge.) Flowers monøecious, without floral envelopes, sereral in a cluster, inclosed in a calyx-like involucre, with 4 to 5 lobes, frequently with 4 to 5 glands; staminate flowers, 9 or more in a cluster, each with 1 stamen and bract; pistillate flower central, with a 3-celled, 3-ovuled ovary on a long pedicel; styles 3 in number, bifid; capsules 3-lobed, with 3 seeds or nuts. Juice milky.

E. Ipecacuanhæ, L. Stems usually short and in clusters, slender, and diffusely, bifurcately branched. Leaves opposite, oblong, linear-lobed, or slit, variable, sessile, heads on thread-like pedicels; seed white, compressed, pitted; root very large, forked, and perennial. Sands of New Jersey and south.

Etymology. - Euphorbia is named in honor of Euphorbus, physician to King Juba of Mauritania. Ipecacuanha is from the Brazilian ipecaaguen, road-side sick-making plant. Spurge is from the Latin expurgare, cleanse. 
I'se. - The E. Iperacuanha is seldom used commercially. True ipecacuanha is obtained from ('ephaelis (see Cephaelis of Rubiacea', p. 16.2).

HEVEA, גul. Calyx j-toothed, valvate; petals wanting; stanens 5 to 10 , ınited, forming a tuhe; anthers extrorse; styles 3 in number, short and emarginatr; inflorescence a raceme, made up of a number of few-flowered cymes; pistillate flowers above, and the staninate ones below; ovary ovoid, :3-celled; capsule large ; exocarp somewhat fleshy, endocarp slightly woody; seeds large, oblong, smooth; testa dry and brittle. Large trees, with 3 foliate leaves.

H. Braziliensis, Mill. (Caontchone.) Trunk 50 to 60 feet high; bark rough, grayish-brown; branching near the top ; branches and branchlets covered with a rough bark, the branchlets disfigured with tumors or swelliugs. Leaves on long petioles, branching at the end into three parts, each division terminated with a fleshy evergreen obovate-acuminate leaflet, dark-green above and light beneath; seeds oval and spotted.

There are 18 genera and 44 species of plants from which the gum elastic of commerce is obtained, mostly large trees. The most important of those that yield the largest quantity of the best quality are, first, the Hevea Braziliensis, order Euphorbiaceæ; Ficus elastica, order Urticacer; and Castilloa elastica, order Urticaceæ.

At the exposition at Philadelphia in 1876, a gum was exhibited procured from an undescribed plant of the Composite, found in Durango, Mexico.

Geography. - The hevea is a native of the region of South America drained by the Amazon and its tributaries. The

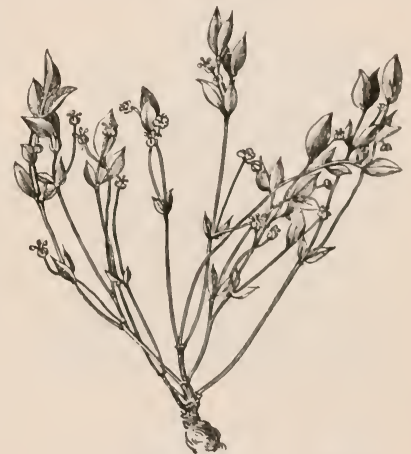

Euphorbia Ipecacuaxh. (Spurge). ficus is distributed over southern $\Lambda$ sia, midlle $\Lambda$ friea, and northern $\Lambda$ ustralia. These, as well as the other trees and rines that yich the gum-elastic, are tropical or strictly subtropical plants. The eastilloas are found on the Pacifie slope in northeru South America, and extend into central America. Castilloa elastica was sent from America in 1875 to Kew Gardens, Eugland, and thence to India, and in 1876 Hevea Braziliensis reached India by the same ronte, and is thriving there and upon the island of Ceylon.

Etymolog!y. - The meaning of hevea is obscure. Braziliensis, the specific name, denotes the country where it is indigenons ; elastica is from the Latiu elasticus, elastic or pliable. The name India rubber has been applied to this substance hecause early in its history it was nsed to erase or rub ont pencil marks, and as it was bronglit from the West Indies it was called India rubber. Gum elastic, another popular name, means "pliable gum." C'nontchonc is the native Sontl Ameriean name.

History. - In 1493 the Spaniards, on the second voyage of Columbus, saw the natives of Ilaiti amusing themselves with elastic halls which they threw and caught. More thin a century after that (in 1615) Torquemada published an aceount of the $\mathrm{XeW}$ World anil its products, in which he says the natives smear the juice of a tree over their bodies, and when it coagulates, they scrape 
it off and knead it into masses, and work it into vessels to hold water and other substances. More than a century after the appearance of 'T'orquemada's work, a scientific description was read before the French Academy by La Condamine, and was published in the transactions of the Academy. Oublet, in 1755, described the hevea botanicall:

At the beginning of the present century the usefulness of the gum had not been developed; in its native state it was soft and sticky in a high temperature, hard and inelastic when expnsed to the cold, and hence of very little practical value. In 1842, three hundred and fifty years after it was first seen by Europeans, experiments showed' 1 t to possess the power of uniting with sulphur. When thus combined, it is said to be vulcanized; it is not affected by temperature, and resists solvents. At the will of the manufacturer it may be made very pliable and more elastic than in its natural state, or very hard.

Preparation. - The mode of harvesting this remarkable substance is to wound the tree by piercing the bark to the down-flowing sap, which is a

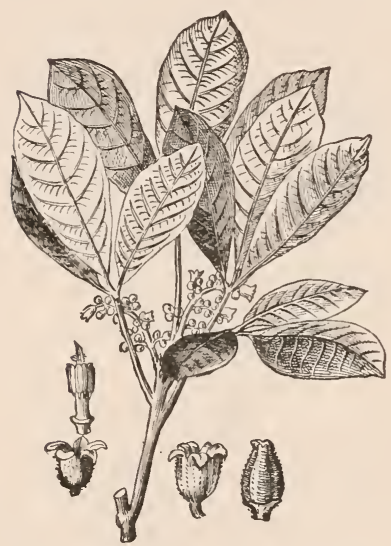

Hevea Braziliensis (Caoutchouc). yellowish-white, milky fluid. This, as it flows out, is caught in vessels of clay or bamboo, and carried to the camp, where it is smeared over an instrument resembling a wooden shovel, and held over a smoky fire. When the first smearing is coagulated or hardened, another coat is put on, and the process is repeated until the successive layers have produced a coating of eight inches or more in thickness, when it is slit down the side, slipped off, and hung up to dry and harden. It at first presents a silver-gray color, soon changing to yellow, and finally to a dingy black, as seen in commerce. It has been suggested that the vinegar of rood, or pyroligneous acid of the smoky fire, plays an important part in its coagulation, as the gum prepared in this manner is superior to that of any other preparation.

The South American gum was formerly hardened upon clay moulds in form of bottles and lasts, and when in a proper state the clay was picked out.

In India the mode of collecting the sap destroyed the trees. The government has takeu it in hand, and formed plantations, and less destructive modes of harvesting are now practiced.

Use. - The uses to which India rubber has been applied since the vulcanizing process has been put into practice are so numerous that only a few can be mentioned here; in fact it would be difficult to enumerate all the uses to which gum elastic has been put. It enters into the manufacture of every sort of waterproof elothing used for man or beast. The messenger boy encases himself in India rubber, and defies the pelting storm. The soldier in the camp spreads down his rubber blanket, and the cavalryman on the march, in a storm, protects himself and his horse by a covering of gum elastic cloth. It is manufactured into toys for the infant, bands for holding papers and packages together, boots, shoes, hats, beds and cushious, life-belts, gardenhose, door-springs, roller-skates, bumpers for railroad cars, etc. 
BUXUS, I. Flowers monnecious; calyx of the staminate flowers 3-sepaled; corolla -petaled; stamens 1 ; pistillate flowers with 4 sepals, 3 petals, and :3 pistils; seed-vessels surmounted by :3 beaks, 3-celled, 2 seeds in a cell. Shrubs and small trees. Evergreen.

B. sempervirens, L. (Box. Box-tree.) Stem from 10 to 30 feet in height, and from 3 to 8 inches in diameter, with densely crowded branches. Leaves oval, about half an inch in length, lark-green, glossy; the flowers in axillary clusters, male and female flowers on the sance plant, greenish and inconspicuous. April.

Var. angustifolia, W., is the same as the above, except that it has narrow leaves.

Var. suffuticosa, W., is a dwarf variety, and is used for borders in the garden and parterre.

Geography. - The geographical range is not great. It is a native of southern Europe, western Asia, and especially the countries of the Mediterranean Sea, Syria, Persia, and the regions south of the Black Sea.

Etymology. - Buxus and box are from the Greek $\pi \dot{v} \xi o s$, box-tree, and our word box comes from the same source, becanse boxes were made of the wood of this tree. Sempervirens, the specific name, is clue to its evergreen foliage. Ingustifolia is from the Latin angustus, narrow, and folium, leaf. Suffruticosa is from the Latin, fruticosa, bushy.

History. - The box was known to and used by the ancients. The wood was used by them to make combs and musical wind-instruments, and the Romans used it to ornament their planted grounds; and as it bear's the knife well, they clipped it into various shapes, mak-

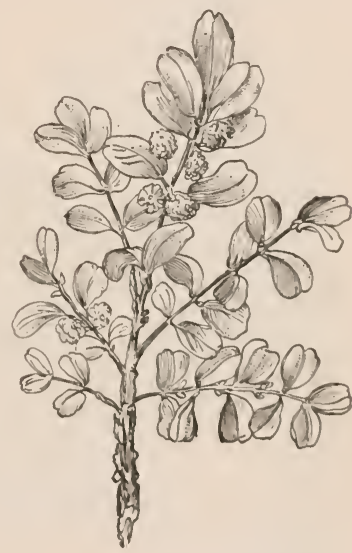

BUXUS SEMPERYiRENS (Box). ing it represent lions and other wild heasts among their shrubbery. It was brought by colonists to North Ameriea, and is found in planted grounds throughont the middle States and Virginia ; it is not hardy north of $41^{\circ}$ north latitule.

$L^{\top}$ se. - The dwarf form is used for ornamental purposes in planted grounds, and as borderings for gardens. The wood of the box-tree is nsed by turners and musical-instrument makers, ilso for mathematical instruments, scales, rulers, sheaves, pestles, screws, inlaving for tables and other cabinet ware, and especially for wood-engraving, for which purpose, on aceount of its close grain, it is invalnable.

It also enters into the materia medica. In extract is prescribed for intermittent fevers and for kidney complaints. Its seeds are purgative, and all parts of the plant are poisonons, expecially the leaves. It is said that in those parts of l'ersia where it grows, camels caunot he kept, as they are sure to feed upon it and poism themselves.

Marts. - The supply of the wood of the box comes from Smyma, Constantinople, and the islands of the Grecian Archipelago. It is sold by weight. kingland imports abont so,000 pounds ammally.

PR. FL. -16 
CROTON, L. Flowers monœcious; calyx of the staminate flowers 1-5-parted, cylindric, and valvate in the bud; corolla, with petals cor-. responding to the division of the calyx, small; stamens 5 to 20 ; calyx of the pistillate flower 5-, sometimes 8-parted; corolla minute, sometimes wanting; styles 3-forked, sometimes compound-forked; seedvessel 3-lobed, with 3 cells; cells 1 -seeded. Plant downy and aromatic.

C. tiglium, L. (Croton-oil Plant.) Stem 15 to 20 feet in height, erect. Leaves alteruate, acuminate, serrate, smooth, with 2 glands at the base; petioles shorter than the

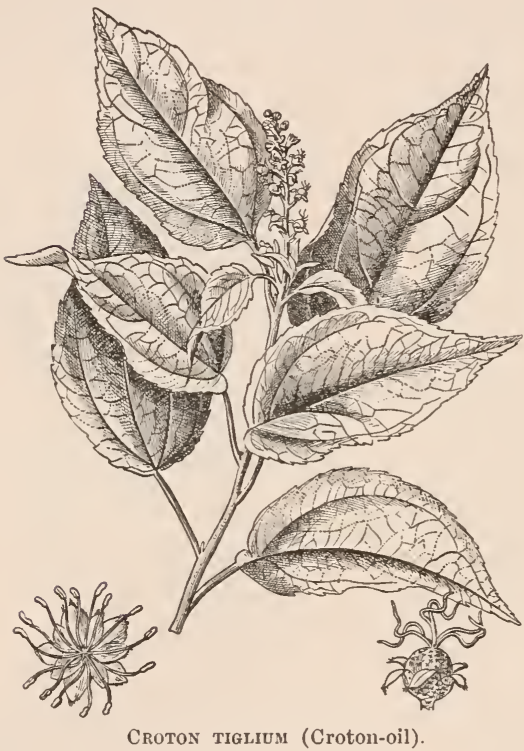
blade. Flowers in terminal racemes. Fruit 3 -celled ; cells 1-seeded.

There are about 500 species.

Geography. - The C. tiglium has a narrow geographical range; it is tropical and subtropical. It is under cultivation in southern Hiudustan and the East India islands.

Etymology. - Croton is from the Greek word $\kappa \rho o \tau \omega^{\prime}$, a tick, - because the seed in shape resembles the sheep-tick. Tiglium, the specific name, is of obscure signification.

History. - The Croton tiglium was described by Acosta in 1578, and the seeds came in use as a purgative medicine under the name of grana tiglii in the seventeenth century, but fell into

disuse. In 1812 the English physicians in India revived its use, and a few years afterwards the expressed oil was brought to the notice of medical men.

Chemistry. - The oil is about the consistency of castor oil, and is obtained from the seeds by pressure. Chemists have thus far failed to obtain the substance which gives efficacy to the oil. Its chemical formula is $\mathrm{C}_{9} \mathrm{H}_{14} \mathrm{O}_{2}$.

Use. - Croton oil is used sparingly, and administered with great caution in very small doses as a purgative after other remedies have proved ineffective. One drop mixed with olive or some other sweet oil is a full dose; a drop placed upon the tongue produces irritation throughout the entire intestinal canal; a few drops mixed with olive oil applied to the surface of the body cause an almost immediate eruption of the cuticle. It is used for a counter. irritant. 
MANIHOT, Plum. Flowers monocious and apetalons; calyx of the staminate flowers 5-parted and imbricated; stamens 10, in two series; filaments free, slender; anthers attached by their backs to the filaments; cells along the sides covered with cracks, running lengthwise; calyx of the pistillate flowers 5-parted, deciduous; receptacle below the base of the ovary sometimes furnished with stamen-like processes; style 3-lobed; ovary :3-valved, 3-celled; ovules 1 in each cell. Fruit in a capsule, 5-berried; berries 2-valved; seeds smooth. Leaves alternate, digitate; stipules small, deciduous; inflorescence a branched raceme, terminal or axillary. Fertile flowers occupy the lower part of the raceme. Root fusiform and fleshy.

M. utilissima, P'ohl. (Tapioca. Bitter Cassava.) Stem slender, 5 to 9 feet high, woody below, branched above, smooth, bark whitisl. Leaves large, on long purplish foot-stalks, warty near the base, falling off early; stipules narrow, triangular, acute, smooth, falling, blade divided into 3 to 7 oblong, acute, narrow lobes, 2 to 4 inches long, smooth above, glaucous beneath. Flowers monoecious, in axillary or terminal racemes; perianths bell-shaped, deeply cut into 5 acute segments; pistillate Howers, larger and occupying the lower part of the raceme; ovary surrounded at the base by a ring-like receptacle, smooth and purple, 3-celled, an orule in each cell; style short, surmounted by 3 stigmas. Fruit on short stalks; fruit-ressel half an inch long, globular, glabrous, embossed with protuberances, ti-winged, 3-celled, separating into 3 berry-like divisions, with a single seed in each, one eighth of an inch long, oblong, smooth, and gray. Root fleshy, 3 feet long and 6 to 9 inches in

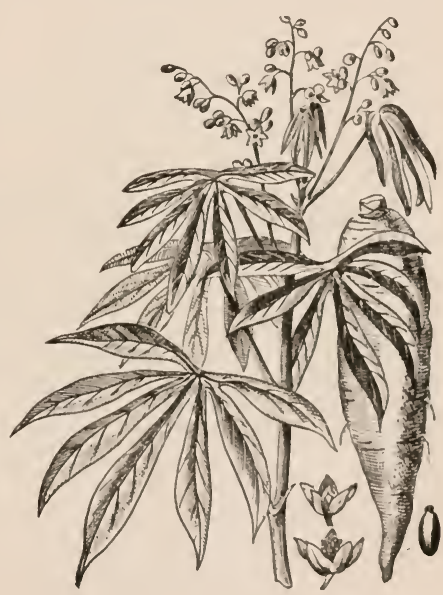

Maxihot utilissima (Tapioca). diameter, weighing 10 to 30 pounds, fusiform in shape, and charged with a milky juice.

There are 30 well-marked varieties of this species grown in Brazil.

Geography. - The home of the tapioca plant is tropical and subtropical South America, whence it has been carried to other warm countries, as southern Asia and western Africa.

Etymology. - The history of the names of the tapioca plauts is somewhat obscure; the names have been frequently changel, and there are a number of synonyms. Loudon places the species nuder the genus Jatropha, and makes the cassava plant. . manihot; but I'ohl places the two species under manihot, as follows: Manihot utilissima, M. api, regarding all others as forms or varieties of these two.

Janihot is a name applied by the natives. Utillissima, the superlative of the Latin adjective utilis, signifies "very useful." Tapioca is a name in the Brazilian native dialect for the starels or substance prepared from the root of 
the plant. Jatrophe is derived from two Greek words: iatpós, physician, and $\tau \rho \circ \phi \dot{\eta}$, food, due to the fact that physicians order it as food for invalids. Api, Aypi, or Aipi, is an ancient native name, whose meaning is unknown. Cassava, like tapioca, is a native name, whose signification is obscure.

Cultivation. - The root grows best in loose, dry, well-fertilized, sandy loam. During the first month or six weeks it needs rain or irrigation; after that, it grows well without either, and is the most productive and valuable crop to be made in its region, far exceeding either coffee, sugar, or cotton. One acre will produce about $4,000,000$ of pounds when the root is full grown, that is, from a year to eighteen months after planting, which is done by plunging 'slips of the plant into small prepared hillocks of sand, or by burying a section of a stem containing a bud. The M. api varieties mature in about eight months.

Preparation. - The roots of the rarieties of the M. api species are not poisonous; they are prepared by roasting, and have the taste of roasted chestnuts. The varieties of the M. utilissima produce the larger roots, which are prepared as follows: 'The natives peel the roots, then reduce them to pulp by rasping them upon a rude grater made by inserting rough fragments of stones in a piece of bark; the juice is then forced out by allowing it to drain in loosely made baskets, and then baking the pulp in ovens ; or it is made into flat cakes baked or dried upon hot stones.

The tapioca brought to market is largely made by reducing the roots by circular rasps or graters turned by water, placed into coarse bags, the juice being removed by a press. The pulp is then subjected to heat in open ovens or on iron plates, and constantly stirred till dry.

Farina is the coarse meal made from the root, universally used by the Brazilians. The fine siftings make the tapioca.

Use. - The fresh-grated pulp, and the juice which is expressed from it, is charged with a substance analogous to prussic acid; yet when the pulp and the juice are subjected to heat, the poisonous character disappears, and the pulp is turned into a wholesome starchy food that sustains life in large and densely populated districts, and is used for puddings for dessert, and for invalid food, all over Europe and the United States.

The root, cut in slices and exposed to heat, is an excellent food for cattle. The natives of Brazil make a fermented liquor of the juice, which is highly intoxicating.

The fresh juice has been administered to cats and dogs, which die with convulsions in about twenty-five minutes. Thirty-six drops administered to a criminal caused death in six minutes.

RICINUS, Tourn. Flowers monœecious, valvate in the bud; sepals narrow and reddish, 3 to 5 in number ; no corolla; stamens numerous ; filaments repeatedly branching; anthers from the tops of the branches of the filaments; orary globose, 3-celled, 1 orule in a cell; style short; stigmas 3-bifid, plumose, and colored; capsule large, 3-celled, covered with blunt, rough spines; seeds large, oily, somewhat in shape of a tick that infests sheep. Annual.

R. communis, L. (Castor-oil Plant.) Stem round, stout, frosted or glaucous, white, shining, purplish, red towards the top, 6 to 12 feet in height in the mirdle United States, reaching 15 to 20 feet in hot climates, where it is perennial. Leares alteruate, on long petioles, 6 to 10 inches in diameter; subpeltate 
divided into 7 lanceolate, pointed, serrate segunents; staminate flowers on the summit, fertile ones on the lower part of the spike.

Geography. - The geographical range is broal. Though a subtropical plant, it grows well and matures its seeds in a latiturle as high as 420 .

Etymology. - Ricinus, the generic name, is from the Latin ricinus, a sheep. tick, which the seed resembles. Commnnis is latin, signifying "common," The common name, rustor-oil plant, is believed to have heen due to the resemblance of the oil to a liquid contained in little sacks in the grenin of the castor (beaver). Another suppmsition is that it was called in the West Iudies agno casto, and that casto has been corrupted into castor.

History. - The home of this plant is southern Asia. De Candolle believes its home to be eastern $\mathrm{Africa}$. It was known to the ancients, and is spoken of by Dioscoricles, who states that the seeks are violently eathartic. When it was first cultivaterl is not known. It was grown in southern Europe and the countries of the Levant at least 300 years before the Christian era. It is cultirated in Japan, Bengal, eastern and northern Africa, southern Europe, and the United States.

It was bronght to America by European colonists. It is largely cultivated in the sonthwestern United States to pro. luce the oil of commerce. Since the invasion of Kansas. by the grasshoppers, the cultivation of the castor-oil plant has been largely practiced.

Preparation. - The mode of procuring the oil is by expression. The coats of the seeds are first removed; the

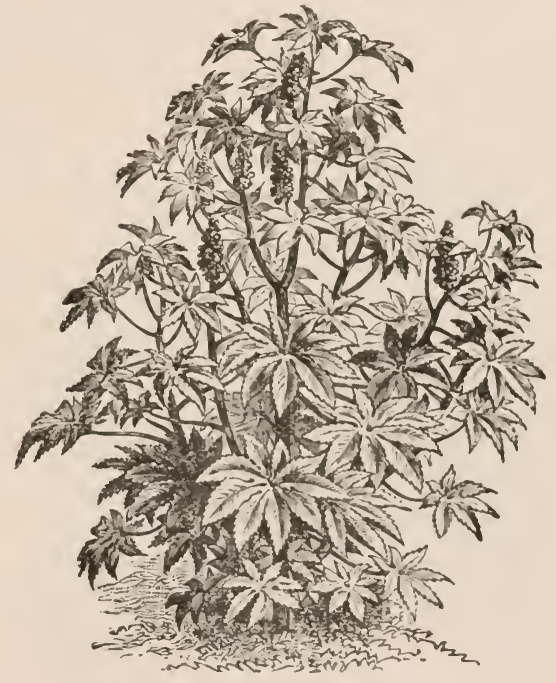

Ricrnos commesis (Castor-oil). oil is squeezed out and then boiled with water; the foreign sulstances are thereby coagnlated, and the (lear oil floats npon the top), whence it is drawn off and put into suitable casks and ressels for market. The best is male in Italy, where it is mamufactures in large quantities and with great rare, in the vicinity of Verona, from seed grown in Italy and imported from $\Lambda$ frica and India.

Use. - The plant is grown for ornament, ancl anong tropical plants makes a desirable oliject.

The oil is a mild, speedy, and safe purgative, and for children is the hest cathartic medicine in use.

It is used in the preparation of silves, liniments, and ointments, and dissolved in alcohol is largely used in preparations for hair-l resings.

It mixes with alcohol in all proportions, leeomes sulicl at 0 Falirenleit, and boils at $265^{\circ}$. It is the heaviest of all oils. The purgative primeiple is not known to chemist.s. 


\section{Order l. URTICACE无. (Nettle Family.)}

Trees, shrubs, or herbs. Leaves generally alternate and stipulate. Flowers unisexual or polygamous, and axillary; perianth single, sometimes adnate to the ovary in the female flower, or wanting; stamens, when present, usually equal and opposite the lobes of the perianth; ovary 1-celled, 1-carpelled; style simple or 2-cleft; ovule solitary. Fruit an akene or drupe, or many fruits coalescing into a syncarp, with fleshy accrescent torus.

Genera, 108; species, 1,500; habitat, warm and temperate countries.

MORUS, Tourn. (Mulberry.) Flowers unisexual, usually monœcious, but in some plants diœcious or polygamous; male flowers spiked and

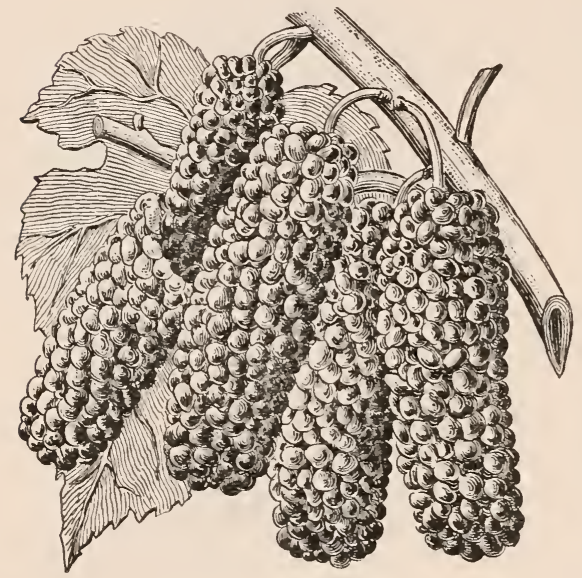

Morus RUBra (Red Mulberry). axillary. Sepals 4, equal, imbricate in æstivation, but expanded in flowering; stamens 4. Pistillate flowers, with a 4-sepaled calyx, in opposite pairs, 1 pair larger, all upright and persistent, and becoming pulpy and juicy. Leaves alternate, simple, exstipulate, deciduous, lobed, rough, 3-4 inches broad. Flowers greenish - white. Fruit the aggregate of the ovary, called "mulberry."

1. M. rubra, L. (Red Mulberry.) Leaves ovate. cordate, serrate, rough above, soft and downy

beneath, frequently lobed on young shoots. Flowers often diœecious. Fruit dark-purple (when ripe turning black), cylindrical, half to three quarters of an inch in diameter. Fruit ripe in July. Tree 15 to 30 feet high, but sometimes grows to a much greater height; head 12 to 15 feet in diameter.

2. M. alba, L. (White Mulberry.) Leaves obliquely orate, heart-shaper, acute, serrate, frequently lobed, smooth and shining above. Fruit whitish, soft, sweet, insipid.

Geography. - M. rubra is a common tree in western New England, the southern parts of Upper Canada, the Dakotas, Kansas, and the South. M. alba flourishes in southern Europe and Asia. It is also found in the Lnited States south of the forty-third parallel of latitude in the older parts of the country.

Etymology. - Morus is from the Greek $\mu$ ópov, a mulberry. Rubra is Latin for "red," and alba is Latin for "white." Mulberry is from the Old English

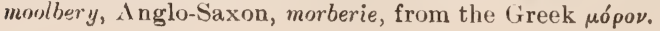


History. - The white mulherry is a native of China and Japan; it was introduced into Europe about the mildle of the fifteenth century, and soon became naturalized in Italy and Greece, as well as in Asia Minor and Armenia. Cortes procured its introduction into Mexico in 1522; it was sent to Virginia in 1619 by order of James I., and its cultivation was commanded by law.

Ep to the time of the Revolution the British government paid a bounty on raw silk prorluced in the North American colonies; some of this silk was, in 17.2 , presented to the queen and to the wives of the proprietors of l'ennsylvania by 1)r. Franklin, then the agent of Pennsylvania in London. In the same vear a colony of Saltzburgers, who were familiar with the mulberry and silk culture, sent to England from their settlement of New Ebenezer, in Georgia, nearly 500 pounds of silk. Shortly afterward the settlement was broken up. and the industry was obliterated during the Revolution. Upon the restoration of peace, efforts were made in many of the states, dating from 1783 in Connecticnt to 1866 in California, to revive the industry by legislation. In 1838 a mania for the importation of and speculation in the plants of M. allba, var. multicaulis, of the Sonth Sea Islands, broke ont in the United States, hundreds of thousands of dollars having been invested during a single week in Peunsylrania alone. The passion for the cultivation of the tree subsided within a year, but the species remains, and has become naturalized.

On account of the absence of cheap and abundant skilled labor in North America, all stimulations by government aid have failed to establish the mulberry and silk culture there, while China, Japan, westeru India, Italy, and the Levant, where cheap skilled labor can be found, have become the sources of the world's smpply.

Use. - M. rubra, or the red mulberry, has a hard, light, durable wood, much nsed in ship-huilding in the southern Lnited States for the light timbers of ressels and boats. The fruit is blackish-red, with an agreeable subacid taste. It is wholesome and refreshing when eaten directly from the tree before the acetous fermentation sets in. The leaves are rough, and are used for feeding silk-worms, but for this purpose are inferior to the leaves of the M. alba.

II. alba, or the white mulberry, is the tree so extensively grown for the ('nlture of silk-worms, and the finest and strongest silks are produced from worms fed upon its leaves. It is a much more rapid grower than the other species of this genus, and is distinguished by its many slender white-barked shoots. Its leaves are slender, and highly chargerl with a glutinous, milky substance resembling the sap of the hevea. This substance gives strength to the silk produced by the silk-worms fed on its leaves. Trees grown upon high, gravelly, poor soil, in hilly localities produce better silk than trees grown upon generous soil.

ULMUS. (Elm.) Flowers in lateral groups, appearing in adrance of the leaves, bisexual and moncecious; calyx campammlate, i- or $1-8$ lobed, imbricate in the bud, persistent; stamens equal in number to segments; style short, or wanting; stigmas 2. Fruit a samara, with a membranous wing. Leaves alternate, stipulate, serrate, featherveined, usually unequal at the base, rough to the touch. Flowers reddish-white.

1. U. Americana, 1. (American Viln. White lilu. Weeping Elm.) Trunk 2 to 5 feet in diameter near the base, usually dividing into 2 or more branches 
within 15 to 50 feet from the ground, which when growing near each other interlace and form graceful curves and arches; the leading branches sometimes reach the height of 120 feet.

2. U. fulva, Mx. (Slippery Elm. Red Elm.) Trunk 40 to 60 feet high, 12 to 2.5 inches in diameter ; wood reddish-yellow, tough, inner bark highly charged with mucilage. Branches rough, not forking as in No. 1. Leaves oblong-ovate, acuminate, more nearly equal at base than in No. 1, unevenly serrate, pubescent, rough; buds, before expansion, clothed with soft hairs, large. Flowers at the end of young twigs; calyx downy and sessile. Stameus short, 7. Flowers in April.

3. U. racemosa, Thomas. (Corky Elm.) Trunk 50 to 80 feet high, $1 \frac{1}{2}$ to 3 feet in diameter, in habit and appearance like No. 1 ; branches, when young, slightly pubescent; scales of the buds ciliate; bark of the branches roughened

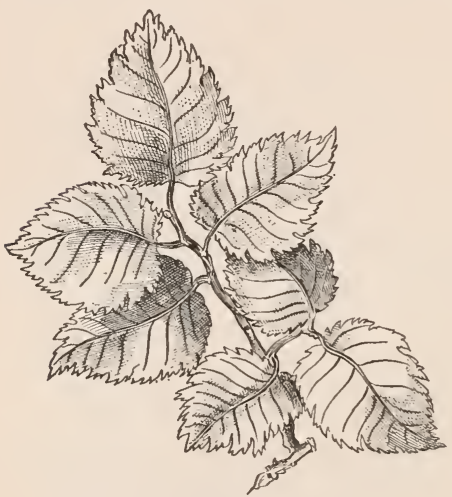

Ulmos CAMPESTRIS (English Elm).

by corky lines. Leaves as in No. 1, with more regular veins. Flowers in racemes.

4. U. alata, MIx. (Winged Elm.) Trunk 29 to 30 feet high, 10 to 15 inches in diameter. Branches here and there roughened with corky ridges, or wings, otherwise smooth; scales of the buds and young branchlets glabrous. Leaves unequal at base, downy beneath, oblong-ovate or lanceolate, sharp, thick, small, and donbly serrate; petioles short.

5. U. campestris, L. (English Elm.) Trunk 60 to 80 feet high, branching irregularly, branches extending sub-horizontally; bark of a dull lead-color, smooth when young, cracking into irregular strips with age. Leaves rough, doubly serrate, rather small. Flowers rusty-brown; samara oblong, deeply cleft, smooth, and yellow. Flowers in March; seed ripens in May.

The English elm is an important timber-tree, and much attention has been given, especially in England, to its cultivation. No tree sports more freely than the elm, and English writers describe abont 20 well-marked varieties to be found in Furope.

There are abont a dozen species of the elm, with a large number of varieties. Linnæus went so far as to adrance the belief that all the elms are varieties of one species.

Geography. - The geographical range of the elm extends, in Europe, from the Mediterranean conntries to the middle of Fnropean Russia ; in America, from the southern banks of the St. Lawrence River to the Gulf of Mexico; and west to the foot-hills of the Rocky Mountains.

Etymology. - Ulmus is from the German ulm, Latinized into ulmus, supposed to come from the base $a l$, grow, and believed to have been applied on account of the rapid growth of this tree. $E / m$, the common name, is from the old European name, $u l m$ or $i l m$. The specific names of the American species are 
Americana, derived from America, its native country ; fulca, Iatin, yellow, due to the color of wool; racemosu, the flowers heing borne in racemes; alata, from the Latin ala, a wing, due to the rilges in the hark of the branches, which are wing-like; campestris, Latin campester, pertaining to a plain or field, due to the fact that the plant grows in open plac'ss.

History. - The elm is mentioned by Pliny. Little is known of its early history, and at what clate it hegan to assume importance as an ornamental tree is not recorded. There are some remarkalile specimens mentioned for size and age. One planted by Ienry IV. of France was standing in 1790. One in England, planted by Queen Elizabeth, was cut down in 1745 ; this was more than four feet in diameter.

The elm is the most majestic tree we have in planted grounds; the most desirable are the U. Americana of America, and the U. campestris of Europe.

Use. - The Llmus Americana is a farorite ornamental tree, on account of its majestic form; it forks into large branches, and when planted in parallel rows along walks and drives, the branches interlace, forming graceful curves and pointed arches. The timber of this tree has not been used much in America, because an abundance of better timber is to be found. The European $U$. campestris is not only prized as an ornamental tree, but it yields an excellent lumber, which is remarkable for its durability, especially in water.

The American species, U. fulva, has a thick inner bark, which is highly charged with mucilage, and is used in medical practice for throat and bron. chial troubles, and for poultices.

HUMULUS, I. Flowers dinecious; calyx of the staminate flowers 5-petaled, with 5) stamens; anthers with 2 pores; pistillate flowers axillary in short strobiliform spikes: bracts leaf-like, laxly imbricated, 2-flowered, each floret sessile at the base of a scale-like involucre, embraced by its involute margin; calyx urceolate, truncate, with small teeth; ovary ovoid, compressed ovule, single and pendulous; strobile membranaceous, made up of the enlarged imbricated bracts and scales. Fruit roundish. egg-shaped, inclosed in the trumcated calyx; cotyledons linear, spirally involute. Peremnial twining herb, with opposite leaves.

H. lupulus, L. (Common Hop.) Root branching; stem 20 feet long, a number from the same root, twining with the sun, striate or angular, twisted; slender branches near the top, upon which the flowers and fruit appear. Leares opposite, and lobed near the root, alternate and entire above, scabrous on the upper surface; petioles long; stipules elliptical-lanceolate and werlge-shaped helow, the scales sprinkled with resinous dots, which resin produces the peculiar odor and taste of the hop. July.

'There are several varieties, which differ very little from each other.

Geography. - The hop grows wild throughout middle Europe and siheria, as far worth as the 62d parallel, the Levant, and Asia Ninor, and has been introducel into Eigyt. It is also indigenous to sonthern Japan and to North America, along the fouthills of the Rocky Mountains, along the upper Arkansas, Missomri, and Mississippi rivers, and near the shores of Lake Wimnipeg, also thronghont the Itlantic States north of Virginia. The variety in cultivation was l,rought to northeast $\Lambda$ merica by European eolonists. 
Etymology. - The name humulus, from the Latin, humus, earth, was given to this plant because it delights in new rich earth. Its native haunts are in the deep soils of swamps and low grounds. The specific name is a diminutive of lupus, the Latin for wolf, "a little wolf." As it grows among the willows it twines about them and chokes them, as the wolf does a flock of sheep. The common name, hop, is from the Old English hoppen, which signifies "climb," hence the climbing plant.

History. - When this plant was introduced into cultivation we have no means of knowing. It is said to have been brought into England from Flanders, and to have attracted the attention of gardeners and agriculturists first in the reign of Henry VIII. more than 400 years ago. Malted liquors had been formerly called ale; but the use of hops made them beer. This plant

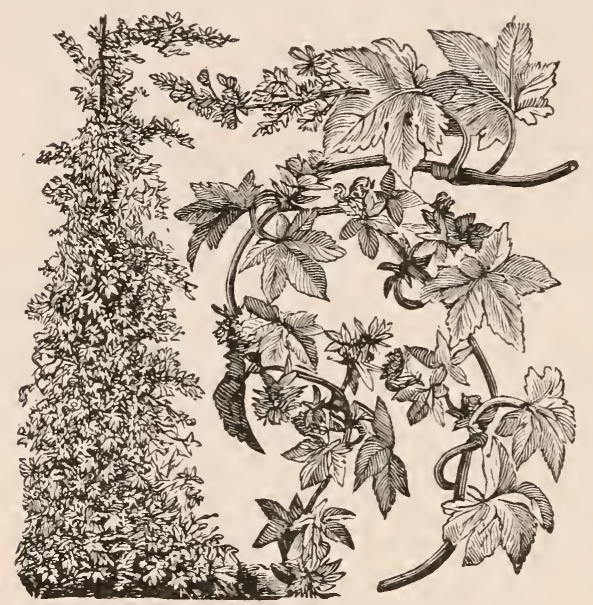

Humulus lupulus (Common Hop). was known to the Romans before the Christian era. Pliny speaks of it as a garden-vegetable.

Use. - The hop plays an important part in the manufacture of beer and ale. The plant furnishes the substance known as lupulin, in which the virtues of the hop reside in part. It is said to clarify these liquors, and to prevent acidification.

It is aromatic, astringent, tonic, sudorific, and anodyne, and promotes sleep in some cases of insomnia when other remedies fail. A pillow filled with hops is said to have heen used by George III. of England in his severe

illness in 1787 , by direction of his physician, Dr. Wrillis.

It is an important ingredient in the domestic materia medica. It is used also in making yeast. Foung shoots were formerly prepared for the table and eaten as a substitute for asparagus. In Sweden a strong cloth is made of the fiber of the stem.

FICUS, Tourn. (Fig Tree.) Flowers monøcious. lining the interior surface of a hollow globular or pear-shaped fleshy receptacle, at the top of which is an opening, which is shut by small scales, staminate flowers above, and the fertile ones beneath; calyx of the staminate flowers 3-parted; stamens 3; pistillate flowers with 2 stigmas and a 5-cleft calyx. Leaves simple, alternate, stipulate, deciduous, and lobed. Fruit in shape of a little bottle, edible.

1. F. Carica, L. (Common Fig.) A small, irregularly branched tree, 5 to 20 feet high; or an irregular straggling bush branching near the root, forming an irregular head. Branches cylindrical; bark pale-reddish, young branches 
showing scars, from which the leaves and stipules have fallen; twigs downy. Leaves alternate, on long, thick, curved, and downy petioles; blades 4 inches long, nearly as wide, stiff and rough on the upper side, soft, woolly underneath, cordate at base, 3 to 5 palmate, broad, blunt lohes, irregularly and coarsely toothed; stipules large, clasping the whole stem or branch, lalling off early. Fruit axillary and solitary, on short stalks, varying from 1 to 3 inches in length, smooth, purplish, turning to a dingy yellow when rije, soft and fleshy, with numerous seed-like nuts, l-celled.

2. F. elastica. (Indian Fig. India Rubber.) Trunk from 80 to 120 feet in height, and 5 to 10 feet in dianeter. Like the $\mathrm{F}$. Bengalensis it produces aerial roots, which it throws to the ground, where ther frequently take ront in the soil or in the crevices of the rocks among which it delights to grow. A singular feature of this tree is its enormous roots, which lie upon the surface of the ground, coiling and curling over and about the rocks like great serpents. Branches large and irregular; bark gray. Leaves ovoid or elliptical, dark-green, thick, leathery, and regularly veined, and acuminate and glossy. Flowers in axillary panicles, crimson. Fruit small, and not edible.

This tree yields the India rubber of the East Indies.

3. F. Bengalensis, IV. (Banyan Tree.) This tree is the most remarkable of the genus Ficus, and seems to deserve a place here.

The trunk is from 5 to 9 feet in diameter, and rises to the height of

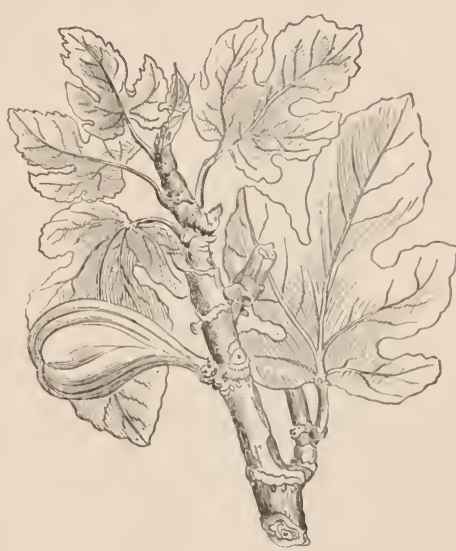

Ficus Carica (Common Fig). 100 feet. The branches extend horizontally, and send down vertieal branches to the ground, which take root, become stems, and branch throwing down other branches, which take root in the same way, until the whole presents the appearance of a vast leafy canopy, supported in some cases by more than fifty pillars, covering a space from 300 to as much as 400 feet in diameter. It is stated by travellers that these strange unions of trees sometimes rise in pyramidal form to the vast height of 150 feet.

The ficus genus is large, including some curious and interesting trees. The edible figs are confined entirely to the species carica and its numcrons rarieties.

The varieties of $\mathrm{F}$. Carica are as follows: 1 st, growing withont cultivation, with small and nearly entire leaves; $2 d$, under cultivation, with large leares, deeply eut and lobed, fruit white or dark; 3l, muder cultivation, with large leaves, nearly entire.

These three divisions separate into several varietics, each depending upon the size, shape, and color of the fruit.

Geography. - The fig grows well in all subtropical cunntries: and while it will endure the temperature of $40^{\circ}$ north latitude, and with slight protection fruits sparingly, it Hourishes hest just in the edge of the region of no frost. 
Etymology. - The word ficus has been derived from the Latin word, fecundus, fruitful, on account of its heavy bearing; also from fag, a Hebrew name; as well as from the Sanscrit feg. Fig is a mere translation of the word ficus. Carica is from Caria, from which town fine figs were exported in ancient times. Banyan, Hindu for " merchant," is applied to these trees on account of their frequent use as market places. The other names are self-explanatory.

History. - The fig is spoken of frequently in Scripture. Greek tradition carries back the use of the fig to remote antiquity, leading to the inference that it was used prior to the cereals, and figured as largely in the support of human life as the plantain family. Even so late as after the Exodus we find the Israelites deploring the failure of the fig crop as a great calamity. In the days of Vergil the cultivation of the fig near Rome was carried on to greater perfection than that of the vine.

The home of the fig is believed to be western Asia, perhaps Persia, whence it has worked its way both eastward and westward. In very early times it had spread throughout the Mediterranean basin, along both shores, and as far west as the Canary Islancls. In the days of Theophrastus, who lived about 300 years before the beginning of the Christian era, it was a well known fruit. It has spread through all the subtropical countries where European colonization has been established. The tree endures the climate of southern England, but does not fruit well there. Some trees, carried to England in 1525, and planted in the garden of Cardinal Pole, are now in good health; some of them being 50 feet in height and 10 inches in diameter. The fig is supposed to have been taken into England in the first century by 1 gricola.

Use. - The fig is a farorite dessert fruit, both in a natural and a preserved state. In southrestern Asia, southern Europe, and northern Africa it constitutes the principal food of a large number of people, and is eaten just as it is taken from the tree. When figs are dried in the sun or in a kilu and packed tightly, they keep well, and endure long royages without damage.

Medicinally, they are laxative, and roasted they are used as a poultice for boils, and applied to the gums to allay inflammation.

Some of the Chinese and Indian fig-trees are the abodes of the lac insect, Coccus lacca. The females make their homes upon the ends of the twigs of the fig-tree, and deposit thereon a resinous substance, which enters into the manufacture of sealing-wax, varnish, waterproof hats, etc.

Marts. - The markets of the world are supplied by Turkey and Greece, Spain and Egypt. About $7,000,000$ pounds are taken from these countries to the United states annually, and about $20,000,000$ pounds are taken to England.

CANNABIS, Tourn. Flowers diøecious; staminate flowers in a raceme; calyx with 5 nearly equal sepals; stamens 5, nodding; pistillate flowers spicate, clustered, single-bracted; calyx urceolate, 1-sepaled, and membranous; ovary globose, 1-celled, inclosing a single ovule; style terminal ; seed hanging. An erect annual. Leaves alternate above, opposite below, digitate.

C. sativa, L. (Hemp.) Stem 5 to 18 feet high, roundish, angular, sulcate, and rough-branched. Leaves opposite below, alternate above, digitately divided; leaflets 5 to 7 , linear-lanceolate, and toothed, the two at the base smaller and frequently entire, the stipulate foot-stalks 1 to 3 inches long. 
Staminate flowers green, perlunculate, axillary, crowded at the summit of the stem and branches; pistillate flowers sessile, nstlally in pairs.

Geography - The geographical ramge of hemp is very wide. It flourishes throughout the elges of the tropics, and all through the temperate andes, to about the 50th parallel.

Etymology. - Cannabis is said to be derived from the Arabic word caunab, made up of cun, a reed, and $a b$, small; hence, a little reed. Satira, the specific name, is from the Latin satious, sown or planted. The meaning of the word hemp is obscure.

History. - The home of the hemp is supposed to be Chinese Tartary, northern India, and southwestern siberia, whence it is supposed to have been carried into Enrope by the Sicythians about 1,500 year's before the ('hristian era. Herodotus states that the ancient Sicythians burnt the seed, and were intoxicated by breatling the fumes.

Hemp is an important (rop in China, Chinese 'Tartary, Japan, P'ersia, Hindustan, Egypt, southern Africa, most of the states of Europe, and especially Russia. It has been introduced into America, and is cultivated in Canada ancl the United States. Hemp of a superior quality is raised in sonthern Russia and Poland. The hemp of the North produces the hest fabric's and cordage. The plant when grown in hot countries possesses qualities wholly unknown to it when raised in colder regions. That grown in the tropics and subtropical regious yields substances that are nareotic and intoxicating.

$U$ se.-The fiber of the hemp plant is among the most important of all the textile products. It is made into cloth, and furnishes material for the coarse clothing of a large part of the people of northem

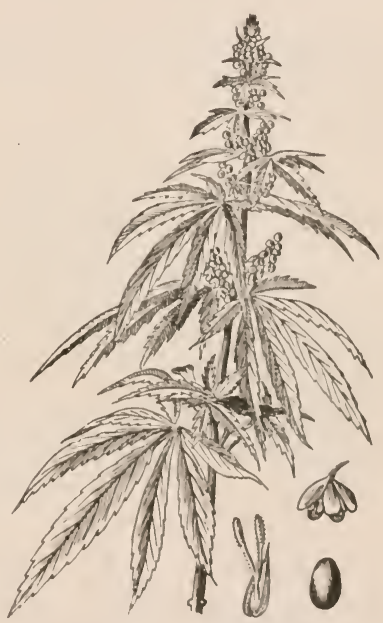

Cannabis sativa (Hemp). Europe and Asia. 'The bagging-cloths, and the sails and cordage for vesscels all over the world, are made of hemp. The lussians obtain an oil from hemp seeds, which they use in their culinary preparations and to mix their paints, and in the manuficture of soft soap). The seed is also fed to caged hirds, and is said to change the color of their plumage from red to hlack.

The leaf, when grown in warm climates, is smoked, and produces a nareotic and intoxicating effect upon the smoker, which is saicl to alleviate pain, increase the appetite, and give rise to mental cheerfulness It alsu produces violent coughing and spitting of hlood. From the whole plant alsi exules a resinous substance, which, when smoked, produces intoxication: when taken internally in small doses, it produces furor and imparts wonderful strength, when taken in larger quantities it produces hilarity and stimulates the appetite, but the patient fually hecomes insensille, and his limbs will remain in any position they may be placed. After a time the person recovers without any apparent ill effects to either mind or body. The resinous sulsistance is the celebrated hashish of the Arabs. Bhang is a narcotic intoxicating drug, pre- 
pared from the leaves and seed-vessels of hemp. It is a favorite drink in the East Indies.

Those who frequent places in Egypt where hashish is sold are of the lowest class, and the term has come to convey the idea of disorderly or riotous people. The plural, hashshasheen, is believed to be the origin of our word "assassin." because the Arabs in the time of the Crusades used the drug to produce insensibility in their victims.

\section{Order LI. JUGLANDACE 2 S.}

Flowers monocious, staminate ones small, and often in hanging catkins; perianth single, attached to the inner face of a bract which is 6-lobed, sometimes 2-3-lobed; stamens 3 to 40 , inserted at the base of the bract; filaments very short, free or coherent at the base; pistillate flowers terminal, solitary or few, and clustered; calyx tube ovoid, limb 4-toothed; styles 2, very short; stigmas 2, elongated, recurved. Fruit drupaceous, rarely nut-like, containing a single nut; epicarp fleshy, fibrous within, indehiscent ; nut woody, rugose, and irregularly grooved lengthwise. Trees or shrubs, with watery, resinous, aromatic juice. Leaves odd-pimnate, exstipulate; staminate catkins from last year's branches, or at the base of the younger branches.

No. of genera, 5; species, 3 ; temperate regions, and mountains in the tropics.

JUGLANS, L. Bract of the pistillate flower with its bractlets closely adhering to the ovary, irregularly toothed at the perianth limb so as to

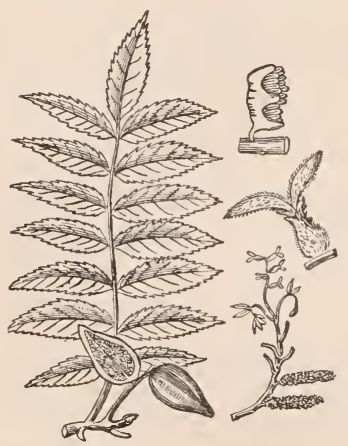

JUgLANS cinerea (Butternut). resemble an outer perianth; exocarp of the drupe closely adhering to the wrinkled endocarp, or at last coming away irregularly. Staminate and pistillate flowers separate, but upon the same plant; staminate flowers in solitary, drooping catkins; calyx composed of 5 to 6 scale-like sepals ; stamens 18 to 36 , usually about 20 . Pistillate flowers, 1 to 5 in a group, terminal on the new wood; calyx ovate, and 4-toothed; petals 4 in number; styles short, 2 in number; stigmas 2. Fruit a drupe, nut rugose, hard, globose, a little compressed laterally, 2-valved. Covering of the nut a fleshy husk, indehiscent. Kermel large, oily, sweet.

1. J. cinerea, I. (Butternut.) Stem from 10 to 30 feet in height, irregularly branched, and from 6 inches to 1 foot in diameter. Leaf made up of 7 or 8 pairs of leaflets, and a terminal one; leaflets rounded at the base, elliptical. lanceolate, serrate, and pubescent underneath; aments cylindrical. Flowers greenish, appearing in April and May. Fruit cylindrical, 2 inches long and 
1 inch in diameter, ending with an acuminate tip. Exocarp or suter shell like that of J. nigra, but thinner; nut corrugated in the direction of the longer axis; kernel sweet and buttery.

Geography. - Geographical range between the parallels of $48^{\circ}$ and $36^{\circ}$ north latitude, from the Atlantic to the Mississippi River.

Etymology. - Juglans is derivel from the words Jovis, Jupiter, and glans, Latin for "nut," - that is, nut or fruit for Jupiter or the gods, on account of its delicate quality as a food. The common uame, butternut, is due to the delicate buttery taste of the keruels. The specific name, cinerea, comes from the Latin cinerens, ash-colored, due to the ashy-gray color of the bark.

History. - The home of the butternut is northeastern North America. It is sometimes planted for ornament, but delights in rocky places, and loves the hills; has been planted in middle Europe and in England, and grows and fruits well there.

Cse. - The butteruut is a favorite dessert nut. $A$ delicate salad oil is obtained from the keruels by expression, and the fruit in an unripe state is used for pickling.

The wood has a coarse grain, but takes a good polish, and is used for cabinet ware and for wainscoting. The chips are also used to manufacture beer.

The outer shell of the fruit furnishes a dye, which is largely used to color home-made fabrics in the western part of Kentucky and Tenuessee.

$A$ decoction of the bark is boiled down to a mass and made into pills, which are administered as a gentle eathartic.

2. J. nigra, L. (Black Walnut.

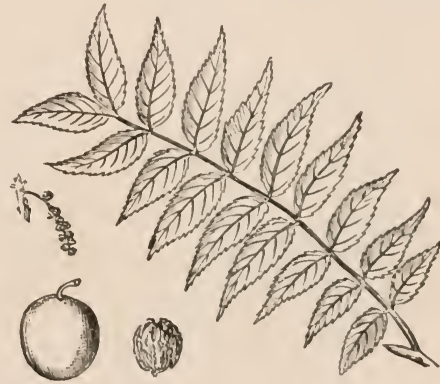

Juglans NigRA (Black Waluut).

Black-wooded Walnut Tree.) Stem straight, 40 to 80 feet high, and 1 to 4 feet in diameter; branches crooked and straggling, forming an open and picturesque head, from 15 to 30 feet in diameter. Leaves compound, with 7 to 8 pairs of leaflets and a terminal one, odd one frequently wanting; leaflets slender, corlate, acuminate, unequal at the base, on short petioles. Flowers greenish, appearing in May in the northern limits, and in $\Lambda$ pril further south. Fruit ripens in October.

Geography. - The black walnut is indigenons in southwestern New York, and further south to the Gulf of Mexico, and west some distance beyond the Mississippi River. It has been introduced into the eastern middle States and southern New England, where it grows and fruits well.

Etymology. - Nigra is from the Latin niger, black, from the color of the wood. The word wulnut was given in England, and means "a strange or foreign nut," signifying that it came from abroal, from Anglo-kiaxon wealk, st range, and mut.

History-The black walunt has been introduced into England and southern Europe by seeds from America. It grows well in England, but is becoming very scarce in the United states

Lse. - The wood of the black walnut is hard, very dark, and takes a good polish; it is stroug and tough, and is largely used in the maunfacture of cabi 
net ware, especially tables, bedsteads, bureaus, and chairs; also in joining, wainscoting, and for floors, panels, and doors. In the southwest it is used largely for lumber and for fencing. It takes the place of mahogany with us in the mannfacture of furniture and cabinet ware.

'The fruit is highly esteemed as a dessert, and is used wheu in an umripe state for pickles and catsups. A good salad oil is expressed from the kernel, and the shells are used for dyeing purposes.

3. J. regia, L. (English Walnut.) Stem 20 to 40 feet in height, and from 10 to 20 inches in diameter; branches rather straight, head symmetrical; leaves consisting of 3 to 5 pairs of leaflets, increasing in size towards the top, terminating with a single one ; leaflets ovate, acute, margins wary, on short petioles; catkins oblong, 2 to $2 \frac{1}{2}$ inches long, peduncle short. Fruit subglobose, mucronate, about 2 inches in diameter; exocarp leathery, smooth, ovoid; shell

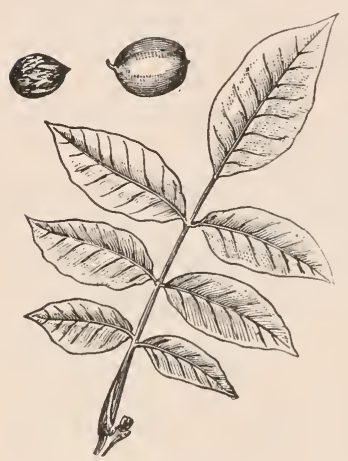

JUgLans REgia

(English Walnut). or endocarp wrinkled; kernel large and sweet. Flowers in early summer; nut matures in October.

Like other trees grown from the seed it has many varieties, the most important of which are :-

Var. maxima (large fruited). Nut twice the size of the J. regia, but perishable.

Var. tenera (tender-shelled). The shell is thin, so that small birds pierce it before it is ripe; very delicate to the taste, but not a prolific bearer.

Var. serotina. Endures the frost, and can be cultivated in higher latitudes than the J. regia.

There are many other forms, differing from the species only in the size or quality of the fruit.

Geography. - Though a native of the sonthern parts of the temperate zone, the English walnut fruits in a latitude of $45^{\circ}$ in Europe and Asia, and grows well in the Atlantic States of North America, but does not fruit freely north of Virginia. It is extensively cultivated in southern California. Its home is a region below $40^{\circ}$, extending from the country sontheast of the Black Sea eastward to Japan.

Etymology. - The specific name, regia, is the Latin for "royal "or "kingly," due to the high esteem of its quality.

History. - Food plants necessarily attracted the attention of man in the earliest period of his existence; and nuts, on acconnt of their edible character in an uncooked state, have always been favorites. At the present day nuts form an important part of the foor of the laboring classes, and with them the walnut holds high rank. London, in his work on trees, states that between Heidelberg and Darmstadt the walnut is the principal tree, not only for the fruit, but for shade. In that region when a young farmer desires to marry, he is obliged to furnish proof to the intended bride's father that he has planted with his own hands a stated number of walnut trees, which are already in an advanced stage of growth.

Use. - In the Levant, where the English walnut reaches perfection, it constitutes a large portion of the food of the masses. It is highly prized in 
Europe and America for a dessert nut. I table oil is expressed from it; and in a green state it makes an excellent pickle. It is also used to flavor sauces, and is an important article in the celebrated walnut sauce. The wood takes a good polish, has a brown color, is richly veined, and is highly prized by cabinet maker's, rivalling mahogany. 'The plain kind is used for gunstocks. The root is guarled, and when sawed into thiu slices makes valuable veneering.

HICORIA, Raf. (Hickory Nut.) Flowers unisexual; both staminate and pistillate flowers and leaf developed from the same bud; the pistillate flowers terminal, few in number; bract small or none; bractlets none; staminate flowers in jendulous catkins in the axils of the lower leaves; 3 on a peduncle, their perianth irregularly 2-3-lobed; stamens 3 to 10 ; pistillate fiowers shortly spicate, few, with a minute bract or none; perianth enfolding and adhering to the ovary, with a free 4-parted tip; stigma sessile upon the ovary, 2-4-lobed. Husk or outer shell of fruit fleshy, 4-valved nut, somewhat 4-sided, smooth or slightly wrinkled. Flowers greenish.

1. H. ovata, Mill., Britton. (Carya Alba, Nutt.) (Shell-bark. Hickory nut. White Walnut.) Stem from 40 to 60 feet high, and from 1 to 2 feet in diameter, rather regularly branched, forming a symmetrical head. Bark gray, and falling in strips. Leares composed of two pairs of leaflets and a terminal one, lateral ones sessile, terminal one petioled, all oblanceolate, the lower pair smaller, subacuminate, sharply serrulate, downy beneath. Fruit flattish, globose, with four grooves extending along the length of the husk, which, when ripe, separate into four sections,

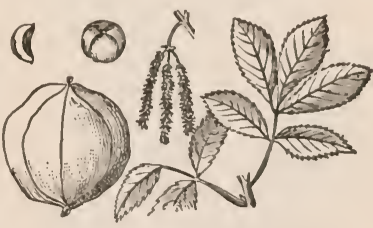

Hicoria ovata (Hickory Nut). freeing itself from the nut, which is marked by four seams or ridges extending lengthwise; shell thin; kernel delicate. Ripens in November; flowers in April and May.

2. H. sulcata, Britton. (Carya suleata, Nutt.) (Thick Shell-bark.) This species differs from the last in the size of the fruit, which is much larger than that of the C. alba, and the leaf has from 3 to 4 pairs, and the nut has an acuminate tip; in other respects it is well described in C. ovata. $A$ larger tree than $\mathrm{C}$. alba.

Geography. - The geographical range of these last species is the northern and midlle States, from the Atlantic to the Mississippi River, and it bears well in corresponding latitudes in Europe.

Etymoloqy. - The generic name, hicoria, is of unknown origin, supposed to be an aboriginal name of the tree or its fruit, probahly the latter. 'The old generic name, caryu, is from the Greek word kápunov, the walnut tree, said to have been given in honor of Carya, daughter of Dion, king of Laconia, who, according to the Greek myth, was clianged by Bacchus into that tree. 'The specific name, svata, is froin the I atin orum, an egg, referring to the shape of a plane of the fruit parallel to the axis of growth. Sulcata, from the Iatin sulcus, a furrow, derives its name from markings on the fruit.

PR. HL. -17 
History. - The home of these species of hicoria is North America; they have been introduced by seed into Europe, where they grow and fruit well. Seeds were first planted in Europe in 1629. These are the most important of the hickories. There are several other species whose wood is similar, but which bear inferior fruit.

Use. - The fruit of the $H$. ovata and $H$. sulcata is very delicate, and is valued for a table dessert. The shell is full, and the kernel sweet. Both yield an excellent salad oil, which is obtained by expression.

The wood splits easily, but is hard and tough, and is used largely in the manufacture of agricultural instruments, axe and hammer handles, and hubs and spokes of carriage-wheels. It is a very valuable material for fuel.

3. H. olivæformis, Nutt., Britt. (Pecan Nut.) Stem 80 to 90 feet high, and from 1 to 2 feet in diameter; bark rough and shaggy. Leaves with slender petioles ; leatlets in 6 to 7 pairs, and a terminal one, lanceolate-falcate, acumi-

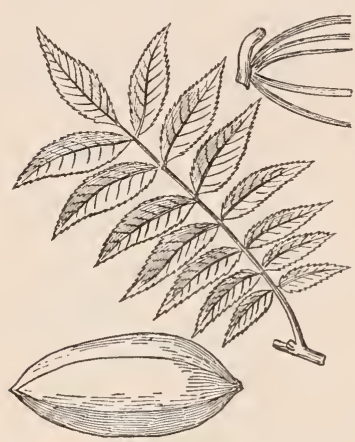

Hicoria oLIV EFormis (Pecan Nut). nate, and sharply serrate, on short petioles. Flowers greenish. Fruit oblong, 4-angled, with distinct valves, the green husk inclusing an olive-shaped nut with a thin shell; keruel fills the entire shell, and possesses a delicate, pleasant flavor.

Flowers appear in May. Fruit ripe, October and November.

Geography. - The Hicoria olivæformis is indigenous to southern North America, and delights in a damp rich soil; it will grow and fruit in the latitudes south of $40^{\circ}$, and north of $20^{\circ}$.

Etymology. - The specific name was suggested by its shape: olivaformis, olive-shaped.

History. - Nuttall, the English botanist, first described this tree, whose fruit Pursh sent to Europe. It was planted in Prussia, and found its way into England in 1766.

Use. - The pecan nut is a favorite dessert nut, and has become an important article of commerce. It is shipped to the West Indies, also to Europe. In its native forests it is highly valued as a mast upon which droves of swine fatten, which are allowed to run at large while the nuts are falling.

The wood of this tree is white, tough, and durable, and used largely in the manufacture of agricultural implements, and, like other species of the genus, makes excellent fuel. It is characteristic of North America, no wood equally tough, elastic, and suitable for these purposes being known in Europe.

\section{Order LII. CUPULIFER}

Flowers monœcious; staminate flowers in pendulous, bractless catkins, on last year's branches, or at the base of this year's branches; calyx usually 5, occasionally 5-12-parted; stamens 2-20; anthers 2-celled. Pistillate flowers solitary or clustered, terminating fewleaved branches; calyx attached to the ovary, 6-toothed or wanting; ovary 2-3-celled; ovules 1-2 in a cell, pendulous. Fruit, a nut, 1-seeded by abortion, 1-3 in a cup or shell. Leaves alternate, pin- 
nately veined, simple, falling or persistent, stipulate, with an involucre of accurrent woody bracts.

Number of genera, 111, species, 400; chiefly in north temperate regions and in tropical mountains.

CAstanea, 'Tourn. (Chestnut.) Male flowers in clusters of long, slender, eylindrical, erect aments; calyx 6-parted; stamens i) to 15 in number. Fertile flower's in 3's, surrounded by a 4-lobed involucre, which when ripe is leathery and beset with weak prickles about half an inch long; calyx 5-6-lobed, the tube adhering to the 3-6-celled ovary ; Number of stigmas equal to the number of cells. Involucre 4-valved; nuts usually 3 in number, sometimes 1 ; when the involucre contains 1 nut, it is top-shaped; when there are 2 , the nuts are plane on one side and convex on the other; when there are 3, the outside ones are plano-convex, and the middle one flattened into a wedge shape. The nuts are from three quarters to an inch in length, and sometimes as wide as long. Covering shell thin and horny. Leaves simple.

1. C. vesca. Gaert. (Chestnut.) Trunk from 50 to 70 feet in height, ranging from 1 to 5 feet in diameter, throwing out branches nearly horizontal, which extend 20 to 30 feet, sometimes forming a head 50 feet in diameter. Leaf oblong-lanceolate or oval, mucronately serrate, glabrous on both sides. Flowers yellowish, appearing in May. Fruit in October.

Var. Americana is the American chestunt, and differs from the European chestnut only in hearing a smaller and more delicate fruit. The tree grows to the height of 80 feet, and when in the forest reaches the height of 40 or 50 feet without a branch, but when standing alone branches low.

2. C. pumila, Mx. Stem 6 to 15 feet in height, branching low and profuse, shrub-like in appearance. Leaf oblong, ovate, or obo-

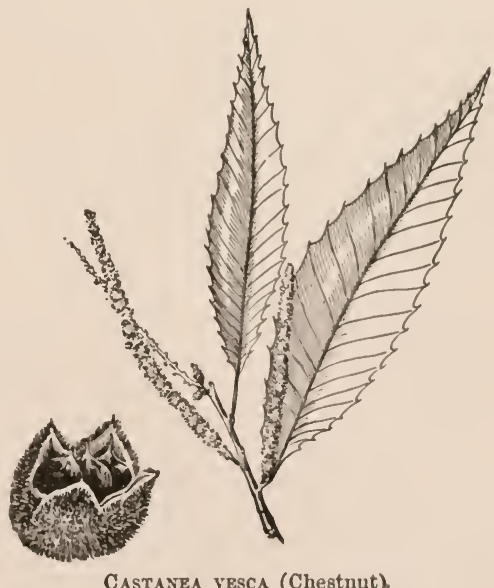

Castanea vesca (Chestnut). vate, mucronately serrate, hoary, tomentose on the under side, 3 to 5 inches long and about 2 inches broad, smooth above, acute at the apex, and obtuse at the base; petioles long. Flowers axillary; nut solitary, small, and very sweet.

In Europe great efforts have been made to improve the chestnut; and as the trees are produced from sepl, the varieties are numerous. The Imerican tree is believed to be identical with the European Castanea vulgaris, Iam. In America no efforts have been put forth to improve the fruit, hence no varieties have arisen.

Out of about twenty varieties grown in England, four are considered as greatly improved. In France also much attention has been given to the 
improvement of the chestnut, and many varieties have been produced, differing only in the size and quality of the fruit.

Several species of chestnuts have been found in eastern Asia recently, which were formerly classed under the oaks, and there has been a species discovered in Nepaul, northern India, recently.

Geography. - The geographical range of the chestnut is very broad. It grows well and is indigenous all along the eastern coast of North America, from $40^{\circ}$ to $43^{\circ}$ north latitude, extending west to eastern Kentucky and Tennessee. The C. pumila is found between $30^{\circ}$ and $40^{\circ}$ north latitude, - from southern Pennsylvania to northern Georgia. The C. vesca grows well throughout the middle and southern counties of England, in all the countries of middle and southern Europe and northern Africa, and in the countries of the Levant and southern and eastern Asia, wherever it has been planted.

Etymology. - Castanea was named for Castane, a city of Thessaly, famous for chestnuts. Vesca is from the Latin vescor, eat, referring to the edible character of the fruit. The common name, chestnut, is due to the fruit or nut being inclosed in a box or chest.

History. - The home of the chestnut is not exactly defined. De Candolle says it forms natural forests from the Caspian Sea westward to Portugal. It has also been stated that its home is the country between the Black and Mediterranean seas, and that it was carried west after the Roman conquests. Pickering says it is native to China, and Thunberg saw it near Jeddo, in Japan. It is believed that the Emperor Tiberius took it to Italy from Asia Minor, and that it thence spread all over southern Europe. It is also indigenous in North America.

There are some very remarkable chestnut-trees in the world, some of which have reached a greater diameter of trunk than any other tree. The most noted is the celebrated Mount Etna chestnut, under which a hundred mounted horsemen took shelter. The enormous size of this tree has led to the belief that it is the union of a group of trees that stood near each other in their youth. M. Jules Honel, a French scientist, nearly a hundred years since, made a journey to measure and make a drawing of it. He found it to be 160 feet in circumference, and on the closest and most careful examination could find no evidence that it is not a single trunk. There are other large trees in the neighborhood, measuring from 36 to 40 feet in diameter.

There are three large chestnut-trees in the southern suburb of the city of Yonkers (just outside the northern limits of New York City.) Two of these measure respectively 24 feet 10 inches, and 19 feet 6 inches in circumference. These are of the American variety, and are in an advanced state of decay. By a calculation from the best known data, the largest of these trees is about 210 years old.

Use. - The chestnut is a farorite nut in many parts of Europe; and in the countries of the Levant it constitutes a very important article of food. It is roasted or boiled, and eaten with salt. It is also eaten raw. A flour is made of the nuts in a dried state, which is used for various culinary purposes, principally for griddle cakes.

The wood is not hard, but is very durable, and takes a high polish. It is used for cabinet work, bedsteads, tables, etc., and by reason of its durable character is very highly valued for fencing material. It is also a strong and valuable timber for building purposes.

The nut forms an important article of commerce. The best European nuts come from Spain. 
QUERCUS, L. (Oak.) Staminate flowers in groups of slender hanging catkins; stamens 5 or more, surrounded by sepal-like bracts, 6 to 8 in number. Pistillate flowers axillary and erect; ovary surrounded by an adnate calyx, the limb of which is toothed; style short; stigma 3-lobed; ovary 3-celled, rarely $1-5$, containing $(j$ ovules, 5 of which are abortive. Fruit oblong, somewhat in the form of a modern musket-cartridge, with the base inserted in a cup, which is clothed with imbricated scales. Flower's greenish, appearing in regions of frost during th month of May. Leaves simple, alternate, stipulate, deciduous, but persistent. A few evergreen in the southern fringe of the north temperate zone.

1. Q. alba, L. (White ()ak.) Trumk 60 to 80 feet high, 4 to 5 feet in diameter ; bark grayish-white; much-branched. Leaves 3 to 5 inches long, sinuate-lobed, in opposite pairs, 1 to 4 pairs of lobes, with a terminal one; lobes coarsely and irregularly toothed, pubescent underneath; acorn on short peduncles, large and sweet, edible.

Var. pinnatifida, Mx. Like Q. alba, except the leaves, which have 3 to 4 pairs of well marked lobes.

Var. repanda, Mx. Leaves with a wavy margin.

Geography. - The oak thrives best in the temperate zones, above $35^{\circ}$, and is found in a zone between $30^{\circ}$ and $60^{\circ}$ quite around the globe. It is found in the mountain-top as well as in the valley and the plain below, and is indigenous in the above-named parallels in both hemispheres. The white oak is common in the United States and Canada.

Etymology. - Quercus, the geuerie name, is derived from Latin quercus, an oak. The popular name of the oak among the Celts was drew, from which the word Druid was derived, signifying "priest of the oak." Alba, the specific name of this species, is from the Latin alba, white, and is lne to the grayishwhite bark of the trunk. Oak comes from the Anglo-Saxon name of the tree, $\bar{a} c$.

History. - The oak is famous in all ancient writings in which trees are mentioned. Among the Gauls it was held sacred. Oak groves were the abodes of priests, and no religions ceremony was complete without oak-boughs or oak-leaves. The Greeks and liomans also dedicated the oak to their gods: and the Roman peasants initiated the harvest by a festival, in which their heads were adorned with wreaths woven with the leaves of the oak. It was upon the oak that the Druid priests found the mistletoe, which figured so largely in their religious ceremonies.

Many oaks are noted for historical events. Less than a hundred rears ago the oak was still standing in the New Forest against which the arrow glanced that killed William Rufus. The Roval Oak at Boscobel concealed the person of Charles II. after the disastroms battle at IForcester The oak at Torwood, at the place where Wallace convened his followers, still stands. Alfred's Oak, at Oxford, which was in existence when the miversity was founded, may still be seen. Ind in our own country an oak in the city of Hartford, Conn., concealerl the charter of that colony, and was known after wards as the Charter ()ak.

Abraham's Oak ( $Q$ pseuclococcifera), near Hebron, in Palestine, is many hundred years old ; it measures twenty-three feet in circumference, and its branches extend forty-five feet from the stem, forming a head uinety feet in diameter 
Use. - The white oak furnishes a hard, durable timber for frames of buildings, axles of carriages, floors, tables, chairs, handles for axes and hammers, wainscoting, panelling, church furniture, shipbuilding, and mill-gearing. The bark is highly charged with tannin, and is a valuable material in the manufacture of leather. The fruit of the Q. alba, which is the sweetest of all the species, is excellent for fattening swine; the pork thus fatted is said to

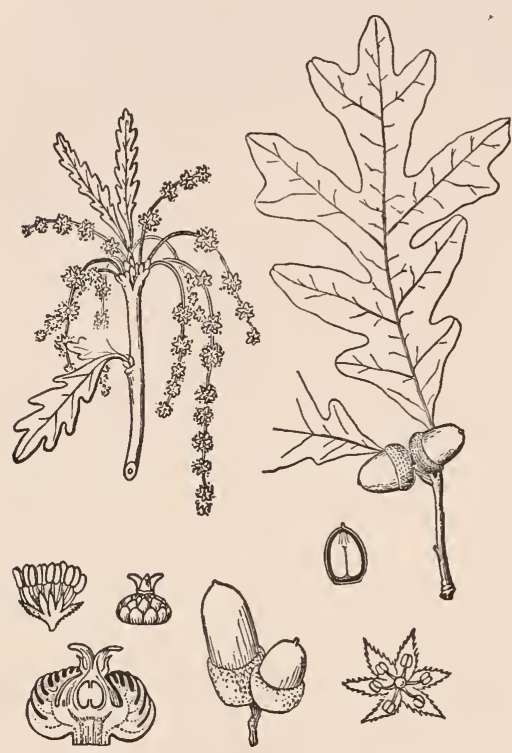

QUERCUS ROBUR (British Oak). produce the most delicious bacon. 'The delicate flavor of the Virginia hams is said to be due to the feeding of swine upon acorns.

\section{Q. robur, L. Q. peduncu-} lata, Willd. (British Oak.) Trunk 50 feet high and upward to 100 feet; when standing in open grounds it branches low, spreading out so as to form a head whose diameter is greater than the height; branches crooked, gnarled, and very large; bark gray and rough; leaves on short petioles, blade oblong, made up of 3 to 5 unequal pairs of lobes, and a terminal one; sinuses narrow, lobes rounded. Fruit sessile or on long peduncles, oblong, elongated, brown, buried to one fourth of its length in the hemispherical cup, which is clothed with rough imbricated scales. Flowers greenish-white, appearing in April. Fruit ripens in September.

Like all trees that propagate themselves by means of their seeds, the Quercus robur has run into a great variety of forms, of which the following are the most prominent, and may be found growing in the public grounds in Washington:-

Var. sessiliflora.

Var. pubescens, Lodd. Leaves downy beneath.

Var. fastigiata, Lodd. Branches compact and upright.

Var. pendula, Lodd. Branches decidedly pendulous, or weeping.

Var. heterophylla, Loudon. Leaves varying greatly in size and form; some lobed, others lanceolate and entire.

Var. foliis variegatis, Lodd. Leaves variegated with white and red streaks. A beautiful specimen is growing in the public grounds at Washington.

Var. purpurea, Lodd. Foot-stalks of the leaves tinged with purple, and the leaves when young entirely purple.

There are many other varieties, but less striking.

Geography. - The British oak is indigenous to the continent of Europe, and most likely to England. It grows in the south of Europe, the Levant, and northern Africa. 
Etymology. - The many names by which the British oak has been known to botanists constitute not the least of its features. Robur is from the I atin word robur, and indicates strength; it is also an old name for the oak tree. Pedunculata refers to the long foot-stalks of the fruit. The variety names, with the exception of heterophylla, are all derived from the Latin, as follows: sessiliflora, sessile-tlowered; pubescens, covered with down ; fastigiata, sloping to a point; pendula, hanging down; foliis variegatis, variegated leaves; pur. pureu, purple-colored. Heterophylla is from the Greek $\epsilon$ t $\epsilon \rho s$, different, and $\phi \dot{\lambda} \lambda \lambda_{\nu}$, a leaf, hence varying leares.

History. - The celebrated character of the British oak seems to call for a special notice. Some of the most remarkable specimens of this tree are interesting for their age and size. The Framlingham oak, used in the construction of the "Royal Sovereign," squared four feet nine inches, and yielded four square beams, each forty-four feet in length. An oak felled at Whitney Park, Shropshire, in England, in 1697, was nine feet in diameter without the bark, and yielded from the trunk alone twenty-eight tons of timber. The head of this great tree was one hundred and forty-four feet in diameter. Another English oak, in Holt Forest, Hampshire, measured, seren feet from the ground, thirty-four feet in circumference. Another, at Newbury, measured forty-five feet around. Still another, in the vale of Gloucester, was fifty-four feet in circumference; and one in Dorsetshire gave a girth of sixty-eight feet.

Use. - The wood of the British oak is hard and tough, and resists great force without fracture; these qualities make it rank very high as a material for shipbuilding. Its acorns formerly took a high place in European history as food.

The oak forests of central Europe furnished food for swine and other domestic animals, and the people themselves subsisted largely upon acorns. It was regarded as one of William the Conqueror's most oppressive acts that he deprived the people of England of the use of the oak forests, where they had been accustomed to collect the acorns for their swine.

3. Q. bicolor, Willd. (Silver-leaved Oak. Swamp White Oak.) Trunk 60 to 70 feet high, 4 feet in diameter; bark scaly, and greenish-white. Leares nearly sessile, downy, white underneath, bright-green above; obovate, coarsely and bluntly toothed, entire near the base. Acorns in pairs, peduncles longer than the petioles; nut long, lark-brown; cup shallow, and fringed with short, slencler, thread-like processes

Geography. - It is well distributed throughout the eastern and northeastern United Sitates.

Etymology. - Bicolor, the specific name of this oak, is from the Latin word bicolor, two colors, and refers to the contrast in the colors of the two sides of the leaf, one of which is a bright-green, and the other a silvery white. Silverleaved arises from the color of the under side of the leaf. The name swamp, white oak is due to its fouduess for wet ground.

$I^{\top}$ se. - The lumber is valuable for building purposes; it is hard, durable, and takes a goor polish; it also makes excellent fuel The bark is highly charged with tamnin, but is thin, and is not profitably obtained for markets where thicker bark is available.

4. Q. coccinea, Wang. ('icarlet Oak.) Trunk 60 to 80 feet in height, sometines + feet in diameter; bark thick, gray outside and red within. 
Leaves divided into 3 to 4 pairs of lobes, much like the leaves of the Q. palustris ; petioles longer than in Q. rubra, deep-green, slining on both sides ; lobes cut, toothed and acute, turning scarlet with the early frosts. Acorn ovate, half buried in the scaly top-shaped cup.

Geography. - Indigenous to southeastern North America; the northern limit is southern New England; commou in the middle and southern Atlantic States.

Etymology. - Coccinea is from the Latin coccineus, scarlet, and has reference to the color of the leaves after frost.

Use. - The wood is largely used for making barrels, and the bark is a favorite with tanners. The tree is also used in planted grounds.

Var. tinctoria, Gray. (Black Uak. Yellow-barked Oak. Dyers' (Jak.) Trunk 70 to 100 feet in height, and 3 to 4 feet in diameter; bark furrowed, dark without, and yellow within. Leaves downy beneath, oborate, oblong, broad-lobed, broadest near the end, sinuses not deep, lobes coarsely toothed, teeth pointed. Acorn flat, globose, half buried in the flat, thick cup.

Geography. - The Q. tinctoria is a native of eastern North America, and is widely distributed throughout the eastern and middle states.

Etymology. - Tinctoria is from the Latin tinctor, a dyer, because the bark furnishes a dye. The popular name, black oak, is due to the color of the bark.

Use. - The wood of this tree is sometimes used for cooperage and construction, and is excellent fuel. The bark is largely used for dyeing; it yields the querciton, which is much nsed in calico printing, to give the yellow color to cotton fabrics. It is also used for tanning.

5. Q. falcata, Mx. (Spanish ()ak. Sickle-leaved Oak. Downy-leaved ()ak.) Trunk 60 to 70 feet high, 4 to 5 feet in diameter. Bark thick, black, and furrowed. Leaves on long petioles, blade 6 inches long, downy beneath, obtuse at the base; in the northern limits of the tree the leaves take on a slender entire form, widening towards the upper end, where they terminate in three lobes; further south the usual form of the leaf is in 1 to 2 pairs of pointed, mucronate, scythe-like lobes, entire or irregularly and coarsely toothed sinuses, deep and wide. Acorn globular, small; cup shallow.

Geography. - It is native from southern New Jersey (where it seldom attains a height greater than 40 feet) to the shores of the Gulf of Mexico, where it grows to its full size, 60 to 80 feet. It is a subtropical tree, and Hourishes best below the parallel of $35^{\circ}$.

Etymology. - Falcata, the specific name of this tree, is from the Latin word falcatus, scythe-like, from the supposed resemblance of the lobes of the leares to the shape of a scythe. Spanish oak, the common name, is obscure in its origin and meaning.

Use. - The Spanish oak is a beautiful, well-formed tree, used for ornamental purposes. The wood is an excellent fuel. The bark is highly charged with tannin, and extensively used in the mannfacture of leather.

6. Q. macrocarpa, Mx. (Moss-cu), Oak. Burr Oak. Mossy-cup White Oak.) Trunk 50 to 70 feet high, and 2 to 3 feet in diameter, lranching into a symmetrical head. Bark grayish, rough, the bark on the brauches roughened by longitudinal corky ridges. Leaves downy heneath, lyrate, larger than those of any other species, frequently a foot long and 8 inches broad, made 11 , of 3 to 5 pairs of lobes and a terminal one, the terminal lobe greatly expanded and notched. Fruit larger than the fruit of any other species in America. 
Acorn subglubular, two thirds inclused in the cup, the oritice of which is fringed with long, flexible, thread-like processes.

Geography. - It is found sparingly in western New kngland and in New York, but abounds in western Virginia, lientucky, and Tennessec, and west and south.

Etymology. - Macrocarpa, the specitic name, comes from the two Greek

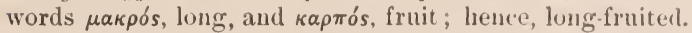

Use. - This oak is a beatiful, symmetrical tree, and for that reasun is to be found in all large collections of trees in planted grounds.

The wood is stroug, tough, and durable. The bark is used for tanning hides. The fruit is highly prized for food for swine.

7. Q. obtusiloba, Mx. (Post Oak. American Turkey ()ak. Iron ()ak. (pland White Uak.) Trunk 40 feet high, 12 to 18 inches in diameter. Park thin, grayish-white, hranching irregularly. Leaves leathery, dark-green abure, and grayish beneath, blade cut by deep sinuses into two pair of lobes and at terminal one; lobes rounded. Acorus small, and deeply buried in the roughish gray eup.

Geogruphy. - It is seldom found in the northeastern Lnited States, but abounds in the middle Atlantic and southern and sonthwestern states, east of the Mississippi.

Etymology. - Obtusiloba is due to the blunt, rounded lobes of the leaves. As to the common names, - iron oak alludes to the hardness and durability of the wood ; turkey oak is so called because turkeys feed on the acorns; upland oak takes its name from the localities where the tree grows; post oak is so named because the wool is used for posts.

Use. - The wood is hard and durable, takes a good polish, and is much used for timber where exposure to the weather is required, - especially for bridges, fence-posts, and railroad ties. The fruit is sweet, and is used for feeding swine; also turkeys and other poultry.

8. Q. nigra, I. (Black Jack Oak. ()ak of the Barrens.) Stem from 20 to 30 fert in height, and 6 to 15 inches in diameter. Bark rery dark; branehing irregularly: Leaves on short petioles, blacle firm in texture, wedge-shaped, sometimes: 3-5-lobed; lobes abruptly pointed and terminating in spines. Acorn globular, half covered by the cup. Not abundant.

Goography. - Geographical range is from Massachusetts to the southern States, and west to Illinois. This tree is an important feature in many barren regions.

Etymolog!y. - Nigra, the specitic name, is from the Latin niger, black, and refers to the color of the bark, as dhes the common name.

Use. - The wood of this species is too small to be valuable for lumber, but makes excellent fuel. The hark is rich in tannin, but on aceount of the small size of the tree, it camot well he ohtained in large quantities, and is but little used.

9. Q. palustris, Hu Liny. (l’in ()ak. Swamp) Spanish ()ak. Water (Jak.) Trunk 50 to 70 feet high, aud 2 to 4 feet in diameter, branching low and forming a graeceful head. Bark smooth and dark. Leaves divided intu 3 to 5 pairs of lobes, separated hy deep, broad sinuses, distinguished from (2. rubira hy more narrow lubes, and a color and cunsistency more delicate. Nut subglobose; cup flat. 
Geography. - It is found growing in southern New York, New Jersey, and west in the same latitude to the Mississippi; it is not common in northern New York and New England.

Etymology. - The specific name, pulustris, is from the Latin word palustris, boggy, wet, marshy, alluding to the favorite locality of this species, which is generally found in wet places. This is also indicated in the common names: swamp Spanish oak, water oak, meudow oak. The name pin oak arises from the circumstance that the knots are slender, and sometimes on splitting the wood they draw out, appearing like pins. It on this account splits with difficulty.

Use. - Q. palustris is used sparingly in planted grounds for ornament. It forms a beautiful head, and its abundant delicate foliage makes it a rival of the Q. rubra as an ornamental tree. The lumber is coarse and poor, and not as good for fuel as the Q. rubra. The bark of this tree is sometimes used in tanning.

10. Q. Phellos, L. (Willow-leaved Oak) 'Trunk 30 to 60 feet in height, straight, 10 to 20 inches in diameter. Bark smooth and thick. Leaves lightgreen, about 4 inches long, and 1 to 2 inches wide; linear-lanceolate, pointed; when young toothed; light-green. Acorn subglobose; cup, saucer-shaped.

Var. sylvatica, Mx. Leaves on the young tree lobed.

Var. latifolius, Lodd. Leaves like those of var. sylvatica, but broader.

There are several other forms, all shrubs.

Geography. - It abounds in southern Virginia and farther south, and is found in New Jersey as far north as Moumouth County. It has been reported as growing in Suffolk County, New York, in planted grounds.

Etymology. - Phellos, the specific name of this species, is from the Greek word $\phi \in \lambda \lambda{ }^{\prime}$ s, a cork; but why applied to this species is not apparent.

Use. - The Quercus phellos is a beautiful object in the lawn, and is always found in the southern states of the United States in planted grounds. 'The wood is soft, and not used in building where better lumber is obtainable. The bark is charged with tannin, but thus far has not been largely used by tanners.

11. Q. Prinus, L. (Swamp Chestnut Oak.) Trunk 75 to 90 feet high, and 2 to 3 feet in diameter. Bark dark-gray, branching regularly. Leaves on long petioles, blade 7 to 8 inches long, 3 to 4 wide, conspicuusly veined beneath, oblong-orate or elliptical, coarsely and deeply erenate toothed, resembling the leaf of the chestnut. Acorn large, sweet, oral, and brown; cup shallow and scaly.

Geography. - The chestuut oak or chestnut-leaved oak is found thronghout the northern Inited States, and as far south as Virginia, and west to the Mississippi. It attains its full size in southern Pennsylvania and northern Maryland aud Virginia.

Etymology. - Primus is from the Greek $\pi \rho$ ivos, ever-green oak. . The name chestnut oak is due to the shape of the leaf, which resembles that of the chestnut.

Use. - The wood of this tree splits easily, is hard, durable, and takes a good polish. It is used for frames of buildings, planks, etc., and is highly esteemed for fuel. The fruit is sweet, and greatly valued as food for swine. In Virginia, southeru Pennsylvania, and the eastern parts of the Carolinas large droves of swine are fattened on acorns, principally of this species.

Var. acuminata, Mx. (Chestnut Oak.) Trunk 40 to 70 feet in height, 1 to 2 feet in diameter. Bark whitish and furrowed, irregularly branched. 
Leaves on longishı petioles, blade oblong, lauceolate, obtuse at the base, sharply toothed, green above and pubescent underneath, resembling the leaf of the chestnut tree. Acorn egg-shaped, deeply set in the hemispherical cup, subsessile.

Geography. - It grows in southern Vermont, where it is a second-class tree. It increases in size sonthward to the southern part of Virginia, where it reaches its full height. It extends westward to the Mississippi, along the ridges that trend through Virginia, Kentucky, and Temessee.

Etymology. - Acuminatu is Latin for pointed, and alludes to the sharppointed leaves.

Use. - The wood of this variety is hard and durable, making timber that endures the weather, and it is much used for rails and shingles. It splits freely, and is highly prized for fuel. The bark is well charged with tannin, and is nsed in the manufacture of leather. The fruit is sweet, large, and abundant, and is used for fattening swine in Virginia, Kentucky, and Tennessee.

Var. monticola, Mx. (Rock ()ak. Kock Chestnut Oak.) Trunk 30 to 40 feet in height, the top made up of straggling, irregular branches, especially in the rocky, hilly localities, where it is found in the northern and middle states of the Inited States. Leares smaller than in Q. prinus, much the same in form, but the teeth are more regular and blunter; when very young, covered with a white down. Acorns in pairs, on short peduncles, and deeply inserted in the cup, which is clothed with loose scales.

Etymology. - Monticola is from the Latin mons, a mountain, and colo, inhabit, and is clue to the localities in which this tree delights. It is found on rocky hills and mountain sides, - sparingly in southern New England, more frequently in sonthern New York, commonly in sonthern Pennsylvania and Virginia. The names rock ouk and rock chestnut oak are also lue to the localities of the tree, and the litter to the shape of the leaf.

Use. - The bark of this species is rich in tannin, and is largely used in the manufacture of leather. The wood is excellent fuel.

12. Q. rubra, L. (Red (Yak.) 'Trunk 50 to 80 feet in height, and 3 to 5 feet in diameter. Branches long and spreading. Bark smooth, and dark grav. Leaves smooth, oblong, divided into 3 to 4 pairs of sharply toothed, acute, mucronated lobes, separated by deep and rounded sinnses. Flowers greenishwhite, appearing in IIay. Nut ovate; cup flat, and saucer-shaped Ripe in ()ctober The foliage varies considerably with the age of the plant and conditions of locality and soil.

Var. runcinata, lingl. Sinuses shorter; lobes more mpright; fruit very :unch smaller; ('up top-shiped at base.

Geography. - The Q. rubra is emphatically an American tree, and in planted grounds where it has rom it forms one of the most graceful objects of the lawn, it is not exceederl in heanty by any of the oaks. It grows throughout northeastem America, and west to the IIssissippi, and south down the Mississippi valley.

Etymology. - The specific name of this oak, rubra, from the Latiu ruber, red. was applied on acrount of the color of the leaf, which after the applearance of frost turus a deep red; hence also the common name red oak.

Use. - The tree is highly prized as an ormament in planted grounds. The wood is strong, but has a coarse grain, and does not take a fine polish. It 
splits easily, and is valuable for barrel staves; it makes an excellent fuel. The bark is prized by tanners.

13. Q. virens, Ait. (Live Oak.) Trunk 40 to 60 feet in height, much branched above, forming a broad, picturesque head. Bark thick, very dark. Leaves subsessile, blade thick, elliptical, oblong, varying in form, - entire, lobed, or irregularly toothed, - downy in star-like spots underneath. Fruit peduncled; acorn long, orate, about one third inclosed in the cup.

Geography. - Its home is North America; its geographical range is narrow. It abounds in the regions of the southern Atlantic and the Gulf States.

Etymology. - Virens, the specific name, is from the Latin adjective virens, green, and is due to the evergreen leaves.

Use. - On account of its great strength, it is highly prized for use in naval architecture; it is also excellent fuel. The geographical range is so small, and the mode of lumbering is so wasteful, that a speedy exhaustion of the supply is to be apprehended, and legislation is suggested to protect the live oak forests of Florida and Georgia.

14. Q. suber, L. (Cork Tree.) Trunk 20 to 35 feet in height. Bark spongy and cracked. Leaves on short petioles, ovate-oblong, leathery, remotely deutate, occasionally entire, downy underneath, and evergreen. Flowers greenish-white, appearing in May. Acorn long and subcylindrical: cup hemispherical, clothed with overlapping scales.

The products of the cork tree are so valuable that the tree has not only been protected, but large plantations have been made; and as the trees are raised from seed, a number of varieties have arisen, the most important of which are the following:-

Var. latifolia, Bauh. Leaves broader than those of the species.

Var. angustifolium, Bauh. Leaves narrow.

Var. dentatum. Leaves large and toothed.

Geography. - The Quercus suber is indigenous in southern Europe and northern Africa; it does not flourish north of the middle of France.

Etymology. - Suber is the old Latin name for the cork tree. Linnæus placed it under Quercus, and made suber the specific name. Cork, the common name, is derived from the Latin cortex, cork, and signifies the outer thick bark between the epidermis and the cuticle.

History. - When cork was first applied to its present uses is not known. The Romans were accuainted with its use during the first century.

Preparation. - Harvesting the bark is begun when the tree is from twentyfive to thirty years old. Remoring the cork does not injure the tree; on the contrary this is said to be conducive to its growth. The first crop is of poor quality. The second stripping occurs ten years after the first, but the third stripping yields the best bark. It is taken from the tree by making an incision with a sharp instrument around the tree near the base, just deep enough to avoid wounding the liber. Three feet above, a parallel incision is made, and so on up to the branches, making in all three or at most four incisions. It is then slit vertically in widths convenient to handle. The pieces are then forced off with a flat piece of wood, which is introduced between the liber and the cortex. It is held over live coals till the surface is slightly charred, to close the pores. It is then subjected to pressure to take the curve out of it, after which it is piled under cover to dry, and when dry it is fit for market.

Use. - Cork is applied to many uses, the most important of which is in the manufacture of corks for bottles, for which purpose it is especially adapter. 
The Romans used it for buoys for fishing-nets and anchors; also for lifepreservers. Camillus wore one when he swan the Tiber during the siege of Rome by the Gauls. It is used now for the same purpose; also for cushions and mattresses, and soles of shoes; and it is worked into a surt of felt floorcloth. In Spain the wealthy line their houses with it. The ancient ligyptians used it for making coflins. The wood is durable, but is not largely used in the arts. The fruit is sweet.

15. Q. infectoria, ()liv. (Gall Oak.) Stem 4 to 6 feet high, much branched, forming a straggling shrub. Leaves ovate, oblong, and smooth on both sides, pale beneath, deeply tootherl. Fruit sessile; nut elongated, ("ylindrical; ('n), tessellated; fruit apjearing next year after the appearance of the flowers.

The insect cynips quercus galli punctures the leaves, and deposits its eggs: in the wounds; these womuls become tumors, from an eighth of an inch to an inch in diameter, subglobular in form, and armed with blunt, spine-like processes. When these tumors are dry and hardened, they constitute the nutgalls of commerce.

Several varieties appear in market, the principal of which are blue and white. The blue gill is gathered before the young insect has gnawed through, and the white afterwards. The blue gall is by far the most valuable.

Geography. - The gall oak is found in all the eastern Mediterranean countries, especially in $\Lambda$ sia Minor aud northwestern Syria. The best galls come from Aleppo.

Etymology. - Infectoria, the specific name of this plant, is from the Latin word infector, a dyer, alluding to the circumstance that its products are used in dreing.

$\dot{U}_{\text {se. }}$ - The nut-gall figures largely in the mamufacture of black ink. $\Lambda$ solution of copperas, mixed with a decoction of nut-galls, produces a jet-black dye. 'The nut-gall is also an important article employed in the tinning of hides.

16. Q. ægilops, L. (Fgilops. Valonia ( )ak.) Trunk 20 to 50 feet in height, and 1 to 2 feet in diameter. Bark grayish, sprinkled with brown spots. Branches spreading, forming a hemispherical head. Leaves on short petioles, blade 3 inches in length, coriaceons, ovate, oblong, pale-green above and downy underneath; coarsely toothed, teeth pointed. Flowers greenishwhite, appearing in May. Fruit large, nearly inclosed in hemispherical cups, which are covered with long, sjreading, lanceolate scales.

Var. pendula. Branches long, slender, and drooping.

Var. latifolia. Leaves broader.

Geography. - It is native in the comntries of the Levant, and abounds throughout Greece and the Grecian Arehipelago; it is found sparingly in Italy, but does not grow in middle or western Enrope.

Etymology and ITistory. - Egilops, the specific name, is from the Greek

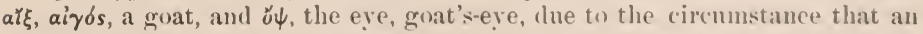
infusion of the shells of the half-grown fruit is used ats a remedy for the disease of the eye known as goat's-eye, thus named because goats are attlicted with it. This tree was known to Dioscoriles and to the ancient freeks.

I'se. - The fruit of this oak formerly constituted the food for a large number of people. The shells or cups are highly chargerl with tannin, especially when half grown; but on account of the "xpense of procuring them in an unripe state, they are allowed to ripeu. 'The shells of the ripe fruit are 
called valonia, the half-ripe ones camata, and those gathered in a still earlier state are called camatina. The camatina are most highly charged with tannin, the camata next, and the valonia least. Ordinarily the tree is not large.

The wood is excellent for the manufacture of furniture, takes a fine polish, and is durable.

As a dye, the shells of the acorns are in great demand.

CORYLUS, Tourn. (Hazelnut.) Catkins of the male flowers cylindirical. Pistillate flowers, with an involucre of imbricated scales, 2 in number, attached at the base, and fastened to the under surface of the bract; stamens inserted upon the scales rear their base, 8 in number; anthers tipped with beard. Female flowers in a flattened, budlike catkin; bracteal scale entire and ovate; calyx membranous, inclosing the whole ovary, terminating in a short fringed tube. The two stigmas long and filiform. Fruit, a nut, egg-shaped and bony.

1. C. avellana, L. (Hazelnut. Filbert.) Stem shrubby, 3 to 5 inches in diameter near the base, made up principally of ramifications, rising from 3 to

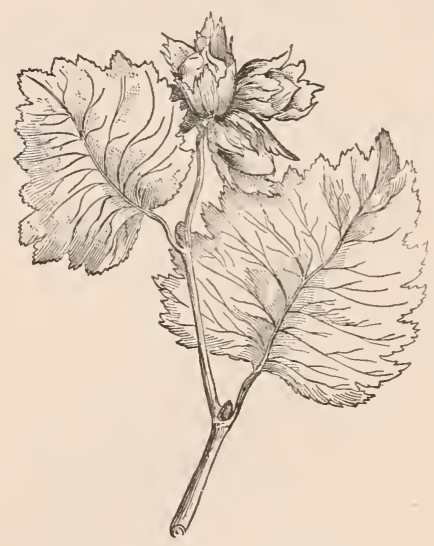

Corylus avellana (Hazelnut).

8 feet high. Leares somewhat roundish, cordate, acuminate, and irregular serrate; stipules lengthened. Fruitcovering bell-shaped, ragged at the margin. Nut brown. Ripe in October.

2. C. colurna, L. (Constantinople Hazelunt.) Trunk 40 to 50 feet high, 12 to 18 inches in diameter; stipules lanceolate, acuminate. Leaves as in No. 1. Fruit larger and longer.

A dozen rarieties are arranged under these two, differing in size and form of the fruit and leaf.

3. C. rostrata, Ait. (Beaked Hazelnut.) Stem much branched, forming a straggling shrub from 4 to 8 feet high. Leares ovate, irregular, serrate, and slightly lobed; stipules narrow-lanceolate. Fruit-envelope tubular, bell-shaped, 2-parted, divisions cut, toothed. Fruit excellent, but smaller than the European species.

4. c. Americana, Walt. (American Hazelnut.) Stem branching, forming a shrub like the last, but somewhat larger, 3 to 8 feet high. Leaf rounded at the base, sometimes slightly cordate. Envelope of the fruit globular, bellshaped; edges coarsely toothed. Nuts as in the last.

The last two species are natives of North America, and abound in thickets and along fence-rows, in the northern and middle States, as far south as Virginia. Of these there are no varieties. The European varieties have doubtless arisen from attempts to improve the fruit by cultivation.

Geography. - The hazelnut grows well between $35^{\circ}$ and $55^{\circ}$ latitude in the northern hemisphere, but is confined to the eastern parts of the westeru hemisphere, and to the western parts of the Old World. 
Etymology. - The name Corylus is said to be derived from the Greek kópus, a helmet, referring to the manner in which the calyx enwraps the fruit. The specific name, avellanu, is derivel from Arellino, the name of a city in southern Italy. Colurna is from the Greek words кónos, mutilated, and oùpá, a tail, referriug to the laceraterl fringe of the fruit-envelope. R'sirata, Latin, signifies "beaked," and refers to the beak-like extremity in which the fruitcovering of this species terminates. The worl Americana explains itself. The common name, hazelnut, is from the Anglo-Saxon husil, a hearl-dress, that is, a nut with a head-dress. Filbert has been regarded as a corruption of the word "full-beard," referring to the fringed envelope.

History. - The history of this plant is very obscure. It is indigenous to the countries of the Levant. It was originally brought into Italy from Pontus, and was called by the Romans nux Pontica, which name was changed in process of time into nux avellana, because the plant was first cultivated near the city Arelliuo, in the kingdom of Naples. It now grows all over middle, southern, and western Europe.

Use. - The hazelnut is a common dessert nut, and in parts of westeru Asia and Europe it constitutes an important article of food.

The wood of the C. colurna is white, and of a fine grain ; it is used for hoops and fishing-rods. The wood of the other species is worthless for timber. The fruit is au article of considerable economic and commercial importance.

FAGUS. L. (Beech.) Staminate flowers in drooping, globose, headlike catkins, 3 to 4 in a group or head, accompanied by minute deciduous bracts: calyx bell-shaped. 5-7-parted; stamens $5-12$. and sometimes 16 in number, attached to the bottom of the calyx, and extending above its month: filaments slender, with 2-celled anthers. Pistillate flowers, in groups of 2 to 6 , usually in 2 's, inclosed within a pitcher-shaped 4-lobed involucre. made up of a number of scale-like processes, interior united; calyx with 6 awl-shaped lobes; styles 3 in number, slender. Fruit, an edged, three-faced nut, dark : shell tough; kernel white and sweet, edible. Leaves simple and alternate. Flowers apetalous, presenting a green hue.

1. F. ferruginea, Ait. (American Beech.) Stem 40 to 60 feet high, and 1 to 3 feet in diameter, regularly and densely brauched, forming a symmetrical head; bark ashy-gray, smooth. Leaves oblong-ovate, pointed, toothed, veins extending into the teeth. Fruit-covering armed with spreading and crooked prickles.

2. F. sylvatica, I. (Beech of Europe.) Trunk from 60 to $s 0$ feet high, 2 to 4 feet in diameter. Leaves ovate, dentate, glabrous, with nargins ciliate. Fruit inclosed in a rough envelope, armed with blunt prickles, otherwise as F. ferruginea Under this species there are several well marked rarieties or subspecies.

3. F. obliqua, Mx. (Oblique-leaved Beech) Leaves oblique, otherwise like F. sylvatica.

4. F. colorata, DC. f. (Cuprea. Copper Beech.) Leaves copper-colored.

5. F. betuloides, Mx. (Birch-leaved Beech.) Leaf like the birch, and evergreen; forms forests in 'Tierra del Fuego; also native in Vau Dieman's Land. 
Remarkable for the production of an edible fungus, which appears on its branches. 'There are three other well marked species in South America.

Geography. - The beech grows well in the temperate zones up to $60^{\circ}$ north latitude, and as far south as $50^{\circ}$, but does not flourish in the tropics.

Etymology. - Fagus, the generic name, comes from the Greek word $\phi a \gamma \in \hat{\imath} \nu$, eat, because the Greeks used the nuts for food. The specific names are derived from the Latin: ferruginea, iron-wooded; sylvatica, from sylva, growing in the woods; betuloides, from betula, birch-like; obliqua, oblique-leaved. The common name, beech, signifies "eat."

History. - The beech was a well-known tree in ancient times, esteemed for its fruit and for its shade by both the Greeks and the Romans. Vergil inmortalized it. He describes Tityrus in his First Eclogue as reclining beneath the shade of a broad-spreading beech tree. All the species have been introduced into the gardens and planted grounds of Europe.

Use. - The nut of the beech in the north of Europe is a highly prized dessert nut, and constitutes an important part of the food of the inhabitants of northeastern Poland and western Russia. A delicate oil, rivalling that of the olive, is obtained from it, which is used for the table, and also for illuminating purposes, and large droves of swine are fattened upon it.

The wood is hard, and is prized for fuel, and used in cabinet ware for chairs, bedsteads, screws, and wooden shovels; also for shoemakers' lasts. The F. ferruginea of North America and F. sylvatica of Europe are the most important for ornameutal purposes.

\section{ORder LIII. SALICACE E.}

SALIX, L. (Willow.) Catkins with entire imbricated scales, subcylindrical; stamens 1 to 5 or more, with 1 to 2 little glands. Fertile

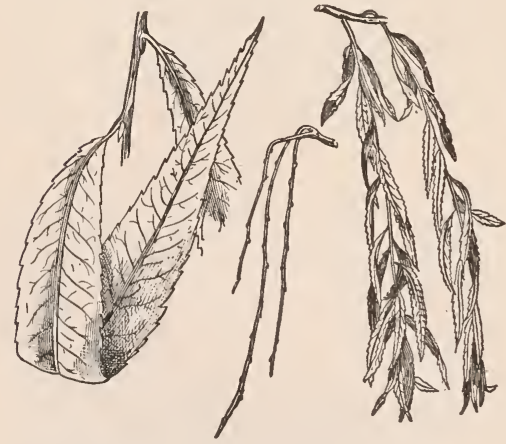

Salix Babylonica (Weeping Willow). flower, with a little gland at base of ovary; pistil stalked or sessile; stigmas 2, short, each occasionally 2 -lobed. Leaves simple, alternate, mostly stipulate, usually lanceolate and serrate. Trees and shrubs. A large genus ; 170 species.

1. S. Babylonica, L. (Weeping (Willow.) Stem 50 to 70 feet high, branching low and irregularly; young twigs slender and weeping. Leaves exstipulate, lanceolate, acuminate, finely serrate, glabrous and glaucous be-

neath; catkins appearing with the leaves.

Geography. - Western and southern Asia.

Of this species there are three well marked varieties, as follows :-

Var. vulgaris. Young shoots pale-green, slender, with an annular or winglike twist just above the axil of the leaf. Leaves furnished with large stipules. Flowers appear in June. 
Geography. - This variety abounds in the southern parts of England, especially about London.

Var. Napoleona. Shoots reddish-green; leates as in var. vulgaris, but exstipulate.

Geography. - This variety is supposed to have arisen from cuttings carried from England and planted in St. Helena. In 1823 cuttings were taken from a tree which stoor near Napoleon's grave, and planted in lingland; from these plantings cuttings were brouglit to Anerica, and the weeping willows of the eastern parts of the United States agree in botanical characteristics with this variety.

Var. crispa, syn. S. annularis. (Curled Willow. Ring-leaved Willow.) Leaves lanceolate, acuminate, serrate, glabrons and glaucous underueath, curled into a ring.

Geography. - The variety native to England has been brought by nurserymen to America, and is found frequently in planted grounds throughout the eastern Lnited States.

Etymology. - Salix, the generic name of the willow, is derived from the two Celtic words, sul, near, and lis, water, due to the circmistance that it delights in wet places. Willow, the common name, comes from the Low German word wichel, give way, or bend, and is due to the pliancy of the branches. Babylonicu, the specific name, is said to have been suggested to Linnæus by the following passage from the 137th Psalm:-

" $\mathrm{By}$ the rivers of Babylon there we sat down;

Yea we wept when we remembered Zion;

We hanged our harps upon the willows in the midst thereof."

History. - It is generally believed that the first thee of this species grown in England was the celebrated Twickenham tree, which has the following history: Alexander Pope, the poet, received from the Levant a box of fresh figs, packed in willow leaves. The poet noticed that the small twigs to which the leaves were attached were alive, and hoping to get a new plant, rooted one, which grew into the renowned tree. Inother aceount says that the poet was present when a package of merchandise from spain was opened; the hoops that bound it were willow, one of which l'ope planted, and thus ohtained the tree. This is said to lave taken place in 1730. Another date is alsu claimed for the advent of the weeping willow into England, 1692, thirty-eight years previous. If it was planted at the earlier late, I'ope conld have had no agency in its plauting, for he was then in his fourth year.

In the Magazine of American Ilistory, it is stated that Sir Henry Clinton bronght cuttings of the weeping willow to America, which were planted on the estate of 'John P'. Custis, in Virginia.

If Sir Ileury Clinton brought the first, he conld not have brought the var. Napoleona, for that was first planted in England in 1823, and Clinton came to America in 1755 , and died in 1795 . If he hronglht the willow, it was a cutting. most likely from the variety volgaris, which is very common in England, and not the Napoleona, which is the variety that prevails among onr nurserymen, and has been brought to America since 18:23. It cannot be true that no weeping willows grew here previons to 1823 , for it scems improbable that some of the large willows should have grown to the size they have attained in so few years. In 1848 a tree in a garden in Flnshing measured 14 feet in circumference, making it abut $+\frac{1}{2}$ feet in diameter.

$$
\text { , ,k. F. }-18
$$


Use. - The weeping willow is used as an ornamental tree; it is a very rapid grower, and forms a beautiful and picturesque object in planted grounds. The

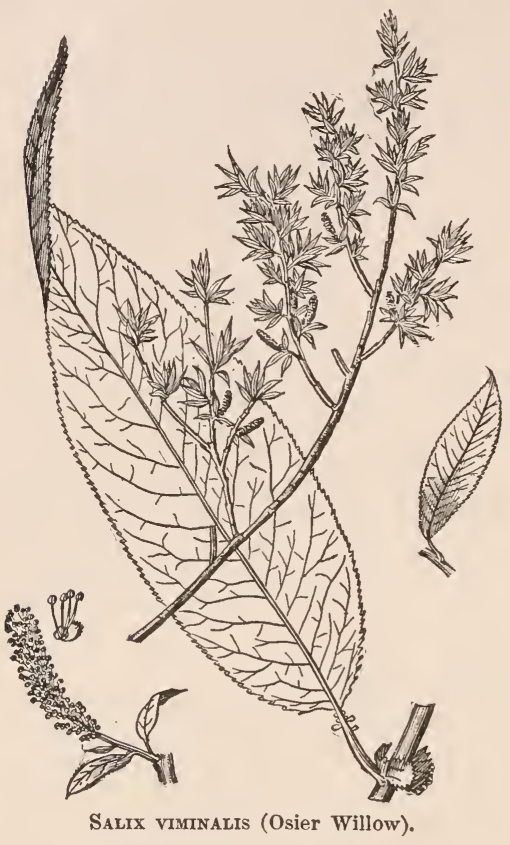

wood is soft and light, and does not make valuable lumber nor good fuel. Its charcoal is used by chemists in some blow-pipe experiments.

2. S. viminalis, L. (Osier Willow.) Stem 20 to 30 feet high, slender, shooting up 10 to 12 feet in a single growing season. Leaves linear-lanceolate, acuminate, sparingly toothed, long, silky beneath; stipules small, aments appearing before the leaves; scales roundish and very hairy; silky down on the under side of leaf, white. The shoots are best for wicker-work and baskets when two years old.

Geography. - Native all over Europe and northwestern Asia; grows easily from slips, and is grown largely in middle Europe.

Etymology. - Viminalis, the specific name, is from the Latin viminalia, an osier.

Use. - The osier willow is used for wicker-work, baskets, chairs, settees, hoops, etc. There are several other species used for the same purposes.

The charcoal of willow is used in the manufacture of gunpowder.

\section{Order LIV. ORCHIDACE无.}

Flowers perfect, or imperfect by arrest, terminal, solitary, or in a spike, raceme, or panicle, bracteate, occasionally springing from the middle of a leaf. Perianth superior, petaloid irregular, made up of 6 parts in two series, free or coherent, persistent or falling; the outer whorl or sepals 3 in number, 2 lateral and 1 inferior, mostly superior by torsion peduncle. Petals 3, alternating with the sepals, the 2 lat eral ones similar, the other lip-shaped, mostly inferior by torsion, varying greatly in form and color, limb of the lip 3-lobed or entire. Stamens usually 1, opposite to the odd sepal, accompanied by 2 rudimentary stamens, adnate to the style in gynandrous columns, pollen-grains often united into masses. Ovary inferior, 1-celled, or occasionally 3 -celled, with 3 parietal placentæ. Capsule membranous or leathery, cylindric, ovoid, winged, or a dehiscent pod. Seeds small and very numerous, testa crustaceous and black. Perennial herb, 
terrestrial or epiphytic. Stem or scape usually simple, cylindric or angular. Leaves mostly radical, those on the stems close together and equitant, alternate or opposite sheathing, and glabrous, cylindrical or linear-lanceolate, entire or emarginate, sometimes cordate; veins usually parallel.

No. of genera, $3: 34$; species 5,000; in warm and temperate regions.

vanilla, Swz. (Vanilla.) Calyx composed of 3 sepals, outer side greenish and petaloid. Petals of the same size and similar to the sepals ; lip entire, its claw adnate to the gynandrous column, its linb broad and concave around the column. Anthers terminal, forming a sort of lid; pollen granular. Fruit a pod, cylindrical, 6 to 10 inches long, and half an inch in dianeter, fleshy; seeds numerous, imbedded in a soft black pulp. Natives of the tropical countries of both hemispheres. They are lianes, climbing over lofty trees.

1. V. aromatica, Swz. (Spicy Vanilla.) Stem 4-sided, climbing, 15 to 30 fect long, epiphytic, but not parasitic, fastening itself to the bark by rootlets given off at every node. Leaves from 10 to 15 inches long, narrow and fleshy. Flowers greenish.

2. V: planifolia, Andrews. (Flat-leaved Vanilla.) Stem cylindrical and slender, very long. Leaves alternate, sessile, 4 to 6 inches long, oval and pointed, sheathing at the base, persistent, dark-green above, paler underneath. Flowers 2 inches in diameter, pale jellowish-green, sessile, in loose axillary spikes, with 8 to 10 short,

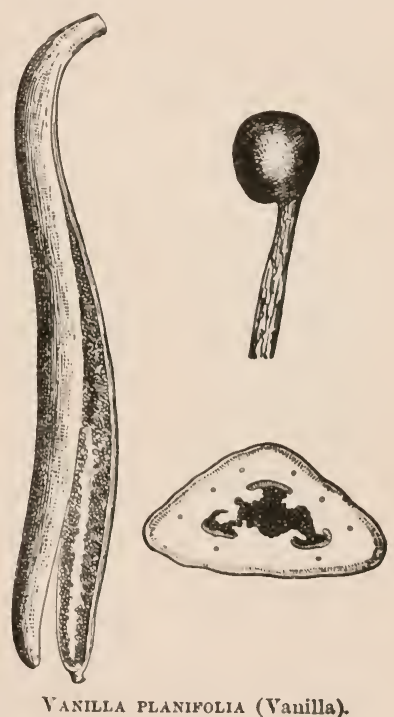
triangular, greeu bracts. l'erianth made up of 6 fleshy deciduous leares, in two rows. Ovary inferior, 2 inches long, cylindrical and stalk-like, fleshy and l-celled. Fruit a fleshy pod, 5 to 9 inches long slenter, filled with small black lens-like seeds.

These two species produce the vanilla of commerce. It is propagated by cuttings; hence there is little opportunity for sporting, and the number of varieties is accordingly limited; there are a few varieties however.

The cuttings are fastened to trees upon which they are to grow, and the fertilization is artificial, by placing the pollen upon the stigma with a splinter of bamboo, or some other delicate instrument.

Geography. - Vanilla is a tropical and subtropical plant, found native in the damp, wooded districts of southern Mexico, and in the coast regions of Vera Cruz and adjacent provinces. It is also cultivated in Guatemala, Guadaloupe, Brazil, Mauritils, Bourbon, Matagascar, and Java.

Etymolog.y. - Vanilla is the diminutive of the Spanish word vaina, sheath, 
rlue to the resemblance of the pod to the sheath of a knife. Aromatica, the specific name, siguifies "spicy." Planifolia means " flat-leaved."

History. - Vanilla is the only orchid whose product is of commercial importance. It is a native chiefly of tropical America, and was brought to the notice of Europeaus by the Spaniards, who found it in use among the Aztecs when they invaded Mexico.

Chemistry. - The flavoring substance of vanilla is called by chemists vanillin. It has been produced artificially in the laboratory.

Preparation. - The best vanilla is the product of the $\mathrm{V}$. planifolia. The beans are removed from the vine as soon as they have attained their full size, but before they are ripe, and are placed in a situation that exposes them to the heat of the sun or to artificial heat, - a part of the time wrapped in cloths, and a part of the time exposed. Under this treatment they attain their aroma and dark color, and are made fit for the market. The pots are fleshy, flexible, compressed or cylindrical, five to ten inches long, dark-brown, slender, hooked at the stalk end, the surface furrowed lengthwise, with a greasy, shining appearance when properly cured. After a few months the surface becomes covered with a bloom of fine crystals of vanillin. The pods are prepared for market by sorting into lengths and qualities, tying up in parcels of fifty each, and packing the bundles in tin boxes that hold twenty to fifty pounds each, which are then incased in cedar boxes, holding four to six tins.

$U_{\text {se. }}$ - Vanilla was formerly used as a medicine for stomach disorders and indigestion. Its use at present is for flavoring. It is added to chocolate, icecream, sauces, syrups for soda-water, tobacco, snuffs, liquors, and perfumery.

\section{ORDER LV. ZINGIBERACE无.}

Flowers irregular, in a raceme, or a terminal or lateral bracteate panicle. Perianth superior, formed of 3 to 4 whorls. Calyx green, 3-leaved, imbricate. Corolla of 3 imbricated divisions, alternating with the divisions of the calyx, colored and tubular at the base; stamens 1-6. Ovary inferior, 1-3-celled; style sometimes dilated, petal-iike, straight or curved, sometimes slender. Stigma terminal; capsule 1-3-celled. Seeds globular or angular; testa leathery. Leaves alternate, simple; petioles sheathing; blade plane large, entire, veins extending from the midrib. Herbs, frequently gigantic.

No. of genera, 36 ; species, 450 ; in warm climates.

curcuma, L. Calyx tubular, 3-toothed. Corolla tube dilated upwards; divisions of the limb equal; upper lip open. Filament petal-like, dilated, fleshy at the top; lateral staminodia united with it below, 3-lobed. Ovary inferior, 3-celled. Style thread-like; stigma capitate. Capsule 3-celled; cells 3-valved. Seeds numerous, arillate. Root tuberous and palmate, perennial. Leaves herbaceous; petioles sheathing; scope simple. Flowers in a simple, erect spike, yellow. Stemless herb.

c. longa, L. (Turmeric.) Stem wanting. Leaves sheathing each other, lanceolate, a foot long, springing from the crown of the root; the scape passes 
through the renter of the leafy tube formed hy the sheathing petioles; scape leafy and crowned with a simple spike of small flowers, creamy yellow.

Of this genus there are about twenty-five species, sevral of them yielding arrow-root; but the $\mathrm{C}$. longa is the only one that yields the coloring-matter known as curcuma, or turmeric.

Geography. - The curcuma is indigenous to the south of $A$ sia and the Malay peninsula; it flourishes only in the regions of no frost. It is cultivated and made an article of commerce in Hindustan, Cochin ('hina, southern India, Bengal, Java, and the isles of the 1'acific.

Etymology. - Curcuma, the generic name, is the Latinized form of the Arabic name kwhum, signifying "yellow." Longa, the specific name, is Latin, signifying "long," and refers to the length of the scape. The common name, turmeric, is of unknown origin.

History. - The home of the curcuma is Farther India and the Asiatic islands. Where its products were first introduced intu domestic economy or the arts is not recorled. The drug was known to the perple of the countries of the Levant and southern Enrope prior to the commencement of the Christian era. Dioscorides speaks of it unler the name of Cyperus Indicus; and it is believed to be the "saffron" spoken of in the Seriptures.

Chemistry. - It vields to the chemist a substance to which the color is due, callerl curcumin: the aromatic taste and smell resicle in another substance known under the name of turmerol.

Use. - The young tubers do not contain a coloringmatter, and are largely nsed for food in the islands of the coast of $A$ sia and in the Pacific. The roung root, dried and reduced to a powler, is the arrow-root of the East Indlies. The pulverized ripened root is used principally for coloring.

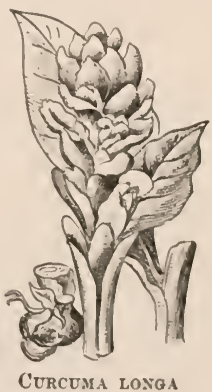

(Turmeric).

In Inclia it enters into curry powder and other culinary preparations. Its dye is not permanent, yet it is largely used.

The medicinal properties are stomachic, slightly tonic, ancl cordial. It is used in coloring foorls, medicines, and cosmeties. In the East it is made into a paste with oil, and used to anoint the body at marriage festivities.

Paper colored with turmeric is used for testing the presence of alkalies in liquids; if alkali is present, the paper becomes brown.

Maranta, Plum. (Arrowroot.) Calyx of 3 distinct lanceolate sepals; staminodia petaloid, united at hase with stamens. Flower perfect, bracted: bracts under the lranches narrow, appressed: corolla tubular at the base, curved, :3 imbricated divisions at the limb, alternating with the sepals.

M. arundinacea, W. (Arrow root.) Stem 2 feet high, branched; rhizome fleshy. Leaves lanceolate, hairy. Flnwers in clusters; 2 flwers on a stalk, peduncles short. Fruit glohular, wne eighth of an inch in diameter : rhizomes from 10 to 15 inches long, half an inch in dianeter, envelopeal by membranaceous scales. 
Geography. - The maranta is a tropical and subtropical plant; it has been found growing in Florida about the 28th parallel.

Etymology. - The name maranta is derived from Bartholomew Maranti, a physician of Venice; and the specific name, arundinacea, reed-like, is from the Latin arundo, a reed. The popular name, arrou-root, is sail to have been applied to this plant because of its efficacy in curing wounds inflicted by poisoned arrows.

History. - When this plant was introduced by civilized man into the materia medica, or as a food plant, is not known, - evidently since the discovery of the New World, as it is a native of tropical America.

Chemistry. - 100 parts of arrow-root yield to the chemist the following substances : -

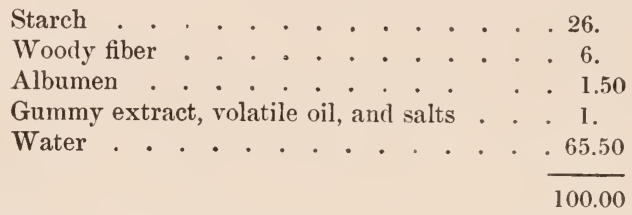

Its starch-grains are convex-elliptical, approaching triangular shape, nearly uniform in size. In commerce it is frequently adulterated with rice, flour,

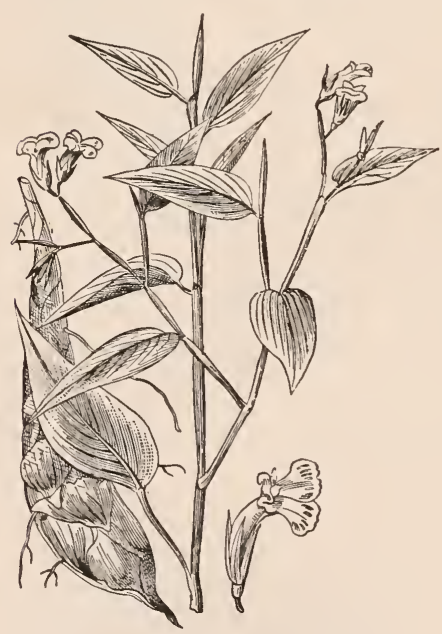

Maranta ARUndinacea (Arrow root). wheat-starch, or potato-starch. These foreign substances are readily detected by the microscope.

Use. - The rhizomas when a year old are dug with instruments made of German silver, and knires made of the same metal are employed for removing the scales. They are then reduced to a pulp in wooden mortars, or by the use of a cylindrical rasp. The mass is placed in water, which holds it temporarily in suspension. After straining to remove the woody fiber, it is repeatedly stirred, and allowed to settle, the water being afterward carefully poured off. The starchy suhstance which remains as a sediment is then dried, either in the shade or sunlight. These manipulations are all conducted with great care. After drying, it is reduced to powder or flowr, and is used for puddings, custards, and other culinary preparations. It is a favorite fool for the sick-room. It constitutes the principal food for the people of many tropical and subtropical countries of the New World. In the West Indies it is adninistered to counteract the effects of poisons.

Tacca integrifolia, Presl, and other species of this genus furnish starchy products which are used as substitutes for arrow-root in the East Indies. 
There are also other plants whose roots yield starches, among which the most prominent are: several cannas, as C. echinus, C. glauca, Rosc., C. edulis, and C. flaccida, Rose. These cannas are now under cultivation in Australia. The C. glauea and C. coccinia yield the starch kuown in commerce as tous les mois. The English have also introduced the cultivation of arrow-root-yielding plants into India, New South WVales, and Queensland. But no plant yields so much and of so good quality as the maranta arundinacea.

ELETtARIA, Maton. Calyx membranous, tubular, short, and 3-lobed. Corolla cylindrical, as long as the calyx; anterior lobe oblong, erect, and concave; side lobes narrower, curved backwards, slightly 3-lobed or toothed; lip obovoid; anthers inserted on the corolla, sessile and linear. Ovary 3-celled, containing many orules. Style thread-like; stigma rising a little above the anthers. Fruit globular or ovoid; seed-ressel tough, and not opening when ripe; seed oboroid and rugose. Rootstock thick, growing just under the surface of the ground. Perennial.

E. cardamomum, Maton. Stems numerous, smooth, 6 to 12 feet high. Leaves sheathing, alternate, 9 to 12 inches long, and 1 to 5 inches wide, elliptical-lanceolate pointed, entire, smooth, and dark-green above, pale beneath, with strong midribs; foot-stalks short; flower-stalk starts from the base of the stem, prostrate. Flowers in a panicle; calyx tubular, toothed at the margin ; corolla funnel-shaped, border lipped, 3-lobed, and spurred at the hase. Fruit a 3-celled capsule, many-seeded.

There are five species of this genus, all natives of the tropical regions of Asia; but the cardamoms of commerce are from this species.

Geography. - The plant grows and fruits well at an elevation of 3,000 to 5,000 feet along the sonthern coast of India; but the seeds of commerce are shipped fron Madras, Allepy, and Ceylon.

The plant yields fruit both in a wild state and under cultivation. It requires a temperature that does not fall below $70^{\circ}$ Fahrenheit. It flourishes best in the mountains of Malabar, at an elevation of about 4,000 feet, under an annual rainfall of ten feet.

Etymology. - Elettaria is the name of the cardamom plant in the Malabar

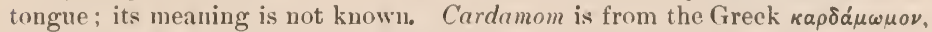
a spice, believed to have heen applied first to the elettaria by Pliny, on account of the pungent spice of its seeds. The cardamoms of commerce are known under names lerived from the places where they are grown: the Malahar, Madras, Allepy, and Ceylon.

Cultivation. - The cultivation consists in clearing the forest in spots where specimens of the plant are found growing spontancously, and then keeping the ground free from weeds and underbrush. The rhizome or underground stem throws up from fifteen to twenty leafy stems or branches. The stems each throw off four flowering stalks near the gromml, upon which the fruit finally appears. The plant fruits when four years old. An acre yields abont twenty-eight pounds.

Cse. - The medicinal properties of the sechls as well as their aromatic character are due to the presence of an essential oil, of which they yield three to five per cent. Their effect upon the human system is stimulant, earminative, and 
stomachic. They are used for flavoring sauces and for disguising unpleasant tastes in medicinal mixtures, and in tinctures, in confectionery and cordials, and they are a well-known masticatory.

ZINGIBER, Adans. Calyx membranous, tubular, and short, 3lobed. Corolla tubular, cylindrical, dilated above; lobes narrow, inner ones incurved, concave, lateral ones spreading; lip small, middle lobe longer, entire or bifid. Anther on the erect filament oblong; connective linear, or awl-shaped, extending beyond the anther cells. Ovary 3-celled, containing many ovules. Style threadlike; stigma projecting beyond the anther cells, sometimes very small and globose. Capsule oblong or globular; seed-vessel hard, opening irregularly; seed large and oblong. It flowers in September, the stem withers away by the first of the following January, and the root is harvested in February.

Z. officinalis, Rosc. (Ginger.) The stem is subterranean, of the rhizome character; the branches or aerial stems are 2 to 5 feet high, solid, erect, with

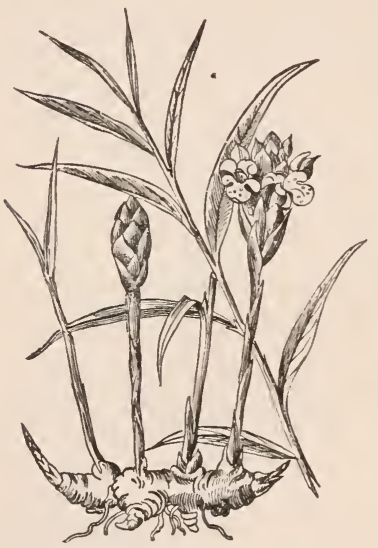

ZiNGIBER officinalis (Ginger). imbricated membranous sheaths. Leares lanceolate, acute, smooth, 5 to 6 inches long and $\mathrm{l}$ inch wide, alternate, with ovate, acuminate sheaths. The scapes are terminated with spikes of whitish or dirty rellowish flowers, whose lips are streaked with purple, and spotted; spikes bracteate, oval, and obtuse; bracts rellowish-green, with mem. branous edges.

The roots or underground stems are 3 to 4 inches long, made up of a number of short lobe-like shoots or knobs, whose tops are marked each with a scar, showing the spot where the stem grew. There are other species of this genus, about twenty in all; but the officinalis furnishes the ginger of commerce.

Geography. - The ginger plant is tropical, or, strictly speaking, subtropical. It is cultivated in sonthern Asia, and on the southern slopes of the Himalayas. It is an important crop in the West Indies, whither it has been carried by Europeans from southern Asia. In the same manuer it has found its way to the western coast of Africa, where it is also largely cultivated.

Etymology. - Zingiber, the botanic name, is claimed by some to be geographical, from the Island of Zanzibar, where it first became known to Europeans. $\mathrm{By}$ others it is believed to be the Latinized form of the Sanscrit word cringa, a horn, due to the fancied resemblance of the root to a stag's horn. Ginger, the popular name, is a corruption of the word zingiber. Officinalis is the Latin for " useful," or "serviceable."

History. - Ginger was known to the Greeks and Romans in the first century of the Christian era, and was in common use in England before the Norman 
conquest, A. D. 1066. Where or when it was first cultivated is not known. It must have been brought under cultivation very early in the history of the Asiatic peoples, for it is not now known to be growing in a wild state. There is good reason to believe that it is a native of southern $A$ sia, whence it has heen carried to the western coast of $A$ frica and to the West Indies.

Chemistry. - It yields to the chenist many distinct substances, anong which stareh is the largest in quantity. The pungency is due to an oily, resinons principle, called gingerine. The perfume and delicate flavor resirle in an essential oil, which is entirely free from pungeney.

Prepuration. - There are three varieties of the root in American commerce: the Jamaica, Cochin, and African. The Jamaica and the Cochin are prepared before they are brought to market, by the removal of the epidermis, and are of a dull-yellow or buff color. The African root, or hlack ginger, is sent to market without preparation, and bears a dark, earthy hue. 'The Jamaica ginger of the shops is white, having been subjected to a bleaching process. and then whitewashed. This variety is preferred on account of its fine Havor and its light color. The Cochin ginger is valuable on account of its strength, and is much used by the manufacturers of the extract. The ground ginger of the grocers is made from the African root, which procluces a dull, brownishyellow powder.

$U$ se. - As a medicine, ginger is stimulant, earminative, and anti-llyspeptic. It is used as a tonic for flatuleney, a carminative in colic, and enters into the preparation of many medicines to assist their action. It is an ever-present domestic remedy. It is an important culinary spice and condiment for flaroring pies, preserves, cake, and aerated waters, beers, and cordials. In China, the root is largely preserved by cooking it in syrup. It reaches us in stone jars holding from a pint to a half-gallon. The Chinese also prepare an excellent eandy by slicing the root and cooking it in syrup.

MUSA, Plum. Perianth attached to the orary, 2-lipued or -2-parted, the lower lip cut at the extremity in five divisions. Stannens s, ovary inferior, 3-celled; ovules numerous. Styles thick, shorter than the stamens, 3-6-lobed. Fruit oblong, angled, and :3-celled, 3-9 inches long, curved, $1 \frac{1}{2}-2$ inches in diameter. Seeds numerous. in a soft, fleshy pulp; covering of the seed black. Flowers in an axillary spadix.

1. M. paradisiaca, L. (Plantain, or Yellow Bauana.) Stem herbaceous, abont 18 feet high, stont, formed by a succession of large sheathing. Leaves 4 to 8 feet long, 15 to 20 inches broad, oblong, entire. Flowers terminal, in a dense spike, 2 to + feet in length, nodding. Fruit 3 to 9 inches long, 1 to 2 inches 11 diameter, scimitar-shaped, pale-vellow when ripe, skin thick and coriaceous, pulp sweet and delicate to the taste, seeds distributed along the axis of growth in the pulp. Inder cultivation the seeds seldom ripen, but the plant is propagated by offshoots at the base. If left in a state of nature, the seell matures, and many varieties are obtained. There are about thirty varieties unler cultivation in Asia and the Asiatic islands, of which the M. paratisian is the parent or a fair type of the numeroms species and rarieties of the plautain.

2. M. sapientum, I, (Banana, or Red Banana.) The description of $\mathrm{N}_{0}$.. I covers the characteristicy of the M. sapientum exactly, except that the stalk 
is marked with purple spots, and the fruit is shorter, more cylindrical, of a dark greenish-red color, and 2 to $2 \frac{1}{2}$ inches in diameter, and has a more delicious taste.

There are many varieties of this species, differing in size and quality of the fruit. It is held by some botanists that the species M. troglodytarum, a native of the Molucca Islands, is the parent of all the cultivated species and

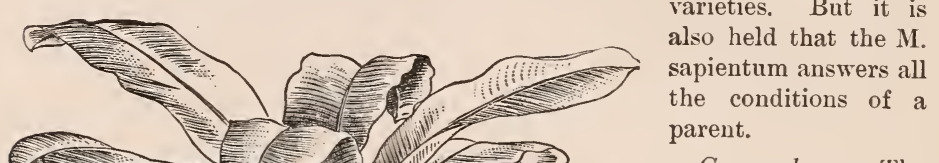

Geography. - The geographical distribution of the banana and plantain is very wide, extending all around the globe, between $38^{\circ}$ north latitude and $35^{\circ}$ south latitude. A mean temperature above $64^{\circ}$ Fahrenheit is necessary to its existence, and it does not fruit freely where the temperature falls below $40^{\circ}$. It is found in the Indian Archipelago, China, Cochin China, and Hindustan. It grows in Australia and the islands of the Pacific, in Madagascar, and on the western shores of Africa. It also adorns the gardens of the Morea, of Sicily, and the south of Spain. In the New World it is grown in Mexico, Central America, Colombia, Peru, northern Brazil, Guiana, and in the

greater part of the West Indies. Recently it has been introduced into the gardens of southern Florida and Louisiana.

Etymology. - The name musa is said to come from the Arabic mouz. It is also said to have been given by Plumier, a French botanist, in honor of Musa, a celebrated physician of Rome, who cured Augustus Cæsar of a disease which had been pronounced by the imperial practitioners incurable ; for which service the emperor knighted him. The specific name sapientum is due to the circumstance that in India the leaves grow to a great height, and its groves were a farorite resort for sages (sapientes), who were accustomed to repose 
under their shalle while partaking of the fruit; hence, the fruit of the wise. The name paradisiacu arises from the story that the banana of this species was the forbidden fruit of Paradise. 'The English or common name, banana, is very obscure in its origin as well as its signitication, but is supposed to be a l'ortuguese corruption of some native name. The word plantain is from the Latiu plantugo, applied on account of its broad, spreading leaf.

Mistory. - Many things point to Asia as the home of the banana. ret it is claimed that it had reached the western coast of South Imerical before the arrival of the Europeans. It has also been suggested that it is indigenous to Imerica, but the weight of history makes it an introluced plant; hence we are constrained to reckon the banina among the food pliuts of $\mathrm{A}$ sia. It was unknown to the ancient Egyptians, but is said to have been male known to the Greeks by Alexauder's expedition into India.

Cultivation. - The bauma has been very properly pointed out as an illustration of the wonderful fertility of tropical regions. In the temperate zones a fruit-tree requires years to mature fruit; but the dweller between the tropics takes a sucker from a banana-plant, places it in the soil on the river bank, and at the end of a few months gathers a crop of delicious fruit.

$U$ se. - The banana is highly prized as a dessert. The uatives of the tropics slice and fry it; it is baked in ovens, and is dried and ground into flour, of which bread and cakes are made. 'Two intoxicating drinks known as banana wine and banana beer are made from the juice by the $\Lambda$ fricans.

As to the economic value of the plantain and banana, they stand next to wheat and rice as food plants. Simmons, a recent English writer on tropical food plants, says: "The banana is to thousands of the dwellers of the tropics what rice is to the Hindoo, rye to the Muscovite, and wheat to the Englishman; it is their main depentance, in more senses than one, their staff of life, grown everywhere in small quantities throughout the tropics." Again he says: "Among the splendid, varied, and profuse vegetation with which tropical countries abouncl, . . the magnificent herbaceous plant, the plantain, attracts particular notice."

The inclividuals of this family rank high among endogenous herbs. Their gigantic size, the magnificence of their foliage, the abundance and character of their fruit, the grandeur of their flowers, give them the very highest place among stemless endogens. The bauana is the queen among ornamental herbs, and the honsehold god of the laborer's cottage.

The structure of the stem furnishes a fiber, of which cordage, mats, and a coarse cloth and paper are manufactured. Sec Musa textilis.

The Chinese use the top of the stem for its juice, which also forms an iuportant ingredient in the manufacture of ink. The pith of the stem and the top of the spike and the roung shoots are edille. Humboldt estimated that an acre will yield 134,900 pounds of food. This far exceels the product of any of the tuber-hearing plants of the temperate zones.

3. M. textilis, Nees. (Manilla) This species of musa is treated separately because its characteristics are so different from the others. First, it is larger than any other, rising to the height of 30 to 50 feet. All the musas produce fiber, but the M. sapientum, M violacea, and M. textilis furnish the best quality, and most of it.

Gengraphy. - The musa textilis is, like the other species, a tropical or suh. tropical plant. It grows best on the slopes of voleanic monntains, among the larger trees that usually cover such declivities. The fiber of commerce, 
obtained from the M. textilis, thus far has been grown in the southern Philippines. Attempts have been made to grow it in other localities without much success. It is now cultivated in India and other parts of the south of Asia.

Etymology. - Textilis, the specific name, is from the Latin texo, weare, alluding to the use made of the fiber obtained from it. Manilla, the popular name, is due to the seaport of that name, from which most of the fiber and its products are exported.

History. - When this plant was first introduced into domestic economy, or when it assumed a commercial importance, is not known. The first recorded export was in 1850, and in $1856,600,000$ pounds were sent from three ports in the Philippines, three fourths of which came to the United States. In 1880 45,584,000 pounds reached Eugland, a large part of which eame thence to America. 'The amount used is rapidly increasing, and the uses to which it is applied are multiplyiug.

Preparation and Use. - Manilla is the prepared fiber of the musa. The plant is cut when eighteen months old. Just before it flowers, the leaves are removed; the stem is then opened lengthwise, and the flower-stalk, which forms a central column, is removed. From this, three successive coats of fiber are taken. The outer coat is the coarsest, and furmishes the material for making ropes, cordage, coarse bags, and mats. The next coat is of finer texture, and is used for manufacturing cloths and paper. The third and inner fiber is much more delicate than the outer coatings, and of it are made the finest fabrics, elegant shawls, and material for soft and delicate underclothing. Ropes and cordage made of the fiber of the outer coating are one fourth stronger than when made of the best hemp.

The fiber is prepared by bruising it between rollers in a mill; it is then boiled in large coppers, - potash, soda, or lime having been added to the water to remove the mucilage. It is taken from the coppers and hung up over manilla ropes on bamboo poles to dry. It is then beaten or combed, when it is fit for market or the factory. The three different sorts are kept separate. Formerly the preparation was all done by hand, but machinery is now employed, which does the work much better. Mixed with silk or cotton, it makes a very fine fabric.

\section{Order LVI. BROMELIACE}

Flowers perfect, usually regular, occasionally irregular, spiked, racemed, or panicled. Perianth inferior or superior, 6-parted, in two series, the outer series or calyx leaf-like, one sometimes shorter; inner whorl or corolla petioled, more or less coherent, twisted in the bud. Stamens 6, variously arranged; filaments subulate, dilated at the base, free or connate; anthers introrse. Ovary inferior, sometimes superior, 3-celled; style simple, 3-cornered, occasionally 3-parted ; stigmas 3. Fruit a 3-celled berry, or capsule; seeds numerous. Leaves mostly all at the base of the stem, or scape; sheathing stiff, channelled; margin armed with spines, or toothed; epidermis clothed with scale-like hairs. Herbaceous, and occasionally woody plants, mostly without stems, sometimes epiphytic. Root perennial.

No. of principal genera, 27 ; species, 350 ; warm parts of America. 
ANANASSA, lind. (Pineapple.) Inflorescence densely strobiliform. Calyx 3-parted; petals 3. Stamens 6 ; style 1, 3-parted. Fruit a spike of densely packed berries, and fleshy bracts, forming a conicalshaped body from 6 to 12 inches long and 3 to 6 inches in diameter, crowned with a tuft of leaves.

A. sativa, schult. (Pineapple.) Stem wanting, the flower-stalk springing from the midst of a tuft of radical leaves which are larger than the leaves that crown the fruit, armed with sharp, hooked teeth, curving upwards and tipped with a strong, sharp spine, lanceulate and fleshy.

There are numerous native sports, in a wild state. 'The plant, when not under cultivation, ripens seed, from which varieties are produced, which when found to be good are broughic under cultivation.
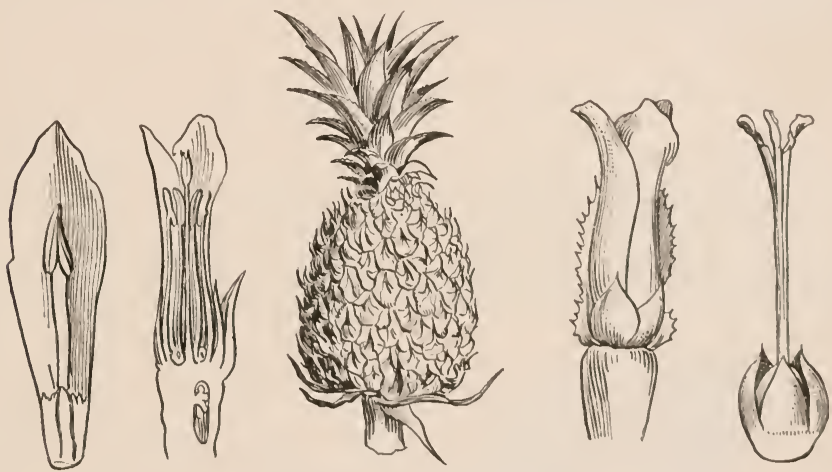

Ananassa sativa (Pineapple).

The principal varieties under cultivation are as follows, varying in size and quality of the fruit: Ripley, Enville, Prickly Cayenue, Simoth Cayeune, Providence, Charlotte Rothschild.

These are the favorite varieties grown in the British West Indies.

Geography. - The cultivation of the pineapple was at one time confined to one of the islands of the Bahama group (Elenthera), and neighboring istets; but it is now spread to all the tropical regions where civilized man has taken up his abode. It is the only important fruit which camot be traced to Isia as its home. Now the southeru shores of the Eastern Continent, the fichls of eastern Ifrica, the isles of the Pavific, as well as the tropical regions of Imerica, all give place to this interesting and lelightful prodnet. In India it has escaped from cultivation, grows and propagates itself in the jungles, and has become thoroughly naturalized.

Etymology. - Linnaus named the pineapple Bromelia, in howor of Olaf Bromel, a Swedish botanist. The name ananassa was given by 'Thunberg, from the Peruvian name nana. Sutiva, the specific name, signifies "planted," or "sown." The names of varieties are for the uriginators or their friends, or from some quality of the plant. The common name, pineapple, aruse from the resemblance of the fruit to pine coues. 
History. - The home of the pineapple is tropical America. It is related that the Spaniards found it in Peru and took it to the West Indies, whence it was carried by the Portuguese to the East Indies. About the middle of the seventeenth century it was taken to Holland by Mr. Le Count, a Dutch merchant, who cultivated it under glass at his country seat near Leyden. It was thence carried to England, where it was successfully fruited under what is known in England as stove culture.

Use. - The pineapple is a most fragrant fruit, and is used for a dessert. It is also preserved in sugar and in brandy, and forms an important article of commerce, both raw and preserved. At Nassau, about two million cans are filled annually and sent to the United States.

Propagation. - The pineapple is propagated by suckers or by the tuft from the top of the fruit.

Marts. - New York is the great mart for this fruit; but it is now carried to Europe, in a crude state, by the fast steamers. It is matured in England under glass, and is sold for ten times more than the imported article.

\section{ORDER LVII. IRIDACE EE.}

Flowers perfect, regular or irregular, terminal in a spike, corymb, or loose panicle, or solitary, each with 2 spathe-like bracts. Inflorescence with a double subfoliaceous bract. Perianth superior, petaloid, tubular, 6-parted, regular or bilabiate; segments in two series, equal, or the inner whorl smaller, dissimilar, usually falling early. Stamens

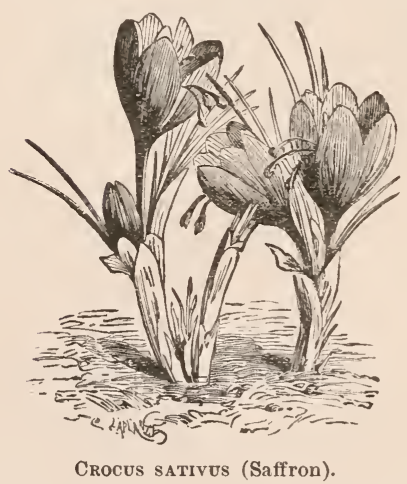

3 ; filaments equal, free; anthers extrorse. Ovary inferior, 3-celled, usually many-oruled. Stigmas 3, opposite the stamens, or alternate, often dilated or petaloid. Capsule 3-cornered or lobed, 3-celled. Seeds numerous, subglobose or contpressed, sometimes winged; testa membranous or papery, sometimes leathery or fleshy. Leaves usually radical, equitant, ensiform or linear, angular, entire, flat or longitudinally folded, those on the stem alternate, sheathing. Pereunial herbs, with tuberous or bulbous rhizome.

No. of genera, 57 ; species, 700 ; warm parts of both hemispheres.

CRocus, L. Flowers nearly sessile, among leaves, tube long and slender, the limb bell-shaped, divided into 6 nearly equal segments. Stigmas dilated, and colored at the top, often fringed; capsule buried among the radical leaves. Rootstock bulbous, coating fibrous and netted.

C. sativus, L. (Saffron.) Scape 1 to 3 inches high. Leaves radical, linear; margins revolute, with white furrow above. Flower-tube loug, white, * 
(rowned with purple elliptical segments. Stigmas long, emarginate, red ur deep orange, extending beyond the tube.

There are many other species, but the sativus is the most important.

Geomraphy. - The geographical rauge is throughout the southern parts of the north temperate zone.

Elymology. - Crocus, the generic name, was given to this plant by Theophrastus, but the meaning is obscure. Sativus is Latin for "sown" or "cultivated."

History. - This plant was known to the ancients; it is mentioned by Dioscorides, Theophrastus, and Pliny. The Romans cultivated it for its perfume; and in later times it was an important crop in England. The parts producing the dye are the style and stigma; and it has been estimated that a single pound of saffron is composed of the stigmas of 200,000 Howers.

$U_{\text {se. }}$ - The medicinal properties are not important. It was formerly administered in infusions in a multitude of disorders, but especially to bring eruptive diseases to the surface. Modern practice has brought in remedies which have crowded it out.

There are two active principles contained in saffron flowers : an oil to which its flavoring and medicinal properties are due; and a coloring substance which furnishes the dye.

As a coloring ageut saffron is now used to color creams and biscuits, and to color and flavor confectionery and cordials. As a dye, it is an important substance. The dye is produced by the presence of a principle which the chemists call polychroite; this substance, when brought into contact with different chemical reagents, produces a variety of beautiful colors and tints.

\section{ORdER LVIII. DIOSCOREACEAE.}

Flowers diœcious, small, inconspicuous, regular, in axillary racemes or spikes. Perianth herbaceous, petal-like, in 6 parts, 2 seriate, equal, and persistent. Stamens 6, inserted at the base of the segments of the perianth ; filaments short, free. Ovary inferior, 3-celled; styles :3, short; stigma blunt or 2-lobed; orules 1-2 in each cell. Fruit capsular, 3-angled or winged, 3-celled ; seeds compressed, winged. Leaves alternate or opposite, petioled, simple, prominently palminerved. entire or lobed. Perennial herbs, with twining stems; tuberous, Hleshy roots.

No. of genera, 8 ; species, 160 ; chiefly tropical.

DIOSCOREA, L. Flowers small; stamens 6 , at the base of the perianth; filaments awl-shaped. Styles of the fertile flowers 3; cells of the capsule usually 2-seeded. Seeds margined by thin membrane; pods 3-angled.

1. D. sativa, L. (Yam.) Stem long, slender, terete, smooth, twining or clambering over shrubbery. Leaves alternate, broad, ovate-cordate, glabrous, nerved, outer nerves forked, margin sinuate. Flowers in dense, axillary spikes, greenish-white. Root gives rise to large edible tubers.

2. D. batatas, Decaisne. (Chinese Yam.) Stem rery long, resembling that of D. sativa. Leaves opposite, smouth, heart-shaped or halbert-shaped, in the 
axils of which bulblets appear. The roots are large, tuberous processes, largest at the bottom, sometimes 6 feet long, tapering from the bottom (where they are sometimes 8 inches in diameter) to the top, the crown being an inch in diameter, the whole tuber sometimes weighing 40 pounds; edible.

There are about 150 species known to botanists. 'The most important edible species are the D. sativa and D. batatas, D. japonica and D. alata.

Geography. - The yam is tropical and subtropical, though it arrives at maturity in higher latitudes; but the tubers do not reach perfection except

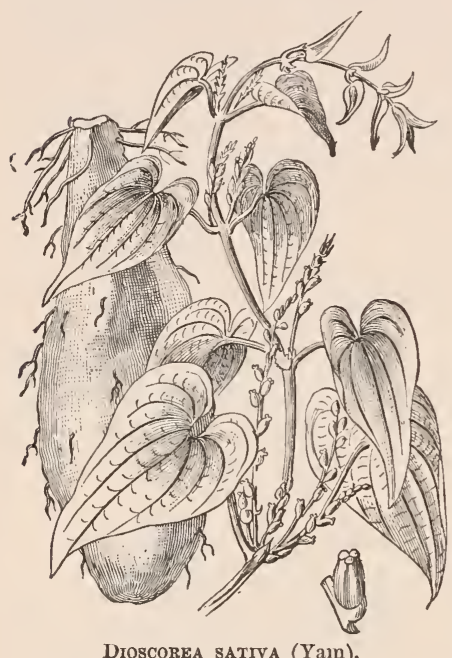

Dioscorea satrva (Yain). under a high temperature. The geographical distribution of this genus is a belt all around the earth, between the parallels of $30^{\circ}$ on both sides of the equator. Some of the species are indigenous to America, some to Africa, but more to Asia. It is but recently that it has been brought under cultivation. Its cultivation is confined principally to Japan, the East India Islands, and siam.

Etymology. - Dioscorea, the generic name, was given by Linnæus in honor of 1)ioscorides, the Greek botanist. The specific name, sativa, siguifies the "sown," or "cultivated," plant. The name batatas is supposed to signify "a club," referring to the shape of the tuber, which is small at the upper end and large at the other. The common name, yam, is supposed to be of African origin, the meaning being unknown.

Use. - The yam is used for a table regetable, and is prepared by boiling, baking, frying, or roasting in hot embers. It is also beaten into a paste and made into cakes; also boiled, mashed, and made into puddings and custards. It constitutes a large portion of the food of the savage and half-civilized tribes of Africa and Malaysia.

\section{Order Lix. LILIACEAs.}

Flowers perfect, mostly terminal, solitarv, racemose or spiked. Perianth tubular, inferior ; limb 6-lobed or parted, or perianth leaves listinct. Stamens 6, inserted on the receptacle or perianth-tube. Ovary free, usually 3-celled; cells few to many-seeded; style simple or 3-cleft. Fruit capsular. Leaves simple, entire, sheathing fascicled at the base, and sessile on the stem, flat or channelled. Herbaceous perennials, sonetimes tree-like and woorly. Root bulbous, tuberous, or with a creeping rhizome.

No. of genera, 187 ; species, 2000 ; cosmopolitan; mostly in damp places, but not in the water. 
smilax, 'Tourn. Flower's dicecious, small, greenish, axillary; perianth decidnons, segments 6 , in two series, outer ones broader, spreading, sepaloid; stamens equal to the number of divisions, shorter than the segments and inserted on their hases. Anthers adnate, 1-celled, with a cross partition. Ovary superior, usually 3-celled; stigmas :', spreading, 2 ovules in a cell. Fruit a berry, globose, 6 seeds, sometines 1-celled, with 1 seed only. Leaves entire, petioled, alternate, palmately $3-5$ veined. Woody peremials.

1. S. officinalis, H. \& Bonpl. (Sarsaparilla.) Stem woody, twining, nearly square, smooth, with scattered spines or prickles; slencler, long, young shoot:; without prickles. Leaves ovate-oblong, acute, cordate, 5 to 7 palmately nerved, thick and leathery, very large, 8 to 12 inches long, and half as wile. Fuot-stalks an inch long, smooth, with tenlrils. Root with long, creeping rootstocks.

2 S. sarsaparilla, 1. (Sarsaparilla.) Stem prickly, nearly square, climbing by tendrils. Leaves 6 to 8 inches long, and 4 to 5 iuches wide, oblong-orate, deep-green cuspidate, subcordate at base, and 5-nerved. Flowers greenish, on long, flat, axillary peduncles. Berries large, globose, 1-seeded, pinkishred when ripe, persistent. Root with long, creeping rhizomes.

This species has found its way into the soutliern L'nited States, or is native there.

3 S. medica, Schlech et Cham. As above, except that the leaves are very smooth, prominently heart-shaped on the lower part of the stem, and ovate above.

This species furnishes the Mexican root.

4. S. papyraceæ, Poir. Leaves membranaceons, oblong-oval, blunt, otherwise as $s$. officinalis.

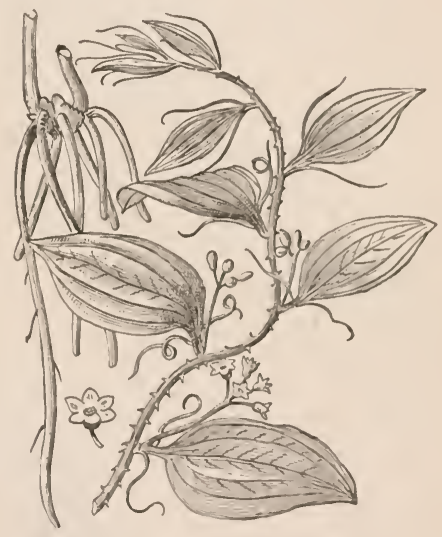

Smilax sarsaparilla (Sarsaparilla).

This species yields the root known as the Para or Rio Negro Sarsaparilla.

Geography. - The species of smilax producing sarsaparilla are found in Mexico, and in central and northern Sonth America.

Etymolon!. - Smilax is from the Greek word $\sigma \mu i \lambda \eta$, a grater, allurling to the armed stems. Officinalis, the specific name, is from the Latin, signifying "of the shops." Sarsaparilia, the common name, is from the Spanish zarza, a hramble, and parilla, a little vine; hence a prickly vine, or prickly littl. vine. The specific name medicr is due to the medieal properties of this species; and papyracer indicates the membranous or paper-like character of the leaf.

IIisfory. - Sarsaparilla was introdnced into melical practice about the middle of the sixteenth century, and attained a great reputation, which it hats not been ahle to sustain.

Use. - When sarsaparilla first hecame known to the healing art, it claimed to be specific in all diseases which affected the blood.

PR. FL. -19 
Its effects upon the system are alterative, sudorific, and secretive; it is used for chronic rheumatism, skin diseases, and is considered especially efficacious as a restorative after an excessive mercurial course. At the present day it is largely used in the manufacture of patent medicines, - the regular physicians having found substitutes which they consider more efficacious.

Marts. - It is believed that the $\mathbf{S}$. sarsaparilla has the same medicinal properties as the $\mathrm{S}$. officinalis; but this is disputed, and it is claimed that the root which supplies the market is from the S. officinalis only. Jamaica sarsaparilla is from Central America, and takes its name from the fact that it is shipped from Jamaica to Europe. The cortex of the root is red, and clothed with short rootlets; it is sent to market in bundles 18 inches long and 5 inches in diameter; these are made up into bales for shipment.

The North American market is supplied with Honduras sarsaparilla, prosured from a species which is not known to botanists, or is not well determined ; it is shipped from Balize in large bales, made up of small bundles, 30 inches long and 6 in diameter, weighing 3 to 5 pounds each; the ends of the bales being corered with green raw-hides.

The market of the United States is partly supplied by what is known as Mexican sarsaparilla; it is shipped from Vera Cruz, and is the root of the S. medica. It is a slender, shrivelled root, done up in large bundles, of 300 pounds each, fastened together with ropes.

Another sort, of rery gool quality, is known as Rio Nigro sarsaparilla, which is the root of S. papyraceæ. It is shipped at Para in neat rolls 3 feet long and 1 foot in diameter, bound together by a vine. Nearly all of this variety goes to Spain and Portugal.

ASPARAGUS, L. Flowers perfect; calyx with 6 equal, narrow, oblong, petal-like sepals, barely connected at the base, spreading. Stamens united near the base; anthers peltate; style short; stigmas 3. Ovary 3-cornered, top-shaped, and 3-celled; cells 2-seeded. Leaves reduced to minute scales. Branches thread-like. Fruit, globular berry; seed angular, outer corering black and leathery; embryo curved and eccentric. Root a mass of long fleshy fibers, about an eighth of an inch in diameter. Perennial herb.

A. officinalis, I. (Asparagus or Sparrow Grass.) Stem paniculately branched, 3 to 4 feet high, starting from the root in a stout shoot. Branchlets in fascicles, thread-like, bristly, and flexible, from half an inch to an inch and a half in length, pale pea-green. Flowers very small, axillary on the branches, solitary or in twos, yellowish-green. Berry with 6 seeds.

There are about 100 species, but the $A$. officinalis is the only one cultivated for food.

The asparagus is propagated from the seed, and sports. There are many varieties; but there are two known to the market gardeners as favorites, under the names of red top and green top. These change in form and size by high culture.

Geography. - The asparagus grows in the middle latitudes of the north temperate zone, is largely cultivated in England, Holland, throughout central Europe, in the countries of the Mediterranean, and on the sandy plains of Poland and southern Russia, about the Caspian Sea.p It wasintroducedipto Hindustan by the Finglish, and is extensively cultivated there; it is also found 
in Japan, and has a native name, which seems to point to its being indigenous to that region. It grows outside of cultivation in Great Britain. It is indigenous to the countries of the Lerant; was brought to North America by

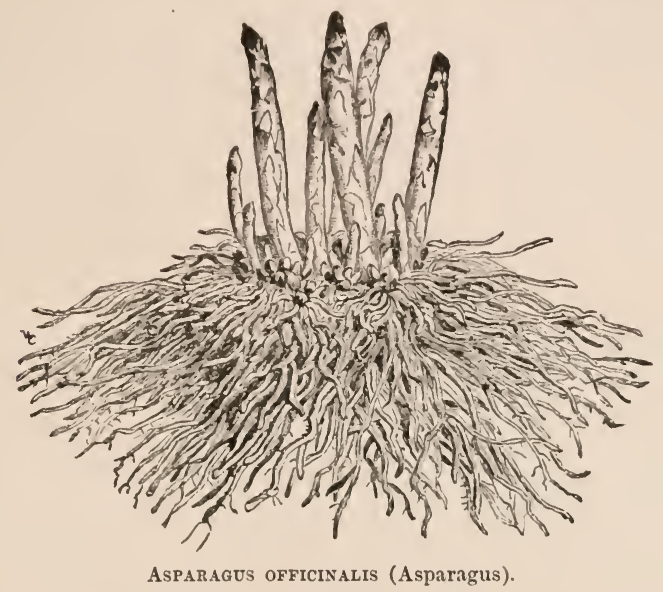

European colonists, where it is under cultivation, and is a favorite table vegetable. It has escaped from the garden, and is growing wild, especially along the seacoast.

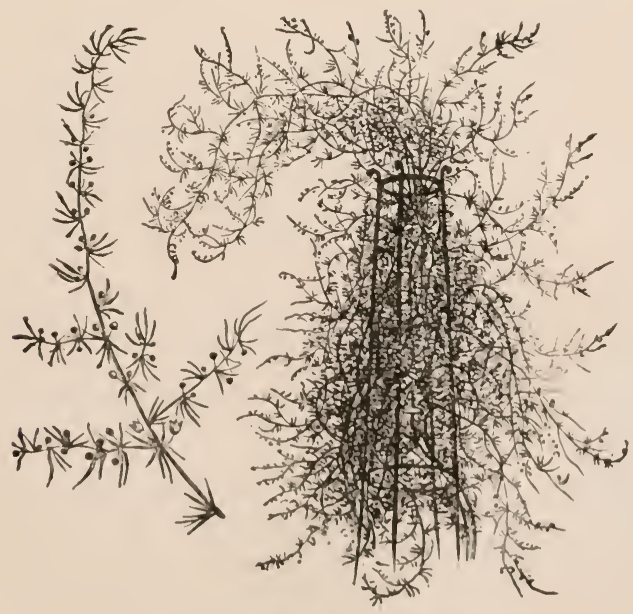

Asparages officisalis (Asparagus).

Etymology. - The name usparagus is derived from the Greek word $\sigma \pi \alpha \rho \alpha \sigma \sigma \omega$, tear, alluding to the thorny character of some of the species. Officinalis, 
the specific name, is from the Latin officina, belonging to trade, or the market. The common name, sparrow grass, is a corruption of asparagus.

History. - Asparagus was known to the Greeks and Romans at least two thousand years ago.

Use. - Asparagus is a very delicate vegetable, and most highly prized as a pot-herb. It is greatly improved by cultivation, both in size and quality. Its tender, fleshy shoots are the parts eaten. When boiled in a small quantity of water with a little salt, it retains its natural delicate flavor, which to the epicure is not improved by disguising sauces. It is also cut into short pieces a quarter of an inch in length, boiled, and served as green peas are. Its medicinal properties are diuretic, and it is recommended for complaints of the kidneys. Its seeds have been used in Europe as a substitute for coffee.

PHORMIUM, Forst. Perianth incurved, segments connate at the base, in a short, top-shaped tube, the three exterior segments lanceolate, the three interior sometimes a little longer and narrower at the apex; stamens 6 , attached to the base of the tube; filaments threadlike; anthers oblong or oblong-linear, erect, attached along their backs to the filaments; filaments intruding into the anther-cells. Ovary sessile, oblong, 3-cornered, and 3-valved; style filiform ; stigma short, head-shaped; ovules numerous; capsule somewhat leathery, 3-sided, cylindrical, often strongly twisted. Perianth cylindrical, funnel-formed, united below. Leaves radical, keeled, not fleshy. Seeds oblong, flattened; seed-vessel black, membranaceous, sharply dilated at the margin, but not properly winged. Embryo long.

P. tenax, L. (New Zealand Flax.) Rhizome short, thick, radical fibers densely matted. Leaves radical, 3 to 9 feet long, narrow, linear, sword-shaped,

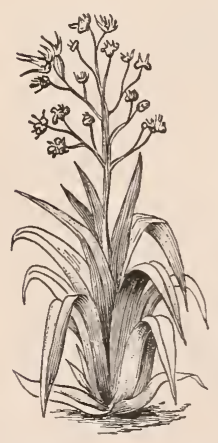

Phormirum tenax (New Zealand Flax). leathery, tenacious, arranged a little way up the stem in two rows on opposite sides for a short distance from the root. Scape leafless and branching above; bracts under the branches, which sometimes fall off. Flowers pediceled, in terminal panicles, or fascicled with the bracts along the branches, varied in color; flower-stalk jointed under the flower. The seed matures in the third year, the stalk rising to the height of 16 feet, when the whole plant dies down, and renews itself from its roots.

Geography. - Its home is New Zealand, where it was applied by the natives to the manufacture of clothing, cordage, and mats before the arrival of Europeans. It has been introduced into southern Europe and northern Africa. It grows in the open air in the southern parts of England and of Ireland; and is grown in the United States in greenhouses.

Etymology. - Phormium is from the Greek фopuós, wicker-work, or a basket, in reference to the use made of the fiber of the leaves. Tenax is Latin, signifying "tenacious," due to the strength of the fiber. New Zealand flax, the common name, indicates the country where it is found native. 
History. - The plant was liscovered in New \%ealand, and carried to Europe by Captain Cook in 1773, and described by linnaus. It is found wild and also under cultivation in its native country.

Preparation. - The leaves are cut into strips, and the outer green part scraped off; the fibers are then separated and kept straight, and are washed, rubbed, and bleached in the sun; it is then creany white, and has a silky luster. While growing, it resimbles the American agave or century-plant.

Use. - It is used in New \%calaud for falrics for garments, and for cordage, and enter's into commerce as a material for cordage and coarse hagging. It is also used to adulterate the fiber of the musa textilis in the manufacture of manilla cordage.

ALOE, L. Perianth tubular, contracted above, straight or slightly curved, 6-lobed at the summit, nearly closed. Stanens 6, inserted below the ovary, exserted; filaments awl-shaperl, as long as the perianth; anthers linear-oblong, introrse, 3-celled, many-oruled; style thread-like; stigma small; capsule leathery, oroid or oblong; seeds numerous, 3-angled or flattened, 3-winged; testa membranaceous and black. Leaves thick, fleshy, in two or three series, crowded near the base of the stem, lanceolate, ends curved down; margins dentate; teeth armed with spines; scape terminal. Flowers yellowish.

1. A. vulgaris, Lamarck. (Aloes.) Stem peremnial, 2 to 3 feet high, 6 to 8 inches in diameter, 'rowned with a dense cluster of leaves, bases wide, lower ones spreading, upper ones more erect, lanceolate, thick, theshy, concave ahove, convex beneath; margins toothed; teeth armed with hooked prickles; surface of the leaf smooth, dark green or mottled; scape either simple or hranched, rising from the crown of leaves, terminated with a slender spike of flowers; bracts triangular, acute, longer than the perlicels, veined, and persistent. Stamens 6, a little longer than the perianth; anthers small, oblong. () vary oblong-oval, bluntly triangular, 3-celled, doulble row of ovules in each cell; style as long as stamens; stigma terminal. Fruit oblong-ovoid, blunt eapsule, an inch long, 3-celled; pericarp thin, hrown, smooth ; seeds numerous, Hattened; testa thin and membranaceous. Flowers yellow, tinged with green.

1. A. socotrina, Lam. This species differs from the last in a taller stem, which, as it grows old, becomes forkedly branched, with tufts of leaves at the smmmits of the branches, prickles on the leaves. l'erianth an inch and a half long, red or pinkish, with greenish-white tips, part of the stamens extending heyond the perianth.

3. A spicata, I. f. Stem about 3 feet high. Leaves enveloping the base of the stem, curverl, and then deflexed, abont 2 feet long. Hat near the base, becoming nearly cylindrical near the end, armed with strong. sharp, triangular prickles, with sereral small ones at the summit. Flowers bright orange-yellow. Stameus louger than periantlı; style louger than stamens.

There are in all about so species of this genus, natives of the hot regions of the Old World. But the aloe of commerce is the product of the species above described, and of other's whose hotanical characters have not been determined, and whose home is not known. 
Geography. - The aloe is a tropical and subtropical plant, and may be cultivated in all regions of no frost. It is found in southern Asia, Arabia, southern Europe, and northern Africa; but it abounds in south Africa, near the Cape of Good Hope. It is largely cultivated in the British West Indies.

Etymology. - Aloe, the generic name, is said to be derived from alloch, an Arabic word. The Greek for the same is à ${ }^{\prime} \eta$; and the Latin, aloe, whose figurative meaning, "bitterness," seems to suit the case, for the name could not be more appropriate. Vulgaris, the specific name, is Latin for " common." Socotrina is from the Island Socotra, where it was formerly cultivated. Spicata, Latin for "spike-bearing," alludes to the form of inflorescence. Ferox, Latin for "wild," in this case signifies " coarse" and "strong."

History. - The aloe was known to the Greeks and Romans; it was mentioned during the first century by both Dioscorides and Pliny. Its home is Asia and Africa; and it has been carried to the West Indies by Europeans. and is cultivated there.

Preparation. - There are three kinds of aloe known in commerce, namely: Cape aloes, Barbadoes aloes, and the aloes of Socotra. The Cape aloes is obtained from the leaves of $\mathrm{A}$. spicata and $\mathrm{A}$. ferox, and perhaps other species. The leaves are cut from the plant and set into vessels to drain; the sap, or juice, is evaporated in iron vessels over a fire; when reduced to a thick syrup, it is poured into vessels to cool, in which condition it is sent to market in large cases. At a temperature below $40^{\circ}$ Fahrenheit, it is hard and brittle; at a higher temperature, it runs like pitch. The Barbadoes aloes is the product of the A. vulgaris, which is under cultivation in that island, and in Jamaica.

The juice, or sap, having been drained from the leaves, is stored in casks until the collecting is over, when it is evaporated in copper kettles to a syrup, then poured into gourds holding from three to seventy pounds, and thus sent to market. This kind was first sold in London in 1693.

Socotrine aloes is manufactured somewhere in the interior of Africa, taken to the ports on the Red Sea, and thence to Zanzibar, from which place it is sent to Bombay, where it is purified and shipped to England. Where the plants grow that yield it, or how it is prepared, is not very well known, but it is very certain that the drug does not come from Socotra.

$U$ se. - Its medicinal properties are, when administered in small doses, stimulant, tonic, stomachic, and anti-bilious. When taken in large doses, it acts violently upon the bowels, producing drastic purgation. It was formerly extensively used in complaints of the liver.

In Africa cords and nets are made of its leaf-fiber. Its juice has been used in embalming, and as a varnish to protect against insects.

Note.-The aloe of the Bible is a different plant. The reference made in the Bible to aloe is always to the wood, and not to the plant; and it is believed that the resinous wood known to the Egyptians and western Asiatics was the product of a tree found in eastern Asia, Aquilaria Agallocha, Roxb., of the order Thymeleaceæ. The wood is very valuable, mostly for its fragrance when burned. It sells in Bombay as high as $\$ 3.00$ per pound for fine specimens.

\section{Order LX. PALMAE.}

Flowers small, diœcious or monœcious, seldom perfect, sessile or on short pedicels ; perianth double, persistent, leathery, formed of a calyx and calyx-like corolla; sepals 3 , distinct or coherent; petals :3, usually 
distinct, valvate in the bud of the male flower, imbricate in the female; stamens hypogynous, or perigynous, 6 in two whorls, opposite the sepals and petals. Inflorescence axillary. Fruit a berry or drupe, with smooth or scaly epicarp; sarcocarp Heshy, oily or fibrous; endoearp membranous, fibrous, woody, or bony. Seed oblong, ovoid, or spherical. Leaves springing from the terminal bud, alternate, base of petiole sheathing the stem, petiole convex below; blade pinnate, fan-shaped or simply split. Perennial woody plants, mostly beautiful and majestic trees. Trunks often tall and slender.

No. of genera, 132 ; species, 1100 ; tropical and subtropical.

ARECA, L. (Betel Nut. Feather Palms.) Flower's monœcious, small, numerous, sessile, bractless, spadix branched. Staminate flowers very numerous; calyx with 3 small ovate seginents; petals 3 , much longer than the calyx, broadly ovate, smooth, thick, and yellow; stamens 3-6; filaments short, red, and attached to the backs of the arrow-shaped anthers. Pistillate flowers with a calyx of 3 ovate rigid sepals; petals 3 , like the sepals, but thimner. Ovary large, 1-celled, one ovule in each cell; stigmas 3 . Fruit two and a half inches long, containing a single seed an inch long and two thirds of an inch in diameter, somewhat in shape of a nutmeg, distinctly marked by a network of red veins, which penetrate the mass and give a marbled appearance to the internal structure. A tree produces about 300 nuts. Leaves pinnately divided.

A. catechu, L. (Betel Nut.) Stem slender, 40 to 60 feet high, 18 to 20 inches in diameter. Fronds 3 to 4 feet long, all terminal. Leaflets numerous and opposite.

Geography. - The geography of the areca is tropical and subtropical. It has spread through the Sunda Isles, the Philippines, Cochin China, Sumatra, and southern India, and has names in each of these countries which point to the probability that it is

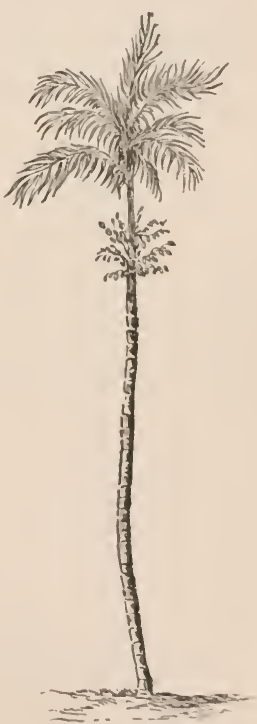

Arfea Catrcho

(Betel-nut). native to all these localities; but there seems to he insufhicient evidence to locate its home in any one of them. It grows best on plains and terraces.

Etymolog!y. - Areca is from arec, the name applied to the young tree in Malabar. Cutechu was applied to this species because it was erroneously supposed to yield the gum catechu. The fruit is callerl betel nut, because the leaf of the piper betel is used in connection with it. Feather Pu/m allncles to the feathery appearance of the leaves, and is applied to several of the genera of this order.

History. - When the betel nut was first nsed as a masticatory is not knowu; it was in use in the East Indies when the country hecame known to Europeans, and its use upon state occasions dates back to the fourth century. 
Use. - When the unt is in an unripe state it is cut into slices and wrapped in the leaves of the piper betel, with a little lime, and in this condition it is chewed. It affects the nerrous system, somewhat in the same manner as tea, coffee, and cocoa; it is stimnlant and astriugent, and is said to check perspiration and alleviate fatigue. When used moderately it is supposed to preserve the teeth, and to fasten them when loose in the gums; but used to excess it destroys the teeth, causing them to crumble and waste away and eventually it causes the death of its rictim. It is of rery general use among the inhabitants of southeastern Asia, extending to all classes, and it is offered to guests un state aud other ceremonial occasions. It is carried in a box, frequently of gold or silver, or ornamented with precious stones, corresponding to the suuffbox used for tobacco snuff.

A liniment made of the juice from the leaves, mixed with oil, is considered a specific in lumbago; the nut is also a reputed remedy for tape-worm.

PHOENIX, L. (Feather Palm.) Flowers diøcious, very small, in large clusters, emerging from a spathe or fleshy shield; number of flowers in a spadix sometimes reaching 12,000. Staminate flowers oblong or ovoid ; calyx cup-shaped, 3-toothed; petals 3 , oblique, oblong, or ovoid, slightly attached at base ; stamens 6 , sometimes $: 3-9$, inserted on the base of the corolla ; filaments awl-shaped ; anthers linear, oblong, erect, and attached to the filaments along their backs. Pistillate flowers with a rotund calyx; stigma sessile. Fruit oblong, terete, 1-seeded. Pericarp fleshy; seed hard, somewhat cylindrical, plane on one side and convex on the other, with a groove extending the whole length of the plane side, from half an inch to an inch in length, having sweet, nutritious pulp. Leaves all terminal, pinnate.

P. dactylifera, L. (Date Palm) Stem 30 to 60 feet high, 12 to 18 inches in diameter, scarred with the marks of fallen leares, which are pinnate, glaucous, 8 to 10 feet long; leaflets lanceolate, acuminate, pinnæ close together. Flowers in branching spadices, the main flower stem long, the heavy mass of flowers causing it to bend downward, each cluster of the female tree bearing from 150 to 200 dates; each flower produces three, two of which are usually abortive. The fruit has a vinous, gummy, sugary taste.

There are twelre species of the phœnix, but the only one of importance as a food plant is the $\mathrm{P}$. dactylifera. The varieties of this species are very great; it is propagated by seed and sports freely, producing varieties which differ from each other in the size and quality of the fruit.

Geography. - The geographical distribution of the date is throughout the hot and arid region between $15^{\circ}$ and $30^{\circ}$ north latitude, from the Atlantic coast along the fringes of the great deserts to the river Indus, and on the oases of the Sahara. It can grow in a higher latitucle, but refuses to ripen its fruit except in a very high temperature. The tree itself will live just in the edge of the region of no frost, but will not fruit, nor even flower. Somewhere in the above-named region it had its origin, but no naturalist has been able to name the spot. Accorling to Loudon, the date derives its generic name, Phonix, from the fact that the best dates were brought from Phœnicia. But if fine dates came from Thonicia, they must have been carried there from further south, for the temperature of the most southern part of Phonicia is too low to ripen the date. They may have been taken from Arabia or from 
more southern parts of Syria, ly earavans, to the seaports of Syria in early times, and shipped there for sonthern and western Enrope.

The date-tree is becoming rare in Syria. It is common near $\Lambda$ cre, skirting the lagoons and erowning the sandhills which ahound there. 'The city of P'almyra got its name from this tree, which is still abundant in its vicinity. It was the symbol of Palestine in the time of the lews. It arlorned the merlals of Vespasian and Titus, as emblems of the country. It is now carefully cultivated near laffa.

Etymology. - The derivation of Phonix, the generic name, las been given. Dactylifera is from the Greek $\delta a ́ \kappa \tau v \lambda o s$, finger, from a fancied resemblance of the fruit to the portion of the finger lietween the joints. Date, the common name, is said to be a corruption of dactyl, and is also claimed to be a sianscrit word signifying " fruit," or " finger fruit."

History. - The date has been culti. vated as a food plant since prehistoric times. 'The ancient Egrptians understood the sexes of the trees, and learned to assist nature by taking the pollen from the male to the female tree. Cakes of dates have been found in the tombs of Thebes, one of which is preserved in the British museum. The ancient llebrews must have been alcquainted with the date, though it could not have been among the fruits of ['a]estine, for it is only indirectly referred to in the scriptures. The tree grows in Judar, and it is said that the fruit ripens as far north as Jerusalem. Bethany, which is near Jerusilem, signifies "the home of clates." It hats been represented as a tree delighting in dry and arid regions, hut recent investigations reveal the fact that it requires an abundant supply of water ; and wherever it is found, even in the

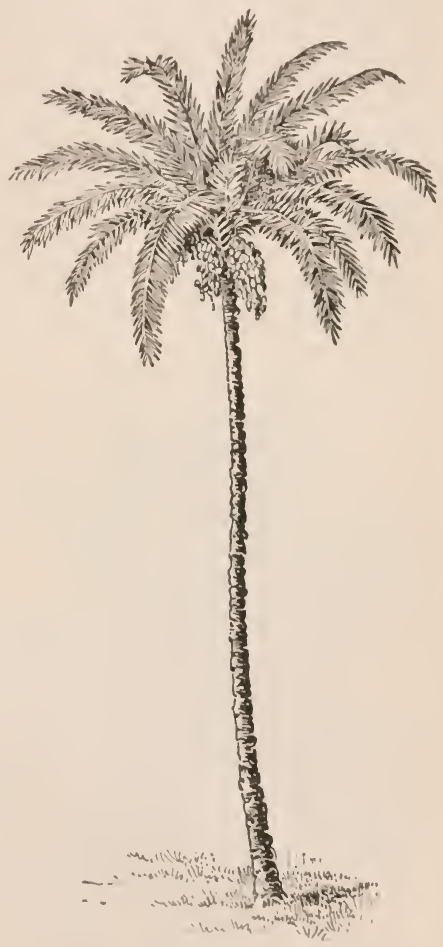

Phanix dactylifera (Date Palm). miclst of the desert, it inlieates the presence of surface springs.

Culticution. - It is artificially fertilized by shaking a hranch of staminate flowers over the pistillate inflorescence.

I'se. - The date is eaten raw in all rases, and furnishes the only foud for thonsands of the inhabitants of the region where it grows. It is conserved with sugar, and packed in hags made of the leaf. It is said that the native Arah will exist for days without inconvenience on a few hamblfuls of this fruit, while his camels are content with date-stones, this may serve to indicate the remarkable anomut of nutriment which the date (ontains.

The uses of the leaf and stem are somewhat similar to the uses to which the cocos is applied. Date trees are employed as articles of trade and dower. 
cocos, Linnæus. (Feather Palm.) Flowers monœecious, on the same spadix. Spathe simple, woody, spindle-shaped; staminate flowers on the upper part of the spadix, and the pistillate ones below. Calyx of the staminate flower 3-leaved; sepals lanceolate, keeled, and frequently united at the base; corolla 3-parted, membranous or fleshy, usually erect. Stamens 6 ; filaments awl-shaped, nearly equal in length; anthers linear and erect; calyx of the pistillate flower ovate or sub-orbicular, 3-leaved; sepals convolute; corolla 3-parted; petals membranaceous, imbricated; ovary ovate or flattened-globose, 1-celled; style short or wanting; stigmas 3. Fruit ovate-elliptical or 3-sided, outer coating thick and fibrous, 6 to 12 inches long, and 4 to 8 inches in diameter. Seed nearly globular; testa horny, marked with three spots at the top. Large palms; trees with a crown of feathery leaves.

C. nucifera, Linnæus. (Cocoanut Palm.) Trunk 50 to 100 feet high, and 1 to 2 feet in diameter. Leaves springing from the terminal bud, alternate,

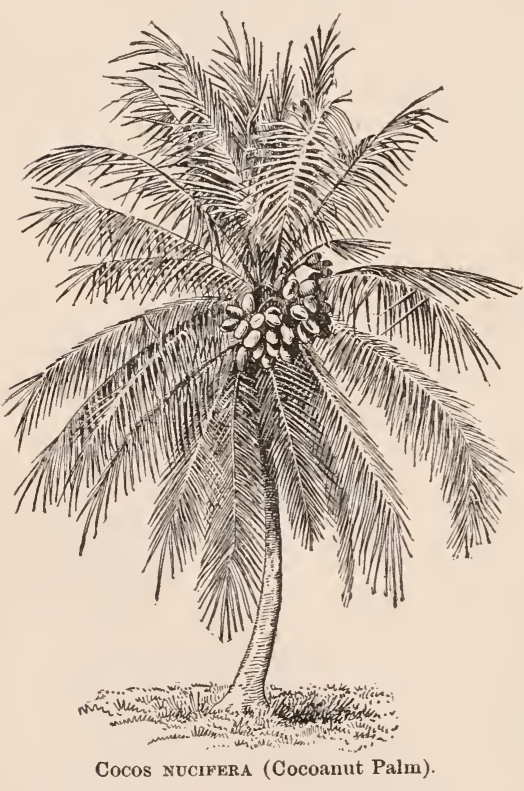

pinnate, sheathing at base; pinules with decurved margins. Flowers enveloped in a spathe. Fruit in elusters of 10 to 20 , 3 -sided, tapering to a blunt point, 6 to 9 inches long and 3 to 5 in diameter; outer husk fibrous, enveloped in a smooth, glossy cuticle; the whole an inch or more in thickness. Seed a prolate spheroid, 4 to 5 inches long and 3 to 4 in diameter, inclosed in a horny shell, rough on the outside, and one fourth of an inch thick, inside of which and adhering to it is a coating or wall half an inch thick, hard, white, crisp, oily, and edible; the cavity within is filled with a rich, limpid liquor, which is very grateful to the palate. I single tree sometimes has upon it 120 of these gigantic nuts at one time.

There are about thirty species to this genus, all tropical or strictly subtropical.

Geography. - The geographical zone of the cocoanut is equatorial, extending twenty-five degrees both sides of the equator in seacoast regions. It is found in higher latitudes, but does not fruit well above $25^{\circ}$, except in localities especially favored by a high temperature, - a temperature which is seldom below $75^{\circ}$ Fahrenheit. It abounds in the coast regions of Brazil, on the West India Islands, the western and eastern coast, and islants of Central America ; 
it is extensively grown in Ceylon, and in all the coast countries of soutbern Asia, especially in Farther India and southwestern ('hina, and delights in a sea exposure.

Etymology. - Cocos, the generic name, is supposed to be derived from the P'ortuguese word coco, a monkey, lue to the three spots on the end of the nut, which make it resemble the face of that animal. It is also believed to come from the Greek word ко́ккоs, a fruit or berry. Nucifera, the specific name, is compounded of the two Latin words, nux, a nut, and fero, bear, and signifies "nut-bearing." Cocoanut, the common name, is made up of coco and nut.

History. - It is on record that this fruit, if not the tree, was known to the ancient Egyptians centuries before the beginning of the Christian era. Columbus found it growing in Central America ou his fourth voyage to the New World. 'The Arabs were acquainted with it, and their physicians wrote of it during the Middle $\Lambda$ ges. It has Indian, Arabic, Persian, and Malay names, showing it to be native in those countries four thousand years ago. The bulk of evidence is that the home of the cocoanut is the East Indian Archipelago, whence it has suwn itself, by means of the ocean currents, on the coasts of eastern $\Lambda$ frica and the far off shores of western America. The character of its fruit is highly favorable to its distribution by sea; and its preference for the seacoast leads to the inference that it has drifted across the ocem and been thrown upon the isles and low shores, where it has become naturalized, - the seed being covered by a strong shell, and the whole inclosed in a light, porous husk, which is impervious to water, on account of a smooth, glossy cuticle which envelops it.

Use. - There is not another individual of the whole regetable kingdom which furnishes so many useful substances to man, no single tree of the vast flora of the world is so completely utilized, as the cocoanut palm. Its products are : sugar, milk, solid cream, wine, vinegar, oil, cordage, cloth, cups, timber for building, and materials for implements of husbandry, furuiture, baskets, mats, and culinary utensils. The inhabitants of large districts subsist almost exclusively upon its fruit alone. The shells are used for goblets, oruamented with carving.

In Cerlon a man's credit and commercial standing is measured by the number of cocoannt trees he has in his plantation.

The frnit is largely used in America and Europe for the preparation of dessert dishes, as pies, custards, cakes, and confections; and the desiccating of the cocoanut has become an important inclustry in the eastern Iuited States. The oil of the nut is treated to extract the stearine which is employed for the mamnfacture of eandles; the more fluid parts are used for salad dressings, for illuminating purposes, and for the manufacture of soap. Soap made with this oil is so soluble as to make it eapable of use in sea water. Imong fibrous plants the cocos holds high rank. The fiber of the husk (coir) is em. ployed in the manufacture of floor cloths, door mats, strings, bags, brushes, hrooms, and many other artieles for donestic use. It dues not decay un water. The leaves serve for thateh, and their strong midribs are divided into splints, and woven into baskets.

METROXYLON, Rottb. (Feather Paln.) Flowers polygamous. Staminate flowers with funnel-shaped calyx, 3-toothed; corolla 3-parted, lapping each other; stamens 6, inserted on the base of the corolla: filaments united at the base; anthers linear and dorsi- 
fixed. Pistillate flowers much like the staminate ones; ovary oblong, 3-celled, conical, with 3 tooth-like stigmas ; ovules 3. Fruit ellipsoidal or subglobular, 1-celled, 1-seeded ; pericarp clothed with scales, imbricated. Leaves terminal, nearly erect, pinnatisect; segments usually opposite, linear-lanceolate, acuminate; petiole convex underneath, furrowed above. Spadix large, branched, loose; spathe leathery. Flowers immersed in a woolly covering, small.

M. sagu, Rottb. (Sago Palm.) Trunk 30 to 50 feet high, and 6 to 15 inches in diameter, straight, cyliudrical, gray, while young armed with strong, sharp spines to protect it against the attacks of the wild hog; these spines fall off when the rind has become hard. Outer coat of the trunk hard, inner part spongy. Leaves few, crowning the stem; entire leaf, including petiole,

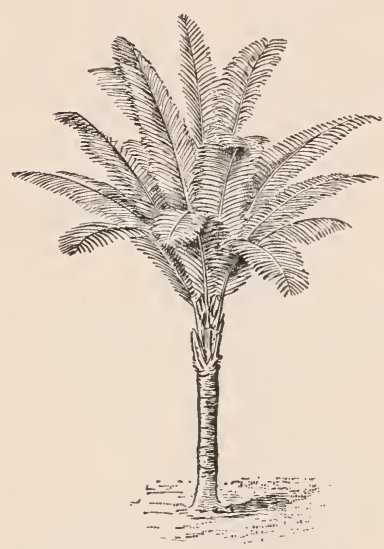

Metroxylon sagu (Sago Palm). about 20 feet long, erect, slightly curved; petiole 6 to 8 inches in diameter near the base, clasping; rachis square below, and keeled or triangular above. Leaflets many and opposite, middle ones longer, straight, stiff, narrow, linear-lanceolate, acute, entire, leathery and smooth, 3-veined, bright-green above, pale beneath. Flowers unisexual or perfect, sometimes mixed in the same spadix, numerous, small, each with three small bracts, smooth within, covered on the outside with a yellowish wool, and in the axil of a strong smooth bract. Inflorescence in a cylindrical, dense spike, 4 inches long. The whole inflorescence consists of numerons spikes arranged along on 6 to 9 main stalks, which crown the tree, making a center-piece for the leaves. Calyx rigid, smooth, and 3-lobed; corolla much larger than the calyx, cut into three obtuse, thin segments : stamens 6 , as long as the corolla, and inserted on it at its base; ovary short-stalked, imperfectly 3-celled, 1 ovule in a cell; style conical, tapering, pointed. Fruit one and a half inches in diameter, spherical, mucronate at summit, clothed with greenish-red scales. Seed solitary, enveloped in a dark-brown testa. The tree matures in from 15 to 20 years, when it flowers and fruits and dies. 'The seeds seldom mature, and the tree is propagated by stolons.

There are six species of this palm, but the sago of commerce is obtained from the following species :-

M. sagu, M. spinosa, and M. lævis.

Gengraphy. - This tree is found only in the tropics, in the hottest and wettest parts of Asia. It flourishes throughout the Fastern Archipelago, extending about 10 degrees both sides of the equator, abounding in swampy localities.

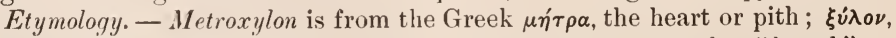
wood or tree; hence pith-tree. Sagu is the Malay name for "bread" or "food." Sago is a corruption of sugu.

History. - There is no reason to believe that the ancients were acquainted with the product of this tree. When the East Indies were first visited by 
Europeans the sago constituted the principal foud of the natives of Malacea, southern China, and the adjacent isles.

Preparation. - The tree grows best in a muldy log. An acre yields about 300,000 pounds, and a single tree produces about 500 jounds, - a very large tree, 900 pounds. It is cut at the foot, just as it is abont to fruit, which occurs when the tree is from fifteen to twenty years ols. 'The top is taken off, and a strip of the shell or outer coating is removed the whole length of the trunk, and with an instrument (onstructed by fastening a sharp stone to a stick the pith is removel, leaving a thin shell not more than an inch thick. 'The pith is kneaded in water, in large troughs, by which process the starch or sago is washed out and sinks to the bottom; the water is then run off. This starch, or sago, is then made into balls or rolls, which weigh thirty pounds each, when it is ready for use, as crude or raw sago. The natives make it into cakes, and bake it, in which condition it will keep for years, and when used it merely needs suaking. One tree will produce sufficient food to keep a mau for a year.

There are several varieties of the sago, due to different methods of preparation. Pearl sago, the variety which reaches the American market, is prepared in Singapore by the Chinese; the raw sago is matle into a paste, forced through sieves and dried in pans over fire, and constantly stirred while undergoing the process.

Use, - Sago furuishes the inhabitants of Malaysia and southeru Asia a food material equal in importance to rice in other parts of Asia. Many millions know no other food but fish and the crude sago.

In Europe and the United States it is a popular material for puddings and custards. It is pure starch, free from all irritating character, and hence constitutes an excellent food for infants, old people, and convalescent invalids.

The leaves are used for thatching; the leaf-stalks, immense in size, furuish building material, and the fiber is used for cordage; in fact, all parts of the plant are applied to some use.

\section{Order LXI. GRAMINEÆ.}

Flowers perfect, occasionally monœcious or dinecious, sometimes polygamous, each mostly with 2 opposite bracts or palere, the lower of which is larger. Inflorescence in spikelets, the spikelets varionsly collected into panicles or spikes. Perianth imperfect, seltlom wanting, composed of whorled hypogynous, membranous, or fleshy, irregular scales, free or commate, 3,2, or 1 in number, the onter alternate with the palex. Stamens hypogynous, 3 or 6 in number, seldom $4-2$ or 1 ; ovary free, 1 -celled, 1-ovuled; styles 2 . very rarely 3 , free or connate at base, or united: stigmas with simple or branched hairs. Leaves alternate, springing from the nodes; petiole dilated, convolute, sheathing; sheath split in front, blade entire, mostly linear; stipule axillary at the top of the leaf-sheath. Stem cylindrical, rarely flattened. fistular or solid, mostly jointed at the insertion of the leaves; nodes anmular, solid, and swollen.

Annuals or perennials, with fibrous or creeping rhizome, frequently stoloniferous at the lower node. 
Some of the cultivated species of this order are not known in a wild state. Number of genera, 1,298; species, 3,200; found in all parts of the world. Our most useful plants belong to this order. The stems and culms of most of species are largely composed of silicates.

ZEA, L. Flowers monøecious; staminate flowers in terminal panicles; pistillate flowers in 1-3 axillary spikes; staminate spikelets 2-flowered, with 2 concave glumes, the lower one 3-nerved, the upper one 2-nerved. Paleæ membranous and without arms, the two collateral and fleshy scales glabrous. Stamens 3 in number, and the linear anthers 4-sided. Pistillate flowers with very short glumes on an axillary spike, which is inclosed by many spathe-like bracts; these form the husk by which the fruit is protected. Style simple, very long, thread-like, far exserted, and hanging.

Z. mays, L. (Indian Corn, Maize.) Stem or culm from 3 to 15 feet high, 1 to 2 inches in diameter, composed of bundles of woody fiber imbedded in pith; the whole inclosed in a smooth, flinty cortex, terete, grooved on one side with a smooth, semi-circular channel, and divided into nodes whose intervals are from 5 to 9 inches long, crowned at the top with a compound panicle of staminate flowers called "the tassel." Root fibrous; the stem throws off aerial roots from the nodes next to the ground, which are called "brace roots."

The pistillate flowers are borne on a close axillary spike, inclosed in a mass of spathe-like bracts, called "the husks," and are characterized by the elongated, filiform styles, which extend far beyond the orifice of the bracts and hang in tresses over the ear or head, like bundles of silk threads; they are called the "silk." The leaf appears at the nodes, clasping the stalk by striate sheaths, which are eared, from 2 to 4 feet long, and from 2 to 4 inches broad, linear-lanceolate. There are no radical leaves.

Fruit a flat, reniform or cuneate-shaped seed, arranged in rows on the rachis, which is from 5 to 12 inches long, and called the "cob"; the number of rows on a cob varies from 8 to 14 , with from 20 to 50 seeds in a row. The cob ranges from three fourths of an inch to two inches in diameter.

Flowers in July or August, and ripens its fruit in September and October.

In common with other plants grown from seed, it sports and forms varieties which depart from the specific character in color, size, and shape of the grain and quality of the meal made therefrom. The gourd-seed varieties are in every way larger, and the seeds not so hard and flinty. The flour-corn has reniform seed, but is softer, and is used largely in the Southern States for bread. The gourd-seed varieties are raised in the South and West. The eight-rowed flint, hoth white and yellow, are grown in New York and the eastern Atlantic States north of New York.

The number of forms resulting from free sporting is very great; about 30 of these are sufficiently characteristic and constant to make species, and would be so regarded if ontside of cultivation.

Geography - Indian corn is now cultivated and is an important crop in all the United States, Upper Canada, Mexico, South America, southern Europe, Africa, and western Asia. It does not grow well above the forty-fifth parallel, but flourishes best below the fortieth, and delights in a hot, sunny clime. 
Tropical and subtropical countries seem to be the lands of its birth. As it hecomes acclimated farther north, the ears diminish in size, and the whole plant hecomes dwarfed. In the warm regions it reaches the height of 12 to 15 feet; in Maine and sonthern Canada it ranges from 3 to 4 feet. The ears in Canada seldom exceed 8 inches in length, while in the southern United States the length is from 8 to 15 inches.

Etymology. - Zer is from the Greek $\zeta^{\prime} \omega$, live, alluding to the capacity this grain has to sustain life. Mays and maize are derived from mahiz, the name by which the American aborigines called this plant, - the meaning of which is obseure. Indian corn is a name given by Europeans, on account of the use of the plant by the aborigines of America.

History. - This cereal is undoubtedly of American origin. Attempts have been made to show that in an old Chinese book found in the national library in Paris there is a figure of a plant identical with corn; and hence the inference is drawn that it is also indigenous to Asia; but there is good reason to doubt that it was known in the Old World before the discovery of America, or before Columbus introduced it into Spain in 1520, twenty-eiglit years after the discovery of the New irorld. Humboldt and other good authorities do not hesitate to say that it originated solely in America. In a marvelously short time it spread over southern Europe, northern Africa, and western Asia, showing conclusively that lad it been known in Asia it wonld have reached Europe before the discovery of America. It is found in the tombs of the ancient Peruvians, and in the mounds of the Mississippi. C. Darwin found it buried with shells fifty-five feet above tidewater. It is nowhere found wild, propagating
itself.

Cultivation. - Maize delights in a light loam, which cannot be male too rich by fertilizers. In the well-worn lands of the Atlantic States large supplies of fertilizers are necessary to abundant crops; but in the rich allu-

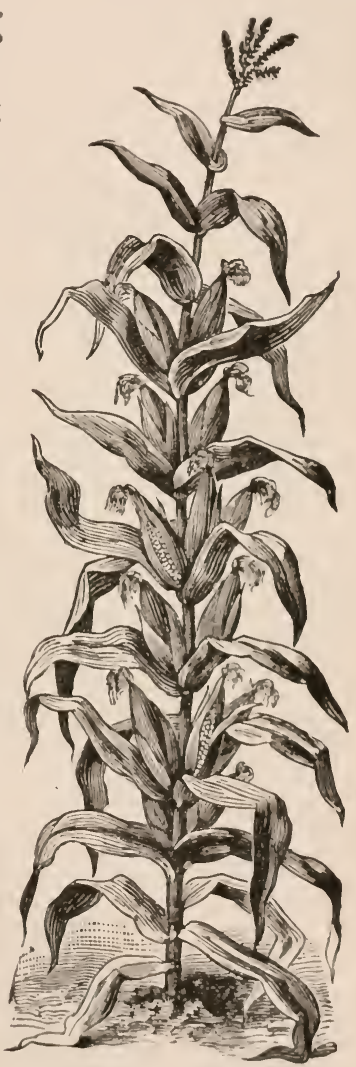

YeA MAYs (Indian Corn). vial bottoms of the Mississippi Valley nothing is needed to insure an abundant harvest but to plough and plant, and stir the soil. It is planted in the intersections of cross-drills, four feet apart each way, by dropping four to five grains in a place and covering with a hoe. In the itlantic states from thirty to forty bushels to the acre are a satisfactory yield; fifty and seventyfive bushels are frequently reached; in the hottom lands of the Mississippi
Valley, sixty to eighty bushels are not uncommon.

In the Atlantic States north of New Jersey the yellow and white flint rarieties are grown, but in the lowlands of New. Jersey and further south the 
gourd-seed varieties are planted, which require a longer season than the climate north of central New Jersey affords.

Use. - As an article of food, Indian corn is used for bread, mush, griddlecakes, puildings, dumplings, etc. When merely cracked, it is called "samp," and is prepared for the table by boiling and serving like a vegetable, or by boiling it with salt meats. IVhen coarsely ground it is called "hominy," and is cooked aud served as oatmeal, and eaten with milk or sauce.

Lange quantities of starch are manufactured from it, both for the table and the laundry. It is also used in large quantities for distilling, and is the chief material for manufacturing the celebrated Bourbon whiskey.

But the most important use made of this grain is as feed for cattle, sheep, horses, and swine ; it excels all other feed for its fattening properties.

The leaves and upper parts of the stalks are good substitutes for hay, and the cobs are excellent fuel. The quantity of corn raised in the United States exceeds the amount of all the other cereals combined. It yields the largest returns of all the cereals.

Marts. - The great marts of North America are Chicago, Buffalo, St. Louis, New Orleans, New York, and Sau Francisco, in the United States, and Toronto in Canada.

TRITICUM, L. Spikelets from 2- to many-flowered, in a stout spike. Florets distichous; rachis zigzag; glumes nearly opposite, not quite equal, sometimes with awns; imner paleæ herbaceous, lower one concave and sometimes awned or mucronate, upper one with 2 aculeate and ciliate keels. Scales 2, usually entire and ciliate. Stamens 3. Ovary sessile, crowned with 2 plumose stigmas.

T. vulgare, L. (IVheat.) Stem or culm 2 to 5 feet high, tapering from the root to the base of the head or the ear, divided by nodes into several internodes, or lengths, from 4 to 7 inches long. At each node is a single, clasping, lance-shaped leaf, strongly veined and rough on the upper side. Flowers appear at the top of the culm in a close panicle.

The grains, or seeds, are oval in shape, a quarter of an inch in length, flat, and marked on the side next the rachis by a groove the whole length, outside convex. It is an annual, and when planted in early spring, it flowers and fruits the same season; when thus cultivated it is known as "summer wheat" or "spring wheat." The best wheat is biennial ; it is planted in early autumn, in time to take root and form root or radical leaves before winter sets in ; it ripens in July of the following year, and is called "winter wheat," because it remains in the ground during the winter.

As wheat is grown from the seed it sports or produces new forms; growers have taken advantage of this circumstance to obtain improved varieties, and very many such varieties have from time to time been recommended by wheat growers, especially in Europe and America. The varieties under which the forms may be classified in America are :-

Var. hybernum. Winter Wheat. T. hybernum, L.

Var. æstivum. Summer Wheat. T. æstivum, L.

Var. nudum. No-bearded Wheat.

Var. album. White IVheat.

Var. rubrum. Red Wheat, or Mediterranean Wheat.

There are many other forms, all referable to the above, which are sufficiently constant to be cousidered varieties. 
T. compositum deserves to be treated as a species, and in all respects resenbles ' $\mathrm{T}$. vulgare, except that the stalk is thicker, and the heal branching. It is grown in northern $\mathrm{Africa}$ and in southern Itals, and was no doubt the wheat of the ancient Hebrews and the Romans.

Geography. - Wheat dues not grow well north of the fifticth degree of north latitude in Nortl America, nor south of the thirtieth degree. In Europe it grows well in southern Russia below $51^{\circ}$, and is cultivated with success throughout central aud western Europe, and as far sonth as southern Italy. It is also cultivated successfully in 'Turkey, Syria, northern and southern $\Lambda$ frica, and in the south temperate zone in South America, - in Brazil, Chile and Buenos Ayres; also in Australia, where it constitutes the most important olject of agriculture. The great wheat-growing regions of the world are the southwestern plains of Russia, the great central plain of North America, the sonthern plains of ('alifornia, and recently, northern India and England.

Etymology. - Triticum is from the Latin verb tero, whose participle is tritus, rubbed, - alluding either to the practice of rubbing it to separate the grain from the chaff, or to the mude of grinding it into flour. The specific name vulgare is the Latin for "common." 'The worl wheat, the conmon name, is supposed to be derived from the sanscrit sereta, meaning " white," and arises from the circumstance that the flour made from this grain is white.

IIistory. - No form of wheat, nor any species closely resembling it, has ever been seen wild. It must, therefore, either have been very much altered from the original wild grass, which tradition and probability wonld lead one to consicter a native of some part of central $\mathrm{Asia}$; or else, by reason of changes of climate in the country of its origin, it has become extiuct as a wild plant. In favor of the latter supposition in preference to the former is the fact that, like otlies. anmul cereals, the wheat shows very little tendency to vary. The forms cultivated in ancient Egypt, in China, and in l'alestine,

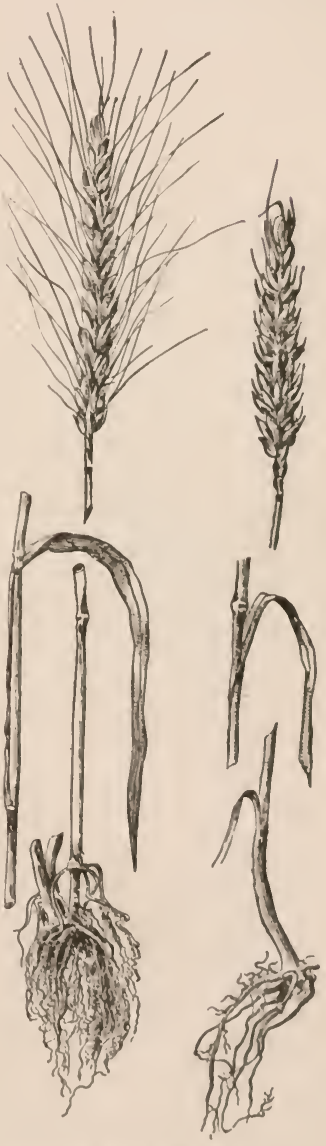

Triticom VUlgare (Wheat). appear to be illentical in all respects with those we are now faniliar with. The home of the wheat is generally helieved to be western $\mathrm{Asia}$, in the comtries watered hy the l'igris and Eiphrates, whence it has found its way into every favorahle clime where agriculture is practiced. Among the ancient Egyltians, and the inlabitants of I'alestine, Mesogutamia, and northern syria,

PR. Fl. -20 
it was the most important crop. In the western hemisphere wheat was not known until the sixteenth century. Humboldt mentions that it was accidentally introduced into Mexico with rice brought from Spain by a vegro slave belonging to Cortes, and the same writer saw at Quito the earthen vase in which a Flemish monk had introduced from Ghent the first wheat grown in south America.

Cultivation. - Wheat is a true patrician ; it will not thrive upon scanty fare, nor flourish without attention. It is what agriculturists call a gross feeder; it not only demands a deep, heary soil, but the soil must be well tilled and highly fertilized in order to satisfy this prince of the cereals. Without these conditions it refuses to rield largely, but responds with liberal harvests to generous cultivation.

In the rich buttom lands of the Mississippi valley, the southern plains of California, and the wheat-growing lands of southeru Russia, nothing is needed but to prepare the ground and sow the seed to insure a large yield; but in old and long cultivated districts the most careful attention to suitable fertilizers is necessary to secure even moderate crops. The yield per acre varies from ten to sixty bushels. In the well-worn fields of the Atlantic states the yield is frequently not more than twelve bushels, and thirty bushels is a very satisfactory crop. In the rich alluvial soil of the central states the yield frequently reaches fifty bushels, and sometimes sixty. The quantities vary with soil, climate, and mode of cultivation.

A notable case of high farming was brought before the court in ancient Rome. A farmer was accused of sorcery for raising better crops of wheat than his neighbors. When the accused appeared before his judges, who sat in the open air, he brought with him and exhibited his agricultural implements, superior in construction, his well-fed oxen, and his callous hands. Pointing to his cattle and implements, he exclaimed: "Here, O Romans, are my tools of witcheraft, which I employ to make my crops." His judges pronounced him innocent, reprimanded his accusers, and advised them to follow his example.

$U$ s . - A bushel of wheat weighs 60 pounds and will make 47 pounds of flour, leaving 13 pounds of middlings, bran, and waste.

This grain now constitutes the staple food of most of the civilized peoples of the earth. The flour is made into bread, cakes, puddings, pastry, crackers, biscuit, etc., and is so well known as to need no further description. 'The Jews were acquainted with the making of leavened bread, which they no doubt learned while in Egyptian bondage. When leavened bread was first used, and who first made it, is nowhere recorded. Homer speaks of leavened bread at the time of the Trojan War. Pliny states that there were no public bakers in Rome until about 200 years before Christ.

The straw of wheat is used for the manufacture of hats for both men and women. The fine Leghorn straws are manufactured from the stalks of the wheat collected while green, and bleached in the sun. Wheat is sometimes used as a forage crop. A variety has been introduced from Japan which seems to be very useful for this purpose.

Marts. - The great wheat markets of the world are: Odessa, on the Black Sea ; Riga, on the Baltic; the North German ports; Constantinople; London and Liverpool, in England; Chicago, San Francisco, and New York, in the United States; and Toronto, in the Dominion of Canada.

ORYZA, L. (Rice.) Spikelets 1-flowered, in compound panicles; flowers perfect, with 2 rery small, bristle-formed glumes; paleæ 2 in 
number, boat-shaped and flattened, the lower one broader, and tipped with a straight awn; stamens 6 in number; stigmas clothed with hairs.

1. 0. sativa, L. (Common Rice.) Stem from 2 to 5 feet high, somewhat like the culm of wheat, with shorter internodes. Leaf linear, elungated, and rough. Flowers in cluse panicles. Branches erect, from 5 to 10 inches long, outer pale, strongly reined and keeled; hispid ciliate, terminating in an awn. Grain white, somewhat fusiform, compressed, slight grooves and ridges extending lengthwise, one fourth of an inch long, and about an eighth of an inch in diameter. Flowers in July; fruits in August and September.

Besides the sativa, we have the following species:-

2. 0. præcox, Eurly Rice.

3. 0. mutica, The mountain Rice.

4. 0. glutinosa, Clammy Rice.

These last three and several others are said to be well-marked and constant species; but as rice is grown from the seed, it sports freely, and many varieties have arisen.

Geography. - Rice grows well in all the low lands of the tropics where alternate flooding and drying can be effected, and in the temperate zones as high as the thirty-sixth parallel. In India there is a species, $O$. coarctata, that grows upon the uplands, and as high above the sea as 4,000 feet. It is extensively cultivated in China, Japan, the East Indies, especially in the southern parts, in Japan and the islands of the Indian Ocean, and in Africa, having been introduced into Egypt in the days of the caliphs. It has in later years been raised sparingly in southern Europe. The mountain or upland rice has been successfully grown in Hungary. It is planted and successfully grown in South America and in the southern United States.

Etymology. - The word oryza is Latinized from eruz, an old Arabic or Sanscrit word, which signifies "grow," and is supposed to have been applied to this plant on account of its prolific character. Sativa, the specific name, means "sown," or "cultivated." The common name rice is supposed to be a corruption of the botanic name.

History. - There is no record that reveals the time when rice first became a food of the human family. It is one of the cereals yearly sown by the Emperor of China; the first record of such sowing was made in the year $2800 \mathrm{Br}$. C. The little that is known about it, early history points to sonthern $A$ sia as the land of its nativity. Alexander the Great brought it to the notice of the

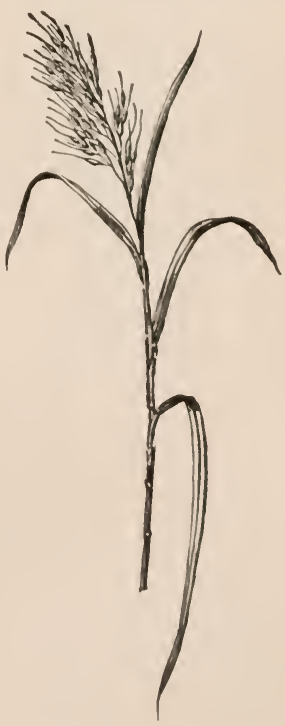

Oryza sativa (Rice). Greeks on his return from his expedition to India $330 \mathrm{~B}$. C. Its cultiration in Italy dates from 1468 of the present era. Since anything has been known of Asia, rice has constitnted the principal food of all classes in that country uot ouly on the continent, but also ou the adjacent islands. 
The growth of rice in America dates from about the year 1700. It is related that a vessel from Madagascar entered one of the ports of South Carolina, believed to be Charleston, and the captain of the vessel presented Mr. Woodward, a settler, with a small quantity of seed rice, which he planted. Soon after this occurrence Mr. Dubois, the treasurer of the East India Co., sent to Carolina a bag of rice. From these two small quantities of seed, coming from different countries, sprang the three varieties of rice grown in America, one of which is now the farorite in the markets of America, as well as in Europe, and is pronounced the best in the world.

Rice of excellent quality is raised in the Sandwich Islands, most of which is brought to the United States via San Francisco.

Cultivation. - The mode of culture is to prepare the ground, plant the seed in drills a foot apart in the row, with the rows far enough apart to work between them in keeping the ground free from weeds. After planting, the field is flooded for some days, and then the water is drained off. When the plants make their appearance above the ground the water is again let on to kill the young weeds. After two or three weeks, in the month of April, the water is again withdrawn, and the ground kept free from weeds with the hoe. When the plants are some eight inches to a foot in height, late in August or early in September, the water is let on and left till the grain is ripe. Then the water is finally withdrawn, and as soon as the ground is sufficiently dry, the crop is reaped, bound in sheaves, and taken to the high land to cure and to be threshed.

A continuation of rainy weather about harvest time, which frequently occurs in southern India, renders the rice crop uncertain there. In 1770 the crop failed, or was destroyed, and ten million persons died of starvation; in 1860 one and a half million persons perished from the same cause.

Use. - Rice, in the United States, is used in many ways : it is prepared by boiling in water and eaten as a vegetable; cooked with milk and eaten as a porridge for dessert; baked with milk and eggs for dessert puddings; ground into flour and used to thicken soups and gravies; and also made into griddlecakes. It is said that the modes of cooking rice in the East are very numerous ; but the masses of Asia boil it in the most simple manner, and eat it without any sort of dressing.

Rice, in India, China, Japan, Egypt, and the islands off the coast of Asia, forms the principal article of food for more than five hundred million persons. The greater part of the teeming millions of Japan, China, and southern India seldom taste any other food. It furnishes food for a far greater number of people than any other plant. Rice does not possess the nutritive qualities of the other food grains, being constituted largely of starch; it should not be eaten until six or eight months after harvesting.

SACCHARUM, L. (Sugar Cane.) Spikelets panicled, in pairs, one pedicellate, and the other sessile, spikelets made up of $\mathbf{2}$ flowers each, at the base of which is a tuft of long silky hairs; lower floret without stamens or pistils, a single bract at the base; upper floret perfect; glumes 2, equal, and without awns; stamens 1 to 3 ; ovary sessile, glabrous; styles 2, elongated; stigma plumose; hairs simple and toothed. Fruit free, perennial.

S. officinarum, L. (Sugar Cane.) Stem or culm 10 to 20 feet high, composed of a strong cortex filled with a pith, charged with a sugary substance. 
Internodes short. Leaves flat, linear-lanceulate, clasping, like the leaves of maize. Flowers in a panicle, 2 feet long; racemes threacl-like, erect, and spreading, elothed with silky hairs.

Sugar cane grown from the seed sports freely, hence there are many species. - The following have been found growing withont cultivation : S. contractum, S. polystachyum, S. dubium, S. rubicundum, S. atrorubens, S. fragile.

Geography. - The sugar cane is a tropical and subtropical plant. The geographical range is a belt extending around the earth, including the torrid zone and some twelve additional degrees both north and south of the tropics. The West Indies, Brazil, Mexico, and the southern United States, in America, the Isle of Mauritius, southern India, the islands of the Pacific, and northern Australia protuce most of the sugar of commerce. In the Lnited states, Louisiana is the sugar-producing region. A small part of Mississippi, and also of Missouri, produce cane.

Etymology. - The name succharum is from the Arabic name sakkar, sukkar, corrupterl into sugar. The specific uames are all the to some characteristic of the plint; as, officinarum, of the shops; contractum, smallness of the whole plant, etc.

History. - The sugar cane is a native of Cochin China; but where it was first brought under cultivation is not known. Circumstances point to India. It is known that the Venetians imported it thence by way of the Red Sea as early as the midlle of the twelfth century; and previous to the discovery of America it was grown "upen the islands of the eastern Mediterranean, - having been introducerl by the Saracens, and carried to sonthern Spain by the same enterprising people. Soon after the discovery of the Wrest Indies the Dnteh manufactured sugar in the Isle of Sit. Thomas, in 1610 , and the English, in 1643, commenced its mannfacture in Barbadoes and Jamaica. Pliny and Galen both speak of sugar as " sweet salt," which was used at that time as a medical

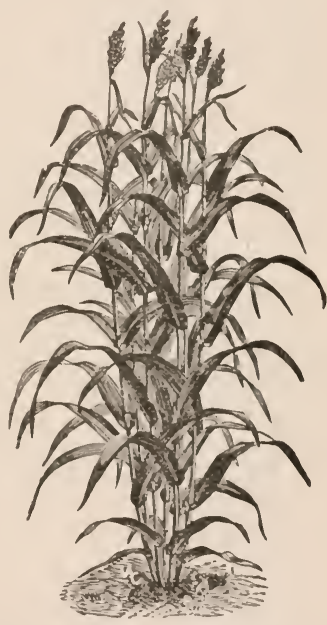

SACCHARUM OFFICINARUM Sugar Cane). remedy. It was first sulstituted for honey in eompounding medieines br Actuarius, a physician of the tenth rentury, and was then called "Indian salt," which points to Inclial als the country of its origin.

Five humlred rears ago sugar as an article of food was not known in Europe, now it is one of the necessaries of life throughout the civilized world, and has largely superseded honey, whose sweetness was so much extolled by the ancients. Alout the end of the sixteenth rentury the l'ortuguese began to import it from Brazil; it was then nsed in medicine or as a great delieacy.

Up to 1872 the varioty known as the Creole had heen enltivated in the United States to the exclusion of all others. It was found to have greatly degenerated, and this led to efforts to introduce new varietiss. Mr Iapice. one of the largest aml most experienced sugar planters, visited the liast Indie: and the islands of the l'acifie to examine the rharacter and endition of the cane. Selecting what seemed to him the hest, he sent home a shiploaded 
with 11,000 cuttings of new varieties. No report has thus far been made of the comparative productiveness of the kinds introduced.

A few years ago thirty-two varieties were sent from Mauritius to the British West Indies; about one half of these proved to be constant, and worthy of the attention of sugar-growers. Besides these forms there are many others, which are either sports or modifications, due to the effects of soil, climate, and mode of culture.

Chemistry. - Saccharose or cane-sugar yields to the chemist carbon, hydrogen, and oxygen, $\mathrm{C}_{12} \mathrm{H}_{22} \mathrm{O}_{11}$, and has a specific gravity of 1.60. It crystallizes in prisms, which are phosphorescent when broken or electrified. Its solutions turn polarized light to the right, and are hence called dextrose. It fuses at $310^{\circ} \mathrm{F}$.; it is soluble in water, and slightly so in alcohol.

Preparation. - Sugar is obtained by crushing the cane between grooved rollers, whose grooves are armed with iron. The expressed juice is then evaporated in pans at a low temperature and in a partial vacunm. $\mathrm{By}$ the use of lime, charcoal, etc., it is refined. The drainings and uncrystallized parts are molasses and syrup.

The cane, after passing through the press, is soaked in water, and the strainings and rougher parts of the molasses are mixed with the water; then it is allowed to ferment. It is then distilled, and produces rum. Large quantities of sugar are obtained from the beet in Europe, and from the maple tree in America. (See Beet, and Sugar Maple.) The sugar of China is obtained from sorghum.

Use. - Sugar is so well known that a description of its use would seem superfluous. It is found on our tables in some form at every meal. It is a perfect preservative for fruits of every description, and the principal ingredient in all confectionery. In fact, few articles of food have attained so wide a usefulness.

Propagation. - To preserve the constancy of species and varieties, the cane is propagated from cuttings either from the upper nodes of the culn or from the rootstock. The new varieties are seedlings, though the plant seldom matures seed in a state of cultivation.

SORGHUM, L. Spikelets panicled in twos or threes on the spreading hranches; the middle spikelet 2-flowered, perfect, lower flower abortive; side spikelets sterile, without awns; pedicels usually smooth. Glumes leathery. Stamens 3. Anmual.

S. saccharatum, I. (Broom Corn.) (Andropogon saccharatum, Pers.) Culm 6 to 9 feet high, solid, with pith intermingled with woody fiber like Indian corn, about $\frac{3}{4}$ of an inch in diameter. Leaves $1 \frac{1}{2}$ to $2 \frac{1}{2}$ feet long, $2 \frac{1}{2}$ inches wide, lanceolate, acuminate, smooth, pubescent at the base; panicle 2 feet long, branches simple or nearly so; flexuons, rongh, with short hairs.

This plant is propagater from seed, hence it sports freely, producing many varieties.

Geography. - Sorghum grows best in the warmer parts of the temperate zone, but will mature its seed in eastern Massachusetts. It is grown in southern India, northern Africa, southern and middle Europe, and throughout the United States of North America.

Etymology. - The word sorghum is derived from sorghi, the Indian name of this plant, the meaning of which is obscure. The common name, broom corn, 
arises from the use to which the rigid hranches of the panicle is applied, i.e., the making of brooms. Saccharatum owes its name to the fact that this species is used for making sugar.

History. - Sorghum is native in the middle of Africa, and was taken to England in the latter part of the cighteenth century, whence it was brought by colonists to eastern North America, where it has for many years been cultivated. It has also been cultivated in Egypt, Abyssinia, and the Deccan.

C'se. - Sorglum was grown formerly in the eastern Lnited States for the manufacture of brooms, and in the South for feed for cattle. $\Lambda$ coarse meal is made of the seed, which is ferl to poultry. I) Iring recent years it has been used for making syrup and sugar.

The government of the United States his given much attention to this plant, in order to ascertain its value as a sugar prodncer, in comparison with that of the cane. Mr. Leonard Wray claims that varieties grown in Natal compare with the sugar cane in the ratio of five to six; that is, where the cane yields thirty, sorghum vields twenty-five. It is cultivaterl in France and French $\Lambda$ frica for the production of alcohol, and in Italy for a syrup used in doctoring wine.

SECALE, L. Spikelets 2-flowered, crowded into a cylindrical spike: florets sessile, distichous, perfect, with a linear rudiment of a third terminal floret. Glumes subopposite, nearly equal, keeled, and sometimes awned. Paler herbaceous, the lower one awned, and keeled with unequal sides, outer side broader and thicker, the upper palea shorter, 2-keeled; scales 2 in number, entire, ciliate; stamens 3 ; orary sessile, hairy; stigmas 2, subsessile, terminal, and plumose; hairs lengthened, simple, and sharply denticulate; grains hairy at the top. Spike simple, compressed, and linear.

S. cereale, L. (Rye.) Stem hairy near the head, and ranging from 3 to 5 feet in heigbt. Leaves lance-linear, edges and upper side rough, glaucous. Heals ahout 5 inches long, linear, flattened. Palce lower, ciliate on the keel and margin. Awns rough and ciliate, long, straight, erect. Annual and hienuial.

There is lut one species under cultivation, S. cereale; but, like all plants grown from the seed, it sports, and the varieties are numerous, though far less attention has been paid to its cultivation in that lirection than to wheat.

Geography. - The geographical range of rye is the colder parts of the temperate regions of the world, between $48^{\circ}$ and $69^{\circ}$ north latitule all aromd the glohe, where the cereals are cultivated. In northeastern Initel States it is an important erop for brearl; in the central states it is largely raised for distilling. It grows well, and is the great cereal of northern Europe, and especially of the sandy districts

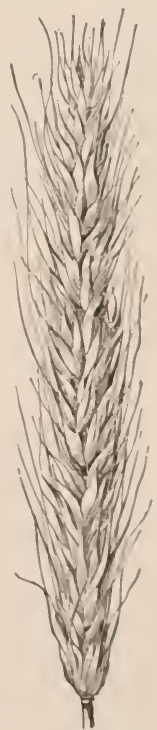

Secale cereale

(Rye). of the Baltic provines, and the shores of the finlf of Finlancl

Rye of an excellent quality for bread making is arrown upon the great plain on Iong Islamel. Williau Cobbet, who in his lay ownel a large tract 
on the northern edge, near the west end, boasted that his rye bread was better than, and nearly as white as, the Englishman's wheaten loaf. Cobbet named his place Hyde Park, a name it still retains.

Etymology. - The word secale is supposed to be derived from the Celtic word sega, a sickle, or from the Latin seco, cut, in allusion to the sharp, rough edges of the leaves. The specific name, cereale, means "bread-corn" or "bread-material," from Ceres, the goddess of food plants. The common name, rye, is from the Anglo-Saxon ryge.

History. - We have no positive knowledge when rye was first cultivated. It was spoken of by writers in the first century of our era. It is native to southern Russia, and the regions north of the Black and Caspian seas. To the North German, the Pole, the Norwegian, the Swede, and the Russian, rye is what wheat is to the inhabitant of southern Europe, the Briton, and the American.

It was used largely in England in early times, probably having been introduced by the I)anes and Saxons. The wheat introducerl earlier by the Romans was regarded as a delicacy, and its use was confined to a few. History relates that among the npper classes in Great Britain hospitality was a prominent feature, and when visitors came, the most lavish profusion was exercised in their entertainment. Among the delicacies proffered on such occasions was wheat brearl; but when the gnest prolonged his stay, he began to be treated as a member of the household, and the rye bread was returned to the table. At first this was taken as a compliment, but it finally came to be understood as a hint that the risit had been sufficiently long. Hence the proverb: "Do not prolong your visit till the rye loaf comes on."

I'se. - Bread, cakes, biscuit, and puddings are made of rye; in fact it is applied to most of the purposes for which wheat is nsed. In the central states rye is extensively used in the manufacture of whiskey. In Holland it is mixed with both barley and buckwheat for distilling; the liquors thus produced are called "Hollands," and when flavored with juniper berries, they form gin.

Rye is an excellent feed for cattle, and especially for cows when giving milk.

HORDEUM, I. (Barley.) Three spikelets at each point of the rachis, each 1-flowered, the side florets sometimes abortive; glumes linear-lanceolate, flat, stiff, awn's awl-shaped; paleæ herbaceous, lower one concare, terminating in an awu. upper one 2-keeled; scales 2, sometimes 2-lobed, ciliate, sometimes smooth; stamens 3; ovary sessile, hairy at the top; stigmas 2, nearly terminal, and sessile. Caryopsis terminating in a hairy summit. It is an annual, flowering and fruiting the same season it is sown.

1. H. vulgare. L. (Barley.) Culm or stem 2 to 3 feet high, smooth. Leaves linear-lanceolate, keeled, and striate, smoothish, eared at the throat; heads 3 inches long, stout, 4-sided, sometimes somewhat 6-sided, lower paleæ crowned with long awns, serrulate on the margin; upper paleæ obtuse or emarginate. Flowers in May. Fruits in Jnly.

2. H. distichum, L. Stem 2 to 3 feet high. Leaves like the last. Hears about 4 inches long, flattened, and 2-ranked. Husk attached to the ripe grain. Flowers in. Tune, and ripens in last of July to August. 
Like other plants raised from the seed, it sjorts freely, and varieties are numerons; but the two species here described are pretty constant, and little attention has been paid to improving or perpetuating varieties, especially in America. The distichum ripens later, and is in some places preferred for that reason.

In Europe the following species are also grown :-

3. H. hexastichon, Six-rowed barley.

4. H. zeocriton, Battledoor Barley.

Barley stands next to rye in importance as a food plant. Its characteristics as to cultivation so resemble those of wheat and rye that little needs to be saicl abont them. It is, however, a more gross feeder than rye, and will not vield heavily without high tillage.

Geography. - Barley grows and ripens over a larger geographical range than either wheat or rye. It ripens and yielks generous erops in latitudes where no more than two mouths in the year are free from frost. It grows well in northern Russia and siberia, where the ground thaws out only to the depth of two feet, and even less. It will ripen also in warm climates, even in the regions of no frost, but delights in a short, hot summer, such as eharacterizes the higher regions of the temperate zones, and like wheat and rye is to be found an enigrant to all the cereal-growing abodes of eivilized man.

Etymology. - The name hordeum is derived from the Latin hordns, heary, because bread made from it is usually heary. The specific name vulgare signifies "common," and distichum, "two-ranked." The common name, borley, is supposed to mean "bearded grain."

History. - The ancient home of the grain is not known. A traditional history of barley among the Egyptiaus makes it the first grain used by man. 'They hold that their godiless Isis

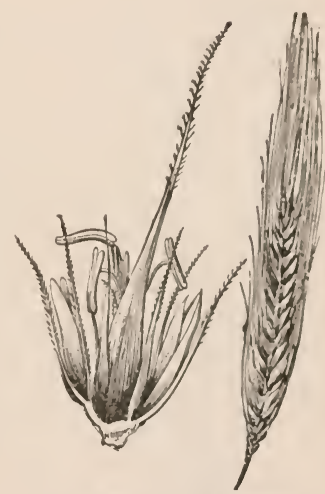

Hordeum vUlgare (Barley). tanght men its use. It was anong the food plants used by man as far back as we have any history of human customs.

A six-ranked barley, II. hexastichon, cultivated by the ancients, has been found in Fgrptian monuments and in the Iake-rlwellings of Switzerland, in deposits belonging to the Stone $\mathbf{I}$ ge. A species known to the ancient Greeks, and denominated the "sacred harley," was used to decorate the hair of the godiless Ceres. Some make its native eomtry 'Tartary, while others claim that it is indigenoms to Siberia. IIistory hears out the belief that its home is in the middle parts of the temperate zone in western $\Lambda$ sia. It does not fruit without cultivation; when it escapes cultivation it ceases in a year or two to ripen its seed, and is lost. In fact this is the ease with other cereals, and is looked upon as a great mystery ; it does not favor or bear ont the doctrine of development, for the other species under this genus refuse unler the most careful cultivation to he anything more than ordinary forage grasses. Barley among the Romans was used for freed for horses and eattle, and it also constitnted the bread-erain of the plebeian classes. l'liny informs us that the gladiators were called "hordearii" (barley-eater's), from the circumstance that they subsisted on barley. 
Use. - Barley at the present day is not largely used as a bread plant. It is regarded as a valuable fattening feed for cattle. In England and Germany it forms the beer-making grain. In Holland and north Germany it is used for distilling, and is the principal grain from which whiskey and Hollands are distilled.

It is used to thicken soups, and sparingly for porridge and cakes. Pearl barley is prepared by removing the hull, and is cooked as rice is. In northern Scotland and adjacent isles it is an important bread grain, and with oats constitutes a large part of bread material.

Marts. - For Russia the principal markets are Odessa on the Black Sea, and Riga on the Baltic; for Turkey, Constantinople and Rodosto on the Sea of Marmora; for France, Marseilles on the Mediterranean, and Havre on the English Channel; for Germany, Hamburg on the Elbe, and Bremen on the Weser. In the United States the markets are local, being confined to brewing centers, as Chicago, Cincinnati, Milwaukee, etc.

AVENA, L. Spikelets panicled, each having 2 to 5 flowers; glumes 2 , loose, membranous, and without terminal awns, about as long as the paleæ, the lower one usually toothed at the top, with a twisted awn on the back; the upper one awnless, with two keels; scales forked and large; stamens 3; stigmas 2, sessile. Fruit subterete, sulcate on the upper side, summit hairy. Annual with pendulous spikelets, or perennial with erect spikelets.

A. sativa, L. (Oats.) Stem 2 to 4 feet high, smooth. Leares about a foot long, linear or linear-lanceolate, nerved and rough; sheaths striate and loose, ligulæ cut; panicle loose and nodding; spikelets all with peduncles, and hanging; lower floret usually with an awn on the back, upper one awnless. Annual. Flowers in July. Fruits in August.

Oats, like wheat and the other cereals, have a tapering stem and numerous root leaves, and possess the same habit of tillering; but the plant is wholly different in its inflorescence and the form of its head, which in wheat, rye, and barley is a compressed spike, or compound compressed spike, whose spikelets are sessile. In the oat the head is a loose panicle; the branches near the base of the head in some cases are four inches long, decreasing towards the top, forming a pyramidal or conical-shaped head. Some varieties have the branching all on one side, and on that account are called one-sided or secund oats.

As this grain is raised from the seed, it departs from the specific form, producing varieties.

The A. sativa, however, is very constant, and little or no attention has been given to the perpetuation or improvement of its varieties. A large-grained secund form and a black-seed variety have in turn attracted the notice of cultivators, but neither of these has become constant enough to gain importance.

Geography. - The geographical range of oats is not so great as that of any of the cereals before described. It endures a colder climate than any other, but does not fill well south of the fortieth parallel in the north temperate zone; in the regions of no frost it does not fruit, except in elevations far above the sea.

Etymology. - Avera, the botanic name of the oat, was given by Linnæus, and is supposed to be derived from the Celtic word aten, eat. The specific 
name sativa means "sown," "rr " cultivated," Uuts, the common name, is supposed to come from the Anglo-Saxon word ata, food. These derivations are not entirely clear, but are the most probable.

History. - The native country of this grain is supposed to be west-central Asia and east-central Europe. It was known to the ancient Greeks and Romans, and was used by them to feed horses and cattle It also covstituterl the food of the slaves and plebeians. It was fomd in the Swiss Lake-dwellings and in the ancient tombs in Germany.

Thongh it possesses less nutritive material than either wheat or rye, it has held and still holds an important place as a food plant. It is found upon the tables of the rich, as well as of the poor in (ireat Britain, northern Europe, and in the United States and Canada. As a feed for live stock it is as highly valued in the British Isles as is maize in the Cniterl States.

In attestation of its ralue as a bread plant as well as for feed, the following aneclote is in point. 1)!. Johnson, the English lexicographer, had a ileejrooted dislike for the Scotch, and lost no opportunity to make it manifest. At one time, in conversation with a Scotch gentleman, Dr. Johnson remarked that oats were a grain that Englishmen fed to their horses, but that Scotchmen ate it themselves. To which the gentleman with characteristic Scotch readiness replied: "Indeed it is true; but see what horses you have in England, and what superior men we have in Scotland."

Cultivation. - Oats need a generous soil to rield large crops. The ground is prepared by the plough and harrow; the seed is sown broadcast in most countries, though in Scotland it is sown in drills and worked with a hoe. It is sown as soon as the frost leaves the ground in the early spring, and ripens about the first of August. It fills best where the lays are sumny and the nights cool. The market value of oats varies according to quality; northern oats, so-called, - that is, oats grown in a cool climate. - are preferred. In good soil and a cool climate an

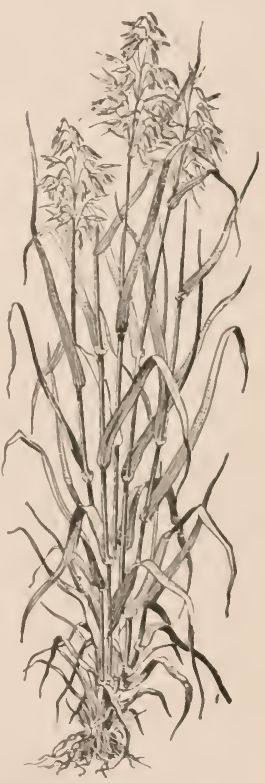

Avena sativa (Oats). arerage yield is forty-five bushels to the acre, hut sixty bushels is not an uncommon vield.

Use. - In Seotland, Irelaud, and the north of Europe, especially in Norway, oats constitute a large portion of the hread material. They are used as a porridge, cooked with milk, or male into a thick pulding and eaten with milk; they are also eaten in the form of gridllle-cakes or "scons." In most countries where horses are used, oats are the staple fecl. Ordiuarily they are best when ground; hut the trainers of race-horses prefer to feed the nats to them in the grain, since, when thus fed, the horse needs no hay, or not so much.

The grain of oats is largely composed of starch ; it contains also sugar. gum, and oil. About 12 per cent of its substance is a proteid, known to chemists as arenine, a substance rescmbling casein. It is mixed with harley in the manufacture of whiskey. Its chaff is used for filling beds. 
SETARIA, Beauv. (Millet. Bengal Grass.) Inflorescence a spikelike panicle; spikelets 2-flowered, surrounded by persistent bristles; the upper floret perfect, lower one staminate or neutral or wanting; lower glume usually short. Stamens in the perfect flowers 3 , the collateral scales truncate, fleshy, and smooth. Number of styles 2, terminal, elongated. Stigmas plumose; inflorescence a spike. Seeds free and compressed.

S. Italica, Beanv., Var. Germanica, Kunth. Stem or culm 2 to 5 feet high, terete, leafy. Leaves from 6 to 15 inches long, linear-lanceolate, broad, flat, and finely serrate on the edges, clasping the stem in a striate sheath; spike compound, yellowish or purplish, oblong, ovoid, or somewhat cylindrical; rachis hirsute, hairs long. Flowers in July. Fruit ripens in August.

Geography. - It grows well where oats and rye can be successfully cultivated ; it has escaped in America, and is ranked among the weeds when without cultivation.

Etymology. - Setaria is from the Latin word seta, a bristle, on account of the bristly character of the spikelet involucres. The specific name Italica denotes the plant's home; and the name of the variety indicates that it arose in Germany. Millet is from the French millet, diminutive of mil, the old Freuch name of the plant. Bengal grass is named from Bengal, where this plant is native.

History. - Setaria is one of the grains which the Emperor of China sows at a public ceremony which has occurred annually since $2700 \mathrm{~B}$. C., and it is believed to be native to China, Japan, and India. Its cultivation spread toward the west through Russia. It is found in the Swiss Lake-dwellings of the Stone Age. It is either completely naturalized or native to western Asia, southern Europe, and Egypt. Though cultivated for forage, it is so inferior in every way to oats that little attention is paid to its improvement. There are a number of species, but the var. Germanica is altogether superior to the others.

Use. - This plant is grown in Italy for seed, used to feed caged birds.

\section{Order Lxit. CONIFER}

Flowers in catkin-like spikes, monœcious or diœcious, naked, or without floral envelopes. Staminate flowers composed of autherbearing scales; catkins longer than broad. Pistillate catkin more or less conical, subglobular-or cylindrical, with few or many flowers, occasionally 1-flowered; ripenerl catkin becoming a strobile or conical subglobular body, formed of woody, imbricated scales, bearing 1 many naked ovules, with 2-15 cotyledons. Seed in most cases furnished with a membranons wing, sometimes solitary, in a fleshy cup. Leaves simple, needle-shaped, alternate, linear or lanceolate, in some cases in groups, inclosed at the base in a membranous sheath, resinous. Trees or shrubs.

No. of genera, 32 ; species, 300 ; temperate zones and mountains.

PINUS, I. Evergreen trees, ranging from 30 to 100 feet in height. Leaves linear, grouped, 2 to 5 in a group, very rarely solitary, inclosed at the base in a scaly sheath. Male flowers grouped in catkins. 
Female flowers in cones mostly ovate, their scales dry, thickened at the tips and spiny, inclosing ¿2 ovules. Cotyledons :3 or none. Flowers appear in spring; seeds mature in the autumn of the following year.

Travellers and naturalists speak of the pine forests of Carolina and Mississippi as possessing an unsurpassing romantic beauty. The tall trunks rising 50 to 70 feet without a branch, with no undergrowth to break the view, the branches festooned with the gray tillandsia mingling and contrasting with the deep-green foliage, give the appearance of a rast decorated roof supported by a cotutless number of graceful columns, which, fadting away in the dark distance, present a scene whose beauty is exceeded only by its grandeur. These valuable pine forests are undergoing rapid destruction, and unless some mode of economic forestry be at once adopted, this valuable timber will soon be exhausted.

1. P. monophylla, Torr. and Fremont. (Single-leaved Nut-pine.) Simall tree, branching irregularly, forming an unsymmetrical head. Bark pale, and falling off in plates. Leaves solitary, tapering, $1 \frac{1}{2}$ inches long, terminating in a spine; sheaths one third to half an inch in length. Male flowers inclosed by 6 bracts; cones nearly globular, about 2 inches in dianeter; seeds long egg-shaped, half an inch in length, shell thick, yellowish-brown; cotyledons 10 or less.

Geography. - The nut-pine is an American tree; the zone of growth is between the parallels of $30^{\circ}$ and $45^{\circ}$ north latitude. It grows along the eastern slopes of the Sierra Nevada mountains, at great elevations, in arid localities.

Etymology. - Pinus is derived from the Latin pimus, a pine-tree. Mono-

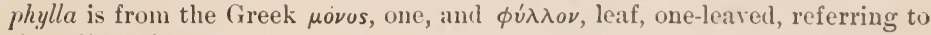
the solitary leaf.

Use. - The tree is of no value in planted grounds on acconnt of its small size and irregular branching. 'The wood is hard, and makes excellent fuel ; it is too small for use as lumber. The frnit is sweet and edlible; it constitutes an important article of food for the wandering aborigines of the l'acific slope. It is collected and sold to passenger's on the line of the Northern Pacific Railway.

2. P. Austriaca, Hoffm. (Anstrian Pine.) Synonym, P. nigra, Link. Stem from 80 to 120 feet in height. When growing in open grounds it forms a subcylinitrical head, branching regularly, though the branches are crooked. Bark grayish. Leaves long, rigid, slender, mucronate in twos, incurved, and inclosed in short, dark-green sheaths; cones 2 to 3 inches long, curved, lightbrown; scales smooth, shining, armed with a blunt spine.

Geography. - Its geographical range is Lower Anstria, Carinthia, Styria, and the neighboring regions.

Etymology. - The specific name, as well as the common name of this tree, is from the comtry where it is fonncl native, Austria.

History. - It is not long since it was bronght to the notice of nurserymen and planters. Its fine head, harty character, and deep dark-green foliage have brought it into favor.

Use. - The tree is valuable for ormamental purposes, and is fomul in most planted grounds. The wood is good for lumber and for fuel. 
3. P. strobus, L. (White Pine. Weymouth Pine. Apple Pine. Sapling Pine. New England Pine. Pumpkin Pine.) 'Trunk 50 to 160 feet in height, from 3 to 7 feet in diameter. With other timber the stem frequently rises to the height of 80 feet without a branch. Branches whorled in the young trees. Bark light gray. Leaves 3 to 4 inches long, bluish-green, in fives, and glaucous, forming a soft, beautiful foliage ; sheaths deciduous ; cones 5 to 6 inches in length; scales 1 to 2 inches long, one half to three fourths of an inch wide; seed less than a quarter of an inch in length, obovate, tapering to a point below with a wing; cotyledons 6 to 5 .

Geography. - It is native to all parts of North America, from the Atlantic west, reaching as far sonth as Virginia.

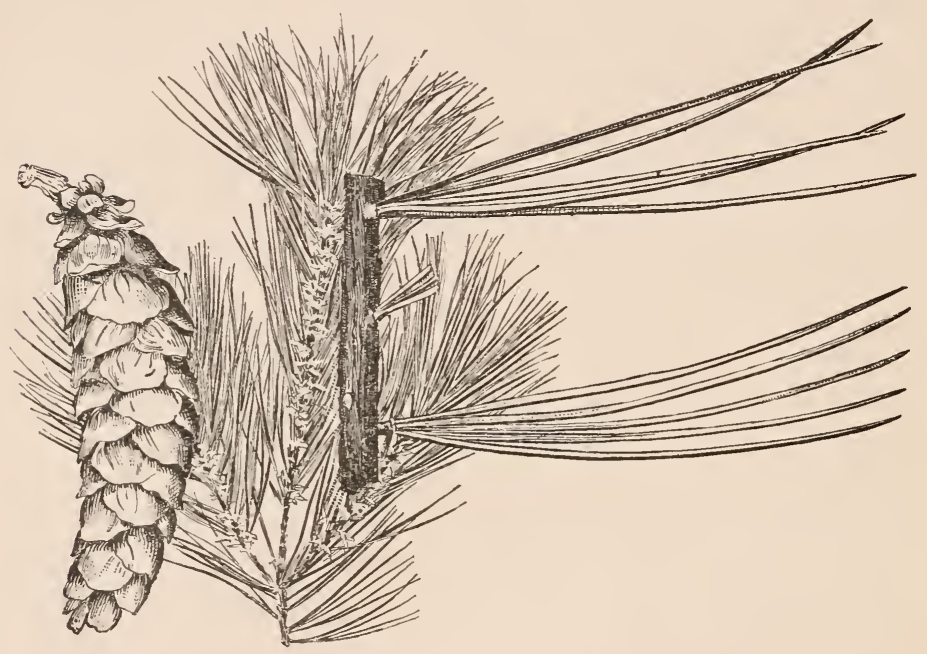

Pinus strobus (White Pine).

Etymology and History. - Strobus is the Latin for an odoriferous gum. It was successfully grown in the grounds of Lord Weymouth (England), and was hence called Weymouth pine. It was introduced into England in 1705.

Use. - This tree is a symmetrical grower; it forms a beautiful object, and produces a pleasant contrast with other evergreens in planted grounds.

The wood is fine-grained, white, and free from resin, strong, easily worked, takes a good polish, and does not warp easily. It is highly prized in carpentry and in joiner's work. The woodwork of the insides of dwellings, doors, sashes, floors, wainscoting, etc., are largely composed of white pine. It is the most valuable lumber tree in the United States.

4. P. mitis, Mx. (Yelluw Pine. Spruce Pine.) Synonym : P. variabilis, Pursh. Trunk 30 to 80 feet high, 18 inches to 3 feet in diameter, branching regularly; bark dark and rough. Leaves channelled, slender, 3 to 5 inches long, in twos or threes, inclosed in lengthened sheaths, bluish-green, scattered over the branches. Cones lateral, conical, or egg-shaped, 2 iaches long, solitary; seeds small, with reddish wings. 
Geography. - The P. mitis is found in the rastern United States, from New Eugland to the shores of the (iulf of Mexico. It attains its full size south of Virginia, and flourishes in the hot samds of the Carolinas and the Gulf states.

Etymology. - Mitis, the sperific name of this pine, is derived from the Latin mitis, soft, or tender, and is due to the delicate feel of the soft young leaves. Variabilis, Latin for variable, refers to the incoustant number of leaves in a cluster, - usually 2, but oceasionally 3. Yellow pine refer's to the color of the wood. The origin of the uame spruce pine is not apparent.

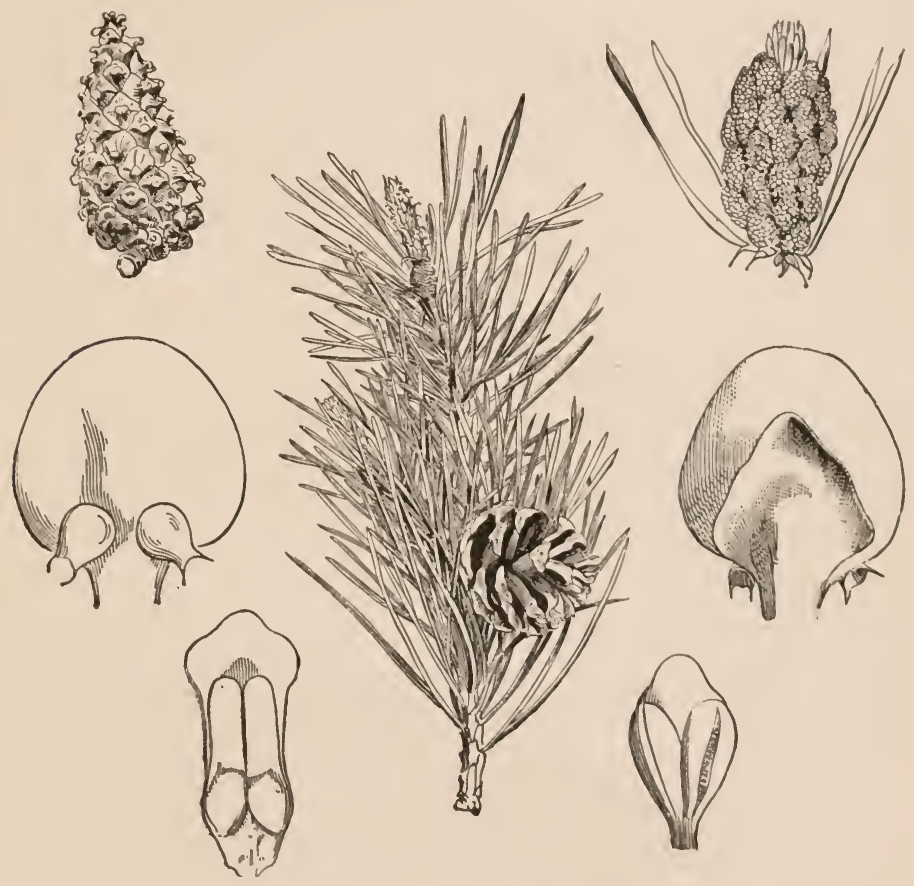

P'inUs sylvestris (Scotch Pine).

Use. - The P. mitis is sparingly used in planted grounds ; it forms a svm. metrical pyramidal hear, and its bluish-green foliage makes it a desirible ornamental tree. The wood is rich in resin, fine-grained, and takes a good polish ; it is used for flooring, and of late years has been largely used in naval architecture, taking the place of oak, especially for decks.

5. P. sylvestris, Ait. (Scotch Pine. Scotel Fir.) 'Trunk 60 to 100 feet high, sometimes reaching the diameter of 6 feet. Branches somewhat straggling, forming a picturesque heal. Frows rapidly in planted grounds. The new growth is frequently erooked by its own weight before it becomes hardened, by reason of which the trunk is frequently very erooked. Leaves rigid, in 
pairs, $1 \frac{1}{2}$ to 3 inches long, twisted, bluish-green; sheaths short, and torn; cones conical, ovate, 2 to 3 inches long, color grayish-brown; point 4-sided, recurred. Seeds small, with a long reddish wing. Cotyledons 5 to 7 .

'There are abont a dozen varieties, for as it is propagated from the seed it sports freely.

Geography. - Its home is in the upper and northern exposures of the Pyrenees, and the Tyrolese, Swiss, and Vosgian mountains It forms exclusive forests throughout Europe and northern Asia, and its trunks are found in great abunclance buried in the peat bogs of Great Britain; hence the rame bog fir. It grows with great rapidity in almost any soil. On account of its straggling, irregular branching, it forms a picturesque rather than a beautiful object; yet it is a favorite with nurserymen and amateurs.

Etymology. - Pinus sylvestris may be translated "the pine of the woods." The common name, Scotch pine, would seem to indicate that its home is Scotland, but there is no reason to believe it is indigenous there.

Use. - The pinns sylvestris, besides being a favorite ornamental tree, is for Europe what the pinus strobus is for America; it is the red and the yellow deal of England; it enters into the structure of buildings, and is largely used in naval architecture all over Europe.

6. P. resinosa, Ait. (Red Pine.) Synonyms: P. rubra, Mx. P. Canadensis bifolia, Du Hamel. Trunk varving in size from 50 to 80 feet in leight, and 2 feet in diameter, branching regularly; when standing alone forming a symmetrical head. Bark smooth and red. Leares in pairs, channelled, and semi-cylindrical, dark-green, 4 to 6 inches long, appearing near the ends of the branches; sheaths long. Cones egg-shaped, 2 inches long, in clusters, on short peduncles; scales unarmed; wood fine-grained, moderately charged with resin, heavy, strong, and very durable.

Geography. - Its home is northeastern North America, from Canada to southern Pennsylvania.

Etymology. - Resinosa is from the Latin resina, resin, due to the resinbearing character of the wood, although it is one of the least resinons of the pines. Rubra is from Latin ruber, red, referring to the color of the bark. Canadensis bifolia is Latin, meaning Canadian two-leaved pine.

$U s e$. - The wood of the red pine is hard and strong, valuable for frames of buildings, and for boards and planks. It is used for flooring and wainscoting.

7. P. rigida, Miller. (Pitch Pine.) Trunk 40 to 70 feet in height, branched irregularly. Bark dark, deeply furrowed. Leaves in threes, rigid, 6 inches long, sheaths short. Cones ovoid, pyramidal, in clnsters ; scales tipper with short, stout, reflexed spines; seed nearly smooth; cotyledons 5 ; wood heavy, with resin.

Geography. - The P. rigida is native throughout eastern North America, but north of Virginia it does not attain to its full size. In Georgia, the Carolinas, Alabama, and Mississippi it is a tree 60 to 80 feet high.

Etymology. - Rigida is from the Latin rigidus, stiff, referring to the leaf. Pitch Pine owes its name to the sap which exudes from the bark.

Use. - The pitch pine is used in the South for the manufacture of turpentine, resin, and tar. The wood is very hard, takes a fine polish, is much used for Hoors and ship.building, and is excellent fnel. 
8. P. cembra, L. (Swiss I'ine. Sitone Pine.) 'Trunk 50 to 80 feet in height, branching in whorls, hranches semi-upright. Bark smooth and dark. l.eaves in tives, 2 to 3 inches long, triangular, slender, straight, crowded, dark-green, sheaths falling. Cones eggr-shaped, 3 inches long; scales blunt, hooked; seeds large, wedge-shaped, shells harl; cotyledous about 13 ; sceds edible.

There are two varieties to be found in planterl grounds.

Var. Siberica, Loudon. Leaves shorter, lighter green, and longer cones; said to be indigenous to castern Siberia.

Var. pygmæa, Fischer. Dwarf, 2 to 4 feet in height. Leaves short; cones globular. Foumd in dry, sterile groumds and rocky hills.

Geography. - The pinus cembra may be found in a range of territory extending from the mountains of Switzerland, through $\Lambda$ ustria, northeastward to Siberia. It adapts itself to almost any soil or climate.

Etymolony. - The specific name of this tree signifies "pine;" so that pinus cembra may be translated "pine pine." The common name, stone pine, is due to the haril shell of the seerl.

History. - The stone pine was introduced into planted grounds about the middle of the eighteenth century, and was brought from elevations in the Alps, rauging from four thousaud to six thousand feet.

Use. - The swiss stone pine is a favorite evergreen with amateurs, on account of its symmetry of growth, its compact branches, and its deep green foliage. Its slow growth alapts it to the wants of those who have small grounds. It hears the knife well, and can be kept back, and almost dwarfed. The wood is soft, has a tine grain, takes a gool polish, and is a favorite wood for joiners, turners, and carvers. Large quantities are used in switzerland in the manufacture of tors. It also furnishes a fragrant resin. The seeds are eaten in siberia.

9. P. palustris, L. (Southern Pine. Freen Pine. I,ong-leaved Pine. Broom Pine. Yellow Pine. Pitch Pine. Georgia P'ine. lied l'ine. Fat Wood.) Trunk 60 to so feet high, and 2 to 3 feet in cliameter. Bark furrowed. Leaves in threes, sometimes reaching the length of 4-8 inches, dark-green, crowled at the ends of the branches; sheaths long, lanceolate, light-colored; cones cylindrical, tapering at each end, 10 inches long; seerk in a thin white covering or testa.

Var, excelsa, Loudon. Whole tree larger. Found in the north of Europe; said also to have been seen on the northern Pacific (oast.

Grography. - This pine has a narrow geographical limit, which extends from southeastern V'irginia south to micllle Florida, thence along the fiulf coast to Louisiana and Texas, in a strip less than 200 miles wicle.

Etymolog!. - The nume palustris, the I atin for "swampy," does not seem very appropriate, as this tree does not grow in swamps. The mumber of popular or common names applied to this species is very umsual, due no doubt to the great value of its products

Use. - The pinns palustris is one of the most important of all our timber trees; no other vields so many valuable products. The wood is harl, takes a fine polish, and is very heary, weighing 4.6.2 pounds to the cubic foot, and is highly valuable for building jurposes, furnishing timber for the frame of a building, boards for the covering, heans and planks for the Hoors, and material for the joiner's work. It is also excellent filel.

$\mathrm{PK}_{\mathrm{K}}$ FL. -21 
Turpentine is the product of this pine. It is obtained by cutting a pocketlike cavity in the side of a tree. The wound thus made discharges the fluid into the pocket or box, which holds about three pints. These cavities fill in about ten days; the contents are then removed, two grooves are cut in the bark above the pocket leading to the cavity, another filling takes place, and the process is continued. The liquid is put into casks made on the spot, and hardens or becomes a semi-fluid, and forms the turpentine of commerce. There are in the markets of the world several varieties obtained from other coniferous trees.

In America a single person attends to the emptying of 4,000 pockets, which yield in a season sixteen barrels, weighing net 320 pounds to the barrel. The crude turpentine has a fixed resin dissolved in oil, with succinic acid.

Spirits of turpentine is procured by distilling crude turpentine and water ; the water and spirits go over together, and are allowed to cool in a vat. The mass will arrange itself into two layers, when the spirits may be drawn off into vessels for market.

Spirits of turpentine is largely used in the arts for dissolving gum resins, for varnishes, and for mixing paints, and before the discovery of petroleum was used for illuminating purposes; mixed with alcohol it formed the burning fluid previously used for illuminating. As a medicine it is diaphoretic and anthelmintic, acting directly upon the kidneys, and in large doses it is powerfully cathartic. It is used by veterinary practitioners as a liniment. The annual product in the United States is about 17,500,000 gallons. Rosin (or colophony) is a residuum of distillation, after the volatile oil of turpentine has gone over.

'Tar is obtained from the dead branches and trunks of trees that have been exhausted by six or more years' tapping. 'The wood is cut into suitable lengths and placed on end in a pyramidal stack upon a floor made of clay, well pounded and concave, outside of which is a well, also lined with clay. In arranging the wood a cavity is left in the center, and filled with combustibles, such as dry cones, shavings, etc. ; the whole is then well covered with earth, a few openings being left around the base. When all is ready fire is thrown down among the combustibles in the center, and when well lighted the top is closed. Great heat is produced, by which the tar is liquefied; it then passes down into the dish-like floor, whence it flows through an opening made for the purpose into the well outside, from which it is ladled into barrels. It is interesting to note that the Greeks obtained tar by a process precisely similar, centuries prior to the beginning of the Christian era. The entire annual yield of tar in Imerica is about 100,000 barrels. It is also obtained in large quantities from Norway and Sweden.

Tar is largely used in the manufacture of naval cordage, as a paint, and otherwise, in naval architecture. As a medicine it was formerly used as a diaphoretic, and as an ointment for scald head, and the rapor was inhaled for lung affections. Tar water, that is, water which has for a time rested upon tar, is also used for stomach disorders.

Oil of tar is procured by distilling tar.

Pitch is a solid black substance, the residuum of distilling tar for tar oil, and is largely used in pavements, and for waterproof cements.

Resin oil is a viscid whitish opalescent liquid obtained by the distillation of resin, and was formerly used as a lubricating substance, and for the manufacture of illuminating gas. 
PICEA, Don. (Spruce.) Leaves scattererl, articulated to the persistent hase of the petiole, partly tetragonal, rigid. Staninate flowers solitary in the axils, the connectire not froduced as a scale-like appendage. Sicales of the reflexerl cone persistent, mostly concealing the small subtending bract.

1. P. nigra, Link. (Black sipruce.) Trunk 70 to 80 feet high. Branchlets spreading horizontally. Bark smooth and dark. Ilead pyramidal, symmetrical, and when young very graceful. Leaves half an inch long, erect, stiff, 4-siled, very dark-green. Cones egg-shaped, hanging, ahout 2 inches long, dark-purple, changiug to reddish-brown; scales ellipsoid; margin unevenly toothed.

Geogruphy. - This tree was introduced into England in 1700, and grows well there; but it nowhere rises to its native grandeur except in its forest home, in the highlands of southern Canada, and the northern United States. Its geographical range is from the Atlantic coast west to the head waters of the Mississippi, between $39^{\circ}$ and $50^{\circ}$ north latitude.

Etymology. - The generic name is from the Latin picens, pitchy. Nigra, the specific name, is Latin, signifying "black," given to this tree on account of the heavy, dark-green color of its foliage aud bark. It forms a tine conical head with a tapering trunk. The common name spruce is derived from the old English Spruce or Pruse, l'russia, the tree having been first known as a native of Prussia.

Use. - The black spruce is largely used in planted grounds. The wood is hard, light, strong, and elastic; it is extensively used for architectural purposes, for framework and flooring in the construction of dwellings. (1) account of its elastic and sonorous qualities it is much used for piano sounding-boarch.

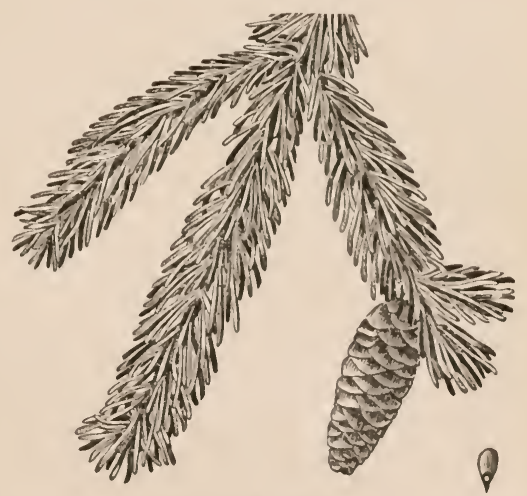

Picea alba (White Spruce).

2. P. alba, Link. (White Spruce.) Trunk 50 feet high, 1 to 2 feet in diameter, tapering, forming a prramidal head. Leaves less than an inch long, sprinkled over the branchlets, needle-shaped, curved upwards, light, glaucous, green. Cones about 2 inches long, subcylindrical; scales entire; the winged seeds very small.

Geography. - When young this tree is very beantiful, and rivals the celebrated Norway spruce. Its geographical range is between $42^{\circ}$ and $67^{\circ}$ north latitude. It abounds in the furests of southern Canada and the northern United States.

Etymolog\%. - Albu, the specific name, is Latin, meaning "white," and refers to the light color of the fuliage; the popular name is due to the same characteristic. 
Use.- The white spruce is a farorite with nurserymen and amateurs, for planted grounds. The wood is strong, and makes excellent lumber for building purposes, and is largely used for floor planks.

3. P. excelsa, Link. (Norway Spruce.) 'Trunk 80 to 150 feet high, branched profusely. As the branches lengthen, the weight of their ends causes them more and more to assume a horizontal position, and finally to droop. Leaves elongated, and though scattered assuming a semi two-ranked arrangement, quadrangular. Cones cylindrical, terminal, and pendent, sometimes 8 inches long and 2 in diameter; scales broad, apex projecting and notched; seed small, one eighth of an inch in length, and half as broad, with a wing. Cotyledons 7 to 9 . Flowers in May, and the cones ripen the following year in the spring.

This tree sports freely, and there are about a dozen well-marked varieties, by the use of which the nurserymen and amateurs are enabled to produce varied effects in planted grounds.

Geography. - The Norway spruce is indigenous throughout northern and middle Europe, and on the northern declivities of the mountains of southern France and Spain. Vast forests on the Alps, at an elevation of nearly 7,000 feet, are wholly composed of the Norway spruce; but it is said to attain its perfection in the forests of Norway, its home and the country from which it derives its common name, where it is the grand monarch of the woods. It is propagated in America from seeds brought from Europe, formerly from Norway. It grows to its full size in deep, damp soils.

Etymology. - The specific name of this tree, excelsa, is the Latin for lofty, and usually relates to excellence in rank or character, not to size or height; but in its application to this fine tree, it seems to have been used with the latter signification.

Use. - On account of its hardness and the symmetrical head it forms, its beantiful deep green, and the patience with which it bears the knife, the Norway spruce has become the most popular and the standard evergreen in our nurseries and in planted grounds, for ornamental purposes. In Europe, though not in America, its wood is used for architectural purposes. The wood is light, elastic, durable, and of a yellowish-white color. It is charged with resin, which is the base of Burgundy pitch. The young trees are cut when six to ten inches in diameter, and used by builders for scaffolding. The larger trees are sawed into planks for flooring. On account of its elasticity and sonorousness it enters into the structure of musical instruments, - especially of the backs of violins and of piano somnding-boards. Cabinet makers line furniture with it, and it is largely used for boxes for packing merchandise. It is fine-grained, takes a good polish, receives a black stain well, and is especially suitable for picture-frames and other articles that are gilded. It is also highly prized by carvers for their purposes.

ABIES, Link. (Fir.) Flowers monoeious; aments in terminal or nearly terminal clusters; scales of the cones thin and flat; seeds winged. Leaves solitary, and without sheaths at the base, scattered, bearing a slight scar, linear, flat above. Staminate flowers solitary in the axils, the connective being barely prominent above the anthers. Scales of the erect cone deciduous with the seeds, the subtending bract conspicuous, but not thickened nor prickly tipped, often equalling or exceeding the ovuliferous scale. 
A. balsamea, Miller. (Balsam Fir. Balm of Gilead. Called in England American Balsam Fir.) Synonyms: Pinus balsamifera, L. ; Picsa balsamifera, Marshall. Trumk 20 to 50 feet in height, 1 to 2 feet in dianeter. Bark darkgray, smooth or blistered, with resinous vesicles. Branches nearly horizontal, numerous and slender, drooping when old. Leaves about an inch long, narrow, linear, spreating, and slightly tmrned hack, green ibove, silvery underneath. Cones eylindrical, + inches long, viulet colored, scales thin, smootll, obovate or sulspatulate, anu slightly mucrouate. Feeds surall, angular.

Var. longifolia, Booth. Leaves longer, brauches more upright, than 1. halsimea.

Var. variegata, Knight. Some of the leaves have a yellowish cast, contrasting with the silvery sheen of the other's, and forming a heautiful object for the lawn. This feature is male the most of by nurservnen and dealers in trees.

Geography. - The home of the halsan fir is northeastem North America. Lower Canada, especially (Quehec, New Brtuswick, and Nova Ficotia abound in this tree. It is found in the mountainoms parts of the middle states, especially in the Adirondack regions, and west to IVisconsin. It loves a cold, damp soil.

Etymology. - Abies is the Latin for fir tree. Balsamen, Latin for "of balsam," is due to the resinous character of the bark. Fir is from the Anglo-Saxon firh, a kind of oak. Balm is a contraction of balsem.

Ilistory. - The balsam fir is a native of North America, and was introduced into England by Bishop Compton abont the end of the seventeenth wntury. It is a beantiful object while young, but on account of the dense ramifieation, the branchlets and leaves of the lower branches near the trunk die for want of light, and the tree hecomes unsightly; on this accomnt it has hecon for many years discarded by planters. In its native wooks, in Noval Seotia particularly, the snow lodging upon its luanches (auses them to droop, and thus partially conceal the silvery sheen of the under surface of the leaves. In the hilly regions of Nova scotia the sides of the wood-roads are walled forty to fifty feet in height with the silvery green of this beantiful tree.

Ise. - The wood of the balsam fir is resinous, yellow, soft, and easily worked, hut is not large enough to he valuable for luilding purposes. The gum, or resin, known as Canada Balsam, is obtained from the hark by puneturing it. From these wounds the resin flows ont in a viscid fluid, about the consistency of honey, which hardens after exposure to the air.

It enters into the materin merlica, and is administered in the form of pills for stomach tromliles, and also for bronchial affections. It is transparont, and used to incase insects and other perishable oljects, for the microseope, and for setting the glasses of microserpic l'nses, and is an ingredient in the manufar. ture of varnisli.

LARIX, Mx. (Larch. Tamarack. IIackmatac.) Iments scattered over the branches, resembling huds; anthers "-celled: cones reflexed. subglobular; seales persistent, the subtending seale conspicuous; seeds winged. Leaves dreciduous, soft, threal-like, in fascicles or scattered on this year's shoots.

1. L. laricina, Dn Roi. (.Imeriean Larch. I3lack Lareh.) Trunk so to 100 feet in height. Bark dark and rough. Branches horizontal or ilrooping: 
branchlets pendent, regular, forming a graceful pyramidal head. Leaves threar-like, slender, and soft to the touch, in fascicles of 10 to 20 . Cones ovoid when young, when open subglobular and purplish, abont an inch long, and nearly the same in diameter; scales thin; margins turned in. Seeds small, with short wings.

2. I. Europæa, DC. (European Larch.) Trunk same as No. 1. Branchlets more pendulous. Leaves an inch long, obtuse, and flat, bright-green. Cones much larger than No. 1, loug egg-shaped, 1-1 $\frac{1}{2}$ inches in length. Scales orbicular, reflexed, bracts extending beyond the

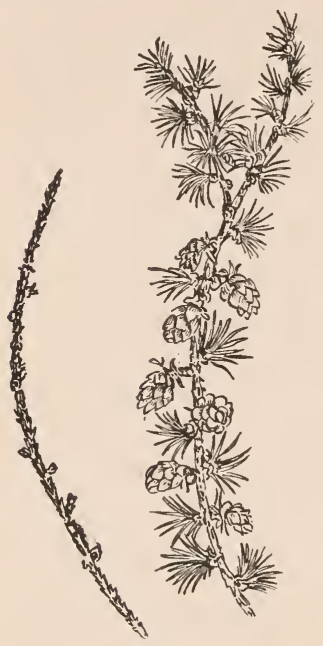

LARIX LARICINA (Larch). scales. Seeds small, ovate, winged. Cotyledons about 7 .

Of this species there are several varieties; the most interesting one is a dwarf, remarkable for its pendent or weeping branches.

Geography. - The American larch is found. uative as far south as southern New York, and north to the fiftieth parallel, in a belt quite across the continent to the Pacific coast. The European larch is found in the mountainous regions of middle Europe.

Etymology. - Larix, the generic name, and laricina, the specific name of this tree, are derived from the Celtic lar, fat, due to the resinous wood. Tamarack and Hackmatac are Indian names of obscure meaning. Europcea indicates that this species is a native of Europe. The common naine, larch, seems to be merely a corruption of the word larix.

History. - The larch was much used in Venice, in the period of its prosperity, for frames and other parts of buildings; and it is said that buildings framed of that material show no signs of decay even at the present day. The paintings of some of the great masters were executed upon larch panels, and their excellent preservation is said to be due to the hardness and perfect condition of the wood upon which the work was executed.

Use. - The larch is a favorite in planted grounds; no collection of trees would be considered complete without it. The wood is hard, heavy, strong and durable; it is used for fencing, for agricultural instruments, bridges, and for heary and strong carriages for transporting stone, hardware, coal, lime, and other coarse and hard articles. It is prized for dock logs and frames for canal gates. When the larch $\log$ is sawed into planks it is necessary to season them in close piles to prevent warping. The bark is highly charged with tannin, and is used in the manufacture of leather. The resin of this tree rields Venice turpentine, which is used in medicine.

JUNIPERUS, L. (Juniper. Cedar.) Flowers diøcious, occasionally monœecious, on separate branches ; aments usually axillary, sometimes lateral, small, ovoid; stamens many, inserted on all sides of the axis. Fertile aments imbricately bracted at the base. Involucre composed of 3 to 6 scales, united at the base, a concave ovule at the base of each 
scale. Fruit formed of the fleshy scales, subglobose, berry-like, containing 1 to 3 hard seeds. Cotyledons oblong, 2 in number. Leaves scale-like, subulate, lanceolate, evergreen. 'Trees and shrubs.

1. J. communis, L. (Common Juniper.) Trunk i) to 10 feet in height (in cultivation 15 to 20 feet high), branches numerous, erect. Leaves in whorls, from half to three quarters of au inch long, sharply lanceolate, chanuelled, keeled helow, aud lisistly pointed, green underneath, and glaucous above. Sterile flowers in little axillary cones. Fertile Howers, on a separate plant, axillary and sessile. Fruit dark-blue, subglobose; berries ripening the next year after the flower appears; sweet, with a taste of turpentine; they contain sugar, aud on fermentation yield a bererage resembling gin.

Var. pyramidalis of the nurserymen is a seedling, and is a very compact, graceful form in planted grounds.

Var. prostrata (synonyms: Var. alpina, L., J. nana, Willd.) is a prostrate, straggling form, covering sometimes an area of fifty square feet; brauchlets assurgent.

2. J. Virginiana, L. (Red Cedar.) Trunk 25 to 50 feet in height, branches extended, making a broad, pyramidal head. Leaves very small and scale-like on the old branches, longer and sharper on the young wood, closely imbricated, and very dark-green; the fertile and sterile florets on separate trees, inconspicuous in longish terminal aments. Fruit, a blue berry. covered with a whitish bloom, size of a small pea; sap wood white; heart wood reddish, light, close-grained, and very durable. It sows itself and sports freely, producing several forms as to foliage and ramification, one of which is sufficiently conspicuous to be entitled to the diguity of a variety.

Var. forma cylindrica. Stem 10 to 30 feet high, branching profusely, branches growing nearly parallel with the trunk, forming a coinpact, cylindrical head, making a beautiful object in the landscape.

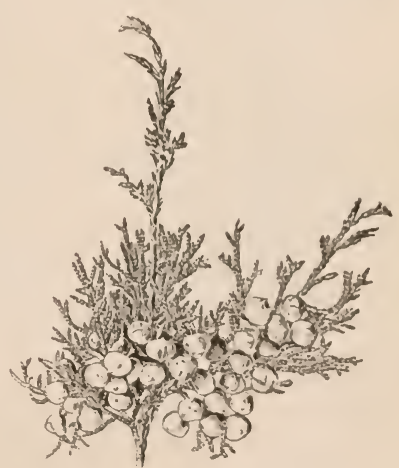

Juntperus Virginiaxa (Red Cedar).

3. J. Bermudiana, L. (Pencil Cedar.) This species is a beautiful, long-leared variety found in the West Indies. The wood is soft and close-grained, and used for making lead pencils.

There are other cedars in Europe and Asia.

Geography. - The J. communis is a native of middle and western Europe, northern Asia, and North America. J, Virginiana is a native of North America and the West India islands; it is found all along the eastern coast of the Atlantic, and as far west as the foothills of the Rocky Monntains.

Etymology. - Juniperus is the Latin for juuiper, from jurenis. young, and purere, produce, referring to the presence of the old fruit after the new has appeared. Cerlar is from the Greek $\kappa \epsilon \delta \rho o s, a$ cedar-tree.

Ise. - The .J. communis is a favorite in planterl grounds; it hears the knife, and may he pruned into any degree of dwarfage. The fruit is used to 
flavor gin, and in medicine is arlministered for kidney complaints ; it is considered one of the nust active diuretics known. 'The J. Virginiana or red - cedar of North America is used sparingly as an ornamental tree, but the wood is very durable, tine grained, and takes a good polish. Its durability makes it valuable for feucing; its fine grain adapts it to fine cabinet work aud for fancy boxes. Trunks are also made of it for storing furs and woollens to protect them against the depredations of the moths, to which its odors are destructive. The wood of this species, as well as that of Bermudiaua, is largely used in the manufacture of lead pencils.

THUJA, Tourn. (Arbor Vitæ.) Flowers monoecious, on the ends of separate branches; sterile flowers in an egg-shaped ament. Anthercells 4 in number, on a scale-like connective or filament. Fertile aments or cones rough or angular, subglobose; scales few. Seeds winged, 2 under each scale, covering membranaceous. Cotyledons 2. Leaves evergreen, imbricated; scales lying close to the flattish branchlets.

T. occidentalis, L. (American Arbor Vitæ.) Trunk 30 to 50 feet high, and 1 to 2 feet in diameter, branching profusely. Branches upright and com-

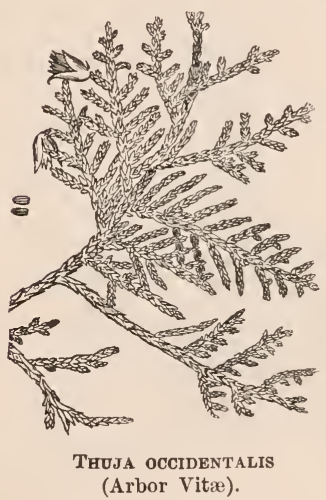
pact, forming a pyramidal or oblong cylindrical head. Leaves small, scale-like, imbricated, in 4 rows on the 2-edged branchlets. Cones eggshaped; scales spreading; seeds winged. The frond-like branchlets are densely ramified, and spread in a lateral direction. The leaves when bruised emit an aromatic odor.

Geography. - The 'T. occidentalis is a native of North America, north of $40^{\circ}$ north latitude. It has been introduced into England as an ornamental tree.

Etymology. - Thuj $九$ is derived from the Greek word $\theta v_{i}^{\prime} a$, an African tree with sweet-smelling wood. Occidentalis is Latin for western, and refers to the western world, the home of this species. The popular name arbor vitce is Latin for "tree of life," and is supposed to arise from the circumstance that the fruit of some of the species is used for medicine. In the East the cypress is called the tree of life, for the reason that the berries are supposed to be a remedy for all cliseases.

Use. - The Thuja occidentalis is largely used for ornamental purposes in planted grounds. It bears the knife well, and is on that account well arlapted for hedging purposes.

The wood is light, durable when exposed to the weather, and furnishes excellent material for fencing. It is also extensively used in the manufacture of casks for packing.

TSUGA, Endl. (Hemlock.) Flowers moncecious; aments in terminal or nearly terminal clusters. Scales of the cones thin and flat. reflexed and persistent, nearly hiding the subtending bract. Leaves linear, flat, and somewhat '2-ranked. 
T. Canadensis, Carr. (IIemlock Spruce.) 'Trunk 50 to 100 feet in height, branching freely. Bark gray, smooth on young trees, lut very rough and furrowed on old tress. Leaves solitary, Hat, slightly toothed, blunt at the apex, in 2 ranks, half an inch long, and less than an eighth of an inch wide. ('ones three fourths of an inch in length, and less than half an inch in diameter, scales suborbionlar, half an inch long; wing less than half an inch broad. Flowers in June; seed matures in the following year in June.

Geography. - The geographical range of the hemlock is confined to a belt on both sides of the forty-fifth parallel, in the Northern Hemisphere, reaching down to I'enusylvania in momtainous regions, and even to North Carolina, aud as far north as (Oregon aud Hudson Bay.
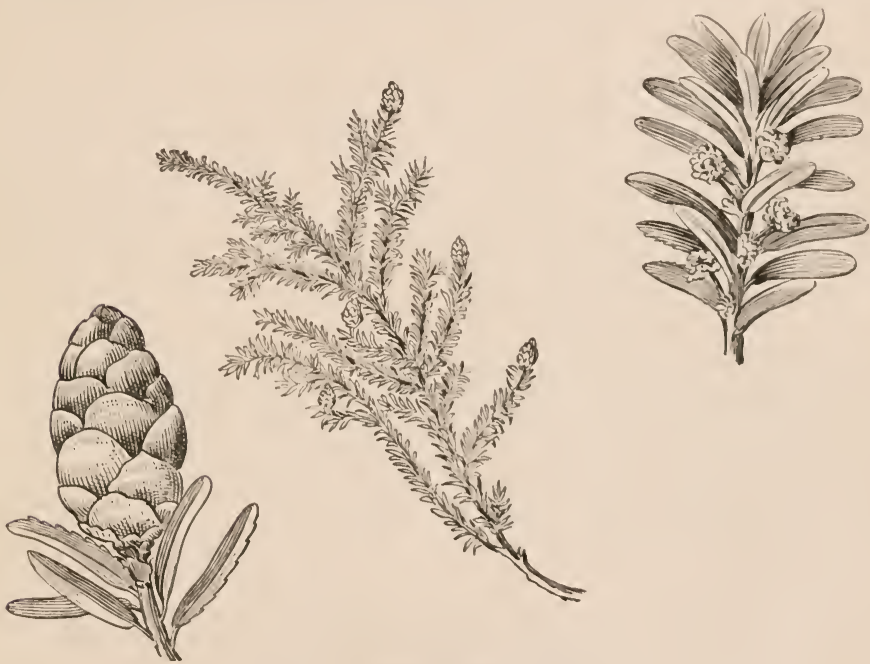

Tsuga Canadensis (Hemlock Spruce).

Etymology. - Tsuga is Japanese for yew-leaved or evergreen. The name Canarlensis comes from Canala, the home of the tree. The origin of hemlock, the common name, is not so easily determined ; it is suggested that it comes from hem, the elge or horder, and loc, fasten, inclose, allnding to the use of the tree in hedging. Again, hem means "injure" or "cripple," and may allude to the poisonous properties of the cicuta, ealled hemlock. These inferences are not to be relied npon, and the origin and meaning of the name must be left in olscurits.

Mistory. - The lemlork is an Ameriean tree; it was taken to Europe soon after the settlement of northeastern America, and grows well in the uorthern parts of Englinil.

Use. - Is an oruamental tree the hemlock is a favorite in large gromuds When not crowded it rises to the height of 40 to 80 feet, a perfort pyramid, its lower liranches resting on the ground. Its foliage is the most delicate of all the conifer:e. It hears the knife well, ant makes a compact and beantiful hedge. The wood is soft, easily split, and has a very coarse grain; yet it is 
strong, holds a nail well, requires a great force to produce a cross fracture, and is very durable. It is largely used in the frames of edifices, for joists and for sheathing, being the cheapest of all the soft-wood lumber. The lumber is obtained from the stripped trunks, which are sawed into 13-feet lengths, which during the following winter are drawn to the frozen streams and left till the spring thaw, when they are floated down to the saw-mills, where they are sawed into boards, scantling, and ceiling laths, and thence sent to market.

The bark is highly charged with tanniu, and is used in immense quantities for manufacturing leather. It is obtained by felling the tree in the early summer when the sap is in its greatest activity; girdles are cut around the. trunk and large branches by means of an axe, and with a wedge-shaped bar the bark is stripped; it is then piled to dry. Its value is estimated by the cord.

CHAM שCYPARIS, Spach. (Cypress.) Flowers monoecious, on different branches of the same tree, in terminal catkins. Staminate flowers in ovoid aments, 4 anthers under the scales. Pistillate flowers in a globular cone; ovules bottle-shaped; scales thick and woody, peltately dilated, bossed in the middle; cones globose ; seeds few, with narrow wings attached to the base; cotyledons 2, or 3. Trees with closely appressed evergreen leaves.

1. C. thyoides, L. (Cupressus thyoides, L.) (White Cedar.) Trunk 40 to 80 feet in height, and 1 to 3 feet in diameter. Branches somewhat spreading, and pendent at the extremities. Bark brown, ragged, soft, exfoliating in strips. Leaves imbricated in four rows, short, scale-like, with a small tubercle on the back of each. Cones in groups; very small, globular scales, shieldshaped, blunt-pointed; seeds small, subglobular.

There are many species, but the thyoides is the most important in eastern North America.

2. C. sempervirens, L. (Cupressus sempervirens, L.), is a native of the countries of the Levant. It is there the gloomy sentinel of the graveyard. It is pyramidal, and hence the emblem of death.

3. C. pendula (Cupressus pendula), of China, has pendulous branches; in habit like the weeping willow.

Geography. - The geographical zone of the chanxcyparis is from $30^{\circ}$ to $42^{\circ}$ north latitude. In America it extends across the continent, and it occupies about the same zone in the ()ld World. It is found sparingly in the middle Atlantic States, especially in New Jersey, and west to the Great Lakes, hut it reaches perfection in the swamps of the Carolinas, Georgia, and Florida.

The cedar swamps of New Jersey, made famous by the botanical excursions of Pursh, Nuttall, Michaux, Bartram, and Gray, have since their day been the Mecca to which every young botanist longs to make a pilgrimage. In these swamps a very important industry is carried on, consisting of mining sunken logs of the cypress, and working them into shingles and barrel staves.

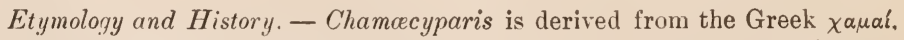

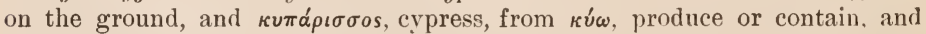
$\pi \alpha$ áros, equal, alluding to the regularity of the branches. According to some 
authors, the name is derived from C'yparissus, son of 'Telephus, who for killing the stag of the guds was transformed into a cypress tree. The common name was derived from the isle of (yprus, where a tree of this genus abounded.

Use. - The wood of chamacyparis thyoides is light, soft, and easily worked, has a fine grain, and takes a good polish. It is used in the manufacture of trunks, boxes for preserving linen and woollen goods, shingles, and staves for casks. Cabinet-makers use it for drawers in fine eabinet ware; and large use is made of the small trees by builders for scaffolding poles, - the poles being light, slender, and strong. It is also used for masts for small vessels. It is remarkable for its durability. 'The doors of St. Peter's church at Rome were of cypress wood from the Levant, and were found to be quite sound after a service of 1,100 years. Its peculiar hittemess preserves it from the attacks of insects, and in part explains its durability. 



\section{GL OSS A R Y.}

A.

ab nôr'mal, contrar!y to the usual or naturul structure.

ab o rig'i nal, wriginal in the strictest sense. a bôr'tiou, non-development of " part.

ab rŭpt', terminating suddenly.

ab sôrp'tion, the act of taling in or sucking up.

ac au lěs'çent, apparenlly stemless.

ac š̌s'so ry, something udded.

ac crĕs'çent, growing ufter flowering.

ac crēte', grou'n 10.

ac cŭm'bent, lying against.

ăçęph'a lous, without head.

aç'er ose or ăç'er ous, needle-shaped.

a chē'ni um ( $p l$. achenia), a small, dry, harl-shelled, one-celled, one-seeded, indehiscent fruit.

ăch la my̆d'e ous, without floral envelopes.

a çic'u lar, finely neelle-shuped.

$\bar{a}^{\prime}$ corn, the fruit of the ouk.

a cot y lěd'o nous, without colyledons.

ăc'ro gens, summit growers.

a $\mathrm{c} \overline{\mathrm{u}}$ 'le ate, armed with prickles.

a cu'́mi nate, drau'n out into " point.

a cūte', ending in a sharp angle.

a dělph'ous, having the stamens joined in $a$ fruternity.

ad e uŏph'o rous, producing glands.

ad hēr'ent, yrowing 10.

ad $\overline{\mathrm{e}} \overline{\mathrm{s}}$ sion, the union of organs of different kinds, as stumens to petals, elc.

ăd'nate, grouring finst to.

ad prěssed', or ap prěssed', brought into contact with, but nat united.

ad ven trittious, out of the usual oriler; accilental.

ad věn'tive, applied to forcign plınts sparingly introduced into a country, but not naturalizet.

ā ër $\bar{a}^{\prime}$ tion, same as respiratiou.

a rư'gi nous, verdigris-colored.

as ti vā'tion, arrangement of the parls of a

flower in the bud.

af $\mathrm{fIn}$ 'ity, resemblance in rssential orguns.

х̄'́a mons, sexless.

$\mathrm{ag}^{\prime}$ gre gate, assembled close together. a glu mā'ceous, without glumes; same as petaloid.

a grěs'tis, growing in fielıls.

air' blăd'der, a suc filled with air.

air' plants, plants uhose roots are in the air. $\overline{\mathbf{a}}^{\prime}$ kene, or a k $\overline{\mathrm{e}}^{\prime}$ ni um, an indehiscent seedvessel ; " nutlet.

$\bar{a}^{\prime}$ la ( $p l$. alie), a wing.

al a băs'trum, a flower-bud.

$\bar{a}^{\prime}$ late, winged.

al běs'çent, whitish, or lurning white.

al bū'men, $a$ deposit of mutritice material within the seel-coats.

al bū'mi nous, like albumen.

al bûr'num, sap-wood.

$\breve{a l}^{\prime}$ gie, sea weeds.

al li $\bar{a}^{\prime}$ ceous, having the odor of garlic.

al lŏg'a mous, haring cross-fertilization.

ă'prัne, belonging to high mountains abore the limit of forests.

al tēr'nate, distributeal singly at difjerent heights of the stem.

al've o late, with pits like the honey-coml.

am'ent, a deciduons spike.

am en tā'ceous, calkin-like, or colkin-bearing.

a môr'phous, without definite form.

am phi cär'pous, prolucing two kinds of fruit.

an phĭt'ro pous, turned both uny.s.

am'pho ra, a pilcher-shapel organ.

am plěc'tant, embracing.

au plex'i caul, cluspring the stem, as the base af somie leares.

am pul lin'ceous, suelling out like a botlle or bladiler.

am y̆l lā'ceous, am'y loid, composed of sturch; starch-like.

a nal'y sis (botaniulul), the process of clnssifying and finding the nomes of plunts.

an ăn'drous, withoul stamens.

an $x_{n}$ 'ther ons, au $x_{n}$ 'thous, w'thout anthers. a nas to mō'sis. union of ressels or reins.

a na'tro pous, haring the orule iuterted at an early period in its development, so that the rluilazi is at the "ppurent uper.

an çip'i tal, two-edged.

an iro'ri un, the stumens of a flower tuken together. 
an drð' $\dot{\mathrm{g}}^{\prime} \mathrm{y}$ nous, having stumens and pistils on the same peduncle.

ăn'dro phore, a column of united stumens, as in the Mallow.

an e mŏph'i lous, wind-loving, said of windfertilized flowers.

an frăc'tu ose, bent hither and thither, as the anthers of a Squash.

ăn'gi o sperms, plants whose seeds are inclosed in a vessel.

ăn'gu lar, a kind of divergence of leaves.

an i sŏm'er ous, having the parts unequal in number.

ăı i so pet'a lous, uith unequal petals.

an i soph'yl lous, having the leaves of a pair unequal.

an nŏt'i nous, yearly, or in yearly growths.

ăn'nu al, yearly.

ăn'nu lar cells, cells with ring-like markings.

ăn'nu late, marked by rings, or furnished with a ring like that of the spore-case of most ferns.

an $\mathrm{te}^{-}$ri or, adjacent to the bract.

an the'la, an open paniculate cyme.

an thel mIn'tic, expelling or killing worms.

ăn'ther, the part of the stamen that contains the pollen.

an ther $\mathrm{Id}^{\prime} \mathbf{i} u \mathrm{~m}$, the organ in cryptogams corresponding to the anther in flowering plants.

an ther If'er ous, anther-bearing.

an the $\bar{e}^{\prime}$ sis, the opening of the flower; flower. ing.

an tho cär'pous, having the fruit and flower united.

ăn'tho phore, a stipe between the calyx and the corolla.

an trôrse', facing toward the anterior.

a pět'a læe, plants without petals.

a pĕt'a lous, without petals.

$\bar{a}$ 'pex, the top or point, especially of a leaf.

ăph'yl lous, without leaves.

ăp'ic al, belonging to the apex or point.

a pic'ulate, tipped with a small, distinct point.

ap o cär'pous, having the sereral pistils of the same flower separate.

ap o pert'a lous, having the petals entirely disconnected.

a pŏph'y sis, a suelling.

ap o sĕp'a lous, having separate sepals.

ap othe'sci um, the fructification of lichens forming masses of various shapes.

ap pĕnd'age, any superinduced part.

ap pen dǏc'u lar, having appendages.

ap prěssed', see adpressed.

ăp'ri cate, to grow in dry and sunny places.

ăp'ter ous, without wings.

a quăt'ic, living in water.

a răch'noid, resembling cobuebs.

ar bo rē'tum, a collection of trees.

är'bor ous, tree-like.

ar che gō'ni um, the organ in mosses analogous to the pistil of flowering plants. ärc'u ate, arched or curved like a bow.

ăr'e nose, grou'ing in sand.

a re'solate, having the surfuce dirided into little spaces or areas.

ar ğěn'te ous, or är'gen tate, silvery.

ar ğĭl'lose, or ar ġı̆l'lous, growing in clay.

ar g $\overline{\mathbf{u}}$ 'tus, acutely dentate.

ăr'il, an extra seed-covering.

a rǐs'tate, with an arista or awn, as the Barley.

a rǐs'tu late, short-awned.

ärmed, bearing prickles, spines, etc.

ar rěct', upright in position.

as cěnd'ing or as cěnd'ent, arising obliquely ; assurgent.

as çĭd'i um, a tubular, horn-shaped, or pitcher-like formation.

ăs'cus, a sac; the spore-case of lichens and some fungi.

as per ğll'li form, shaped like the brush used to sprinkle holy water, as the stigmas of many grasses.

ăs'per ous, rough to the touch.

as $\operatorname{sim} \mathrm{i} \overline{\mathrm{a}}^{\prime}$ tion, the function of producing starch or other plant food.

as sûr'gent, sume as ascending.

ăt'ro pous or ăt'ro pal, not inverted; orthotropous.

at těn'u ate, becoming slender or thin.

au răn'ti $\bar{a}^{\prime}$ ceous, orange-colored.

au're ous, golden.

au tǒğ'a my, self-fertilization.

awl'-shaped, sharp-pointed from a cylindrical base.

awn, the bristle or beard of Barley and like plants.

ăx'i al root, the main root growing dom?ward; tap-root.

ăx'il, the angle between the petiole and the branch on the upper side.

ăx'il la ry, grou'ng ont of the axils.

ăx'is, the stem.

B.

băc'cate, berry-like; covered with pulp.

bac tē'ri um, the smallest organism known; micro-organisms, destitute of chlorophyll, which multiply with marvelous rapidity and cause putrefaction and disease.

băn'ner, the upper petal of a papilionaceous flower.

bär'bate, bearded.

bärbed, furnished with o barb or double hook:

bär'bel late, beset with stiff, short hairs, as bristles.

bar běl'lu late, diminutive of barbellate.

bärk, the outer covering of an exogenous tree or shrub.

bāse, the extremity of any organ by which it is attached to its support.

bā'si fixed, attached by its base. 
băs'i lar, allached to the huse ; basal.

baist-cells, long cells of burk.

bēaked, exding in an extended tip.

bēard'ed, haring tufts of long hairs.

bi artǐc'ulite, twicc-jointed; two-jainted.

bì au rǐc'u late, having twa ears, as the figlenf.

bi căl'lose, huring tu'o hard spots.

bi căr'i nate, two-keeleul.

bi ģı̆p'ital, two-headed; dividing into two parts.

bï'col or, two-colored.

bi cŏı'ju gate, twice-paired, as u'hen upetiole forks twice.

bi cŭs'pid ate, with turo points or cuspss.

bi děn'tate, with two tceth.

bi éu'ni al, of two years' durution.

bi'fid, cleft into two parts.

bi fo'lli ate, with two lenflets.

bi tûr'cate, forked; tu'ice furlued.

bij'ugate, beuring two pairs.

bi la'bi ate, two-lipped.

bi lăm'el late, of two plates.

bi'lobed, two-lobed.

bi lō çĕl'late, divitled into tuo secondary cells. bi lǒc'u lar, divided inta two cells.

bī'nate, two by two; in pairs.

bi nö'dal, having tu'o nodes.

bi nō'mi al, having two names.

bi păl'mate, tuice palmately divided.

bīp'a rous, having two branches or axes (applied to a cyme).

bi pĭn'nate, twice pinnate.

bi pin năt'i fid, twice pinnatifid.

bi pin năt'i sect, tuice pinnately divided.

bॉp'li cate, twice foldel together.

bi se'tri al, bi se'riate, occnpying two rows, one within the other.

bi sĕr'rate, doubly serrate; as when the teeth of a leaf are themselves serrate.

bi sĕx'u al, having both stamens and pistils.

bi tër'nate, trice ternate.

bī'vălved, two-ralreal.

blade, the expanded part of the leaf.

blanched, whitened by lack of light.

blōm, a whitish powder on fruits, leares, etc.

bōat'-shaped, concrie within and keeled withont, lilie a small boal.

brt'a ny, the science $u$ hirh treats of plants.

brăch'e ate, with apposite spreading branches.

brăct, the small lenf or seale from the axil of which " Hnwer or its pedicel proceets.

brăc'te ate, furnished with bracts.

brăc'te o late, furnished with bractlets.

brăct'let, brăc'te ole, a bract on the pedicel or How'er-stalk.

branch, a shoot grouring from the stem.

bris'tles, stiff, sharp huirs.

brYst'ly, beset with brislles.

brŭsh'-shaped, uspergillifm'm: shoped like the brush used in sprinktiuy luoly unter.

bry ŏl'o ġy. that purt of botuny which treats of mosses. bry ơph'y ta, moss-like plants.

bud, the grawing pnint: an undereluped plant is Hower.

bưd'ding, the process of jurming bnds.

bŭd'-seales, romerings of a bual.

bŭlb, an undergrannal bued.

bul bĩf'er ous, learing or pralucing bulbs.

bŭlb'lets, little bulbs.

bŭl'late, "ppenring as if thlistered.

byssā'ceous, composed af fine, flax-like threads.

\section{C.}

ca du'cous, dropping aff early.

cres'pi tose, turf-like; having many stems from one rootstock, or frum many entungled roots.

ca lath'i form, cup-shaperl.

căl'căr ate, furnishel witlı a spur.

căl'çe o late, slipper-shuporl.

căl'lous, hardened.

ca lyç i Ho'rous, having the petals and stamens aluate to the calyr.

căl'y çine, calyır-like.

ca ly̆e'u late, having an outer calyr or calyxlike involucre.

caly'p'tra, the hoorl of the spore-case of "I moss.

ca ly̆p'tri form, shaped like a camlle-prtinguisher.

cā'lyx, the outer floral enrelope.

căm'bi um, on old name for the suppy cell.s between the woorl and bark; nusceut structure.

cam păw'u late, bell-shapeal.

cam py lot'ro pos:s, hai'ing the or'ule curreal, with the apex new the hilum.

can a lǐc'u late, chunnelled.

căn'şel late, Intticed; resembling lattice-work.

căn'di dus, pure white.

ca něs'şent, grayish white.

căp'il la ry, or cap il lā'ceous, resembling hair; long and slender.

căp'itate, hend-shaped, grouing in close clusters or heads.

ca pit'u lum, a little herd.

căp're o late, bearing tendrils.

căp'sule, a dry, dehiscent seed-ressel with more than one carpel.

cär'bon di ðx Tule, a substance consisting of one atom of carbon to two of oxygen.

ca rï'na, a keel.

căr'i nate, boat-shaped; hat'ing a sharp ridge benealh.

căr i op'sis, the one-seeded fruit of grain as. grasses.

cär'ne ous. Hesh-c'ulured; pale red.

cär'pel, a pistil.

car pol'o gy, that department of botany uhuth relates to fruits.

cär'po phore, part of a receptucle prolonged betueen the carpels. 
car ti lăg'i nous, firm and tough in terture, like cortituge.

căr'un cle, un excrescence neur the hilum of some seeds.

căr y o phyl lä'ceous, relating to the Pink fainily.

car y ŏp'sis, a grain; a thin, dry, one-seeded pericarp.

cas sĩd'e ous, helmet-shaped.

căs'sus, empty; sterile.

căt'e nate, or ca těn'u late, end to end, "ss in u chain.

căt'kin, an ament.

cau'date, tailed, or tail-pointed.

can'dex, the trunk or stem of a plant.

cau'di cle, the stulk of " pollen-mass.

cau lěs'çent, haring a distinct stem.

cau'li cle, a little stem, or midimentary stem

of a seedling.

cau'line, relating to the stem.

cau lo cär'pic (stems), same as perennial.

cau'lome, the cauline parts of a plant.

cěll, $a$ sac or bag-like borly containing protoplasm.

cěll-growth, formation and enlargement of cells.

cěl'lu lar třs'sue, tissue formed of cells.

cĕl'lu lose, the substance of which cell-valls are formed.

cen trĭf'u gal in flo rĕs'cence, $a$ flowering from the center.

cen trŭp'e tal in flo rěs'ceuce, a flowering outside toward the center.

çĕph'a lous, head-shaped; growing in close clusters; capitate.

çe'́re al, relating to grains, corn, etc. çēr'nu ous, nodding, but less inclined than pendulous.

chäf, the husks of grasses and grains.

cháff'y, abounding in or resembling chaff.

cha la'za, the part of an ovule where the covering and the nucleus join.

chăn'nelled, hollowed out like a gutter.

chăr'acter, a word expressing the essential marks of a species, genus, etc.

char tā'ceous, having the texture of paper.

chlö'ro phy̆ll, the green substance of leaves and bark.

chlo rō'sis, " condition in which naturally colored parts turn green.

cho ri pĕt'alous, having separate petals; polypetalous.

chō'ri sis, separation of an organ into two or more parts.

chrō'mule, coloring matter in plants.

çie'a trix, the scar left by the fall of a leaf or other organ.

çll' $\mathrm{i}$ ate, fringed with marginal hairs.

ci nē're ous, ashy-gray, ash color.

çī'on, a young shoot.

cir'çi nate, rolled inward from the top.

cir cula'tion, a moving around (as of the $s a p)$.

cir cum scĭs'sile, opening by a transverse slit. cir cum scrīp'tion, general outline.

çĭr'rhose, furnisherl with " tendril.

çĩt're ous, lemon-yellow.

clā'dose, branched or ramose.

clăth'rate, latticed; cancellute.

clä'vate, club-shaped.

cla vǐc'u late, having claviculop, or tittle tendrils or hooks.

claw, the narrow or statk-like base of some petals, as of Pinks.

clěft, cut into lobes.

cleīs tŏg'a mous, fertilized in closed buds.

cleīs tǒg'a my, fertilization in closed buls.

climb'ing, rising by clinging to other objects.

cly̆p'e ate, buckler-shaped.

co a lěs'çent, growing together.

co äre'tate, contracted, drau'n together.

cōat'ed, having an integument, or covered in layer's.

cŏb'web by, bearing hairs like colvebs or gossumer; arachnoid.

coc şı̆n'e ous, scarlet-red.

cŏe eus ( $p l$. cocci), a berry; a one-seeded carpel of separable fruits.

coeh le ăr'i form, spoon-shaped.

cð̌ch'le ate, spiral, like a snail-shell.

co he'sion, union of one organ with another of the same kind.

cō'hort, a division next above the Order.

col lăt'er al, placed sille by sille.

coll'lum, the part of the root where the stem meets it.

cól'ored, of any color except green, which in botany is not a color, while white is.

col u mĕl'la, the axis to which the rarpels of a compound pistil are often atiached, as in Geranium; or which is left when a pod opens, as in Azalea.

cŏl'umn, the combined stamens and styles.

co lŭm'nar, shaped like a column or pillar.

cō'ma, a tuft of hair.

cŏm'mis sure, the joining of the carpels of the cremocarp.

cŏm'mon, belonging alike to several.

com plēte' flow'er, one that has all the organs, - calyx, corolla, stamens, and pistils. cŏm'pli cate, folded upon itself.

cŏm'pound flow'er, one composed of a number of separate flowers crouded on the torus.

cŏm'pound leaf, one composed of separate leaflets, or little leaves.

com prĕssed', flattened on the sides.

cŏn'chi form, shell-or half-shell-shaped.

cŏn'col or, all of one color.

con $\mathrm{d} \overline{\mathrm{u}}$ 'pli cate, folded on itself lengthwise.

cōne, a strobile; a multiple fruit haring the shape of a cone.

con fer ru'mi nate, stuck together, as the cotyledons in "Hor se-chestnut.

cŏn'tlu ent, uniting; coherent.

con formed', similar to something associated or compared; closely fitted, as the skin to the kernel of a seed. 
con gés'ted, conjlomernte; crowiled tugether. con glow'er ate, crowaleal toyether; ilensely clustered.

cŏn'nate-per fō'li ate, huriu!! the lences connate, or united rommil "stemr.

con tĩu'u ous, not jointed or' articuluted.

con tôrt'ed, tuisted.

con tor $\mathrm{tu}^{\prime}$ pli cate, lu'isterl bru'k "pon itself. con trăc'ted, either narroued or shortened. cơn'tra ry, turned in an opposite direction to the ordinury way.

côr'date, heurt-shaped.

cor i $\bar{a}^{\prime}$ ceous, leuther-like.

côrk'y, of the texture of cork.

côrm, "sort of bulb, or flestıy stem.

côr'ne ous, hor'n-like in texture.

cor nǐc'u late, having a smull horn or spur. côr'nute, hormed; bearing a horn-like projection or appendage.

co rǒl'la, inner perianth, made up of petuls. cor ol lā'ceous, like, ar belonging to, a c'orolln. cor'ol line, pertuining to the corolla.

co rō'na, a crounn.

corr'onate, crouned; furnished with a crourn.

côr'ti cal bark, outer bark.

côr'ticate, conted with bark or bark-like colering.

cŏr'ymb, "flut-topped or convex cluster of flowers, ench on its oun foot-stalk, and arising from different points of a common axis.

cor yun břf'er ous, bearing corymbs.

co ry̆m'bose, in corymbs; approaching the

form of a corymb, or branched in that way. cǒs'tate, ribbed; haring rib-like ridges.

cot $\mathbf{y} \mathbf{l} \overline{\mathbf{e}} \mathbf{d}$ ons, lobes or seed-leaves, or first leries of the embryo.

cra těr'i form, of the form of a goblet. creep'er, "t plant that trails on the ground.

crěm'o carp, a dry fruit of two one-sided earpels, which seporale when ripe.

crë'nate, bordered with rounded teeth.

crěu'u late, finely scalloped.

crěst'ed or crǐs'tate, laving an elevated ridge.

cre ta's'ceous, chalky, or chalk-like.

crǐb'ri form, piercel like a sieve with small apertures.

crī'nite, bearing long hairs.

crō'ceous, saffron-coloren ; of " deep reddishbrow'n.

crǒss'-breeds, the progen! "f imterbred warieties.

cross-fer ti li za'tion, the fertilization of $a$ plant by pollen from " diflerent imlividual. crụ'ci form, in the form of " Romun iross. crude sap, sap hefore it has bern expossel to the sun in the leuf.

crus ta'seous, hari, thin, and lrillt,

cry̆p to gā'mi a, mume of the divisiom uf plunts willont flowers.

cit'cul late, rolled up) intn " hond shupe.

cŭlm, the straw of grasses. cŭl'trate, slupped lilie a trowel or brond hnife. cī'ue ate, "I cu uē'i form, wedge-shuped. cŭp'-bltaped, in the jorm of a drinking-r.np. cü'pu late, providul will a cupule. $\overline{c u}^{\prime}$ pule, "littl' rnp, us the cup, of the arorn. cu pu lif'er ous, c'ujule-benring. cûr vi-sé'ri al, in oblique or spiral ranks. cûr'vi-seined, "rith curred ribs or reins. cush'ion, the enluryement ut the insertion or base of " peliole.

cŭs'pi date, huring " shurp, stït point.

cŭt, having sluarp or deep divissions; incised. cū'ti cle, ouler lumimu of u'all oj epielermis. çy ău'ic, blue, or of uny color exeppt yellon.

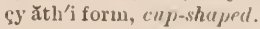

ç.c'lic al, rolled "u circularly, or coiled into "complete rircle.

sy clösis, thr circulation of protoplnsmic gramules within a living regrtuble cell.

cy lin drä'ceous, approuching to the cylindricul form; not tupering; colnmmur.

ç.̆m'bi form, boat-shuped.

ç̄me, flower-cluster wilh the ollest flowers at lhe top) or center.

s. $\vec{y}^{\prime}$ mose, s $\vec{y}^{\prime}$ mous, hating the nature of a cyme; bearing cymes.

ç'́mule, a partial diminutive cyme.

ş' to blas te'ma, the riscous fluid in wich vegetable cells are prouluced and held logether.

$\varsigma \bar{y}$ 'tode, a nucleated mass of protoplusm.

sy'to plasm, a ressel or chamber which sur. rounds or coutuins the protoplasm.

D.

de căg'y nous, having ten pistils or styles. de căm'êr ous, having ten parts.

de cău'drous, having ten slamens.

de şid'u ous, falling at the end of the season. děc'li nate, bent dounuard.

de compound', much componuded or divided.

de $\mathrm{cum}$ 'bent, reclining with the top ascending.

de eŭr'rent, rumning down into, or upon.

de en̆s'sate (leares), opposite and huring the pairs at right angles.

de du pli $\overline{c a}^{\prime}$ tion, separation of an oryun into many parts.

de flexxed', bent dow'nu'ard.

de too'rate, past the flowering stute, as $11 n$ anther ajter it hus discharged its pollen.

de foli a'tion, the crating off of lenves.

de his'sence, mode of the ajiening of seed. ressisel or unther.

de hIs'cent, opmin! hy regulur dehiscence.

del i quĕs'şent. Irunchin!, so that the stem is lost in brumches.

del'toid, like llie lireek letter s in form.

de mirsed', !rmuring belate the surfuce of wenter.

dĕn'droid, trep-like in jorm.

I'R. F'L. -22 
děn'tate, toothed.

dentřc'ulate, toothed with fine or small teeth.

de $n \bar{u}$ 'ded, become naked.

de pau'per ate, less developed than usual.

de pěnd'ent, hanging down.

de prĕssed', flattened from above; low.

de scěnd'ing, tending gradually downwards. de scĕnd'ing ăx'is, the root.

dĕx'trin, a gummy substance produced by the action of diastase upon starch.

dĕx'trorse, twining; turning to the right.

di a děl'phous, having stamens grouped into two sets by united filaments.

di ag nō'sis, a brief statement of the distinctive character of a plant or group.

dialy pět'alous, having separate petals; polypetalous.

di ăn'drous, with two stamens.

di ăph'a nous, transparent, or translucent.

di'as tase, a peculiar ferment in malt, altering starch into dextrine.

di cär'pel la ry, having two carpels.

di ehla my̆d'e ous, having both calyx and corolla.

di ehŏg'a mous, having stamens which ripen before the pistils, or vice rer sa.

di chŏt'o mous, forked, or two-forked.

dic'li nous, having flowers of separate sexes.

di cŏc'cous, splitting into two cocci or closed carpels.

di cot y lěd'on ous, having tu'o cotyledons or seed-lobes.

di cŏt y lē'dons, plants which have two seedleaves in their embryos.

dǐd'y mous, dauble.

di dy̆u'a mous, having the stamens of a fourandrous flower in tu: pairs, one pair shorter than the other.

dif fūse', much divided and spreading.

dY'itate, having several distinct leaflets palmately arranged, as in the leaf of the Hor se-chestnut.

dĭg'y nous, having two pistils or styles.

dY̌m'er ous, made up of two parts, or having organs in two.

di mŭd'i ate (anther), halved.

di môr'phous, having two forms.

di $e^{\prime}$ cious, having staminate and pistillate flowers borne on different plants.

di pĕt'al ous, having two petals.

diph'yl lous, two-leaved.

dīp'ter ous, having two wings.

dǏs'çi form, or disc-shaped, flat and circular, like a disk or quoit.

dis'eoid, having no rays.

dis col'or, of two different colors or hues.

dis crēte', separate; opposite of concrete.

di sěp'al ous, having two sepals.

disk, face of an organ, or a circular spot on cells.

disk-flow'ers, flowers of the disk in Compositae.

dis sěct'ed, cut into deep lobes. dis sĕp'i ment, a partition, a separating tissue.

dis šll'i ent, bursting into pieces.

dǐs'tich ous, arranged in two rows.

dis tinct', separate; not united.

di the'cous, having two thecu, or anthercells.

di văr'i cate, widespread; straggling.

di vēr'gent, spreading with a smaller angle.

di vid'ed (leaves), cut into divisions, down to the base or midrib.

do de căg'y nous, having twelve pistils.

do de căn'drous, having twelve stamens.

do lăb'ri form, ax-shaped.

dôr'sal, on, or relating to, the back.

dot'ted cells, cells with sinall spots.

dot'ted ducts, ducts with spots or dots.

doŭ'ble flow'er, a flower in which the stamens become petals.

down'y, clathed with shart, weak hairs.

dru pā'ceous, like a drupe.

drupe, a stone fruit, as the Peach and Cherry.

dry'ing-press, an apparatus for drying botanical specimens.

dŭcts, elongated cells through which the fluids of a plant pass.

du mōse', bushy; like a bush.

dū'pli cate, in pairs; double.

du rā'men, heart-u'aod.

dwarf'ing, preventing a plant from growing to its full size.

\section{E.}

ēared, auriculate; having ears.

e brăє'te ate, without bracts.

ěch'i nate, prickly; with rigid hairs.

e děn'tate, toothless.

ef fēte', sterile, exhausted.

ef fūse', very loosely branched and spreading.

e glăn'du lose, destitute of glands.

ěl'a ters, spiral, elastic threads accompanying certain spores.

el lip soi'dal, shaped like an ellipsoid.

el lĭp'tic, el lĭp'tic al, having the form of an ellipse.

e lǒn'ga ted, lengthened; extended.

e mär'gi nate, having a notch at the apex or top.

ĕm'bry̆ o, the young plant in the seed.

em'bry o săc, the cell in the ovule in which the embryo is formed.

ĕm'bry o nal, belonging, or relating to, the ovary.

e mersed', raised out of water.

en de căg'y nous, having eleven pistils or styles.

en děm'ic, peculiar to a country geographically.

ěn'do carp, the inner layer of a seed-vessel.

ěn'do chrome, the coloring matter of plants. 
eu dog'e nous struc'ture, structure in which the pith and wooly fiber are indiscriminately mingted.

en'dogeus, plants whose structure is endogenous.

en do phlo'tum, llie mner layer of bark.

eu do pleñ'ra, the inner couting of a seed.

en do rhi'zal, rulicle, or root, sheathed in germination.

en'dos mose, a thrusting, cunsing liquids of different densities to pass through thin membranes and mingle.

ěn'lo sperm, the albumen of u seed.

En'do stome, the orifice in the inner coat of an ovule.

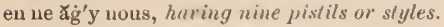
en ne au'drous, having nine stamens.

ěn'si form, su'oril-shapped.

en tīre', mär'gined, huving "l continuous ealye.

ento moph'ilous (Alowers), frequented and fertilized by insects.

e phĕm'er al, enduring for one duy.

epica'lyx, an intolucel like that of the Maliacere.

ép'i carp, the outer layer of a seed-z'essel.

ep i dēr'mis, outer layer of cells.

ep ige'ous, growing on the eurth, or close to the ground.

e prg'y nous, ulnate upon the top of the ocary.

ep İ pět'a lous, groucing upon the petals.

e prph'yl lous, borne on a leaf.

ép'i phytes, plunts on other plants.

e pip'te rous, winged ut the top.

ep'i sperm, the skin of the seerl.

$\overline{\mathrm{e}}^{\prime}$ qual, alike in number or length.

ĕq'ui tant, astrailule.

e rǒs'trate, not beakiedl.

e ryth ro cär'pous, red-fruiled.

es sěn'tial ôr'gans (of " tower ), stamens and pistils.

e'ti o la ted, colorless for waut of light.

ex al bü'mi nous, without ulbumen.

ex cŭr'rent, running theough or beyoud.

ex İg'u ous, puny; small.

ex'o carp, outer layer of " pericar $p$.

ex б̆g'e ur, ё'о geus, plunts which increase by the addition of new material outside of last year's grouth.

ex б̆g'enous struc'ture, structure like an exogen.

ex orhi'zal, radicle in germination, not sheathed.

exx'os mose, flowing out.

Ex'o stome, the orifice in the onter cont of the ovule.

exx'pla uate, spreaul or flattened out.

exx sert', projecting ont of or beyond.

ex stYp'u late, withont stipules.

extine, onter coat of a pollen groin.

exx'tra-ăx'il la ry, groning from without the axils.

ex trôrse', turned outuard.
F.

făl'cate, siythe-shaped; curved.

făı'ily, in botany, same as Urdrr

fa ri'ua, meal or starchy matter.

far i nä'ceous, flour-like in lexture.

far'i nose, mealy on the surjure.

fas'ciate, bunded; also upplisel to monstrons stems which grou Hint.

făs'çi cle, " bundle.

făs'şicled, fasçic'ulate, fas ç̣c'u lā'ted, in the form of a fascicle; grouring in a bunalle or tujt, as the lentes of Larch and roots of Peony.

fas třg'i ate, close, parallel, and upright; as the branches of Lombarly P'oplar.

faux ( $p l$. fau'ces), the throat of a calys, corolla, etc.

fa vē'o late, honeycombel; alreolate.

ferath'er-veined, with all reins from the siules of the midrib or midrein.

fē'male flow'er or plaut, one having pistil only.

fe uĕs'trate, pierced with one or more large holes, like windou's.

fer ru'gi nous, of the color of iron-rust.

fër'tile flow'er, seed-producing flou'er.

fer tili zā'tion, act of making fertile.

fi brǐl'la ( $p l$. fibrillex), fibril, minute lleread.

fi bro-văs'cu lar, containing woody fibers and ducts.

frd'dle-shaped, obovate, with a deep recess on each side.

frl'a ment, the stalk of a stamen.

fil'i form, slender; like a thread.

fim'bri ate, fringed; having the edge bordered with slender processes.

fŕs'sion, a splittiny into parts.

fis sĩp'a rous, multiplying by division of one body into two.

fis'tu lar, hollow, as the leaf of an Onion.

fla běl'li form, fan-shuperl.

fla gēl'li form, whip-shuped; long, topering, and supple.

fla věs'çent, yellowish; turning yellou:

flěsh'y, composed of firm pulp, or fless.

flěx'u ous, zigzug, or wary.

floc'cose, haring tufts of soft hairs.

flo'ra, the spontaneous regetation of a coun-

Iry: a uritten description of the sume.

flörral, relating to flowers.

flo'ral en'vel ōpe, the perianth of u tlouer.

flo'ret, one of the small flowers composiny u compound flower.

flō rif'er ous, moducing flowers.

flos'cule, a floret.

flow'er, the organ which produces the seed.

flow'er bud, on underelopent blossom; the dormant, or slepping, flower.

fo li $\bar{a}^{\prime}$ ceous, leuf-like in texture or form.

fóli ate, provided nill lentes.

fo li à'tion, the net uf leating.

fo'li u late, relating to or beuring leaftets. 
fo'lli ole, a leaflet; a distinct part of a compound leaf.

fó'li ose, bearing many leaves.

fó'li um ( $p l$. folia or foliums), a leuf.

frl'li cle, a one-celled, many-seeded carpel, opening by the ventral suture.

fol lǐc'u lar, like, pertaining to, or consisting of follicles.

foot'stalk, a pedicel, petiole, or peduncle.

fo rā'men, a small opening or orifice.

fo răm in İf'er ous, having small openings.

fo răm'i nous, full of holes.

fôrked, branched into two or three or more.

fôr'ni cate, having an wr'h or scale over the throat of the corolla.

fôr'nix, a small arched scale in the throat of a corolla, as in Comfrey.

fo've o late, having shallow pits.

free, not adherent or adnate.

frǐnged, edged with soft hairs.

frŏnd, an organ which is both stulk and leaf.

frŏn'dent, covered with leaves.

fron děs'cence, the act of bursting into leaf.

frŏn'dose, frond-bearing, leafy.

fruc ti fi ca'tion, the act of producing fruit.

fruit, a ripened pistil; a seed-vessel with its contents.

fru těs'çent, shrubby in character.

fu gā'cious, lasting but a short time.

fŭl'cra, accessory organs, such as tendrils, stipules, etc.

fu lĭg'i nous, of a sooty color; smoky-brown; blackish.

fŭl'vous, dull yellow; tauny.

fü'ni cle, fu nic'ulus, the stalk of an ovile or seed.

fûr'cate, forked; forked-reined.

fur fu rā'ceous, scurfy.

fûr'rowed, marked lengthwise with channels. fŭs'cous, grayish or blachish brown.

fü'si form, spindle-shaped.

\section{G.}

găl'bu lus, the woody cone of the Juniper and Cypress.

gä'le a, the name applied to the upper lip of labiate corollas.

gā'le ate, shaped like a helmet.

gămo pĕt'a læ, plants whose petals are united.

găm o pět'al ous, having the petals united; sympetalous.

ga mŏph'yllous, having united perianth leaves.

găm o sěp'al ous, with the sepals united.

ġĕm'i nate, having two together.

gem $m \bar{a}$ 'tion, formation of new individuals by budding.

germ'mule, a small bud; the plumule.

ğĕn'e ra, spe genus.

ge nĕr'ic, pertaining to a genus.

ġe nǏc'u late, bent at an angle. gē'nus ( $p l$.genera), a group of species alike in their fructifying organs.

germ, the ovary.

gér'men, the old nume for the ovary.

germi na'tion, the development of the seed into a plant; sprouting.

gǐb'bous, having a rounded protuberance at the side or base.

glā'brate, becoming glabrous, or almost glabrous, with age.

glā'brous, smooth; not hairy.

glăd'i ate, sword-shaped.

glănd, an organ of a leaf or branch which secretes a fluid, us oil, resin, etc.

glăn'du lar, consisting of glunds.

glăns, the acorn or mast of the Oak and similar fruits.

glâr'e ose, growing in gravel.

glau çĕs'cent, slightly glaucous, or bluish gray.

gláu'cous, with a bloom or whitish waxy powder, as on fresh plums.

glo bōse', nearly spherical in form.

glo chrd'i ate, tipped with barbs, or with a double-hooked point.

glŏm'er ate, collected into close heads.

glŏm'er ụle, a cyme groun in the form of $\boldsymbol{a}$ head.

glu mā'ceous, glume-like; glume-bearing. glu mĕlles', the inner hushs of grasses.

glumes, bracteal coverings of flowers or of the seeds of grains and grasses.

gǒn'o phore, a stipe below stamens.

gǒs'sy pĩne, cottony; flocculent.

graft'ing, the act of inserting a shoot or scion from one tree into the stem or some other part of another, so that they unite and produce fruit of the kind from which the shoot was tuken.

grain, the guthered seeds of cereal plunts; a grain-like prominence or tubercle, us on the sepals of Dock.

gra min'e ous, grass-like.

grău'u lar, composed of grains.

grǐs'e ous, gray; bluish gray.

grứmous, or grumōse', formed of coarse, clustered grains.

gŭt'tate, spotted as if by spots of something colored.

ġym no cär'pous, having a naked fruit.

ġym no spër'mæ, a class of exogenous plants characterized by naked seeds.

ġym no spërm ous, having naked seeds.

gy năn'drous, bearing stamens on the pistils.

ġy̆n'o base, a process of the torus, on or around which the carpels are suspended.

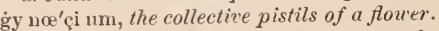

ġy̆n'o phore, a produced torus bearing the ovary on its summit.

ġy̆n o stē'gi um, a sheath around pistils.

ğy̆n o stē'mi um, the column in Orchids consisting of style amel stigma with stamens combined.

ġy'rāte, curced' incord ; circinate. 
II.

hăb'it, the general aspect of a plunt.

hăb'itat, the natural loculit! or growth of a wild plant.

hâirs, outgrouths of epilermal cells.

hâi'y, corered wilh hutr; mudc of or rcsembling hair; hirsute.

nal'berd-shaped, hustate.

bälved, one hulf upparently deficient.

hā'mate, or ha mōse', haring the end hooked or curved.

lı̆m'u lose, haring a small hook.

hap lo stëm'o nous, having only one series of stomens.

has'tate, triangular, with the base-lobes "bruptly spreading, as in a halberd.

hĕad, copitulum; a form of inflorescence.

heärt'shaped, a form which liould be presenterl by the section of a sheep's heart, if cut in halves.

heärt'-wood, the wood near the central part of an exogenous tree or shrub.

hěl'i coid, coiled like a helix or the shell of u snuil.

hêl'met, the hood-formed npper sepal or petal of some floners, as of the Monkshood.

hěl'vo lous, grayish-yellow.

hĕm'i carp, half-fruit; one carpel of an umbelliferous plant.

hep tăg'y nous, haring seren pistils or styles. hep tăm'er ous, having the parts in sevens.

hep tăn'drous, having seren stumen:

hërb, a plunt whose stem is not persistently woody, and does not remain jermanent, but dies at least doun to the yround after. flowering.

her bā'ceous, green and cellular in texture.

her $\mathbf{b a}^{-}$'ri um, a collection of drieul plunts, for the use of students of botimy.

her mălnh'ro dite (flower), having both stanens and pistils.

hes per Id'i um, "l berry with a thick rind, as the orange, etc.

het er o cär'pous, bearing fruit of tu'o kinds or shripcs.

het er o çěph'a lous, liating hemls of two sorts on the same plunt.

het er бg'a mous, haring two sorts of flowers on the same heal.

het er ŏg'ony, haring stamens or pistils of two sorts.

het er o môr' plious, nf two or more shapes.

het er oph'yl lous, hiring tuo sorts of leares on the same stem.

heter ot'ro pous, haring the cmbryo oblique or transverse to the funiculus; amphitropous.

hex ăğ'o nal, six-sided.

hex đun'er ons, in sir parts.

bex ăn'drous, having sir stumens.

hi ber năc'u lum, a uinter bud.

hi'e mal, occurring in winter.

hi'lal, belonging to the hilum. hi'lum, the eye or scar of the seed.

hip po crěp'i form, horse-shoe shaped.

hir sinte', huiry, with ruther long hairs.

hir těl'loia, minumuly hirsute.

hǐs'pid, bristly; huving stiff hairs.

his tŏl'u $\dot{\mathrm{g} y}$, the scirnce of cells and tissues.

hōar'?, frost-colored; yruyish-u'hite.

ho 11 ŏd'ro uous, running in one direction.

ho nŏg'a mous, har'mg all the flowers alike.

ho mo ge'tie ous, of the stime lind or nature.

lio mŏl'o gous, of the same tyje.

ho inort'ro pous, haring the radirle of the seed directed toward the hilum.

hood, the helmet-shaped upper petal of some flowers.

hooked, hooli-slupped; humate.

hor tĕ"n'sial, jit for " gurden.

- hôr'tus sĩc'cus, an herburium; a collectunn of dried plint specimens.

hu'mifuse, spread over the surface of the ground; procumbent.

hy'a lĭue, trunsparent, or neurly so.

h's'brid, a cross-brced between turo species.

hy'dro phyte., water-plants.

liy $\bar{e}^{\prime}$ ni um, the spore-beuring surjace of some jungi.

hy lăn'thi um, a hollow flouer-receptucle, as of a rose.

hy per bö're an, inhubiling northern regions. hyp o era tĕr'i form, sallecr-shaperl.

lyp o gē'an, growing unuler ground.

hy pŏr'y nous, inserteil belou the pistil.

hys ter ăn'thous, huring the blossoms develop earlier than the leares.

\section{I.}

i cosău'drous, having tuenty stamens inserted in the colly.r.

Im'bri cate, imbricuted, overlapped so as to break joints, like shingles on a roof.

im när'giu ate, hri'ing no rim nr londer.

im mérsed', gron'ing whully under water.

Im'par i pru'uate, pinnate with a single lenflet of the apex.

in për'fect flow'er. " Nower wanting rither stamens or pistils.

in äne', empty; soid of an anther which produces no pollen.

in a! pen dĩc'u late, not uppeniluged.

in ea ušs'sent, or in ē̃'unus, hoary, hering a sofl white puhessener.

in cär'uate. flesh-colurerl.

in cised'. divided dreply, as if cut.

in clintl'ed, incloserl or ranfined within: as short stamens in a corolla.

iu com plēte' flow'er. wanting c llyx or corolln. in cras'sate, thi lien il.

In'en bons. hurit a the lip gi ane leaf lying flat orer the buse of the nert alove.

in cŭm'bent, haring tlir ralislr lying agriust the lack of one of the cotyledons.

in carved', gradually curving incard. 
in deff'inite, too numerous or variable for specific enumeration.

in děf'i nite in flo rĕs'çençe, or in de têr'minate inflorescence, $a$ process of inflorescence in which the flowers all arise from axillary buds, the terminal bud continuing to grow, and extending the stem indefinitely.

in de hĭs'çent, not opening.

in de têr'mi nate, see indefinite.

in dĭg'e nöus, native to a country.

in du měn'tum, any hairy covering or pubescence which forms a coating.

in $\mathrm{d} \overline{\mathrm{u}}^{\prime}$ pli cate, having the edges bent abruptly toward the axis.

in $\mathrm{d} \overline{\mathbf{u}}$ 'si um, the shield of the fruit dots (sori) in many ferns.

in $\mathrm{d} \overline{\mathrm{u}}^{\prime} \mathbf{v i}$ ate, clothed with old and withered parts.

in e qui lăt'er al, unequal-sided, as the leaf of a Begonia.

in ër'mis, devoid of prickles or thorns.

In fër'tile, not producing seed or pollen, as the case may be.

in flāt'ed, turgid and bladdery.

in tlět'ed, bent inward; inflexed.

in flo rĕs'çençe, mode of flowering, or the arrangement of flowers on a plant.

In fra-ăx'il la ry, situated beneath the axil.

in fun $d \mathrm{Irb}^{\prime} \mathrm{u}$ li form, funnel-shaped.

In'nate, growing on the top of the part that sustains it.

in no vā'tion, a young shoot or new growth.

in sērt'ed, situated upon, growing out of, or attached to some part.

in sër'tion, the attachment of one part to another.

In'te gral, entire, not lobed.

in tĕg' u ment, a coat or covering.

in tër'ca la ry, inserted or introduced among others.

in ter çěl'lu lar (passages, spaces), lying between the cells or cellules.

in ter foli a'ceous, situated between opposite or whorled leares.

in'ter node, the space between two nodes.

in ter pĕt'i o lar, between the petioles.

in ter rŭpt'ed ly pin'nate, pinnate without a terminal leaflet.

In'třne, innermost coating of a pollen grain.

in tra fo li ä'ceous (stipules, etc.), growing between the leaf or petiole and the stem.

in trôrse'(anthers), turned inward, or toward the axis.

in truse'. projected or pushed inward.

in tus sus çĕp'tion, the interposition of new vital or formative material among the particles already in existence, as in the growth of a cell wall by the introduction of neu matter thronghout the structure, and not by adding to the surface.

in vërse', or in verrt'ed, having the apex in the opposite direction to that of the organ it is comparei with. in $v ð l^{\prime} \mathbf{u}$ çel, a partial or small involucre.

in vo lī'cel late, furnished with an involucel.

in volu $\bar{u}^{\prime}$ crate, furnished with an involucre.

In'volu ere, a cluster of bracts around the base of a flower.

In'vo lute, rolled inward.

ir rĕg'u lar flowers, flowers whose like parts difjer either in size or shape.

i sŏm'er ous, composed each of an equal number of parts, as the nember's of the several circles of a flower.

i so stĕm'o nous, having the stamens equal in number to the sepals or petals.

\section{J.}

joint'ed, haring joints or separable pieces.

jū'gum, one of the ridges com monly found on the fruit of umbelliferous plants; a pair of opposite leaflets.

jụ'li form, or ju $\overline{l u}^{\prime}$ çent, lhaving the form of a catkin or julus.

\section{K.}

keel, the two lowest petals of the corolla of a papilionaceous flower united and inclosing the stamens and pistil ; a carina.

keeled, having a longitudinal prominence on the back; carinate.

kèr'nel, the whole body of the seed within the couts.

kēy-fruit, $\alpha$ dry, indehiscent, usually oneseeded, winged fruit; a samara.

kíd'ney-shaped, laving the shape of a kidney; reniform.

\section{L.}

la běl'lum, the lower petal of an orchidaceous flower.

lä'bi ate, lip-shaped.

la $\bar{a}^{\prime}$ bi $\overline{\mathbf{a}}^{\prime}$ ti flo'sous, having flowers with labiate corollas.

lăç'er ate, torn irregularly by deep incisions; jagged.

la ç̌n'i ate, slashed into deep, narrow, irregular lobes.

lac těs'cent, containing a thick milk-like fuid or juice.

lac tĩf'er ous třs'sue, a tissue whose cells and ducts bear milk-like fluid.

lăc'u nose, having lacunre or holes; furroued; pitted.

la cȟş'trĭne, growing in lakes.

læv'i gate, smooth, as if polished.

la g'é'ni form, bottle-shriped.

la gö'pous, densely covered with long, soft hairs.

lăm'el lar, or lăm'el late, consisting of flat plates or lamellie.

lā'nate. wooly; clothed with long, soft, entangled hairs. 
Ixn'çe o late, lance-shaped.

lis $n \bar{u}$ 'gi nose, covered with down, or fine soft hair.

lap pä'çeous, covered with forked points.

lia'tent, conccaled or undeveloped.

lit'er al, belonging to the side.

lat er I'tious, brick-colored.

lä'tex, the turbill or milky juice of plants.

lat i fō'li ous, broad-lenved.

lēaf, a colored expansion, grouing from the stems or branches of a plant.

leaf bŭd, a bud that develops into a leaf or leajy branch.

leaf'let, one part of " compound leaf.

lēaf scär, a cicutrix on a stem from which a leaf has fallen.

lěath'er y, har'ing the consistency of leather ; coriaceous.

lěg'ume, $a$ seed vessel which opens by both $a$ ventral and dorsal opening, as the bean, pea, elc.

le $g \bar{u}^{\prime}$ mi nous, belonging to the legumes.

lěu'ti çel, a small, oval, rounded spot upon a stem or branch, from which the underlying tissues may protrude, or roots may issue, either in the air or when the stem or branch is covered with water.

len tře'ular, resembling a lentil in size and form.

len tǐg'i nose, bearing numerous dots resembling freckles.

lep'rous, corcred with scurfy scales.

$1 \overline{1}$ 'ber, the inner bark lying next to the wood.

li'ehen, a flowerless plant growing upon rocks, trees, and various bodies.

lid, the cover of the spore case of mosses; the top of an ovary which opens transversely; an operculum.

Irğ'ne ous sy̆s'tem, u'oody system.

IȲ'u late, strap-shaped.

lig'ule, a stipule of grasses.

lil i $\bar{a}^{\prime}$ ceous, like a lily.

limb, border of a petal or sepal.

$1 \mathrm{Im}$ 'bate, bordered, as when one color is edged with another.

line, the twelfth of an inch.

IIn'e ar, long and narrout.

IYn'e ate, marked longitudinally with depressed purallel lines.

IIn'gui form, ligulate.

IIn'gu late, tongue-shaped.

IIp, one of the lobes of "labiate corolla.

IYt'to ral, belonging to the shore.

IYv'id, clouded with bluish brow'n or gray.

Iö'bate, lobed.

lo cể'late, divided into secondary compurtments or cells.

lðc'u lar, relating to the cell or compartment of an ovary.

loc u li ci'dal, dehiscent through the middle of the back of each cell.

lo cirs'ta. the spikelet of a flower cluster of grasses.
1Xd'icule, one of the scales answering in grass flowers to the perianth.

$\overline{l o}$ 'ment, a jointed legume.

lo men táceors, like a loment; having fruits like loments.

10̄'rate, strap-shaped; ligulate.

lū'nate, crescent-shaped.

lü'pu liu, a fine, yellow, resinous pouder, found upon strobiles or fruit of hops.

lu'te ous, yellowish; more or less buff.

lu těs'cent, of a yellowish color.

ly'rate, lyre-shaped, or spatulate and oblong, with small lobes toward the basp.

\section{M.}

măc'ro spore, a large spore of certain flowerless plants.

măc'u late, marked w'ith spots or blotrhes.

māle, staminate.

miam mōse', breast-shaped.

mar cěs'cent, withering, but persistent.

mär'ginal, pertaining to the margin or border.

mär'gin ate, having a margin distinct in appeurance or structure.

măr'i tı̌me, belonging to seaconsts.

mär'mo rate, variegated like marble.

mēal'y, farinaceous.

me'di al, or me'ti an, running through the middle; belonging to the middle.

me dŭl'la, pith; soft cellular tissue occupying the center of a stem or branch.

mẽd'ul la ry rays, rays of cellular tissue seen in a transverse section of exogenous wood, which pass from the pith to the bark:

mĕd'ul la ry shēatl, the tube formal by the spiral reso's around the central column of pith.

mei o stěm'o nous, having fever stamens than the parts of the corolli.

mem bra nä'ceous, neu brā'nous, thin. and rather soft or pliable, as the leares of the Rose, Iench-tree, and Aspen Poplar.

me uIs'coid, crescent-shaped.

merr'i carp, one carpel of a cremocarp of an umbellifer.

mer is mat'ic, diriding into cells or segments by the formation of internal partitions.

mes'o carp, the midlle layer of a pericarp, consisting of three distinct layers.

mes o phlo'wu, the midlle or giern bark. me taxb'o lism, transformation of one kind of substance inta another in assimilation.

mi'cropyle, an opening in the outer coat of a seed through $w$ ich the fecundating pollen enters the orule.

mi'crospure, an exceptingly minute spore found in certain towerless plants.

uIY'rib, $m$ mId'vein, the central rein of a lenif.

mIllk'-vess'sels, certnin cells in the inner hark of plants onnfaining milky juire. 
mIn $\ddot{i}$ ate, vermilion.

mit'ri form, having the form of a miter or peaked cap.

mon a děl'phous, having the stamens united in sne body by the filaments.

mo năn'drous, having but one stumen.

mo nǏl'i form, jointed or constricted at regu-

lar intervals, to resemble a string of beads. mon o cär'pic, fruiting but once.

mou o ehla my̆d'e ous, having "single floral envelope, either calyx or corolla.

mon o cot y le'dou, a plant having only one cotyledon or seed lobe.

mo no'cious, having stamens and pistils on the same plant.

mo nǒg'y nous, having only one style or stigma.

mon o pět'al ous, having but one petal.

mo nŏph'yl lous, having but one leaf.

mon o sěp'al ous, having the calyx in one piece.

mon o spër'mous, having but one seed.

mŏn'strous flow'ers, flowers whose stamens have developed into petals.

mor phŏl'o gy, that branch of biology which deals with the structure of animals and plants, and treats of the forms of organs, describing their varieties, homologies, and metamorphoses.

mos'chate, exhaling the odor of musk.

m̄n'cro, a minute, sharp, abrupt point, as of a leaf.

$\mathrm{m} \overline{\mathbf{u}}$ 'cro nate, ending abruptly in a sharp point.

mu crŏn'u late, tipped with a small point or points.

mŭl'ti fid, cut into many segments.

mū'ri cate, full of sharp points or prickles.

$\mathbf{m} \bar{u}^{\prime} \mathbf{r i}$ form, resenbling a wall of mason work. mus cŏl'o gy, bryology; that part of botany which relates to mosses.

$\mathbf{m} \overline{\mathbf{u}}$ 'ti cous, without a point; blunt.

my ce''li um, the white threads or filamentous growth from which a mushroom or fungus is developed.

\section{$\mathrm{N}$.}

nā'ked seeds, seeds not in a seed ressel.

nā'pi form, turnip-shaped.

nā'tant, floating in water; submersed.

năt'u ral ized, growing spontaneously, but not native.

navic'ular, boat-shaped, as the glumes of many grasses.

nĕck'lace-shaped, looking like a string of beads.

něc'tar, honey.

nec tar if'er ous, secreting honey; having a nectary.

něc'tar $\mathrm{y}, a$ vessel containing honey.

něm'o ral, or nĕm'o rous, pertrining to a uood or grove; wondy; inhabiting groves. nërves, reins. ner vōse,' conspicuously nerved.

nĕt'ted, or nĕt-veined', having the reins interlaced so as to present the appearance of a net.

neu'tral flow'er, a flower without stamens or pistils.

nĭt'id, bright; lustrous ; shining.

n'̀'vai, living in or near snow.

nǐv'e ous, snowy; snow-white.

nŏd'ding, mutant; having the summit bent over, us in the Snoudrop.

nōde, a joint of a stem.

no dōse', knotty; having numerous or conspicuous nodes.

nǒd'ulose, haring small nodes or knots; diminutively nodose.

nō'men cla ture, the technical names used in any particular branch of science or art.

nôr'mal, regular; according to rule.

nōtate, marked with spots or lines, which are often colored.

nu ca men tā'ceous, resembling a small nut; bearing one-seeled, nut-like fruits.

nu cěl'lus, nucleus; kernel.

nu'ci form, shaped like a nut.

nu clē'olus, $a$ dense rounded body within a nucleus.

nū'cle us, a kernel; an incipient ovule of soft, cellular tissue.

nut, the fruit of certain trees and shrubs, consisting of a hard and indehiscent shell inclosing the kernel.

nu'taut, nodding; having the top bent downward.

nŭt'let, a small nut; the stone of a drupe.

O.

ob com prěssed', flattened back and front.

obcôr'date, heart-shaped, with the attachment at the pointerl end.

oblău'ce olate, lanceolate, narrouing toward the point of attachment.

ob lïque', having uniequal sides, as the leaves of an $\mathrm{Elm}$.

ob'long, longer than broad, the sides being nearly parallel.

ŏb'o vate, egg-shrped, haring the broad part at the apex.

ob tinse', blunt at the apex.

ob'verse, haring the base, or end next the attachment, narrower than the top.

ŏb'vo lute, overlapping.

o cěl'late, marked with eye-like spots of color.

o'ehrea, a kind of sheath formed by two stipules uniting around $a$ stem.

oeh ro leü'cous, yellow ish-u'hite.

oc tăn'drous, having eight distinct stamens. oc tŏg'y nons, having eight pistils.

ŏc'u la ted, having spots or holes resembling eyes.

of fĩc'i nal, used in medicine, - therefore kept in the shops. 
Off'set, a short, prostrate shnol, which tukes root and prailuces it luft of leaves.

al er a'ceous, cisculent, as a pot herl.

ol i găn'drous, huring few stumens.

ol i vā'ceous, olive-green; resembling the olive.

$\overline{\mathbf{o}}$ 'ö phore, an alternately produced furm of certain cryptogumons plunts, which bear opposite fructifying orguns.

$\bar{o}$ 'ö plio rĭd'i un, the spore-case containing the larger female spores.

o jāque', dull, not shining.

o pêr'cu lar, horing ulid.

бj'po site, set over ayuinst euch other, but separated by the whole liumeter of the stem; placed directly in front of another part or organ.

бp pos'i ti fō'li ous, placed opposite "leaf.

or b̆c'u lar, or or b̆̌c'u late, haxing u circular or nearly circular oulline.

or chi dā'ceous, like an Orchid in form.

ôr'der, "group below Class.

ôr'gan, any member of a plant, as a leaf, a stamen, etc.

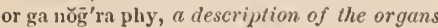
of " plant.

or'thǒs'ti clous, straight-runked.

or thŏt'ro pous, having the nxis of an orule or seed straight from the hilum or chalaza to the orifice.

бs'se ous, bomy; hard, as the peuch-stone.

out'growth, grouth from the surjince of $a$ leaf, petal, etc.

$\overline{\mathbf{o}} \mathbf{} \mathrm{val}$, shaped like the longitudinal spction of an egg.

o'va ry, that part of the pistil containing the ar'te.

o'vate, oral.

o'void, resembling an egg in shape.

$\overline{\bar{o}^{\prime}}$ vule, the young seed.

\section{P.}

pal'ate, a projection of the louer lip of a labiate corolla into the throat, us in Snapdragon, ple

pā'le à, chaff, or chaff-like braft.

pa le $\bar{a}$ 'ceous, chuti!y; haring paleu.

pa lé'o la, a diminutire palen.

pa le'o late, huring palenler, or narrou' palear. y'ăl'et, same ras palea.

păl'mate, lobetl so that the sinuses point to the apex.

pal mat'i fid, palmate, with the lirisions seyarated but litlle more than half way to the common center.

pal măt'i lobed, palmate, w'ith the dirisions separated not half way to the common center.

pal inat'i sect, dirided dou'n to the midrih.

păl'mi veined, having reins or nerves erlending loward the aper.

păl'u dose, living in murshes.

pan dü'ri form, fildle-shriped. păn'i cle, a brancỉing raceme.

păı'i cled, or pan Yc'u late, horing panicles.

jăn'nose, covered with " jelt of wooly hair.

pā'per $y$, of about the ronsistence of letter puper.

pa pirl'io na'ceous, resembling the butterfly.

pa pril'la ( $p l$. pa pril'lie), little nipple-shaped protuberances.

păp'il late, or păp'il lose, cmered with papilla'; resembling papiller.

păp'pus, the scales, aw'ns, or bristles which represent the calyx in C'omposita.

papy rā'ceous, of the consistence of paper: pupery.

parr'al lel-veined, huring the veins or neries extending from the luse of the leaf to the ujer, parallel to the milrein.

pa răph'y sis, " minute-jointed filoment among the archegonin and antheridin of mosses.

păr'a site, a plant obtrining nourishment immediately from another plant, to which it atturhes itself.

pa rĕñ'elıy ma, soft cellular substance of " tissue, like the puly of leares, haring no wood fibre.

pa rĕn'chy ual, consisting of purenchymu.

par en thým'a tous, pertuining to the parenchyma of a tissue or organ.

pari'e tal, attached to the muin wall of the orary.

păripั̆n'nate, having an equal number of leaflets on each side, with no odd leaflei.

pärt'ed, deeply divided into parts.

pär'the no gèn'e sis, the prouluction of seed withont fertilization.

pär'tial În'volucre, a secomlary or small involucre: inrolueel.

pär'tial pe dŭn'cle, $a$ branch of $a$ peduncle. pär'tial nět'i ole, a lirision of " main leafstalk, or the stalk of a leutlet.

par'tial um'bel, an umbellet.

par tr'tion, a wall in a capsule, anther, otc.

pa těl'li form, disk-shaped, like the patella, or kner-pan.

pat'ent, wide open ; spreading.

pat'u lous, half open; expaniled.

peâr'-shaped, oboroid, anil larger ahole.

pèc'ti nate, having teeth like a camb; finely pinnatifill.

pèd'ate, shaped like a birll's font.

pěd'i çel, a stulk which supports nne tinuer or fruit, whether salitary or sme of man! ultimate livisions of a conmmon perluncle.

pĕd'i č̆led, ped i cěl'late, haring a pedicel : supported on a perlierl.

pe dūñ'cle, a Hower-slalk supporting a single flawer or flower-cluster.

pe lo'ri a, an abuormal return to regularity and symmetry in "ln irregular foncer. rommunest in sumpdrugon.

je lō'ric, almarmally regular or symmetrical. pel'tate, shield-shrpel. 
pĕnd'eut, or pĕn'dulous, supported from above; suspended; hanging; drooping.

pen i cěl'late, furnished with a pencil of fine hairs; ending in a tuft of hairs.

pěn'nate, pinnate; having several leaflets arranged on each side of a common petiole.

pěn'ni nerved, feather-veined.

pen tăm'er ous, five-parted; having the parts in fives.

pen tăn'drous, having five stamens.

per ěn'ni al, living several years.

për'fect How'er, a flower having both stamens and pistils.

per fo'tli ate, having the basal part produced around the stem.

pêr'fo rate, pierced with holes or transparent dots resembling holes, as an Orange leaf.

pĕr'ianth, calyx or corolla, or both; the leafy purts of a flower surrounding the stamens and pistils.

pĕr'i carp, the ripened ovary; the covering of the seed.

per i cär'pic, belonging to the pericarp.

pěr'i gone, or per i gō'ui um, an organ inclosing the essential organs of a flower; $a$ perianth.

per i ğy̆n'i um, the bristles, scales, or more or less inflated sack which surrounds the pistil, as in Carex.

pe rĭg'y nous, surrounding the pistil; having a tubular ring or sheath surrounding the pistil, on which the various parts of the flower are inserted.

per i phĕr'ic, around the outside or periphery of any organ.

perr'i sperm, the albumen of a seed, especially that part formed outside the embryo sac.

per'i stome, the fringe of teeth to the spore case of mosses.

per sĩst'ent, remaining long in place.

pér'son ate, masked by a closing of the throat of the corolla, as in the Snapdragon.

per tūse', punched; pierced with holes; slit.

pĕr'u la, a scale of a leaf bud.

pĕr'u late, furnished with scales.

pert'al, one of the lenfy expansions of the corolla.

petăl'o dy, metamorphosis of stamens or pistils into petals, as in double flowers.

pět'al oid, pertaining to a petal ; resembling a petal.

pet'i o late, having a stalk or petiole.

pĕt'i ole, a leaf-stalk; foot-stalk of a leaf connecting the leaf with the stem.

pet i ðl'u late, supported by its own petiolule.

pĕt'i o lule, a small petiole, or the petiole of a leaflet.

phæ no gā'mi a, or phan e ro gā'mi a, name of that division of the vegetable kingdom which bears risible flowers.

phä'lanx ( $p l$. pha lăn'ges), a group or bundle of stamens.

phy cơl'o ġy, the science of Algce, or seaweeds. phyl lo clä'di um, a fattened stem or branch which more or less resembles a leaf, and performs the functions of a leaf.

phyl lo'di nm, a petiole dilated into the form of a blade.

phy̆l'lome, a foliar part of a plant; an organ homologous with a leaf, or produced. by the metamorphosis of a leaf.

phy̆l'lo tax $y$, the order or arrangement of leaves on a stem.

phys i o lŏg'i cal bŏt'an y, that division of the science of botany which treats of the functions of plants.

phy tŏg'ra phy, the science of describing plants in a systematic manner.

phy tŏl'o gy, an account of the composition. of plant organs and the substances that compose them.

pì'le us, the expanded upper portion of many of the fungi.

pi lǐf'er ous, bearing a slender bristle or hair; beset with hairs.

pi lōse', corered with long slender hairs.

pĭn'na, a primary division, with its leaflets, of a bipinnate or tripinnate leaf.

pin'nate, composed of several leaflets, or separate portions, arranged on each side of a common petiole.

pǐn'nate ly lōbed, lobed in a pinnate manner. pin năt'i fid, divided in a pinnate manner, the divisions not reaching to the midrib.

pinnăt'i sect, pinnately divided to the midrib.

pin'nule, one of the small divisions of a decompound frond or leaf.

pì'si form, resembling a pea in size or shape.

pis'til, organ of a flower, made up of ovary, style, and stigma, or ovary and stigma.

prs'til late, having a pistil or pistils, -usually said of flowers having a pistil but no stamens.

pis tillîd'i um, archegonium; the organ in mosses which is analogous to a pistil in flowering plants.

pîtch'er, a tubular or cup-like appendage or expansion of the leares of certain plants.

pith, the soft tissue in the center of the stems of dicotyledonous plants.

pryt'ted, having depressions or excarations.

pit'ted cĕlls, cells with spots or depressions on their walls.

pla çĕn'ta, the part of a pistil or fruit to which the ovules or seeds are attached.

pla çĕn'ti form, having the shape of a circular thickened disk, somewhat thinner about the middle.

plait'ed, folded; doubled over.

plănt, an organized body possessing vitality but not sensation.

plănt grōwth, the manner in which a plant is built $и p$.

plat y phy̆l'lous, broad-leaved.

plei ŏph'yl lous, having several leaves.

pli'cate, plaited like a fan; folded. 
plưm'be ous, resembling lead in eolor. plu mōse', fenthery.

nlī'mule, the first bud or gemule of a youny plant; the bud, or growing point, of thc embryo above the cotyledons.

plu rifó'liolate, huving several or many leaflets.

pðd, a capsule, especially "leyume.

pod o cĕph'a lous, having a heud of flowers on a long peluncle.

jd'o sperm, the stalk of a seed or ovule.

point'less, destitute of any pointed tip, such as a mucro, "lu'n, acumination, etc.

porl'len, the fructifying cells contained in the anthers.

porl'len măss, the united mass of pollen, us in the Milk-weel and Orchis.

pol'len tinbe, the slender tube sent dou: through the style of the pistil, through which the protoplasm of the pollen cell is convcyed to the ovum.

pol li na'tion, the act of furnishing pollen to the stigma.

pol lĭn'i um ( $p l$. pol ľ̌ı'i a ), a ma.ss of pollen. See pollen mass.

pol y a děl'phous, haring the stamens in sereral groups.

pol y ăn'drous, having many, stamens, - more than twelve.

pol y cär'pic, term used by De Candolle in the sense of perennial.

pol y cot y lē'donous, haring many (more thun two) cotyledons, us Pines.

po ly̆g'a mous, having both hermaphrolite and unisexunl flowers.

po ly̆g'y nous, with many pistils or styles.

poly̆m'er ous, having many parts or members in each set.

pol y môr'phous, of several or varying forms. pol y pert'al a, a group of dicotyledonous plants having separnte petals forming a circle inside the calyx.

pol y pert'al ous, having severnl or many separate petals.

pol y sĕp'al ous, having the sepals separate from ench other.

pol y spër'mous, many-speded.

pōme, a fruit like an apple.

po m̌̆f'er ous, pome-hearing.

pðr'rect, outstretcherl.

pos te'ri or, next the axis.

pouch, the silicle or short pod, as of shepherd's-purse.

pre co'cious, flowering before the leaves.

pre fó'li $\bar{a}^{\prime} t i o n$, vernation.

pre môrse', ending abruptly.

prǐck'les, sleuler thorn-like processes.

prǐck'ly, benring prickles or sharp projections.

pri'mIne, the outermost of the two integuments of an orule.

pri môr'di al, earliest formed. Primorlial

leares are the first after the cotyleslons.

pris măt'ic, prism-shroped. proc'ess, an! projection from the surfaer or edge of a body.

pro cŭm'bent, trailing; prostrate.

procurr'rent, running through, but not projecting.

pro dūced', rxtended more than usunt

pro lif'er ons, bcaring offspring, - upplied

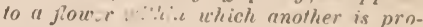
duced, or in a lranch or fromol from which another urises.

pro păb'a !’n, a runuer terminnted t," a gcrminating but.

prosĕn'çy ma, ploul tissue male up of lenathened cells.

prðs'trate, lying flit on the groumd.

pro tăn'drous, pro ter ăı'drous, haring the stamcis come to maturity before the pistil.

proter ¿..'thous, having flowers whell "ppear before tic leures.

proter og'y nous, pro tog'ty nous, havin!) the pistils come ') muturit", lefore the stumens.

prot'ál'li $\cdots$, prothăl'lus, the miunce primury grouth from the spore of jerns, which bears the true sexual organs.

protoph'y ta, one of the primary livisions of vegetable life, containing the smallest and simplest plants.

prō'to plasm, the primary organic substmuce of plants.

prụ'i nose, covered with lust or bloom, so as to give the "ppearmuep at irost.

pter i dŏjh'y ta, a cluss of thouerless plants, embracing ferns, horse-linils, elub mosses, etc.

pu bĕr'u lent, rery minutely tlon'ny.

pu běs'cent, covered with fine short hairs.

pul ver $\overline{\mathbf{a}}^{\prime}$ ceous, or pŭ! vĕr'u leut, huring a finely poudc:irl surfuce.

pŭl'vi nate, $h \sim v i$ ig the form of a cushion.

punc'tate, clotted with sma!l spots of color, or with minutc lepressions or pits.

punc tic'u late, minutely punctatr.

pŭı'gent, prickly-pointcd; hard and sharp. pu uI'ceous, of a brimht red color.

purpü'real, of a purple color, or bluish red.

py răm'idal, in the form of $a$ cone or pyramil.

py rē'na, or py'rene, a nutlet ressmbling $a$ seed; the kernel of a drupe.

py'r'i form, in the inrm of a penr.

py̆x'i date, furnished with a lid.

py̆x'is, a bor which divides cirrularly intn an upper and louer half, the former being a kind of lid.

Q.

quad răı'gu lar, four-angled.

quad ri fó'li ate, four-lentrd.

quad rì'u gate, with, four pairs of lenflets.

quad ri lat'er al, haring four sides.

qui'nate, grming in sels of five. 
quin cŭn'cial, having the leaves of a pentamerous calyx or corolla so imbricated that two are exterior, two interior, and the fifth has one edge exterior and one interior. quIn'tu ple, five-fold.

R.

rāce, a variety of such fixed character that it may be propagated by seed.

ra çēme', a flower cluster with an elongated axis and many one-flowered lateral pedicels.

răç'e mose, growing in the form of a raceme. rā'chis, or rhā'chis, the principal axis in a spilie, raceme, panicle, or corymb.

rā'dial, consisting of, or like, radii or rays.

rā'di ant, having a ray-like appeurance. rā'di ate, diverging from a common center. răd'i eal, belonging to or proceeding from the root.

răd'i cant, taking root on or above the ground; rooting from the stem.

răd'icle, the rudimentary stem of a plant which supports the cotyledons in the seed, and from which the root is developed downeard; a rootlet.

rā'mal, pertaining to a branch.

ram en tä'ceous, beset with thin brownish scales (ramenta), as the scales of many ferns.

răm'i fi cā'tion, process of branching.

răm'u lose, having many small branches.

rā'phe, the continuation of the sepd stalk along the side of an anatropous ovule or seed, forming a ridge or seam.

rāys, radiating branches of an umbel.

reçĕp'ta cle, the apex of the flover stalk, from which the organs of the flower grow, or into which they are inserted.

rĕc'ti nerved, having the nerves or veins straight.

re curved', curved in an opposite lirection ; bent back.

red $\overline{\mathbf{u}}^{\prime}$ pli cate, valvate, with the margins curved ontwarlly, - said of the restivation of certain flowers.

re flěxed', bent backward excessively.

re frăct'ed, bent backward angularly, as if half-brolien.

rĕg'ma, a dry fruit consisting of three or more cells, each of which at length breaks open at the inner angle.

rĕg'ular, hrring all the parts of the same kind alike in size and shape.

rĕn'i form, kidney-shaped.

re pănd', having a slightly undulating margin.

rē'pent, prostrate and rooting.

ré'plum, the framework of some pods (as of the Prickly Poppy and Cress), persistent after the valves fall away. rĕp'tant, repent; creeping.

res pi rā'tion, breathing; the absorption by plants of oxygen, the oxidation of assimilated products, and the release of carbon dioxide and watery vapor.

re sū'pi nate, inverted; appearing to be upside down or reversed.

re třc'u late, netted.

rĕt'i nerved, having reticulate veins.

rétroflexed, bent or turned abruptly backward.

re trôrse', bent backward or downward.

re tūse', having the end rounded and slightly indented.

rěv'o lute, rolled bachward or downward.

rhā'chis, see rachis.

rha'phe, the continuation of the seed stall: along the side of an anatropous ovule or seed, forming a ridge or seam.

rhăph'i des, minute, transparent, often needle-shapel crystals, found in the tissues of plants.

rhi zăn'thous, producing flowers from a rootstock, or apparently from a root.

rhi zō'ma, or rhi zōme', a rootstock; a stem which has the appearance of a root.

rhŏm'bic, shaped like a rhomb.

rhom boid'al, shaped like a rhomboid.

rĭbs, the chief reins of a leaf; ridges.

ri mōse', full of fissures or chinks.

rǐn'gent, gaping, like an open mouth.

rings of wood, circular rings which appear in a cross section of an exogenous stem.

ri pā'ri ous, growing along river banks.

root, the descending axis of a plant; the part of a plant that grows downuard into the ground.

root' cap, a mass of dead cells which cover and protect the growing cells at the end of a root.

roōt'lets, single roots or root branches.

roōt'stoek, " perennial underground stem, producing leafy stems or flower-stems from year to year.

rossa'ceous, like a rose in shape or appearance.

rǒs'tel late, having a rostellum, or small beak; terminating in a beak.

ros těl'lum, a small beak-like extension of some part.

rŏs'trate, beaked; having a process resembling the beak of a bird.

rō'su late, arranged in little rose-like clusters, - said of leaves and bracts.

rō'tate, having the parts spreading out like a wheel; wheel-shaped.

ro ta'ttion, circulation of fluids in the cell. ró'tund, round or roundish in outline. rụ'bi cund, red; ruddy.

rụ'di ment, an imperfect organ or part; $a$ minute part.

ru fěs'cent, reddish; tinged with red. ru gōse', wrinkled; having the veinlets sunken and the spaces between them elevated. 
ru'mi na ted, having a hurd albumen penetrated by irregular channels filled with softer matler.

run'çi nate, pinnately cut, with the lobes sloping dounwarls.

rŭn'ner, a slender prostrate branch, rooting at the end.

\section{S.}

săb'u lose, growing in sandy places.

săc, uny closed membrane, or a cleep purseshapel cavity.

săc'cate, sac-shuped.

săg'it tate, arrou-shaped.

sal sū' 'gi nous, growing in brackish places, or salt marshes.

săl'ver-shaped, tubular, with a spreading border.

sa mā'ra, a winged fruit or seed ressel.

săm'a roid, resembling a samara, or uinged seed ressel.

săp, the watery fluid taken up by the root, and moved through the ressel up to the leares.

săp'wood, the last growth of wood in an exogen.

sär'co carp, the fleshy part of a drupaceous fruit.

sär'ment, a prostrate, filiform stem or runner, like the Strawberry.

sär men tā'ceous, bearing sarments or runners, either spreading or procumbent.

sar men töse', long and filiform, and almost naked, or having leares only at the joints uhere there are roots; bearing sarments; sarmentaceous.

saw'-toothed, serrate.

scā'brous, rough ; scaly.

sca lăr'i form (cells), resembling a ludder ; having transrerse bur's or markings, like the rounds of a ladder.

scāle, a thin, scurious body.

scal'loped, having the edge or borter cut or marked with segments of circles.

scāl'y, furnished with scules, or scule-like in texture.

scău'dent, climbing.

scāpe, a flower stalk springing from the ground.

scā'pi form, resembling a scape.

scär, a mark left "pon a stem or branch by the foll of a leatlet or frond, or upon a seed, by the separation of its support.

scā'ri ose, or scā'ri ous, thin, dry, membranous and not green.

scăt'tered, irregular in position; having no reqular orler; somptimes used for alternate.

sçi' ou, a young shoot used for grafting.

sele rĕı'chy ma, harıl, stony tissue.

sclē'rous, liard ; bony; indurated.

scðb'i form, resembling sau'dust. scro bIc'u late, having numerous small shallow depressions or hollou's; pitted.

scarf, minute scales on the surfice of many leares, as in the Gioosefoot.

scur'ti ness, quality of being scurfy.

scū'tate, or scū'ti form, buckler-shaped; shield-shuped; rounu, or neurly round.

scū'tel late, or scu těl'li form, snucer-shruped, or platter-shayed.

sēa'green, light bluish-green; gluncescent.

se'cund, arranged on one side only; turned only one way.

sěc'un dine, the second coat or inteynment of un orule; tegmen.

seed, matured orule.

sĕg'ment, a sublivision or lobe of any cleft boly.

sĕg're gate, separated from others of the scume kind.

sem i lu'uar, shaped like a half moon.

sĕı'i nal, pertaining to, contuining, or consisting of, seed or semen.

sem i nIf'er ous, seed-beuring; producing seeds.

sem i-săg'it tate, partly sngittute.

sem per vī'reut, always fresh; evergreen.

sĕn'ar y, containing six; in sixes.

se'pal, one of the foliaceous parts of the calyx. sěp'al oid, sepal-like.

sěp'ar a ted flowers, those having stumens or jis. ${ }^{\prime}$; only.

sép'tate, divided by partitions.

sěp'ten ate, haring parts in serens; heptamerous.

sěp'ti çi dal, dividing the partitions; suill of a method of dehiscence in which the pod splits through the partitions and is divided into its component carpels.

sep tǐf'ra gal, breuling from the purtitions; said of a method of dehiscence in which the ralves of a pod break away from the partitions, and these remain attuchel to the common axis.

sĕp'tum, a partition betucen tu'n spaces.

sé'rial, or s' $\bar{e}^{\prime}$ ri ate, in rous; as biserial, in two rou's.

se rǐ́ceous, silky.

se rơt'i nous, appearing or blossoming later in the season than is customary with ullied species.

serr'rate, notched on the ellge like a sau.

sěs'sile, resting directly upon the main stem or branch, $u$ ithout a petiole or footstull: se $\mathbf{t a}^{\prime}$ ceous, hristle-like; set with bristles sē'tio, bristles.

se'tous, or se'Tig'erous, rovered with bristles.

sĕt'u la, a diminutive lrislle.

sět'u lose, provinled will sptular.

sex ăn'gu lır, six-mngled.

sleath. the bust uf a leuf when corering a stem or branch.

slēath'ing, inclosing with a sheath.

shiëld'shaped, scutute; peltate. 
shrŭb, a woody perennial plant less than fifteen feet in height.

sig'moid, curved in two directions, like the letter s or the Greek sigma.

sil'ti cle, the short pod of many cruciferous plants.

sill'ique, the long pod of many cruciferous plants.

sĩl'i quose, bearing siliques (us the crucifers). silk'y, glossy, with a coat of fine and soft, close-pressed, straight hairs.

sil'ver y, shining white or bluish-gray, usually fiom a silky pubescence.

sĭm'ple, of one piece; not compound.

sin'is trorse, trining from right to left.

sin'u ate, having a wavy margin or edge.

sì'nus, a recess or bay; the reëntering angle between two lobes or projections.

sleep of plants, a state of plants, usually at night, when their leaflets approach each other, and the flowers close and droop, or we covered by the folded leaves.

sobolif'er ous, bearing shoots from near the ground (sŏb'o les).

sŏl'i ta ry, growing alome or singly.

sôr'did, dull or dirty in hue.

so ré'diate, bearing patches of granular. bodies on the surface.

so ro'sis, a fleshy multiple fruit, as the Mulberry.

sō'rus, a fruit dot of ferns.

spa dř'ceous, chestnut-colored ; bearing ,fouers on a spadix.

spā'dix, a spike with a fleshy axis.

span, the distance between the tip of the thumb and the little finger when the hand is outstretched, - abont six or seven inches.

spa thä'ceous, having or resembling a spathe.

spāthe, a large bract, or a pair of bracts, inclosing a flower cluster.

spăt'u late, shaped like a druggist's spatula. $\mathbf{s p} \overline{\mathbf{e}}$ 'cies, the unit in natural history classification; a group of individuals believed to be descended from common ancestors, agreeing in essential characteristics, and capable of continued fertile reproduction. spër'ma to phore, spër'mo phore, or spër'mo spore, one of the names of the placenta.

spi'cate, or spī'ci form, resembling a spike; spike-shaped.

spike, an inflorescence in which the flowers are sessile on a lengthened axis.

spī ke'let, a little spike, as in grasses.

spĩn'dle-shaped, tapering from the middle both ways.

spine, a woody thorn.

spiněs'cent, armed with spines; becoming hard and thorny; tapering gradually to a rigid, leafless point.

spi niff'er ous, or spī'nose, thorny; full of spines.

spī'ral arrangement (of leaves), an arrangement wherein the leaves are alternately arranged around the stem or branch. spi'ral cells or vessels, long, slender cells arranged in a coil.

sponge'let, or spon'gi ole, a supposed spongelike expansion of the tip of a rootlet for absorbing water.

spo răd'ic, videly dispersed.

spō răn'gi um, a spore case in cryptogamous plants.

spōre, a reproductive grain in flowerless plants, analogous to seeds in flowering plants.

spōre case, a sporangium.

$\mathrm{sp} \overline{\overline{0}}$ 'ro phore, the generative organ in certain plants which reproduces asexually.

spōrt, a newly appearel variution.

spōr'ule, a little spore; a spore.

spu mĕs'cent, appearing like froth.

spûr, a stiff;, sharp spine; a slender projecting appendage.

squa mā'ceous, squā'mate, or squamōse', covered with or consisting of scales; resembling a scale.

squa''mi form, having the shupe of a scale.

squăm'u late, or squăm'u lose, having little scales.

squar rōse', divided into shreds or jags; having widely divaricating scales, as the involucral scales of the Composito.

stalk, the stem, petiole, peduncle, etc., of a plant.

stā'mens, the organs that produce pollen, consisting of filament and anther.

stăm'i nate, furnished with stamens; producing stamens. A staminate flower is one having stamens, but lacking pistils.

stăm'i nō'di um, a stamen without an anther; an organ resembling an abortive stamen.

stănd'ard, the upper petal, or banner, of "t papilionaceous corolla.

stärch, a widely diffused vegetable substance found especially in seeds, bulbs, and tubers, from which it is extracted as a white granular or powdery substance, without taste or odor.

stā'tion, the particular situation in which a plant occurs.

stěl'late, or stěl'lu lar, starry, or star-like; spreading out from a common center, like a star.

stĕm'less, destitute, or apparently destitute, of a stem.

ste nŏph'yl lous, having narrow leaves.

stěr'ile, barren; not bearing seeds; unproductive.

stig'ma, the part of the pistil, usually the end, fitted to receive the pollen.

stig măt'ic, of or pertaining to a stigma.

strngs, stinging hairs; hairs sufficiently rigid to perforate animal tissue, and of which, having entered, the apex breaks off, discharging an irritating fluid.

stipe, the stalk of the ovary or ovaries; the stem of a Mushroom. 
sti'pel, un appendage to a leaflet correspond ing to a stipule in "lenj.

sti pěl'late, furnished with stipels, us in the bean tribe.

střp'i tate, sujported on a stipe.

stY̌'u late, furnished with stipules.

střp'ule, an appentuge, or little lenf, on each side of the base of a petiole or leaf.

stǒck, a ward used for ruce or source; also, for any root-like base from which the herb grou's up.

stō'lon, a brunch at the base of a plant which roots easily.

stō'lo nur'er ous, proulucing stolons.

stō'ma, a mouth; one of the openings in the epilermis of a leaj; a brenthing pore.

stra mǐn'e ous, straw-like, or straw-colored. străy'-shaped, flut, narrow', and straight.

strī'ate, or strīat ed, marked with slender longitudinal bars or stripes.

strǐct, erect and very straight.

stri gōse', set with stiff, straight bristles.

strøb'ile, a multiple fruit in the form of $a$ cone, as of the Hop and Pine.

strom bü'li form, twisted, like il spiral shell. stro'phi o late, furnished with "s strophiole or caruncle about the hilum.

strō'phi ole, a crest-like excrescence ubout the hilum of certain seeds.

strŭc'tur al bŏt'an y, the science which treats of the organs or parts of plants, of their forms and uses.

strug'ma, a wen; a suelling or protuberance of any oryan.

stu pōse', composed of or having tufted filaments like tow.

style, that part of the pistil between the orary und the stigma.

sty lĭf'er ous, bearing one or more styles.

st $\bar{y}^{\prime}$ loid, having the form of or resembling a style.

sty lo pō'di um, an epigynous disk, or enlargement at the buse of the style.

sŭb' class, a natural group, more important than an Order.

su be're ous, or sū'ber ose, having a corky texture.

sub ôr'der, a group of genera "little lourer in rank than un Oriler, and of greater importance than " Tribe or Family.

sŭb' tribe, " division of a Tribe.

sū'bu late, aul-shaped; very narrow, and tupering gralually to "fine point from " broalish base.

suc cise', appearing as if cut off ut the extremily.

suc'cu bous, having the lantes so placed that the upper part of each one is covered by the base of the lenf above.

sha'cu lent, very juic! and cellulur.

shck'er, "shoot coming from " part of the stem beneath the ground. suf fru těs'cent, slightly woodly at the base. suf fry'ti cose, wooly in the lower part of the stem; more woody thun suffirutescent. sŭl'cate, fitrroved.

su pē'ri or, abote the oinry.

su pe'ri or cā'lyx, calyx adherent t" ovary. su pē'ri or $\bar{o}^{\prime}$ va ry, ovury free from culyx. su prer nu'merary (buds), exceerliny the numlier stated or prescribed.

sū'per vo lūte', rolled up from the sides. sū'pine, lying flut, with fuce upuard. sū'pra-ăx'il la ry, situuted ubore the uxil. sū'pra-de cŏm'pound, divided many times. sîr'cu lose, proulucing suckers, or shoots resembling suckers.

sus pěnd'ed, liunging downward.

su'tural, pertuining to a suture; taking place ut a suture.

sū'ture, the line of junction of two contiguous parts grown together.

sy cō'nus, a collective, fleshy fruit, in which the ovaries are hidden within a hollow receptacle, as in the Fig.

syl věs'tri au, growing in woods; sylvan.

sy̆m'metry, equality in the number of parts of the successice circles in a flower; like. ness in form and size of Jloral organs of the same kind; regularity.

sym pert'al ous, having the petals united; gemopetalous.

sym phy̆l'lous, with perianth leares united.

sy̆m'pode, or sym pō'di um, u stem resem. bling a simple axis, but composed of snperposed branches, as the stem of the grapevine.

syn an'tlier ous, having the stamens united by their anthers.

syn cär'pi um, an aggregate fruit, in which the ovaries cohere in a solid mass.

syn cär'pous, composeal of several curpels, united into one oxary.

syn ge ne'sious, having the strmens attacheal to each other so us to form u ring.

sy̆u'o nym, an equivalent name.

syn sěp'al ous, having unitel sepals; gamo. sepalons.

sys tem at'ic bŏt'any, that department of botany which pertains to the classification of plants.

T.

tāil, any long and sleniler prolongation of un organ.

tā'per-point'ed, acuminate.

tạp'root, a simple descending root.

taw'ny, a dull, yellowish brown.

tax $\gamma_{n}$ 'o uy, that division of natural science which treats of the clussification of animals and plants.

teg'men, the inner seell cont.

ton'dril, a shred-like process. which helps the plunt to cling to other plants. 
ter a tǒl'o gy, that branch of biological sci. ence which treats of abnormal and unusual formations.

te rēte', cylindrical and slightly tapering; columnar.

têr'mi nal, situuted at the end or apex.

terminol'ogy, the terms used in a business or science; nomenclature; technical terms.

tēr'nate, in threes.

tĕs'sel la ted, checkered; marked like a checker-board.

těs'ta, the outer seell coat.

testā'ceous, having a dull red-brick or brownish-yellow color.

tět'ra dy̆n'a mous, having four long and two short stumens.

te trăg'o nal, having four prominent longitudinal angles.

te tră $\dot{g}^{\prime} \mathbf{y}$ nous, having four pistils.

tět'ra spore, a non-sexual quadruple spore.

thăl'a mi flö'rons, berring the stamens and petals directly on the torus or thalamus.

thăl'a mus, the receptacle of a flower; " torus; a thallus.

thăl'lo gen, or thăl'lo phyte, one of u large class or division of the regetable kingdom, including all flowerless plants, composed of cellular tissue, and showing no distinction of root, stem, and leaf.

thăl'lus, a mass of cellular tissue, usually in the form of a flut stratum or expansion, instead of stem and leaves.

thë'ca, sherth; case; spore case.

the'ca phore, a surface or receptacle bearing " theca or thecr"; the stipe upon which a simple pistil is sometimes borne, being the petiole of the carpellary leaf.

thôrn, a hard and sharp-pointed projection from a wooly stem; a spine.

thrōat, orifice of a monopetalons corolla.

thyrse, or thyr'sus, a dense egg-shaperl panicle, as in the Lilac.

trs'sues, the materials of which plants are composed.

tō'men tose, corered with short, mutted, woolly hairs.

tongue'-shaped, long and flat, but thickish and blunt.

toothed, furnished with teeth or sharp projections of any sort on the margin; as a sali-toothed margin.

tŏp'-shaped, inver sely conical.

tŏr'u lose, cylindrical, with alternate suellings and contractions.

tón'rus, the axis on which all the purts of a flower, except the calyx, are seaterl.

trā'che a, a spiral duct.

trā chy spēr'mous, rough-seeded.

trans vërse', across; being right and left, instead of up and down.

tree, a woody plant, branching so as to form a symmetrical head, growing to the height of twenty jeet, or higher. tri a děl'phous, having stamens joined by filaments into three bundles.

tri ăn'drous, having three distinct and equal stamens in the same flower.

trībe, a group higher than a Genus.

tri ehŏm'a tous, having the nuture of hair or pubescence.

trǐch'ome, a hair on the surface of a leat or stem, or any modification of a hair.

tri chŏt'o mous, three-forked; trifurcate.

tri Łŏc'cous, having three roundish oneseeded carpels.

tri'col ored, having three colors.

tri cŭs'pid ate, enling in three points; three. pointed ; tridentate.

tri ĕu'ni al, lasting three year's.

tri fa'ri ous, facing three ways; in three ver. tical ranks.

tri'fid, three-cleft; split to the middle into three parts.

tri fō'li ate, with three leaves or leaflets.

trifûr'cate, three-forked; trichotomous ; triangular.

trĭg'y nous, haring three pistils or styles. tri $\overline{0}^{\prime}$ bate, having three lobes.

tri lŏc'u lar, having three cells or curities.

tri'mer ous, haring the parts in threes.

tri nërv'ate, three-nerved, or with three slen. der ribs.

tri oe'cious, having three sorts of flowers on the same or different plants, as in the Red Maple.

tri pärt'i ble, divisible into three purts.

trĭp'ar tite, diviled into three parts; more deeply split than trifid.

tri pêt'al ous, having three petuls.

trīph'yl lous, having three leaves.

tri prn'nate, thrice pinnate.

trǐ'ple veiued, hating three reins or nerres.

tri quē'trous, three-sided; three-angled.

tri se'si al, or tri se'ri ate, arranged in three vertical or spiral rous.

trǔs'tieh ous, arranged in three rerticul rows.

tri stig măt'ic, or tri str̆g'ma tose, having three stigmas.

tri sŭl'cate, having three furrows or forks.

tri tèr'nate, thrice ternate.

trǐv'i al name, the specific name.

trŏch'le ar, pulley-shaped.

trŭm'pet-shaped, tubular, and enlarged at or toward the summit.

trŭn'cate, cut off at the tip.

trŭnk, the main stem.

try'ma, a drupe, or drupaceous nut, with a fleshy exocrip.

tūbe, a hollow', elongated borly, usually cylindrical; applied especially to a gamopetalous corolla or gamosepalous calyx.

tūbe'-form, tubular ; trumpet-shaped.

$\mathrm{t} \overline{\mathrm{u}}$ 'ber, a fleshy underground ste $\dot{\mathrm{m}}$, or branch, with buds.

tu bēr'cu lar, having the form of a tuber; bearing tubercles. 
tu bër'culate, covered with warts or tubercles.

tu ber If'er ous, bearing or praducing tubers. tū'ber ose, consisting of or bearing tubers, resembling a tuber.

tū'bu lar co rðl'la, a corolla having the form of a tube.

tū'bu li tio'rous, having the flowers of a heal all with tubular corollas.

tū'mid, su'ollen or inflated.

tu'n'ni cate, covered or coated with layers, as a bulb.

târ'bi nate, shaped like a top or inverted cone.

tu''ri on, a shoot or sprout from the ground.

twin'ing, ascending by coiling round $a$ support.

tỹpe, the ideal pattern.

ty̆p'i cal flow'er, a flower which series for a pattern.

\section{U.}

u $\mathrm{II}_{\mathrm{g}}$ i nose, growing in muddy or swampy places.

urm'bel, an inflorescence in which the pedicels all spring from the same point, like the ribs of an umbrella.

um'bel late, bearing umbels.

ŭm'bel let, a small or partial umbel.

um bIl'i cate, having a sharp depression at one end.

ŭm'bo nate, bossed; having a conical or rounded projection, like a boss (umba).

um brăc'u li form, umbrella-shaped.

un ärmed', having no stings or thorns.

un'cial, an inch in length.

an'cinate, hooked; bent at the tip in the form of a hook.

tn'der shrub, a low shrub.

un'du late, wavy.

un '̈'qual ly pIn'nate, pinnate, with an odd terminal leaf.

un gurc'u late, furnished with hooks or clau's. un $i$ cêl'lu lar, composed of a single cell.

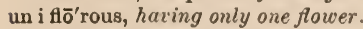
un i fo'li ate, having only one leaf.

$\overline{\mathrm{u}}$ 'ui form, having always the same form.

$\overline{\mathrm{u}} \mathrm{ni}$ lat'er al, one-sided; on one side only.

$\bar{u} \mathrm{ni} 1 \mathrm{cc}^{\prime} \mathrm{u}$ lar, having only one cell or cavity.

$\overline{\mathbf{u}}$ ni sē'ri al, having only one row or series.

$\bar{u}$ ni sĕx'u al, having stamens or pistils only.

$\bar{u}$ 'ni valved, having but one valve.

un sym met'ri cal flow'ers, flowers in which similar parts are of different size or shape, or the parts of successive circles differ in number.

Ar'ce o late, shaped like a pitcher or urn.

$\overline{\mathbf{u}}$ tri cle, a little bladdery seed-vessel; a little sac or vesicle, as the air cell of a sea-u'eed.

$\overline{\mathbf{u}}$ trǐc'ular, resembling a small bladder or bag.

I'R. FL. -23
V.

văg'i nate, invested with a sheath. Vaginate leaf, one invested by the tubular base of a leaf.

vălv'ate, opening as by doors.

valve, one of the pieces into which a capsule naturally separates when it bursts; $a$ small portion of certain anthers, opening like a trap-door.

valv'u lar, having valves; serving as a valve. va rì'e ty, a particular form of species.

vas'cu lar cry̆p'to gams, cryptogams that have vascular tissue.

văs'cu lar tY̌s'sue, tissue furnished with ressels or ducts.

vault'ed, arched.

veins, the system of branching vascular woody tissue seen in leaves.

vein'lets, or vein'ulets, little veins, or smaller branches in the network of a leaf.

vē'late, having a veil; veiled.

ve lu't'i nous, velvety.

vøn'e nate, poisoned.

venōse', haring numerous or conspicuous veins; veiny.

ven'tral, pertaining to that side of an organ of a flower which looks towards the axis or center of the flower; opposite of dorsal.

věn'tri cose, suelling out on ane side, or unequally.

věn'u lose, having veinlets.

vermĭc'ular, worm-like; shaped like a u'arm.

vër'nal, appearing in the springtime.

ver $\mathbf{n} \overline{\mathbf{a}}$ tion, the arrangement of leaves within the leaf bud; prefoliation.

vêr'ni cose, having a brilliantly polished surface.

věr'ru cose, covered with warts; tuberculate; warty.

vèr'sa tile (anther), swinging or turning on its support.

ver'tex, summit; apex.

vër'tical, up and down; parallel with the axis.

ver ti çil läs'ter, a whorl of flowers, apparently of one cluster, but composed of turo opposite axillary cymes.

ver tĭç'il late, $u$ horled.

ve sIc'u lar, bladdery.

věs'per tine, blossoming in the erening.

věs'sels, ducts.

vex Yl'lum, the upper petal of a papilionaceous flower; the standard.

vil lōse', covered with long, fine hairs.

vi mIn'e ous, producing lang, slender twigs or shoots.

vine, a roody climbing or trining stem.

vi rěs'cent, or vir i děs'cent, greenish; turning green.

vir'gate, straight and slender; haring the form of a straight rod.

vIs'eid, or vIs'cous, sticky; glutinous. 
vi těl'line, pertaining to the yolk of the egg; yellow.

vit'ta ( $p l$. vít'tæ), one of the oil tubes in the fruit of umbelliferous plants.

vi vịp'ar ous, sprouting or germinating uthile attached to the parent plant.

vorl'u ble, having the power or habit of turning or twining.

vo lüte', rolled up in any direction.

vŏl'va, a sac-like envelope of certain fungi, which bursts open as the plant develops.

W.

wā $\mathbf{v}^{\prime} \mathbf{y}$, undulating on the border or surface. wăx'y, resembling wax in texture or appearance.

wědg' ${ }^{\prime}$-shaped, broad and truncate at the summit, and tapering down to the base.

wheel-shaped, expanding into a flat, circular border at top, with scarcely any tube, as a wheel-shaped corolla.

whôrl, a circle of two or more leaves, flowers, or other organs, about the same part or joint of a stem.

whôrled, arranged in whorls.

wing, any membraneous expansion; either of the two side petals of a papilionaceous flower.

whnged, furnished with a leaf-like appendage, as the fruit of the Ash and Elm.

witch grass, a troublesome areed, with creeping underground stems.

wood, the hard or solid part of a stem or branch.

wood cěll, a slender cylindrical or prismatic cell, usually tapering to a point at both ends, and the principal constituent of woody fiber. wood'y plant, a shrub, tree, or plant in which the stems and branches are woody. wool'ly, clothed with long and entangled soft hairs.

X.

xăn'thic, yellowish.

xe nŏg'a my, cross-fertilization; fertilization of a flower by pollen from a flower of another plant of the same species.

$\mathbf{x} \overline{\mathrm{e}}$ 'rophil, a plant that requires great heat and little moisture, and is specially adapted to arid regions.

$\mathbf{x} \bar{y}$ 'lem, that portion of a fibro-vascular bundle dereloped into wood cells.

$\mathbf{x} \bar{y}^{\prime} l o$ carp, $a$ hard and woody fruit.

Y.

yēast plant, a unicellular plant which is the active agent of fermentation; it has the pover of disintegrating starch and setting carbon dioxide free.

\section{Z.}

$z \bar{o}^{\prime} 0$ phyte, any one of the numerous species of invertebrate animals which more or less resemble plants in appearance or mode of growth.

zō'o spore, a spore provided with one or more slender cilia, by the vibration of which it swims in the water.

$\mathbf{z} \mathrm{y̆g}^{\prime}$ spore, a spore formed by the union of two or more cells. 


\section{N D E X.}

\begin{tabular}{|c|c|c|c|}
\hline$A^{\text {BIES }}$ & $29,308,309$ & $\begin{array}{l}\text { Auemone pateus, var. Nut- } \\
\text { taliana }\end{array}$ & B.ALM of Gilead \\
\hline balsamea & 309 & Pennsylvanica $\quad 30,31$ & Balsau Fir \\
\hline var. longifolia & 309 & Virginiana $\quad 3: 23$ & $28,265,266$ \\
\hline var. variegata & 309 & Anemonella thalictroides & Banyan Tree \\
\hline cacia 1 & $15,111,112$ & 12,33 & Baptisia tiuctoria \\
\hline $\begin{array}{l}\text { Catechu } \\
\text { dealbata }\end{array}$ & 112 & Angiosperms, apetalous & $\begin{array}{l}\text { Burbadoes aloes } \\
\text { Barberry }\end{array}$ \\
\hline $\begin{array}{l}\text { ealbata } \\
\text { yenantha }\end{array}$ & $\begin{array}{l}112 \\
112\end{array}$ & $\begin{array}{lc}\text { dicotyledonous } 6-8,9,10 \\
\text { dicotyledonous } \quad 5,12-27\end{array}$ & $\begin{array}{l}\text { Barberry } \\
\text { Barley }\end{array}$ \\
\hline & 111,112 & glumiferous monocot- & Bassia latifolia \\
\hline Seyal & 112 & yledonous 11 & Parkii \\
\hline Suma & 112 & monocotyledonous $5,28,29$ & Battledoor Barley \\
\hline cer & $16,91-93$ & petaloideous monocot- & Beaked Hazelnut \\
\hline nigrum & 91 & yledonous & Bean $\quad 17,103-105$ \\
\hline ccharinum & 91 & florous mono- & Beech \\
\hline $\begin{array}{l}\text { var. nigrum } \\
\text { Achras sapota }\end{array}$ & 91 & $\begin{array}{l}\text { cotyledonous } \\
\text { sympetalons dicotyled- }\end{array}$ & $\begin{array}{l}\text { Beech of Europe } \\
\text { Beechwood Muskmelon }\end{array}$ \\
\hline $\begin{array}{l}\text { Achras sapota } \\
\text { Egilops }\end{array}$ & 253,254 & $\begin{array}{l}\text { sympetalous dicotylea- } \\
\text { onous } 8,9\end{array}$ & Beer $\quad 234,267$ \\
\hline gave & 277 & Anise $\quad 21,147,148$ & $26,208,209,294$ \\
\hline andrian Senua & 108 & $14,63,14$ & Bell Flower \\
\hline pice $\quad 2$ & $20,13 \tilde{3}, 136$ & $22,16 t, 167$ & Bell Pepper \\
\hline lmond & 19,122 & arvensis & Bell-shaped Cranberry \\
\hline oes & $28,27 \pi, 278$ & nobilis & Bengal Grass \\
\hline ferox & 278 & Hore pleno & Berberidacea $\quad 6,13,42$, \\
\hline $\begin{array}{l}\text { rina } \\
\text { ta }\end{array}$ & $277, \frac{277}{278}$ & $\begin{array}{l}\text { Apetalie } \\
\text { Apetalous dicotyledonous }\end{array}$ & $\begin{array}{l}\text { Berberis vulgaris } \\
\text { Bertholletia excelsa }\end{array}$ \\
\hline vulgaris & 277 & angiosperms $\quad 9,10$ & Beta $\quad 26,208, \div 09$ \\
\hline Arbor V & 312 & A pium graveolens $21,1+6,147$ & maritima \\
\hline n Balsam 1 & 309 & cere 96 & 208,209 \\
\hline American Beech & $25 \overline{5}$ & Apopetalie & var. cicla \\
\hline American Elm & 231, 232 & A popetalm, inferior $\quad 12-21$ & var. mangel-wirzel \\
\hline American Goosebe & rry 13! & Apopetalous dicotyledon- & var. rapa \\
\hline rican Hazelnu & 254 & agiosperms $\quad$ li-s & Betel Nut \\
\hline American I pecacua & anha 163 & $19,123-125$ & Betel Pepper \\
\hline American Larch & 309,310 & Apple, Carthage & e-producing Plants \\
\hline American Senua & 108 & Crab & ider) $12 \pi$ \\
\hline Am & erry & earing Sage & (beer and wine) $2 \mathrm{fit}$ \\
\hline American Turkey & 249 & Apple Pine & hiskey) \\
\hline Amorpha fruticosa & & Apricot $\quad 18,120$ & $\begin{array}{l}\text { Cocoa } \\
\text { Cocoanut Palm (milk, }\end{array}$ \\
\hline $\begin{array}{l}\text { Ampelidere } \\
\text { Amygdalus commu }\end{array}$ & $\begin{array}{l}6,16,88-91 \\
\text { unis } 122\end{array}$ & $\begin{array}{lr}\text { Arachis hypogrea } & 17,99,100 \\
\text { Arbor Vitie } & 29,312\end{array}$ & $\begin{array}{l}\text { Cocoanut Palm (milk, } \\
\text { vinegar, and wiue) } 2 \& 3\end{array}$ \\
\hline An & $6,93-96$ & Areca Catechu $29,279,280$ & e 162 \\
\hline pccide & intale $16,9 \pi$ & Arrow-leaved Violet $\quad(60,61$ & nt (wine) \\
\hline & 89,20 & $28,261-263$ & e (wine) \\
\hline Andropogo & ratum & $21,149-151$ & Hops (beer) 23 \\
\hline & $\begin{array}{l}29: 4 \\
-33\end{array}$ & $\begin{array}{l}\text { A sclepiadacea } \\
\text { Asparagus officinalis } 28,274\end{array}$ & Indian Corn (whiskey) \\
\hline loba & 31 & $\begin{array}{l}\text { Asparagus officinalis } 28,274 \\
\text { Astragalus } 17,97-99\end{array}$ & \\
\hline ana & 30 & 98,99 & Teá \\
\hline & 30 & antha & y) \\
\hline & 30 & $24,191,192$ & ndy) \\
\hline & 30,31 & belladomu & \\
\hline & 31 & & (brandy) \\
\hline & 31,32 & 301 & Rye (whiskey) \\
\hline & 31,32 & Autunual Marrow $1+4$ & Tea \\
\hline parviflora & 32 & $29,295,299$ & Bind-weed Jalap \\
\hline patens & & sativa & Birch-leaved Beech \\
\hline
\end{tabular}


Bird-foot Violet

Bird Pepper

Bird's-eye Maple

Biting Crowfoot

Bitter Almond

Bitter Cassava

Bitter Orange

Bixa orellana

Bixineæ

Blackberry

Black Cap

Black Currant

Black Huckleberry

Black Jack Oak

Black Larch

Black Maple

Black Mustard

Black Oak

Black Pepper

Black Raspberry

Black-rock Musk

Black Spanish Watermelon

\section{Black Spruce}

Black Tea

Black Walnut

Blackwood

Black-wooded Walnut Tree

Blé Saracin

Blood Orange

Blueberry

Blue Cardinal Flowe

$14,63,64$

$14,63,64$

18
113

128,129

172

249

309,310

91

48,49
248

248

113

141

307

66

239,240

108, 109

239,240

211

79

172

170 ,

171

Blue Sweet Violet

Blumea balsamifera

Bog Fir

Bore Cole

Borneo Camphor
Borraginaceæ $\quad 8,23,182,183$

Box 27, 225

Bradford Watermelon 14:

Brandy

Brassica

alba

campestris

var. rutabaga

juncea

napus

nigra

oleracea

rapa

var. depressa

Brazil Nut

Brazil Wood

Bread-producing Plants

Arrowroot

Barley

Bitter Cassava

Buckwheat

Cocoanut Palm

Date Palm

Indian Corn

Oats

Rice

Rye

Sago Palm

Tapioca

Wheat

Bristly Crowfoot

British Oak

Broom Corn

Broom Pine

Buckthorn

Buckwheat
114,122

48,49

$49-51$

50

48,49

51

48,49

47,48

50

50

20,137

17,109

262

.298

\section{8}

211

283

281

288

299

292

296

285

228

288

37

246,247

305,306

$16,87,88$

26,211
$29,268-270$
Bugle-shaped Cranberry

Bulbous Crowfoot

Bull Pepper

Burr Oak

Bush Bean

Buttercup

Butternut

Butter Tree

Buxus

sempervirens

var. angustifolia

var. suffruticosa

\section{( $\mathrm{ABBAGE}$}

Cresalpinia

Braziliensis Crista

Calisaya

Caltha

leptosepala

palustris

Camomile

35
193
248,249

Castanea

pumila

$27,243,244$

243,244

243,244

103,104 Castilloa elastica

12, 33-3s Castor-oil Plant 27, 228, 229

27, 238, 239 Catmint 206, 207

176 Catnip 25, 206, 207

27, 205 Cauld Kail $\quad 48$

225 Cauliflower 47

225 Cayenne Pepper 24, 193

225 Ceanothus Americauus 16,88

Cedar 29, 310-312

Celery 21, 146, 147

Celery-leaved Crowfoot $3 \pi$,

47,48

Celery Parsley

155

17,109 Century-plant $\quad 277$

109 Cephaëlis Ipecacuanha 22 ,

$109162,163,223$

157 Ceratonia Siliqua 17, 108

$12,39,40$ Chamæeyparis 29, 314,315

t0 pendula 314

Campanulaceæ $8,22,170,171$ Charlotte Rothschild Pine-

Camphor Tree $27,217,218$ apple

Canada Pumpkin

Canada Violet

145

269

Canna coccinia

echinus

edulis

flaccida

glauca

$56,5 \%$

Cheese-shaped Cranberry 173

263 Chenopodiaceæ $9,26,208-210$

263 Cherry 18, 118

263 Cherry Currant 128

263 Cherry-shaped Cranberry 173

$26,243,244$

Cannabis sativa 27, 236-238 Chestnut Oak 250, 251

Cannon-ball Tree

137

Cantaloupe

Caoutchouc

Cape Aloes

Caper

140-14:2

Capparidaceæ $\quad 6,13,54-56$

Capparis

ferruginea

soldada

spinosa

$13,5+-56$

sella Bursa-pastoris 13 ,

Capsicum

annuum

fastigiatum

frutescens

24, 192-194

192,193

grossum

Caraway

Cardamom

Cardinal Flower

Carob Tree

Carolina Anemone

Carolina Indigofera

Carolina Watermelon

Carrot

$21,154,155$

Carthage Apple 139

Carthamus tinctorius

Carum

Carui

petroselinum

169,170

Carya alba sulcata

Cashew Nut

Cassava, Bitter

Cassia

acutifolia

angustifolia

fistula

Marilandica

obovata

China Orange

Chinese Yam

$28,271,272$

Chrysanthemum 22, 167, 168

carneum

cinerariifolium

167

var. rotuudis

corymbosum 167

roseum 167

Wilmoti 167

Cicuta

Cider

Cinchona

calisaya

cordifolia

$21,157-159$

lancifolia $\quad 15 \%$

mierantha 157

officinalis $\quad 157$

Pitayensis $\quad 157$

\begin{tabular}{lr} 
succirubra & 157 \\
\hline
\end{tabular}

Cinchonaceæ $\quad 27,217-220$

camphora $\quad 217,218$

cassia

219,220

iners

220

obtusifolium

pauciflorum

Zeylanicum

Cinnamon

Citron Muskmelon

219,220

27,219

155,156

Citron Watermelon

241

itrullus vulgaris $20,142,143$

16,95 


Clammy Rice
Clearing Nut
Clematis
crispa
cylindrica
ochroleuca
Pitcheri
verticillaris
viorna
Virginiana

Cloves
Cluster Cucuunber

Coca

Coccus lacea

Cochlearia

armoracia ofticinalis

Cocoa

Cocoanut

Cocoamut Palm

Cocos nucifera

Coffea

acuminata

Arabica

Australis

biflora

Chamissonis

ciliata

densiflora

Indica

jasminoides

kaduana

laurina

Liberica

longifolia

magnolifolia

meridionalis

Mexicana

minor

Mozambicana

nitida

nodosa

obovata

occidentalis

paguiodes

parvifolia

pedunculata

racemosa

rosea

semiexserta

sessilis

spicata

stipulacea

subsessilis

tetraudra

Travancorensis

truncata

umbellata

verticillata

Wightiana

Coffee

Zanguebarica

Cold Chon

Cold Slaw

Colophony

Coloring Indigofera

Combretace: $7,1 !), 131,13$.

Counfrey $23,1 \times 2,1 \times 3$

Common Blue Violet 58

Common Cabbage

Common Camomile.

47

Coummon Fielul Punukin 14

Common Fig 234,235

Common Flax

Common Hol,

Common Juniper

$14,70-72$

282,283

$21,160-16$

160

160

160

160

160

160

160

160

160

160

160

160
160

160
160

160

160

160
160

160

16
Marjora!n

Common Myrtle

Common Red Curraut

40 Common Ricos

40 Common Sage

1 Common Sumacl

140

15,$71 ;$

$2: 36$

13,52

$29,282,283$

160
160

160

160

160

160

160

160

160

160

160

160

is

और

(Ni

Common Virgin's Bowe

Compositie 8, 22, 11;

Cone Family $301(1-315$

Conifer: $5,11,29,30(1)-315$

Coniferous gymuosperms 11

Constantinople Hazelnut 254

Convolvulace: $8,24,183-185$

Colper Beech

Corchorus

capsularis

olitorius

siliquosa
Cordage-producing Plants -

14, 73,7

Aloe Annatto

Annatto

Cocoanut Palm

Flax

Manilla

New Zealand Flax

Sago Palm

Coriander

Cork

Cork Tree

Corky Elm

Corn, Broom Indian

Coru Poppy

Corylus

Americana

avellana

colurna

rostrata

Cotton

Cotton Plant

Cow Cabbage

Cowslip

Cow Tree

Crab Apple

Crauberry

Creeping Crowfoot

Creeping Spearwort

Crocus sativus

Croton tiglimu

Croton-oil Plant

Crowfoot

Crowned Squash

Crucifer:

Cucumber

Cucumis

melo

sativus

Cucurbita

maxima

var. corona

melopepo

ovifera

var. medullosa

pepo

verrucosa

Cucurbitacea

Cumin

Cuminum

ryminแแ

sativum

:33. 234 Cuprea

311 Cupressus pendula
$21,152,153$

$$
\begin{array}{r}
153 \\
252,253
\end{array}
$$

252

$29,294,295$

$29,286-288$

$27,254,255$

255

254

254

254

14, (isi-io

$67-70$

47

12, 39,40

176

$23,172-174$

174

36

$28,270,271$

$27,2-26$

$12,33-38$

(i, $13,46-.54$

2), 13!\%, 140

$20,13: 1+142$

14(1)-14:

$139,1+11$

20. $143-14 i$

144,$141 ;$

$1+4$

$14::$

144

$1+4$

$14 i, 1+1 i$

143,144

6, 20, 139-14t;

$21,1,3$

21,$1 ; 3$

153

153

25

314

Cupressus sempervirens 314 thyoides 314

Cupulifer: $\quad 9,27,242-256$

Curacoa Orange 81

Curcuma longa $2 s, 260,261$

Curled Willow

Currant 19, 128-131

Currants, Zante

Cursed Crowfoot 37,38

Custard Squash $\quad 1 \neq 4$

Cynauchum oleafolium 108

Cypress $29,314,315$

JALBERGIA $17,108,109$

latifolia -

ligifolia

108,109

Damson Plum $11-$

Date Palm 29, 280, 2\$1

Dancus 21, 154, 15.

carota 15

var. sativa $15+$

Deadly Nightshade 24. 191,

Delicate Violet

Dew of the Sea $\quad 2(15,206$

Dichopsis gutta $23,174,175$

Dicotyledonous angiosperms

Dioscorea

alata

batatas

Japonica

sativa

$5,12-27$

$28,271,272$

271,272

$2 \pi 1, \frac{2 \pi}{2 \pi}$

Dioscoreacea $10,28,271,272$

Diospyros $\quad 23,176,17 \%$

ebenum $\quad 176,177$

melanoxylon 176

Virginiaua $\quad 176$

Dog Violet $5 \pi$

Downy-leaved Oak $\quad 248$

Dowuy Yellow Violet 60

Drinks. Siee Beverages.

Drumhead Cabbage 47

Dryobalanops Camphora 215

Dwarf Almond 122

Dwarf Curled Parsley 15is

Dwarf Tobaceo 187

Dwarf Whortleberry 171,172

Dyer's Oak 248

Dye-producing Plants -

Aunat to

Black Oak

Black Walnut

Brazil Wood

Butteruut

Cramberry 


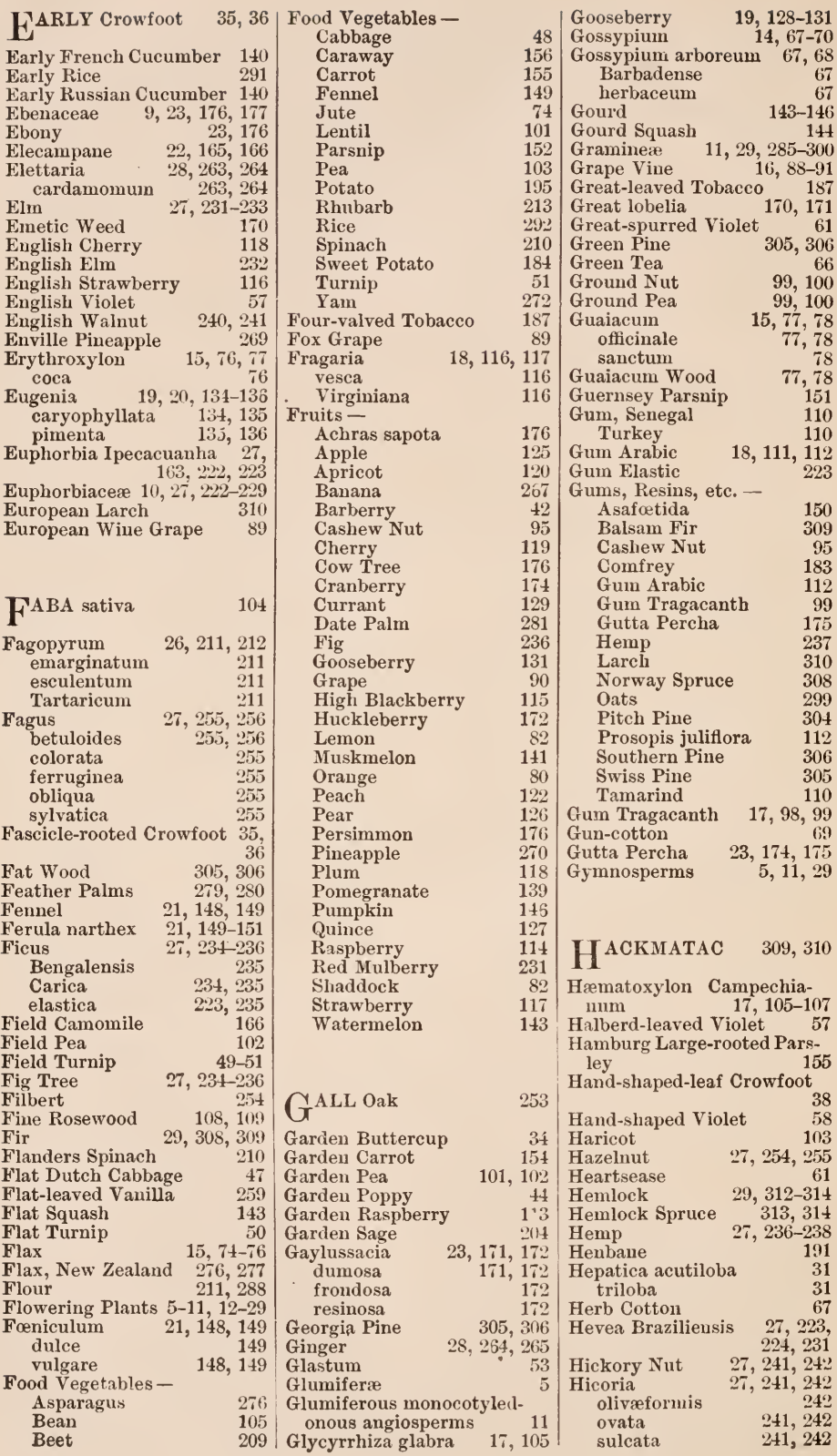


Hide-tanuing Rhus

High Blackberry

High Blueberry

Hoarhound

Holly

Hooked Crowfoot

Hop, Common

Hordeum

distichum

hexastichon

vulgare

Zeocriton

Horse Radisl

Hubbard Squash

Huckleberry

$23,171,172$

Humulus lupulus '27, 233, 23t

Hymenca combaril $\quad 110$ verrucosa

110

ILEX Paraguayensis $\begin{array}{r}15, \\ 85-87\end{array}$

Ilicinex
Illicium anisatum

India Ink

132

India Rubber 223, 224, 235

Indian Corn 29, 286-288

Indian Fig

235

Indian Rosewood

109

Indian Tobacco $22,170,171$

Indigo

Indigofera

argentea

Caroliniana

tinctoria

Iudigo Plant

Iuferior apopetalæ $\quad$ 12-21

Ink-producing Plants -

Banana

Brazil Wood

Cashew Nut

Gall Oak

Myrobalaus

Sumach

$17,96,97$

36

96,97

1

267

109

95

132

95

Inula Helenium $22,165,166$; Ipecac, Ipecacuanha 22, 163,

$\begin{array}{lr}\text { Ipomaea } & 24,183-185 \\ \quad \text { batatas } & 183,184 \\ \text { purga } & 184,185 \\ \text { Iridacere } & 10,28,270,271 \\ \text { Irish Potato } & 194 \\ \text { Iron Oak } & 249 \\ \text { Isatis tiuctoria } & 13,53 \\ \text { Ivy, Poison } & 93\end{array}$

\section{JAPAN Quince}

Jatropha manihot 227,228 Jesuits' laark Juglandacere

$9,27,238-242$

Juglans

cinerea

nigra

regia

var. maxima

var. serotina

var. tenera

Juniper

Juniperus

Bermudiana

communis

var. alpina

var. prostrata

$27,238-241$

238,239
239,240

240,241

240

240
240

240

$310-312$

$29,310-312$

311

311

311

311

var. pyramidalis
Juniperus nana

Virginiana Jute var. forma cylindrica 311

\section{IDNEY Bean}

Kittatinny Blackberry

311 Mahogany

$15,83,84$

$286-288$

Malvacex $\quad 6,14,67-70$

73 Mandarin Orange 81

Mandragora officinalis 43 officinarum 191

Mandrake $\quad 13,42,43$

Manihot 2i, $2, \pi, 228$

api $\quad 227,2: 28$

IBIAT AE 8, 24, 25, 198- Manilla 28, 267, 26:8

\begin{tabular}{rr|lr} 
ABIAT A 8, 24, 25, & $198-$ & Manilla & Many-cleft Anemone 31, 32 \\
Lance-leaved Violet & 57 & Maple $16,91-93$
\end{tabular}

Lance-leaved Violet $29,309,310$ Maple, Sugar 294

Large-fruited Cranberry $17 \%$, Maple Sugar

Large Prickly Spinach $\quad \begin{array}{ll}173 \\ 210\end{array}$

Large-ribbed Muskmelon 141

Large-rooted Beet

Larix

Europea

laricina

$29,309,310$

208
310

Lauracere $9,26,27,217-220$

Lavandula $\quad 25,198,199$

spica

var. alba

var. latifolia

stœchas

vera

Lavender

laranta arundinacea 28

Marjoram $261-263$

Marrubium vulgare 25,207

Marselenia tinctoria 96

Marsh Marigold 12, 39, 40

Marsh Violet 53

May Aplle $\quad 13,42,43$

Meadow Rue 12, 39

Meadow Violet 59

Meconium

Medicinal Plants -

Allspice 136

Lawton Blackberry 20,115

Leather 246, 248, 251, 310, 314

Leather Back

Leather Flower

145

Leguminos: $7,16-18,96-112$

Lemou

15,82

Lens

$17,100,101$

esculenta

100

var. lutea

160

var. Provence

100

Lentil 17, 100,101

Lettuce-leaved Spinach 210

Lignum-vit:e $\quad 15$, it, is

Liliacex $10,28,27,2-278$

Lima Bean

Lime

103,104

Lime Juice

Linacere

Linseed Oil

Linum

angustifolium

usitatissimum

Virginianum

Liquorice

Live Oak

Lobelia

cardiualis

intlata syphilitica

Loganiace:e

Logwood

Long Beet

82,83

83

$6,15,74-77$

15, $74-7 i$

Allspice
Aloe

Anise

Annatto

Asafoetida

Asparagus

Balsam Fir

Barberry

Betel Nut

Betel Pepper

Black Pepper 155

Blue Cardinal Flower 171

Box 205

Butternut

Camomile 166,167

Camplior Tree $\quad 218$

Caper $\quad 56$

Caraway $\quad 156$

Cardamom $\quad 263$

Cashew Nut 95

Cassia 200

Castor-oil Plant 209

Catnip $\quad 207$

Celery 14i

Cinchona Bark $\quad 159$

Cinnamon 219

Cloves 135

Coca

Comfrey 183

Common Hop 234

Common Juniper 312

Common Sumach

Coriander $\quad 152,153$

Cotton 70

Croton-oil Plant 226

Cumin 15.3

Flecampane $166^{\circ}$

Emetic Weed 171

Fennel 149

Fig

Flax

Ginger

Great Lobelia

Gum Arabic

I $\mathrm{ACE}$

216

Madder

Gum Tragacanth

Henbane

$22,163,164$

High Blackberry

Hoarlioiud 
Medicinal Plants -

Horse Radish

Indian Tobacco

Ipecac

Jute

Larch

Lavender

Lignum-vitæ

Liquorice

Logwood

Mace

Madder

Mahogany

Mandrake

Marjoram

Mustard

Myrobalans

Myrtle

Nutmeg

Parsley

Pennyroyal

Pepper

Peppermint

Pomegranate

Poppy

Quince

Rhubarb

Safflower

Sage

Sandal-wood Tree

Sarsaparilla

Sharp-lobed Hepatica

Slippery Elm

Southern Pines

Spearmint

Strawberry

Strychnine

Tamarind

Tansy

Tapioca

Thyme

Turmeric

Vanilla

Violet

Mediterranean Wheat

Meliaceæ

Melon

Mentha

piperita

var. subhirsuta

pulegium

viridis

Metroxylon

lævis

sagu

spinosa

Milk Vetch

Millet

Mimusops elata

$7,15,83-85$

142,143

$25,199-201$

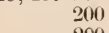

200

201

199,200

29, 283-285

284

284,285

284

29,300

Mitchell's Matchless Parsley

Monkey Nut

Monocotyledonous angiospermis

Morello Cherry

Morus

alba

var. multicaulis rubra

230,231

230,231

231

230,231

248,249

Moss-cup Oak Mossy-cup White Oak 248 ,

249

Mountain Rice

Mountain Sumacl

Mountain Sweet Watermelon
Much-divided-leaved Crow-

foot

Mulberry

Musa

paradisiaca

sapientum

textilis

violacea

Muskmelon

Mustard

yatt's Triple-curled Parsley

Myristica

fatua

fragraus spuria

$27,230,231$

$28,265-268$

$265,266,267$

267,268

267

$20,140-142$

155

26, 215-217

216

216

Myristicaceæ $\quad 9,26,215-217$

Myrobalaus 19,131

Myrtace $\quad \tau, 19,20,132-137$

Myrteæ

$132-137$

Myrtle

$19,133,134$

Myrtus

$19,133,134$

communis

var. Belgica

var. Bœotica

var. mucronata

var. Romana

var. Tarentiua

133

133

133

133

133

133

\section{APA-BRASSICA}

Naples Parsley

50

Narrow-leaved Flax

Nasturtium officinale

$13,53,54$

75

Nectarine

53,54

Nepeta cataria $\quad 25,206,207$

Nerium tinctorium

Nettle Family

96
$230-238$
302

New England Pine

New Jersey Tea 16, 88
New Rochelle Blackberry 115

New Zealand Flax 28, 276,

(1)

macrophylla

nana

Persica

quadrivalvis

repanda

rustica

tabacum

Norway Spruce

Nut-gall

Nutmeg

Nutmeg Muskmelon

24, 187-191

187

187

187

187

187

187

187

308

253

Nuts -

Almond

Beech-nut

Black Walnut

Brazil Nut

Butternut

Cashew Nut

Chestnut

English Walnut

Hazelnut

Hickory Nut

Peanut

Pecan Nut

Pine Nut

Shag-bark

Shell-bark

Thick Shell-bark

Walnut

White Walnut
26,216

141

123

256

240

137

239

95

244

240,241

255

241,242

100

242

301

241,242

241,242

241,242

240-242

241,242

Nux Avellana

250

Poutica

Vomica

$23,180,181$

$\mathrm{O}^{\mathrm{AK}}$

$27,245-254$

Dak of the Barreus 249

Oats 29, 298, 299

Oblique-leaved Beech 255

Oblong-leaved Crowfoot 36

Odell's Large Watermelon 142

Oil of Tar

Oil-producing Plants -

Allspice

Anise

Asafoetida

Beech

Black Walnut

Brazil Nut

Butternut

Butter Tree

Camomile

Camphor Tree

Caraway

Cardamom

Castor-oil Plant

Cinnamon

Cloves

Cocoauut Palm

Coriander

Cotton

306

136

148

150

256

239

137

238

176

167

218

156

263

229

219

135

283

152

69

Croton-oil Plant $\quad 226$

Cumin 153

Englislı Waluut 240,241

Fenuel 149

Flax

Hemp

Lavender

76

Iime

199

Mace 217

Marjoram 203

Mustard 49

Nutmeg 217

Oats 299

Olive 180 


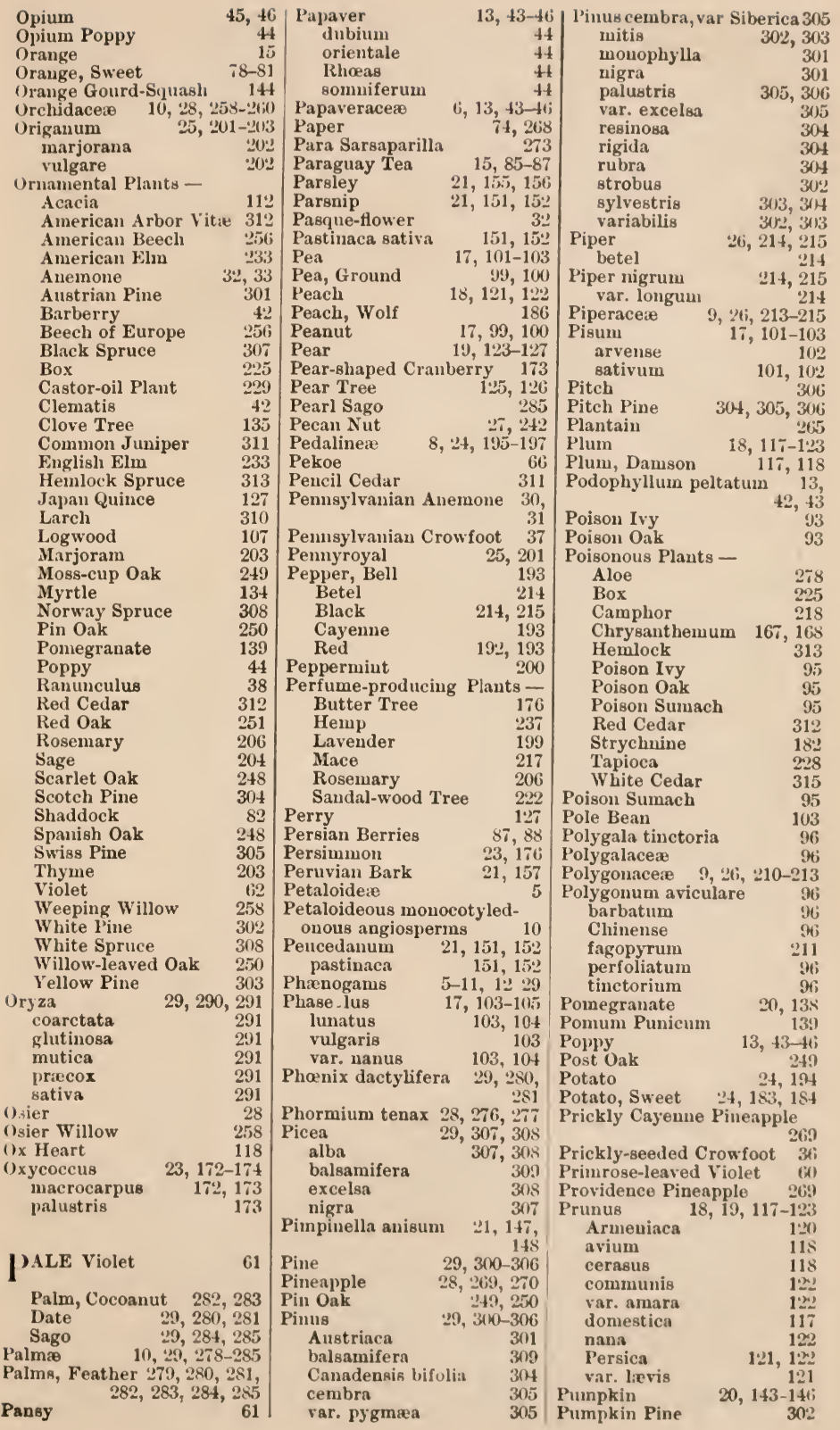


Punica

granatum

var. alba

var. plena

Puny Crowfoot

Puritan Squash

Purple Cabbage

Purple Sweet Violet

Purplish Meadow Rue

Pyrus

communis

Cydonia

Japonica

malus

$19,123-127$
$125-127$
127
127
$123-125$

\section{$Q^{\text {UERCUS }}$}

$27,245-254$

ægilops

var. latifolia

var. pendula

alba

var. pinnatifida

var. repauda

bicolor

coccinea

var. tinctoria

falcata

Ilex

infectoria

macrocarpa

nigra

obtusiloba

palustris

pedunculata

Phellos

var. latifolius

var. sylvatica

Prinus

var. acuminata

var. monticola

pseudococcifera

robur

var. fastigiata

var. foliis variegatis

var. heterophylla

var. pendula

var. pubescens

var. purpurea

var. sessiliflora

rubra

var. runcinata

suber

var. angustifolium

var. dentatum

var. latifolia

virens

Quince

Quince, Japan

$$
253,254
$$

253

253

245

245

245

247

247,248

248 Red Grape Currant

248 Red Mulberry

86 Red Oak

253 Red Pepper

248, 249 Red Pine

249 Red Raspberry

249 Red Root

249, 250 Red Top Turnip

246, 247 Red Wheat

250 Revalenta

250 Rhamnaceæ

250

250

250,251

251

245

246,247

246

246

246

246

246

246

246

250,251

251

252

252

252

252

127

127

R ANDIA aculeata

96

Ranunculaceæ $\quad 6,12,30-42$

Ranunculus $\quad 12,33-38$

abortivus

var. micranthus

acris

alismæfolius

ambigens

aquatilis

var. tricophyllus

bulbosus

Cymbalaria

fascicularis

flammula
33,34
Rhamnus chlorophorus infectorius utilis

Rheum compactum palmatum rhaponticum undulatum

Rhomboid-leaved Crowfoot 37

Rhubarb

Rhus

copallina

coriaria

Cotinus

glabra

Toxicodendron

typhina

venenata

Ribes

cynosbate

floridum

Grossularia

hirtellum

nigrum

oxyacanthoides

rotundifolium

rubrum

Rice

Ricinus

communis

$26,212,213$

$16,93-95$

93

93,94

$93,94,95$

93,95

93

93,95

$19,128-131$

129,130

128

129

130

129

130

130

128

Ring-leaved Willow

$29,290,291$

$27,228,229$

Ripley Pineapple

Rock Chestnut Oak

Rock Maple

Rock Oak

T $18,19,113$
Rosemary

Rosewood

$25,205,206$

Rosin

Rosmarinus

$17,108,109$

306

$\begin{array}{ll}\text { officinalis } & 205 \\ \text { var. variegata } & 205\end{array}$

$25,205,206$

Round-leaved Violet $\quad 60$

Round-lobed Hepatica 31

Rubia

$22,163,164$

Chiliensis

cordifolia

164

tinctorum

163,164

Rubiaceæ 9, 21, 22, 157-164

Rubus

fruticosus

Idæus

occidentalis

strigosus

villosus

var. frondosus

var. humifusus

Rue Anemone

Russia Turnip

Russian Rhubarb

Rutabaga

Rutaceæ

Rye

223

$18,113-115$

115

113

113

$88,113,114$

114,115

115

115

12,33

50

213

50

7, $15,78-83$

$29,295,296$

\section{SACCHARUM $\quad 29,292-294$}

atrorubens 293

contractum 293

dubium 293

fragile 293

officinarum $\quad 292,293$

polystachyum 293

rubicundum 293

Sacred Barley 297

Safflower 22, 169, 170

Saffron $28,169,170,270,271$

Sage 25, 204

$\begin{array}{ll}\text { Sago, Pearl } & 29,284,285\end{array}$

Salads -

Beet

Cabbage

209

Caper

Celery $\quad 147$

Cowslip 40

Cucumber $\quad 140$

Fennel 149

Ranumculus ficaria $\quad 38$

Tomato 186

Water-Cress 54

Salicaceæ $\quad 9,28,256-258$

Salix 28, 256-258

annularis 257

Babylonica 256

var. crispa 257

var. Napoleona 257

var. vulgaris 256,257

viminalis 258

Salvia 25,204

officinalis 204

var. variegata 204

pomifera 204

Sandal-wood Tree 27, 220-222

Santalace $\quad 9,27,220-222$

Santalum $\quad 27,220-222$

album $\quad 220,221$

Freycinetianum 221

myrtifolium 221

yasi

Sapindacer $\quad 7,16,91-93$ 
Sapotacep $\quad 9,23,174-176$

$\begin{array}{lr}\text { Sapling Pine } & 302 \\ \text { Sarasin Wheat } & 211 \\ \text { Sarsaparilla } & 28,273,274 \\ \text { Savoy Cabbage } & 47 \\ \text { Saxifragacer } & 7,19,128-131 \\ \text { Scarlet Oak } & 247,248 \\ \text { Scotch Fir } & 303,304 \\ \text { Scotch Pine } & 303,304 \\ \text { Scurvy Grass } & 52 \\ \text { Sea Island Cotton } & 67 \\ \text { Seaside Crowfoot } & 35\end{array}$

Seaside Crowfoot

Secale cereale $29,295,296$

Secor's Mammotl, Black. berry

115

Senna

Sesame

Sesamum

Indicum orientale

Setaria Italica var. Germanica

Seville Orange

Shaddock

Slag-bark

Sharp-lobed Hepatica

Shell-bark

Shepherd's Purse

Sickle-leaved Oak

$17,107,108$ 24,196

$24,195-19$

196

196

29,304

300

300

$7 !), 81$

$81,8:$

241
31

241

Silk

Silver-leaved Indigofera

Silver-leaved Oak

Single-leaved Nut-pine

Six-rowed Barley

Slippery Eluı

Small Crauberry

$13,46,4$

248

231

96

301

301

$23 \%$

133

Small-flowered Anemone 3 :

Small-flowered Crowfoot 33 ,

smaller Spearwort $\quad 34,36$

Smilax

medica

officinalis

$28,273,274$

papyrace

Sarsaparilla

Sinoke Tree

Smootl Cayenue Pineapple

Smooth Sumach

Snake-wood

Socotrine Aloes

Solanacere $8,24,185-195$

Solanum 24, 194, 195

Commersonii 194

immite

tuberosum

verrucosum

194

194

194

Sorghum saccharatum

Sour Cherry

Southern Pine

Spadiciflorie

Spadiciflorous monocotylednous angiosperius

Spanish Oak

Sparrow Grass

Spearmint

Spearwort

Spices, Condiments, ete. -

Allspice
Anise
Arafoetida
Black Pepper
Caper
Caraway

294,292

118

.

Swamp Cliestmut Oak

Swaup Suavislo Oak

Swamp White Oak 247

10 Swedish Turnip 50

248 Sweet Marjoram

$274-276$ Sweet Orauge

25, 199, 200 $\quad$ Sweet Potato 24, 183, 184

34, 36 Sweet Potato Squas] 14

Sweet Thyme 25,203

Sweet Thyme

148 Swietenia mahogani $15, \times 3-85$

151 Swiss Pine 305

215 Sympetala

56 Sympetalous dicotyleilo-

156 nous angiosperms 8.9
Symphytum officinale 182, 183

$23,182,183$ var. Bohemicum 182

ACCA integrifolia

262

Tall Meadow Rue

39

Tamarack \%)9, 310

Tamarind 18, 109-111

Tamarindus Indiea $18,109-$

Tanacetum vulgare 22,168 ,

169
179

Tangleberry 172

Tannin-producing Plants -

Allspice 136

Black Jack Oak 249

Black Oak 248

Cliestuut Oak 251

Dyers' Oak 248

Gall Oak

Gum Arabic 112

Hemlock Spruce 314

Larch 310

Moss-cup Oak 243

Myrobalans 132

Myrtle 134

Pin Oak 250

Pomegranate 139

Red Oak 25:

Rock Oak 251

Scarlet Oak 248

Silver-leaved Oak 247

Spanish Oak 248

Sumach 94

Valonia Oak 254

Wlite Oak "2t6

Willow-leaved Oak 250

Yellow-barked Oak 248

Tansy $\quad 22,168,169$

Tapioca $\quad 27,227,228$

Tar 304, 306

Tea 14, $64-67$

Tea, New Jersey $16,8 s$

Paraguay 15, 85-8\%

Teak 24,197, 198

Tectona grandis 24, 197, 198

Tephrosia apollinea tinctoria

toxicaria

Terminalia $\quad 19,131,132$

angustifolia

bellerica 13:

catappa 13:

chebula 131

citrina $13: 9$

Ternstromiacez $7,14,64-67$

Textile Fabrics -

Coconint Palm 283

Common Hop 234

Cutton 69

Flax 70

Hemp 237

74

Ianilla 265

Thalictrum $\quad 12,39$

anemonoides 33

clavatum 39

Cornuti 39

diöicuin 39

polygamum $\quad 39$

purpurascens $\quad 39$

var. ceriferum $\quad 39$ 


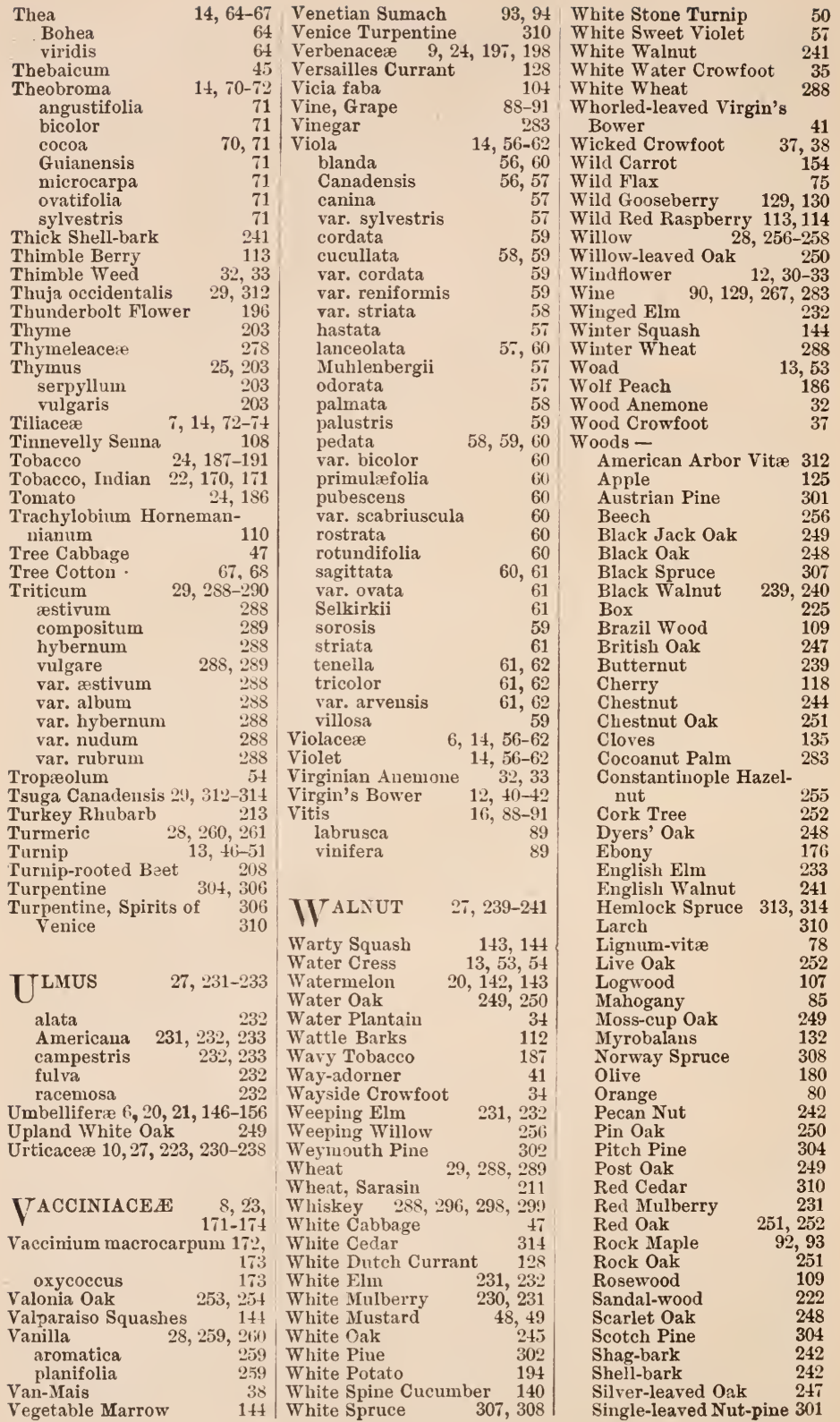




\begin{tabular}{|c|c|c|c|c|}
\hline Woods - & & Woods - & & Yellow Jute \\
\hline Southern Pine & 305 & White Spruce & 308 & Yollow Lentil \\
\hline Spanish Oak & 248 & Yellow-barked Oak & 248 & Yellow Pine $30: 303,305,306$ \\
\hline Strychnine & 182 & Yellow Pine & 303 & Yellow Water Crowfoot 36 \\
\hline Sugar Maple & $9: 2,93$ & Wrightia tinctoria & $y 6$ & Yerba Maté $\quad 85-87$ \\
\hline $\begin{array}{l}\text { Swamp Chestnut Oak } \\
\text { Swiss Pine }\end{array}$ & K $\begin{array}{l}250 \\
305\end{array}$ & Wrinkled Cabbage & 47 & \\
\hline Tamarind & 110 & & & ' ANTE Curral \\
\hline Teak & 198 & 28,271 & 1,272 & \\
\hline Thick Shell-bark & 242 & & & Zea mays $\quad 29,286-2$ \\
\hline Valon & 254 & Yellow Banana & $2(i 5)$ & Ziugiber offlcinalis 28,20 \\
\hline edar & 315 & Yellow-barked Oak & 248 & \\
\hline White Oak & 246 & Yellow Berries & 8., 88 & Zing \\
\hline Wlite Pine & 302 & Yellow Cinchona Bark & 157 & Zygophyllaceze \\
\hline
\end{tabular}









$$
\begin{gathered}
\langle>>7>7 \\
>>>7 \\
7>7 \\
7
\end{gathered}
$$




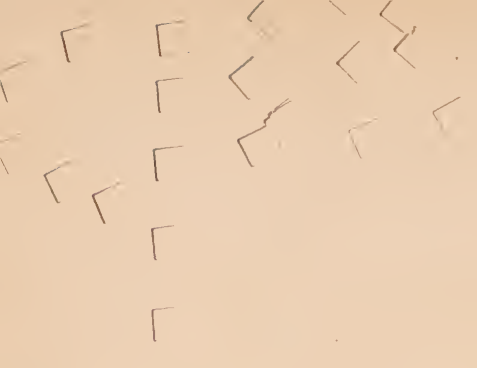


THIS BOOK MAY BE KEPT OUT TWO WEEKS

And is subject to a fine of Five Cents a day

thereafter. It was taken out on the day indicated below: 
North Carolina State University Libraries

QK47 .W6

PRACTICAL FLORA FOR SCHOOLS AND COLLEGES

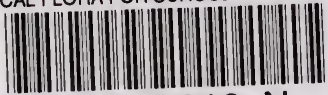

S02776916 N 